\title{
Oorzaak en gevolg : causaliteitsdiscussies in Nederland in de tweede helft van de 19de eeuw
}

Citation for published version (APA):

Scheurwater, G. J. L. (1999). Oorzaak en gevolg : causaliteitsdiscussies in Nederland in de tweede helft van de 19de eeuw. [Doctoral Thesis, Maastricht University]. Eburon. https://doi.org/10.26481/dis.19990423gs

Document status and date:

Published: 01/01/1999

DOI:

10.26481/dis.19990423gs

Document Version:

Publisher's PDF, also known as Version of record

\section{Please check the document version of this publication:}

- A submitted manuscript is the version of the article upon submission and before peer-review. There can be important differences between the submitted version and the official published version of record.

People interested in the research are advised to contact the author for the final version of the publication, or visit the DOI to the publisher's website.

- The final author version and the galley proof are versions of the publication after peer review.

- The final published version features the final layout of the paper including the volume, issue and page numbers.

Link to publication

\footnotetext{
General rights rights.

- You may freely distribute the URL identifying the publication in the public portal. please follow below link for the End User Agreement:

www.umlib.nl/taverne-license

Take down policy

If you believe that this document breaches copyright please contact us at:

repository@maastrichtuniversity.nl

providing details and we will investigate your claim.
}

Copyright and moral rights for the publications made accessible in the public portal are retained by the authors and/or other copyright owners and it is a condition of accessing publications that users recognise and abide by the legal requirements associated with these

- Users may download and print one copy of any publication from the public portal for the purpose of private study or research.

- You may not further distribute the material or use it for any profit-making activity or commercial gain

If the publication is distributed under the terms of Article $25 \mathrm{fa}$ of the Dutch Copyright Act, indicated by the "Taverne" license above, 
Oorzaak en Gevolg 
Uitgeverij Eburon

Postbus 2867

$2601 \mathrm{CW}$ Delft

info@eburon.nl

http://www.eburon.nl

ISBN 90-5166-679-9

(C) 1999 G.J.L. Scheurwater. Alle rechten voorbehouden. Nicls uit deze uitgave mag worden verveelvoudigd, opgeslagen in een geautomatiscerd gegevensbestand, of openbaar gemaakt, in enige vorm of op enige wijze, hetzij elektronisch, mechanisch, door fotokopieën, opnamen, of op enig andere manier, zonder voorafgaande schriftelijke toestemming van de rechthebbende.

(C) 1999 G.J.L. Scheurwater. All rights reserved. No part of this publication may be reproduced, stored in a retrieval system, or transmitted, in any form or by any means, electronic, mechanical, photocopying, recording, or olherwise, without the prior permission in writing from the proprielor. 


\section{OORZAAK EN GEVOLG}

CAUSALITEITSDISCUSSIES IN NEDERI_AND IN DE TWEEDE HELFT VAN DE I9IDE EI:UW

\section{PROEFSCHRIFT}

ter verkrijging van de graad van doctor aan de Universiteit Maastricht, op gezag van de Reclor Magnificus, Prof. Dr. A.C. Nieuwenhuijzen Kruseman volgens het besluit van het College van Decanen, in het openbaar te verdedigen op vrijdag 23 april 1999 om 16.00 uur

door

Gerrit Jan Leenderl Scheurwaler 
Promotor:

Prof. Dr. H. Visser

Beoordelingscommissie:

Prof. Dr. H.J. van den Herik (voorzitter)

Prof. S.J. Doorman, M.Sc. (Technische Universiteit Delft)

Prof. Dr. A. Labrie

Prof. Dr. M.J. Petry (Erasmus Unniversiteit Rotterdam) 
'For the problematic history of philosophy (....) the philosopher is essentially a puzzled man. (.....) The problematic approach (...) is the only one which throws light on the inner development of philosophy; it lets us see how our understanding ol philosophical problems advances.'

J.A. PASSMORE 1965, The idea of a history of philosophy. 
VOOR MARIEKE \& SOPHIE 



\section{DANKBETUIGING}

Veel dank ben ik verschuldigd aan mijn promotor Henk Visser, die mij in de afgelopen jaren met grote persoonlijke betrokkenheid nauwgezet heeft begeleid. Aan de gastvrijheid van de familie Visser op de vele vroege zaterdagochtenden denk ik met veel plezier terug. Tevens dank ik de volgende personen voor hun waardevolle suggesties bij enkele delen van deze studie: Jacob Fokkema, Babelte Franken, Jorien van der Kuil, Kees Maring, Ruud Moerkerken, Marietta Spiekerman-Middelplaats, Rob de Vos en Kees de Waal. Daarnaast ben ik zowel mijn collega's bij de Technische Universiteit Delft als mijn vrienden, en niet in de laatste plaats mijn ouders, zecr erkentelijk voor de door hen gctoonde belangstelling voor de voorbereiding van dit onderzoek. De aanmoedigingen van mijn echtgenote Marieke Butter waren voor mij een belangrijke drijfveer om wat eenmaal begonnen is ook te voltooien. Door haar scherpzinnige kritiek heeft de tekst veel aan helderheid gewonnen. Ten slotte: ons dochtertje Sophie doet met haar verstandige ogen haar naam nu al alle eer aan. Misschien dat zij later dit boek nog eens zal doorbladeren, en dat zij zich dan zal verwonderen over de voor haar wat curieuze belangstelling van haar vader voor de geschiedenis van de filosolie in Nederland in de tweede helft van de 19 de ecuw. 


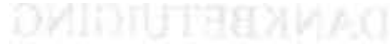


INLEIDING

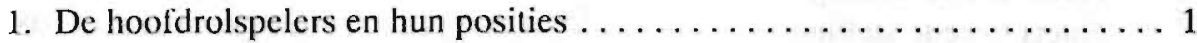

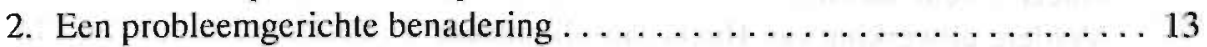

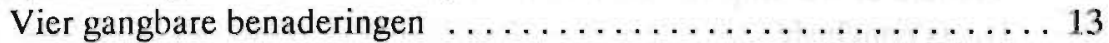

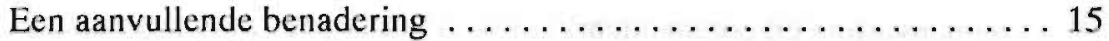

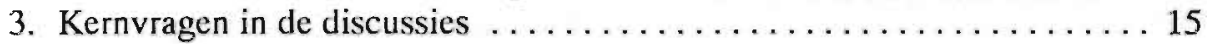

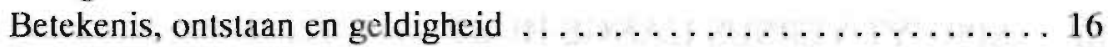

4. Begrenzingen van het onderzoek $\ldots \ldots \ldots \ldots \ldots \ldots \ldots \ldots \ldots \ldots \ldots \ldots \ldots \ldots \ldots$

I. OPZOOMER EN VAN DER WIJCK VERSUS SPRUYT $\ldots \ldots 21$

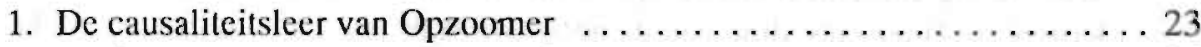

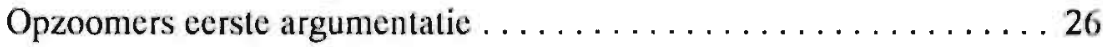

Opzoomers tweede argumentatie . . . . . . . . . . . . 30

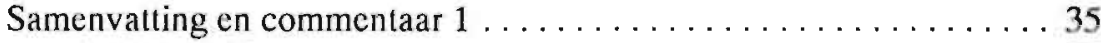

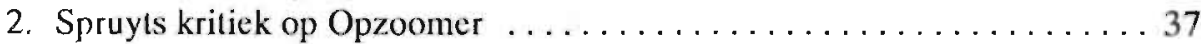

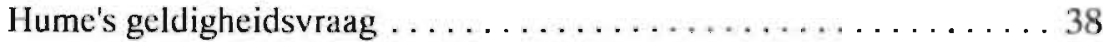

Kritick op Opzoomers eerste argumentatie $\ldots \ldots \ldots \ldots \ldots \ldots \ldots .41$

Kriliek op Opzoomers tweede argumentatie . . . . . . . . . . 42

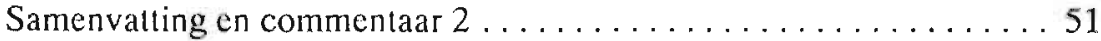

3. Opzoomers repliek op Spruyt . . . . . . . . . . . . . . . . 54

Nogmaals: 'innig en vast verband' . . . . . . . . . . . . . 54

Kritiek op Spruyts argumentatiestrategic . . . . . . . . . . 56

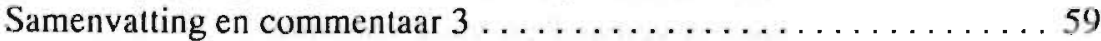

4. Van der Wijcks verdediging Opzoomer ................. 60

De oorsprong en grenzen der kennis . . . . . . . . . . . . . 60

Kritiek op Spruyts notie 'aangeboren waarnemingsvorm' . . . . . . 65

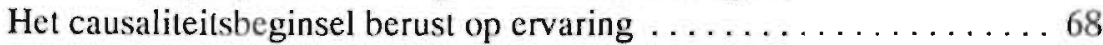

Kritick op Hume's associatietheorie $\ldots \ldots \ldots \ldots \ldots \ldots \ldots \ldots 70$

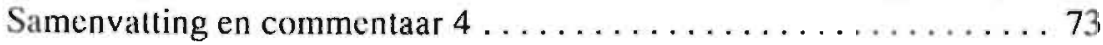

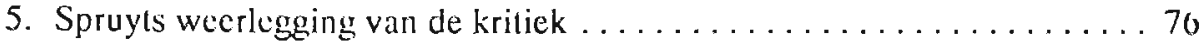

De empirische afleiding van het causaliteitsbeginsel $\ldots \ldots \ldots \ldots 77$

Het causalileitsbeginsel is a priori $\ldots \ldots \ldots \ldots \ldots \ldots \ldots \ldots \ldots$ 
II. L'ANGE HUET VERSUS OPZOOMER EN SPRUYT . . . . . . 85

1. Huets formulering van het causaliteitsvraagstuk $\ldots \ldots \ldots \ldots \ldots$

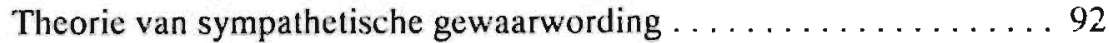

2. Huets kritiek op Spruyt en Opzoomer . . . . . . . . . . . . . . . 94

Kritiek op Opzoomers cerste argumentatie . . . . . . . . . . 95

Kritick op Opzoomers tweede argumentatic . . . . . . . . . . . 97

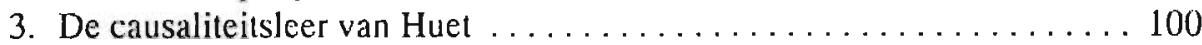

Huets eerste stelling . . . . . . . . . . . . . . . . . . . 101

Hucts tweede stelling . . . . . . . . . . . . . . . . 108

Verdere uitwerking van Huets causaliteitsleer $\ldots \ldots \ldots \ldots \ldots \ldots 114$

Hucts conclusic . . . . . . . . . . . . . . . . . . 118

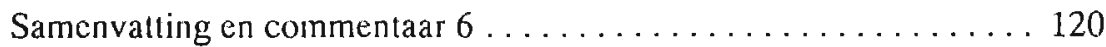

III. SPRUYT VERSUS L'ANGE HUET $\ldots \ldots \ldots \ldots \ldots \ldots \ldots \ldots$

1. Spruyts kritick op Huet . . . . . . . . . . . . . . . . 126

Nogmaals: theorie van sympathetische gewaarwording $\ldots \ldots \ldots 126$

Waardering van Huets kritiek op Opzoomer en Hume . . . . . . . 132

Krilick op Huets alleiding van de notie 'oorzaak' . . . . . . . . . 134

De notie 'verklaren' en hel beginsel van voldoende grond . . . . . . 136

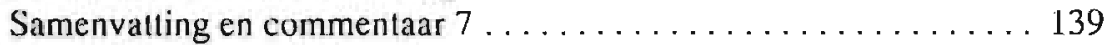

2. De causaliteitsleer van Spruyt . . . . . . . . . . . . . . . 141

Kritiek op Hume en navolging van Kant . . . . . . . . . . . . 143

Samenvalting en commentaar $8 \ldots \ldots \ldots \ldots \ldots \ldots \ldots \ldots$

IV. PIERSON VERSUS SPRUYT $\ldots \ldots \ldots \ldots \ldots \ldots \ldots \ldots \ldots$

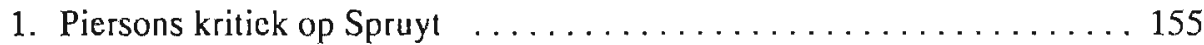

Kritiek op Kants tweede analogie der ervaring . . . . . . . . 155

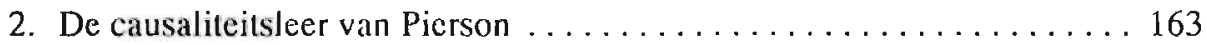

'Oorzaak', 'oorzakelijk verband' en 'vaste volgorde' . . . . . . . . . 163

Onderlinge betrekking tusschen feiten? . . . . . . . . . . . . 170

Nogmaals: 'lijdsorde' en 'oorzakelijk verband' ............ 175

Samenvalting en commentaar $9 \ldots \ldots \ldots \ldots \ldots \ldots \ldots \ldots \ldots$

V. HEYMANS VERSUS BETZ, JELGERSMA EN BOLLAND . . 183

1. Het causalitcitsvraagstuk volgens Heymans . . . . . . . . . . . 185

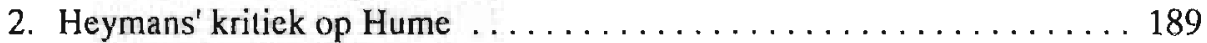

Hume's oplossing en Heymans' kritiek . . . . . . . . . . . . 190 
3. De causaliteitsleer van Heymans $\ldots \ldots \ldots \ldots \ldots \ldots \ldots \ldots \ldots \ldots \ldots . \ldots \ldots$

Het postulaat en de hypothese van Hamilton $\ldots \ldots \ldots \ldots \ldots \ldots 200$

Toetsing en bevestiging van de hypothese van Hamilton . . . . . 203

Filosolische rechtvaardiging van Hamiltons postulaat ........ 215

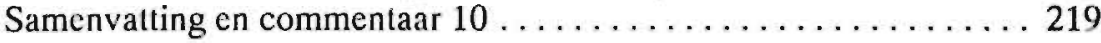

4. Reacties van Land, Vogels en Bierens de Haan . . . . . . . . . 222

5. Betz' kritiek op Heymans . . . . . . . . . . . . . . . . 224

Causale axioma's zijn niet a priori ................. 225

Het postulaat van Hamilton en de hypothese van Heymans . . . . 227

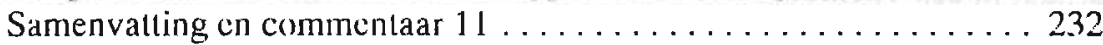

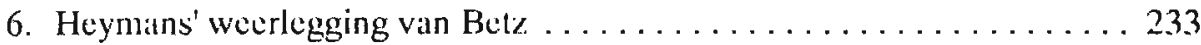

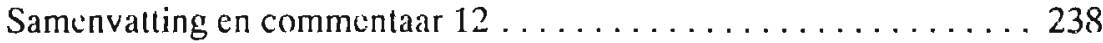

7. Jelgersma's kritick op Heymans . . . . . . . . . . . . . 239

Kritick op Heymans' formulering van het causaliteitsvraagstuk . . . 240

Ontstuan onzer causale olertuigingen door associatie . . . . . . . 242

Associatie ten gevolge van coëxistentie . . . . . . . . . . . . 243

Heymans' oplossing van het psychologische causaliteitsvraagstuk . . 247

Causale axioma's verklaard door associatie ............. 251

Heymans' oplossing van het filosofische causalitcitsvraagsluk . . . . 253

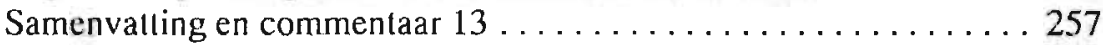

8. Heymans' polemiek met Jelgersma $\ldots \ldots \ldots \ldots \ldots \ldots \ldots \ldots \ldots \ldots . \ldots \ldots$

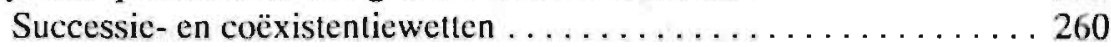

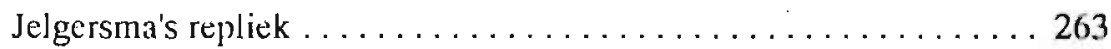

Nog cens: cansaliteit . . . . . . . . . . . . . . . . 265

Jelgersma's diagnose van de polemick . . . . . . . . . . . 268

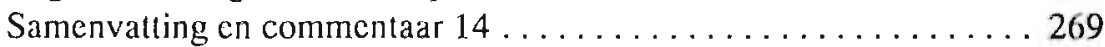

9. Heymans en Bolland . . . . . . . . . . . . . . . . 270

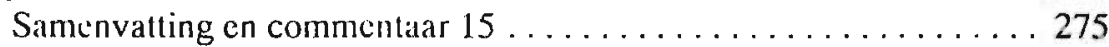

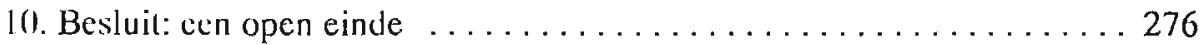

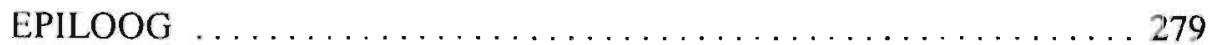

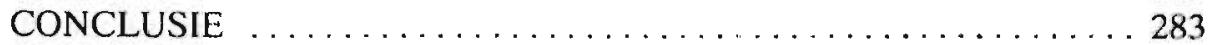

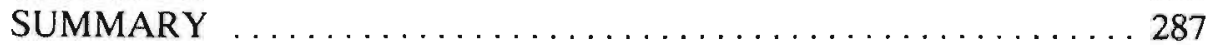

LITERATUUR EN BRONNEN ... . . . . . . . . . . . . . . . . 293

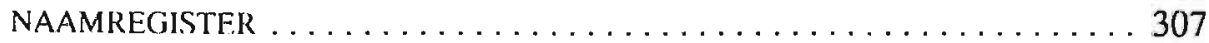

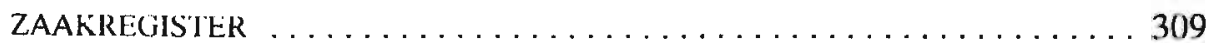

AUTEUR . . . . . . . . . . . . . . . . . . . . . . 311 


\section{CITATEN, VOETNOTEN EN BRONNEN}

Alle relevante passages uit het bronnenmateriaal zijn ter controle voor de lezer in noten onder de hoofdtekst geplaatst. De notatic die hicrbij is gevolgd, luidt: cf. [achternaam], [initialen], [(jaartal)], [titel], [pagina] '[citaal].' Als een boek of artikel in een voetnoot voor de cerste maal wordt aangehaald, wordt de volledige titel cursief aangegeven. Citaten die daarop volgen en die op hetzelfde boek of arlikel betrekking hebben, worden aangeduid met: ef. [achlernaam], [initialen], [(jaartal)], [op. cit.] [pagina], '[citaat].' Als in citaten binnen voetnoten wordt geciteerd of als in citaten binnen voetnoten wordt verwezen naar cen bepaald begrip, wordt dit met “......" weergegeven. De notatie van voetnoten die alleen verwijzen naar literatuur luidt als volgt: cf. [achternaam], [initialen], [(jaartal)].

Citaten die in de hoofdtekst zijn opgenomen, zijn cursief gemarkeerd; met cen voetnoot wordt verwezen naar de vindplaats van het betreffende citaat. Delen van teksten die zijn weggelaten, worden aangegeven met (.....); dit geldt zowel voor weglatingen in de voelnoten als in de gecursiveerde citaten. Overdrachtelijke taaluitingen in de hoofdtekst worden met "....." aangegeven. De notatie die in de hoofdtekst is gevolgd bij het verwijzen naar een bepaald begrip of naar een uitspraak wordt mel '......' aangegeven; bijvoorbeeld: de nolie 'causaliteit'. Als in de hoofdtekst naar literatuur wordt verwezen, wordt dit als volgt aangeduid: [naam, jaartal]. Aanduidingen van titels van bocken en van tijdschriften in de hoofdtekst worden gecursiveerd gemarkeerd; bijvoorbeeld: $A$ treatise of human nature.

De kopjes bij secties binnen een paragraal worden vetgedrukl aangegeven. In gevallen waar de titel van een kopje van een sectie binnen een paragraal is ontleend aan een citaat of aan een boek- of brochuretitel is dit vetgedrukt en cursief aangegeven. Kupjes bij subsecties binnen cen paragraal worden cursief aangegeven.

Ieder substantieel deel van het onderzoek wordt besloten met een samenvatting op hoofdlijnen van de besproken argumentaties. Het begin van een samenvatting wordt aangegeven met .-.............; elke samenvatting wordt direct, na een witregel, gevolgd door een kort commentaar. Als dat relevant is, worden wederom met ........... de samenvatting en het commentaar afgesloten.

De notatic die is gevolgd in het overzicht van literatuur en bronnen luidt voor boektitels als volgt: [ACHTERNAAM], [INITIALEN] [jaartal], [boektitel]. [plaats]: [uitgever]. Als cen boek als proefschrift is verschenen wordt dit apart vermeld. De notatie van titels van tijdschriftartikelen in het overzicht van litcratuur en bronnen luidt: [ACHTERNAAM], [INITIALEN] [jaartal], '[titel tijdschriftartikel]'. In: [lijdschrift], no. [nummer], [pagina's]. 




\section{INLEIDING}

Deze studie vormt een filosofisch-historisch onderzoek natar discussies over causaliteit die in Nederland in de tweede helft van de 19de ceuw werden gevoerd tussen zes toen vooraanstaande Nederlandse filosofen, te weten: C.W. Opzoomer, B.H.C.K. van der Wijck, C.B. Spruyt, J. L'Ange Huel, A. Pierson en G. Heymans.

De hoofdvraag die in deze studie wordt beantwoord, luidt: hoc ontwikkclden zich in Nederland de discussies over causaliteit in de tweede helft van de 19de ecuw?

De aanleiding tot dit onderzoek wordt gevormd door het vermoeden dat deze discussies, als onderdeel van het filosofische erfgoed van Nederland, zowel vanuit een historisch als vanuit een filosofisch-inhoudelijk oogpunt meer te bieden hebben dan doorgaans wordt aangenomen.

Het doel van deze studie is om de discussies, die nog niet eerder stelselmatig zijn onderzocht, in hun onderlinge samenhang tc beschrijven en om zo een "witte vlek" op de kaart van de geschiedenis van de filosofie in Nederland in te kleuren.

De argumentaties die de deelnemers aan de discussies naar voren brachten zijn voor de huidige lezer dikwijls moeilijk toegankelijk. Dit komt niet alleen doordat onze "intellectuele horizon" cen andere is dan die van de 19de eeuwse lezer, maar ook door de eigen stijl van redeneren die zij hanteerden. Met behulp van een probleemgerichte benadering wordt getracht meer helderheid te scheppen in hun redeneringen, en daardoor in de discussies. De vraagstellingen en de argumentaties die de deelnemers zélf formuleerden om tot een bepaalde oplossing van het causaliteitsvraagstuk te komen, vormen het uitgangspunt van deze benadering.

Ter inleiding komen in dit hoofustuk de volgende vier soorlen vragen aan de orde. Ten eersle: wie zijn de hoofdrolspclers in de discussies en wat zijn hun posities? Ten tweede: wat zijn de benaderingen die men op het gebied van de geschiedenis van de filosofie in Nederland kan onderscheiden? En: wat zijn enkele achterliggende overwegingen bij de keuze van de probleemgerichte benadering? Ten derde: wat zijn de kernvragen in de discussies? En: hoe kan men de vragen en de benaderingen dic in de discussies naar voren komen typeren? Ten slotte: wat zijn de historische begrenzingen van dit onderzoek?

\section{DE HOOFDROLSPELERS EN HUN POSITIES}

Nederland telde in de 19de ecuw vijf universiteiten. In de 16de en 17de eeuw waren de universiteiten te Leiden (1575), Groningen (1614) en Utrecht (1634) gesticht. In de 19de eeuw kwamen daar twee universiteiten bij: de Universiteit van Amsterdam 
(1877) en in 1880 de Vrije Universiteit Amsterdam.' Het merendeel van de deelnemers aan de discussies bekleedde een leerstoel in de filosofie aan één van deze universiteiten of was daar als privaatdocent aan verbonden. Tegen deze achtergrond speelden de discussies over causaliteit zich in hoofdzaak af. Dit onderzoek kan daarom ook als een "hoofdstuk" uit de geschiedenis van de academische filosofie in Nederland worden gezien. ${ }^{2}$

Het doel van deze paragraaf is tweeledig: het introduceren van de denkers die in dit onderzoek een hoofdrol spelen en het schetsen van de hoofdlijn in de discussies. Biografische gegevens worden afgewisseld met een korte karakterisering van de filosofische posities die werden ingenomen. ${ }^{3}$

Cornelis Willem Opzoomer (1821-1892) is de eerste hoofdrolspeler die optreedt in de Nederlandse causaliteitsdiscussies. Na zijn promotie tot doctor in de rechtswetenschappen aan de Rijksuniversiteit Leiden op het proefschrift De naturali obligatione (1845), werd hij in 1846 als opvolger van J.F.L. Schröder (1774-1845) ${ }^{4}$ benoemd tot buitengewoon hoogleraar aan de Rijksuniversiteit Utrecht. Eén jaar later werd hem door de Rijksuniversiteit Leiden de titel doctor honoris causa verleend. Het hoogleraarsambt in Utrecht bekleedde hij meer dan veertig jaar: tot 1889 .

Opzoomer hield zich niet alleen bezig met technische filosofische kwesties, maar hij ging bijvoorbeeld ook uitvoerig in op ethische problemen, op theologische vragen en op staatsrechtelijke onderwerpen. ${ }^{5}$

Tegenwoordig is Opzoomer beter bekend als jurist dan als filosoof, en wel als

'Met de wet op het Hoger Onderwijs (1876) werden de universiteiten te Leiden, Groningen en Utrecht rijksuniversiteiten; dat wil zeggen, door de overheid gefinancierde instellingen voor hoger onderwijs. Deze universiteiten worden in het navolgende genoemd: Rijksuniversiteit Leiden, Rijksuniversiteit Groningen en Rijksuniversiteit Utrecht.

${ }^{2}$ Voor cen goed overzicht van de matschappelijk-politieke achtergronden, de ontwikkelingen van het universitaire (filosofie-)onderwijs en onderzoek in de $19 \mathrm{de}$ eeuw, en het onderwijs- en welenschapsbeleid van de overheid zij verwezen naar Wijck, B.H.C.K. van der (1898b); Zie ook: Brookman, F.H. (1979); Berkel, K. van (1985); Willink, B. (1991); Otterspeer, W. (1992).

'De biografische gegevens voor deze paragraaf zijn ontleend aan de volgende bronnen (in chronologisclie volgorde): Anlal, G. von (1888). Wijck, B.H.C.K. van der (1888); Wijck, B.H.C.K. van der (1893); Pierson, A. (1893); Naber, S.A. (1897); Wijck, B.H.C.K. van der (1898a), (1898b); Ritter, P.H. (1904); Wijck, B.H.C.K. van der (1904); Boersema, K.H. (1924); Bie, J.P. de (1931); Sassen, F.L.R. (1941); Poortman, J.J. (1948); Faber, W. (1954); Sassen, F.L.R. (1954); Brugmans, H.J.F.W. (1957); Sassen, F.L.R. (1959); Dooren, W. van (1959/60); Veer, H. van 't (1961); Graaf, D.A. de (1962); Vries, J.W. de (1969); J. Romein (1979); Veen, H.G. van der (1983); Hubbeling, H.G. (1980a), (1980b); Draaisma, D. (1983); Hubbeling, H.G. (1983); Dooren, W. van (1983); Hubbeling, H.G. (1988); Dooren, W. van (1990); Otlerspeer, W. (1992); Visser, H. (1992); Krop, H.A. (1995); Veen, H. van der (1997).

${ }^{4}$ Voor een overzicht van de geschiedenis van de filosofie in Nederland vóor omstreeks 1850 zij verwezen naar Sassen, F.L.R. (1959), hooftlsluk IV, \$ 1-4.

sef. Opzoomer, C.W. (1848a), (1864-1867), en (1875). 
de auteur van het elfdelige commentaar (1874-1887) op het Burgerlijk wetboek. In de jaren vijftig en zestig van de vorige eeuw zag men hem echter vooral als dé figuur die een nieuwe wending gaf aan de filosofiebeoefening in Nederland, te weten: één van speculatieve metafysica naar empirisme. Zijn leerling Van der Wijck typeerde deze verandering van filosofische oriëntatie later als volgt: ervaring, geen ijdele bespiegeling was voortaan zijn leus. ${ }^{1}$ Opzoomers colleges en publikaties over de grondslagen en methodologie van de natuur- en geesteswetenschappen, zoals $D e$ weg der wetenschap, een handboek der logica $\left(1851^{2}\right)$, Wetenschap en wijsbegeerte $\left(1857 ; 1862^{2}\right)$ en Het wezen der kennis, een leesboek der logica $\left(1863,1867^{2}\right)$ hadden in die periode groot gezag. Zijn denkbeelden vielen vooral ook bij zijn directe Utrechtse collega's, de "Utrechtse Kring", in goede aarde. Van dit gezelschap maakten prominente wetenschapsbeoefenaren deel uit, zoals de scheikundige G.J. Mulder, de fysioloog F.C. Donders, de meteoroloog C. Buys Ballot en de zoöloog P. Harting. ${ }^{2}$

Opzoomers empiristische wetenschapsmethodologie was sterk geënt op John Stuart Mills System of logic (1843). Net als Mill ging Opzoomer er van uit dat ervaring de bron van kennis is. Op grond van zijn empiristische uitgangspunten formuleerde Opzoomer in De weg der wetenschap en in Het wezen der kennis twee argumentaties die moesten aantonen dat zowel de twee noties 'oorzaak' en 'noodzakelijkheid' als het causaliteitsbeginsel door ervaring ontstaan.

Cornelis Bellaar Spruyt (1842-1901) is de tweede hoofdrolspeler in de discussies. $\mathrm{Na}$ cen studie natuurkunde aan de. Rijksuniversiteit Utrecht (1860-1866) werkte hij eerst als leraar wis- en naluurkunde te Den Haag. Van 1866 tot 1877 was hij als leraar verbonden aan de HBS te Utrecht. ${ }^{3}$ Tijdens zijn leraarschap promoveerde hij in 1867 aan de Rijksuniversiteit Utrecht op het natuurwetenschappelijke proefschrift De electromotorische kracht van het element van Daniell bij verschillende temperaturen. In 1877 volgde zijn benoeming tot hoogleraar in de filosofie aan de zojuist gestichte Universiteit van Amsterdam. Zeer waarschijnlijk had hij dit te danken aan zijn publikaties over filosofische onderwerpen die hij in de loop van de jaren zeventig had geschreven. ${ }^{4}$

Twee jaar na zijn benoeming publiceerde Spruyt in 1879 het boek Proeve van eene geschiedenis van de leer der aangeboren begrippen (verder te noemen: Proeve). Hij componeerde dit werk naar aanleiding van een prijsvraag die in 1877 was uitgeschreven door het prestigieuze Leidse Stolpiaansch Legaat. ${ }^{5}$ De Proeve werd

'cf. Wijck, B.H.C.K. van der (1890), Nog eens: oorsprong en grenzen van kennis, p. 4.

${ }^{2}$ cf. Veer, H. van '1 (1961): zie ook: Romein, J. (1979) en Theunissen, B. (1995).

${ }^{3}$ Voor een interessante beschrijving van de positie van de toen net gevormde Hogere Burger Scholen zij verwezen naar: Berkel, K. van (1985) en Willink, B. (1991).

cf. Spruyt, C.B. (1871a), (1871c), (1872), (1873) en (1876).

'Het Stolpiaansch Legaat is in 1753 ingesteld overeenkomstig de testamentaire wens van 'het lidmat van de Leidse Universiteit' Jan Stolp. Stolp had de wens te kennen gegeven dat om de twee jaar een prijsvraag zou worden uitgeschreven voor verhandelingen, in het Latijn of het Nederlands, op hel gebied van de natuurlijke religie en de ethiek. Het Curatorium was 
door het Legaat prompt met goud bekroond. Hier wordt later in deze paragraaf nog op teruggekomen.

Spruyt pleitte voor een kantiaanse benadering van kennis. In het artikel Aangeboren waarnemingsvormen (1871a) brak hij bijvoorbeeld een lans voor de opvatting dat de notie 'causaliteit' een aangeboren begrip of aangeboren waarnemingsvorm was. Naast ervaring spelen in Spruyts opinie aangeboren of verstandelijke, niet tot ervaring herleidbare elementen een rol bij het vormen van kennis.

In Aangeboren waarnemingsvormen vormden vooral Opzoomers boeken De weg der wetenschap en Het wezen der kennis het doelwit van Spruyts kritiek. Spruyt meende te hebben bewezen dat Opzoomers argumentaties, die moesten aantonen dat zowel de twee noties 'oorzaak' en 'noodzakelijkheid' als het causaliteitsbeginsel op ervaring berusten, tot contradicties leidden. Het empirisme was daarom in zijn ogen een onhoudbaar filosofisch standpunt. Omdat Opzoomers argumentaties tot tegenstrijdigheden leidden, concludeerde Spruyt dat dit alleen maar kon betekenen dat de notie 'causaliteil' en het causaliteitsbeginsel aangeboren waren. Spruyt gebruikte in Aangeboren waarnemingsvormen in hoofdzaak een negatieve argumentatiestrategie; directe argumenten voor zijn eigen positie gaf hij nauwelijks.

Opzoomer was door Spruyts kritiek diep gekrenkt. Meteen na het verschijnen van Spruyls in Opzoomers ogen aanmatigende artikel, publiceerde Opzoomer in 1871 de brochure Een nieuwe kritiek van de wijsbegecrle der ervaring beschouwd (verder te noemen: Nieuwe kritiek). Hicrin trachtte hij Spruyt voor de ogen van het lezerspubliek op zijn plaats te zetten.'

Niet alleen Opzoomer, maar ook de Groningse hoogleraar in de lilosolie en Opzoomers epigoon Bernhard van der Wijck (1836-1925) was verontwaardigd door Spruyts kritiek. Van der Wijck is de derde hoofdpersoon in dit onderzock. Net als Opzoomer doorliep Van der Wijck een bliksemcarrièrc. Na een studic theologie aan de Rijksuniversiteit Utrecht en na een kortstondige betrekking als predikant, werd hij door Opzoomer bij de Minister van Binnenlandse Zaken voor benocming tot hoogleraar voorgedragen. Kort daarop werd Van der Wijck op 28-jarige leeftijd bij Koninklijk Besluit benoemd tot hoogleraar in de filosofic aan de Rijksuniversiteit Groningen als opvolger van F.C. de Greuve (1792-1863). Dit ambt bekleedde Van

samengesteld uit ecn aantal hoogleraren van de Rijksuniversiteit Leiden. In de loop van de 19 de ecuw werden door het Curatorium onderwerpen gekozen die meer aansloten bij algemeen filosolische en wetenschappelijke onderwerpen. Tot in de jaren zestig van de 20ste seuw heeft het Sinlpiaansch Legaat gefunctioneerd. Het Curatorium had een hoog wetenschappelijk gehalte. Beroemde curatoren van het Legaat uit het begin van de 20 ste eeuw waren bijvoorbeeld Lorentz, Ehrenfest en Huizinga.

' De Leidse hoogleraar J.P.N. Land reageerde vanaf de zijlijn op de discussie tussen Opzoomer en Spruyt: zie hiervoor het artikel van Land (18716), getiteld 'In zake Opzoomer contra Spruyt' (in: De Nederlandsche spectator). Hierin gaf hij aan dat Opzoomers virulente reactie weinig vruchtbaar was voor het filosofische debat. Dit artikel heeft echter geen rol gespeeld in de discussies. en het wordt daarom in deze studie niet verder besproken. 
der Wijck tot 1890, waarna hij een benoeming tot hoogleraar in de filosofie aan de Rijksuniversiteit Utrecht aanvaardde; ditmaal als opvolger van Opzoomer. Hier zou hij tot zijn emeritaat in 1906 blijven.

Net als zijn leermeester Opzoomer stelde Van der Wijck belang in de fundamentele aspecten van filosofie, waarvan De oorsprong en grenzen der kennis (1863) en $M r$. Joh. Kinker als wijsgeer $\left(1864^{2}\right)$ voorbeelden zijn. Het manuscript van dit laatstgenoemde boek werd in 1863 overigens bekroond door de Hollandsche Maatschappij van Fraaije Kunsten en Wetenschappen. Deze bekroning vormde voor de Rijksuniversiteit Utrecht mede de aanleiding om hem in 1864 met de titel doctor honoris causa te bekleden. Naast zulke technische publikaties maakten ook beschouwingen over figuren uit de geschiedenis van de filosofie en publikaties over psychologie cn ethiek deel uit van Van der Wijcks oeuvre.'

Van der Wijck schaarde zich na Spruyts kritiek uit 1871 achter Opzoomers empirisme. In het artikel De wijsbegeerte der ervaring verdedigd (1871) ging hij uitvoerig in op Spruyts Opzoomer-kritiek. Net als Opzoomer betoogde Van der Wijck dat de notie 'causaliteit' ontstaat door ervaring en dat het daarom geen aangeboren begrip kon zijn.

De tegenargumenten van Opzoomer, maar vooral die van Van der Wijck zetten Spruyt aan tot het schrijven van De laatste gedaantewisseling van de wijsbegeerte der ervaring toegelicht (1871b), waarin hij de tegenargumenten van Van der Wijck probeerde te weerleggen. Spruyt concludeerde dat diens argumenten niet steekhoudend waren, voornamelijk omdat zij tot dezelfde tegenstrijdigheden leidden als de argumentaties van Opzoomer. Dit kon volgens Spruyt wederom alleen maar betekenen dat de notie 'causaliteit' een aangeboren begrip moest zijn.

Op dit punt in de discussies maakt de vierde hoofdrolspeler zijn opwachting: Josué L'Ange Huet (1840-1924). Huets maatschappelijke positie wijkt sterk af van die van de andere hoofdrolspelers in de discussies, omdat hij namelijk nooit een academische betrekking als privaatdocent of als hoogleraar bekleedde. Evenmin heeft hij ooit op de kansel gestaan, hoewel men dat toch op grond van zijn Leidse theologiestudie kon verwachten. Huel werkte voornamelijk als journalist, onder andere als Nederlands correspondent van de Java-bode. Omstreeks 1873 vertrok hij naar het toenmalige Nederlands-Indië, waar hij in 1875 zijn beroemde neef Conrad Busken Huct opvolgde als hoofdredacteur van het in 1872 gestichte Algemeen dagblad van Nederlandsch Indï. In dit dagblad verscheen kort na zijn aantreden als hoofdredacteur een artikel van Conrads hand dat door koning Willem III als zeer beledigend werd ervaren. Omdat Huet als hoofdredacteur de eindverantwoordelijkheid droeg, daagde men hem voor de rechter. Hicrop volgde een veroordeling tot drie maanden cel. Onbekend is of hij ook daadwerkelijk gevangen is gezet. Na dit incident gaf L'Ange Huet zijn redlaclcurschap op, en trok hij zich voor de rest van zijn leven terug op een afgelegen kofficplantage in Tjempaka.

'cf. Wijck, B.H.C.K. van der (1868a), (1868b), (1872), (1873), (1877) en (1898a). 
In 1866 was Huet aan de Leidse theologische faculteit gepromoveerd op het proefschrift De methode der positieve filosofie volgens August Comte (verder te noemen: Methode). Hierin pleitte hij voor het belang van Comtes wetenschapsmethodologie voor de hedendaagsche wetenschappelijke theologie. Dit proefschrift was niet alleen een onderzoek naar de filosofische grondslagen van de theologie, maar het boek vormde ook het eerste systematische overzicht van Comtes filosofie in het Nederlandse taalgebied. ${ }^{1}$ Bovendien formuleerde Huet in zijn proefschrift een eerste aanzet voor een causaliteitsleer overeenkomstig de uitgangspunten van Comtes positivisme. Deze aanzet werkte hij systematisch uit in zijn boek Nieuwe oplossing van een oud vraagstuk. De methode van het positivisme toegepast op het begrip oorzaak-en-gevolg (verder te noemen: Nieuwe oplossing), dat in 1872 verscheen.

Huet mengde zich met de Nieuwe oplossing in de discussies toen deze in zijn ogen in een impasse terecht waren gekomen. In dit boek betoogde hij dat noch het empirisme van Opzoomer en Van der Wijck noch het idealisme van Spruyt ooit tot een bevredigende oplossing van het causaliteitsvraagstuk konden leiden. Hun fout was dat zij een alternatieve benadering hadden uitgesloten: het positivisme. De kern van Huets kritiek op Opzoomer, Van der Wijck en Spruyt was dat zij waren uitgegaan van een vaststaande betekenis van de notie 'causaliteit', waardoor zij het causaliteitsvraagstuk niet juist hadden kunnen formuleren. Huet analyseerde de notie 'causaliteit' geheel in termen van bewustzijnstoestanden, waarmee hij wilde aantonen dat de oorsprong van het besef van causaliteit uiteindelijk is terug te voeren tot een eenmalige impressie van oorzakelijke werking.

In de Nieuwe oplossing sloot Huet zich aan bij Comtes leer van de drie stadia. Deze leer hield in dat de ontwikkeling van het denken drie fasen doorloopt: het theologische, het metafysische en het wetenschappelijke (of positieve) stadium. Huet concludeerde dat 'causaliteit' een begrip was dat thuis hoorde in een vroegere fase van het denken. In de wetenschappelijke fase van het denken was deze notie overbodig geworden. Met deze conclusie verwierp Huet het empirisme van Opzoomer en Van der Wijck, een denkrichting waarin deze notie wél een centrale functie vervulde. Ook wees hij daarmee de opvatting van Spruyt van de hand, die de notie 'causaliteit' als een aangeboren begrip beschouwde.

Spruyt reageerde met het artikel Oude dwalingen in een nieuw kleed (1873) kritisch op Huets Nieuwe oplossing. Hij stelde zich hierin ten doel de belangrijkste stellingen van Huet te ondergraven. Net als in zijn kritick tegen Opzoomer en Van der Wijck constateerde Spruyt dat Huets theorie tot tegenstrijdigheden leidde, op grond waarvan

' Voor een overzicht van publikaties in Nederland over Comtes denkbeelden vóór Huets proetschrift (1866), zie: Veer, H. van 't, (1962). Huet laat deze publikaties geheel onbesproken. 
Spruyl wederom concludecrde dat de notic 'causaliteit' een aungebure'n warnemingsvorm mocst zijn.'

Tot dusver bestond Spruyls bijdrage an de discussies voornamelijk uil het bekritiseren van anderen. Echter, zes jaar na zijn kritick op Huct werkte Spruyl in de Proeve zijn cigen standpunt meer systematisch uit. ${ }^{2}$ Hierin liepen beschrijvingen van de denkbeelden van "grote" fïlosofen en Spruyts kritiek daarop door clkaar. Opvallend was dat Spruyt in de Proeve vooral rechtstreeks teruggreep op de causaliteitsleren van Hume en Kant. De denkbeclden van Opzoomer, Van der Wijck en Huet speelden in dit werk geen rol van betckenis. Het valt ook op dat Spruyt in de Proe've' een directe argumentatie leverde voor zijn overtuiging dat de notie 'causaliteit' als ecn aangeboren waarnemingsvorm moest worden gezien; dit had Spruyt in zijn artikelen die waren gericht tegen Opzoomer, Van der Wijck en Huct grotendecls nagelaten. Wel slout Spruyts directe argumentatie (1879) voor het aangeboren karakter van de notie 'causalitcit' nauw aan bij de beschouwing over causaliteit die Kant in de Kritik der reinen Vernunft naar voren had gebracht. ${ }^{3}$

${ }^{1}$ Terzijde zij opgemerkt dat ook de pater Jezuïet F. Becker (1838-1884), later hoogleraar in de filosofie aan het Seminarie te Culemborg, en later te Woodstock, Maryland (VS), van cen afstand de discussies tussen Opzoomer, Van der Wijck, Spruyt en Huet volgde. Becker was van mening dat alle deelnemers aan de discussie op een verkeerd spoor terecht waren gekomen. In het artikel uit 1873 'Oude oplossing van een oud vraagstuk' (in: De wachter) ontvouwde hij een traditionele Scholastieke visie op het causaliteitsvraagstuk. Beckers denkbeelden bleven echter geheel onbesproken, en zij vormden geen aanleiding voor een kritische discussie. Zij worden derhalve in dit onderzoek niet verder behandeld.

${ }^{2}$ De Proeve is in het buitenland niet geheel onopgemerkt gebleven. In 1880 publiceerde J.P.N. Land in het Engelse tijdschrift Mind hierover een lovende recensie. In de 'Critical notices' van dit tijdschrift merkte hij het volgende op: 'The Trustees of the Stolpian Fund (...) have done particulary good service to philosophical readers of our language in publishing Dr. Spruyt's prize-essay on the Doctrine of Innate Ideas. As a graduate in natural science, this writer takes an in interest in the subject from its bearing upon our everlasting religious differences, and by his close criticism and lucid exposition fully justifies his recent appointment to the chair of Philosophy in the new University of Amsterdam.' cf. Land, J.P.N. (1880), p. 581.

${ }^{3}$ In 1879 verscheen Van der Wijcks overdrachtsrede als Rector Magnificus van de Rijksuniversiteit Groningen, getiteld Het raadsel der ervaring. Hierin roerde hij het causaliteitsvraagstuk marginaal aan. Nicllemin is hel opmerkelijk dat hij in deze rede steeds meer afstand nam van Opzoomers empirisme. De kern van zijn betoog was dat ervaring als hel samenstel moest worden gezien van zowel gewaarwordingen als aangeboren elementen. Ook in zijn inaugurele rede uit 1890, Nog eens: oorsprong en grenzen der kennis, die hij nota bene in 1890 als opvolger van de aartsempirist Opzoomer aan de Rijksuniversiteit Utrecht hield, kwam dit nog pregnanter naar voren. Ook hierin kwam het causaliteitsvraagstuk slechts terloops ter sprake. Hij wees hier zowel Opzoomers empirisme als de speculatieve metafysica van de hand. In de discussies speelde Van der Wijcks opvattingen uit 1879 en 1890 geen rol. Van der Wijcks opvaltingen na zijn "wending" in 1879 tot het Kantianisme worden in deze studie daarom niet besproken. 
Spruyts Proeve was voor Allard Pierson (1831-1896), de vijfde hoofdrolspeler, dé aanleiding om zich via Wijsgeerig onderzoek. Kritische prolegomena van esthetiek (1882) met de discussies te bemoeien. Net als Van der Wijck en Huet had Pierson een theologische achtergrond. Hij studeerde theologie in Leiden en Utrecht, waar hij sterk werd beïnvloed door Opzoomers empirisme. In 1854 promoveerde hij aan de Rijksuniversiteit Utrecht op een analyse van de ontwikkeling van het universaliaprobleem van Anselmus tot Ockham. ${ }^{1} \mathrm{Na}$ zijn promotie was hij ruim tien jaar predikant, eerst in Leuven (1854-1857) en daarna in Rotterdam (1857-1865). Omdat hij zich niet meer kon verenigen met de artikelen des geloofs trad hij in 1865 terug als predikant. In datzelfde jaar ging hij studeren aan de Universiteit van Heidelberg bij onder anderen Hermann von Helmholtz. In 1869 vestigde hij zich in Heidelberg als Privat Dozent, en aanvaardde hij daar korte tijd later een benoeming tot buitengewoon hoogleraar in de godsdienstgeschiedenis. Na een verblijf van negen jaar in Duitsland kwam hij in 1874 terug naar Nederland. Tot 1877 woonde hij als ambteloos burger te Utrecht. In dat jaar werd hij benoemd tot hoogleraar in de esthetica en kunstgeschiedenis aan de Universiteit van Amsterdam. Deze functie bekleedde hij tot 1895 .

Naast Piersons nog steeds lezenswaardige cultuurhistorische studies, zoals de boeken Geestelijke voorouders: studiën over onze beschaving (1887b) en Hellas (1891a), publiceerde Pierson ook regelmatig over filosofische onderwerpen. De bocken Bespiegeling, gezag en ervaring (1855) en Richting en leven (1863) zijn hier voorbeelden van. In die twee geschriften bracht hij zijn toenmalige theologische en filosofische positie onder woorden, waarin de invloed van Opzoomers empirisme duidelijk merkbaar was. In het artikel Een keerpunt in de wijsgeerige ontwikkeling (1871) verruilde hij kortstondig zijn empiristisch getinte opvattingen voor een aan Helmholtz ontleende kantiaans georiënteerde kennistheorie. ${ }^{2}$ Enkele jaren later herriep Pierson in Eene levensbeschouwing (1875a) zijn positie zoals hij deze in het Keerpunt-artikel had verwoord. Piersons filosofische chef d'oeuvre en zijn bijdrage aan de discussies wordt gevormd door Wijsgeerig onderzoek. Kritische prolegomena van esthetiek (verder te noemen: Wijsgeerig onderzoek). Hierin wilde hij vooral Spruyts aan Kant ontleende causaliteitsopvatting weerleggen. Dit deed hij door een rechtstreekse aanval te openen op Kants tweede analogic der ervaring. Het hoofdpunt van zijn kritiek op Kant, en daarmee ook op Spruyt, was de onderstelling dat lijdsrelaties het fundament zouden vormen voor de aangeboren notic van 'causaliteit'. Uit Wijsgeerig onderzoek blijkı dat Pierson overigens meer waardering had voor

' De volledige titel van Piersons proefschrift luidt: Disquisitio historicu-dogmatica de realismo et nominalismo quatanus vim habuerint in praecipuis placitis theologicae scholasticae, inde ab Anselmo usque at Guillelmus ab Occamo.

${ }^{2}$ Deze kortstondige "wending" tot Helmholtz' kennistheorie kwam Pierson te staan op cen kritische reactie van Land (1871a), getiteld 'Het keerpunt in de wijsgeerige ontwikkeling van Jr. A. Pierson toegelicht' (in: De Nederlandsche spectator). Het causaliteitsvraagstuk komt hierin nauwelijk aan de orde. Lands reactie wordt in deze studie als cen zijlijn beschouwd, en zij komt daarom niet verder ter sprake. 
Hume. Echlcr, ook deze laatste spaarde hij niet. Piersons kritick op Hume was in hooldzaak gericht op de door hem aan Hume loegeschreven notic 'relatie lussen leiten'. Deze notic had volgens Picrson in de filosofie veel verwarring gezaaid, vooral als het de vraag betrof wat de betekenis van de notie 'causalitcit' was. Not als Huet, maar volgens een gehecl andere argumentatie, concludecrde Pierson ten slotte dat de notie 'causaliteit' voor wetenschappelijke doeleinden weinig waarde had.

In de kleine kring van de academische filosolie in Nederland vond Piersons standpunt weinig weerklank. Spruyt bijvoorbecld vond het kennelijk nict nodig om Pierson uitvoerig te wecrleggen. Dit is opvallend omdat Spruyt, die bovendien Piersons collega was aan de Universiteil van Amsterdam, het belangrijkste doclwit was van Piersons kritiek. Er is slechts én zeer summiere reactic van Spruyt bekend; deze reactic verwoordde hij in het artikel Die Geschichte der Philosophie in Holland von 1878 bis 1888, dat in het Archiv fiir die Geschichte der Philosophie (1888). Het enige wat hij daarin nogal zuur opmerklc, was dat Pierson de Proeve kennelijk als een grok' sleen des aanslools zag. ${ }^{1}$ In 1895 , ruim tien jaar na het verschijnen van Wijsgeerig onderzoek treft men nog een terloopse kritick op Pierson aan van J.D. Bierens de Ilaan (1866-1943), de latere redacteur van het in 1906 opgerichte Tijdschrift voor wijsbegectle. Dit gebcurde in de brochure De psychische afkomst van het oorzaakbegrip (1895a). Ook Van der Wijck reagecrde laat en lauw. In het overzichtsartikel Kant in Holland, dat in 1899 in Kant-Studien verscheen, merkt hij over Piersons Kant-kritiek hel volgende op: ich will gerne bekennen, dass ich mein Leben lang nie bei einem grïndlichen Denker einer so seltsumen Behauptung begegnet bin.?

Nicl geheel ten onrechte zou men kunnen denken dat met Piersons Wijsgeerig onderzoek het vuur uit de discussies enigszins was verdwenen. Echter, acht jaar na het verschijnen van Wijsgeerig onderzoek ontvlamden de discussies opnieuw.

Met Gerard Heymans (1857-1930), de zesde hoofdrolspeler, krijgen de discussies een nieuwe impuls. Na een studie politieke economie aan de Rijksuniversiteit Leiden promoveerde Hcymans daar in 1880 op het proefschrift Karakter en methode der staathuishoudkunde. Vervolgens zelle Heymans zijn studies voort bij Windelband

' Sassen (1959) merkt op dat Spruyt in zijn diesrede uit 1899 getiteld Het empiriocriticisme, de jongste vorm van de 'wijsbegeerte der ervaring' 'terloops een vertraagd antwoord (gaf) op den aanval, dien A. Pierson met Wijsgeerig onderzoek (1882) op zijn Proeve had gedaan.' Dit gezichtspunt wordt in deze studie niet gedeeld. In zijn diesrede recapituleert Spruyt de uitgangspunten en het uiteindelijke deficit van Opzoomers filosofische programma. Nadat hij dit heeft geconstateerd, wijst Spruyt er op dat het programma van de Oostenrijkse filosoof R. Avenarius (1843-1896) op gelijksoortige uitgangspunten is gebaseerd, en die in filosofisch opzicht weinig vruchtbaar blijken te zijn. In het hele geschrift komt de naam van Pierson niet voor; evenmin worden er allusies gemaakt op Wijsgeerig onderzoek. Bovendien komt het causaliteitsvraagstuk niet ter sprake. Spruyts rede uit 1899 wordt dan ook in deze studie niet verder inhoudelijk behandeld.

'cl. Wijck, B.H.C.K. van der (1899), 'Kant in Holland'. In: Kant-Studien, p. 455. 
en Riehl aan de Universiteit van Freiburg. In Freiburg promoveerde hij in 1882 nogmaals; ditmaal in de filosofie op de dissertatie Zur Kritik des Utilismus. Na zijn terugkeer in Nederland liet de Rijksuniversiteit Leiden hem in 1883 toe als privaaldocent in de filosofie, waar hij zich tot zijn benoeming in Groningen in 1890 als opvolger van Van der Wijck uitvoerig bezig hield met Kants kennistheorie.

Heymans schrecf zijn Schets eener kritische geschiedenis van het causaliteitsbegrip in de nieuwere wijsbegeerte (1890a) (verder te noemen: Schets) naar aanleiding van een prijsvraag die in 1888 was uitgeschreven, alweer door het Leidse Stolpiaansch Legaat. Ondanks enige aarzeling bij het Curatorium van het Legat werd Heymans' studie met goud bekroond. In datzelfde jaar volgde nog het eerste deel van Heymans' Die Gesetze und Elemente des wissenschaftliches Denkens. Ein Lehrbuch der Erkenninisstheorie in Grundzïgen (verder te noemen: Gesetze und Elemente). Hiervan verscheen het tweede deel in 1894.

Heymans bood in de Schets een kritisch-historisch overzicht van causaliteitstheorieën die sinds Descartes waren geformuleerd. Dit boek was voor Heymans ook de gelegenheid om een causaliteitsleer te ontwikkelen die geënt was op het postulaat dat door de Engelse filosoof W.R. Hamilton was geformuleerd: het werkelijk bestaande is in beginsel onveranderlijk. Als men uitgaat van de overtuiging a priori dat wat werkelijk bestaat onveranderlijk is, dan kan men het waarnemen van veranderingen slechts als schijn opvatten. Dit postulaat kon volgens Heymans alle verschijnselen van het causale denken verklaren, zoals het onderscheid tussen successie- en coëxistentiewetten en de rol van causale axioma's in het causale denken.

Net als in Spruyts Proeve werden in de Schets historische beschrijvingen en kritiek nauwelijks van elkaar gescheiden. Heymans' eigen denkbeelden over causaliteit kleurden daardoor sterk de weergave en de beoordeling van de opvattingen van anderen. In tegenstelling tot de Schets was Heymans' tweedelige Gesetze und Elemente niet historisch, maar systematisch van opzet. Net als Opzoomer dat in De weg der wetenschap had gedaan, ontvouwde Heymans in Gesetze und Elemente een wetenschapsmethodologie. Ook in dat boek, en vooral in het tweede deel daarvan, nam Heymans het postulaat van Hamilton als uitgangspunt voor zijn eigen causaliteitsleer.

De Schets bracht in Nederland de filosofische gemoederen danig in beroering. Bij het Curatorium van het Stolpiaansch Legaat, dat de Schets per slot van rekening moest beoordelen, was enige aarzeling te bespeuren om de prijs toe te kennen. Deze aarzeling betrof vooral Heymans' filosofische rechtvaardiging van het postulaat van Hamilton. Nog voor het daadwerkelijk in druk gaan van de Schets ging Heymans dan ook in een naschrift op de bedenkingen van het Curatorium in.

Het is niet onwaarschijnlijk dat de kritiek van het Curatorium van het Legaat afkomstig was van de Leidse hoogleraar en promotor van Heymans' eerste proefschrift J.P.N. Land (1834-1897), die destijds optrad als president-curator van het Legaat. Na de publikatie van de Schets verwoordde Land zijn bedenkingen zowel in een

'cf. Heymans, G. (1886), (1888), (1889a), (1889b) en (1889c). 
beknople recensie getiteld Dr. Heymans over het hegrip veroorzaking (1890a), als in het uitgebreide artikel uit datzelfde jaar, Oorzaken e'n gevolgen (1890)). Heymans liet Lands kritick onbeantwoord. Dit gold ook voor de kritick die de hoogleraar in de lilosolie en theologie aan de studiehuizen der Jczuïeten I. Vogels (1860-1929) op Heymans' leer leverde in het artikel Dr. Heymans en de school van sir. W. Hamilton (1894). 'Typerend voor Vogels' stijl van redeneren is de volgende uilspraak die hij naar aanleiding van Heymans' causalitcitsleer naar voren bracht: hot walgt ons, zulke wijsbegeerte of liever zulke dwaasheden te moeten weerleggen.' Heymans voclde zich kennelijk niet geroepen om op deze belediging in te gaan; er is in elk geval tot dusver geen reactic van Heymans op Vogels bekend. Ook de ecrder genoemde Bicrens de Haan bekriliseerde Heymans' leer. Dit gebeurde in dezclfde brochure als warin Bierens de Haan ook Picrsons causaliteitsopvatting terloops aanrocrde, namelijk in De psychische afkomst van het oorzaakbegrip (1895a). Ouk deee kritiek legde Hcymans naast zich neer. ${ }^{2}$

De kriticken waar Heymans wél op reageerde waren die van H.J. Betz (1842-1905), D.G. Jelgersma (1856-1930) en G.J.P.J. Bolland (1854-1922). Betz, medicus in redacleur van het tijdschrift De levensbode, uitte in het artikel getiteld Rezwaren van een leek tegen het causaliteitsbegrip van dr. G. Heymans (189l) vooral kritiek op Heymans' onderstelling dat de werkelijkheid als een in beginscl onveranderlijk geheel opgevat moest worden. Dankbaar makkle hij gebruik van Lands conslatering (1890b) dat Heymans met dic onderstelling ons weder in de buturt der Eleaten brengt. Heymans replicecrde direct. In Dr. Bctz en hel causalitcitsbegrip (1891) trachtle hij de argumenten die tegen zijn leer werden aangevoerd te weerleggen. In de\% replick betichtte Heymans Bctz er van dat hij zijn causaliteitsleer niet goed had begrepen.

In het artikel Causaliteit (1891), dat later werd opgenomen in de verzamelbundel Wijsgeerige strijdschriften (1896b), reagecrde Jelgersma, leraar klassieke talen en tevens privaaldocent aan de Universiteit van Amsterdam, vanuit een Humeaans perspecticf op de Schets. Hierin trachtle hij zowel Heymans' kritiek op Hume's causaliteitslecr als het door Heymans overgenomen postulaat van Hamilton te weerleggen. Heymans maakte vervolgens in het tweede deel van Gesetze und Elemente (1894) van de gelegenheid gebruik om voornamelijk op één specifiek punt van Jelgersma's argumentatie in te gaan. Dit betrof diens kritiek op Heymans' 403.

' cf. Vogels, I. (1894), 'Dr. Heymans en de school van sir W. Hamilton'. In: Studiën, p.

2 Bierens de Haans brochure uit 1895 was echter voor de chemicus en privaatdocent aan de Universiteit van Utrecht Ch.M. van Deventer (1860-1931) wẻl aanleiding voor een reactie die in het Tweemaandelijksch tijdschrift werd afgedrukt, getiteld 'Over het oorzaakbegrip' (1895). Hierop volgde weer een repliek van Bierens de Haan getiteld 'Strijdbaar beraad over het oorzaakbegrip' (1895b). Heymans hield zich bij deze schermutseling afzijdig. Deze discussie wordt in deze studie als een uitloper gezien van de hoofddiscussies, en zij valt daarom buiten het bestek van dit onderzoek. In het slot van het laatste hooldstuk wordt op deze discussie kort teruggekomen. 
onderscheid tussen wetten van successic en wetten van coëxistentie. Jelgersma liet Heymans' reactie niet onweersproken, want in een tweede artikel van zijn hand, wederom getiteld Causaliteit (1896a) ging hij in op Heymans' tegenargumenten. Hierop schreef Heymans een geprikkeld weerwoord. In een open brief aan Jelgersma, Nog eens: causaliteit (1896a), werd hem, net als Betz, te kennen gegeven dat hij zowel de Schets als Geselze und Elemente niet gocd had begrepen. Het laatste woord in deze polemiek was afkomstig van Jelgersma. Ook hij reageerde met een open brief, eveneens getiteld Nog eens:causaliteit (1896c), waarin hij constateerde dat zij langs elkaar heen praatten en dat verdere discussie door Heymans' nogal hautaine houding geen zin had. Hierna verstomde lussen beiden de discussie.

Ook Bolland, die in 1896 als opvolger van Land was benoemd tot hoogleraar in de filosofie te Leiden, liet van zich horen. In zijn inaugurele rede Verandering en tijd (1896) bekritiseerde Bolland vooral Heymans' filosofische rechtvaardiging van het postulaat van de onveranderlijkheid van het werkelijk bestaande. Heymans beantwoordde deze kritiek vervolgens in zijn artikel Bolland's oratie (1896b). Hiermee begon een polemiek tussen beide hoogleraren, die omstreeks 1910 naar aanleiding van Heymans' rede De toekomstige eeuw der psychologie (1909) overigens pas goed losbarsite.'

Na de schermutselingen van Heymans met Betz, Jelgersma en Bolland luwden de discussies over causaliteit. Dit neemt niet weg dat er toch nog Nederlandse filosofen waren die zich met dit onderwerp bezighielden. Echter, van een werkelijke discussie was er toen geen sprake meer. ${ }^{2}$ Naar aanleiding van Heymans' causaliteitsleer flakkerden de discussies rond de jaren twintig toch weer op. Ditmaal betrof het geen kritiek van filosofen, maar van fysici zoals Ph. Kohnstamm (1875-1941), J. Clay (1882-1955) en J.D. van der Waals jr. (1873-1971). ${ }^{3}$ De kern van de kritiek

1 Voor een vermakelijk overzicht van deze discussie zij verwezen naar Otterspeer, W. (1995), p. 367-377. Zie ook: Verwey, G. (1995), p. 191-194.

${ }^{2}$ Hier kan worden gewezen op de overigens summiere behandelingen van het causaliteitsvraagstuk in respectievelijk Opmerkingen over de vorming en den aard onzer kennis (1895) van R.P. Mees (1834-1915), Inleiding tot de wijsbegeerte (1905) en David Hume (1907). De twee laatstgenoemde bocken zijn van C.J. Wijnaendts Francken (1863-1944). Ook kan nog worden gewezen op de door voornamelijk Ph. Kohnstamm gereconstrueerde notities van Spruyt die als voorbereiding hebben gediend van Spruyts colleges over de geschiedenis van de filosofie. Deze reconstructie verscheen onder de titel Geschiedenis der wijsbegeerte (1904). Hierin wordt een korte kritiek op Heymans' causaliteitsleer aangetroffen. Heymans heeft op deze kritiek niet gereagecrd. Aan het slot van deze studie wordt kort op de kritiek van Spruyt-Kohnstanmm teruggekomen.

${ }^{3}$ Ph. Kohnstamm, hoogleraar natuurkunde aan de Universiteit van Amsterdam, ging in zijn inaugurele rede getiteld Determinisme en naruurwetenschap (1908) in op Heymans' causaliteitsleer. Dit deed hij ook in de brochure Ontwikkeling en ontroning van het begrip natuurwet (1916) en in het artikel 'Over natuurwetten, wetmatigheid en determinisme' (in: Onze eeuw, 1921). Heymans zag in deze geschriften geen aanleiding voor discussie. De natuurkundige en neo-hegeliaan J. Clay, privaatdocent aan de Technische Hoogeschool te Delft (1913) en later hoogleraar natuurkunde te Bandoeng (1923), viel Heymans aan in zijn artikel (1915a) getiteld 'Noodzakelijkheid en oorzakelijkheid' (in: Tijdschrift roor wijsbegeer- 
van de filosofen richtte zich vooral op Heymans' filosofische rechtvaardiging van Hamiltons postulaat. De kritiek van de hierboven genoemde fysici was echter vooral geïnspireerd door de toenmalige ontwikkelingen in de moderne natuurkunde, waarin de notie 'causaliteit', als men het al een bruikbare notie achtte, alleen als een speciaal functioneel verband werd gezien. Door deze natuurwetenschappelijke benadering kwam het denken over het causaliteitsvraagstuk in een duidelijk ander vaarwater terecht. Deze discussies vallen echter buiten het bestek van dit onderzock; zij zijn een aparte studie waard [Verwey, 1995; 1998].

Tot besluit van dit inleidende overzicht zij opgemerkt dat, net als dat voor ieder historisch onderzoek geldt, ook dit onderzoek op selectie berust, en daarom in beginsel onvolledig is. Het gaat in deze studie echter vooral om de hoofdlijnen van de discussies die destijds in Nederland over causaliteit werden gevoerd. De consequentie hiervan is dat de opvattingen van sommige tijdgenoten van de hoofdrolspelers slechts in het voorbijgaan worden genoemd; andere tijdgenoten worden zelfs geheel buiten beschouwing gelaten. Aanvullend onderzock naar de opvattingen van dic andere tijdgenoten zou deze leemtes kunnen opvullen.

\section{EEN PROBLEEMGERICHTE BENADERING}

Een verkenning van het onderzoek dat op het gebied van de geschiedenis van de Nederlandse filosofie is verricht, leert dat in elk geval vier gangbare benaderingen onderschiiden kunnen worden.

\section{Vier gangbare benaderingen'}

De ecrste benadering is het ordenen en toegankelijk maken van materiaal. Een goed voorbeeld hiervan is Poortmans Repertorium der Nederlandse wijsbegeerle (1948). In dit naslagwerk wordt een groot deel van het bronnenmateriaal per filosoof en per onderwerp gerangschikt, waardoor het van onschatbare waarde is voor het doen van

(e). Dit deed hij ook in zijn boek Schets eener kritische geschiedenis van het begrip natuurwet in de nieuwere wijsbegeerte (1915b). In dat boek wijdde Clay een kritisch hoofdstuk aan Heymans' begrip 'natuurwet'. Hierop reageerde Heymans (1916) met het artikel getiteld 'Natuurwetenschap en philosophie' (in: Tijdschrift voor wijsbegeerte). Echte discussie over het causaliteitsvraagstuk ontslond er echter pas weer toen de natuurkundige Van der Waals jr. in 1917 Heymans' causaliteitsleer bekritiseerde in het artikel getiteld 'Over de causaliteitstheorie van Hamilton-Heymans' (in: Tijdschrift voor wijsbegeerte). Heymans (1917) repliceerde met het artikel getiteld 'Prof. Van der Waals en de theorie van Hamilton' (in: Tijdschrift voor wijsbegeerte). Deze discussie werd privatim voortgezet in de briefwisseling tussen Heymans en Van der Waals.

1 Voor een verhelderende behandeling van de verschillende typen van historisch onderzoek op het gebied van de geschiedenis van de filosofie zij verwezen naar Gracia, J.J.E. (1992) en Rorty, R. (1984a). 
filosofisch-historisch onderzoek. Bovendien heeft de in de jaren tachtig uitgegeven reeks Geschiedenis van de wijsbegeerte in Nederland een nieuwe impuls gegeven aan het verder toegankelijk maken van historisch materiaal. Het voornaamste doel van deze reeks is het bezorgen van belangrijke filosofische teksten uit het Nederlandse taalgebied.

De tweede benadering is de doxografische. Het werk van de historicus van de filosofie Sassen is hiervan een treffend voorbeeld.' In zijn bijdragen ligt de nadruk op het ordenen van opvattingen van een groot aantal Nederlandse filosofen. Als men zich wil oriënteren op de geschiedenis van de filosofie in Nederland, zijn Sassens onderzoekresultaten waardevol. Echter, Sassens benadering is ontoereikend om duidelijk te maken wat de argumenten zijn geweest die Nederlandse filosofen tot een bepaalde opvatting hebben geleid. Het verbindende element tussen deze denkers - het formuleren van argumenten voor het oplossen van filosofische vraagstellingen komt nauwelijks aan bod; hierdoor blijft het volstrekt onduidelijk wat zij bijdroegen aan het verhelderen van zulke vragen.

De dercle benadering is de intellectuele biografie. Zo'n biografie schept een beeld van de intellectuele ontwikkeling van een persoon of een groep van personen in een bepaalde wetenschappelijke en maatschappelijke context. In het Nederlandse taalgebied zijn hiervan interessante, recente voorbeelden te vinden, zoals biografieën over Belle van Zuylen [Dubois, 1992] en over de filosofen H.J. Pos [Derkx, 1994] en G.J.P.J. Bolland [Otterspeer, 1995]. ${ }^{2}$

De vierde benadering is de receptie-geschiedenis. Hier wordt in Nederland, met name door de Werkgroep Sassen ${ }^{3}$, sinds het begin van de jaren negentig relatief veel aandacht aan besteed. Deze vorm van receptie-geschiedenis beoogt na te gaan op welke wijze filosofische ideeën van vooraanstaande denkers elders in Europa invloed hebben gehad op de opvattingen van Nederlandse filosofen. Hierdoor wordt het mogelijk om zulke opvattingen in een bepaalde filosofische stroming te plaatsen. Bovendien kan daardoor de positie van Nederlandse filosofen in de Westeuropese filosofische traditie duidelijk worden gemaakt. Deze benadering kan er echter toe leiden dat Neclerlandse filosofen alleen als navolgers van anderen worden gezien of als representanten van een bepaalde filosofische stroming worden beschouwd. Hierdoor ontstaat geen duidelijk beeld van hun eigen argumentaties.

1 cf. Sassen, F.L.R. (1959). Een voorbeeld van deze benadering kan ook worden aangetroffen in Struyker-Boudier (1985), waarin voomamelijk een historisch overzicht wordt geboden van de ontwikkeling van het neo-thomisme in de Nederlanden, België en Luxemburg.

${ }^{2}$ Naast het biografische deel wordt in de studie van Derkx, getiteld H.I. Pos 1898-1955. Objecrief en onpartijdig. Biografie van een filosoof en humanist, onder andere ook een reconstructie gegeven van de discussies tussen Pos en de logicus E.W. Beth over de relatie; tussen wetenschap en filosofie.

3 De acliviteiten van de Werkgroep Sassen zijn overigens niet beperkt tot receptiegeschiedenis. Naast voornoemde benadering wordt ook veel aandacht besteed aan bronnenonderzoek, vertalingen, biografische schetsen en het analyseren van filosofische denkbeelden. 


\section{Een aanvullende benadering}

Als aanvulling op de vier genoemde benaderingen wordt er in deze studic voor gekozen om de Nederlandse discussies over causaliteit met behulp van een probleemgerichte benadering te onderzoeken; een benadering die nog niet eurder systematisch is toegepast op de geschiedenis van de filosofie in Nederland.

Een achterliggende gedachte bij dezc benadering is de opvatting van Reichenbach dat de geschiedenis van de filosolie met meer vrucht wordt bestudeerd als deze vecleer als het ontdekken, articuleren en heantwoorden van vraagstukken wordt opgevat, dan als de presentatie van een recks theoretische stelsels. 'Dit sluit goed aan bij Passmore's opvalling dat de beoefening van de filosofie gezien moet worden als een continu streven naar het oplossen van filosofische problemen. ${ }^{2}$ Filosofie wordt datarmec primair opgevat als een intellectuele onderneming dic bestat uit argumenteren en debatteren.

De eerder genoemde hoofdvraag van deze studic luidde als volgt: hoe ontwikkelden zich in Nederland de discussics over het causaliteitsvraagsluk in de tweede helft van de 19de ceuw?

Uitgaande van de opvattingen van Reichenbach en Passmorc worden de vraagstellingen en argumentaties die door de deelnemers aan de discussies zélf werden geformuleerd als het uitgangspunt van dit onderzoek gekozen. De hoofdvraag van deze studic kan daarom als volgt worden toegespitst: wat zijn de specificke argumentaties die Nederlandse filosofen uit die tijd naar voren brachten om tot oplossingen van het causaliteitsvraagstuk te komen? Het beantwoorden van deze laatsle vraag vormt het belangrijkste decl van dit onderzoek.

\section{KERNVRAGEN IN DE DISCUSSILS}

Om een indruk te geven van het soort vragen en het soort oplossingen dic in dit onderzoek de revue zullen passeren, worden in deze paragraaf twee vragen aan de orde gesteld, te weten: wat voor problemen hadden die de hier behandelde Nederlandse filosofen op het oog als het ging over causaliteit? En, hoe kan men in algemene termen de vragen en benaderingen typeren die in de discussies naar voren kwamen?

' cf. Reichenbach, H. (1951), The rise of scientific philosophy, p. 25, The discovery of fundamental questions is in itself an essential contribution to intellectual progress, and when the history of philosophy is conceived as a history of questions, it offers a much more fruitful aspect than when it is regarded as a history of systems.'

${ }^{2}$ cf. Passmore, J.A. (1965), "The idea of a history of philosophy'. In: History and theory. Beiheft 5, p.29, 'For the problematic history of philosophy (....) the philosopher is essentially a puzzled man. (....) The problematic approach (....) is the only one which throws light on the inner development of philosophy; it lets us see how our understanding of philosophical problems advances.' 


\section{Betekenis, ontstaan en geldigheid}

Als men het materiaal dat op de discussies betrekking heeft overziet, dan treft men vragen als: wat verstaan wij door een oorzaak?' Of, (.....) wat beteekent eigenlijk, wanneer men het in zijn allereerste ontstaan nagaat, dat veelbesproken begrip van oorzaak en gevolg $?^{2}$ Of, wij willen nagaan of (...) wij een bruikbare bepaling vinden van hetgeen onder het woord: oorzaak is te verstaan. ${ }^{3} \mathrm{En}$, wat is toch mijn bedoeling, wanneer ik B na A waarnemende zeg, dat A de oorzaak is van $B ?^{4}$ En ook, wat hebben wij te verstaan onder een oorzaak, wat onder haar werking of haar gevolg $?^{5}$ Deze kwesties kan men als betekenisvragen opvatten met de volgende vormen: wat is de betekenis van de notie 'oorzaak"? En, wat is de betekenis van de uitspraak: 'een bepaald verschijnsel is de oorzaak van een bepaald ander verschijnsel'?

Uit het materiaal kan men ook vragen destilleren die het ontstaan van de notie 'oorzaak' betreffen, bijvoorbeeld: het wordt de vraag, of dit begrip (van oorzaak) empirisch van oorsprong is, dan wel of het de naam van aangeboren moet dragen?" Of, (....) hoe ontstaat bij den mensch de voorstelling van eene oorzakelijke werking van 't een op 't ander?'

Tevens treft men vragen aan die de rechtvaardiging van de onderstelling betreffen dat er tussen bepaalde verschijnselen een noodzakelijk verband zou bestaan, zoals: waarop berust ons geloof aan de noodwendigheid van het causaalverband, terwijl de natuur ons nooit iets anders kan aanwijzen, dan zijne geldigheid in vroegere gevallen? ${ }^{8}$ Of, hoe komen wij (...) aan de overtuiging, die ons in de verschijnselen een noodwendig verband doet aanmemen tusschen het voorafgaande en het volgende, de oorzaken en de gevolgen $?^{9} \mathrm{En}$, (......) welken grond hebben wij, om een noodzakelijk verband tusschen de gegeven verschijnselen aan te nemen $?^{10}$ En ook, hoe is het te verklaren dat in ons bewustzijn uit bepaalde waarnemingen de zekerheid ontstaat van een niet waargenomen noodzakelijk verband tusschen de objecten dier waarnemingen $?^{11}$

In de discussies komen ook vragen naar voren dic ingaan op de kwestie of het causaliteits- en regelmatigheidsbeginsel aangeboren zijn of dat zij op ervaring berusten. Enkele voorbeclden hiervan zijn: (......) hoe ontstuat de verwachting dat

' cf. Opzoomer, C.W. (18512), De weg der velenschap, p. 104.

${ }^{2}$ cf. L'Ange Huet, J. (1872), Nieuwe oplossing yoor een oud vraagstuk, p. 1.

${ }^{3}$ cf. Pierson, A. (1882), Wijsgeerig onderzoek. Kritische prolegomcna van esthetiek, p. 256.

${ }^{4}$ cf. Jelgersma, D.G. (1891), 'Causaliteit'. In: De nieuwe gids, p. 40-41.

st. Spruyt, C.B. (1904), Geschiedenis der wijsbegeerte, p. 93.

"cf. Opzoomer, C.W. (1863;1867²), Het wezen der kennis, p. 79.

${ }^{7}$ cf. L'Ange Huet, J. (1872), op. cit. p. 5.

${ }^{8} \mathrm{cf}$. Spruyt, C.B. (1871a), 'Aangeboren waarnemingsvormen'. In: De gids, p. 49.

${ }^{9}$ cf. Spruyt, C.B. (1879), Proeve van eene geschiedenis van de leer der aangeboren begrippen, p. 165.

${ }^{10} \mathrm{cf}$. Heymans, G. (1890a), Schets eener kritische geschiedenis van het causaliteitsbegrip in de nieuwere wijsbegeerte, p. 9.

"cf. Heymans, G. (1890a), op. cit. p. 11. 
bij gelijke omstandigheden gelijke gevolgen zullen plaatsvinden?' Hoe weten wij dat alles eene oorzaak moet hebben? ${ }^{2}$ Gelijke omstandigheden, gelijke verschijnselen! Wat brengt ons die uilspraak op de lippen? ? $^{3}$ Of, waarom nemen we voor ieder verschijnsel een oorzaak aan? $?^{4} \mathrm{En}$, waarom gelooven wij dat iedere verandering eene oorzaak moet hebben? ${ }^{5}$ En ook, (....) behoort de wet der causaliteit (....) als eene aan alle ervaring voorafgaande wet van ons denken te worden beschouwd?

Ten slotte rijzen er voor bepaalde deelnemers aan de discussies vragen die betrekking hebben op de geldigheid van generalisaties en op de notie 'regelmatigheid van de natuur'. Enkele voorbeelden van vragen die de geldigheid van generalisaties betreffen, luiden: (.... ) maar als ik in een of meer gevallen ontdekt heb, dat het eene verschijnsel er oorzaak van het andere geweest is, met welk regt durf ik dan beweren, dat het ten alle tijde er de oorzaak van zal zijn, het altijd zal voortbrengen?' Of, door welke redeneering verkrijgen wij de stoutmoedigheid van te meenen, dat verschijnselen, die wij eenige malen elkander hebben zien volgen, ook in de toekomst op elkander volgen zullen?" $\mathrm{En},(.$.$) waarop berusten al de besluiten die wij uit onze$ ervaring afleiden?" En ook, (....) hoe is het te verklaren, dat onze verwachting omtrent de toekomstige opeenvolging onzer waarnemingen bevestigd wordt $?^{10}$ Enkele voorbeclden van vragen die sommige deelnemers aan de discussies naar voren brachten ten aanzien van de notie 'regelmatigheid van de natuur', zijn: (....) waarop steunt (...) mijn aunnemen van zulk een regelmatigheid der natuur ?" En, berust dat onwankelbare geloof aan de regelmatigheid der natuur op eene redeneering of (...) berust het (...) op ervaring? ? $^{\text {i2 }}$

Men kan al deze vragen grofweg in drie soorten onderverdelen: betekenis-, ontstaans- en geldigheidsvragen. Het beantwoorden van de betekenisvraag kan als cen preliminaire vraag worden gezien. Het meest opvallende in deze opsomming van vragen is namclijk de tegenstelling tussen ontstaans- en geldigheidsvragen. Deze tegenstelling weerspiegelt de rode draad die door discussies loopt: de ontstaansbenadering versus de geldigheidsbenadering. In de eerste benadering gaat het vooral om het traceren van de herkomst van bepaalde begrippen en principes. In de tweede benadering gaat het om aan te tonen dat bepaalde begrippen en principes geldig zijn. In het algemeen houden empiristisch georiënteerde filosofen zich bezig met ont-

'ef. Opzoomer, C.W. $\left(1851^{2}\right)$, op. cit., p. 109.

cl. Wijck, B.H.C.K. van der (1863), De oorsprong en grenzen der kennis, p. 17.

cf. Wijck, B.H.C.K. van der (1863), op. cit. p. 28.

${ }^{4} \mathrm{cf}$. Opzoomer, C.W. (1871), Een nieuwe kritiek van de wijsbegeerte der ervaring beschouwd, p. 19.

${ }^{5}$ cf. Spruyt, C.B. (1871a), op. cit. p. 47.

${ }^{6} \mathrm{cf}$. Wijck, B.H.C.K. van der (1871), De wijsbegeerte der ervaring verdealigd, p. 38.

'cf. Opzoomer, C.W. (18512), op. cit. p. 108.

${ }^{8}$ cf. Spruyt, C.B. (1871a), op. cit. p. 35.

"cf. Spruyt, C.B. (1879), op. cit. p. 164.

"cf. Jelgersma, D.G. (1891), op. cil. p. 42.

"cf. Opzoomer, C.W. $\left(1851^{2}\right)$, op. cit. p. 108.

${ }^{12} \mathrm{cf}$. Spruyl, C.B. (1873), 'Oude Jwalingen in een nieuw kleed'. In: De gids, p. 243. 
staansvragen, waarbij zij menen dat daarmee tevens geldigheidsvragen worden beantwoord. Filosofen die het laatste betwijfelen, richten zich daarentegen van begin af aan op het beantwoorden van geldigheidsvragen.

In de ontstaansbenadering komen vragen aan de orde zoals: hoe ontstaan de noties 'oorzaak en gevolg' en 'noodzakelijkheid'? En, hoe ontstaat het causaliteitsbeginsel en het daarvan afgeleide regelmatigheidsbeginsel? Zulke kwesties worden vooral door Opzoomer, Van der Wijck, L'Ange Huet en Jelgersma behandeld. Algemeen gesteld gaan deze auteurs er van uit dat alle begrippen ontstaan door ervaring. In dat opzicht sluiten zij aan bij opvattingen van Hume, Mill en Comte.

In de geldigheidsbenadering komen voornamelijk de volgende vragen aan de orde: wat is de geldigheid van de noties 'oorzaak en gevolg' en 'noodzakelijkheid'? En, wat is de geldigheid van het causaliteitsbeginsel en het daarvan afgeleide regelmatigheidsbeginsel? Dit is het soort vragen dat vooral Spruyt en Heymans willen beantwoorden. Expliciet verwerpen zij de benadering die er van uitgaat dat alle begrippen door ervaring ontstaan. Zij zijn er van overtuigd dat bepaalde begrippen en principes niet berusten op ervaring, maar inherent zijn aan het denken. Hiermee sluiten zij aan bij opvattingen van Kant, Whewell, Schopenhauer en Hamilton.

\section{BEGRENZINGEN VAN HET ONDERZOEK}

Tot besluit van dit inleidende hoofdstuk wordt nog kort op de twee volgende vragen ingegaan: waarom kreeg het causaliteitsvraagstuk in Nederland juist in de periode 1850-1900 zoveel aandacht? En, waarom luwden de discussies over causaliteit rond de eeuwwisseling?

Bij het beantwoorden van de eerste vraag is het zinvol om te wijzen op een onderliggende tendens in de wetenschap en filosofie van de 19 de eeuw. In de loop van de 19 de eeuw volgden wetenschappelijke ontdekkingen en belangrijke formuleringen van algemene natuurwetten elkaar in hoog tempo op. Niet voor niets wordt deze eeuw als het "tijdperk van de natuurwetenschappen" getypeerd [Knight, 1986]. Natuurwetten werden destijds dikwijls opgevat als causale wetten. Zulke wetten zagen velen als het standaardvoorbeeld van zekere en noodzakelijk geldende kennis. Het gegeven dat men toen relatief veel onderzoek deed naar de filosofische grondslagen van die natuurwetten wordt in dit licht begrijpelijk. Immers, velen wilden de vraag beantwoorden waarom aan causale relaties, en daarmee ook aan natuurwetenschappelijke kennis, zekerheid en noodzakelijkheid kon worden toegeschreven [Zwart, 1967].

Het bovenstaande vormt een schetsmatig antwoord op de vraag waarom causaliteit toen als een belangrijk onderwerp werd gezien. Om deze vraag op een meer gedetailleerde wijze te beantwoorden, zou een apart onderzoek moeten worden ingestcld. 
Om de tweede vraag - waarom de discussies over causaliteit rond de eeuwwisseling luwden - te beantwoorden is het zinvol om te kijken naar enkele ontwikkelingen op het gebied van wetenschap en filosofie rond die tijd. Het tegelijkertijd optreden van twee tendensen kan als een mogelijk antwoord dienen: (1) de "wetenschappelijke wending" in de filosofie, en (2) de verdere verbreiding van het neo-kantianisme alsmede de organisatie daarvan in de Marburgse en de Badense school.

Veel filosofische kwesties werden rond de eeuwwisseling steeds meer gezien in het licht van de methoden en resultaten van natuurwetenschappelijk onderzoek. Dit staat in de literatuur bekend als de "wetenschappelijke wending" in de filosofie [Passmore, 1980]. Nederlandse vertegenwoordigers van deze benadering waren de eerder genoemde J. Clay, J.D. Van der Waals jr. en Ph. Kohnstamm. "Klassieke" filosofische vraagstukken, zoals de aard van tijd, ruimte en causaliteit, werden steeds vaker in een nauwe samenhang gezien met de ontwikkelingen in de toenmalige wisen natuurkunde. Dit leidde er toe dat veel formuleringen en analyses van het causaliteitsvraagstuk die in de 19 de eeuw naar voren kwamen, in de eerste helft van de 20 ste eeuw steeds meer plaats maakten voor analyses in de context van concrete wetenschapsgebieden. Vanaf die tijd worden causale verbanden in die context veelal als speciale functionele verbanden gezien.

Voor zover filosofen nog vasthielden aan een meer "klassieke" benadering van filosofische kwesties, kan worden geconstateerd dat de invloed van het neokantianisme in academisch Nederland, net als in Duitsland, in de loop van de tweede helft van de 19de eeuw steeds groter werd [Sassen, 1941; Köhnke, 1986]. Dit komt in het begin van de 20ste eeuw tot uitdrukking door de toenemende invloed van de Marburgse en Badense school. Hierdoor werd de geldigheidsbenadering, die immers besloten ligt in het kantiaanse gedachtengoed, aan de Nederlandse universiteiten au courant. Het is waarschijnlijk dat het steeds minder urgent werd geacht om deze benadering te verdedigen ten opzichte van de ontstaansbenadering. Het causaliteitsvraagstuk leende zich uitstekend om de noodzaak van de geldigheidsbenadering in de filosofie aannemelijk te maken. Toen dat niet mee zo noodzakelijk was, raakte daarmee ook het causalitcitsvraagstuk zcl[ op de achtergrond.

Met Sassen [1961] kan daarom worden gesteld dat de ontwikkeling die in de tweede helft van de $19 \mathrm{de}$ eeuw is begonnen, de herleving van het criticisme, zich in de eerste helft van de 20ste eeuw heeft geconsolideerd. Dit blijkt bijvoorbeeld uit het feit dat rond 1900 de meeste leerstoelen in de filosofie waren bezet door hoogleraren die in eén of andere vorm door Kant werden beïnvloed: Heymans in Groningen, Spruyt in Amsterdam en Van der Wijck in Utrecht [Visser, 1992]. Ook stonden veel van hun opvolgers direct of indirect onder Kants invloed: Ovink in Utrecht, Polak in Groningen, Pos in Amsterdam en de Sopper in Leiden. Ook buiten de kleine kring van Nederlandse academische filosofen kan er in de eerste helf van de 20ste eeuw een steeds groter wordende, meestal positieve, belangstelling voor Kant worden geconstateerd. Dit blijkt bijvoorbeeld uit Poortmans Repertorium der Nederlandse wijsbegeerte, waar men onder het lemma 'Kant' een waslijst van artikelen aantreft over of naar aanleiding van Kant. 
Al met al: de "wetcuschappelijke wending" in de filosofic en de tocnemende belangstelling voor de filosofie van Kant geven een mogelijke verklaring voor het leit dat de discussies over causaliteit rond 1900 luwden.

In deze studie wordt een tot dusver vrijwel onbekend gebied betreden. Met behulp van cen problecmgerichte benadering wordt getracht een verborgen rijkdom in het filosofische erfgoed van Nederland aan het licht te brengen. 
In 1846 werd Opzoomer benoemd tot buitengewoon hoogleraar in de filosofic aan de Rijksuniversiteit Utrecht, waardoor hij in een omgeving lerechtkwam waar natuurwetenschappelijk onderzock cen hoge vlucht nam. In Utrecht verkeerde hij in een kring van internationaal vooraanstaande vertegenwoordigers op het gebied van de scheikunde, biologie en fysiologie, zoals G.J. Mulder, P. Harting en F.C. Donders. Vooral Opzoomers goede contacten met Mulder, prominent scheikundige en onldekker van het proteïne, zijn van belang. In 1849 had deze latste een redevoering gehouden met als titel De weg der wetenschap, waarin hij de zegeningen telde van de moderne wetenschappelijke aanpak. Het contact met Mulder kan een verklaring bieden voor Opzoomers grociende belangstelling voor methodologische vraagstukken. Het feit dat Opzoomers methodologische handboek De weg der wetenschap uit 1851 dezellede litel draagt als Mulders redevocring uit 1849 is in dit opzicht veelzeggend.

Thorbecke, staatsman en hoogleraar te Lciden, had in de jaren vecrlig de veclbelovende rechtenstudent Opzoomer gewezen op de Duitse speculatieve filosool Krause. Kennelijk werd Opzoomer zo door deze denker gegrepen dat hij hel plan opvatte voor een thcologisch-filosofisch boek met als titel De leer van God, bij Schelling, Hegel en Krause. Alleen het decl over Krause (1847) heeft het levenslicht gezien en verscheen in het jaar waarin Opzoomer zijn werkzaamheden in Utrecht begon. Al snel verloor hij echter zijn belangstelling voor Krauses speculatieve metafysica om in plaats daarvan Mills empirisme lc omarmen. Opzoomers rede De twijfel des tijds. De wegwijzer der toekomst (1850) en zijn eerdergenoemde De weg der wetenschap symboliseren deze overgang van speculatieve metafysica naar empirisme.

Ter illustratie van Opzoomers overgang naar het empirisme kan in De twijfel des tijds dit, enigszins gezwollen geluid worden aangetroffen: de wijsbegeerle die zich den eerenaam der positieve heeft toegekend, en wier beginsel het is, niets te erkennen wat zich boven den kring van het zimnelijke verheft, wijst ons naar de ervaring als eenige kenbron der waarheid. (....) Mar die ervaring mag zich niet bepalen tot onszelven of den kleinen kring, waarin wij ons bewegen; zelfs de geheele wereld, zooals zij legenwoordig zich aan onzen blik vertoont, is te beperkt voor onze waarneming. Niet tevergeefs hebben de voorgeslachten geleefd, op wier graven wij wandelen; niet in ijdelheid is hun denken en werken vervlogen. Zij staan daar voor ons, de groote voorgangers in de wetenschap, om van hunne ervaring getuigenis af te leggen; en de toestand der eeuwen, die voorbij zijn gegaan, is de fakkel, die ons voorlicht naar het doel, dat wij in het oog hebben. Daarom is het de geschiedenis, 
die wij moeten raadplegen; de geheele menschheid moet het veld onzer waarneming zijn.'

De weg der wetenschap sluit hierop aan; daar heet het dat melafysica moet worden afgewezen omdat het louter berust op redeneren en niet op ervaring. Metafysica kan daardoor nooit tot zekerheid leiden. Alleen systematisch empirisch onderzoek dat wordt uitgevoerd volgens regels die in de natuurwetenschappen worden gebruikt, mondt uit in zekere kennis. Ervaring staat hierbij centraal, en niet ijdele bespiegeling. Wetenschap en wijsbegeerte moeten in het teken staan van Lord Bacons motto: nut en vooruitgang. ${ }^{2}$ lmmers, onderzoek leidt tot kennis. Op basis van kennis kan men voorspellingen doen; en op grond van dusdanig gefundeerde voorspellingen kan men handelen.

Opzoomers denkbeclden veranderden na 1851 nauwelijks. In Opzoomers latere publikaties Wetenschap en wijsbegeerte $\left(1857 ; 1862^{2}\right)$, De waarheid en hare kenbronnen $\left(1859 ; 1862^{2}\right)$, Het wezen der kennis $\left(1863 ; 1867^{2}\right)$ en in Een nieuwe kritiek van de wijsbegeerte der ervaring beschouwd (1871) treft men vrijwel dezelfde denkbeelden aan.

Tussen de wetenschapsmethodologie van Opzoomer en Mills System of logic (1843) bestaan opvallende overeenkomsten [Van Dooren, 1959/1960; Van 't Veer, 1961]. ${ }^{3}$ Net als Mill formuleert Opzoomer zowel in De weg der wetenschap als in de herziene uitgave daarvan, Het wezen der kennis, methodologische regels voor het verrichten van wetenschappelijk onderzoek die de basis vormen voor dergelijk onderzoek. Ook gaat Opzoomer daarin na of men zulke regels kan gebruiken bij het onderzoek op het gebied van de geesteswetenschappen. ${ }^{4}$ Door deze niet te miskennen overeenkomsten met Mills Logic wordt Opzoomer ook wel de Nederlandse John Stuart Mill genoemd [Van Dooren, 1959/1960].

Deze "geaccepteerde" visie op Opzoomer, alsof hij slechts een navolger van Mill zou zijn, maskeert overigens het feit dat Opzoomer wel degelijk een eigen filosofisch profiel had. De probleemgerichte methode die in dit onderzoek wordt toegepast laat dit profiel wél duidelijk zien.

Als men Opzoomers filosofische positie kort zou willen karakteriseren, dan moet men allereerst zijn "inductivisme" nocmen. Opzoomer beschouwt inductie als de belangrijkste methode van het natuurwetenschappelijk onderzoek. Deze methode

'cf. Opzoomer, C.W. (1850), De twijfel des tijds. De wegwijzer der toekonst, p. 28-31.

${ }^{2}$ cf. Opzoomer, C.W. $\left(1851^{2}\right)$, De weg der wetenschap, p. vi, 'De wijsbegeerte heeft de grote leenspreuk van Baco: nut en vooruitgang! in den wind geslagen (...) Waar jjdele bespiegeling het meest woekerde, daar zelfs hooren wij overal het woord: lalen wij terugkeeren tot de ervaring, tot den weg, ons door Baco gewezen.'

${ }^{3}$ In de publikaties van Van Dooren $(1959 / 1960)$ en Van 't Veer (1961) wordt de schatplichtigheid van Opzoomers wetenschapsmethodologische opvattingen aan John Siuart Mill aannemelijk gemaakt.

${ }^{4}$ cf. Opzoomer, C.W. $\left(1851^{2}\right)$, op. cit. p. 8, 'De vraag moet dus gedaan en kan beantwoord worden: welke is de methode der natuurstudie en is zij ook voor de geestelijke wetenschappen te gebruiken?' 
lijkt echter op het eerste gezicht alleen tot waarschijnlijke en niet tot zekere kennis te leiden; dat wil zeggen, uilspraken die overal en altijd gelden. Door het gebruik van de inductieve methode zijn wetenschappelijke uitspraken immers per definitie gebaseerd op een beperkt en daarmee op een eindig aantal waarnemingen. ${ }^{1}$ Dit leidt tot de vraag of men op die manier in de natuurwelenschappen wel algemeen geldende en zekere uitspraken kan doen. Met andere woorden: sluit de inductieve methode zekere kennis niet per definitie uit? Opzoomers antwoord luidt: neen. Het inzicht dat een bepaald verschijnsel door een bepaalde oorzaak wordt voortgebracht, ontstaat via inductie. Inductic is de basis voor het formuleren van algemeene stellingen, en zij leidt tot zekere kennis van natuurwetten. Natuurwetenschappelijke kennis, die door inductie tot stand komt, is daarom zekere, en geen waarschijnlijke kennis. ${ }^{2}$

Daarnaast neemt Opzoomer de positie in die inhoudt dat causale verbanden los van onze ervaring bestaan. Het doel van de natuurwetenschap is om oorzaken van verschijnselen letterlijk te ontdekken, waardoor men vervolgens algemeen geldende wetten kan opsporen. Toeval bestaat niet. ${ }^{3}$

Zoals uit de navolgende paragraaf blijkt betekent één en ander echter niet dat Opzoomer filosofische problemen rond causaliteit uit de weg gaat. Opzoomers causaliteitsleer vormt dan ook het startpunt voor de discussies over causaliteit in Nederland. Uit het navolgende zal bovendien blijken dat Opzoomer zich in zijn causaliteitsleer ook afzette tegen de filosofische opvattingen van de Engelsman William Whewel].

\section{DE CAUSALITEITSLEER VAN OPZOOMER}

De helderste formulering van de vraag of aangeboren begrippen al of niet bestaan, treft men aan in Opzoomers Nieuwe kritiek (1871): hebben wij in onze natuurkennis een aangeboren, niet aan de ervaring ontleend bestanddeel? $\mathrm{Zijn}$ antwoord luidt

' cf. Opzoomer, C.W. $\left(1851^{2}\right)$, op. cit. p. 23, 'Maar hoe kunren de naturwetenschappen ons ooit tol zekerheid leiden, daar wij zelven het door hare methode, de inductie, slechts tot. waarschijnlijkheid kunnen brengen?'

${ }^{2}$ cf. Opzoomer, C.W. $\left(1851^{2}\right)$, op. cit. p. 23-24, 'Een blik op de natuurwetenschappen leert ons dan ook, dat zij ons wel degelijk zekerheid geven. ' Zie ook: Opzoomer, C.W. $\left(1851^{2}\right)$, op. cit. p. 107 , ' Zoo dikwijls ons de inductie tot kennis van oorzaken brengt, geeft zij ons het regt tot algemeene stellingen, warop geen enkele vitzondering bestaat, en leert ons natuurwetten kennen, die niet waarschijnlijk, maar zeker zijn.'

${ }^{3}$ cf. Opzoomer, C.W. $\left(1851^{2}\right)$, op. cit. p. 110-121, 'Het doel der natuurstudie bestaat in het vinden van de oorzaken van verschijnselen, de omstandighedien waaronder zij worden voortgebragt en ten allen tijde voortgebragt moeten worden. De kennis dier oorzaken stelt ons in staat, algemeene natuurwetten aan te wijzen. (...) Wetteloosheid (mag) (...) nergens in de naluur worden aangenomen.'

${ }^{4}$ cf. Opzoomer, C.W. (1871), Een nieuwe kritiek van de wijsbegeerte der ervaring beschouwd, p. 16. 
ontkennend. Alle begrippen ontstaan door ervaring en zijn dus a posteriori. Aangeboren begrippen bestaan niet. 'Hicrmee sluit Opzoomer aan bij Hume en Mill. ${ }^{2}$ Evenals Mill bestrijdt Opzoomer $r^{3}$ de opvalling van Whewcll dat sommige begrippen en principes, zoals de notic 'oorzaak' en bovenal de wet van causaliteit, geen oorsprong hebben in de ervaring, maar uit de menselijke geest ontspringen. ${ }^{4}$

Opzoomer werpt daarom de vraag op of dit begrip (oorzaak) empirisch van oorsprong is, dan wel of het de naam van aangeboren moet dragen. ${ }^{5} \mathrm{Zijn}$ antwourd ligt voor de hand: de notic 'oorzaak' stoclt op ervaring. Dit antwoord strookt gehcel met de empiristische uitgangspunten die Opzoomer in De weg der wetenschap en Het wezen der kennis had geformuleerd, en het staat lijnrecht tegenover Whewells opvatling dat dezc notie aan de menselijke geest ontspringt. Whewell had hiervoor het "bewijs" gegeven dat men uitsluitend de successic van verschijnselen kan waarnemen, en dat men het bewerken van een bepaald verschijnsel door een bepaald ander verschijnsel, de causale relatie zelf, niet kan waarnemen. ${ }^{6}$ De notie 'oorzaak' vatte hij daarom op als cen aangeboren begrip.

In $D e$ weg der wetenschap wijst Opzoomer Whewells zogenaamde bewijs en daarmee diens opvatting voor het aangeboren zijn van de notie 'causaliteit' van de hand. Successie en causaliteit zijn weliswaar verschillende relaties, maar zij berusten beide op ervaring. De notie 'oorzaak' is gebascerd op het waarnemen van de successie

' cf. Opzoomer, C.W. (1871), op. cit. p. 14, 'Het karakter van de wijsbegeerte der ervaring is, voorzover het al onze natuurkennis betreft, hierin te zoeken, dat volgens haar al onze natuurkennis van zinnelijke waarneming der verschijnselen uitgaat.' Zie ook: Opzoomer, C.W. (1857;1862²), Wetenschap en wijsbegeerte, p. 226, 'Dat onze begrippen nimmer zelfstandig zijn geweest, maar altijd mel waarneming, met gewaarwording vereenigd, altijd bezig in hare verbinding, dat zij voortdurend door onze ervaring worden gewijzigd, untwikkeld en bepaald, ziet men zich telkens gedwongen te erkentien. Maar als dit zoo is, als er nooit een begrip was zonder de ervaring, dan mogen wij wel hij wijze van abslractie ze van elkander scheiden en elk afzonderlijk beschouwen, mar wij mogen het niel zoo voorstellen, alsof de begrippen in ons waren, voor door waarneming de stof in ons kwam, die dan van die begrippen terstond haren vorm zou hebben ontvangen.'

${ }^{2}$ cf. Hume, D. (1739/1740), A rreatise of human nature, book 1, section I, p. 7; zie ook: Mill, J.S. (1843), System of logic, Introduction, p. 3.

${ }^{3}$ cf. Opzoomer, C.W. (1864-1867), De godsdienst, p. 92, 'Het zij mij vergund, hier van een onzer beroemdste tijdgenooten te spreken, wiens denkbeelden ook in dit punt (de wet van causaliteit) met de mijne in hevigen strijd zijn. Ik bedoel Whewell.'

${ }^{4} \mathrm{cf}$. Whewell, W. (1840), The philosophy of discovery, p. 166, This Idea (of Cause) (....) is not derived from experience, but has its origin in the mind itself.'

${ }^{5}$ cf. Opzoomer, C.W. $\left(1863 / 1867^{2}\right)$, Het wezen der kennis, p. 79.

' $c f$. Opzoomer, C.W. $\left(1851^{2}\right.$ ), op. cit. p. 63, '... van dit begrip oorzaak beweert men, dat het niet aan de ervaring ontleend is. Men grond die bewering daarop, dat de natuur ons wel opvolging, maar geen veroorzaking van feiten, wel het post, maar niet het propter vertoont.' Zie ook: Opzoomer, C.W. $\left(1863 / 1867^{2}\right)$, op. cit. p. 79, 'Die het laatste beweren beroepen zich terstond daarop, dat de ervaring ons niets meer dan de opvolging van verschijnselen, het ene na het andere, doet aanschouwen, maar nooit het bewerkt zijn van verschijnselen door elkander, het ene door het andere, kan leren kennen.' 
van bepaalde verschijnselen onder bepaalde omstandigheden. ${ }^{1}$ Net zoals de ervaring aangeeft dat bepaalde verschijnselen elkaar volgen, zo geeft de ervaring namelijk tevens aan dat een bepaald verschijnsel een bepaald ander verschijnsel veroorzaakt. De axioma's die men uit de notie 'oorzaak' kan afleiden zijn daarom ook gebaseerd op ervaring. Voorbeelden van zulke axioma's zijn: niets geschiedt zonder oorzaak, oorzaak en gevolg zijn evenredig, reactie is gelijk en tegenovergesteld aan actie. Omdat men denkt dat zulke axioma's algemeen gelden en noodzakelijkheid zijn, neemt men ten onrechte aan dat zij niet op ervaring berusten. Echter, voor elk van deze axioma's kan men aangeven dat zij beperkt geldig zijn of geleidelijk door ervaring zijn ontstaan, aldus Opzoomer. ${ }^{2}$

De betekenis van de notie 'aangeboren begrip' moet men overigens niet al te letterlijk opvatten. Een veelvoorkomende betekenis hiervan is dat de notie 'aangeboren begrip' verwijst naar een dispositie om door bepaalde stimuli of onder bepaalde omstandigheden een begrip te vormen. Deze notie verwijst doorgaans niet naar een begrip dat reeds kant-en-klaar in het denken besloten zou liggen. ${ }^{3}$ Whewell kan als cen representant van die dispositie-opvatting worden gezien, omdat hij van mening was dat sommige begrippen ontspringen aan de menselijke geest. Hiermee zegt hij dus niet dat bepaalde begrippen al kant-en-klaar in het denken liggen besloten.

Als Whewells "bewijs" juist zou zijn, dan zou men nooit over de notie 'causalitcit' of de notie 'oorzaak en gevolg' kunnen spreken, zo beloogt Opzoomer. Want, zo laat hij hierop volgen, als men alleen de successie van verschijnselen waarnecmt, op welkc gronden kan men dan de notie 'causaliteit' gebruiken? En, als men al gerechtvaardigd

${ }^{\prime}$ cf. Opzoomer, C.W. $\left(1851^{2}\right)$, op. cit. p. 63, '...de ervaring, die ons leert, dat het eene feit na het andere komt, leert ons evenzeer, dat hel door het andere ontstaat. (...) Niet de opvolging, maar de opvolging op ecn bepaalde wijze, met bepaalde omstandigheden er bij, brengt ons tot het begrip van oorzaak.'

${ }^{2}$ cf. Opzoomer, C.W. (18512), op. cit. p. 63-64, 'Men beroept zich verder op de axiomen, die uit het begrip van oorzaak voortvloeijen, en om haar algemeenheid en noodzakelijkheid niet op ervaring kunnen rusten (...) a. Niets bestaat, niets geschiedt zonder oorzak. Maar zoo weinig algemeen en noodzakelijk is deze stelling, dat zij voor de helft der verschijnselen, voor de geestelijke, door de helft des menschen de voorstanders der vrijheid, ontkend wordt. En dat dit beginsel op de wereld zelve, den kring der ervaring, wordt toegepast, om een oorzaak der wereld te leeren, rust alleen op analogie. b. Gevolgen zijn evenredig aan hunne oorzaken, en oorzaken worden gemeten door hare gevoglen. Maar men moet erkennen, dat er bij dit axioma een belangrijke beperking bestaat, en deze kan ons toch alleen door de ervaring geleerd zijn. (....). c. Reactie is gelijk en tegenovergesteld aan aclie. Maar het aprioristische bewijs, dat men er voor aanvoert en dat zich inderdaad geheel van de ervaring vrij houdt, mist alle waarde. De geschiedenis leert ons daarenboven bij Galilei en Newton, wannecr dit axioma in de wetenschap is opgenomen. d. Niets geschiedt zonder oorzaak, en deze kan niet in plaats en tijd liggen, die op zich zelven niets zijn. - Maar eerst langzaam is men tot deze waarheid gekomen, en zelfs thans nog ligt zij buiten het bereik van velen (......).'

${ }^{3}$ cf. Nelson, J.O. (1967), 'Innate ideas'. In: The encyclopedia of philosophy (P. Edwards, ed.), p. 196, '.... innatist sometimes mean by "idea" not an object of awareness but, rather, a dispostion of the mind or reason to form a deteterminate conception under certain conditions or slimuli.' 
zou zijn om de notie 'causaliteit' te gebruiken, op grond waarvan kan men dan beslissen om hetzij de notie 'causaliteit' of de notie 'successie' toe te passen? ${ }^{1} \mathrm{Met}$ andere woorden: de overgang van het waarnemen van successie naar het vaststellen van een causaal verband tussen verschijnselen kan men op grond van Whewells "bewijs" niet rechtvaardigen. En als men deze overgang al zou kunnen rechtvaardigen, quod non, dan is het onduidelijk wanneer men de notie 'causaliteit' moet gebruiken.

Alleen al door het stellen van zulke retorische vragen is Opzoomer er van overtuigd dat Whewells zogenaamde bewijs is weerlegd, waardoor hij zich genoodzaakt ziet om zélf aan te tonen dat de notie 'oorzaak' door ervaring ontstaat. Hiertoe formuleert Opzoomer twee argumentaties. De eerste argumentatie is te vinden in De weg der wetenschap; deze argumentatie handelt vooral over de uniformiteit in de natuur, de daarbij betrokken notie 'oorzaak', het causaliteitsbeginsel en het beginsel van de regelmatigheid van de naluur. De tweede argumentatie is te vinden in Het wezen der kennis. Hiermee wil Opzoomer aannemelijk maken dat zowel de twee noties 'oorzaak' en 'noodzakelijkheid' als het causaliteitsbeginsel zijn gebaseerd op de inwendige en uitwendige waarneming.

\section{Opzoomers eerste argumentatie}

In De weg der wetenschap (18512) vraagt Opzoomer zich allereerst af wat de betekenis is van de uitspraak: 'een bepaald verschijnsel is de oorzaak van een bepaald ander verschijnsel"? In Opzoomers termen: wat verstaan wij door een oorzaak ? ${ }^{2}$

Een bepaald verschijnsel kan men, zo beantwoordt Opzoomer deze betekenisvraag, alleen dan als de oorzaak van een bepaald ander verschijnsel opvatten als aan twee voorwaarden is voldaan. Het optreden van cen bepaald verschijnsel moet altijd worden gevolgd door het optreden van een bepaald ander verschijnsel. En ook: het optreden van het ene verschijnsel moet onder iedere omstandigheid na het optreden van een tweede verschijnsel volgen, tenzij het optreden van het tweede verschijnsel door tegenwerkende oorzaken wordt verhinderd. ${ }^{3}$ Opzoomer leidt hieruit af dat men met regt een onderscheid moet maken lussen twee verschijnselen die elkaar volgen (post) en verschijnselen waarbij het cerste de oorzaak van het tweede verschijnsel is (propter). De notie 'causaliteit' of het 'verband van oorzaak en gevolg' ontstant

${ }^{\prime}$ ct. Opzoomer, C.W. (1863/18672), op. cit. p. 79-80, 'Aan dit bewijs kan ik geen waarde hechten. Reeds daarom niet, omdat, indien, het juist mocht heten, het ons onmogelijk zou zijn, ooit van een verband van oorzaak en govolg te spreken. Wanneer toch de natuur ons enkel opvolging deed zien, wat zou ons het recht geven, om niet bij dat begrip te blijven, maar vooft te gaan tot dat van causaliteit? Of indien we dat recht bezaten, wat zou ons bevoegd maken om het nu eens wel, dan weer niet te gebruiken? Waarom zouden we soms niets meer dan opvolging beweren, soms daarentegen haar tot causaliteit te verheffen?'

${ }^{2}$ cf. Opzoomer, C.W. $\left(1851^{2}\right)$, op. cit. p. 104.

${ }^{3}$ cf. Opzoomer, C.W. $\left(1851^{2}\right)$, op. cit., p. 104, 'Wanneer een verschijnsel door een ander niet slechts altijd gevolgd wordt, maar de omstandigheden van dien aard zijn, dat het, onder welke omstandigheden ook gebragt, er altijd door zal moeten gevolgd worden, tenzij er tegenwerkende ourzaken bestaan, dan noemen wij het eerste verschijnsel de oorzaak van de laatste.' 
niet door het waarnemen van louter successie. Deze notie ontstaat als een bepaald verschijnsel onder specifieke omstandigheden wordt gevolgd door een bepaald ander verschijnsel. ${ }^{1}$ Met andere woorden: de vraag naar de betekenis van de notie 'oorzaak' beantwoordt Opzoomer in termen van het ontstaan van die notie. Ten slotte wijst hij er nog op dat het bij wetenschappelijk onderzoek niet gaat om het opsporen van metaphysische betrekkingen tussen oorzaak en gevolg; met zulke betrekkingen heeft Opzoomer het zoeken naar zogenaamde eindoorzaken op het oog. ${ }^{2}$

Op dit laatste punt sluit Opzoomer expliciet aan bij de opvattingen van Comte en Mill. ${ }^{3}$ Ook zij hadden de opvatting gehuldigd dat het zoeken naar eindoorzaken van verschijnselen geen nut heeft, omdat zulke oorzaken onkenbaar zijn. Het enige wat men kan doen is om door inductie de onveranderlijke wetten tussen de verschijnselen op te sporen. ${ }^{4}$

Op grond van inductie kan men algemene regels formuleren: natuurwetten, aldus Opzoomer. Zulke wetten vormen zekere kennis en gelden zonder uitzondering. ${ }^{5}$ Deze wetten onderstellen dat de natuur een regelmatig verloopt kent. Met dit laatste geeft hij en passant een antwoord op de geldigheidsvraag omtrent de rechtvaardiging van naluurwelten.

Eerst gaat men, aldus Opzoomer, op grond van het herhaald waarnemen van gelijksoortige verschijnselen van de verwachting uit dat de natuur volgens een uniform patroon verloopt. Echter, als men meer waarnemingen verzamelt, dan neemt men verschijnselen waar die niet volgens de verwachte uniforme regels optreden. Hieruit wordt vervolgens geconcludeerd dat de natuur geen eenvormigheid kent, maar

' êt. Opzoomer, C.W. $\left(1851^{2}\right.$ ), op. cit. p.104, 'Wij hebben dus regt, zooals ik vroeger recds aanwees, post en propter te onderscheiden. Niel de opvolging vãn verschijnselen, maar de opvolging onder zeer bepaalde omstandigheden, op zeeir bepaalde wijze, doet ons een verband van oorzak en gevolg aannemen.'

${ }^{2}$ cf. Opzoomer, C.W. $\left(1851^{2}\right)$, op. cit. p. 103, 'Immers mogen wij ook de oorzaken der dingen door haar opsporen, zoo wij ons maar wachten voor het aannemen van metaphysische betrekkingen tusschen de oorzaak en het gevolg, en ons met de kennis van natuurwetten tevreden stellen.'

${ }^{3}$ cf. Opzomer, C.W. $\left(1851^{2}\right)$, op. cit. p.104.

${ }^{4}$ ef. Comte, A. (1830), Cours de philosophie positive, p. 25-26, '.... le caractère fondamental de la philosophie positive est le regarder tous les phénomènes comme assujettis à des lois naturelles invariables, dont la découverte précise et la réduction au móndre nombre possible sont le but des tous nos efforts, en considérant comme absolument inaccessible, et vide de sens pour nous la recherche de ce qu'on appelle les causes, soil premières, soil finales.' Zie ook: Mill, J.S. (1843), op. cit., book III, chapter V, \& 2, p. 213, I premise, then, when in the course of this inquiry I speak of the cause of any phenomenon, I do not mean a cause which itself not a phenomenon; I make no research into the ultimate or ontological cause of anything.'

cf. Opzoomer, C.W. $\left(1851^{2}\right)$, op. cit. p. 105-107, 'Inductie is die verrigting van den geest, die ons uit de waarneming en vergelijking van bijzondere tot een algemeenen regel opvoert, en die ons somtijds slechts tol waarschijnlijkheid, maar dikwijls ook tot zekerheid brengl. Dit laatste is het geval wanneer zij ons met natuurwetten bekend maakt, die ons ten onregte door velen zijn voorgesteld, als altijd van uitzonderingen vergezeld.' 
alleen regelmatigheid. Het feit dat de natuur regelmatig is, is cen onbetwijfelthare wuarheid. Deze waarheid berust op het inzicht dat veranderingen alleen betrekking hebben op wat in tijd cn ruimte bestat. Alleen het veranderen van bepaalde omstandigheden resulteert in andere gevolgen. Dit inzicht verwoordt Opzoomer in het regelmatigheidsbeginsel: gelijke omstandigheden, gelijke gevolgen. Anders geformuleerd: als de omstandigheden gelijk blijven, dan blijven ook de gevolgen gelijk. Op dit beginsel stoelt inductie. ${ }^{.}$De redencring over de regelmatigheid van de natuur lcidt hem tot dezc geldigheidsvraag: als ik in één of meer gevallen ontdekt heb. dat het eene verschijnsel er oorzaak van het andere geweest is, met welk regt durf ik dan beweren, dat het te allen tijde er de oorzaak van zal zijn, het altijd zal voortbrengen??" Met andere woorden: waarop stoelt de gedachte dat op grond van het feit dat een bepaald verschijnsel in het verleden altijd door een bepaald ander verschijnsel is gevolgd, dit laatste verschijnsel ook in de toekomst zal volgen als het cerste is opgetreden.

Opzoomer verwijst op dit punt wederom expliciet naar Mill die van mening was dat men een duidelijk onderscheid moet maken tussen de regelmatigheid en de uniformiteit van de natuur. ${ }^{3}$ Het algemene principe van de regelmatigheid van de natuur is, aldus Mill, ontstaan door het waarnemen van vele specifieke gevallen waarbij verschijnselen samengaan. ${ }^{4} \mathrm{Nu}$ rijst echter voor Opzoomer de vraag: en waarop steunt dan mijn aannemen van zulk een regelmatigheid der natuur? ? $^{5}$ Volgens Opzoomer was Mill van mening dat het beginsel van de regelmatighcid van de natuur berust op inductic; dat wil zeggen, het waarnemen van vele specilicke gevallen. Als het regelmatigheidsbeginsel echter zelf ook door inductie tot stand komt, en als men onderstelt dat dit beginsel het fundament vormt van inductie, dan rechtvaardigt men

' ef. Opzoomer, C.W. $\left(1851^{2}\right)$, op. cit. p. 108, 'Hij (de mens) ontmoet afwijkingen en onderzoekt de gevallen, waarin zij voorkomen. Hij vindt daarin veranderde omstandigheden, en komt daardoor van de cenvormigheid tot de regelmatigheid der natuur, waardoor zij aan gelijke oorzaken gelijke gevolgen verbindt, d.i. waardoor verandering in gevolgen onmogelijk is zonder verandering in omstandigheden, in oorzaken. Verwacht de mensch in den loop der natuurversehijnselen eerst eenvormigheid, de afwijkingen, die hij waarncemt, dwingen hem weldra, haar met regelmatigheid der natuur te verruilen. Beschouwt hij die regelmatigheid van nabij, dan leert hij haar als een onbetwijfelbarc waarheid erkennen, die (....) eenvoudig daarop rust, dat (....) dus alleen verandering in hetgeen in tijd en ruimte bestaat, in oorzaken, in omstandigheden, de aanleiding kan zijn van verandering in gevolgen. In de erkenning dezer waarheid ligt de grond der geheele induclie.'

${ }^{2}$ cf. Opzoomer, C.W. $\left(1851^{2}\right)$, op. cit. p. 108.

${ }^{3}$ cf. Opzoomer, C.W. $\left(1851^{2}\right)$, op. cit. p. 108, 'Volgens Mill ontleen ik dat regt aan de regelmatigheid der natuur, die met cenvormigheid niet te verwarren is.'

${ }^{4}$ cf. Mill, J.S. (1843), op. cit., book III, chapter IV, \$ 1, p. 206, 'In the contemplation of that uniformity in the course of nature which is assumed in every instance from experience, one of the first observations that present themselves is, that the uniformity in question is not properly uniformity, but uniformities. The general regularity results from the co-existence of partial regularities.'

${ }^{5}$ cf. Opzoomer, C.W. $\left(1851^{2}\right)$, op. cit. p. 108. 
inductie met behulp van een andere inductie. ${ }^{1}$ Dit acht Opzoomer een cirkelredenering, waarmee geen antwoord wordt verkregen op de hierboven gestelde vraag: waarop steunt dan mijn aannemen van zulk een regelmatigheid der natuur? ${ }^{2}$

Opzoomer stelt daar een alternatief tegenover. Het beginsel van de regelmatigheid van de natuur is het concrete besef dat onder gelijksoortige omstandigheden gelijksoortige gevolgen optreden. Omgekeerd geldt daarom ook dat men bij andere gevolgen andere omstandigheden onderstelt. Dit besef berust daarmee op het causaliteitsbeginsel of de wet van oorzaak en gevolg: aan iedere verandering ligt een oorzaak ten grondslag. Zo'n oorzaak is altijd tijd-ruimtelijk bepaald. 'Tijd' en 'ruimte' zijn, los van ervaring, lege begrippen. Hieruit volgt dat men oorzaken moet zoeken in de verandering van bepaalde omstandigheden. Of, zoals Opzoomer deze beslissende, maar tamelijk ondoorzichtige redenering zelf verwoordt: hij (de mens) ziet in dat deze stelling onbetwijfelbaar is, als rustende op de volgende redenering: $a$. iedere verandering moet een oorzaak hebben; $b$. die oorzaak der verandering kan zijn of in tijd en plaats of in hetgeen in tijd en plaats is, d.i. in omstandigheden; c. tijd en plaats zijn op zich zelven niets; $d$. dus moet de oorzaak bestaan in veranderende omstandigheden. ${ }^{3}$ Echter, berust het causaliteitsbeginsel dan niet zelve alleen op inductie en wel per enumerationem simplicem? Opzoomers antwoord luidt ondubbelzinnig: ja. Bovendien acht hij dit antwoord niet problematisch. Het causaliteitsbeginsel is namelijk een generalisatie met deze vorm: 'voor alle gebeurtenissen in de natuur geldt dat zij een oorzaak hebben'. Dit beginsel ontstaat door het waarnemen van gevallen waarin telkens wordt geconstateerd dat aan het volgen van verschijnselen een oorzaak ten grondslag ligt. Hoewel het causaliteitsbeginsel geleidelijk door waarneming moet zijn ontstaan en daardoor a posteriori is, is het niet meer nodig dat dil beginsel door verdere waarneming wordt bevestigd. ${ }^{4}$

Ondanks zijn kritiek op Mill meent Opzoomer vreemd genoeg dat er in zijn eigen oplossing geen probleem schuilt. Het gaat Opzoomer namelijk niet om de vraag in hoeverre het causaliteitsbeginsel algemeen geldig is of in hoeverre dit beginsel beperkt geldig is. Hij acht het belangrijker om zich af te vragen op welken grond men, zoover die wet zich uitstrekt, bij gelijke oorzaken gelijke gevolgen mag verwachten. ${ }^{5} \mathrm{De}$ rechtvaardiging hiervan ligt besloten in zijn voorafgaande argumentatie voor de

' cf. Mill, J.S. (1843), op. cit., book III, chapter III, § 3, p. 205.

${ }^{2}$ cf. Opzoomer, C.W. $\left(1851^{2}\right)$, op. cit. p. 108 , 'En waarop steunt dan mijn aannemen van zulk een regelmatigheid der natuur? Op inductie, is het antwoord, en wel op inductie per enumerationem simplicem. Maar naar die voorstelling zou de inductic zelve op inductie berusten, (...). Het zijn die redenen, waarom wij de gehele beschouwing verwerpen.'

${ }^{3}$ ef. Opzoomer, C.W. $\left(1851^{2}\right)$, op. cit. p. 109.

“ cf. Opzoomer, C.W. $\left(1851^{2}\right)$, op. cit. p. 109-110, 'Maar steunt niet de eerste stelling der redenering (...), dat namelijk iedere verandering een oorzaak moet hebben, zelve alleen op inductie, en wel per enumerationem simplicem? Zonder twijfel; maar daarin is geen bezwaar. (...) Heeft men hier alzoo geen waarheid a priori, die op geen waarneming steunt? Geenszins; het beginsel heeft wel geen bevestiging door waarneming noodig, maar het is toch door waarneming geworden.'

${ }^{5}$ cf. Opzoomer, C.W. $\left(1851^{2}\right)$, op. cit. p. 109. 
onbetwijfelbaarheid van het beginsel van de regelmatigheid van de natuur. ${ }^{\text {' }}$

\section{Opzoomers tweede argumentatie}

Ongeveer twaalf jaar later formuleert Opzoomer in Het wezen der kennis $\left(1863 ; 1867^{2}\right)$ een tweede argumentatie, waarmee hij wil aantonen dat zowel de twee noties 'oorzaak' en 'noodzakelijkheid' als het causaliteitsbeginsel uit ervaring afgeleid kunnen worden. Opzoomers kernvraag luidt of dit begrip (oorzaak) empirisch van oorsprong is, dan wel of het de naam van aangeboren moet dragen ${ }^{2}$

Hij gaat er in zijn tweede argumentatie van uit dat de noties 'oorzaak' en 'noodzakelijkheid' of noodwendigheid van opeenvolging ontstaan door inwendige of uitwendige waarneming. Inwendige waarneming is het soort waarneming waarvan wij zelf het voorwerp zijn; dat wil zeggen, het ervaren van (eigen) psychische en lichamelijke processen. ${ }^{3}$ De uitwendige waarneming is het soort waarneming die op de dingen buiten ons is gericht; dat wil zeggen, het ervaren van objecten en gebeurtenissen. Opzoomer neemt in zijn twee argumentatie voor het vinden van een empirische basis van de noties 'oorzaak' en 'noodzakelijkheid' een specifieke inwendige waarneming als uitgangspunt: het willen van iets. ${ }^{4}$

Deze gedachtengang is overigens eerder ontwikkeld door F.P. Maine de Biran. Het is goed denkbaar dat Opzoomer zijn wilstheorie aan deze destijds invloedrijke Franse denker heeft ontleend. ${ }^{5}$ Opmerkelijk is echter dat Opzoomer met geen woord rept over Hume's (1748) belangrijke argumenten tegen het afleiden van de noties 'oorzaak' en 'noodzakelijkheid' uit wilservaringen. ${ }^{6}$ Evenmin gaat hij in op Hume's stelling dat de notie 'noodzakelijk verband' uiteindelijk berust op associatie en gewoonte.' Opzoomer poneert zonder meer de stelling dat de notie 'noodzakelijkheid'

${ }^{\prime}$ cf. Opzoomer, C.W. $\left(1851^{2}\right)$, op. cit. p. 109-110, 'Het is hier niet te doen, om de algemeenheid of beperktheid der wet van oorzaak en gevolg, maar om de vraag, op welken grond men, zoover die wet zich uitstrekt, bij gelijke oorzaken gelijke gevolgen mag verwachten. En dien grond geeft ons die redeneering, zonder dat er eenige nieuwe waarneming noodig is.'

${ }^{2}$ cf. Opzoomer, C.W. (1863/18672), op. cit. p. 79.

${ }^{3}$ cf. Opzoomer, C.W. $\left(1863 / 1867^{2}\right)$, op. cit. p. 80, 'Het valt niet moeilijk, het ontstaan van het begrip van oorzaak uit de ervaring alleen aan te wijzen. Er is tweecerlei weg waarop wij het vormen, die der inwendige waarneming, waarvan wijzelf het voorwerp zijn, en die der uitwendige waarneming, die op de dingen buiten ons gericht zijn.' Zie ook: Opzoomer, C.W. (1871), op. cit. p. 22.

cf. Opzoomer, C.W. (1863/18672), op. cit. p. 80, 'Aan een verschijnsel, hetzij in ons, helzij buiten ons, gaat een verschijnsel in onszelf, een wilsbepaling vooraf.'

"cf. Maine de Biran, F.P. (1805), Mémoire sur la décomposition de la pensée, p. 216. Het is ook mogelijk dat Opzoomers wilstheorie is ontleend aan zijn ambstvoorganger Schröder; zie hiervoor, Sassen, F.L.R. (1954), p. 29.

${ }^{6} \mathrm{cf}$. Hume, D. (1748), An enquiry concerning human understanding, section VII, part I, p. 53.

cf. Hume, D. (1739/1740), op. cit., book I, section XIV, p. 165, The idea of necessity arises from some impression. There is no impression convey'd by our senses, which can give rise to that idea. It must therefore, be deriv'd from some internal impression, or impression of 
ontspringt aan het zelfbewustzijn: het besef dat een wilsbepaling gevolgd wordt door een bepaalde handeling. In Het wezen der kennis werkt Opzoomer deze gedachte als volgt uit.

Causale relaties verschillen van het louter toevallig volgen van verschijnselen doordat zulke relaties een noodzakelijk karakter hebben. In het als noodwendig ervaren karakter daarvan schuilt dus het oorzakelijke element van causale relaties. Daarom is het verkeerd te menen dat uit het herhaalde waarnemen van het volgen van verschijnselen (constante successie) de notie 'causaliteit' ontstaat. Constante successie kan alleen leiden tot een vermoeden, dat een bepaalde opeenvolging van een reeks verschijnselen causaal samenhangt. Constante successie speelt dus alleen een heuristische rol om causale samenhangen op te sporen. ${ }^{1}$

Opzoomers opvatting ten aanzien van successie wijkt overigens sterk af van de rol die bijvoorbeeld Hume had toegekend aan successie. Hume zag hierin één van de essentiële kenmerken van causale relaties, naast de kenmerken van de tijdruimtelijke nabijheid en het constante samengaan van verschijnselen. ${ }^{2}$

De notie 'noodzakelijkheid' of 'noodwendigheid van opeenvolging' kan men afleiden, zo betoogt Opzoomer, uit de inwendige waarneming van het willen van iets. Deze notie ontstaat door het waarnemen van een wilsbepaling (zeg: een A) en het daarop volgend optreden van een handeling (zeg: een $B$ ). Het volgen van een A en een B kan op twee manieren worden gekarakteriseerd. Hetzij: een B treedt toevallig op nadat een A is opgetreden. In dit geval is er alleen sprake van het volgen van een $B$ op een $A$. Het optreden van een B is dan niet afhankelijk van een wilsbepaling. Of: het is ook mogelijk dat men meer dan opvolging waarneemt; het volgen van een $\mathrm{B}$ na een $\mathrm{A}$ is dan van een geheel bijzondere aard. Een $\mathrm{B}$ treedt in dat geval noodzakelijk op nadat een $\mathrm{A}$ is opgetreden.

Het criterium om toevallige van noodzakelijke verbanden van elkaar te

reflexion. There is no internal impression, which has any relation to the present business, but that propensity, which custom produces, to pass from an object to the idea of its usual attendant. This therefore is the essence of necessity.'

${ }^{\prime}$ ef. Opzoomer, C.W. (1863/18672), op. cit. p. 80, 'In die noodwendigheid der opvolging, en in haar alleen, ligt het eigenaardige van het causaliteitsbegrip. De noodwendigheid der opvolging, het niet toevallige maar noodwendige post, dat juist, en dat alleen, is het propter, het per, de causa. Ten onrechte heeft men gewoonlijk datgene, wat ons de successie tot causaliteit doet verheffen, in het constante gezocht. Niet het constante, maar alleen het noodwendige der opvolging makk het causaalverband uit. Het constante der opvolging kan nooit meer dan het middel zijn, dat mij tot het vermoeden, en misschien tot het vinden, van een noodwendig verband brengt.'

${ }^{2}$ cf. Hume, D. (1739/1740), op. cit., book I, part III, section II \& III.

${ }^{3}$ ct. Opzoomer, C.W. $\left(1863 / 1867^{2}\right)$, op. cit. p. 80, 'Hier is dus een opvolging. Zij kan van die aard zijn, dat ik ook niet meer dan opvolging waarneem. Het tweede verschijnsel heeft toevallig, niet noodzakelijk plaats, niet afhankelijk van mijn wilsbepaling, niet door maar enkel na haar. Soms daarentegen is die opvolging van een geheel bijzondere aard, zoodat ik niet van opvolging alleen blijf spreken, maar de causaliteit aanneem, een noodwendig plaatshebben van het tweede verschijnsel na de wilsbepaling, en dus een plaatshebben ervan door de wilsbepaling.' 
underscheiden is dat de waarneming van het willen van icts leidt tot het besef dat een bepaalde handeling door mij wordt veroorzaakt. Hierin ligt ook het besef van noodzakelijkheid besloten. Dit besef, dat stoelt op de inwendige waarneming, is daarom één van de belangrijkste bronnen voor het ontstaan van de nolie 'oorzaak'. Dit neemt echter nict weg dat men dic notic ook kan afleiden uit de uitwendige waarneming. ${ }^{1}$

In het resterende deel van deze paragraaf zal blijken dat Opzoomer eerst de stelling motiveerl dat de notie 'oorzaak' uil de inwendige waarneming kan worden afgeleid. Daama gaat hij in op de manier waarop het causaliteitsbeginscl en de notie 'causaliteit' uit de uitwendige waarneming zijn ontstaan.

\section{Afleiding van de notie 'oorzaak' uit de inwendige waarneming}

$\mathrm{Bij}$ het afleiden van de notie 'oorzatak' uit inwendige waarnemingen moet een onderscheid worden gemaakt tussen middellijke en onmiddellijke oorzaken. Bijvoorbeeld: iemand wil een bepaald voorwerp verzellen en met dit doel voor ogen pakt hij dat voorwerp vast. De wil om een voorwerp te verplaatsen kan men als oorzaak voor een verandering zien; in dit voorbeeld is dat dus het verzetten van cen voonwerp. Zo'n wilsbepaling hoeft echter niet onmiddellijk samen te hangen met het waargenomen gevolg hiervan. Het proces van het willen van iets en vervolgens het waarnemen van een verandering die het resultaat is van wat men wil, moet men opvatten als een keten van nict-onmiddellijk waarneembare of in het geheel nict waar te nemen verschijnselen. Het willen van iets (zeg: cen A) leidt tot een B. Een B is ecn lichamelijke verandering. Dit kan vervolgens leiden tot wat met een A wordt beoogd: handeling C. Schematisch weergegeven onderstelt Opzoomer zo een keten van onmiddellijke oorzaken: als cen $\mathrm{A}$ leidt tot cen $\mathrm{B}$, en een $\mathrm{B}$ leidt tot een $\mathrm{C}$, dan leidt een $\mathrm{A}$ via een $B$ tot een $C$. Zo'n aaneenschakcling kan ad libitum worden uilgebreid. Een $B$ is een middellijke of tussenliggende oorzaak, terwijl een $\mathrm{A}$ als de onmiddellijke oorzaak van een B moet worden gezien. Het willen van iets dient men als de onmiddellijke 'oorzaak' in eigenlijke zin op te vatten. Alleen hieraan kan men de eigenschap van noodzakelijkheid toeschrijven. Echter, naarmate men meer tussenliggende oorzaken onderkent, is het waarschijnlijker dat het beoogde gevolg niet zal optreden door het inwerken van tegenwerkende oorzaken. ${ }^{2}$

${ }^{1}$ cf. Opzoomer, C.W. $\left(1863 / 1867^{2}\right)$, op. cit. p. 80, 'Mijn zelfbewustzijn zegl mij hier, dal het feit door mij geschiedt, dat ik niet enkel een antecedent, dat ik een oorzaak ben. Maar al datzelfde, dat begrip van causaliteit tegenover bloote successic, (.....). kin ik vok uit de waarneming der buitenwereld verkrijgen. Ook daar spreek ik van een causaalverband zoo dikwijls ik mij verplicht zie, de opvolging van twee verschijnsclen nict voor toevallig, al ware hel dan ook constant, maar voor noodwendig te houden.'

${ }^{2}$ cf. Opzoomer, C.W. (1863/1867²), op. cit., p. 80-81, 'Mijn wil is de onrzaak van een feit buiten nij, maar slechts middellijke, door middel van mijn handen. (.....) Wanneer ik nu cen der gevallen, waarin ik causaalverband moet annemen, nauwkeuriger heschouw, dan kom ik tot inzicht in het onderscheid tussen onmiddellijke en middellijke oorzaken. (...) Dring ik nu in dat onderscheid dieper door, dan zie ik, dat eigenlijk alleen de onmiddellijke oorzaak in de ware en volle zin des woords de naam van oorzaak verdient, daar bij haar alleen ten volle 
Het is zeer aannemelijk dat Opzoomer met de notie 'tegenwerkende oorzaken' Mills curieuze notie 'preventing or counteracting causes' op het oog heeft.' Wat Opzoomer er precies mee bedoelt, werkt hij echter niet uit.

\section{Afleiding van het causaliteitsbeginsel uit de uitwendige waarneming} Opzoomers antwoord op de vraag of dit begrip (oorzaak) empirisch van oorsprong is, dan wel of het de naam van aangeboren moet dragen is duidelijk geworden: de notie 'oorzaak' is afgeleid uit ervaring. Dit antwoord geldt ook voor het ontstaan van het causaliteitsbeginsel of de wet van causaliteit, dat is de groote wet, dat een verschijnsel niet kan beginnen te ontstaan, zonder een oorzaak van zijn ontstaan te hebben. ${ }^{2}$ Opzoomer wil weten hoe wij alleen door ervaring tot kennis van dat groote beginsel van causaliteit zijn gekomen $?^{3}$ Zijn antwoord zal moeten zijn dat het causaliteitsbeginsel niet in het denken ligt besloten, maar door ervaring is ontstaan.

Lange tijd was men zich niet bewust van het causaliteitsbeginsel, aldus Opzoomer. In een eerder stadium van de menselijke geschiedenis, in de kindsheidsperiode van ons geslacht, ging men er van uit dat verschijnselen in de natuur spontaan, dus zonder oorzaak, gebeuren; of, dat gebeurtenissen in de natuur louter op toeval berustten. Uiteraard kan dit niet in overeenstemming worden gebracht met het causaliteitsbeginsel dat inhoudt dat toeval niet bestaat. Dit beginsel vormt het basisprincipe van de wetenschap, en het is verweven met iedere specifieke wetenschappelijke uitspraak. Dit laatste betekent echter niet dat het besef van hel causaliteitsbeginsel aan alle specifieke uitspraken of bijzondere stellingen vooraf zou zijn gegaan, en dat het beginsel dus a priori zou zijn. Dit is de groote fout van het idealisme, de tegenpartij. Neen, iedere specifieke wetenschappelijke uitspraak bevestigt het causaliteitsbeginsel opnieuw, waardoor het geleidelijk aan onbetwijfelbaar is geworden. Als men een natuurwet ontdekt, bevestigt dit wederom de overtuiging van de regelmatigheid van de natuur. ${ }^{4}$ Met andere woorden: het concrete besef dat gelijke omslandigheden

noodwendigheid bestaat. (...) Immers de mogelijkheid van het uitblijven van een gevolg door de kracht van tegenwerkende oorzaken wordt te grooter, naarmate dat gevolg verder van de eersle oorzaak verwijderd is.'

' cf. Mill, J.S. (1843), op. cil., book III, chapter V, § 3, p. 217-218.

${ }^{2}$ cf. Opzoomer, C.W. $\left(1863 / 1867^{2}\right)$, op. cit. p. 81.

${ }^{3}$ cf. Opzoomer, C.W. $\left(1863 / 1867^{2}\right)$, op. cit. p. 81.

${ }^{4}$ cf. Opzoomer, C.W. (1863/18672), op. cit. p. 82, 'Dic aanwijzing zal het best doen zien, dat dit beginsel geen oorspronkelijk deel onzer kennis is, hetwelk aan al onze begrippen over de buitenwereld, zelfs aan de erkenting van haar bestaan, zou voorafgaan. Van het bestaan ener wereld om ons heen zijn wij reeds jaren lang overtuigd, eer wij, al ware het maar in ruwe woorden, dat beginsel kunnen uitspreken. (...) Lang blijft men ook in de natuur van een vanzelf beginnen, vooral van een vanzelf ophouden, en nog meer van een toeval spreken, die niet minder onverenigbaar is met dat beginsel. (...) Het algemene beginsel (van causaliteit), dat in het systeem ten grondslag is der bijzondere stellingen, en waarop men zich, is het eens goed erkend, ook beroepen zal om nieuwe bijzondere stellingen te vinden of te staven, gaat geenszins aan de erkenning van alle bijzondere stellingen vooraf, maar dringt met die stellingen zelf langzaam meer en meer door, met iedere nieuwe zelf weer in vastheid tocne- 
gelijke gevolgen hebben, is door ervaring ontstaan en wordt door nieuwe ervaringen van regelmatigheid telkens bevestigd.

Als deze visie op de ontwikkeling van het menselijk denken wordt geaccepteerd, dan moet ook worden geconcludeerd, zo betoogt Opzoomer, dat het besef van het causaliteitsbeginsel geleidelijk is ontstaan. Bij iedere nieuwe ontdekking van een natuurwet wordt dit besef sterker. ${ }^{1}$

In alle gevallen neemt men namelijk waar dat aan een bepaald verschijnsel een bepaald ander verschijnsel vooraf gaat. Deze ervaring is zo door en door bevestigd dat het tegendeel daarvan ondenkbaar is geworden. Bovendien scherpt de ontwikkeling van kennis de blik dat ieder nieuw verschijnsel altijd inniger is verbonden met een bepaald ander verschijnsel dat daar aan vooraf gaat. Op grond van het waarnemen van dat innige verband concludeert men dat beide verschijnselen noodzakelijk, en daarom causaal, samenhangen. ${ }^{2}$

Opzoomer had de notie 'causaliteit' al gedefinieerd als onvoorwaardelijke opeenvolging. Op grond van die definitie was het dus gerechtvaardigd om in zulke gevallen over een causale relatie te spreken, en daarom ook van een noodwendigheid van opvolging. Een nieuw verschijnsel wordt niet alleen vooraf gegaan door andere verschijnselen (antecedenten), maar sommige van die antecendenten moet men opvatten als oorzaak voor het optreden van dat nieuwe verschijnsel. Als een verschijnsel op die manier een oorzaak is voor een ander verschijnsel, dan zijn beide noodzakelijk met elkaar verbonden. ${ }^{3}$ Dit $n u$, en niets anders is het grote beginsel, de wet van causaliteit.

Opzoomers "historiserende" benadering van het ontstaan van het causaliteitsbeginsel sluit overigens aan bij een zeer sterke tendens in het denken van de $19 \mathrm{de}$ eeuw. Uiteenlopende 19de eeuwse filosofen als Hegel, Marx, Comte en Mach trachtten allerlei diepgewortelde denkbeelden te verklaren door het ontstaan daarvan te zoeken in de geschiedenis van het menselijk denken [Mandelbaum, 1971].

mend. Ook tegenwoordig nog bevestigt en versterkt ons het vinden van elke natuurwet in onze overtuiging van de regelnatigheid van de natuur.'

'cf. Opzoomer, C.W. (1863/1867'), op. cit. p. 82, 'Is deze voorstelling juist, komen we cerst allengs tot het aannemen van het beginsel der causaliteit, en worden wij er nog van dag tol dag in versterkl, dan kan het in niets anders dan in de ervaring gegrond zijn,....'

2 cf. Opzoomer, C.W. $\left(1863 / 1867^{2}\right)$, op. cit. p. 82-83, Zo dikwijls er een verschiinsel platsheeft en er dus iets nieuws ontstaat, nemen wij waar, dat er iets aan voorafgaat. Het tegendeel is zelfs (....) ondenkbar. Een waarneming, die niet een uilzondering heeft, leert ons dus overal opvolging kennen. En hoe verder wij nu in onze naluurkennis vorderen, des te meer zien wij telkens, dat het nieuwe verschijnsel met een of meer der antecedenten in een inniger verband is dan met al de andere, een verband zo nauw dat wij van noodwendigheid van opvolging, en dus van causaliteit, durven spreken.'

${ }^{3}$ cf. Opzoomer, C.W. $\left(1863 / 1867^{2}\right)$, op. cit. p. 83, '.... een nieuw verschijnsel (wordt) niet alleen door een oneindig aantal antecendenten vooralgegaan, maar (heeft) tevens in een of meer dier antecendenten zijn oorzaak, zodat het daarmee noodwendig, met al die andere slechts toevallig verbonden is. Dit nu, en niets anders, is het grote beginsel, de wet, van causaliteit: 
Samengevat komt Opzoomers argumentatie in hoofdlijnen neer op het volgende. Het uitgangspunt wordt gevormd door de stelling dat alle begrippen via ervaring ontstaan. Opzoomers argumentatiestrategie kent vervolgens een negatief en positief deel. Het negatieve deel is er op gericht om aannemelijk te maken dat de leer der aangeboren begrippen tot inconsequenties leidt. Met het positieve deel beoogt hij te bewijzen dat de twee noties 'oorzaak' en 'noodzakelijkheid' en ook het causaliteitsbeginsel door ervaring ontstaan, waartoe hij twee argumentaties formuleert.

In de eerste argumentatie sluit Opzoomer aan bij Mills definitie van de notie 'oorzaak' als onvoorwaardelijke opeenvolging. Bovendien wijst hij er met Mill en Comte op dat het zoeken naar eindoorzaken zinloos is. Immers, hiermee zou men buiten de grenzen van de ervaring treden. Bovendien strookt dit niet met Opzoomers uitgangspunt dat alle kennis ontstaat via ervaring. Verder onderschrijft Opzoomer Mills standpunt dat aan de natuur geen uniform patroon kan worden toegeschreven. Uit de ervaring blijkt namelijk dat men alleen kan spreken over het waarnemen van regelmatigheid van het volgen van verschijnselen. Dit wordt uitgedrukt in het regelmatigheidsprincipe: onder gelijksoortige omstandigheden kunnen gelijksoortige gevolgen worden verwacht.

Als het gaat om de rechtvaardiging van dit principe bewandelen Mill en Opzoomer echter verschillende wegen. De kernvraag is waarop inductieve uitspraken berusten: op grond van het feit dat een bepaald verschijnsel in het verleden altijd door een bepaald ander verschijnsel is gevolgd, zal dit laatste verschijnsel ook in de toekomst volgen als het cerste is opgetreden. Mill verdedigde de stelling dat zulke uitspraken berusten op het regelmatigheidsbeginsel. Bovendien was hij van oordeel dat dit beginsel ook zelf weer op een reeks van enkelvoudige waarnemingen was gefundeerd. Hiermee rechtvaardigde hij inductieve uitspraken door het gebruik maken van inductie. Opzoomer concludeert dat dit een circulaire rechtvaardiging is.

Opzoomer meent aan deze circulariteit te ontkomen door een andere weg te bewandelen. Hij gaat er van uit dat het regelmatigheidsbeginsel, of het besef dat bij gelijke omstandigheden gelijke gevolgen optreden, uiteindelijk berust op het abstracte causaliteitsbeginsel. Dit beginsel luidt: aan iedere verandering ligt een oorzaak ten grondslag. Dit roept voor hem de vraag waarop men dit laatste beginsel baseert. Hij verdedigt vervolgens de stelling dat het causaliteitsbeginsel ontstaat door het waarnemen van gevallen waarin men steeds constateert dat aan het volgen van verschijnsclen cen oorzaak ten grondslag ligt. Ook Opzoomer ontkomt hier niet aan een cirkelredenering. Immers, net als Mill het regelmatigheidsbeginsel liet berusten op een recks van enkelvoudige walarnemingen, latat Opzoomer het causaliteitsbeginsel berusten op een inductio per enumerationem simplicem.

Opzoomers tweede argumentatie bestaat uit twee delen. Ten cerste wil hij de noties 'oorzaak' en 'noodzakelijkheid' afleiden uit de inwendige waarneming van het willen van iets. Ten tweede construcert hij een historisch gerichte verklaring die er 
op is gericht het causaliteitsbeginsel en de notie 'causaliteit' uit de uitwendige waarneming af te leiden.

Het uitgangspunt van het eerste deel van Opzoomers tweede argumentatie is dat men wilsbepalingen waarneemt. De wil om iets te doen kan als oorzaak voor een verandering worden gezien. Hierbij wordt een onderscheid gemaakt tussen onmiddellijke en middellijke oorzaken. Het besef van iets te willen dient als de onmiddellijke 'oorzaak' in eigenlijke zin te worden begrepen; alleen hieraan kan men de eigenschap van noodzakelijkheid toeschrijven.

Het uitgangspunt voor het tweede deel van zijn tweede argumentatie is dat het besef van het causaliteitsbeginsel in de loop van de menselijke geschiedenis is ontstaan. Door het geleidelijk accumuleren van ervaring ontstond de overtuiging dat iedere gebeurtenis een oorzaak heeft. Deze overtuiging werd door verdere observaties steeds bevestigd. Dit leidde geleidelijk tot de onbetwijfelbare overtuiging dat alle gebeurtenissen inderdaad een oorzaak hebben.

Het valt op dat Opzoomers argumentaties zich goed lenen voor een probleemgerichte behandeling. Immers, Opzoomer onderscheidt heel duidelijk drie soorten kwesties: betekenis-, geldigheids- en ontstaansvragen. Hierbij kan men aantekenen dat hij consequent betekenis- en geldigheidsvragen in termen van ontstaansvragen wil beantwoorden. Dit leidt op zijn minst tot verwarring, hetgeen uit de navolgende twee opmerkingen naar voren komt.

Opzoomers eerste argumentatie $\left(1851^{2}\right)$ is er op gericht om Mills argumenten ten aanzien van het rechtvaardigen van generalisaties te weerleggen. Hierbij staat het besef van de regelmatigheid van de natuur, dat via inductie ontstaat, centraal. Met dit besef wordt uitgedrukt dat er wetmatige verbanden zijn tussen twee natuurverschijnselen (zeg: een A en een B). Algemeen geformuleerd luidt dit: 'voor alle gevallen geldt: als een A optreedt zal ook een B optreden'. Dit wetmatige verband onderstelt het causaliteitsbeginsel. Ook dit beginsel ontstaat via het waarnemen van singuliere gevallen, en dus via inductie. Opzoomers antwoord op de vraag waarom men er van overtuigd is dat een $B$ ook in de toekomst zal volgen na een $A$, als een A in het verleden altijd door een B is gevolgd, is daarom even circulair als Mills oplossing.

Opzoomers verklaring $\left(1863 ; 1867^{2}\right)$ omtrent het ontstaan van het causaliteitsbeginsel door een beroep te doen op de geschiedenis van het menselijk denken is een speculatieve hypothese. Opzoomer laat na om deze hypothese aan de hand van historisch feitenmateriaal te onderbouwen; dit strookt niet met een belangrijk uitgangspunt van zijn empirisme, namelijk dat ervaring en feiten de grondslag moeten vormen van kennis. Men kan opmerken dat Opzoomer door deze hypothese zonder meer te poneren zijn positie nodeloos verzwakt.

In de volgende paragraaf wordt ingegaan op de kritiek van Spruyt bij de twee argumentaties van Opzoomer. 
De jaren zestig waren de hooglijdagen van Opzoomers empirisme. Opzoomers invloed werd versterkt door de henoeming van zijn lecrling Van der Wijck tot hoogleraar in de filosofic aan de Rijksuniversiteit Groningen in 1863. Vooral in deze periode trad deze laatste op als een trouwe secondant en verdediger van Opzoomers empirisme. Aan deze intcllectuele hegemonie kwam echter aan het begin van de jaren zeventig een einde door de kritick van een toen nog relatieve buitenstaander in lilosulische kringen: Cornelis Bellaar Spruyt. ${ }^{1}$

Spruyt studeerde, werkte en promoveerde in het bastion van Opzoomers cmpirisme: Utrecht. Het is daarom niet onwaarschijnlijk dat Spruyt Opzoomers denkbeelden uit de ecrsle hand had: via het volgen van zijn colleges of door het bijwonen van Opzoomers vele openbare lezingen. En misschien hebben zij zelf tijdens één van deze gelegenheden al de degens over het causaliteitsvraagstuk gekruist.

Hoc dit ook zij, met het artikel Aangeboren waarnemingsvormen (1871a) opent Spruyt zijn publieke aanval op Opzoomers causaliteitsopvatting. In de inleiding van dat artikel constaleert hij clat de verwerping van metafysica één van de belangrijkste

' Ook in de jaren vijftig en zestig kan men al kritiek beluisteren op Opzoomers denkbeelden. Tussen de theoloog J.H. Scholten (1811-1885) en Opzoomer ontstond er bijvoorbeel een verhitte discussie over de "moderne richting" in de theologie. Zie hiervoor: Roessingh, K.H. (1914). Ook Land bekritiseerde Opzoomer in de artikelen 'Een wijsgeerig programma' (in: Godgeleerde bijdragen, 1863) en 'Dienstbare wijsbegeerte' (in: De gids, 1864). Hierin leverde Land kritiek op Opzoomers "utilistische" benadering van wetenschap en wijsbegeerte. Daarnaast werd diens empirisme onder vuur genomen door de theoloog W. Scheffer (18231904). In Scheffers artikel 'Een nieuw boek over logika' (in: Godgeleerde bijdragen, 1864) recenseerde hij Opzoomers Het wezen der kennis (1863). Het causaliteitsvraagstuk kwam in dic recensie overigens niet aan de orde. Ook F.A. Hartsen (1838-1877) bekritiseerde Opzoomer in de drie geschriften Het empirisme van Opzoomer door zichzelven geoordeeld (1865a), Ziel voor de waarneming (1865b) en in Schema van den wijsbegeerte: proeve van antwoord op de vraag 'welke zijn de kenbronnen van de waarheid' (1865c). Hartsens opvattingen werden [Sassen, 1959] in Nederland niet serieus genomen. Opzoomer is nooit ingegaan op diens opvattingen. Het causaliteitsvraagstuk vormt bovendien slechts een marginaal deel van Hartsens gedachtengoed. Bovendien bekritiseerde de theoloog A.J. Sandberg (1841-1878) Opzoomer in de twee brochures Het stelsel der ervaring van mr. C.W. Opzoomer aan de werkelijkheid getoetst (1865a) en Is "De weg der wetenschap" van mr. C.W. Opzoomer de weg tot de wetenschap? (1865b). Sandberg betwijfelt of Opzoomer [Sassen, 1959] wel over voldoende kennis van de natuurwctenschap beschikt om over de methodologie daarvan gezaghebbende uitspraken kan doen. Ook in de jaren zeventig, na Spruyts kritiek, werden Opzoomers opvattingen door enkelen van uit scholastieke hoek bekritiseerd, zoals door de paters jezuïeten F. Becker (1838-1884) in het artikel 'Oude oplossing van een oud vraagstuk' (in: De wachter, 1873), en H. Te Braake (1829-1887) in het artikel 'De wijsbegeerte der ervaring op de leerstoelen der wijsbegeerte te Utrecht en te Groningen' (in: Studiën, 1876). Ook op de kritiek van beide paters heeft Opzoomer niet gereageerd. 
tendensen in het 19 de eeuwse filosofische en wetenschappelijke denken is. 'Deze ontwikkeling begon met Lockes argumenten tegen het bestaan van aangeboren begrippen en culmineerl in de opvattingen van empirische wijsgeren zoals Mill, Comte en ook Opzoomer zelf. ${ }^{2}$ Met veel (natuur)wetenschappelijke onderzoekers waren dezen namelijk van mening dat wetenschappelijke verklaringen niets anders zijn dan het beschrijven van wetmatige verbanden tussen verschijnselen. ${ }^{3}$

Spruyt wil met zijn kritiek op Opzoomer aannemelijk maken dat Opzoomers twee argumentaties die moeten aantonen dat zowel de twee noties 'oorzaak' en 'noodzakelijkheid' als het causaliteitsbeginsel op ervaring berusten circulair zijn of tot onacceptabele conclusies leiden. De kern van zijn kritiek is dat men de notie 'causaliteit' als een aangeboren waarnemingsvorm moet zien, en niet als een empirisch begrip. Waarnemingsvormen als 'ruimte', 'tijd' en 'causaliteit' maken ervaring mogelijk. Zij berusten daarom niet zelf op ervaring, en worden intü̈tief tocgepast om zintuiglijke gewaarwordingen te ordenen. ${ }^{4}$

Zulke vormen worden overigens door Spruyt zonder meer gepostuleerd. Hij acht het niet nodig om te bewijzen dat zij a priori zijn, hetgeen in schril contrast staat met de moeite die Kant zich in de Kritik der reinen Vernunft getroost om de aprioriteit van bepaalde begrippen aan te tonen.

\section{Hume's geldigheidsvraag}

De vraag die Spruyt het meest principieel acht is Hume's geldigheidsvraag: welke is de redeneering, die ons machtigt algemeenheid toe te schrijven aan een regel, dien wij slechts in weinige gevallen hebben zien opvolgen ${ }^{5}$ Met andere woorden: hoe kan men rechtvaardigen dat men op grond van eerdere waarnemingen van het optreden van een bepaald verschijnsel na het optreden van een bepaald ander verschijnsel verwacht dat het ene verschijnsel in toekomstige gevallen altijd zal volgen na het optreden van dat andere verschijnsel. Spruyt acht dit de kern van het causaliteitsvraagstuk dat door Hume werd geformuleerd. ${ }^{6}$

' cf. Spruyt, C.B. (1871a), 'Aangeboren waarnemingsvormen'. In: De gids, p. 6, 'Zoo mogelijk zijn zij (wetenschappelijk onderzoekers) nog levendiger dan de empirische wijsgeeren zelven overtuigd vañ de onhoudbaarheid, de ijdelheid, de dwaasheid van alle metaphysiea. In die svertuiging ligt het onderscheidend kenmerk van onze eeuw.'

${ }^{2}$ cf. Spruyt, C.B. (1871a), op. cit. p. 8 ff.

${ }^{3}$ cí. Spruyt, C.B. (1871a), op. cit. p.2, '...(ik) herken den empirischen wijsgeer aan zijn verwerping van iedere verklaring, die iets meer is dan eene wet der verschijnselen.'

${ }^{4}$ cf. Spruyt, C.B. (1871a), op. cit. p. 12, '(Kant) verklaart zeer duidelijk, dat onze voorstelling der ruimte in het geheel geen begrip is; mat hij beschouwt de ruimte als een aangeboren watamemingsvorm, als vorm der zinnelijkheid. Evenzoo zijn ook de categorieën ons niet als abstracte begrippen aangeboren, maar zij zijn, volgens Kant, de vormen, waarin wij onze zinnelijke gewaarwordingen, zoo uitwendige als innerlijke, intuitief opvatten.

cf. Spruyt, C.B. (1871a), op. cit. p. 36-37.

"cf. Hume, D. (1739/1740), op. cit., book I, part III, section III, p. 82, 'Why we conclude, that such particular causes must necessarily have such particular effects, and why we form an inference from one to another?' 
Hume had geconcludeerd, zo betoogt Spruyt, dat het in beginsel onmogelijk is om de argumentatie aan te geven op grond waarvan men kan rechtvaardigen dat op basis van een beperkt aantal waarnemingen dat een bepaald verschijnsel blijkt te volgen op een bepaald ander verschijnsel, de algemene uitspraak wordt gedaan dat dit altijd zo zal gebeuren. Zulke uitspraken berusten uitsluitend op gewoonte. ${ }^{1} \mathrm{De}$ geldigheid van uitspraken waarin een causaal verband wordt uitgedrukt, is daarom beperkt tot eerdere waarnemingen van relaties tussen verschijnselen. In Hume's termen betekende de notie 'oorzaak', aldus Spruyl, niets anders dan dat een bepaald verschijnsel in alle gevallen wordt gevolgd door een bepaald ander verschijnsel. De notie 'noodzakelijkheid' kwam voor Hume neer op herhaalde waarneming en de daardoor gevormde gewoonte op grond waarvan men kan voorspellen dat een bepaald verschijnsel in toekomstige gevallen zal volgen op een bepaald ander verschijnsel. De notie 'gevolg' had voor Hume, ten slotte, de betekenis dat herhaaldelijk is waargenomen dat een bepaald verschijnsel regelmatig en zonder uitzondering volgt op een bepaald ander verschijnsel. Hierdoor ontstaat geleidelijk de opvatting dat het ene verschijnsel de oorzaak is van het andere verschijnsel: het gevolg. ${ }^{2}$

Spruyt acht Hume's vraag naar de geldigheid van causale uitspraken volkomen terecht. Want, zo vraagt Spruyt in navolging van Hume zich af, hoe is het mogelijk dat onze geest zonder eenige redeneering uit de ervaring iets geheel anders afleidt dan de onvervalsche inhoud van die ervaring?

Hume's antwoord op deze geldigheidsvraag, namelijk dat causale uitspraken uiteindelijk berusten op gewoonte, acht Spruyt daarentegen onbevredigend. ${ }^{4}$ Hierbij sluit hij nauw aan bij Kants kritische oordeel over Hume's oplossing. ${ }^{5}$ De ruwe stof

' ef. Spruyt, C.B. (1871a), op. cit. p. 19. 'Indien nu onze meening, dat een toestand, die in hel verleden altijd door een anderen toestand gevolgd is, ook in de toekomst altijd doer den tweeden toestand zal gevolg worden, zoo dikwijls hij zich vertoont, niet berust op eene redeenering, aan welken invloed dankt zij dan haar ontstaan? Zij berust op niets anders dan op de kracht der gewoonte.'

${ }^{2}$ ef. Spruyt, C.B. (1871a), op. cit. p. 20. 'Wat is dus eene oorzaak? Een verschijnsel dat door een ander gevolgd wordt, ingeval alle verschijnselen die daaraan gelijk zijn, altijd door cen gelijk tweede verschijnsel gevolgd worden. Wat beteekent de noodwendigheid van het verband van oorzak en gevolg? Niets meer, dan dat wij na zeer vele malen een cerste verschijnsel door een tweede te hebben zien volgen, geen het minste bezwaar hebben in de voorspelling, dat zij ook in de toekomst in dezelfde orde op elkander zullen volgen. (...) gevolg zijn is niets anders dan een regelmatig yolgen zonder eenige waargenomen uitzondering (...) Een post, dat zich vrij dikwijls herhaalt, begint ons een propter te schijnen: een onmiskenbaar propter is toch niets anders dan een altijd waargenomen post.'

${ }^{3}$ cl. Spruyt, C.B. (1871a), op. cit. p. 22.

4 cf. Spruyt, C.B. (1871a), op. cit. p. 22, 'Hume had zich de vraag niet in hare algemeenheid voorgesteld, en daarom een antwoord gegeven, dat onbevredigend is. (...) Wanhopende aan het vinden van een redelijken grond voor onze verwachling, had hij die verwachting alleen doen berusten op de kracht der gewoonte:'

cf. Kant, I. (1783), Prolegomena zu einer jeden künftigen Metaphysik die als Wissenschaft wird auftreten können, p. 9. 'So übereilt und unrichtig auch seine Folgerung war, so war sie doch wenigstens auf Untersuchung gergründet, und diese Untersuchung war es wohl 
van de ervaring, het empirisch(e) gegeven, wordt door de aanschouwingsvormen van tijd en ruimte bepaald, zo betoogt Spruyt. Zulke tijd-ruimtelijk bepaalde aanschouwingen worden vervolgens verbonden met de vormen van ons verstand. Dit leidt uiteindelijk tot het waarnemen van cen voorwerp van onze voorstelling. 'Ervaring' weerspiegelt daarom niel rechtstreeks de ons omringende werkelijkheid, zoals Hume had beweerd; 'ervaring' moet daarentegen worden opgevat als een samenstel van zintuiglijke en verstandelijke elementen. ${ }^{2}$ Dit geldt ook voor natuurwetten. In tegenstelling tol de gedachte dat kennis van natuurwelten geleidelijk door ervaring ontstaat, moet zulke kennis mede als het gevolg worden gezien van de aanschouwingsvormen tijd en ruimte enerzijds, in combinatie met verstandsvormen, zoals die van causaliteit, anderzijds. ${ }^{3}$ Beide soorten vormen worden door Spruyt onder de noemer van 'waarnemingsvorm' gebracht. Het causaliteitsbeginsel is nict door ervaring onlstaan, maar het is één van die verstandsvormen; en daarom is dit beginsel a priori. Men kan derhalve pas over de 'natuur' spreken als de voorwerpen der ervaring door het causaliteitsbeginsel met elkaar in verband zijn gebracht. ${ }^{4}$ Spruyt grijpt vervolgens Hume's geldigheidsvraag aan om te concluderen dat Opzoomers twee argumentaties tot contradicties leiden: door welke redeneering verkrijgen wij de stoutmoedigheid van te meenen, dat verschijnselen, die wij eenige malen elkander hebben zien volgen, ook in de toekomst op elkander volgen zullen?' Of anders gesteld: welke is de redeneering, die ons machtigt algemeenheid toe te schrijven aan een regel, dien wij slechts in weinige gevallen hebben zien opvolgen?" Deze vraag kan men op twee manieren beantwoorden. Hetzij door uit te gaan van Hume's theorie; of door uit te gaan van Kant. 'Hune's oplossing had Spruyl al van de hand gewezen, waardoor derhalve allcen Kants benadering overblij[l.

wert, dass sich die guten Köpfe seiner Zeit vereinigı hâtten, die Aufgabe, in dem Sinne, wie er sie vortrug, wo möglich, glüklicher aufzulösen, woraus denn bald eine gänzliche Reform der Wissenschaften hätte entspringen müssen.'

${ }^{\prime}$ cf. Spruyt, C.B. (1871a), op. cit. p. 24-25, 'Wat ons empirisch gegeven is, nemen wij op in de vormen van onze zinnelijkheid, den tijd en de ruimte, en verkrijgen op die wijze eene aanschouwing: wat ons die aanschouwing levert nemen wij op in een der vormen van ons verstand en geraken op die wijze tot de bekendheid met een voorwerp van onze voorstelling.'

${ }^{2}$ cf. Spruyt, C.B. (1871), op. cit. p. 24, 'Onze ervaring is niet alleen een bloote afspiegeling van het niel-ik, maar zij voor hel grootste deel ons eigen maaksel.'

${ }^{3}$ ef. Spruyt, C.B. (1871a), op. cit. p. 25, 'De wetten der natuur worden ons dus niet uitsluitend door de ervaring bekend; integendeel, de hoogste natuurwetten worden door onzen geest in de ervaring gelegd, en de natuur bestaat slechts ten gevolge van de wetten, die onze zinnelijkheid en ons verstand aan haar hebben voorgeschreven.'

${ }^{4}$ cl. Spruyt, C.B. (1871a), op. cit. p. 26. 'Die hoogste wet der causaliteit is dus geenszins aan de natuur ontleend, maar de natuur ontslaat eerst, omdat wij de voorwerpen van onze ervaring geplaatst hebben in den vorm der causaliteit.'

s cf. Spruyt, C.B. (1871a), op. cit. p. 35.

${ }^{6}$ cf. Spruyt, C.B. (1871a), op. cit. p. 36-37.

7 cf. Spruyt, C.B. (1871a), op. cit. p. 37, 'Bestaat er geen dergelijke redeneering, zooals hoogstwaarschijnlijk het geval is, dan blijft er ter verklaring van ons denkbeeld van causaalverband nog altijd geen andere weg open, of de theorie van Hume of de leer van Kant.' 
In de twee navolgende secties wordt ingegaan op Spruyts weerlegging van de twee argumentaties van Opzoomer.

\section{Kritiek op Opzoomers eerste argumentatie}

In De weg der wetenschap stond Opzoomer voor de volgende vraag: als ik in éen of meer gevallen ontdekt heb, dat het eene verschijnsel er oorzaak van het andere geweest is, met welk regt durf ik dan beweren, dat het ten allen tijde er de oorzaak van zal zijn, het alijd zal voorbrengen?' Opzoomer had Mills antwoord op deze vraag verworpen, omdat Mill van mening was dat de grondslag voor inductie zou berusten op een inductio per enumerationem simplicem. Opzoomer had dit onaanvaardbaar geacht, omdat het zou leiden tot een circulaire redenering. Immers, hierdoor zou inductie zelf weer worden gebaseerd op een andere inductie; dat wil zeggen, het besef dat er regelmatigheid in de naluur bestaat, het regelmatigheidsbeginsel, zou berusten op het causaliteitsbeginsel. En dit laatste beginsel zou uiteindelijk weer berusten op een inductio per enumerationem simplicem.

Met de woorden dat Opzoomers argumentatie voor de opvalting dat het regelmatigheidsbeginsel onbetwijfelbaar is, duister en onbegrijpelijk is, velt Spruyt een vernietigend oordeel. ${ }^{2}$ Hieruit blijkt dat Spruyt de achilleshiel van Opzoomers eerste argumentatie feilloos aanvoelt. Tegen deze argumentatie formuleert Spruyt Iwee bezwaren.

Opzoomer had de onbetwijfelbare overtuiging of het besef dat gelijksoortige oorzaken leiden tot gelijksoortige gevolgen gebaseerd op het principe dat iedere verandering een oorzaak heeft. Het regelmatigheidsbeginsel liet hij daardoor berusten op het causaliteitsbeginsel. Het causaliteitsbeginsel had Opzoomer ten slotte weer laten berusten op inductie. Spruyt merkt hier allereerst over op dat diens kritiek op Mill ook voor Opzoomer zélf geldt. Weliswaar laat Opzoomer in tegenstelling tot Mill niet het regelmatigheidsbeginsel op bloote inductie rusten, maar dat doet Opzoomer wel met het causaliteitsbeginsel. ${ }^{3}$ Met andere woorden: Opzoomers argumentatic kan men geen verbetering van die van Mill noemen. Het verschuift alleen het problcem van het concrete regelmatigheidsbeginsel naar het abstracte causaliteitsbeginsel.

cf. Opzoomer, C.W. $\left(1851^{2}\right)$, op. cil. p. 108.

${ }^{2}$ cf. Spruyt, C.B. (1871a), op. cit. p. 45-46, Te vergeefs heb ik in de meer uitvoerige geschriften van Opzoomer naar eene toelichting van deze, voor mij zoo duistere, redeneering. Hoe menigmaal ik haar ook heb herlezen, hoe menigmaal ik haar heb overdacht, zij is mij altijd even onbegrijpelijk gebleven.'

${ }^{3}$ cf. Spruyt, C.B. (1871a), op. cit. p. 46 'Terwijl Mill ons geloof aan de stelling dat gelijke ourzaken gelijke gevolgen hebben, onmiddellijk doet besusten op den laagsten vorm der inductie, leidt Opzoomer dat geloof af uit een andere bewering (i.e. iedere verandering dient een oorzaak te hebben), die wij toch alleen door dezellde soort induclie leren kennen. Niet tevreden met het betoog van Mill, omdat deze de wet der causaliteit afleidt uit eene inductie door bloote optelling, geeft Opzoomer toch voor diezelffe wet geen andere grond dan diezelfde inductie door bloote optelling.' 
Spruyts tweede bezwaar betreft Opzoomers antwoord, of liever het ontbreken van een antwoord, op Hume's vraag: welke is de redeneering, die ons machtigt algemeenheid toe te schrijven aan een regel, dien wij slechts in weinige gevallen hebben zien opvolgen?'

Opzoomer was van mening dat een wijziging in omstandigheden de oorzaak voor voor verandering is; dit had hij afgeleid uit het causaliteitsbeginsel. ${ }^{2}$ Hume's vraag betrof, zo merkt Spruyt op, de rechtvaardiging van dit beginsel: waarom gelooven wij, dat iedere verandering een oorzaak moet hebben $?^{3}$ Opzoomer had deze vraag echter omzeild. Als hij al een antwoord had gegeven, dan moet dit worden gezocht in de bewijsgrond die Opzoomer had aangevoerd voor het causaliteitsbeginsel; dat wil zeggen, het beginsel dat inductie mogelijk maakt. Voor Opzoomer lag die bewijsgrond voor dit beginsel wederom in inductie. Met andere woorden: de basis waar inductie op berust, het causaliteitsbeginsel, verklaart Opzoomer door een andere inductie. Dit antwoord acht Spruyt geen rechtvaardiging van het causaliteitsbeginsel, maar een cirkelredenering. Het onderstelt immers wat juist gerechtvaardigd zou moeten worden: waarom gelooven wij, dat iedere verandering een oorzaak moet hebben? Opzoomer had Hume's vraagstuk ten onrechte "weggedefinieerd". 5

Elders in Aangeboren waarnemingsvormen merkt Spruyt nog expliciet op dat geen enkele inductie mogelijk (is), zonder de intütieve toepassing van de wet der causaliteit. ${ }^{6}$ Spruyts onderstelling dat het causaliteitsbeginsel niet op ervaring berust, maakt duidelijk vanuit welke hoek Opzoomer wordt aangevallen.

Spruyt concludcert dat Opzoomer in zijn duistere en onbegrijpelijke redeneringen Humc's vraag volledig uit het oog heeft verloren. Maar, zo stelt hij sarcastisch vast, wij achten er zijne' schranderheid niets te minder om, want de vraag van Hume is de moeilijkste, die ooil gedaan is.

\section{Kritiek op Opzoomers tweede argumentatie}

Spruyt acht Opzoomers tweede argumentatie op twee fronten aanvechtbaar: de argumentatie dat de notie 'noodzakelijk verband' of 'noodwendigheid van opvolging' uil de uitwendige waarneming kan worden afgeleid, en de argumentatie dat de twee noties 'oorzaak' en 'noodzakelijkheid' uit de inwendige waarneming afgeleid kunnen

'cf. Spruyt, C.B. (1871a), op. cit. p. 36-37.

${ }^{2}$ cf. Spruyt, C.B. (1871a), op. cit. p. 46-47, 'Om een antwoord te geven op de ondubbelzinnig gestelde vraag van Hume, geeft Opzoomer eene redeneering waaruit ons blijken moet, dat elke verandering veroorzaakt wordt door gewijzigde omstandigheden. (.....) Zij wordt toch afgeleid uit de stelling: Iedere verandering moet eene oorzaak hebben.'

${ }^{3}$ ef. Spruyt, C.B. (1871a), op. cit. p. 47.

${ }^{4} \mathrm{cf}$. Spruyt, C.B. (1871a), op. cit. p. 47.

5 cf. Spruyl, C.B. (1871a), op.cit. p. 46, 'Opzoomers antwoord op de vraag van Hume is dus te zoeken in zijne bewijsgronden voor de laatste stelling (i.e. dat iedere verandering een oorzaak moet hebben). (...) Deze laatste stelling nu berust ook op inductie, berust dus op de werkzaamheid van onze geest, naar wier rechtsgrond Hume gevraagd had.'

"cf. Spruyt, C.B. (1871a), op. cit. p. 41.

${ }^{7}$ eff. Spruyt, C.B. (1871a), op. cit. p. 47. 
worden. In het navolgende wordt op deze twee kritiekpunten ingegaan, te weten: Spruyts kritiek op Opzoomers notie 'innig en vast verband' en diens afleiding van de noties 'oorzaak' en 'noodzakelijkheid' uit de inwendige waarneming.

\section{Kritiek op Opzoomers notie 'innig en vast verband'}

In Het wezen der kennis had Opzoomer geconstateerd dat sommige verschijnselen met bepaalde verschijnselen inniger zijn verbonden dan met andere verschijnselen. Op grond van het waarnemen van zo'n innig verband had hij geconcludeerd dat er sprake moet zijn van een noodzakelijke relatie tussen twee verschijnselen. Hieruit leidde hij vervolgens af dat er sprake moet zijn van een causaal verband. Spruyt (1871a) vindt dit een misleidende formulering, omdat Opzoomer hiermee de noodzakelijkheid van causale relaties gelijk had gesteld met één of ander innig verband.' Bovendien suggereert Opzoomer hiermee ten onrechte dat Hume's geldigheidsvraag is opgelost. Deze vraag wordt door Opzoomers versluierende terminologie evenwel niet beantwoord ${ }^{2}$, en zij blijft daarom onverkort van kracht: waarop berust ons geloof aan de noodwendigheid van het causaalverband, terwijl de natuur ons nooit iets anders kan aanwijzen, dan zijne geldigheid in vroegere gevallen ? $^{3}$

In Aangeboren waarnemingsvormen constateert Spruyt verder dat Opzoomers notie 'innig verband' niets anders is dan Mills eerder genoemde notic 'standvastige, onvoorwaardelijke opvolging'. ${ }^{4}$ Bovendien trapt Opzoomer hier weer in dezelfde val als Mill: de redenering is circulair. Als men er namelijk van uitgaat dat de notie 'causaliteit' geleidelijk door inductie ontstaat, langdurige ondervinding, onderstelt dit dat inductie reeds mogelijk is. Immers, in inductieve uitspraken wordt veelal een causaal verband gelegd tussen bepaalde verschijnselen. Echter, dit kan alleen als men de notie 'causaliteit' onderstelt. ${ }^{5}$ Met andere woorden: ook in dit geval laat Opzoomer inductie weer op cen andere inductie berusten.

Spruyt completeert zijn kritiek op Opzoomers redenering met de volgende drie tegenargumenten. Het feit dat de notie 'causaliteit' abstract is, impliceert nog niet dat het is ontstaan op grond van ervaring. Het kan dus net zo goed een notie a priori zijn; dat wil zeggen, een aangeboren waarnemingsvorm. Daarnaast vormt het feit

' cf. Spruyt, C.B. (1871a), op. cit. p. 49, 'Wat is toch dat innige, dat nauwe verband, dat in de voorlantste zinsnede min of meer pathetisch optreedt om ons te doen gelooven aan de noodwendigheid van het causaalverband? Niets anders dan de rhetorischen vorm voor onveranderlijke, onvoorwaardelijke opvolging.'

2 cf. Spruyt, C.B. (1871a), op. cit. p.49, 'Want door die verraderlijke nauwheid en innigheid van verband brengt men den oppervlakkigen lezer in den waan, dat nu eindelijk de vraag van Hume beantwoord is.'

${ }^{3}$ cf. Spruyt, C.B. (1871a), op. cit. p. 49.

4 cf. Spruyt, C.B. (1871a), op. cit. p.49, 'En toch weet de schrijver zeer goed, dat het nauwe en innige verband alleen in die standvastige, onvoorwaardelijke opvolging te zoeken is.'

${ }^{5}$ cf. Spruyt, C.B. (1871a), op. cit. p. 50, 'Inductie, langdurige ondervinding, heeft ons langzamerhand tot het begrip der causaliteit gebracht, maar de mogelijkheid van die inductie onderstelt reeds de toepassing van het begrip der causaliteit.' 
dat nog nooit het tegendeel van de algemene geldigheid van de wet van oorzaak en gevolg is aangetoond geen bewijs voor de bewering dal deze wet ook noodzakelijk zou zijn. Het toont alleen aan dat het tot nu toe onverbrekelijk is gebleken. Bovendien is het een feit dat deze wet in de onderzoekpraktijk in veel gevallen niet herkenbaar is. Dit betekent echter nog niet dat geconcludeerd mag worden dat men daardoor zou twijfelen aan de algemene geldigheid hiervan.'

Spruyt concludeert dat Opzoomers argumentatie niet leidt tot het beantwoorden van Hume's vraagstuk, maar alleen het genoeglijk uitzicht biedt op oratorische schoonheden. ${ }^{2}$

\section{Wilsbepaling als bron van de noties 'noodzakelijkheid' en 'oorzaak'?}

Meer nog dan Opzoomers afleiding van de notic 'oorzaak' uit de uitwendige waarneming, sluit diens afleiding van de noties 'noodzakelijkheid' en 'oorzaak' uit de inwendige waarneming op Spruyts uitvoerige en scherpe kritick.

Allereerst merkt Spruyt fijntjes op dat Opzoomer had kunnen weten dat Hume in de Enquiry de weg om de notie 'causaliteit' af te leiden uit de relatie tussen wilsbepalingen en daarmee corresponderende handelingen al had geblokkeerd. Hume's argumenten waren voor Opzoomer kennelijk niet overtuigend genoeg. Spruyt formuleert daarom een uitvoerige tegenargumentatie die nog minder ruimte moet bieden voor zulke afleidingen. ${ }^{3}$ Voor een goed begrip van Spruyts complexe tegenargumentalie is het noodzakclijk hier uitgebreid op in te gaan.

De kern van Opzoomers wilstheorie komt, zo betoogt Spruyt, neer op het onderscheid tussen de relatie tussen bewuste wilsbepalingen en handelingen enerzijds, en de relatie tussen onbewuste wilsbepalingen en handelingen anderzijds. Spruyt acht het zeer onwaarschijnlijk dat een aartsempirist als Opzoomer het bestaan van onbewuste wilsbepalingen zou willen aannemen, omdat men zulke wilsbepalingen niet kan waarnemen, maar alleen kan onderstellen. Waarneming kan immers per delinitie nooit aangeven dat er sprake is van een onbewuste, en daarom niet-

${ }^{\prime}$ cf. Spruyt, C.B. (1871a), op. cit. p. 50, 'De langzame verspreiding der erkenning van het abstract begrip der causaliteit bewijst niets tegen de leer van Kant, volgens welke diezelfde causaliteit als waarnemingsvorm an de eerste intuitieve voorstelling voorafgaat. Dat, eindelijk, niemand ooit in staat geweest is, een geval aan te wijzen, waarin het tegendeel der wet van oorzaak en gevolg openbaar is, kan, ten eerste, niet de noodwendigheid van het causaalverband bewijzen, maar hoogstens zijne onverbreekbaarheid tot op dezen dag. Ten tweede, zoo als reeds vroeger door mij is opgemerkt, levert de wetenschap ons honderden gevallen, waarin hel causaalverband niet herkenbaar is, tegen een, waarin wij het kunnen ontdekken.'

${ }^{2}$ cf. Spruyt, C.B. (1871a), op. cit. p. 50.

${ }^{3}$ cf. Spruyt, C.B. (1871a), op. cit. p. 52, 'Liever echter dan mij op zijne (Hume's) autoriteit de beroepen, of ook zijne beweringen nog eenmal te herhalen, wil ik eenige uitbreiding geven aan zijn veroordelend vonnis. Nanst de argumenten van Hume laten zich toch eenige andere beschouwingen stellen, die ook reeds toereikend zijn om de stelling van Opzoomer te doen vallen, en die mij toeschijnen minder gelegenheid tot uitvluchten te geven dan Hume's denkbeelden over dit onderwerp.' 
warneembare wilsbepaling. Hieruit leidt Spruyt af dat Opzoomer alleen bewuste wilsbepalingen op het oog moet hebben gehad.' Als van dit principe wordt uitgegaan, dan kan Opzoomers wilstheorie worden samengevat in de volgende drie constatcringen. Allerecrst: men ervaart in zichzelf bewuste wilsbepalingen. Vervolgens: men ervaart dat een bewuste wilsbepaling wordt gevolgd door cen hiermee corresponderende lichaamsbeweging of handeling. Ten slotte: men ervaart dat een bepaalde handeling noodzakclijk samenhangt met een bewuste wilsbepaling, waardoor men die wilsbepaling moet opvatten als de oorzaak van zo'n lichaamsbeweging of handeling. ${ }^{2}$ Deze dric conslateringen hadden Opzoomer tol de slotsom gebracht dat men op grond van ervaring niet alleen het volgen van verschijnselen waameemt, maar ook hel noodzakelijk volgen van verschijnselen. ${ }^{3}$ Omdat Opzoomer noodzakelijkheid als het kenmerk van causaliteit opvatte, betekent dit dus dat de notie 'causaliteit' uit ervaring kan worden afgeleid.

Spruyt ziet Opzoomers derde constatering als hot "draaipunt" in diens redenering: deze constatering vormt bovendien de basis voor diens conclusic dat de nolic 'causaliteit' uit ervaring kan worden afgeleid. Deze conclusie is volgens Spruyt geheel onjuist. Tegen Opzoomers derde constatering voert hij drie tegenargumentaties aan. De eerste tegenargumentatic berust op de overtuiging dat er wel degelijk onbewuste wilsbepalingen bestaan en dat Opzoomer juist het tegendecl bewijst van zijne conclusie. De tweede tegenargumentatie komt er op neer dat Opzoomers derde constatering feitclijk onjuist en geheel onhoudbaar is. De derde tegenargumentatie moet de genadeslag toedienen; deze laatste tegenargumentatie houdt in dat Opzoomer de wil ten onrechte als oorzak voor handelingen had opgevat. In plaats daarvan moct men er van uitgaan, zo betoogt Spruyt, dat alleen motieven als oor zaken van handelingen gezien kunnen worden. Spruyts drie tegenargumentaties worden in het navolgende uitgewerkt.

Onbewuste wilsbepalingen bestaan wel degelijk en liggen ten grondslag aan het merendeel van ons doen en denken. Deze stelling is het uilgangspunt voor Spruyts eerste tegenargumentatie tegen Opzoomers wilstheorie. Spruyt leidt hieruit af dat

' cf. Spruyt, C.B. (1871a), op. cit. p. 52, 'Wij kunnen er bijna niet aan twijfelen, of Opzoomer heeft bij zijn betoog uitsluitend gedacht aan de eerslgenvemde, de bewuste wilsbepalingen. Want vooreerst volgt uit zijn gehecle stelstel, dat hij het bestaan der onbewuste wilsbepalingen moet ontkennen; ten tweede is het volkomen duidclijk, dat de waarneming ons nimmer onmiddellijk kan leeren, dat een zeker verschijnsel op een onbewuste wilsbepaling volgt, daar wij die onbewuste wilsbepaling zelve niet bemerken.'

${ }^{2}$ cf. Spruyt, C.B. (1871a), op. cit. p. 53, 'Het betoog van Opzoomer komt dus neer op het volgende. Ten eerste, wij bemerken in ons zelven bewuste wilsbepalingen (....). Ten twcede, wij zien dat deze wilsbepalingen gevolgd worden door de handeling, die den inhoud van de wilsbepaling uitmaakt (....) Wij bemerken, ten derde, dat de genoemde bewiging niet slechts een opvolgend verschijnsel, maar een noodwendig gevolg van onze bewuste wilsbepaling is, en heschouwen daarom onzen wil niet enkel als een antecedent maar als eene oorzaak.'

'cf. Spruyt, C.B. (1871a), op. cit. p. 5.3, 'Dus wijst ons de ervaring niet slechts opvolging, maar ook noodwendige opvolging of causaliteit.' 
het een uitzondering is dat een verschijnsel volgt na een bewuste wilsbepaling.' Opzoomer was er van uitgegaan dat alleen bewuste wilsbepalingen oorzaken kunnen zijn van handelingen of verschijnselen. Echter, het overgrote deel daarvan treedt op zonder dat daar een bewuste wilsbepaling aan ten grondslag ligt. Opzoomer had moeten concluderen dat het merendeel van de handelingen of verschijnselen nietveroorzaakt en dus toevallig is. Spruyt leidt hier echter uit af dat bij deze laatstgenoemde categorie van verschijnselen alleen kan worden gesproken over successie van verschijnselen, en niet van een noodzakelijk gevolg. ${ }^{2}$

Bovendien roept Opzoomers derde constatering bij Spruyt de volgende retorische vraag op: van waar ontleenen wij dan het rechl om dit begrip van noodwendig verband ook uit te strekken over de andere, elkander opvolgende verschijnselen,

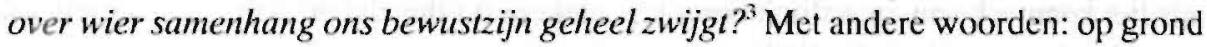
waarvan kan men de notie 'noodzakelijk verband' toepassen op successieve verschijnselen waarvan men niet bewust is? Hier had Opzoomer kennelijk nict aan gedacht. Bovendien, als men al zou uitgaan van de juistheid van Opzoomers derde constatering - dat wil zeggen, dat een handeling noodzakelijk volgt op een bewuste wilsbepaling - dan zou hij zijn conclusie moeten veranderen. In Opzoomers termen zou deze conclusie moeten luiden dat de ervaring tot dusver alleen heeft laten zien dat sommige handelingen noodzakelijk volgen op een wilsbepaling. Dit brengt Spruyt tot de conclusie uit het ongerijmde dat men er tot dusver ten onrechte van uit zou zijn gegaan dat er tussen alle verschijnselen een noodzakelijk verband bestaat. Als men derhalve de oorsprong van de notie 'noodzakelijk verband' zoekt in het bewustzijn van de relatie tussen bewuste wilsbepalingen en handelingen, dan slaat dit de bijl aan de wortel van de overtuiging dat ieder verschijnsel een oorzaak heeft. Een dergelijke conclusie is echter voor niemand acceptabel, zo betoogt Spruyt. ${ }^{4}$

' cf. Spruyt, C.B. (1871a), op. cit. p. 53-54, 'Om mijne cerste uitspraak te rechtvaardigen, begin ik. te herinneren dat verreweg de meest lichaamsbewegingen en zielsverschijnselen piaats hebben zonder bewuste wilsbepaing. (...) Tegen een enkei geval, waarin wij een physisch of psychisch verschijnsel zien volgen op de uitspraak van ons bewustzijn, die gewoonlijk voor eene bewuste wilsbepaling wordt gehouden, zijn er honderden, waarin wij diezelfden verschijnselen zien optreden, zonder dat onze wil hun ontstaan verlangd heeft.'

${ }^{2}$ cf. Spruyi, C.B. (18719), op. cit. p. 54-55, 'Indien wij nu, in overeenstemming met Oproomer's meening, de eerste verschijnselen aanzagen als noodwendig veroorzaakı door onzen wil, dan zouden de andere en veel talrijker verschijnselen ons als toevallige, niet verooraakte, verschijnselen moeten voorkomen. Wij zouden bij die laatste verschijnselen slechts mogen spreken van waargenomen opvolging, niet van noodzakelijk gevolg zijn.'

${ }^{3}$ cf. Spruyt, C.B. (1871a), op. cit. p. 54-55.

${ }^{4}$ cf. Spruyt, C.B. (1871a), op. cit. p. 55 'De ervaring heeft ons niet anders getoond dan het noodwendig verband tusschen onze wilsbepalingen en sommige onzer handelingen. Ten onrechte hebben al degenen tot op dezen dag, die men gewoonlijk beschouwt als de verstandigsten onder het menschelijk geslacht, dat noodwendig verband even goed erkend tusschen elk verschijnsel en zijne onvoorwaardelijke antecedenten. De verdediging van het determinisme berust op niets anders dan op eene geheel onhoudbare illusie, ten gevolge waarvan wij de aanwezigheid van causaalverband ook verwachten bij andere opvolgingen, dan waarin ons bewustzijn ons tot de erkenning van dat verband machtigt.' 
Op dit bewijs uit het ongerijmde laat Spruyt een directe argumentatie volgen tegen de inhoud van Opzoomers derde constatering; deze argumentatie moet aantonen dat die constatering onhoudbaar is. ${ }^{1}$

Bewuste wilsbepalingen en daarmee corresponderende handelingen zijn niet noodzakelijk met elkaar verbonden. Sterker nog: bewuste wilsbepalingen en handelingen volgen dikwijls niet eens regelmatig op elkaar. Dit is het uitgangspunt voor Spruyts tweede argumentatie. Men kan namelijk iets willen zonder dat de handeling daarop volgt. Het ontbreken van een noodzakelijk verband wordi duidelijk als men de relaties tussen een bewuste wilsbepalingen en innerlijke verschijnselen beschouwt. Bijvoorbeeld: als iemand graag één of ander wiskundig vraagstuk wil oplossen, dan is het niet gezegd dat de oplossing ook noodzakelijk zal volgen omdat iemand dat wil. Dit feit geeft al aan dat er tussen bewuste wilsbepalingen en waarneembare handelingen of innerlijke verschijnselen geen onveranderlijke, noodzakelijke opvolging of een causale relatie bestaat. ${ }^{2}$

Principiëler is echter dat men niets met zekerheid kan weten over de inhoud van een bewuste wilsbepaling zolang de handeling die men met zo'n wilsbepaling beoogt nog niet heeft plaatsgevonden. Dit komt doordat wilsbepalingen die vooraf gaan aan de beslissing om een bepaalde handeling te verrichten niet meer zijn dan een diffuus geheel van wenschen en begeerten. Bovendien kan men geen duidelijk onderscheid maken tussen bewuste willekeurige handelingen en onbewuste willekeurige handelingen. De bewuste willekeurige handelingen worden niet voorafgegaan door een expliciete wilsbepaling. Dit betekent echter nog niet dat zulke handelingen nietveroorzaakt en toevallig zijn. Uit deze opsomming van feitelijke overwegingen leidt Spruyt de conclusie af dat bewuste wilsbepalingen handelingen niet noodzakelijk kunnen veroorzaken. En als men zulke wilsbepalingen al zou opmerken, vormen zij slechts een toevallige omstandigheid. ${ }^{3}$ Met deze twcede argumentalic slaat Spruyt

' cf. Spruyt, C.B. (1871a), op. cit. p. 55, '.... de stelling, dat ons bewustzijn ons een noodwendig verband zou aanwijzen tusschen onze wilsbepaling en de correspondeerende handeling, is onhoudbaar.'

${ }^{2}$ cf. Spruyt, C.B. (1871a), op. cit. p. 55-56, '....ten eerste is de handeling, die het doel is van de psychische werkzalamheid (....) zoo weinig noodwendig verbonden met die wilsbepaling, dat zij er niet eens regelmatig op volgt: zij kan uitblijven. (....) Evenmin worden de wilsbepalingen ten aanzien van innerlijke verschijnselen met noodwendigheid door de correspondeerende verschijnselen gevolgd. (...) Dus bestaat er tusschen onze wilsbepalingen en de correspondeerende, voor ons waarneembare handelingen, niet die onveranderlijke, onvoorwaardelijke opvolging, warin het causaalverband bestaat.'

${ }^{3}$ ef. Spruyt, C.B. (1871a), op. cit. p. 57-59, 'Onze bewuste wilsbepaling wordı ons nimmer met zekerheid bekend, voordat de correspondeerende handeling heeft plaats gehad. (...) $\mathrm{Zij}$ zijn nog niets anders dan wenschen, begeerten, die krachtiger of minder krachtig kunnen zijn, en waaruit wij met grootere of kleinere waarschijnlijkheid kunnen vermoeden, hoe onze wilsbepaling zal uitvallen, als wij geroepen worden om te beslissen. Onze bewuste handelingen kunnen onmogelijk door scherpe grenzen worden gescheiden van onze onbewust, willekeurige handelingen (....) Onze bewuste, willekeurige handelingen worden nu door ons verricht zonder eenige voorafgaande wilsbepaling of voorafgaanden wensch. Maar toch zeker niet zonder voorafgaanden toereikenden oorzaak. Dus is de bewuste wil volstrekt niet 
de feitelijke basis voor Opzoomers wilstheorie weg door Opzoomer in diens eigen termen te weerleggen.

Met de laatste tegenargumentatie beoogt hij Opzoomers theorie de genadeslag toe te brengen. De kern van Spruyts derde tegenargumentatie komt er op neer dat Opzoomer er ten onrechte van uit was gegaan dat het eigenaardig verband tussen een wilsbepaling en handeling die daarmee overeenkomt een causale relatie is. ${ }^{1}$ Met andere woorden: Opzoomer had de wil ten onrechte als de oorzaak voor handelingen opgevat.

Herhaling maakt dat handelingen of lichaamsbewegingen die men eerst bewust verricht geleidelijk overgaan in onbewuste, automatische handelingen. ${ }^{2} \mathrm{Hel}$ instuderen van een muziekstuk voor piano is hiervan een goed voorbeeld. In het begin moet men nog nadenken welke toetsen men moet gebruiken; na een tijdje wordt het muziekstuk vloeiend gespeeld, zonder dat men iedere keer hoeft na te denken over de keuze van de toetsen. Omdat er kennelijk een geleidelijke overgang bestaat van bewuste naar onbewuste handelingen, kan men daaruit afleiden dat de wil geen oorzaak kan zijn van bewuste handelingen. De opvatting dat de wil oorzaak is van bewuste handelingen onderstelt namelijk dat bewuste en onbewuste handelingen scherp van elkaar onderscheiden kunnen worden, en dat acht Spruyt onjuist. Deze opvatting leidt bovendien tot de foutieve opvatting dat bewuste handelingen door bewuste wilsbepalingen en dat onbewuste handelingen door motieven zouden worden veroorzaakt. $^{3}$

Met 'motieven' bedoelt Spruyt overigens verschillende gewaarwordingen, voorstellingen, herinneringen, die hunnen invloed op die handeling hebben uitgeoefend. ${ }^{4}$

Spruyt sabelt Opzoomers verklaring dat wilsbepalingen de oorzaak zijn van bewuste handelingen neer als de meest overtollige hypothese die zich denken laat. Want, zo vraagt Spruyt zich af, wat is er tegen om ook bij bewuste, en niet alleen bij onbewuste handelingen motieven als de oorzaken daarvan aan te merken? Met andere woorden: welk bezwaar is er in de meening dat ook bij de bewluste

de noodzakelijke oorzaak van onze lichaamsbewegingen, maar, als hij waargenomen wordt, eene toevallige omstandigheid.'

' cf. Spruyt, C.B. (1871a), op. cit. p. 62, '... de stelling van Opzoomer toch moet worden verworpen, omdat het eigenaardig verband, dat er tusschen onze wilsbepaling en de correspondecrende handeling bestaal, in het getieel geen causaalverband is.'

${ }^{2}$ cf. Spruyt, C.B. (1871a), op. cit. p. 65 , 'Elke bewuste handeling blijft slechts zoo lang bewust, als zij nog niet tot eene gewoonte is geworden; wordt zij zeer dikwijls herhaald, dan gaat zij onvermijdelijk over tot de groote schaar der onbewuste, automatische handelingen.'

${ }^{3}$ cf. Spruyt, C.B. (1871a), op. cit. p. 65, 'Uit den langzamen overgang tusschen bewuste en onbewuste handelingen, volgt nu gemakkelijk, dat het verkeerd is den wil te beschouwen als de oorzaak der bewuste handelingen. Want als men dat doet, maakt men eene scherpe scheiding tusschen bewuste en onbewuste handelingen. De onbewuste handelingen worden dan veroorzaakt uitsluitend door hunne motieven, zekere gewaarwordingen of voorstellingen, zonder dat de medewerking van eenige wilsuiting noodig is.'

${ }^{4}$ cf. Spruyt, C.B. (1871a), op. cit. p. 66. 
handelingen alleen de motieven de toereikende oorzaken zijn ${ }^{1}$ Dit acht Spruyt consistent met de inwendige waarneming. Aan bewuste handelingen gaat altijd een wirwar van motieven vooraf, maar nooit een bewuste wilsbepaling. Door motieven in plaats van wilsbepalingen als oorzaak van handelingen op te vatten, wordt ook de langzame overgang van bewuste naar onbewuste handelingen inzichtelijk. ${ }^{2}$

Echter, als men alleen motieven als oorzaken opvat van handelingen, wat bedoelt men dan met 'wilsuitingen'? In Spruyts woorden: maar als dan de wilsuiting niet de oorzaak is der handelingen, wat kan die wilsuiting dan wel zijn? $?^{3}$ Spruyt is het eens met Schopenhauer dat wilsbepalingen of wilsuitingen en handelingen keerzijden zijn van één medaille. ${ }^{4}$ Een wilsuiting valt samen met een handeling zoals men die handeling innerlijk ervaart of beleeft. Men kan daarom ook geen scherp onderscheid maken tussen wilsbepalingen en handelingen. Een wilsbepaling kan derhalve geen oorzaak zijn van een handeling. Opzoomers onderscheid tussen het waarnemen van wilsbepaling die aan een daamee corresponderende handeling vooraf zou gaan, acht Spruyı dus onmogelijk. Een wilsbepaling is alleen kenbaar in of na de handeling zelf. ${ }^{5}$ Met andere woorden: de notie 'wilsbepaling', opgevat als oorzaak voor een handeling, is een overbodige theoretische constructie.

Spruyts kritiek op Opzoomer brengt hem tot de volgende conclusie. Opzoomers twee argumentaties om de notie 'oorzaak' en 'noodzakelijk verband' uit ervaring af te leiden moeten worden verworpen als antwoorden op Hume's geldigheidsvraag: waarop berust ons geloof aan de noodwendigheid van het causaalverband, terwijl de natuur ons nooit iets anders kan aanwijzen, dan zijne geldigheid in vroegere gevallen ${ }^{6}$ Zonder dit echter verder in het eerste deel van het artikel Aangeboren waarnemingsvormen te motiveren, beschouwt Spruyt Kants transcendentaal idealisme, zoals dit werd overgenomen en uilgewerkt door Schopenhauer en Helmholtz,

'cí. Spruyt, C.B. (1871ã), op. cit. p. 66.

${ }^{2}$ cl. Spruyt, C.B. (1871a), op. cit. p. 66, 'De inwendige waarneming strijdt volstrekt niet met deze meening; zij vertoont ons bij onze bewuste handelingen nimmer iets anders dan een strijd van motieven, maar volstrekt geen wilsbepaling die aan de handeling zou voorafgaan. De langzame overgang der bewuste handelingen in onbewuste is op deze wijze geheel begrijpelijk.'

${ }^{3}$ cf. Spruyt, C.B. (1871a), op. cit. p. 66.

${ }^{4}$ cf. Schopenhaver, A. (1813/18472), Uber die vierfache Wurzel des Satzes vom zureichenden Grunde, $\S 21$, p. 101, '...zwischen dem Willenakt und der Leibesaktion ist gar kein Kausalzusammenhang; sondern Beide sind unmittelbar Eins und das Dasselbe, welches. doppelt wahrgenommen wird; cin Mal im Selbstbewustseyn, oder innern Sinn, als Willensakt; und zugleich in der äussern, rảumlichen Gehirnanschauung, als Leibesaktion.'

cf. Spruyt, C.B. (1871a), op. cit. p. 66, 'Beiden (Spencer en Schopenhauer) stemmen volmondig overeen in de slelling, dat de eenige oorzaken van onze handelingen te zocken zijn in de motieven, dat is in de verschillende gewaarwordingen, voorstellingen, herinneringen, die hunnen invloed op die handeling hebben uitgeoefend. (.....) Zij beschouwen beiden de wilsuiting als de ontstaande handeling. subjectief waargenomen. Zij is dus niet de oorzaak van die handeling maar is met die handeling identisch. (...) De wilsuiting kan dus nielt voor de. handeling worden waargenomen, maar alleen tegelijk met, of na de handeling.'

${ }^{6}$ cf. Spruyt, C.B. (1871a), op. cit. p. 49. 
zonder meer als het enig mogelijke antwoord op Hume's vraag. In Schopenhauers Über die vierfache Wurzel des Satzes vom zureichenden Grunde $\left(1813 / 1847^{2}\right)^{1}$ en in Helmholtz' Physiologische Optik (1860) ${ }^{2}$ werd namelijk de aprioriteit onzer kennis van het causaalverband op onwederlegbare wijze vastgesteld. ${ }^{3}$

Het tweede deel van Aangeboren waarnemingsvormen is voor een groot deel gewijd aan een uiteenzetting van de Transcendentale Ästhetik, zoals Kant die in de Kritik der reinen Vernunft had geformuleerd en aan een weergave van Schopenhauers beschouwing $\left(1813 ; 1847^{2}\right)$ over het principe van voldoende grond. Met deze uiteenzettingen wil Spruyt zijn eerder getrokken conclusie onderstrepen dat men het causaliteitsvraagstuk niet kan oplossen door verder te zoeken naar de oorsprong van het causaalverband. De empiristische benadering van dit vraagstuk heeft al met al niets opgeleverd. Bovendien concludeert hij dat de eene helft der empirische wijsgeeren (zich) onverholen aansluit bij Hume; de andere helft ontkent op onhoudbare gronden de verdienste, die er in zijne vraag ligt, en streeft er met alle kracht naar, de wetenschap van het menschelijk kenvermogen terug te voeren naar het lagere standpunt, waarop zij voor Hume stond. ${ }^{4}$

Spruyt voegt echter geen nieuwe elementen toe aan Kants opvatting over tijd en ruimte en evenmin aan Schopenhauers beschouwing over het principe van voldoende grond. Hij gebruikt Kants leer als argument om te benadrukken dat de waarheid van Kant's leer over tijd en ruimte met waarschijnlijkheid (volgt) dat hij ook in het vraagstuk van het causaalverband recht heeft tegen Hume; ; en, zo kan men er aan toevoegen, als argument tegen de empiristische filosofen ná Hume. Uit het feit dat men er van overtuigd is dat de wet van oorzaak en gevolg noodzakelijk is, moet

'cf. Schopenhauer, A. (1813/18472), op. cit, § 21, p. 89, 'Ich habe alle diese das Sehn betreffende so ausführlich dargelegt, um deutlich und unwiderleglich darzuthun, dass in ihnen vorwaltend der Verstand thätig ist, welcher dadurch, dass er jede Veränderung als Wirkung auffasst und sie auf ihre Ursache bezieht, auf der Unterlage der apriorischen Grundanschautungen des Raums und der Zeit, das Gehirnphänomen der gegenständlichen Welt zu Stande bring, wozu ihm die Sinnesempfindungen bloss einige Data liefert. Und zwar vollzieht er dieses Geschâft allein durch seine eigene Form, welche das Kausalitätsgeselz ist, und daher ganz unmittelbar und intuitiv, ohne Behülfe der Reflexion, d.i. der abstrakten Erkenntnisss, mittels Begriffen und Worten, als welche das Material der sekundären Erkenntniss, d.i. des Denken, also der Vernunft ist.'

2 cf. Helmholtz, H. (1860), Plysiologische Optik, § 26, p. 453, 'Das Causalgesetz ist wirklich ein a priori gegebenens, ein transcendentales Gesetz. Ein Beweis desselben aus der Erfahrung ist nicht möglich; denn die ersten Schritte der Erfahrung sind nicht möglich, ohne die Anwendung von Inductionsschlüssen, d.h. ohne das Causalgesetz; und aus der vollendeten Erfahrung, wenn sie auch lehrte, dasz alles bisher Beobachtete gesetzmässig verlaufen ist- was zu versichern wir doch lange noch nicht berechtigt sind - würde immer noch erst durch einen Inductionsschluss, d.h. unter Voraussetzung des Causalgesetz folgen können, dasz nun auch in Zukunft das Causalgesetz gültig sein würde.'

${ }^{3}$ cf. Spruyt, C.B. (1871a), op. cit. p. 67.

4 cf. Spruyt, C.B. (1871a), op. cit. p. 414.

${ }^{5}$ cf. Spruyt, C.B. (1871a), op. cit. p. 467. 
volgen dat die wet een vorm is (...) die door het subject uit de eigen middelen wordt voortgebracht. ${ }^{1}$ Men heeft alleen kennis van het noodzakelijk en algemeen geldende causaliteitsbeginsel door het besef dat bij gelijke omstandigheden gelijke gevolgen zullen optreden. Bovendien gebruikt Spruyt Schopenhauers leer van voldoende grond als argument voor de opvatting dat men intuitief uitgaat van het causaliteitsbeginsel, en dat dit besef pas manifest wordt door het ervaren van bijzondere gevallen. ${ }^{2}$

In het tweede deel van Aangeboren waarnemingsvormen komen echter geen nieuwe argumenten naar voren die voor de discussies van belang zijn. Wel wordt in dit deel Spruyts schatplichtigheid aan Kant en Schopenhauer duidelijk, omdat hij hen als autoriteiten gebruikt om zijn eigen standpunt meer gewicht te geven.

Samengevat komt Spruyls argumentatie in hoofdlijnen op het volgende neer. Centraal in Spruyts betoog staat Hume's geldigheidsvraag: hoe kan men rechtvaardigen dat men, op grond van eerdere waarnemingen van het optreden van een bepaald verschijnsel nadat een bepaald ander verschijnsel is waargenomen, concludeert dat het ene verschijnsel in toekomstige gevallen altijd zal volgen na het optreden van het andere verschijnsel? Vanuit deze vraagstelling bekritiseert Spruyt Opzoomers twee argumentaties die moesten aantonen dat zowel de twee noties 'oorzaak' en 'noodzakelijkheid' als het causaliteitsbeginsel op ervaring zouden berusten.

De kritiek op Opzoomers eerste argumentatie betreft ten eerste zijn opvatting dat het regelmatigheidsbeginsel berust op het causaliteitsbeginsel. Opzoomer is van oordeel dat dit laatste beginsel uiteindelijk is gefundeerd op inductie. Spruyt wijst er op dat hiermee inductie weer door een andere inductic wordt gerechtvaardigd, en dat Opzoomers redenering daarom circulair is. Spruyt merkt bovendien op dat Opzoomer Hume's geldigheidsvraag "wegdefinieert".

De kritiek van Spruyt op Opzoomers tweede argumentatie bestaat uit twee delen. Het eerste deel betreft een kritiek op Opzoomers stelling dat de notie 'noodzakelijk verband' berust op inwendige waarneming. Spruyt merkt op dat Opzoomer ten onrechte de notie 'noodzakelijk verband' gelijk stelt met de notie 'innig verband'. Dit acht hij een misleidende formulering, waardoor Opzoomer ten onrechte de suggestie wekt alsof hij hiermee Hume's vraag beantwoordt. Spruyt wijst er vervolgens op dat Opzoomer er van uitgaat dat de notie 'innig verband' door herhaalde waarneming

${ }^{1}$ cf. Spruyt, C.B. (1871a), op. cit. p. 467.

${ }^{2}$ cf. Spruyt, C.B. (1871a), op. cit. p. 467, '.... onze kennis van de wet der causaliteit (bepaalt zich), voor zoover zij algemeen en noodzakelijk is, slechts tot het bewustzijn, dat bij gelijke omstandigheden gelijke verschijnselen te verwachten zijn; dat de wet in het algemeen. gelden moet. Onze kennis van de werking der wet in bijzondere gevallen berust alleen op ervaring. (....) Slechts door, als Schopenhauer, het bewijs te leveren, dat onze allereerste waarneming moet zijn voorafgegaan door de intuitieve toepassing der wet van oorzaak en gevolg, kan met zekerheid worden aangetoond, dat ook de vorm der causaliteit met de vormen van tijd en ruimte behoort $10 t$ de waarnemingsvormen....' 
ontstaat. Ook deze redenering is circulair. Immers, als men zegt dat de notie 'innig verband' via inductie ontstaat, gaat men er impliciet van uit dat inductic reeds mogelijk is. Inductieve uitspraken waarin een causaal verband wordt gelegd tussen verschijnselen onderstellen al de notie 'causaliteit'. Ook op dit punt laat Opzoomer inductic wederom op een andere inductie berusten.

In het tweede deel van zijn kritiek op Opzoomers tweede argumentatie constateert Spruyt dat eersigenoemde vreemd genoeg met geen woord rept over Hume's belangrijke argumenten tegen het afleiden van de notie 'noodzakelijkheid' (en 'oorzaak') uit de relatie tussen wilsbepalingen en daarmee corresponderende handelingen.

Eén van de meest discutabele punten in Opzoomers redenering acht Spruyt de constatering dat het ervaren van een noodzakelijk volgen van een handeling op een bewuste wilsbepaling als de bron moet worden gezien voor het ontstaan van de notic 'noodzakelijkheid'. Spruyt tracht deze constatering door drie tegenargumentaties te weerleggen.

De eerste tegenargumentatie gaat er van uit dat onbewuste wilsbepalingen bestaan. Het merendeel van handelingen vindt plaats zonder dat men daarvoor een bewuste wilsbepaling kan aanwijzen. Omdat Opzoomer kennelijk niets wil weten van het bestaan van onbewuste wilsbepalingen, betekent dit dat hij daarom het merendeel van onze handelingen als niet-veroorzaakt moet opvatten. Ook voor een empirist als Opzoomer moet dit een onacceptabele conclusie zijn. En, als men al uit zou gaan van de opvatting dat een handeling noodzakelijk volgt op een bewuste wilsbepaling, dan leidt dit er toe dat Opzoomer evenzeer moet ontkennen dat alle verschijnselen een oorzaak hebben. Immers, Opzoomers bewijs toonde alleen aan dat sommige handelingen op een wilsbepaling volgen.

Spruyts tweede tegenargumentatie gaat er van uit dat bewuste wilsbepalingen en daarmee corresponderende handeling niet noodzakelijk met elkaar zijn verbonden. Dit blijkt uil de feiten. Men wordt zich pas bewust van een wilsbepaling nadat een handeling heeft plaatsgevonden. Er is bovendien geen duidelijk onderscheid tussen bewusic willekeurige en onbewuste willekeurige handelingen. Ten slotte worden bewuste willekeurige handelingen niet vooraf gegaan door expliciete wilsbepalingen. Daarom concludeert Spruyt dat er geen noodzakelijk verband bestaat tussen handelingen en bewuste wilsbepalingen.

De derde tegenargumentatie moet de genadeslag vormen voor Opzoomers theorie, want de relatie tussen wilsbepalingen en handelingen is in het geheel geen causale relatic. Wilsbcpalingen zijn geen oorzaak voor handelingen, omdat zij met handelingen samenvallen. In plaats van wilsbepalingen vormen alleen motieven de oorzaken voor bewuste en onbewuste handelingen. Opzoomers notic 'wilsbepaling' vormt derhalve een overbodige theoretische constructic.

In het tweede deel van Aangeborch waarnemingsvormen onderstrecpt Spruyt nogmaals het deficit van de empiristische benadering van het causaliteitsvraagstuk. De ontstaansbenadering die in deze denkrichting ligt besloten, heelt tot niets geleid. Spruyt onderschrijft ten slolte volledig de conclusies van Kant en vooral van die van 
Schopenhauer dat de notie 'causaliteit', in Spruyts terminologie, een aangeboren waarnemingsvorm is.

Spruyt sluit op het punt van de formulering van het causaliteitsvraagstuk expliciet aan bij Hume. Met Kant beschouwt Spruyt Hume's formulering daarvan terecht als een geldigheidsvraag: door welke redeneering verkrijgen wij de sioutmoedigheid van te meenen, dat verschijnselen, die wij eenige malen elkander hebben zien volgen, ook in de toekomst op elkander volgen zullen? Voorts sluit Spruyt expliciet aan bij Kant als het gaat om de stelling dat de notie 'causaliteil' a priori is. Redenerend vanuit een geldigheidsbenadering luidt Spruyts principiële verwijt tegen Opzoomer dat hij ontstaans- en geldigheidsvragen met elkaar verwart. Dit leidt tot inconsequente, circulaire argumentaties; bovendien is het beantwoorden van de vraag hoe zowel de twee noties 'causaliteit' en 'noodzakelijkheid' als het causaliteitsbeginsel ontstaan nog geen antwoord op de vraag wat de redenen zijn voor de geldigheid van het gebruiken van deze noties en dat beginsel. Uit Spruyts behandeling van het causaliteitsvraagstuk blijkt overigens dat dit zich goed leent voor een probleemgerichte benadering.

Een tweede kanttekening betreft Spruyts argumentatiestrategie die moet aantonen dat Opzoomers argumentaties om de twee noties 'oorzaak' en 'noodzakelijkheid' en het causaliteitsbeginsel uit de ervaring af te leiden inconsequent en circulair zijn. Het gaat hier primair om een "logische" kritiek. Zodra de inconsistenties in Opzoomers argumentaties zijn aangetoond, volgt bij wijze van een reductio ad absurdum dat 'causaliteit', 'noodzakelijkheid' en het causaliteitsbeginsel a priori zijn. Hoewel Spruyt door deze argumentatiestrategie in veel gevallen de vinger op de zere plek in Opzoomers redeneringen legt, ontbreekt het toch aan een directe en inhoudelijke argumentatic voor het a priori karakter van de twee genoemde noties en het causaliteitsbeginsel. Een positieve uitzondering op deze strategie komt naar voren in een aantal van Spruyts inhoudelijke argumenten tegen Opzoomers wilstheorie. Echter, op het punt waar het spannend gaat worden en waar men een uitvoerige onderbouwing van het a priori karakter van de notie 'causaliteit' zou verwachten, verwijst Spruyt aan het slot van het eerste deel van Aangeboren waarnemingsvormen en in het gehele tweede deel van dat artikel zonder verdere omhaal naar Kant, Schopenhauer en Helmholtz. Dit vormt een treffend voorbeeld van het gebruiken van autoriteitsargumenten.

Daarnaast moet worden gewezen op Spruyts eigenzinnige Kant-interpretatic, waardoor het kantiaanse onderscheid tussen vormen en begrippen vervaagt. Kant maakte een onderscheid tussen aanschouwingen (Anschauungen) en begrippen (Begriffe). Spruyt verstaat onder de notie 'waarnemingsvorm' zowel aanschouwingsvormen als verstandsvormen.

Ten slotte kan worden opgemerkt dat Spruyts weergave van wat Hume met de notie 'oorzaak' bedoelt, selectief is. Hume beweert dat zowel contiguïteit en successie 
als noodzakelijkheid de essentiële kenmerken van de notie 'oorzaak' zijn.' Spruyt noemt hiervan vreemd genoeg alleen de laatste twee elementen. Kennelijk acht hij contiguïteit niet van belang. Echter, als contiguitteit als een essentieel element van causaliteit wordt gezien, dan betekent dit dat de analyse hiervan zich tot voorbeelden van concrete mechanische beweging beperkt. Immers, zulke verschijnselen vinden plaats in tijd-ruimtelijke nabijheid, zoals naar voren komt in Hume's beroemde voorbeeld van kaatsende biljardballen. Spruyt omzeilt deze beperking echter door impliciet over te gaan op causaal gedetermineerde ketens.

In de volgende paragraaf wordt Opzoomers reactie op Spruyts kritiek onder de loep genomen.

\section{OPZOOMERS REPLIEK OP SPRUYT}

Spruyts kritiek valt bij Opzoomer niet in goede aarde. Verontwaardigd en met onverholen woede reageert hij in Een nieuwe kritiek van de wijsbegeerte der ervaring beschouwd (1871). Zijn weerwoord opent met een persoonlijke aanval op Spruyt die bedoeld is om hem als serieuze discussiepartner ongeloofwaardig te maken. Hij schildert Spruyt af als een filosofische snotneus die net komt kijken, aanmatigend is, de verkeerde grapjes maakt, op een foute manier polemiseert en redeloos aanschopt tegen het filosofische establishment in Nederland: wanneer in een gezelschap een onbekend man heeft plaatsgenomen, die terstond niet alleen het hoogste woord neemt, maar tevens iedereen beledigingen naar het hoofd werpt, dan hoort men een tijd lang verbaasd en stilzwijgend hem aan. Maar eindelijk raakt het geduld ten eind. Men staat op en vraagt naar rang en titel, om zoo veel aanmatiging te dekken. ${ }^{2}$

\section{Nogmaals: 'innig en vast verband'}

Spruyt had in Aangeboren waarnemingsvormen Opzoomers opvatting op de korrel genomen dat sommige verschijnselen inniger met elkaar verbonden zijn dan andere. Uit het waarnemen van zo'n innig verband zou men afleiden dat men te maken heeft met een noodzakelijke relatie tussen twee verschijnselen. Hieruit zou men weer kunnen concluderen dat er sprake moet zijn van een causaal verband tussen zulke verschijnselen. Spruyt had voor deze opvatting geen goed woord over, omdat Opzoomer de innigheid van zo'n verband impliciet gelijk had gesteld met de noodzakelijkheid van causale relaties. Bovendien leek Opzoomers notie 'innig

' cf. Hume, D. (1739/1740), op. cit., book I, part III, section II, p. 76-77, 'Having this discover'd or suppos'd the two relations of contiguity and succession to be essential to cause and effects, I find I am stopt short, and can proceed no farther in considering any single instance of cause and effect. (....) There is a necessary connexion to be taken into consideration; and that relation is of much greater importance, than any of the other two abovemention'd:'

${ }^{2}$ cf. Opzoomer, C.W. (1871), op. cit. p. ?. 
verband' verdacht veel op Mills notie 'standvastige en onvoorwaardelijke opvolging', met alle bezwaren van dien. Ten slotte had Opzoomer met zijn verhullende taalgebruik gesuggereerd dat Hume's geldigheidsvraag zou zijn opgelost. Dit waren niet mis te verstane tegenargumenten.

Met merkbare tegenzin over zoveel onbegrip zet Opzoomer zich in de Nieuwe kritiek er toe om nog eens uit te leggen wat die notie 'innig en vast verband' inhoudt. Het gaat hem overigens niet zozeer om de zaak zelf, maar vooral om het publiek te laten zien dat Spruyt op een oneerlijke manier polemiseert tegen het grote gelijk van de Utrechise professor.

Met de notie 'innig en vast verband' wordt alleen aangegeven, zo betoogt Opzoomer, dat aan ieder verschijnsel (consequens) één of meer gelijktijdige verschijnselen vooraf gaan (antecedens). Zulke verschijnselen zijn echter niet alle op dezelfde wijze verbonden met de consequens; dat wil zeggen, de consequens kan optreden ook al ontbreekt één of meer van de antecendenten. In dat geval is er sprake van een toevallige relatie tussen antecendenten en de consequens. De consequens treedt niet op als daar niet bepaalde antecedenten aan vooraf zijn gegaan. Dit wijst er op dat sommige antecedenten inniger dan andere samenhangen met de consequens. Hieruit kan men afleiden dat zulke antecedenten een geheel eigenaardige natuur moeten hebben, die men de 'oorzaak' van een bepaald verschijnsel noemt. ${ }^{1}$ Met andere woorden: als het gaat om causale relaties dan worden daarmee alleen onveranderlijke, onvoorwaardelijke opvolging bedoeld.

Opzoomer wil (niet) uitweiden over de onkunde van dr. Spruyt, den natuurvorscher. ${ }^{2}$ Wat hij echter nog wel wil opmerken is dat Spruyts kennelijke gebrek aan filosofisch raffinement blijkt uit diens onbegrip dat in de filosofie het inzicht dat een verschijnsel met sommige antecedenten nauwer samenhangt dan met andere allang gesneden koek is. Ook is Spruyt er niet van op de hoogte, aldus Opzoomer, dat Mill al had aangetoond dat de causale samenhang tussen verschijnselen alleen neerkomt op onvoorwaardelijke opvolging. Bovendien heeft het weinig zin om zich nog af te vragen of de notie 'onvoorwaardelijke opvolging' verschilt van de notie 'noodwendige opvolging'. Ten slotte acht Opzoomer het overbodig om zich verder in te laten met de vraag of Mill en hijzelf er in zijn geslaagd om de onvoorwaardelijk-

${ }^{\prime}$ cf. Opzoomer, C.W. (1871), op. cit. p. 11, Ieder verschijnsel, van welken aard het ook zij, wordt voorafgegaan door een groot aantal van gelijktijdige verschijnselen. Te zamen zijn die antecedenten. Maar van al die antecedenten is het niet met alle even vast verbonden. Vele antecedenten kunnen ontbreken, terwijl toch het verschijnsel volgt. Zoodra daarentegen andere ontbreken, blijft het verschijnsel uit. Komen ze er weer bij, dan volgt ook weer het verschijnsel. Met deze is het verschijnsel dus veel vaster, nauwer, inniger verbonden dan met de andere. Ze zijn niet maar, gelijk de laatste, antecedenten alleen; ze zijn antecedenten van zoo geheel eigenaardige natuur, dat wij er ook een eigen naam, dien van oorzaak, aan geven.'

${ }^{2}$ cf. Opzoomer, C.W. (1871), op. cil. p. 12. 
heid van het causaalverband te bewijzen, en daarmee ook te hebben aangetoond dat causale relaties noodzakelijk zijn. ${ }^{{ }^{\prime}}$

Spruyt kón zijn redenering niet misverstaan, maar hij vond het voor zijn doel kennelijk beter er de meest valsche en oneerlijke uitlegging aan te geven, zo merkt Opzoomer op. Hij acht het zinloos om al deze vaststaande inzichten nog eens te beargumenteren. Wat zou het mij baten zijn lange redeneeringen te bestrijden en er even lange redeneeringen tegenover te stellen? Verschil van gevoelen, uit waarheidsliefde geboren, kan op dien weg tot een beslissing worden gebracht. Maar tegen zulk een polemiek helpt geen betoog. ${ }^{2}$ Opzoomer voegt daar nog aan toe: als een dief mijn huis is binnengedrongen, laat ik mij niet in met een juridischen twist over mijn eigendomsrecht, maar werp hem buiten de deur. Spruyts kritiek moet Opzoomer dus heel erg hoog zitten. Evenmin strijd ik met bewijzen tegen oneerlijke opvatting van woorden. Wat zouden de treffendste bewijzen uitrichten? Dr. Spruyt blijft altijd aan het laatste woord, zoolang hij zich het recht toekent, mijne woorden of te verdraaien of valsch te verklaren. Tegenover zulk een handelwijze baat alleen ontmaskering, eens voor altijd. ${ }^{3}$

Op welke manier Spruyt volgens Opzoomer oneerlijk polemiseerde en hoe Opzoomer hem denkt te ontmaskeren komt in de volgende sectie aan de orde.

\section{Kritiek op Spruyts argumentatiestrategie}

Spruyts algemene kritiek op het empirisme kwam er op neer, zo betoogt Opzoomer, dat deze denkrichting de drie noties 'causaliteit', 'tijd' en 'ruimte' ten onrechte als begrippen en niet als aangeboren waarnemingsvormen beschouwt. Opzoomer acht Spruyts semantische kritiek irrelevant. Het maakt Opzoomer niet uit of men het aangeborene als een begrip of als een vorm opvat: aan den naam van het kind is ons niets gelegen. Alles komt daarop alleen aan, of het kind inderdaad leeft. Wat Spruyt kennelijk niet door had, was dat de notie 'begrip' dubbelzinnig is. Spruyt had hem geïnterpreteerd alsof hij die notie alleen in de betekenis van een op basis van ervaring gevormde abstractie had gebruikt; dat wil zeggen, gebruikt als een empirisch begrip. Dit acht Opzoomer verkeerd. Hij wijst er op dat de notie 'begrip' een veel ruimer(e) betekenis heeft, omdat hiermee doorgaans zowel empirische begrippen

' cf. Opzoomer, C.W. (1871), op. cit. p. 12-13, 'Ik wil thans niet uitweiden over de onkunde van dr. Spruyt, den natuurvorscher, die er vreemd van opkijkt, als iemand hem herimnerl, dat een verschijnsel met sommige antecedenten nauwer samenhangt dan met andere. Ik wil evenmin mij ophouden bij de miskenning van de leeren van Mill en van mij, die beiden den causaalsamenhang nooit in iets anders hebben gezocht dan juist in de onvoorwaardelijke opvolging, $\mathrm{cn}$ die herhaalde malen in de meest uitdrukkelijke bewoordingen daarvoor zijn uitgekomen. Ik wil evenmin vragen of onvoorwaardelijke opvolging dan verschillend is van noodwendige opvolging, en of Mill en ik, zoo het ons gelukte de onvoorwaardelijkheid van het causaalverband te bewijzen, die ook dr. Spruyt zelf aanneemt, dus niet het bewijs geleverd hebben der noodwendigheid van het causaalverband.'

${ }^{2}$ ef. Opzoomer, C.W. (1871), op. cit. p. 13.

${ }^{3}$ cf. Opzoomer, C.W. (1871), op. cit. p. 14. 
als aangeboren waarnemingsvormen worden bedoeld. Dat dit zo is, daarvan is hem (Spruyt) nooit iets bekend geworden. Het is daarom niet van belang hoe gij het aangeborene doopt; veel belangrijker is de vraag of het aangeborene bestaat. ${ }^{1}$ Anders gesteld: hebben wij in onze natuurkennis een aangeboren, niet aan de ervaring ontleend bestanddeel om het even hoe dat dan genoemd worde? Empiristen en idealisten geven op deze vraag een totaal verschillend antwoord. Empiristen zoals Opzoomer zeIf, zeggen: neen. Idealisten zoals Spruyt, beantwoorden deze vraag met: ja. ${ }^{3}$ Immers, het empirisme gaat er van uit dat alle kennis van natuurverschijnselen uitsluitend is gebaseerd op zintuiglijke waarneming. ${ }^{4}$ Met andere woorden: voor verstandsvormen of begrippen a priori is in het empirisme geen plaats. Het idealisme gaat er van uit dat niet al onze natuurkennis is gebaseerd op zintuiglijke waarneming. Sommige elementen in die kennis, zoals de notie 'causaliteit', zijn geen resultaat van ervaring, maar vormen het oorspronkelijk bezit des geestes. ${ }^{5}$ Zo'n antwoord op de vraag echter verklaart niets, aldus Opzoomer. Empiristen ondernemen ten minste serieuze pogingen om aan te tonen dat noties die men doorgaans als aangeboren opvat toch uit de ervaring zijn af te leiden. Idealisten baseren zich bovendien voornamelijk op een negatieve en indirecte bewijsvoering; zij gaan enkel ontkennend te werk. Met inhoudelijke, directe argumenten komen zij niet voor de dag. De argumentatiestrategie van idealisten is er in de eerste plaats op gericht om aannemelijk te maken dat de argumenten die er volgens het empirisme voor pleiten dat alle begrippen herleidbaar zijn tot ervaring spaak lopen. Zodra dat is gedaan, concluderen zij zonder meer dat sommige begrippen een inherent deel vormen van het denken, en daarom aangeboren zijn. ${ }^{6}$

${ }^{\prime}$ ef. Opzoomer, C.W. (1871), op. cit. p. 15, 'Noem dit (het aangeborene) naar hartelust aangeboren - of oorspronkelijk - bezit, eigendom, of hoe ge maar wilt, van den geest, noem het begrip, vorm of wat dan ook, aan den naam van het kind is ons niets gelegen; alles komt daarop alleen aan, of het kind inderdaad leeft.'

${ }^{2}$ cf. Opzoomer, C.W. (1871), op. cit. p. 16.

${ }^{3} \mathrm{cf}$. Opzoomer, C.W. (1871), op. cit. p. 16, 'Op die vraag nu antwoordt de empirische wijsgeer ontkennend; Kant en alle andere idealisten, hoe ver ook in andere dingen viteenlopend, antwoorden bevestigend.'

${ }^{4}$ ef. Opzoomer, C.W. (1871), op. cit. p. 14, 'Het karakter van de wijsbegeerte der ervaring is, voor zoover het de natuur betreft, hierin te zoeken, dat volgens haar al onze natuurkennis van zinnelijke waarneming der verschijnselen uitgaat.'

${ }^{5} \mathrm{cf}$. Opzoomer, C.W. (1871), op. cit. p. 15, 'Volgens haar (het idealisme), is er in onze natuurkennis een bestanddeel, dat niet aan de warncming der natuur, noch aan het enkel scheiden en verbinden van den geest te danken is, maar dat de geest uitsluitend aan zich zelf ontleent. Dit bestanddeel heet dan ook niet verkregen, maar aangeboren, of (....) oorspronkelijk, het oorspronkelijk bezit des geestes.'

${ }^{6}$ cf. Opzoomer, C.W. (1871), op. cit. p. 16, 'De idealisten daarentegen gaan enkel ontkennend te werk. Zij trachten het onvoldoende der empirische verklaring te bewijzen, om vervolgens op de vraag, hoe de begrippen of vormen, waarover gehandeld wordt, zoo zij niet aan de ervaring ontleend zijn, dan toch het decl zijn geworden van onzen geest, niets anders aan te voeren dan het eentonige: ze zijn altijd deel van onzen geest geweest.' 
De twee vragen: hoe komt onze geest aan die voorstellingen?' en: waarom nemen we voor ieder verschijnsel een oorzaak aan $?^{2}$ worden door Spruyt afgedaan met het weinigzeggende en gemakkelijke antwoord: dat is nu eenmaal zoo de inrichting van onzen geest. ${ }^{3}$ Opzoomer concludeert dat Spruyts argumentatie voor het bestaan van aangeboren waarnemingsvormen vaag is. Als Spruyt geen heldere voorstelling kan verbinden aan zijn termen en begrippen, dan kan zijn verklaring ook niets voorstellen. Spruyts idealisme levert niet meer op dan loze woorden. ${ }^{4}$ Opzoomer laat dan ook deze waarschuwing horen: Als we op dien weg moeten voortgaan, zullen onze landgenooten zeer spoedig in de duisternis der idealistische bespiegelingen verzonken zijn. (.....) Heerlijke toekomst die ons wacht, als zulk een idealisme ooit wortel schiet in den bodem van Nederland!

Opzoomer gaat tot besluit van zijn repliek nog kort in op Spruyts kritiek op zijn wilstheorie. Spruyt had deze theorie op verschillende punten aangevallen. Ook hier voelt Opzoomer zich geen recht gedaan. Het enige wat hij had willen aantonen was het volgende. Als na een wilsbepaling een handeling volgt, dan beseft men dat de wilsbepaling de oorzaak is van dic handeling. Dit wijst er vervolgens op dat er sprake is van een causale relatic tussen een wilsbepaling en een handeling. Opzoomer is van mening dat Spruyt hier alleen tegen had aangevoerd dat het mogelijk is dat na een wilsbepaling soms geen handeling volgt. Dit acht Opzoomer een trivialiteit, en hij ziet hierin ook geen weerlegging van zijn wilstheorie. Nogmaals: als het gaat om causale relaties, zo benadrukt Opzoomer, dan betreft het alleen onveranderlijke, onvoorwaardelijk opvolging. ${ }^{6}$

Voor Opzoomer is het geen genoegen om met Spruyt te debatteren. Dit laat hij duidelijk merken aan het eind van de Nieuwe kritiek: (...) het is mijn doel niet, dr.

'cf. Opzoomer, C.W. (1871), op. cit. p. 16.

${ }^{2}$ cf. Opzoomer, C.W. (1871), op. cit. p. 19.

${ }^{3}$ ef. Opzoomer, C.W. (1871), op. cit. p. 19, 'De idealist (...) maakt er zich gemakkelijk van af. Ons kenvermogen is nu eens zoo ingericht, dat wij ieder verschijnsel beschouwen als het gevolg van een oorzaak. Meer weet hij ons niet te vertellen. Hij lierhaalt slechts het door niemand betwiste feit, maar denkt niet eens aan de gevraagde oplossing. Waarom nemen we voor iedei verschijnsel een oorzaak aan? was de vraag. Omdat we het moeten doen, omdat de natuur het zoo wil, luidt het antwoord.'

'cf. Opzoomer, C.W. (1871), op. cit. p. 19-21, 'Welke klare voorstelling kunt gij er mee verbinden, als u verzekerd wordt, dat gij de wet van oorzaak en gevolg als een aangeboren waarnemingsvorm in u hebt, dat zij tot de oorspronkelijke inrichting ban uwen geest behoort? Het blijven woorden, anders niet. (....) Op woorden en onderscheidingen van woorden loopt alles uit. Daarop worden we rijkelijk onthaald. Van duidelijke voorstellingen is er zelfs geen sprake.'

"cf. Opzoomer, C.W. (1871), op. cit. p. 21-22.

" cf. Opzoomer, C.W. (1871), op. cit. p. 27-28, 'Ik beweer, dat als na de wilsbepaling de handeling plaats heeft, ons zelfbewustzijn ons getuigt, dat ze ook door de wilsbepaling plaats heeft, door haar voortgebracht, veroorzaakt is, zoodat zich hier een verband van oorzaak en gevolg openbaart. En wat voert dr. Spruyt tegen die bewering aan? Dat het wel eens gebeuren kan, dat na de wilsbepaling de handeling geen plaast heeft. (.....) ...causaalverband bestaat in een onveranderlijke, onvoorwaardelijke opvolging......' 
Spruyt, te overtuigen en een wetenschappelijk geschil tusschen ons tot beslissing te brengen. Dat zou onbegonnen werk zijn. (....) Als geen hooger belang het mij tot plicht maakt, zal ik mij (...) niet meer met dr. Spruyt inlaten. ${ }^{1}$ Opzoomer heeft woord gehouden, want nergens kan een aanwijzing worden gevonden van verdere discussie tussen beiden.

Opzoomers weerwoord is gekleurd door emotie. Bovendien gaat hij niet op alle punten van Spruyts kritiek in. Dit acht hij ook niet nodig, want het enige wat hij wil aantonen is dat Spruyt hem moedwillig verkeerd heeft begrepen. Opzoomer komt daardoor niet veel verder dan het herhalen van zijn eerder ingenomen standpunten $\left(1851^{2} / 1863 ; 1867^{2}\right)$, waarbij hij er zonder meer van uitgaat dat zij geen nadere argumentatie nodig hebben. Voorts houdt hij vast aan de door Spruyt bekritiseerde gedachte dat de twee noties 'oorzaak' en 'noodzakelijkheid' berusten op ervaring. Dit blijkt uit zijn opmerking dat het empirisme er van uitgaat dat alle kennis van natuurverschijnselen uitsluitend is gebaseerd op zintuiglijke waarneming, en dat dit derhalve ook geldt voor de noties 'oorzaak' en 'noodzakelijk verband'.

De kritiek van Opzoomer op Spruyts argumentatiestrategie bevat echter wel een kern van waarheid. Het is inderdaad zo dat Spruyt vooral indirecte bewijzen aanvoert voor het a priori karakter van de notie 'causaliteit', en vrijwel geen directe bewijzen. Terecht verwijt Opzoomer Spruyt dat diens antwoord op de geldigheidsvraag wat de rechtvaardiging is van het causaliteitsbeginsel wel al te genakkelijk is. Bovendien is Opzoomers constatering juist dat Spruyt zich verschuilt achter Kant, Schopenhauer en Helmholtz. Echter, op dit punt verwijt de pot de ketel: net als Spruyt denkbeelden ontleent aan bijvoorbeeld Kant, is Opzoomer schatplichtig aan Mill.

Opmerkelijk is dat Opzoomer nauwelijks ingaat op Spruyts belangrijke bezwaren tegen zijn wilstheorie, die toch een hoeksteen vormt voor Opzoomers causaliteitsopvatting. Hij selecteent slechts één van Spruyts tegenargumenten om zijn eigen gelijk nogmaals te onderstrepen. Opzoomer heeft gelijk dat het door hem aangehaalde tegenargument van Spruyt weinig hout snijdt. Immers, een enkele inwendige waarneming van een wilsbepaling en een handeling zou al voldoende moeten zijn om te constateren dat er een causale relatie tussen wil en daad bestaat. Echter, Spruyts belangrijkste tegenargument bespreekt Opzoomer niet, namelijk dat de notie 'wilsbepaling' een overbodige theoretische constructie zou zijn.

In de volgende paragraaf wordı nagegaan met welke argumenten Van der Wijck Opzoomers denkbeelden tegen Spruyts aanval meent te kunnen verdedigen.

'cf. Opzoomer, C.W. (1871), op. cit. p. 34-35. 
Met de benueming in 1863 van Van der Wijck tot hoogleraar in de lïlosofie aan de Rijksuniversiteil Groningen werd de positie van Opzonmers empirisme versterkt. Dit bleef nict unopgemerkt. De immer kritische Johannes Van Vloten (1818-1883) bijvoorbeeld wijdde hicr zelfs cen artikel aan, getiteld De ridder Opzoomer en zijn .x.hildknaap (1865). De speelse titel geclt aan hoe kennelijk werd gedacht over de verhouding tussen beide denkers en over de toenemende invloed van Opzoomers empirisme. Het geelt ook cen indruk hoe sommigen mel lede ogen aanzagen dat Van der Wijck optrad als Opzoomers Groningse “zetbaas". In dit opzicht is het vermeldenswaard hoe Spruyt in 1899 in zijn diesrede Het empiriocritisme terugblikt op deze periode, en waarin hij het empirisme van Opzoomer vergelijkl met de uitgangspunten van de kenthcoric van de Oostenrijkse filosoof Avenarius. Opzoomer's leer heeft haar invloed verloren. Zijn naam wordt zelden meer genoemd; zijn werk'n zelden gelezen, veel minder dan zij verdienen; en de jongeren onder $U$ zullen er zich allicht over verwonderd hebben die leer bij deze gelegenheid wit de onderwereld te zien uproepen. Toch was dic' in'loed dertig jaar geleden groot, ja drukkend groot. ${ }^{1}$

Vooral in het begin van zijn carrière als hoogleraar is Opzoomers invloed op Van der Wijck duidelijk te merken. Dit komt bijvoorbeeld tot uitdrukking in zijn vroege publikaties, zoals in het hekroonde Mr. Johannes Kinker als wijsgeer (1864²). Hicrin bekritisecrde hij vanuit het perspectief van Opzoomers empirisme Kinkers (1764$1845)$ vorm van kantianisme. Ook in zijn inaugurcle rede De oorsprong en grenzen der kennis (1863) valt Van der Wijcks intellectucle verwantschap met Opzoomer duidelijk op. Toen Opzoomers denkbeelden over causaliteit in 1871 direct in Spruyls schootsveld kwamen te liggen, keek men dan ook niet vreemd op dat Van der Wijck met De wijsbege'erte der envaring verdedigd (1871) voor Opzoomer in de bres sprong.

Voor cen goed begrip van de argumenten die in dat laatstgenoemde geschrift naar voren komen, is het zinvol om ecrst in te gaan op de denkbeelden die Van der Wijck in zijn inaugurcle rede De oorsprong en de grenzen der kennis ontvouwt. ${ }^{2}$

\section{De oorsprong en grenzen der kennis}

Vóór men bepaalde vragen kan beantwoorden, moet men eerst onderzoeken of zulke vragen überhaupt wel beantwoord kunnen worden, zo meent Van der Wijck. Dit betekent dat men een onderzoek moet instellen naar de krachten van den menschenlijken geest; dat wil zeggen, het onderzoeken van de vraag wat men kan kennen. Als

' cf. Spruyt, C.B. (1899), Het empiriocriticisme, de jongste vorm van de 'wijsbegeerte der ervaring', p. 10.

${ }^{2}$ Een kritische reactie op Van der Wijcks inaugurele rede is te vinden in de brochure van de thcoloog J. Roos getiteld De eerste wijsgeer der ervaring aan de Groningse Hoogeschool: kritisch-wijsgeerige beschouwing der inwijdingsrede van den hoogleraar B.H.C.K. van der Wijck (1863). Van der Wijck heeft op deze kritick niet gereageerd. Roos' kritiek wordt in deze studie niet verder besproken. 
men deze kwestie niet eerst met de fakkel der psychologie oplost, dan ontstaat het gevaar dat men alleen hersenschimmen najaagt. ${ }^{1}$ De grenzen van kennis komt men op het spoor door de volgende vraag te beantwoorden: op welke weg waren (voorstellingen en wetenschappen) verworven? Met andere woorden: hoe ontstaat kennis? Als men hiervoor een verklaring kan geven, dan duidt dit tevens de grenzen van kennis aan. ${ }^{2}$ Dit is de centrale vraag die Van der Wijck in De oorsprong en grenzen der kennis wil beantwoorden.

Van der Wijck constateert dat de vraag naar de oorsprong van kennis in de geschiedenis van de filosofie op verschillende manieren is beantwoord. Hierbij speelde de onderstelling van het al of niet bestaan van aangeboren begrippen een sleutelrol. Locke bijvoorbeeld had met verve verdedigd dat aangeboren begrippen niet bestaan, en dat alle begrippen ontstaan door ervaring. ${ }^{3}$ Andere filosofen, voorstanders der aangeboren begrippen, dachten dat er voorstellingen en kundigheden bestaan die niet door ervaring zijn ontstaan, maar inherent zijn aan het denken. ${ }^{4}$ Bovendien heeft het standpunt dat men inneemt over de vraag of aangeboren begrippen bestaan directe gevolgen voor het beantwoorden van het causaliteitsvraagstuk. Dit komt duidelijk naar voren in Hume's causaliteitsleer en Kants reactic daarop, zo constateert Van der Wijck.

Vóór Hume, zo betoogt hij, was de overtuiging dat natuurverschijnselen door causale relaties met elkaar zijn verbonden boven iedere twijfel verheven. De natuur is ziclızelf getrouw. ${ }^{5}$ Deze overtuiging werd door Hume kritisch onderzocht. Hume wilde namelijk een antwoord op de vraag wat de geloofsbrieven van de twee noties 'causaliteit' en 'noodzakelijkheid' waren. Met andere woorden: hoe kan men de notie 'causaliteit' rechtvaardigen? Hume had geconcludeerd dat men de "klassieke" notie van 'causaliteit' niet kan rechtvaardigen door een beroep te doen op ervaring. Men kan immers alleen het volgen van verschijnselen waarnemen, en niet de causale relaties tussen verschijnselen. Het herhaald waarnemen van het volgen van een

${ }^{1}$ cf. Wijck, B.H.C.K. van der (1863), De oorsprong en grenzen der kennis, p. 5-6, 'Als de denker vergeet zich tot zijne ontdekkingsreizen van de fakkel der psychologie te voorzien, zoo loopt hij kennelijk gevaar hersenschimmen in plaats van werkelijkheid na te jagen.'

${ }^{2}$ ef. Wijck, B.H.C.K. van der (1863), op. cit. p. 7, 'En mocht de oplossing van deze vráag eens zijn gelukt, zoo was die andere, aangaande de grenzen der kennis, geen eeuwig raadsel meer.'

${ }^{3}$ cf. Wijek, B.H.C.K. van der (1863), op. cit. p. 9, Alle kennis is geestelijk, maar de geest weet van nature niets, bezit ook geen oorspronkelijke kiemen der waarheid: hij moet alles leeren.'

${ }^{4} \mathrm{cf}$. Wijck, B.H.C.K. van der (1863), op. cit. p. 9, 'Zij (voorstanders der aangeboren begrippen) meenen dat $\mathrm{er}$ in den onbewusten achtergrond der ziel voorstellingen en kundigheden schuilen, die niet in ervaring haren oorsprong vinden, maar slechts op warneming of nadenken wachten om terstond in het bewustzijn op te treden, ...'

${ }^{s}$ cf. Wijck, B.H.C.K. van der (1863), op. cit. p. 12, 'Tot op dien Schotsen denker (Hume) had geen man van wetenschap aan het verband van oorzaak en gevolg getwijfeld. Niets scheen zoo zeker als dat de natuur aan zich zelve getrouw is, m.a.w. dat de dingen en toestanden dezer wereld bij elkander behooren.' 
bepaald verschijnsel nadat een bepaald ander verschijnsel is opgetreden, leidt er toe dat de gewoonte ontstaat om ene verschijnsel als oorzaak van het andere te beschouwen. Dit heeft als resultaat dat men aanneemt dat beide verschijnselen noodzakelijk met elkaar zijn verbonden. De noties 'causaliteit' en 'noodzakelijk verband' berusten uiteindelijk op gewoonte. Een verdere rechtvaardiging van de notie 'noodzakelijk verband' kan men niet geven. ${ }^{1}$

In reactie op Hume was Kant uiteindelijk tot de conclusie gekomen dat kennis is samengesteld uit ervaring én verstandelijke elementen: de inrichting onzes geestes. 'Causaliteit' is één van de vormen a priori die in het denken liggen besloten. Zulke vormen brengen structuur aan in de ongeordende stof van de gewaarwordingen. ${ }^{2}$ Deze hypothese had Kant uiteindelijk tot de conclusie gebracht dat het causaliteitsbeginsel een wet van mijn denken is, en niet uit ervaring kan worden afgeleid. ${ }^{3}$

Kant had hiermee tegenwicht willen bieden aan Hume's conclusie dat de noties 'causaliteit' en 'noodzakelijkheid' op ervaring en gewoonte zouden zijn gebaseerd. Deze conclusie had Kant opgevat als een gevaar voor de zekerheid van kennis. Kant sloeg hiermee echter de plank volledig mis, aldus Van der Wijck. Immers, Hume had alleen willen aantonen dat de notie 'causaliteit' berust op gewoonte, en dat deze notie niet door ervaring kan worden gerechtvaardigd. Hume had zich echter niet willen uitlaten over de vraag of verschijnselen los van onze ervaring causaal met elkaar zijn verbonden. Dit zou best mogelijk kunnen zijn, maar men kan dat niet waarnemen. ${ }^{4} \mathrm{Om}$ aan te tonen dat causale relaties wél noodzakelijk zijn, en dat

' cf. Wijck, B.H.C.K. van der (1863), op. cit. p. 12, 'Hume kwam op den inval, aan het begrip van causaliteit zijn geloofsbrieven af te vragen. Hij zocht ze in de ervaring, maar te vergeefs. Deze toch, aldus redeneert hij, vertoont ons slechts opvolging van verschijnselen; zij doet ons niet zien dat het eene gewrocht wordt door het ander. De gewoonte verleidt ons om verschijnselen, die wij na elkander plegen waar te nemen, als noodzakelijk verbonden voor te stellen; maar dat besluit kan niet gewettigd worden.'

${ }^{2}$ cl. Wijck, B.H.C.K. van der (1863), op. cit. p. 13-14, 'Volgens hem (Kant) bezit de mensch geen enkele voorstelling, spreekt hij geen enkel oordeel uit, trekt hij geen enkel besluit, waarin niet twee verschillende elementen vereenigd zijn: een dat aan ervaring, een ander dat aan de inrichting onzes geestes moet worden dank geweten. (....) Natuurlijk, zegt Kant, want tijd, ruimte en causaliteit zijn in iederen menschenlijken geest voor alle ervaring voor handen; het zijn de vormen, waarin wij de ongeordende stof, die ons door gewaarwording en aandoening toegeschoven wordt, overgieten moeten.'

${ }^{3}$ cf. Wijck, B.H.C.K. van der (1863), op. cit. p. 15, 'Neen, zegt Kant, de causaliteit is niet. buiten mij, maar in mij. De causaliteit is eene wet van inijn denken. Ziedaar waarom ik van ieder verschijnsel zeg: het moet eene oorzaak hebben. Ervaring toch toont slechts wat is, niet wat zijn moet, wat niet anders zijn kan.'

ci. Wijck, B.H.C.K. van der (1863), op. cit. p. 15, Door deze redeneeringen meende Kant de zekerheid terug te schenken, die door Hume was geroofd geworden. Maar de groote denker bedroog zich hier zeer. Hume zegl, dat het causaliteitsbegrip voor de vierschaar der wetenschap niet kan gerechtvaardigd worden. Zijn bewijsvoering is tegen ons ingebeeld. weten, niet tegen het verband van oorzaak en gevolg gericht. Hij laat de werkelijkheid van dit laatste in het midden. Het is mogelijk dat de dingen en toestanden dezer wereld bij elkander behooren, ook wanneer wij niet in staat zijn het waar te nemen. 
daarom kennis zeker is, had Kant de hypothese naar voren gebracht waarin deze de notie 'causaliteit' als inherent aan het denken opvatte. De notie 'causaliteit' moest daardoor als een aangeboren begrip worden gezien. Van der Wijck oordeelt dat Kant met deze zienswijze de wetenschap en filosofie absoluut geen dienst heeft bewezen. De notie 'causaliteit', en zelfs het geheel van wetenschappelijke kennis, kan door Kants zienswijze geen aanspraak meer maken op objectieve geldigheid. Waarheid wordt hierdoor onbereikbaar.'

De analyse van de opvattingen van Hume en Kant roept voor Van der Wijck de vraag op hoe weten wij dat alles eene oorzaak moet hebben $?^{2}$ Hiervoor acht hij twee verklaringen mogelijk. Hetzij: het denken bepaalt de ervaring; of: de ervaring bepaalt het denken. Als men van de eerste verklaring uitgaat, neemt men aan dat de verschijnselen causaal met elkaar samenhangen doordat causaliteit instinctief door den geest aan de werkelijkheid wordt toegevoegd. ${ }^{3}$ Als men van de tweede verklaring uitgaat, dan onderstelt dit ook dat alle verschijnselen causaal met elkaar samenhangen. In dit geval komt dat cchter omdat de verschijnselen, los van de ervaring, in werkelijkheid met elkaar samenhangen. Het denken ontleent in dit laatste geval aan de werkelijkheid zowel de vorm als de inhoud of stof van begrippen. ${ }^{4}$

Uit het bovenstaande blijkt al duidelijk dat Van der Wijck de laatste verklaring onderschrijft. De nadere uitwerking daarvan wordt aangetroffen in zijn beschouwing over het regelmatigheids- en causaliteitsbeginsel.

Het regelmatigheidsbeginsel is het algemeen geldende basisprincipe van de wetenschap, en het komt neer op het besef dat bij gelijke omstandigheden, gelijke verschijnselen volgen. Als men zou aannemen dat dit principe niet algemeen zou gelden, dan zou men ook moeten aannemen dat de werkelijkheid ongeordend is en dat kennis van de werkelijkheid pure fictie is. Dit acht Van der Wijck ondenkbaar. Het besef dat bij gelijke omstandigheden gelijke verschijnselen volgen heeft twee functies. De eerste functie is dat men waargenomen singuliere gevallen kan onderbrengen in een algemene wet. De tweede functie is dat men altijd oorzaken zoekt voor veranderingen. Echter, wat brengt ons deze uitspraak (gelijke

' cf. Wijck, B.H.C.K. van der (1863), op. cit. p. 16, 'Hij wil dat het causaliteitsbegrip voor alle ervaring in onzen geest reeds is aangelegd, en ontkent daardoor dat het ceuwige aanspraak op objectieve geldigheid kan maken. Wij zijn met Kant geen schrede gevorderd; integendee!, onze toestand is verergerd; de waarheid heeft ons voor eeuwig vaarwel gezegd.'

${ }^{2}$ ef. Wijck, B.H.C.K. van der (1863), op. cit. p. 17.

${ }^{3}$ ef. Wijck, B.H.C.K. van der (1863), op. cit. p. 17.

${ }^{4}$ cf. Wijck, B.H.C.K. van der (1863), op. cit. p. 17, 'Nu is er tweederlei oplossing mogelijk. Of de wereld der ervaring schikt zich naar onzen geest, of onze geest schikt zich naar de wereld der ervaring. In het eerste geval nemen wij de dingen in tijd en ruimte waar, onderstellen of bespeuren wij allerwege causaliteit, omdat tijd, ruimte, causaliteit instinctief door den geest aan de werkelijkheid wordt toegevoegd; m.a.w. bij de ervaring draait het noodlot ons een rad voor oogen ! In het tweede geval nemen wij de dingen in tijd en ruimte waar, onderstellen of bespeuren wij allerwege causaliteit, omdat de werkelijkheid in de vormen van iijd, ruimte, causaliteit tot ons dringt, en onze geest aan de werkelijkheid zoowel den vorm als de stof van zijne begrippen ontleent.' 
omstandigheden, gelijke gevolgen) op de lippen?' Met andere woorden: hoe ontstaat dit besel? Het idealisme onderstelt dat generaliseeren of het formuleren van algemene uitspraken een aangeboren drang is. Het besef dat bij gelijke omstandigheden, gelijke verschijnselen volgen is de basis voor inductic. Dit betekent dat het regelmatigheidsbeginsel niet zélf op inductic kan berusten, ondat men dan inductie door een andere inductie rechtvaardigt. Het idealisme concludeert daaruit dat de drang tot generaliseren inherent is aan het denken, en dat die neiging niet op ervaring is gebaseerd. ${ }^{2}$

Deze redenering leidt er volgens Van der Wijck toe dat kennis van de natuur niet anders wordt dan een herschenschim. Met andere woorden: als men aanneemt dat zowel de notie 'causaliteil' als het causaliteitsbeginsel subjectief (dat wil hier zeggen: de bijdrage van het kensubject) zijn, kan kennis geen aanspraak meer maken op objectieve geldigheid. Om het idealisme op dit punt te weerleggen gebruikt Van der Wijck het "argument van de geschiedenis". Hoewel men tegenwoordig aanneemt dat natuurwetten algemeen geldig zijn, was men zich daar vroeger niet van bewust. Dit besef is geleidelijk ontstaan..$^{3}$ Ook het besef dat bij gelijke omstandigheden gelijke gevolgen optreden is de rijpe vrucht van geleidelijke, langdurige ontwikkeling. ${ }^{4}$ Het regelmatigheidsbeginsel moet men daarom zien als een principe dat door ervaring is ontstaan. Hoewel men dit beginsel tegenwoordig als een regel van ons denken opvat, vinden alle wetten des geestes of denkwetten echter hun oorsprong in de ervaring. Men is er van overtuigd dat de werkelijkheid een geordend geheel is, omdat dil via ervaring wordt "ontdekt". Herhaalde waarneming bevestigt steeds de overtuiging dat dit inderdaad zo is. ${ }^{5}$ Dit geldt ook voor het besef van de regel: gelijke omstandigheden, gelijke gevolgen. Die regel is door zoveel waarnemingen bevestigd dat

' ef. Wijck, B.H.C.K. van der (1863), op. cit. p. 28.

2 cf. Wijck, B.H.C.K. van der (1863). op. cit. p. 27-28, 'Gelijke omstandigheden, gelijke verschijnselen! Moeilijk kan er eene stelling gevonden worden, welke gewichtiger rol speelt bij de vorming der wetenschap. Mocht zij onjuist zijn, zoo ware het heelal een chaos, al onze kennis ijdele waan. $\mathrm{Zij}$ is het, die ons ieder op zich zelf staand geval als voorbeeld van eene wet beschouwen doet; zij is het, die ons iedere verandering naar hare oorzaak vorschen doet. (...) De voorstander der redewaarheden bcroept zich hier op een aangeboren drang des menschen om te generaliseeren. Hij meent dat deze stelling, welke de hoeksteen is van alle overige inducties, niet zelve aan inductie haar bestaan verschuldigd kan zijn. Wij zouden het enkel aan de inrichting onzes geestes, niet aan de natuur der dingen hebben toe te schrijven, dat door ons uit waargenomen tot niet waargenomen gevallen besloten werd.'

${ }^{3}$ ef. Wijck, B.H.C.K. van der (1863), op. cit. p. 28, 'Bespeurt gij niet dat, indien deze theorie op vasten grond rust, al onze natuurkennis eene herschenschim is? Daarbij: het bewustzijn van onkreukbare natuurwetten heeft niet gegolden in alle eeuwen; het is de rijpe vrucht van geleidelijke, langdurige ontwikkeling....'

${ }^{4}$ cf. Wijek, B.H.C.K. van der (1863), op. cit. p. 29.

s cf. Wijck, B.H.C.K. van der (1863), op. cit. p. 29, 'Gelijke omstandigheden, gelijke verschijnselen! Het is waar: dit is thans een regel voor ons denken. Maar ook hier moeten de welten der natuur niet uit de wellen des geestes, omgekeerd de welten des geestes uil die der natuur worden afgeleid. Wij gelooven dat het heelal aan zich zelf getrouw blijft, daar het zich als zoodanig voor onzen blik ontsluyerd heeft. Hetgeen eenmaal onder onze oogen voorviel, wordt, bij herhaling der omstandigheden, wederom wargenomen.' 
het de hoogst mogelijk graad van zekerheid heelt. Deze empirische bevestiging vomt tegelijk de rechtvaardiging voor die regel. ${ }^{1}$ Van der Wijck besluit zijn inaugurcle rede dan ook met de algernene conclusie dat de oorsprong en de grenzen van alle kennis zijn gelegen in zintuiglijke ervaring.

\section{Kritiek op Spruyts notie 'aangeboren waarnemingsvorm'}

Van der Wijcks Wijsbegeerte der ervaring verdedigd (1871) kan men als cen verderc uitwerking van zijn inaugurele rede uit 1863 zien, en waarin Van der Wijck Spruyts aanval op Opzoomers causaliteitsleer probeert te pareren.

In Wijsbegeerte der ervaring verdedigd treft men cen veelheid van argumenten aan tegen Spruyts standpunten. Men zou Opzoomer er bijna van verdenken dat hij hel eigenlijke filosofische "spitwerk"aan Van der Wijck overlaat. Veel van Van der Wijcks argumenten hebben cchter nict direct met causaliteit te maken, en zij worden daarom in dit onderzock buiten beschouwing gelaten. Van der Wijcks argumentatie, althans voor zover het causaliteit betreft, is er vooral op gericht om Spruyts stelling te ontkrachten dat de notie 'causaliteit' een aangeboren waarnemingsvorm zou zijn. Na zijn kritiek op Spruyt voert Van der Wijck tevens argumenten aan tegen Humc's associatietheorie om de opvatting te weerleggen dat verwachtingen uit de associatie van voorstellingen zouden kunnen worden afgeleid.

Van der Wijck heeft grote moeite met Spruyts onderscheid tussen hel empirisch gegeven(e) en de waarnemingsvormen; kortweg: stof en vorm. Als men van dit onderscheid uitgaat, waar, zo vraagt hij zich af, blijft dan het onderscheid tusschen "de subjectieve elementen onzer voorstelling en de objectieve" ? ${ }^{3}$ En ook, hoe is het dan mogelijk de grens te trekken, die dr. Spruyt bepalen wil, de grens tusschen de eigenschappen van den waarnemer en die van het waargenomene? ${ }^{4}$ Van der Wijck concludeert dat er geen strikt onderscheid kan worden gemaakt tussen de waarnemer enerzijds en het waargenomene (voorstellingen en aanschouwingen) anderzijds. Immers, de dingen buiten het bewustzijn bepalen door hun werking de inhoud van de waarneming. De aard van die werking is echter ook afhankelijk van de aard van waar die werking op wordt uitgeoefend: de waarnemer. Retorisch vraagt hij dan ook: maar hoe zult gij die twee naturen scheiden, terwijl zij bij iedere werking samenwerken ${ }^{5}$ Met andere woorden: het is onmogelijk om wat men waameemt strikt

${ }^{1}$ cf. Wijck, B.H.C.K. van der (1863), op. cit. p. 30, 'Ook de overtuiging (...) dat wat eenmaal en ergens geschied is, bij herhaling der omstandigheden, wederom geschieden moet ook deze overtuiging wortelt in eene waarneming op zoo reusachtig uitgebreide schaal, dat wij zeggen mogen hier zekerheid erlangd te hebben, in zooverre zij voor wezens voor ons geslacht bereikbaar is.'

${ }^{2}$ cf. Wijck, B.H.C.K. van der (1863), op. cit. p. 33-35, 'Indien al onze begrippen, zelfs van het noodzakelijke en oneindige, uit hestanddeelen der ervaring zamenvloeyen, zoo moet ervaring en zij alleen de grens van het weten zijn.'

${ }^{3}$ cf. Wijck, B.H.C.K. van der (1871), op. cit. p. 30.

${ }^{4}$ cf. Wijck, B.H.C.K. van der (1871), op. cit. p. 35.

${ }^{5}$ cf. Wijck, B.H.C.K. van der (1871), op. cit. p. 35. 
te scheiden van wie waarneemt.'

Met deze algemene bedenking voor ogen, kan men zich vervolgens afvragen waar Spruyts duistere theorie vandaan komt dat bepaalde begrippen aangeboren zouden zijn. Er moet eene aanleiding zijn, welke haar ontwerpen deed? ${ }^{2}$ Voor Van der Wijck is deze vraag de aanleiding om in te gaan op de negatieve argumentatiestrategie van Spruyt, en om vervolgens enkele andere bezwaren tegens diens opvattingen aan de orde te stellen.

Voor de wijsbegeerte der ervaring of het empirisme is het evident dat het merendeel van voorstellingen, begrippen en kundigheden geheel stoelt op ervaring. Dit ligt ook voor de hand, omdat de empirische oorsprong van het merendeel van kennis en begrippen duidelijk is te traceren. Echter, voor sommige begrippen ligt dat niet zo eenvoudig, zoals voor noties als 'ruimte', 'tijd', 'causaliteit' en 'materie'. Van zulke noties is daarentegen evenmin bewezen dat zij niet op ervaring zijn gebaseerd. Uit het feit dat de empirische afleiding van zulke noties nog niet is geslaagd, mag men niet concluderen dat zo'n afleiding ook nooit zal lukken, aldus Van der Wijck. ${ }^{3}$ Met moet daarom vasthouden aan de methodologische regel dat alle begrippen een empirische oorsprong hebben. Een voorbeeld van een notie waarvan de empirische oorsprong onduidelijk was, is de notie 'materie'. Toch kan worden bewezen dat ook deze notie ontspringt aan de ervaring, namelijk door het te beschouwen als weerstandbiedende oorzaak van gewaarwordingen. ${ }^{4}$

' cf. Wijck, B.H.C.K. van der (1871), op. cit. p. 35, 'Men kan den waarnemer en het waargenome niet van elkander scheiden. Het denkbeeld van waarnemer verdwijnt, als men van het waargenomen abstraheert. En omgekeerd evenzoo. Immers beide termen, zoowel die van waarnemer als van wargenomen object, sluiten in zich eene betrekking. (....) Onze voorstellingen en aanschouwingen zijn werkingen, welke de dingen daar buiten in ons bewustzijn te voorschijn roepen. Iedere werking hangt, het spreekt van zelf, zoowel van de natuur van wat werkt af, als van de natuur van datgene, waarop gewerkt wordt. Maar hoe zult gij die twee naturen scheiden, terwijl zij bij iedere werking samenwerken?'

${ }^{2}$ cf. Wijck, B.H.C.K. van der (1871), op. cit. p. 17.

${ }^{3}$ cf. Wijck, B.H.C.K. van der (1871), op. cit. p. 36-37, 'De wijsbegeerte der ervaring leert, dat de draden, waruil onze voorstellingen, begrippen en kundigheden geweven worden, enkel gewaarwordingen, ondervindingen zijn. (....) Het is duidelijk, dat we het grootste deel onzer kennis uit de ervaring putten (...). Zoo kunnen we de meeste van onze begrippen en kundigheden rechtstreeks uit de ervaring afleiden. (...) Het is duidelijk, dat we het grootste gedeelte onzer kennis uit de ervaring putten. (...) Zoo kunnen we de meeste van onze begrippen en kundigheden rechtstreeks uit de ervaring atleiden. Men zou geheel blind moeten zijn om den empirischen stempel niet te zien, waar deze zoo duidelijk zichtbaar is. Maar er zijn enkele begrippen en kundigheden, van welke men erkennen moet, dat zij niet terstond een empirischen oorsprong verraden. (...) De analogie evenwel verpíicht ons, zoolang het bewijs van het tegendeel niet geleverd wordt, ze ook als empirisch aan te merken. Stel dat het nog niet gelukt is ze uit de ervaring af te leiden. Volgt er uit, dat die afleiding nimmer gehkken zal ?'

${ }^{4} \mathrm{cf}$. Wijck, B.H.C.K. van der (1871), op. cit. p. 38, '... ik geloof dat ons denkbeeld van materie als eene weerstandbiedende oorzak van veelsoortige gewaarwordingen uit empirische gegevens kan worden afgeleid. Ik meen dat zelf te hebben aangetoond.' 
De conclusie dat sommige begrippen aangeboren zijn, omdat nog niet is aangetoond dat zij uit de ervaring kunnen worden afgeleid, ligt niet alleen ten grondslag aan Spruyts, maar ook aan Helmholtz' argumentatiestrategie, zo betoogt Van der Wijck; een strategie die heeft geleid tot de theorie van aangeboren waarnemingsvormen.

Spruyt (1871a) had verwezen naar Helmholtz' Physiologische Optik (1860) waarin de aprioriteit onzer kennis van het causaalverband op onwederlegbare wijze (wordt) vastgesteld.' Net als Spruyt trekt Helmholtz naar Van der Wijcks smaak te snel conclusies. Bijvoorbeeld: het feit dat men nog niet heeft aangetoond dat de notie 'ruimte' uit ervaring kan worden afgeleid, betekent immers niet dat zo'n empirische verklaring in beginsel onmogelijk zou zijn. Het houdt ook niet in dat men mag concluderen dat die notic oorspronkelijk, aangeboren of intütief is. ${ }^{2}$ Nadruk wil ik hierop leggen, dat het hoogst willekeurig en voor de studie doodelijk is, wanneer van ieder begrip, welks afleiding uit de ervaring niet terstond gelukken wil, gezegd wordt: ergo is het oorspronkelijk, onverklaarbaar, aangeboren. ${ }^{3}$

Van der Wijck acht het onwaarschijnlijk dat noties - voorstellingen en kundigheden - die men niet rechtstrecks uit de ervaring kan afleiden, aangeboren zijn. Immers, in de meeste gevallen is gebleken dat voorstellingen en kundigheden wél door ervaring ontstaan. Men moet het daarom als een uitzondering op de regel beschouwen dat de empirische oorsprong van bepaalde noties nog niet duidelijk is. Dit betekent dat niet de wijsbegeerte der ervaring moet aantonen dat zulke noties toch uit de ervaring ontstaan. Neen, de advokaat van het aangeborene moet bewijzen dat het onmogelijk is om zulke noties uit de ervaring af te leiden." Met andere woorden: de voorstanders van de theorie van aangeboren waarnemingsvormen draaien dus met hun negatieve argumentatiestrategie ten onrechte de bewijslast om.

Echter, aan de theorie van aangeboren waarnemingsvormen kleeft nog een ander bezwaar: deze theorie is ontoetsbaar. Het is bijvoorbeeld onduidelijk hoe men kan toetsen dat de notie 'ruimite' aan iedere gewaarwording vooraf gaat. ${ }^{5}$ Bovendien menen

cf. Spruyt, C.B. (1871a), op. cit. p. 67.

${ }^{2}$ ef. Wijck, B.H.C.K. van der (1871), op. cit. p. 38-39, 'Stel dat nog niet gebleken is, dat de gewaarwordingen van spier- en tastgevoel zoodanig begrip kunnen doen ontstaan. Geeft ons dat recht het onderzoek: voor gesloten te verklaren en te zeggen: ergo is hei begrip van ruimte onverklaarbaaĩ, m.a.w. ọorspronkelijk, ångeburen, intuïtief?'

${ }^{3}$ cf. Wijck, B.H.C.K. van der (1871), op. cit. p. 39.

${ }^{4}$ cf. Wijck, B.H.C.K. van der (1871), op. cit. p. 40, 'Verder pleit de waarschijnlijkheid tegen de leer, dat wij onze voorstellingen en kundigheden ten deele niet aan ervaring verschuldigd zouden zijn. Want de regel is, dat wij ze wel door ervaring verwerven, dat wij ze door beweging en zinnelijke indrukken machtig worden. En daarom drukt de bewijslast niet op den schouders van hem, die het bestaan van uitzonderingen loochent, maar moet geheel alleen door den advokaat van het aangeborene gedragen worden.'

ef. Wijck, B.H.C.K. van der (1871), op. cit. p. 41, 'Maar hoe zal men staven, dat van den aanvang af de gewaarwordingen, welke door van buiten komende indrukken in de ziel van het kind worden opgewekt, de aanschouwing cener in de ruimte uitgebreide wereld tevoorschijn roepen?' 
de voorstanders van de theorie der aangeboren waarnemingsvormen dat zulke vormen pas manifest worden door ervaring en abstractie. Hierdoor geven zij derhalve toe dat hiervoor ervaring noodzakelijk is. Voor Van der Wijck is dit laatste aanleiding om zich het volgende af te vragen: welken waarborg hebben wij dan, dat zij niet geheel de vrucht dier ervaring en ontwikkeling zijn? Wie zal nu later met vaste hand de grenslijn trekken tusschen wat oorspronkelijk en verworven, niet en wel aangeleerd heeten? ${ }^{1}$ Met andere woorden: wat pleit er tegen om aan te nemen dat ook noties waarvan de empirische oorsprong nog onduidelijk is op ervaring berusten? Ten slotte onderstelt de theorie van aangeboren waarnemingsvormen het bestaan van onbewuste waarheden en onbewuste beginselen. Net als waarnemingsvormen kan men zulke onbewuste waarheden en principes niet waarnemen, waardoor het onmogelijk is om zich hiervan een duidelijke voorstelling te maken. ${ }^{2}$

De bovenstaande tegenwerpingen brengen Van der Wijck tot deze beslissende vragen: (is) er iets door het intellect zonder ervaring verkregen $?^{3}$ En: hoe talrijk (zijn) de aangeboren vormen of kundigheden? Hierop geven de voorstanders van de theorie van aangeboren waarnemingsvormen geen antwoord. Van der Wijck buit dit uit. Immers, als men niet duidelijk kan aangeven hoeveel van zulke vormen en kundigheden er zijn, dan is de weg vrij om een veelheid van aangeboren vormen en principes aan te nemen. Wat is er dan tegen om te onderstellen dat bijvoorbeeld ook het principe van het behoud van energie of het principe van het behoud van massa aangeboren is? Met andere woorden: de theorie van aangeboren waarnemingsvormen leidt tot verregaande willekeur. ${ }^{5}$

Met het methodologische argument dat men er in beginsel van uit moet gaan dat alle begrippen een empirische oorsprong hebben, met het argument dat de voorstanders van de theorie der aangeboren waarnemingsvormen ten onrechte de bewijslast omdraaien, en ten slotte met het argument dat die theorie ontoetsbaar is en tot willekeur leidt, acht Van der Wijck Spruyts opvatting weerlegd.

\section{Het causaliteitsbeginsel berust op ervaring}

Na de algemene kritiek op de nulie 'aangeboren waarnemingsvorm' vervolgt Van der Wijck zijn verdediging van Opzoomer met deze vraag: en welke zijn nu de

'cf. Wijck, B.H.C.K. van der (1871), op. cit. p. 41-42.

2 cî. Wijck, B.H.C.K. van der (1871), op. cit. p. 42, 'Waarheden en beginselen, van welke men bewustzijn heef, treft ieder in zich zelf aan: onbewuste waarheden en onbewuste beginselen liggen buiten het bereik van het oog des geestes, en het gevolg is, dat niemand zich van de door die woorden aangeduide zaken een helder begrip kan vormen.'

${ }^{3}$ cî. Wijck, B.H.C.K. van der (1871), op. cit. p. 42.

${ }^{4} \mathrm{ef}$. Wijck, B.H.C.K. van der (1871), op. cit. p. 42.

${ }^{5}$ cf. Wijck, B.H.C.K. van der (1871), op. cit. p. 42-43, 'Maar indien deze aangeboren zijn, waarom dan ook niet onze begrippen van onvernietigbaarheid der stof en behoud van arbeidsvermogen, onze overtuigingen van zelfstandig bestaan des geestes en persoonlijke identiteit? (....) Zoo zien we ons door de theorie van het aangeborene aan de grootst mogelijk willekeur prijs gegeven.' 
gewichtige argumenten waarmede al deze bezwaren moeten uit den weg geruimd? ${ }^{1}$ Anders gezegd: wat kan Spruyt tegen Van der Wijcks argumenten inbrengen?

In zijn kritiek op Opzoomers circulaire rechtvaardiging van het regelmatigheidsen causaliteitsbeginsel was Spruyt tot de slotsom gekomen dat iedere vorm van inductic de intuïtieve toepassing van het causaliteitsbeginsel onderstelt. ${ }^{2}$ Van der Wijck merkt hierover op dat toen ik die woorden voor den eersten keer gelezen had, ik ternauwernood mijne oogen durfde te vertrouwen. ${ }^{3}$ Want, zo vervolgt hij, inductie komt er eenvoudigweg op neer dat men op grond van een beperkt aantal waarnemingen van gevallen dat iets geldt de algemene uitspraak doet dat dit ook geldt voor alle nog niet waargenomen gevallen.

Van der Wijck verwerpt Spruyts hypothese, omdat het slechts de helft van de feiten verklaart, tot wier verklaring zij strekken moet. Spruyt was er namelijk ten onrechte van uilgegaan dat inductie alleen het regelmatig volgen van verschijnselen betreft; dat wil zeggen, standvastige opeenvolging. Als men herhaalde malen heeft waargenomen dat op een bepaald verschijnsel een bepaald ander verschijnsel volgt, dan is men er van overtuigd dat het laatste verschijnsel in toekomstige gevallen altijd op het eerste verschijnsel zal volgen. Deze overtuiging had Spruyt gebaseerd op het aangeboren beginsel: gelijke omstandigheden leiden tot gelijke gevolgen. Echter, Spruyt had volledig uit het oog verloren dat er naast deze vorm van inductie, ook inductie bestaat die het standvastig gepaard gaan van verschijnselen betreft. In zulke gevallen is het beginsel gelijke omstandigheden gelijke gevolgen niet van toepassing. Immers, als men heeft waargenomen dat een bepaalde eigenschap altijd is samengegaan met een andere eigenschap, op grond waarvan mag men dan concluderen dat zo'n eigenschap ook toekomt aan gevallen die men nog niet heeft waargenomen? In elk geval niet op grond van de intuütieve kennis van het causaalverband, zo merkt Van der Wijck op, omdat hier helemaal geen sprake is van een causale relatie. Spruyts verklaring heeft daarom alleen betrekking op het regelmatig volgen van verschijnselen; zij biedt echter geen verklaring voor het regelmatig gepaard gaan van verschijnselen. ${ }^{4}$

${ }^{1}$ cf. Wijck, B.H.C.K. van der (1871), op. cit. p. 43.

${ }^{2}$ ef. Spruyt, C.B. (1871a), op. cit. p. 41, 'Geen enkele inductie is mogelijk, zonder de intuïtieve toepassing van de wet der causaliteit.' Geciteerd bij Van der Wijck (1871), p. 43.

${ }^{3}$ cf. Wijck, B.H.C.K. van der (1871), op. cit. p. 44.

4 cf. Wijck, B.H.C.K. van der (1871), op. cit. p. 43, 'Inductie, ieder weet het, grijpt dan plaats, als we, hetgeen we in enkele gevallen hebben waargenomen, tot andere niet waargenomen gevallen uitbreiden. Als voorbeeld van iemand, die induceert, noem ik den reiziger, die, in een herberg, een vrouw met rood haar ziet, en terstond in zijn journaal deze woorden neerschrijft: "De vrouwen hebben rood haar in dit land". Men toone mij hier eene toepassing van de wet der causaliteit! Het is duidelijk, dat dr. Spruyt, toen hij die verrichting des geestes, welke men induclie noemt, verklaren en rechtvaardigen wilde, enkel aan gevallen gedacht heeft waarin wij eene standvastige opvolging, niet aan gevallen, waarin wij een standvastig gepaard gaan van verschijnselen aannemen. (...) Stel, dat we onze vingers een, twee, drie maal aan vuur gebrand hebben. Vanwaar de overtuiging, dat, als wij een vierden keer de vingers in hel vuur steken, voor cen vierde maal de pijnlijke gewaarwording van het branden volgen zal? 
Later in de discussies, en met name in de polemiek tussen Heymans en Jelgersma, zal overigens juist dit element sterk op de voorgrond treden. Het kernpunt in die discussie is of er een principieel onderscheid bestaat in onze reactie bij afwijkingen van coëxistentie- en successiewetten.

Naast de beperktheid van Spruyts verklaring, werpt Van der Wijck nog een principiëler bezwaar op. Dit bezwaar houdt rechtstreeks verband met de methodologische regel dat men er in beginsel van uit moet gaan dat alle begrippen een empirische oorsprong hebben. Dit geldt ook voor het abstracte causaliteitsbeginsel en het concrete, daarvan afgeleide, regelmatigheidsbeginsel. Resoluut schuift Van der Wijck daarom Spruyts overtuiging opzij dat het besef dat in alle gevallen gelijke omstandigheden tot gelijke gevolgen leiden aangeboren of a priori is. Deze overtuiging is zonder waarde. Immers, de waarheid van dit besef moet altijd blijken uit ervaring. Ook als men er van zou uitgaan dat het causaliteitsbeginsel en het daarvan afgeleide regelmatigheidsbeginsel a priori zijn, dan moet de ervaring altijd nog uitwijzen of het inderdaad geldt.' Van der Wijck komt tot de slotsom dat aangeboren kennis eene ongerijmdheid is. Men kan alleen van het vermoeden uitgaan dat de uitspraak 'voor alle verschijnselen geldt dat zij een oorzaak hebben' waar is. Nogmaals: of dit inderdaad zo is, kan alleen de ervaring bevestigen. ${ }^{2}$

\section{Kritiek op Hume's associatietheorie}

Gewoonlijk denkt men dat een voorstelling der toekomst of een verwachting ontstaat doordat men in het verleden verschijnselen regelmatig heeft zien samengaan. Van der Wijck acht Hume een belangrijke vertegenwoordiger van deze opvatting. Deze had in de Enquiry het ontstaan van een verwachting als volgt geillustreerd. Als men in het verleden in vele gevallen heeft waargenomen dat vuur en hitte of sneeuw en kou altijd blijken samen te gaan, dan zal men door gewoonte als men vuur ziet ook hitte verwachten. Men is er van overtuigd dat die hitte bestaat, en doorgaans blijkt

Ziedaar de vraag die hij zich deed, en tot wier beantwoording hij deze hypothese koos: Het inzicht, dat, bij gelijke omstandigheden, gelijke gevolgen te wachten zijn, is mensch en dier aangeboren. (...) Laat ons een oogenblik aannemen, dat dit antwoord bevredigend is. Toch zou het ons niet ten volle baten. Wij zouden nog blijven vragen: Vanwaar dat wij, na bij Jan, Piet en Klaas te hebben waargenomen, dat zij een hoofd op hun schouders dragen, dit ook van Willem en Arthur gelooven, die zich nog nooit aan ons verioond hebben?'

'cf. Wijck, B.H.C.K. van der (1871), op. cit. p. 44-45, 'Zij (het beginsel: gelijke omstandigheden, gelijke gevolgen) zou niet alleen een aan de ervaring voorafgaand oordeel en dus een vooroordeel zijn, zij zou een valsch vooroordeel kunnen zijn en dus geen vertrouwen verdienen, zoolang de juistheid er van niet door de feiten gestaafd ware. (....) Al ware dus het vooroordeel, dat een algemeene wet der causaliteit bestaat, ons van nature ingeprent, toch zou dr. Spruyt nog aan de ervaring het bewijs dier wet ontleenen moeten, voordat hij het recht zou hebben haar als een waarheid af te kondigen.'

${ }^{2}$ cf. Wijck, B.H.C.K. van der (1871), op. cit. p. 45 , 'Het is eene ongerijmdheid van aangeboren of intuitieve kennis der waarheid te spreken. Een bloot vermoeden zou aan de ervaring des noods kunnen voorafgaan; kennis der waarheid kan alleen vrucht der ervaring zijn.' 
die hitte ook werkelijk te bestaan.' De gewoonte is de groote leidsvrouw in het leven. ${ }^{2}$

Van der Wijck meent dat de kern van Hume's theorie neerkomt op het gelijkstellen van verwachtingen of overtuigingen met een ideeënassociatie die door gewoonte is gevormd. Hume's theorie is onbevredigend, zo betoogt Van der Wijck, omdat verwachtingen of overtuigingen méér inhouden dan alleen een onafscheidelijke associatie van ideeën. ${ }^{3}$ Het volgende voorbeeld moet dit aantonen. Als het baasje van een hond de tafel dekt, dan verwacht de hond dat er voedsel op tafel wordt neergezet. Gewoonlijk denkt men dat dit komt omdat die hond gewend is geraakt aan het volgen van deze twee feiten: het dekken van een tafel en het verschijnen van voedsel. Als de hond door herhaalde waarneming de voorstelling van een gedekte tafel en die van voedsel onafscheidelijk heeft verbonden, dan wil dat alleen zeggen dat de hond door het zien van de gedekte tafel een voorstelling van voedsel heeft. Het is echter niet zo, dat bij die hond door het zien van die tafel ook de verwachting of overtuiging ontstaat van voedsel. ${ }^{4} \mathrm{Met}$ andere woorden: uit de onafscheidelijke associatie van voorstellingen ontstaal geen verwachting of overtuiging, omdat voorstellingen alleen andere voorstellingen kunnen oproepen. Van der Wijck concludeert daarom dat het ontstaan van verwachlingen een raadsel is. Echter, dát men verwachtingen of overtuigingen heeft, is een psychologisch feit; dit feit zou men alleen kunnen verklaren door een oorspronkelijk vermogen des geestes aan te nemen. Aan een verklaring hoe dit vermogen precies werkt waagt Van der Wijck zich echter niet: wij staan hier voor het groote raadsel, dat op psychologisch gebied telkens terugkeert, het raadsel, dat de geest niet enkel in het heden, maar ook in het verleden en in de toekomst leeft. ${ }^{5}$

cf. Hume, D. (1748), op. cit., section V, part I, p. 36-37, 'Custom, then, is the great guide of human life. (.....) Having found, in many inslances, that any two kinds of objects, flame and heat, snow and cold, have always been conjoined together; if flame or snow be presented anew to the senses, the mind is carried by custom to expect heat or cold, and to believe, that such a quality does exist, and will discover itself upon a nearer approach. This belief is the necessary result of placing the mind in such circumstances. It is an operation of the soul, when we receive benefits; or hatred, when we meet with injuries.' Geciteerd in Van der Wijck (1871), p. 45-46.

${ }^{2}$ cf. Wijck, B.H.C.K. van der (1871), op. cit. p. 45.

${ }^{3}$ cf. Wijck, B.H.C.K. van der (1871), op. cit. p. 46, 'Ik moel erkennen, dat deze leer (Hume), welke ook bij Herbert Spencer wordt aangetrolfen, mij niet ten volle bevredigen kan. Eene verwachting, eene overtuiging, is naar mijn oordeel, meer dan eene onatscheidelijke associatio idearum.'

${ }^{4}$ cf. Wijck, B.H.C.K. van der (1871), op. cit. p. 46, 'Hier is onafscheidelijke associatie, maar welke geen geloof, geen overtuiging na zich sleept. Ziet de hond de tafel van zijn meester dekken, dan verwacht hij, dat er spijzen zullen worden opgedragen; het is, zegt men, omdat hij aan die opvolging van feiten gewoon is; maar indien door veelvuldige herhaling de voorstelling van een gedekte tafel en die van voedsel zijn samengesteld, dan verklaarl dit alleen, dat door de aanschouwing der gedekte tafel de voorstelling, niet dat door haar de verwachting van voedsel, de overtuiging dat voedsel komen zal, wordt te voorschijn geroepen.'

sf. Wijck, B.H.C.K. van der (1871), op. cit. p. 46-47. 
Los van de kwestie hoe verwachtingen ontstaan, vraagt Van der Wijck zich ten slotte af wat het karakter onzer verwachtingen bepaalt? ${ }^{\prime}$ De antwoorden die op deze vraag zijn gegeven lopen uiteen. Hume had de inhoud of het karakter van verwachtingen verklaard door het ontstaan van gewoonten. Eerdere ervaringen bepalen de inhoud van verwachtingen of voorstellingen omtrent de toekomst. Spruyt had geantwoord dat het causaliteitsbeginsel a priori pas het karakter van verwachtingen verklaart, omdat wat men onder 'ervaring' verstaat alleen betrekking kan hebben op het verleden en niet op de toekomst. ${ }^{2}$ Naar aanleiding hiervan wijst Van der Wijck er op dat men twee betekenissen van de notie 'ervaring' kan onderscheiden. Hetzij: 'ervaring' in engere zin, waarbij deze notie verwijst naar het geheel van de eerdere ervaring; dat wil zeggen, de som van al onze voorafgaande gewaarwordingen of ondervindingen. ${ }^{3}$ Of: 'ervaring' in ruimere zin; in dat geval verwijst de notie 'ervaring' naar de op raadselachtige wijze ontstane verwachtingen. ${ }^{4}$

Afgezien van het raadsel hoe verwachtingen of overtuigingen ontstaan, is het voor Van der Wijck duidelijk dat het karakter of de inhoud daarvan bepaald wordt door ervaring in engere zin. ${ }^{5}$ Het is daarom niet nodig om aan te nemen dat het besef dat gelijke omstandigheden gelijke gevolgen hebben a priori is. Immers, uit eerdere ervaring blijkt dat de ervaring voldoende uniformiteit of eenvormigheid kent om te constateren dat onder bepaalde omstandigheden altijd bepaalde gevolgen zullen optreden. ${ }^{6}$ Als men er van uitgaat dat de ervaring voldoende uniformiteit bezit, dan is het geen raadsel dat het denken uitsluitend op grond van eerdere ervaring iets afleidt wat niet in die ervaring lag besloten. De uniformiteit van ervaring biedt dus voldoende garantie, zo concludeerl Van der Wijck, dat loekomstige ervaringen op eerdere

${ }^{1}$ cf. Wijck, B.H.C.K. van der (1871), op. cit. p. 47.

${ }^{2}$ ef. Wijck, B.H.C.K. van der (1871), op. cit. p. 47, 'David Hume verwijst ons hier naar de gewoonte, naar de ervaring van wat is voorafgegaan; dr. Spruyt naar de intuïtieve kennis van de wet der causaliteit. Ervaring, bloote ervaring, zegt laatstgenoemde, leert enkel wat geweesl is, niet wat zijn zal.'

${ }^{3}$ ef. Wijck, B.H.C.K. van der (1871), op. cit. p. 47.

${ }^{4}$ cf. Wijck, B.H.C.K. van der (1871), op. cit. p. 47, 'Maar wie bespeurt niet, dat hier van de dubbele beteekenis van den term ervaring wordt misbruik gemaakt? In den engeren zin beteekent ervaring de som van al onze voorafgaande gewaarwordingen of ondervindingen. In den ruimeren zin omvat zij tevens het produkt van verwachting of overtuigingen, dat die gewaarwordingen of ondervindingen met zich voeren.'

${ }^{5}$ ef. Wijek, B.H.C.K. van der (1871), op. cit. p. 47, 'Ik ben er rond voor uitgekomen, dat het mij onbegrijpelijk is, dat er verwachtingen of overtuigingen ontstaan. Maar even nadrukkelijk moet ik er op wijzen, dat, indien er verwachtingen of overtuigingen ontstaan, de ervaring voldoende is om haar een bepaalden inhoud te schenken.'

${ }^{6} \mathrm{cf}$. Wijck, B.H.C.K. van der (1871), op. cit. p. 47, 'Wij hebben niet van noode met dr. Spruyt aan te nemen, dat voor alle ervaring de formule: "gelijke omstandigheden, gelijke gevolgen", reeds in onzen geest sluimeren zou, want door de ervaring wordt ons genoegzaam geleerd, dat zij in bepaalde richtingen eenvormig is.' 
ervaringen zullen gelijken. En als dit laalste nict zou gelden, dan vervalt hiermee iedere rechlvaardiging van inductic.'

Samengeval komt Van der Wijcks argumentatic in hoofdlijnen op het volgende neer. Van der Wijcks uitgangspunt in De oorsprong en grenzen der kennis is dat ervaring het denken bepaalt, en niet andersom. Dit betekent dat ook het beginsel: gelijke omstandigheden gelijke gevolgen door ervaring is ontstaan. Dit beginsel onderstelt dat de natuur een impliciete orde heeft, die door ervaring wordt "ontclekt". Herhaalde waarneming bevestigt dat deze ordening bestaat. Ook in De wijsbegeerte der ervaring verdedigd gaat Van der Wijck van dezc gedachtengang uit.

Van der Wijck heeft grote moeite met Spruyts onderscheid tussen het ruwe ervaringsmateriaal en waarnemingsvormen - tussen wat wordt waargenomen en wie waarnecmt - omdat hiertussen volgens hem een wisselwerking bestaat.

Vervolgens attaqueert hij Spruyts argumentatiewijze. Van der Wijck verdedigt de stelling dat Spruyt te snel heeft geconcludecrd dat, omdat nog niet is aangeloond dat de notic 'causaliteit' uit ervaring kon worden afgeleid, deze notic derhalve een aangehoren warmemingsvorm is. Van der Wijck huldigt het principe dat men er in bcginsel van uit moet gaan dat alle begrippen uit ervaring ontstaan. Het feit dat dit voor de notie 'causaliteit' nog niet gelukt is aan te tonen, impliceert derhalve nog nict dat deze notie aangeboren is. Het is veeleer een aansporing voor verder onderzoek naar de empirische wortels van deze notie.

Naast dit methodologische argument betoogt Van der Wijck vervolgens dat de leer der aangeboren waarnemingsvormen ontoetsbaar is. Zelfs de voorstanders van deze leer gaan er van uit dat eerst door ervaring het aangeboren causaliteitsbeginsel manifest wordt. Dit ziet hij als een bewijs te meer dat men moet blijven uitgaan van de methodologische stelregel dat alle kennis ontstaat door ervaring. Bovendien, de voorstanders van de leer der aangeboren begrippen kunnen niet duidelijk aangeven welke begrippen wel en welke niet aangeboren zijn. Voor Van der Wijck is dit aanleiding om als tegenargument te poneren dat deze leer de deur wagenwijd openzet voor het willekeurig aannemen van allerlei aangeboren begrippen en principes.

Vervolgens kruist hij de degens met Spruyt over diens stelling dat inductie alleen mogelijk is door de intuïtieve toepassing van het causaliteitsbeginsel. Van der Wijck wijst er op dat Spruyt uit het oog heeft verloren dat het causaliteitsbeginsel niet bij alle algemene uitspraken die gebaseerd zijn op een reeks van waarnemingen een rol speelt. Er bestaan namelijk ook algemene uitspraken waarbij er alleen sprake is van

' cf. Wijck, B.H.C.K. van der (1871), op. cit. p. 48, 'Wij behoeven dus niet "verwonderd te blijven stilstaan bij de ontdekking, dat onze geest uit de ervaring (in engeren zin ) iets geheel anders afleidt dan de onvervalschte inhoud dier ervaring". Of is eenvormigheid der ervaring geen waarborg dat de toekomst, gelijk tot dusverre het geval was, op het verleden gelijken zal, zoo antwoord ik, dat het recht om te induceeren zich evenmin staven laat als dat om twee benen te hebben.' 
het samengaan of gepaard gaan van verschijnselen, en niet van het regelmatig volgen van verschijnselen. Bij de eerste soort uitspraken speelt het causaliteitsbeginsel geen enkele rol. Nadat hij dit heeft geconstateerd, verwerpt hij nogmaals Spruyts stelling dat het causaliteitsbeginsel aangeboren is. Immers, de geldigheid van dit beginsel moet nog altijd maar blijken uit ervaring. Met andere woorden, onderstellen dat het a priori zou zijn, is daarom overbodig.

Ten slotte verwerpt Van der Wijck Hume's stelling dat verwachtingen uit de associatie van voorstellingen kunnen worden afgeleid. Deze stelling berust namelijk op het verwarren van voorstellingen enerzijds en verwachtingen anderzijds. Van der Wijck vermoedt dat het feit dat men verwachtingen heeft, kan worden verklaard door het hebben van verwachtingen als een natuurlijk vermogen van het denken op te vatten; een feit waarvoor in de psychologie overigens nog geen bevredigende theorie is geformuleerd. Hoe dit ook zij, de inhoud van verwachtingen wordt geheel bepaald door ervaring. Om dit te verklaren acht Van der Wijck het onnodig te onderstellen dat het causaliteitsbeginsel a priori zou zijn. Het is namelijk goed mogelijk om op grond van ervaring te stellen dat in gelijksoortige situaties gelijksoortige gevolgen zullen optreden. Met andere woorden: de uniformiteit van de ervaring is voldoende grond om daaruit af te leiden dat toekomstige ervaringen overeen zullen komen met eerdere ervaringen. Ten slotte: als men niet van de uniformiteit van ervaring uit zou kunnen gaan, is inductie geheel onmogelijk.

In navolging van Opzoomer houdt Van der Wijck een krachtig pleidooi voor een ontstaansbenadering van het causaliteitsvraagstuk. Zowel in De oorsprong en grenzen der kennis (1863) als in De wijsbegeerte der ervaring verdedigd (1871) komt deze benadering duidelijk naar voren. Het valt op dat hij in 1863 de ontstaansbenadering nog onbevangen presenteert, waarschijnlijk omdat hij zich sterk gesteund weet door Opzoomer. Na Spruyts Opzoomer-kritiek (1871a) is deze onbevangenheid echter verdwenen. Van der Wijck argumenteert dan duidelijk vanuit een verdedigende positie. Dit blijkt niet alleen uit de titel van zijn betoog, maar vooral uit zijn antwoord, of juist het ontbreken van een antwoord, op de vraag hoe het bestaan van verwachtingen, en daarmee het causaliteitsbeginsel, op empirische gronden kunnen worden verklaard. Hiertoe doet hij immers een beroep op de notie 'oorspronkelijk vermogen des geestes'. Hiermee formuleert Van der Wijck een nieuwe vraag, waarvan hij erkent dat hij de oplossing niet weet. Hij vertrouwt er echter op dat deze vraag door verder psychologisch onderzoek zal worden opgelost. Het open karakter van deze vraag biedt, zoals nog zal blijken, voor Spruyt een aanknopingspunt om hieruit te concluderen dat Van der Wijck geen empirist is, en dat hij zonder het te willen een pleidiooi houdt voor Spruyts geldigheidsbenadering.

Het is overigens de vraag of Van der Wijcks (1863) argumentatiestrategie recht doet aan Kants filosofische programma. Het doel van dat programma is onder andere om Hume's stelling te weerleggen dat zowel de twee noties 'causaliteit' en 'noodzakelijkheid' als het causaliteitsbeginsel op gewoonte berusten. In de Kritik der reinen Vermunft poogt Kant de stelling te bewijzen dat alle veranderingen geschieden volgens 
een wet a priori die oorzaak en gevolg met elkaar verbindt.' Centraal hierin staat de verhouding van tijdsorde tussen verschijnselen. Het doel van dit bewijs is aan te tonen dat uitspraken over het volgen van gebeurtenissen in de tijd geen subjectieve, op gewoonte gebaseerde uitspraken zijn, zoals Hume beweerde, maar dat het uitspraken zijn die algemeen gelden en noodzakelijk zijn. ${ }^{2}$ Om dit te bewijzen worden door Kant twee soorten ervaringen onderscheiden waarin tijdsrelaties liggen besloten: omkeerbare en onomkeerbare opeenvolgingen in de tijd. Bijvoorbeeld: het bekijken van de gevel van een huis kan van boven naar beneden, en van beneden naar boven geschieden; dit zijn waarnemingen waarin de tijdsrelatie tussen de waarnemingen omkeerbaar is. Bij de waarnemingen van een schip dat stroomafwaarts gaat, zijn de tijdsrelaties tussen de waarnemingen echter onomkeerbaar. ${ }^{3}$ Een uitspraak over opeenvolging van waarnemingen waarin een onomkeerbare tijdsrelatie ligt besloten, onderstelt een regel waardoor deze waarneming van opeenvolging wordt bepaald. ${ }^{4}$ Deze regel houdt in dat in de waarneming $A$ die aan de waarneming $B$ voorafgaat de voorwaarde besloten ligt volgens welke $B$ noodzakelijk moet volgen. Hieruit wordt geconcludeerd dat het beginsel van voldoende grond de voorwaarde is voor de mogelijkheid van objectieve ervaring. Dit betekent: algemeen geldende kennis van verschijnselen ten aanzien van de tijdsrelaties tussen deze verschijnselen. ${ }^{5}$ Over Van der Wijcks stelling (1863) dat Kants opvatting de genadeslag betekent voor de objectieve geldigheid van kennis, kan men opmerken dat dit juist het tegendeel is wat Kant had geprobeerd aan te tonen. Echter, als Van der Wijcks kritiek al zou gelden, dan ontbreken hiervoor expliciete argumenten tegen Kants bewijsvoering geheel. Hieruit volgt dat Van der Wijcks reductio ad absurdum argumentatie tegen Kants standpunt onvoldoende, en daarom ook niet overtuigend is. Immers, net als dat bij Opzoomer is opgemerkt, gaat ook Van der Wijck geheel voorbij aan Kants directe bewijsvoering: de transcendentale deductie.

Ten slotte: zowel in De oorsprong en grenzen van kennis, maar vooral in De wijsbegeerte der ervaring verdedigd pleit Van der Wijck voor een methodologische benadering die lijkt op Ockhams beroemde "scheermes-methode": entia non sunt sine ratione multiplicanda. Van der Wijcks methodologische regel luidt immers dat uitgegaan dient te worden van de empirische oorsprong van alle begrippen, totdat

' cf. Kant, I. (1787'), Kriiik der reinen Vernunft, B-uitgave, p. 232, 'Alle Veränderungen geschehen nach dem Gesetze der Verknüpthung der Ursache und Wirkung.'

${ }^{2}$ cf. Körner, S. (1955), op. cit. p. 86.

${ }^{3}$ cf. Kant, I. (1787²), op. cit., B-uitgave, p. 236-237.

cf. Kant, I. (17872), op. cit., B-uitgave, p. 238, 'Diese also wird in der Ordnung des Mannigfaltigen der Erscheinung bestehen, nach welcher die Apprehension des einen (was geschieht) auf die des anderen (das vorhergeht) nach einer Regel folgt.'

${ }^{5}$ cf. Kant, I. $\left(1787^{2}\right)$, op. cit., B-uitgave, p. 245-246, 'Diese Regel aber, etwas der Zeitfolge nach zu bestimmen, ist: dass in dem, was vorhergeht, die Bedingungen anzutreffen sei, unter welcher die Begebenheit jederzeit (d.i. Notwendiger Weise) folgt. Also ist der Satz vom zureichenden Grunde der Grund möglicher Erfahrung, nämlich der objektiven Erkenntnis der Erscheinungen, in Ansehung des Verhältnisses derselben, in Reihenfolge der Zeil.' 
gebleken is dat dit niet zo is. Het feit dat de empirische oursprong van een aantal hegrippen nog niet is aangetoond, is geen bewijs dat zij derhalve aangeboren zijn. Als tegenargument kan hierbij echter nog worden opgemerkt dat Van der Wijck vrijwel geheel voorbij gaat aan het bezwaar van Spruyt dat empirische afleidingen van het causaliteitshegrip leiden tot circulaire verklaringen.

\section{SPRUY'TS WEERLEGGING VAN DE KRI'IIEK}

Spruyt voclt zich nict in het nauw gedreven door Van der Wijcks kritick. In De laatste gedaanteverwisseling van de wijsbegeerte der ervaring toegelicht (187lb) wil Spruyt aantonen dat Van der Wijcks weerlegging uit 1871 van zijn kritiek op Opzoomer geen doel treft, omdat Van der Wijck verzuimt op de belangrijkste argumenten tegen Opzoomer in te gaan. Bovendien merkt Spruyt in de inleiding van Do' laatste gedaant'verwisseling op dat Van der Wijck, zonder dit kennelijk te beseffen, helemaal geen empirist of een verdediger daarvan is. Sterker nog: Van der Wijck ondergraaft met zijn eigen argumenten zelfs het empirisme dat hij zo graag wil verdedigen.'

Spruyt herinnert er aan dat hij in Aangeboren waarnemingsvormen had willen aantonen dat het empirisme ten onrechte voorbij is gegaan aan Kants kentheorie. Iliertoc had hij argumenten geformulecrd die moesten bewijzen dat Opzoomers argumentatics, die moesten aantonen dat de nolic 'noodzakelijkheid' in de notie 'causaliteit' ligt besloten, tot niets hebben geleid. Hierdoor had Spruyt het deficit van het gehele empiristische programma aannemelijk willen maken.'

${ }^{1}$ ef. Spruyt, C.B. (1871b), De laatste gedaanteverwisseling van de wijsbegeerte der ervaring toegelicht, p. 4-5, 'Dat mijne aanmerkingen op de wijsbegeerte der ervaring door prof. van der Wijck wederlegd zouden zijn, moet ik ten sterkste ontkennen. De belangrijkste van die aanmerkingen werden toch door hem in het geheel niet besproken. Wat meer zegt, de empirische wijsbegeerte, in den vorm, waarin zij zich historisch ontwikkeld heeft en hier te lande door Opzoomer verkondigd is, wordt door van der Wijck niet minder dan door mij veroordeeld.'

${ }^{2}$ cf. Spruyt, C.B. (1871b), op. cil. p. 5-6, 'In mijn artikel over aangeboren waarnemingsvormen heb ik trachten aan te toonen, dat de empirische wijsgeeren ten onrechte Kant's denkbeelden over het menschelijk kenvermogen verwerpen. Om dit doel te bereiken heb ik eene kritiek gegeven van de redeneeringen, waarmede genoemde wijsgeeren willen bewijzen, dat onze kennis aangaande de onverbreekbaarheid van het causaalverband en onze denkbeelden over ruimte en tijd aan de ervaring ontleend zijn. (...) ....(ik heb) de moeite genomen aan te toonen, dat al de redeneeringen, waarmede Opzoomer en Mill den empirischen oorsprong van de genoemde voorstellingen trachten aan te wijzen, valsch zijn. De conclusie ligt voor de hand. Als Mill, die door geheel Europa als het hoofd der empirische school erkend wordt, en Opzoomer, die hier te lande haar oudste en beste vertegenwoordiger is, buiten staat zijn geweest de stellingen te bewijzen, waarop de wijsbegeerte der ervaring berust, dan behoort deze wijsbegeerte veroordeeld te worden.' 
Van der Wijcks kritiek treft geen doel, omdat Van der Wijck niet alleen ver $\angle u$ imt om op Spruyts belangrijkste tegenargumenten in te gaan, maar vooral ook ondat hij èn verkecrde argumentatiestrategie volgt. Hij had volgens Spruyt cein van de volgende twee dingen moeten doen. Van der Wijck had ofwel duidelijk mocten maken in welke opzichten Spruyts oordeel over Opzoomers positie verkecrd zou zijn; of hij had met Spruyt moeten toegeven dat Opzoomers argumenten ongegrond waren, om vervolgens met betere argumenten voor de dag te komen. Echter, Van der Wijck deed noch het één noch hel andere.' Dit leidt tot onduidelijkheid. Is Van der Wijck het met Spruyt nu wel of niet eens dat het onmogelijk is om het causaliteitsbeginsel uit ervaring af te leiden $?^{2}$ Uit dezc onduidelijkheid leidt Spruyt af dat Van der Wijck een positic verdedigt die nooit is aangevallen. Bovendicn bekritiseert hij een stelling die nooil door Spruyt is ingenomen. ${ }^{3}$

\section{De empirische afleiding van het causaliteitsbeginsel}

Van der Wijck spreidt een groote wankelmoedigheid ten toon als het gaat om de empirische afleiding van het causaliteitsbeginsel. In navolging van Mill had Opzooner ten minste nog vastberaden pogingen gedaan om argumenten voor zo'n afleiding te formuleren. Met zou verwachten dat Van der Wijck die afleiding had omarmd, maar hiervan is geen sprakc, aldus Spruyl. ${ }^{4}$

Van der Wijck had terloops geopperd dat men de notic 'materie' uil de ervaring kan afleiden. Spruyt acht het echter onduidelijk wat hij hiermee op het oog had. Ook op dit punt blijkt Van der Wijcks wankelmoedigheid. Wil hij nu zeggen dat men aanneemt dat de notie 'oorzaak' bestaat en dat ervaring vervolgens leidt tot het waarnemen van materie als weerstandbiedende oorzaak? Of bedoelt hij dat bij het waarnemen van materie legelijkertijd de notie 'oorzaak' ontstaat? ${ }^{5}$ Kennelijk heeft Van der Wijck (1871) de cerste mogelijkheid op het oog, omdat hij immers later in

' cf. Spruyt, C.B. (1871b), op. cit. p. 6, 'Wie mij op doeltreffende wijze wilde bestrijden, moest op de volgende wijze te werk gaan. Hij moest mij duidelijk maken, in welke opzichten ik Mill en Opzoomer verkeerd beoordeelde. Of wel, hij kon met mij erkennen, dat de bekende argumenten van Mill en Opzoomer onhoudbaar zijn, en trachten andere en betere te geven.'

${ }^{2}$ cf. Spruyt, C.B. (1871b), op. cit. p.6, 'Erkent Prof. van der Wijck dan, dat zoowel Mill's als Opzoomer's afleiding van de wet der causaliteit onhoudbaar is $(\ldots .$.$) ? '$

${ }^{3}$ cf. Spruyt, C.B. (1871b), op. cit. p. 7,' ....hij de wijsbegeerte der ervaring (prijs geeft), die ik bestreden heb, en eene andere wijsbegeerte verdedigt, die ik nimmer heb aangevallen.'

${ }^{4}$ ef. Spruyt, C.B. (1871b), op. cit. p. 14-15, 'Ik noem dit onderwerp in het bijzonder, omdat de verdediging van prof. van der Wijck op dit punt van groote wankelmoedigheid getuigt. Terwijl zijne beroemde voorgangers althans beproeven eene empirische afleiding van de wet van oorzaak en gevolg te geven, durft hij op geen enkele plaats beweren, dat die afleiding reeds gegeven zou zijn.'

${ }^{5}$ cf. Spruyt, C.B. (1871b), op. cit. p. 15, 'Doch het blijft hierbij onbeslist, of hij alleen gelooft, dat indien eenmaal het begrip van oorzaak als bestaande wordt aangenomen, de ervaring ons tot de waarneming der materie als eene weerstandbiedende oorzaak kan brengen, dan wel of hij meent, dat bij het ontstaan onzer waarneming der materie tegelijkertijd het begrip van oorzaak in ons geboren wordt.' 
De wijsbegeerte der ervaring verdedigd stelt dat Hume's afleiding van oorzakelijk verband uit ervaring en gewoonte ontoereikend is. Een ander belangrijk argument voor deze interpretatie is, aldus Spruyt, dat Van der Wijck het bestaan van overtuigingen of verwachtingen onbegrijpelijk acht. Op grond hiervan had hij geconcludeerd dat het niet inzichtelijk is dat men er intuitief van overtuigd is dat het beginsel gelijke omstandigheden, gelijke gevolgen geldig is. Spruyt wijst er op dat Van der Wijck nooit tot deze conclusie had kunnen komen als hij bijvoorbeeld in navolging van Opzoomer de mogelijkheid van een empirische afleiding van dat beginsel had onderschreven. Dit is een belangrijke indicatie voor Spruyt dat Van der Wijck eigenlijk geen empirist is. Een tweede indicatie hiervoor is dat Van der Wijck voor een verklaring van het psychologische feit dat verwachtingen of overtuigingen bestaan, wijst op een oorspronkelijk vermogen des geestes. ${ }^{1}$ Voor Spruyt betekent dit dat hij voor deze term net zo goed de term 'aangeboren waarnemingsvorm' had kunnen gebruiken. ${ }^{2}$ Op dit punt schijnt Van der Wijck immers met de ene hand weer terug te nemen wat hij met de andere heeft gegeven. Hij was namelijk van mening dat ervaring de inhoud van verwachtingen of overtuigingen bepaalt. Dit acht Spruyt evident en een overbodige toevoeging; natuurlijk is het zo dat alleen door ervaring specifieke causale betrekkingen worden gekend. ${ }^{3}$ Spruyt acht dit daarom ook geen relevantie kwestie. Ironisch merkt hij op dat ik er volkomen tevreden (mee ben) dat zelfs de verdediger der empirische wijsbegeerte erkent, dat de empirische afleiding van de wet der causaliteit nog niet gegeven is. ${ }^{4}$

' cf. Spruyt, C.B. (1871b), op. cit. p. 15, 'Dat nu alleen de eerstgenoemde uitlegging aan zijne woorden mag gegeven worden, volgt uit de zinsneden in zijne brochure, waarin hij erkent, dat Hume's afleiding van onze kennis van het causale verband uit de kracht der gewoonte hem niet bevredigt. "Het feit, dat men verwachting of overtuiging noemt, wijst op een oorspronkelijk vermogen des geestes, dat niei uit de associatio idearum kan afgeleid worden". En verder: "Ik ben er rond voor uitgekomen, dat het mij onbegrijpelijk is, dat er verwachtingen of overtuigingen ontstaan." Dus vindt prof. van der Wijck onze intü̈tieve overtuiging van de geldigheid der wet: gelijke omstandigheden, gelijke gevolgen onbegrijpelijk. Dit zou hij niet kunnen doen, wanneer hij van de juistheid van eene der bekende empirische afleidingen van genoemde wet overtuigd was. Hier is het eerste belangrijke vraagstuk, bij welks behandeling prof. van der Wijck de wijsbegeerte verlaat, die ik heb aangevallen en die hij wenscht te verdedigen. Daarenboven erkent hij, dat het bestaan der verwachtingen of overtuigingen wijst op een oorspronkelijk vermogen des geestes.'

${ }^{2}$ cf. Spruyt. C.B. (1871b), op. cit. p. 16, 'Prof. van der Wijck noemt nu datgene, waarvan wij niet weten, dat het van onze ervaring afkomstig is, het voortbrengsel van een "oorspronkelijk vermogen des geestes". Ik heb het hetzelfde voortbrengsel een aangeboren waarnemingsvorm genoemd. Doet de naam veel ter zake?'

${ }^{3}$ cf. Spruyt, C.B. (187I b), op. cit. p. 16, 'Niemand ontkent, dat alleen de ervaring ons de bijzondere causale betrekkingen kan doen kennen.' Zie ook: Spruyt, C.B. (1871b), op. cit. p. 17-18, 'Nu is dit causaalverband tusschen twee verschijnselen a priori niet te ontdekken, maar wordt ons alleen door ervaring bekend. (....)... alleen de ervaring (heeft) ons met de verschillende causale betrekkingen kunnen bekend maken.'

${ }^{4}$ cf. Spruyt, C.B. (1871b), op. cit. p. 16. 
Principiëler is voor Spruyt echter de volgende vraag: hoe ontstaat de verwachting dat bijgelijke omstandigheden gelijke gevolgen zullen plaais vinden ${ }^{1}$ Van der Wijck had deze vraag niet kunnen of willen beantwoorden. Hij gaat in zijn verdediging van Opzoomers empirisme bovendien voorbij aan het merkwaardige verschijnsel dat Hume al had gesignaleerd, namelijk dat men, zonder dat hiervoor een argumentatie aangegeven kan worden, op grond van eerdere ervaringen iets afleidt wat niet in die ervaringen ligt besloten. Net als Hume verwondert Spruyt zich hierover. ${ }^{2}$ Spruyt (1871a) kon zich echter niet verenigen met Hume's conclusie, omdat de verwachting dat gelijke omstandigheden gelijke gevolgen hebben door het denken aan de ervaring wordt toegevoegd; deze verwachting ontstaat niet door gewoontevorming. ${ }^{3}$ Spruyt wijst er op dat Van der Wijck op dit punt inconsistent is. Nu eens stelt Van der Wijck dat verwondering over Hume's vraag onnodig, en niet relevant is; dan weer meent hij dat het psychologische feit dat men verwachtingen heeft onbegrijpelijk is en juist wel een relevante kwestie vormt, dat door verder psychologisch onderzoek zou kunnen worden opgelost. Ook Van der Wijcks uitweg om Hume ervan te betichten dat hij misbruik maakte van de dubbele betekenis van de notie 'ervaring' acht Spruyt niet terecht. Hume's vraag was immers gericht op het verklaren van ervaring in ruimere zin; dat wil zeggen, het geheel van de eerdere ervaring plus het product van verwachtingen of overtuigingen, dat die gewaarwordingen of overtuigingen met zich mee voeren. ${ }^{4} \mathrm{Met}$ andere woorden: 'ervaring' opgevat als de verwevenheid van waarnemingen en verwachtingen. Spruyt merkt op dat men het doorgaans als evident beschouwt dat op grond van eerdere ervaring (ervaring in engere zin) ervaring in ruimere zin volgt; dat wil zeggen, op grond van eerdere ervaring heeft men verwachtingen over het optreden van nog niet waargenomen gevallen. Echter, voor Hume ging het er juist om, om de rechtsgrond van zulke verwachtingen te onderzoeken. Hume's originaliteit schuilt volgens Spruyt dan ook in het formuleren van deze geldigheidsvraag.

${ }^{\prime}$ cf. Spruyt, C.B. (1871b), op. cit. p. 16.

${ }^{2}$ cf. Spruyt, C.B. (1871b), op. cit. p. 16, 'Ik had beweerd, dat Hume te recht verwonderd was blijven stilstaan bij de ontdekking van het feit, dat onze geest zonder eenige redeneering uit de ervaring iets geheel anders afleidt dan den onvervalschten inhoud van die ervaring.'

${ }^{3}$ cf. Spruyt, C.B. (1871b). op. cit. p. 16, 'Datgene, wat onze geest aan den inhoud der ervaring toevoegt, is de verwachting, dat zij ook voor het vervolg zal gelden.'

${ }^{4}$ cf. Spruyt, C.B. (1871b), op. cit. p. 17.

${ }^{5}$ cf. Spruyt, C.B. (1871b), op. cit. p. 17, 'Want de vraag van Hume handelt juist over het ontstaan van die ervaring in den ruimeren zin. Daarom heeft Hume geen "misbruik gemaakt van de dubbele beteekenis van den term ervaring." (....) Voor de meeste menschen spreekt het zoozeer van zelf, dat uit de ervaring in den engeren zin de ervaring in den ruimeren zin volgt, dat zij niel kunnen begrijpen, hoe iemand op het denkbeeld kan komen om naar den rechtsgrond der verwachtingen te vragen, die de ervaring in den ruimeren zin van de andere onderscheiden.' 


\section{Het causaliteitsbeginsel is a priori}

Spruyt sloot in Aangeboren waarnemingsvormen expliciet aan bij Helmholtz' opvatting (1860) dat het causaliteitsbeginsel a priori is. Van der Wijck had aangegeven dat Helmholtz (en daarmee ook Spruyt) een verkeerde argumentatiestrategie had gevolgd. Dit oordeel over Helmholtz is volgens Spruyt volkomen verkeerd. Helmholtz was juist één van de weinige wetenschapsbeoefenaren die bij de verklaring van verschijnselen zo weinig mogelijk gebruik makkte van het onderstellen van elementen a priori: aangeboren vermogens, aangeboren inrichtingen en wat dies meer zij. ${ }^{\prime}$ Als dat toch gebeurde, zoals bij de wet van oorzaak en gevolg, had hij daar goede argumenten voor. Spruyt onderschrijft dan ook Helmholtz' conclusie dat deze wet a priori is, omdat het onmogelijk blijkt om haar uit de ervaring af te leiden. ${ }^{2}$

Ook had Spruyt in Aangeboren waarnemingsvormen al naar voren gebracht dat het regelmatigheidsbeginsel - gelijke omstandigheden gelijke gevolgen - in de praktijk van het wetenschappelijk onderzoek door talloze ervaringen wordt bevestigd. Hoewel men schijnbare afwijkingen van deze regel constateert, leidt dat echter nooit tot de conclusie dat die regel niet algemeen zou gelden. In zulke gevallen wordt alleen gesteld dat onze kennis kennelijk onvolledig is. In de onderzoekpraktijk wordt echter nooit aan de algemeengeldigheid van dit beginsel getwijfeld. ${ }^{3}$ Als men een verklaring voor een verschijnsel zoekt, onderstelt men altijd dat het causaliteitsbeginsel - niets geschiedt zonder oorzaak - en het concrete besef dat gelijke omstandigheden tot gelijke gevolgen (leiden) algemeen gelden. ${ }^{4}$ Bovendien ziet Spruyt in de intuïtieve kennis die men heeft van het causaliteitsbeginsel de leidraad voor iedere handeling, en hiermee dus ook voor het verrichten van welenschappelijk onderzoek. Op grond hiervan kon Helmholiz in zijn Physiologische Optik $(1860)^{5}$ terecht concluderen dat het causaliteitsbeginsel niet ontstaat door ervaring, maar a priori is. ${ }^{6}$

${ }^{1}$ cf. Spruyt, C.B. (1871b), op. cit. p. 35.

${ }^{2}$ cf. Spruyt, C.B. (1871b), op. cit. p. 35, 'De wereld kent geen strenger rechter over de aangeboren vermogens, aangeboren inrichtingen en wat dies meer zij, dan den beroemden Helmholtz. (...) Maar hij, die veel meer uit de ervaring meent te kunnen afleiden dan eenig ander physioloog, erkent de aprioriteit der wet van oorzaak en gevolg. Met het maken van deze uitzondering werd hij niet ontrouw aan zijne beginselen. Want de algemeene wet der causaliteit is eene waarheid, waarvan wij duidelijk kunnen weten, dat onze empirische kennis haar nooit bereiken kan.'

${ }^{3}$ cf. Spruyt, C.B. (1871b), op. cit. p. 35, 'Tegenover de vele gevallen, waarin wij den regel: gelijke omstandigheden, gelijke gevolgen, door de ervaring bevestigd zien, bemerken wij evenvecl malen schijnbare, maar voorloopig onverklaarbare, afwijkingen van dien regel. Nooit komt het in ons op, aan de juistheid van die wet te twijfelen; altijd schuiven wij de schuld op de onvolledigheid van onze kennis.'

${ }^{4}$ cf. Spruyt, C.B. (1871b), op. cit. p. 36, 'Welk voorbeeld men ook kiezen mogen, het is elken mensch onmogelijk in concreto te twijfelen aan deze twee waarheden: niet geschiedt zonder oorzaak, en: volmaakt gelijke omstandigheden geven volmaakt gelijke gevolgen.'

${ }^{5}$ cf. Helmholtz, H. (1860), op. cit., p. 453-455.

${ }^{6}$ cf. Spruyt, C.B. (1871b), op. cit. p. 37, 'Overwegen wij nu, dat de mensch al zijne handelingen bepaalt door zijn onuitgesproken geloof aan, zijne intuitieve kennis van de wet der causaliteit, en dat toch zijne ervaring hem meer schijnbare uitzonderingen op dic wet 
Ten slotte: Van der Wijck had Spruyts opvalting verworpen dat inductie alleen mogelijk is door te onderstellen dat men de wet der causaliteit op een intuïtieve wijze toepast. Allereerst had hij er op gewezen dat er naast algemene uitspraken over het regelmatig volgen van verschijnselen ook algemene uitspraken bestaan die betrekking hebben op het gepaard gaan van verschijnselen. Bij de ecrste soort uitspraken speelt het causaliteitsbeginsel een rol, maar bij de tweede soort uitspraken niet. Hij had vervolgens geconcludeerd dat Spruyt de tweede soort uitspraken niet kon verklaren. Bovendien, en dat was principiëler, had Van der Wijck er op gewezen dat het causaliteitsbeginsel niet a priori is. Immers, de geldigheid van dit beginsel zou altijd nog moeten blijken uit ervaring. Spruyt meent dat Van der Wijck met dit laatste argument de plank volledig misslaat. De kernvraag blijft immers: hoe zullen wij de inducties verklaren, die wij over het gepaard gaan van verschijnselen vormen, als onze intü̈tieve kennis slechts reikt tot hare opvolging?' Niet het feit dat men generaliseert behoeft verklaring, maar wel dat de neiging tot generaliseren de onmisbare leidstrouw is bij het formuleren van algemene uitspraken die betrekking hebben op het regelmatig volgen van verschijnselen. ${ }^{2}$ Ook hier is het feit dat men generalisecrt geen probleem. Wat men wél moet verklaren is dat men nooit aan de rechtmatigheid van dat generaliseren kan twijfelen. De rechtmatigheid van het doen van algemene uitspraken is echter een onverklaarbaar probleem, als men, zo betoogt Spruyt, blijft vasthouden aan de gedachte dat het causaliteitsbeginsel uit de ervaring kan worden afgeleid. Spruyt concludeert daarom nogmaals dat dit beginsel geen generalisatie kan zijn, maar als cen aangeboren beginsel moet worden beschouwd. ${ }^{3}$

Samengevat komt Spruyts argumentatie in hoofdlijnen neer op het volgende. Eén van de hoofdpunten in Spruyts weerlegging van Van der Wijcks tegenargumenten is dat laatstgenoemde een verkeerde argumentatiestrategie volgde, waardoor het

vertoont dan schijnbare bevestigingen; overwegen wij verder, dat al die uitzonderingen hem in de toepassing geen oogenblik doen twijfelen aan de waarheid van zijne intuïtieve overtuiging, dan moeten wij erkennen, dat Helmholtz te recht ons geloof aan de wet der causaliteit als onafhankelijk van onze ervaring beschouwl.'

'cf. Spruyt, C.B. (1871b), op. cit. p. 37-38.

${ }^{2}$ cf. Spruyt, C.B. (1871b), op. cit. p. 38 , 'De neiging tot generaliseeren behoeft niet verklaard te worden; de aard van onze opvoeding brengt die neiging van zelve mede. Maar dat dezelfde neiging (......) onze onmisbare leidsvrouw is bij de inducties over successieve verschijnselen, dat was het vraagstuk, wat ik trachtte op te lossen.'

${ }^{3}$ cf. Spruyt, C.B. (1871b), op. cit. p.39, 'Ook in dit geval is het niet vreemd, dat wij aanvangen met te generaliseeren; maar wel vreemd, en, naar het mij voorkomt, onverklaarbaar, dat wij niet, op zekere hoogte gekomen, de rechtmatigheid van onze neiging tot generaliseeren kunnen gaan betwijfelen; dat wij overtuigd blijven van de waarheid, dat gelijke omstandigheden gelijke gevolgen hebben. Onverklaarbaar, tenzij wij aannemen, dat die waarheid niets anders is dan de oorspronkelijke overtuiging van ons ik, waarnaar zich onze voorstelling van het niet-ik moe! geschikt hebben.' 
onduidelijk wordt welke positie Van der Wijck nu eigenlijk in het causaliteitsdebat inneemt.

Vervolgens attaqueert Spruyt Van der Wijcks opmerking over de empirische afleiding van de notie 'materie' en diens verwerping van Hume's afleiding van oorzakelijk verband uit ervaring en gewoonte om te suggereren dat Van der Wijck eigenlijk geen empirist is. Een ander argument hiervoor is dat Van der Wijck een natuurlijk vermogen van het denken aanneemt als het gaat om het verklaren van het bestaan van verwachtingen. In Spruyts optiek is het namelijk om het even of men spreekt over een 'natuurlijk vermogen' of over 'aangeboren waarnemingsvormen'.

Ook constateert Spruyt dat Van der Wijck een onduidelijke positie inneemt ten aanzien van de vraag hoe het besef ontstaat dat bij gelijke omstandigheden gelijke gevolgen optreden. Bovendien wijst hij er op dat Van der Wijck verzuimt om Hume's geldigheidsvraag te beantwoorden: hoe kan men rechtvaardigen dat men op grond van eerdere waarnemingen van het optreden van een bepaald verschijnsel na het optreden van een bepaald ander verschijnsel concludeert dat het ene verschijnsel in toekomstige gevallen altijd zal volgen na het optreden van dat andere verschijnsel? Van der Wijcks argument dat Hume misbruik maakte van de dubbele betekenis van de notie 'ervaring' acht Spruyt ongegrond.

Ten slotte: Van der Wijcks kritiek op de stelling dat het causaliteitsbeginsel a priori is, acht Spruyt weerlegd door er op te wijzen dat men de neiging tot generaliseren nooit kan rechtvaardigen als men blijft uitgaan van de gedachte dat het causaliteitsbeginsel uit ervaring kan worden afgeleid. Omdat zulke afleidingen niet succesvol zijn geweest, concludeert Spruyt dat dit beginsel daarom als een aangeboren beginsel moet worden opgevat.

Spruyt houdt vast aan zijn geldigheidsbenadering. De vraag: hoe ontstaat de verwachting dat bij gelijke omstandigheden gelijke gevolgen zullen plaats vinden? kan niet met behulp van een ontstaansbenadering worden opgelost; dit leidt tot circulaire redeneringen, zoals bij Opzoomer het geval was. Terecht oordeelt Spruyt dat Van der Wijck op dit punt inconsistent is. Enerzijds vormt het voor hem geen probleem, maar anderzijds verklaart Van der Wijck dat het bestaan van verwachtingen überhaupt voor hem een raadsel is, zonder dat hij overigens probeert dit op te lossen.

Spruyt constateert ook terecht bij Van der Wijck cen verschuiving van het "pure" empirisme (1863) naar een meer dubbelzinnige positie in 1871. De stok om de hond te slaan is natuurlijk Van der Wijcks notie 'oorspronkelijk vermogen des geestes'. Verwachtingen worden hiermee op een natuurlijk vermogen gebaseerd, maar uit dit vermogen kan geen noodzakelijkheid worden afgeleid. Spruyts opmerking dat zo'n natuurlijk vermogen op hetzelfde neerkomt als de notie 'aangeboren waarnemingsvorm' gaat echter te ver. Immers, men kan natuurlijke vermogens onderstellen zonder dat dit meteen categorieën a priori impliceert.

Ten slotte: net als in Aangeboren waarnemingsvormen levert Spruyt geen directe bewijzen voor de stelling dat het causaliteitsbeginsel als aangeboren moet worden beschouwd. Ook in De laatste gedaanteverwisseling maakt hij gebruik van een 
autoriteitsargument, in dit geval door wederom naar Helmholtz te verwijzen. Los daarvan kan nog worden opgemerkt dat het feit dat in de onderzoekpraktijk kennelijk nooit word getwij feld aan de algemeengeldigheid van dit beginsel, op zichzelf nog geen filosofische rechtvaardiging vormt voor de stelling dat het causaliteitsbeginsel aangeboren is. Bovendien blijft Spruyt vasthouden aan zijn negatieve argumentatiestralegie. Spruyts conclusie dat de afleiding van het causaliteitsbeginsel op empirische gronden in beginsel onmogelijk is en tot circulariteit leidt, is nog geen rechtstreeks bewijs voor het aangeboren karakter daarvan; Spruyts redenering vormt slechts een bewijs uit het ongerijmde.

De laatste gedaanteverwisseling uit 1871 vormt een natuurlijke begrenzing van de behandeling van het causaliteitsvraagstuk die bij Opzoomers De weg der wetenschap (1851) is begonnen. Gesteld kan worden dat tot 1871 Opzoomers en Van der Wijcks empirisme onbedreigd de belangrijkste benadering vormt van filosofische kwesties. De kantiaans georiënteerde kritiek van Spruyt stelt deze benadering, weliswaar merendeels op grond van negatieve argumenten, ter discussie.

De discussie gaat tot dusver vooral ook over de vraag of aangeboren begrippen al of niet bestaan. Dit gebeurt aan de hand van de vragen die het causaliteitsvraagstuk oproepen. De probleemgerichte benadering blijkt goed in staat om de polariteit tussen de ontstaansbenadering van Opzoomer en Van der Wijck enerzijds en Spruyts geldigheidsbenadering anderzijds scherp te zien.

Opmerkelijk is dat noch Opzoomer en Van der Wijck noch Spruyt twijfelen aan het noodzakelijke karakter van causale relaties. Het gaat hen vooral om de vraag op welke wijze causale noodzakelijkheid kan worden verklaard; zij blijven hiermee binnen het 19 de eeuwse filosofische denkkader, waarin de vraag centraal staat waarom men aan causale relaties noodzakelijkheid kan toeschrijven.

Naar aanleiding van de gevoerde discussies, komt er radicale kritiek van Josué L'Ange Huet op de tot dusver ingenomen filosofische posities. In Nieuwe oplossing van een oud vraagstuk. De methode van het positivisme toegepast op het begrip oorzaak-eng'volg (1872) stelt Huct dat de discussie tussen Opzoomer, Van der Wijck en Spruyt niel lundamenteel genoeg is gevoerd, en dat het daarom ook weinig vruchtbaar is gebleken. Zowel Opzoomer en Van der Wijck als Spruyt gaan volgens Huet uit van verkecrde ondersicllingen.

In het volgende hoofdsluk wordt nagegaan hoe volgens Huet het causaliteitsvraagstuk wél moet worden benaderd en kan worden opgelost. 


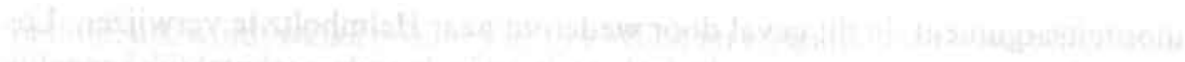

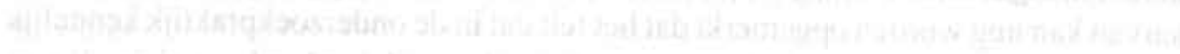

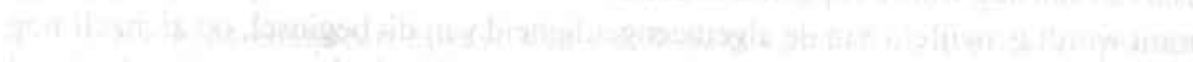

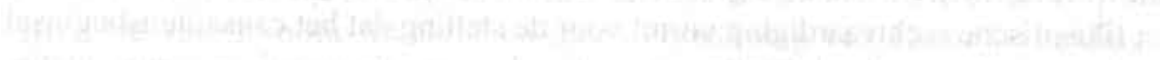

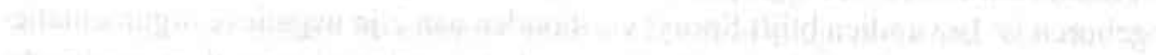

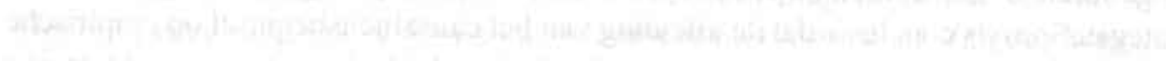

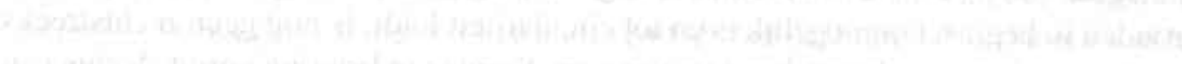

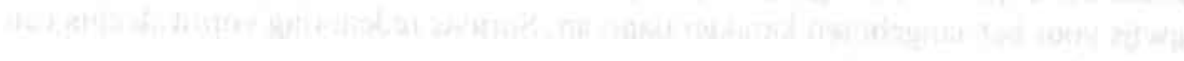

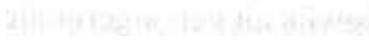

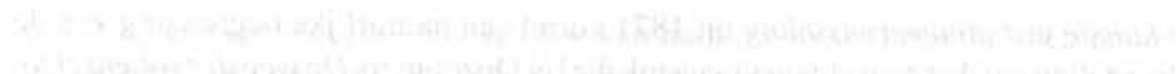

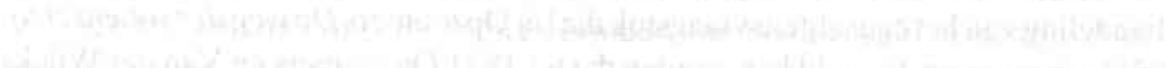

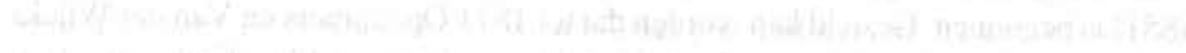

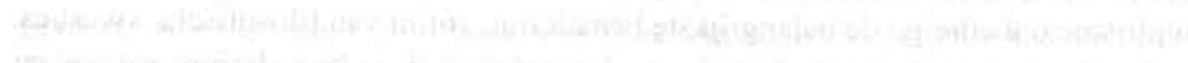

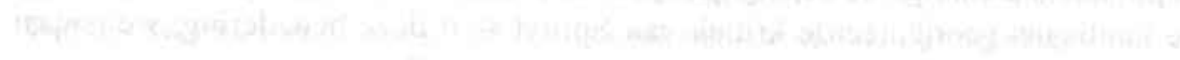

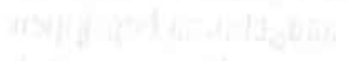

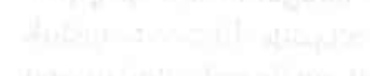




\section{L'ANGE HUET VERSUS OPZOOMER EN SPRUYT}

In 1866 promoveerde Huet aan de Rijksuniversiteit Leiden tot doctor in de theologie op het proefschrift De methode der positieve filosofie volgens August Comte. Vóor die tijd was er aan Comtes positivisme in Nederland relatief weinig aandacht besteed. Geheel onbekend was Comte hier echter niet. Twintig jaar voor Huets promotie verscheen er bijvoorbeeld een vertaling in het Nederlands van de eerste twee lessen uit Comtes Cours de philosophie positive (1830), getiteld Algemene grondslagen der stellige wijsbegeerle (1846). Ook werden rond die tijd twee geschriften gepubliceerd waarin werd aangesloten bij Comtes opvattingen over samenleving en religie, te weten: De nieuwe wijsgerige school (1847) van A. Kretzer en De stellige wijsbegeerte tegenover geloof en religie (1848) van de hand van J.Tideman. Bovendien was in 1857 het boek verschenen van Baron W.A. Constant Rebecque, getiteld Synthetische overdenkingen in den geest van het positivisme betreffende wijsbegeerte, zedeleer en religie. ${ }^{2}$ Enkele jaren later, in 1859 , volgde nog van zijn hand het artikel Iets naders over het positivisme. ${ }^{3}$ Daarnaast namen in 1866 de Wetenschappelijke bladen een vertaling op van het artikel August Comte van de Engelse denker G.H. Lewes. Dit artikel was kort daarvoor in het Engelse tijdschrift The forthnightly review verschenen. Ten slotte bleek ook dat Opzoomer Comte had gelezen, althans hij verwees op een enkele plaats naar hem [Opzoomer, $1851^{2} ; 1863 / 1867^{2}$ ]. Echter, totdat Huets proefschrift verscheen was er van een kritisch overzichtswerk in het Nederlands over Comtes denkbeelden geen sprake.

Huet zet in zijn proefschrift Comtes belangrijkste filosofische uitgangspunten uiteen; ook geeft hij hierin diens wetenschapsmethodologie weer, ten einde het eigenlijk standpunt der waarlijk moderne en wetenschappelijke wijze van denken over het voetlicht te brengen. ${ }^{4}$ Huet gaat vooral in op de vraag in welk opzicht men

I Voor een overzicht van de receptie van Comle's denkbeelden in Europa zij verwezen naar het boek van W.M. Simon, European positivism in the nineteenth century. An essay in intellectual history (1963). De receptie van Comte's denkbeelden in Nederland blijft in Simons boek ten onrechte onbesproken.

${ }^{2}$ Dit boek was in 1856 in het Frans verschenen onder de titel Réflexions synthétiques, au point de vue positiviste, sur la philosophie, la morale et la religion. De Duitse filosoof Ludwig Büchner (1824-1899) recenseerde de Nederlandse versie van dit geschrift in het tijdschrift Tijdgenoot op het gebied der rede (1859).

${ }^{3}$ Zie voor de receptie in Nederland van Comtes denkbeelden vór het verschijnen van Huets proefschrift (1866), Veer, H. van 't, (1962) en Valk, J.J.M. de (1979). i.

• cf. L'Ange Huet, J. (1866), De methode der positieve filosofie volgens Augusi Comte, p. 
Comtes denkbeelden in de theologie kan gebruiken om dit vakgebied op de hoogte der moderne wetenschap te brengen.'

Wat zoekt de wetenschap? En meer in het bijzonder: wat zijn natuurwetten?2, zo vraagt Huet zich af. Zijn antwoord luidt dat naturwetten regels zijn die door mensen worden waargenomen; zulke regels geven een verband aan tussen verschijnselen die tegelijkertijd of na elkaar optreden. Echter, dit soort regels zegt niets over een al of niet objectief bestaand verband tussen verschijnselen en evenmin over wat achter de verschijnselen zou bestaan. ${ }^{3}$ Natuurwetten zijn slechts een korte uitdrukking van de gelijkheid der wijzigingen van twee of meer verschijnselen. ${ }^{4} \mathrm{Het}$ zoeken naar essenties en eindoorzaken van verschijnselen - het innerlijk wezen en de eindelijke oorzaken - acht Huet onwetenschappelijk. Het doel van wetenschappelijk onderzoek is het in verband brengen van waarnemingen: de koördinatie van observatiën. ${ }^{5}$ Hiermee sluit Huet vrijwel letterlijk aan bij Comtes Cours de philosophie positive (1830). ${ }^{6}$

Eên en ander verschaft Huet in 1866 een aanzet voor een positivistische analyse van het causaliteitsbegrip, waarmee hij een leemte opvult, aangezien Comte geen eigen causaliteitsleer had geformuleerd. Echter, om diens filosofische positie goed te kunnen bepalen ziet Huet zich genoodzaakt om zich eerst af te vragen wat Comte "oorzaak" (zou) noemen?"

'cf. L'Ange Huet, J. (1866), op. cit. p. i.

${ }^{2}$ ct. L'Ange Huet, J. (1866), op. cit. p. 115.

${ }^{3}$ cf. L/Ange Huet, J. (1866), op. cit. p. 115, 'Een natuurwet is voor deze filosofie niet iets - 't zij dan afzonderlijk en buiten de werkelijkheid bestaande of niet - waaraan de verschijnselen gebonden zijn, maar een regel, dien de mensch opmerkt in de gelijktijdigheid of opvolging der onderscheiden verschijnselen. 't Kan wel zijn, dat, als men lust kreeg om zich een voorstelling te maken van het objectief verband tusschen die regelen en de feiten, men het zich op de gewone metafysische wijze zou moeten voorstellen. Doch dit zou fantasiewerk zijin, geen wetenschap, .....'

"cf. L'Ange Huet, J. (1866), op. cit. p. 119.

" cf. L'Ange Huet, J. (1866), op. cit. p. 131, 'Iedere waarheid dus, die meer zoekt dan koördinatie van observatiën, die meer wil zijn dan een eenvoudig algemeen feit, die tracht een uitspraak te doen omtrent het innerlijk wezen en de eigenlijke oorzaak der verschijnselen, is onwetenschappelijk en verlaat den weg, waarop alleen eenheid te vinden is in onze kennis aangaande de werkelijkheid.'

"ct. Comte, A. (1830), Cours de philosophie positive, p. 26, 'Chacun sait, en effet, que, dans nos explications positives, même les plus parfaites, nous n'avons nullement la prétension d'exposer les causes génératrices des phénomènes, puisque nous ne ferions jamais alois que reculer la difficulté, mais seulement d'analyser avec exactitude les circonstances de leur production, et de les rattacher les unes aux autres par des relations normales de succession et de similitude.'

' cf. L'Ange Huet, J. (1866), op. cit. p. 193, 'Wat zou Comte "oorzaak" noemen? Al heeft zich zelf nergens met deze kwestie ingelaten, zoo is voor ons meer opzettelijk onderzoek naar zijn wijsgeerig standpunt de vraag naar het positieve begrip van oorzaak en gevolg te gewiglig om onbeantwoord te blijven.' 
Huet wijst resoluut de vraag van de hand wat de oorzaak van ieder verschijnsel is ${ }^{1}$, omdat men deze vraag nooit in het algemeen kan beantwoorden. De betekenis van de notie 'oorzaak' staat niet vast, omdat het afhankelijk is van de concrete gevallen die men onderzoekt en omdat het afhankelijk is van het standpunt van waaruit men zulke gevallen beschouwt. ${ }^{2}$ Net als Comte $^{3}$ gaat hij er van uit dat het vragen naar oorzaak en gevolg niets anders is dan het zoeken naar vaste gelijktijdigheid en opvolging van verschijnselen, waarvan ieder onderzoek naar zekere bepaalde oorzaak een bijzonder geval, een konkreete toepassing is. ${ }^{4} \mathrm{Met}$ andere woorden: het gaat om het zoeken naar wetmatige verbanden tussen verschijnselen, en niet om wat er zich achter die verschijnselen zou bevinden.

Huets Methode werd door een aantal recensenten zeer positief ontvangen. F.W.B. van Bell (1822-1896), hoogleraar in de theologie aan de Rijksuniversiteit Groningen, bijvoorbeeld oordeelde in het Theologisch tijdschrift dat de Methode blijkt geeft van niet gewone gave en studie. ${ }^{5}$ Johannes van Vloten, redacteur van De levensbode, ging in zijn bewondering nog veel verder; iets wat voor deze polemist en vrijdenker hoogst ongebruikelijk was. Eerst gaf hij in de recensie Stellige wijsbegeerte (1867) Opzoomer en Van der Wijck er van langs. Hij adviseerde hen om toch maar het beroep te kiezen waarvoor zij waren opgeleid: ziedaar inderdaad een wijsgeerig proef, dat in den volsten zin van 't woord tevens een meesterstuk heeten mag, en dat onwillekeurig tot den vromen wensch moet dringen, "wijsgeeren" als Opzoomer of zijn Boswell, Van der Wijck, hun misbruikten wijsgeerigen leerstoel, hoe eer hoe beter, met den modernen kansel hunner eigenlijke roeping te zien verwisselen, om zich op genen door dezen jongen Leidschen "Godgeleerde" vervangen te zien. ${ }^{6} \mathrm{Dit}$ was echter niet alles. Van Vloten lanceerde in dezelfde recensie ook een voorstel om Huet onmiddellijk te benoemen tot buitengewoon hoogleraar: in vollen ernst gesproken: zou er geen gelegenheid bestaan, hem al aanstonds, als buitengewoon hoogleraar - niet aan de Godgeleerde zijner herkomst, maar - aan de Leidsche faculteit der Bespiegelende wijsbegeerte toe te voegen (....). Wij geven ' $t$ den eventueelen minister van Binnenlandsche Zaken met het nieuwe jaar in bedenking. Wij houden ons overtuigd, dat hij (de Minister) er én 't hooger onderwijs én der Nederlandsche wijsbegeerte een belangrijken dienst mee zou doen. ${ }^{7}$ Ondanks dit dringende advies zou Huct nooit het acadernische spreekgestoelte betreden.

Zes jaar na het verschijnen van de Methode constateert Huet dat de discussie tussen Opzoomer, Van der Wijck en Spruyt is verzand. Deze observatie is de

cf. L'Ange Huet, J. (1866), op. cit. p. 200.

${ }^{2}$ cf. L'Ange Huel, J. (1866), op. cit. p. 200, '..... die beteekenis (van hel begrip oorzaak) (is) zeer veranderlijk, (is) zeer konkreet, en (hangt) altijd (af) van het bijzondere geval, dat men beschouwt, ja zelfs van de wijze, waarop men het beschouwt.'

3 cf. Comte, A. (1830), op. cit. p. 26.

${ }^{4}$ cf. L'Ange Huet, J. (1866), op. cit. p. 200.

'ci. Bell, F.W.B. van (1867), 'Bespreking'. In: Theologisch tijdschrift, p. 100.

cf. Vloten, J. van (1867), 'Stellige wijsbegeerte'. In: De levensbode, p. 47.

${ }^{7}$ ć. Vloten, J. van (1867), op. cit. p. 48. 
aanleiding voor zijn Nieuwe oplossing voor een oud vraagstuk. De methode van het positivisme toegepast op het begrip oorzaak-en-gevolg (1872). In de inleiding tot de Nieuwe oplossing merkt Huet over de toenmalige stand van het debat op dat zowel Opzoomer, Van der Wijck als Spruyt een negatieve argumentatiestrategie hadden gevolgd. Spruyt had willen aantonen dat men de notie 'causaliteit' of het 'oorzakelijkheidsbegrip' niet geheel door ervaring kon verklaren, waaruit hij concludeerde dat men deze notie daarom als een aangeboren waarnemingsvorm moest opvatten. Ten onrechte had Spruyt er op gerekend dat Opzoomer en Van der Wijck niets tegen zijn kritiek konden inbrengen, aldus Huet. Bovendien was Spruyt er van uitgegaan dat zij daarom wel gedwongen waren om zijn standpunt over te nemen. Echter, Opzoomer en Van der Wijck waren nauwelijks op Spruyts argumenten ingegaan. In plaats daarvan voerden zij argumenten aan tegen Spruyts opvatting dat de notie 'causaliteit' een aangeboren waarnemingsvorm zou zijn. En, zo hadden zij gerededeneerd, als Spruyt op zijn beurt deze argumenten niet kon weerleggen, dan moest dit wel betekenen dat zij het gelijk aan hun zijde hadden. Huet wijst er op dat beide partijen ten onrechte dachten dat zij de juiste oplossing voor het causaliteitsvraagstuk in handen hadden: het empirisme of het idealisme; zij hadden evenwel een alternatieve benadering uitgesloten: het positivisme.'

In de Methode had Huet al een programmatische aanzet gegeven voor een positivistische causaliteitsleer. Hierin had hij echter alleen de richting (aangeduid) waarin zulk een onderzoek (zich) zou moeten bewegen; maar het onderzoek zelf is er, als buiten de grenzen van het boek (Methode) liggende achterwege gebleven. ${ }^{2}$ In de Nieuwe oplossing wil hij zo'n leer volledig uitwerken.

${ }^{\prime}$ cf. L'Ange Huet, J. (1872), Nieuwe oplossing voor een oud vraagstuk. De methode van het positivisme toegepast op het begrip oorzaak-en-gevolg, p. i-iii, 'Reeds meer dan een jaar geleden is tusschen de heeren Opzoomer en v.d. Wijck ter eener - en Spruyt als aanvaller, ter anderer zijde, een filosofische brochurenstrijd gevoerd, waaraan het groote publiek zekere mate van aandacht gewijd heeft. Het onderwerp van den strijd was de vraag, of sommige onzer groote en algemeene begrippen al dan niet verklaarbaar waren zonder de hypothese van een aangeboren instinctmatige onbewuste redeneering. Onder die begrippen behoorde ook het begrip van het oorzakelijk verband, waarvan Spruyt volhield, dat het - met een geringe verandering van Schopenhauers terminologie, - een 'Aangeboren Waarnemingsvorm' was. $\mathrm{Nu}$ deed Spruyt niet veel meer dan de empirische school weerleggen; want, dacht hij: "als ik aangetoond heb, dat het oorzakelijkheidsbegrip niet enkel uit empirie ontstaan kan zijn. dan zal men mij moeten toestemmen, dat er iets aangeborens in is". (...) .... empirici lieten zijn argumenten tegen hen voor 't grootste deel rustig liggen, en dachten van hun kant: "als wij slechts gewichtige bezwaren tegen de aangeborenheidsleer kunnen inbrengen, en de heer Spruyt kan die niet ontzenuwen, dan blijft hem niets anders over dan de waarheid onzer leer te erkennen." Toen beide nu elkanders taktiek bemerkten, klaagden zij steen en been over elkanders wijze van doen, en .... liep de strijd in 't riet..... (.....) In dit geval der causaliteit, dachten beide werkelijk, dat een derde, cen andere weg dan of die der aangeborenheid of die der empirie, onmogelijk kon bestaan. Dit was echter een dwaling; en een dwaling. dic verholpen zou zijn geweest, zoo een der partijen eenig juist begrip had gehad van het Positivisme. '

${ }^{2}$ ef. L'Ange Huet, J. (1872), op. cit. p. iv. 
Huct rekent ecrst af met een zijn inziens verkecrde formulering van het causaliteitsvraagstuk, en geeft vervolgens een positivistische formulering daarvan. Daarna weerlegt hij de causaliteitsopvattingen van Spruyt en in het hijzonder die van Opzoomer.

\section{HUETS FORMULERING VAN HET CAUSALITEITSVRAAGSTUK}

Huets onderzoek start mel de volgende vraag: hoe had het (oorzakelijksheids)probleem behooren te worden gesteld?' Hij constateert dat causaliteitsdiscussies tot dusver vrijwel uitsluitend waren gericht op Iwee kwesties: het vaststellen van het belang en de reikwijdte van de notie 'causaliteit' of 'het denkbeeld van oorzaak en gevolg', en het beantwoorden van de vraag in hoeverre causale uitspraken op waarnemingen zijn gebaseerd. ${ }^{2}$ Hierdoor was men echter ten onrechte voorbij gegaan aan twec fundamentele betekenisvragen: wat beteekent het eigenlijk, wanneer men het in zijn allereerste ontstaan nagaat, dat veelbesproken begrip van oorzaak en gevolg zelf? En: wat (betckeenen) eigenlijk de woorden "alles heeft een oorzaak"?"

Men denkt gewoonlijk, zo merkt Huct op, dat de betekenis van de notie 'causaliteit' of het 'denkbeeld van oorzaak en gevolg' volstrekt duidelijk is. ${ }^{4}$ Men vraagt zich daarom, ten onrechte, meteen af hoe deze noties ontstaan; oftewel, vanwaar (kan) de mensch dat begrip verkregen hebben $?^{5}$ Vervolgens denkt men ook dat men deze vraag kan beantwoorden door, wederom ten onrechte, gebruik te maken van de koninklijke heirbaan der logische redeneering. ${ }^{6}$ Zowel het empirisme als het idealisme maken van deze "logische" benadering gcbruik, zoals naar voren kwam bij Opzoomer en Spruyt. ${ }^{7}$ Zo'n benadering verschilt echter hemelsbreed van dic van

' cf. L'Ange Huet, J. (1872), op. cit. p. 1.

${ }^{2}$ cf. L'Ange Huet, J. (1872), op. cit. p. 1, 'Het verdient opmerking, dat in bijna iedereen strijd en iedere discussie over causaliteit wel veel gesproken wordt over de portee van het begrip oorzaak en gevolg, wel gevraagd wordt in hoeverre onze uitspraken dat dit oorzaak is van dat enkel uit observatie kunnen ontstaan.

${ }^{3}$ cf. L'Ange Huet, J. (1872), op. cit. p. 1.

${ }^{4}$ cf. L'Ange Huet, J. (1872), op. cit. p. 1, 'In de meeste discussies over dit onderwerp staat bij de strijdende partijen het denkbeeld oorzaak en gevolg eigenlijk recds buiten quaestie, boven kritiek en discussie. (.....) Men neemt het begrip, zonals, nu ja, zonals iedereen dat kent; - want: wie weet niet, wat oorzaak en gevolg beteekent?'

${ }^{5}$ cf. L'Ange Huet, J. (1872), op. cit. p. 1.

'cf. L'Ange Huet, J. (1872), op. cit. p. 2.

${ }^{7}$ cf. L'Ange Huet, J. (1872), op. cit. p. 1-2, '....daarbij bovendien wel zorg dragende, dat de beschrijving van den weg, waarlangs de mensch tot dat begrip zal zijn doorgedrongen, de koninklijke heirbaan der logische redeneering zij, waarlangs wij weten, dat de mensch tot de waarheid komt: (....) Dit is de gewonen methode, die niet slechts der empirische maar ook der min of meer idealistische, in een woord alle niet positivistische filosofic sedert Locke en sedert Kant.' 
het positivisme. Voor het positivisme is de betekenis van de notie 'causaliteit' juist niet boven kritiek en discussie verheven. Het onderzoeken van de betekenis van begrippen staat in de positivistische benadering centraal. Als men zich afvraagt: wat

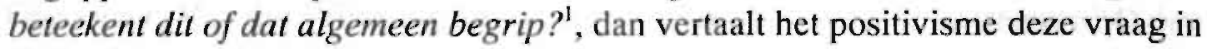
bewustzijnstermen: welke is die psychologische toestand van den mensch, waarmede bij hem een zoodanige voorstelling samengaat, als onder den invloed der voortgaande ervaring het leven heeft kunnen geven aan het begrip, naar welke beteekenis wij thans zoeken ?

Aan het empirisme en idealisme kleven echter nog andere bezwaren, zo betoogt Huet. Een belangrijk bezwaar is dat beide richtingen zich concentreren op de relatie die begrippen zouden hebben met 't geen is. Bovendien gaan deze twee denkrichtingen er van uit dat begrippen ook een juiste beschrijving vormen van wat er is. Het positivisme beschouwt begrippen daarentegen alleen als een combinatie of herleiding van voorstellingen, die onder zekere voorwaarden in het menschelijke brein (zijn) ontstaan. ${ }^{3}$ Deze voorstellingen komen overeen met een zekeren toestand van den mensch. Met andere woorden: begrippen zijn niets anders dan combinaties van voorstellingen die beantwoorden aan bepaalde bewustzijnstoestanden. ${ }^{4}$

Huets opvalting over de aard van begrippen heeft directe gevolgen voor zijn formulering van het causaliteitsvraagstuk, die als volgt luidt: welke inwendige gewaarwording gevoelde de mensch op het oogenblik, dat hij begonnen is te spreken van oorzaak en gevolg? $?^{5}$ Door het vraagstuk zo te verwoorden blijft men geheel binnen de grenzen van de ervaring. Bovendien zijn alle uitspraken die men doet te controleren door de waarneming, de innerlijke waarneming in het individu en in de geschiedenis der menschelijke denkbeelden. ${ }^{6}$

Het doel van het positivisme is het beschrijven van de historische ontwikkeling van menschelijke denkbeelden. Ook in dit opzicht volgt Huet Comte. Iedere uitspraak moet namelijk worden gezien als een feit in de natuurlijke geschiedenis van het

'cf. L'Ange Huet, J. (1872), op. cit. p. 2.

${ }^{2}$ cf. L'Ange Huet, J. (1872), op. cit. p. 2.

${ }^{3}$ cf. L'Ange Huet, J. (1872), op. cit. p. 3.

${ }^{4}$ cf. L'Ange Huet, J. (1872), op. cit. p. 3, 'Alle niet-positivistische filosofen bekijken het begrip; de positivistische school houdt den blik op den mensch gevestigd. Voor den eersten waartoe ook de empirischen school behoort - is een begrip een min of meer juiste beschrijving van 't geen is; voorzoverre namelijk 's menschen begrippen zich bij het zijn, al is het op een afstand, kunnen aansluiten. Voor den laatsten, den positivist, daarentegen is een begrip, een combinatie of herleiding van voorstellingen, onder zekere voorwaarden in het menselijk brein ontstaan, en ieder beantwoordende aan zekeren toestand van den mensch.'

${ }^{5}$ cf. L'Ange Huet, J. (1872), op. cit. p. 3.

${ }^{6}$ cf. L'Ange Huet, J. (1872), op. cit. p. 3, 'Zoo blijft de positivist zich bewegen op het gebied der ervaring; zijn uitspraken blijven tot op den bodem vatbaar voor de controle der waarneming, der innerlijke waarneming in het individu en in de geschiedenis der menschelijke denkbeelden.' 
menschelijke denken. ${ }^{1}$ Het idealisme en het empirisme achten kennelijk het beschrijven van het ontstaan van begrippen en voorstellingen alleen onvoldoende, omdat beide stromingen ook menen dat bij zo'n beschrijving de waarheid of onwaarheid van begrippen en voorstellingen zou moeten worden aangetoond. ${ }^{2}$ In zijn proefschrift had Huet er al op gewezen dat het empirisme en het idealisme ten onrechte vasthouden aan de stelling dat geen begrip voor waarheid (geldt), dat niet met het zuiver-objektieve volkomen overeenkomstig gebleken is. Of: de eisch naar bewezen overeenkomst tusschen de begrippen en het objektieve. ${ }^{3}$ Dit betekent dat beide stromingen aannemen dat begrippen alleen dan waar zijn, als zij overeenkomen met iets dat buiten ons denken bestaat; er zou daarom een relatie moeten bestaan tussen begrippen en de objectieve waarheid van dat begrip.

Alleen Hume, zo betoogt Huet, lijkt op het eerste gezicht te zijn ontkomen aan de onderstelling dat de verklaring van het ontstaan van de notie 'oorzakelijke werking' ook een garantie moet bieden voor de objectieve waarheid daarvan. Hume ging er namelijk van uit dat de mensch na telkens het een op 't ander te hebben zien volgen den indruk krijgt van een werking tusschen het voorgaande en het volgende. ${ }^{4}$ Ogenschijnlijk bleef Hume met deze formulering strikt binnen de grenzen van de ervaring. Echter, zo merkt Huet op, in de bovenstaande formulering van het causaliteitsvraagstuk zijn de noties 'een' en 'ander' binnengeslopen, waardoor Hume impliciet aannam dat er buiten onszelf dingen bestaan die op elkaar inwerken. Hume's formulering van het causaliteitsvraagstuk acht Huet daarom verkeerd. ${ }^{5}$

Huet wijst er namelijk op dat men echter pas dan een causaliteitsleer kan formuleren, als men eerst aannemelijk heeft gemaakt dat er inderdaad dingen buiten ons bestaan. Derhalve moet er eerst een antwoord worden gegeven op de vraag: hoe ontstaat tij den mensch de voorstelling van een oorzakelijke werking van 't een op 't ander?' En fundamenteler nog dan die vraag is deze kwestie: hoe ontstaat bij ons

' cf. L'Ange Huet, J. (1872), op. cit. p. 4, 'Van zulk een natuurlijke historie heeft August Comte cen schitterende proeve geleverd. (...) De geschiedenis der menschelijke denkbeelden wordt door hem gegeven. En het resultaat van dit werk is voor hen, die het bestudeeren, dat zij leeren iedere menschelijke uitspraak te beschouwen als een feit in de natuurlijke geschiedenis van het menschelijk denken.'

${ }^{2}$ cf. L'Ange Huet, J. (1872), op. cit. p. 4, 'Alle niet-positivistische filosofen wenschen meer te doen dan enkel het ontstaan onzer begrippen en voorstellingen te beschrijven; zij stellen zich tevens ten regel, dat die beschrijving zoo zal moeten zijn, dat het begrip welks ontstaan daardoor verklaard wordt, nu ook een waarheid genoemd mag worden - of wel, zoo zij 't voor onwaar houden, nu ook zal blijken onwaar te zijn.'

${ }^{3}$ cf. L'Ange Huet, J. (1866), op. cit. p. 20-21.

${ }^{4} \mathrm{cf}$. L'Ange Huet, J. (1872), op. cit. p. 5.

s cf. L'Ange Huet, J. (1872), op. cit. p. 5, 'Slechts van Hume's leer (...) zou wellicht niet mogen gezegd worden, dat hij zich de handen laat binden door de vooropgezette onderstelling, dat de verklaring van het ontstaan van ons begrip van oorzakelijke werking tevens de waarborg der objektieve waarheid van dat begrip moet zijn. Ongelukkig kan echter die Jeer van Hume te dezen opzichte niet gezegd worden het probleem te verklaren, maar moet zij veeleer gerekend worden het enkel te stellen; en dat wel onzes inziens verkeerd.'

${ }^{6} \mathrm{cf}$. L'Ange Huet, J. (1872), op. cit. p. 5. 
(...) de voorstelling van iets buiten ons? Deze twee kwesties komen in Huets theorie van sympathetische gewaarwording aan de orde.

\section{Theorie van sympathetische gewaarwording}

Huet gaat er van uit dat mensen alleen de eigen gewaarwordingen kunnen kennen. ${ }^{2}$ Dit fenomenalistische standpunt sluit aan bij zijn opvatting dat begrippen alleen bestaan uit combinaties van voorstellingen die beantwoorden aan bepaalde bewustzijnstoestanden. Nu rijst de vraag: hoe koint de mensch die nooit iets gevoeld heeft dan zijn eigen lichaam en zijn eigen zintuigen in telkens veranderenden toestand, tot de voorstelling, - waar of onwaar, dat is onverschillig - maar hoe komt hij tot de voorstelling zelve van iets wat niet zijn eigen lichaam of zijn eigen zintuigen zijn zou $?^{3}$ Vóor men hierop een antwoord kan geven, moet men zich eerst het volgende afvragen: gevoelt de mensch bij de gewaarwording van zekeren toestand zijner eigen zintuigen nog iets meer of iets anders dan dien zintuigtoestand zelve? $?^{4}$ Huet beantwoordt deze vraag positief, omdat mensen onmiddellijk de reacties van andere mensen blijken te herkennen. Dat gebeurt al bij baby's, omdat zij bijvoorbeeld meteen de reaclies van hun ouders herkennen. Maar: hoe kan de mensch, ja het zeer onontwikkelde kind, op 't ong iets herkennen, wat hij nog nooit gezien heeft? Ja, hoe kan hijzeljs, op dat gelaat terstond uitdrukkingen herkennen van pijn, vriendelijkheid, schrik, toorn, enz.? ? $^{5}$ Met andere woorden: hoc kan dit onmiddellijke herkennen van reacties - herkenning van den mensch door den mensch - verklaard worden? De enige verkluring voor dit verschijnsel is dat mensen en dieren door een instinct geleid worden: de aungeboren nabootsingszucht. Dit werkt als volgt. Als mensen bepaalde visucle gewaarwordingen voelen die zij het beeld van onze natuurgenoten noemen, dan zijn zij door dil instincl er toe geneigd om bepaalde bewegingen die men visueel gewaarwordt zélf na te doen. Door dit instinct herkent men bij zichzelf het zijn en doen van andere mensen. Met andere woorden: de reaclies van andere mensen wil men nadoen, waardoor men deze reacties ook bij zichzelf herkent. De gewaarwordingen die zo ontstaan noemt Huet het voelen van sympathetische gewaarwordingen. De verzameling van visuele gewaarwordingen die men associeert met het beeld van onze natuurgenoten of de notie 'andere mensen', blijft echter wel binnen de grenzen van de eigen bewustzijnstoestanden. De aangeboren nabootsingszucht is daarom voor Huet de bron waardoor de voorstelling van het bestaan van andere

${ }^{1}$ cf. L'Ange Huet, J. (1872), op. cit. p. 5.

${ }^{2}$ cf. L'Ange Huet, J. (1872), op. cit. p. 28, 'De mensch (gevoelt), (...) toch wezenlijk nooit iets anders, dan zijn eigen gewaarwordingen; die zich steeds blijft bewegen in de wereld zijner eigen gewaarwordingen; wiens gehele weten en denken niets anders behelst dan combinaties van eigen gewaarwordingen....'

${ }^{3}$ cf. L'Ange Huet, J. (1872), op. cit. p. 32.

4 cf. L'Ange Huet, J. (1872), op. cit. p. 32.

${ }^{5}$ cf. L'Ange Huet, J. (1872), op. cit. p. 32. 
mensen ontstaat. ${ }^{1}$ Bijvoorbeeld: als men zélf loopbewegingen maakt, dan komen de musculaire gewaarwordingen die men daardoor voelt niet overeen met de visuele gewaarwordingen die men voelt als men iemand ziet lopen. Het feit dat men deze visuele gewaarwordingen die betrekking hebben op het loopgedrag van anderen toch herkent, komt omdat men bij zichzelf de aandrang van musculaire gewaarwordingen voelt om zelf te lopen; dit laatste gebeurt naar aanleiding van de visuele gewaarwordingen van loopbewegingen van anderen. Of in Huets woorden: de herinnering aan zijn eigen lopen is verbonden met zeker spiergevoel en met een op eigenaardige wijze bewegen van de beelden op het netvlies. (...) ....ons gevoel van zelf te loopen, gelijkt in niets op het gevoel van een ander te zien loopen. Toch herkennen wij het; omdat wij bij die nieuwe gewaarwording in ons oog een sympathetisch gevoel van een begin der beweging van loopen in onze ledematen ontwaren. $^{2}$

Als baby kan men nog geen onderscheid maken tussen zichzelf en andere mensen, dieren en dingen, zo betoogt Huet. Het identiteitsbesef van baby's, het bewustzijn van ons $i k$, bestaat alleen uit de herinnering aan de verzameling van voorstellingen van musculaire gewaarwordingen en die van gewaarwordingen van lust en onlust. ${ }^{3}$ De visuele gewaarwording van het lopen van anderen en het gevoel om zelf overeenkomstige bewegingen na te bootsen, sympathetische gewaarwordingen, vormen de gewaarwordingen voor het ontstaan van het besef van een niet-ik. Door de sympathclische gewarwording ontstaan vergelijkenderwijs vervolgens geleidelijk twee soorten gewaarwordingen: de gewaarwordingen die men als 'ik' en die welke men als 'niet-ik' bestempelt. ${ }^{4} \mathrm{De}$ theoric van sympathetische gewaurwording verklaart dat de voorstelling van het bestaan van anderen ontstaat, terwijl men binnen de eigen

' cf. L'Ange Huet, J. (1872), op. cit. p. 33-35, 'In ons huist namelijk het instinct om, wanneer wij op ons netvlies zekere eigenaardige gewaarwordingen gevoelen, die wij het beeld van onze naluurgenoten noemen, daarbij zekere correspondeerende bewegingen met onze ledematen te willen maken. (....) Het is door die neiging nu, dat wij het zijn en doen van onze natuurgenoten herkennen. (....) Immers ook bij de waarneming van andere menschen, is datgene wal de mensch bemerkt, toch nooit mecr dan zich zelf.'

2 ef. L'Ange Huet, J. (1872), op. cit. p. 36.

${ }^{3}$ cf. L'Ange Huet, J. (1872), op. cit. p. 37-39, '... hij (weet) van zijn eigen ik niets, dan de herinnering aan de verschillende gewaarwordingen, allen samengaande met het, in een gevoel van lust en onlust gegradueerde, gevoel van ik. (....) Vrocger bestond ons bewustzijn van ons $i k$ in niets anders dan in de voorstelling der gewaarwording van spiergevoel of lust en onlust die alleen ons bekend werd.'

${ }^{4}$ cf. L'Ange Huet, J. (1872), op. cit. p. 37-39, '...een groep, nu niet enkel van zintuiggewaarwordingen, maar nu tevens een groep van langs sympathethischen weg ons voelbaar geworden gewaarwordingen en bevindingen, die niet onze ik-gewaarwordingen zijn, (...), nu ook een voelbaar geworden ander ik is, het bewustzijn van een ik, dat niet ons ik is. (....) De wereld der gewaarwordingen splitst zich nu in tweeën. En thans kunnen wij ons eigen ik gevoelen in tegenstelling van iets anders; terwijl vrocger alles ons ik was, en dat is dus eigenlijk ons niet bewust werd. (...) Wanneer de mensch sympathetische gewaarwording heeft, komt er een niet-ik tot zijn bewustzijn; en zijn ik wordt hem daardoor tevens als nieteen-ander bekend.' 
gewaarwordingen blijft.' De stap naar het ontstaan van de voorstelling van het bestaan van dingen of levenlooze voorwerpen is nu snel gezet. Immers, als men iemand ziet bewegen, dan ontstaat het sympathetisch gevoel van bewegen, bijvoorbeeld van loopbewegingen. Het verstand kan het bewegen van een bepaald voorwerp niet herkennen, als men niet eerst op een sympathetische manier bewust is geworden van beweging in een concrete vorm, zoals lopen. Via visuele gewaarwording van loopbewegingen ontstaat derhalve een sympathetische gewaarwording die de herinnering oproept aan waarnemingen waarbij ook een sympathetische gewaarwording van loopbewegingen is ondergaan. Via deze omweg ontstaat uiteindelijk de voorstelling van het bestaan van dingen. ${ }^{2}$

Met deze theorie van sympathetische gewaarwordingen zet Huet in de Nieuwe oplossing een eerste slap om te komen tot een eigen causaliteitsleer. Echter, eerst moet hij nog afrekenen met de opvattingen van Spruyt en Opzoomer. Dit komt in de volgende paragraaf aan de orde.

\section{HUETS KRITIEK OP SPRUYT EN OPZOOMER}

Aan de wecrlegging van het idealisme van Spruyt maakt Huet maar weinig woorden vuil. Allereerst wijst Huet er op dat de notie 'waarnemingstorm' een fictic is en niets verklaart. Het is inmers onmogelijk om deze begrippen te herleiden tot combinaties van voorstellingen die beantwoorden aan bepaalde bewustzijnstoestanden. Daarnaast merkt hij op dat de aanhangers van de theorie dat er zulke waurnemingsvormen bestain zich alleen bedienen van een bewijsvoering uit het ongerijmde. Zij kiczen deze benadering om aan tonen dat het afleiden van de notie 'causaliteit' uit ervaring tot contradicties leidt. En als zij die contradicties hebben aangetoond, concluderen

' ef. L'Ange Huet, J. (1872), op. cit. p. 40, 'In zooverre is nu reeds verklaard, hoe wij, hoewel blijvende in den kring van onze eigen gewaarwordingen, toch kunnen komen tot de voorstelling, of liever tot het sympathetisch bewustzijn van een ik, een bestaan, dat niet ons eigen ik is, of gelijk men het triviaal uitdrukt, van iemand buiten ons.'

${ }^{2}$ ef. L'Ange Huel, J. (1872), op. cit. p. 52-55, 'Ziehier nu, hoe het tot nog toe met menschen dierwaarnemingen samengaand sympathetisch gevoel als overgang dienen kan, om ook bij voorwerp-waarnemingen dat gevoel te wekken, dat dan natuurlijk nog minder rationeelverstandig is. Het zien van een bewegend voorwerp wekt in ons het sympathetisch bewustzijn van bewegen, van loopen. (...) Het verstand zou echter het bewegen van een voorwerp onmogelijk voor loopen kunnen houden, zou het niet eerst aan menschen en dieren voortbeweging in het algemeen sympathetisch als loopen, had leeren herkennen. (...) De bal die voortrolt, kan ons niet herinneren aan ons loopen; maar zij herinnert ons onmiddellijk aan die mensch- en dierwaarnemingen, waarbij wij het sympathetisch gevoel van loopen hebben gehad. Langs dien omweg wekt dan de gezichtgewaarwording van den bal nu ook dezelfde sympathetische gewaarwording. 
zij zonder meer dat deze is aangeboren. ${ }^{1}$ Hiermee wordt duidelijk dat Huet en Spruyt principieel van opvalting verschillen. Liever dan uitvoerig in te gaan op Spruyts opvattingen richt Huet zijn kritiek op Opzoomers twee argumentaties die moesten aantonen dat zowel de twee noties 'oorzaak' en 'noodzakelijkheid' als het causaliteitsbeginsel op ervaring zouden berusten.

\section{Kritiek op Opzoomers eerste argumentatie}

Het herhaald waarnemen van het volgen van een bepaald verschijnsel nadat een bepaald ander verschijnsel is opgetreden, leidt volgens Hume tot de indruk van oorzakelijke werking. In Huets woorden: ' $t$ Is volgens hem 't herhaalde post, dat op den mensch den indruk van een propter maakt. ${ }^{2}$ Zo luidde volgens Huet Hume's antwoord op de vraag hoe de notie 'causaliteit' ontstaat. Hume had toegegeven dat hij geen antwoord wist op de vraag hoe het komt dat alleen door herhaalde waarneming de indruk kan ontstaan dat een bepaald verschijnsel de oorzaak is van een bepaald ander verschijnsel. ${ }^{3}$ Dit was de vraag waarvoor de empirische school zich vervolgens zag gesteld.

Als vertegenwoordiger van deze stroming was Opzoomer er in De weg der wetenschap van uitgegaan dat men weet dat er een band van causaliteit bestaat. Echter, zo merkt Huet zijdelings op, als men zich afvraagt hoe de notie 'causaliteit' ontstaat, dan loopt men op de zaken vooruit als men zegt dat er causale relaties beslaan. Opzoomer was, zo betoogt Huet, verder van mening dat de causaliteitsrelatie een band is die, los van de ervaring, bestaat tussen een bepaalde toestand der wereld en een bepaalde andere toestand der wereld die daar onmiddelijk aan vooraf gaat. Alleen als een bepaalde eerste toestand onmiddellijk vooraf is gegaan, zal een tweede toestand op precies dezelfde manier optreden. Huet constateert dat de band van causaliteit volgens Opzoomer hier op neerkomt: we zijn er volkomen zeker van, dat, zoo ooit weer een staat der dingen terugkeerde, waarin de wereld juist zoo was, als ze zoo even geweest is, er onmiddellijk een toestand op volgen zou, volmaakt gelijk aan dien, waarin de wereld zich thans bevindt. ${ }^{4}$

'cf. L'Ange Huet, J. (1872), op. cit. p. 72-73, 'Het woord "aangeboren" is natuurlijk geen verklaring. Wij hebben reeds gezien, hoe de aangeboren onbewuste redeneeringen, of waarncmingsvormen, rechtstreeks niet te constateren zijn. (....) Zij allen moeten zich bepalen tot het bewijs, dat het onmogelijk is, op eenige andere wijze het ontstaan van het begrip, dat zij door iets aangebonrens willen verklaren. duidelijk maken; om dan tot de conclusie te kumen dat, daar het onnogelijk is een andere verklaring te geven, men zich wel zal moeten neerleggen bij de hunne.'

${ }^{2}$ cl. L'Ange Huet, J. (1872), op. cit. p. 72.

${ }^{3}$ cf. L'Ange Huet, J. (1872), op. cit. p. 73, 'Hoc zulk een post, allecn door zich te herhalen, eindigen kan met den indruk te maken van iets anders dan 't was, van een propler? dit erkende Hume niel nader te kunnen verklaren.'

"cl. L'Ange Huet, J. (1872). op. cit. p. 74, "Wij weten", zoo lezen wij, "dat er een band van causaliteit bestaat". Het is echter duidclijk, dat, op het punt waartoe ons onderzock gevorderd is, namel. tot de vraag hoc het begrip van causaliteit ontstaat? wij dat nog niet weten. Wij vragen dus: "wat is die band van causaliteit" en hoe kennen wij haar?" "IDie 
Opzoomers redenering deugt niet, aldus Huet. Opzoomer was er namelijk van uitgegaan dat de werkelijkheid cen aggregaat van verschijnselen is. Bovendien was hij van oordeel dat tussen deze verschijnselen causale verbanden zijn waargenomen. Ook onderstelde hij dat op een bepaalde toestand der wereld slechts één bepaalde andere toestand der wereld kan volgen. Hieruit had Opzoomer vervolgens afgeleid dat er tussen specifieke verschijnselen causale verbanden bestaan. ${ }^{1}$

Huet merkt op dat Opzoomers redenering moet worden omgekeerd, en wel als volgt. Alleen omdat men tussen specifieke verschijnselen een band van onvoorwaardelijke opvolging heeft gevonden, kan men concluderen dat één bepaalde toestand der wereld noodzakelijk gevolgd zal worden door één bepaalde andere toestand der wereld. Hierbij vat men de notie 'toestand der wereld' op als de verzameling van alle verschijnselen. ${ }^{2}$ Met andere woorden: als vertegenwoordiger van de empirische school ging Opzoomer er ten onrechte van uit dat de notie 'causaliteit' al voorhanden is. Opzoomer trok, zo merkt Huet op, te snel conclusies, want men kan immers alleen via causale inductie te weten komen of bepaalde verschijnselen elkaar onvoorwaardelijk volgen. Opzoomers voorbarige conclusie heeft er toe geleid dat Opzoomer de notie 'oorzaak', opgevat als onvoorwaardelijke en constante opvolging, en het causaliteitsbeginsel, de stelling dat alles een oorzaak moet hebben, ten onrechte als het uitgangspunt van onderzoek ziet, en niet als het resultaat daarvan. ${ }^{3}$ En, zo

band", zoo lezen wij verder, is, "die welke tusschen den geheelen tegenwoordigen en den geheelen onmiddellijk voorafgaanden toestand der wereld bestaat. We zijn er volkomen zeker van, dat, zoo er ooit weer een staat der dingen terugkeerde, waarin de wereld juist zoo was, als ze zoo even geweest is, er onmiddellijk een toestand op volgen zou, volmaakt gelijk aan dien, waarin de wereld zich thans bevindt" '. Dit is zeer waarschijnlijk een parafrase van Opzoomer $\left(1851^{2}\right)$, op. cit. p. 121, ' ledere toestand in de wereld is het gevolg van den vorigen tocstand. De kennis dezer waarheid kan echter niets meer worden dan een geheel algemeene, onbepaalde overtuiging, daar het noch aan 's menschen blik noch aan zijn geest gegeven is, het heelal, zij het maar in een enkel tijdstip te omvatten. (....) Zij (de wetenschap) wil weten, welke schalm in dien oneindigen keten van oorzaken met welken schalm in dien oneindigen keten van gevolgen zamenhangt.'

' cf. L'Ange Huet, J. (1872), op. cit. p. 74, 'Wij zijn toch eerst zeker van 't geen hier omschreven wordt wannecr wij de wereld voorstellen als een aggregaat van verschijnselen, lusschen welke wij een verband van oorzakelijke werking reeds hebben opgemerki (....) (1) op een zekere toestand van de wereld, kan maar cén bepaalde tweede toestand volgen; (2) dus moet ook tusschen de enkele verschijnselen zulk een verband te vinden zijn.'

${ }^{2}$ ef. L'Ange Huet, J. (1872), op. cit. p. 74, 'Maar onze redenering is, juist omgekeerd: 1. tusschen de enkele verschijnselen hebben wij een verband van onvoorwaardelijke opvolging gevonden; en 2. daaruit volgt, dat alle verschijnselen te samen genomen, de wereld, ook door één bepaalden anderen toestand der wereld gevolgd zal moeten worden.'

${ }^{3}$ ct. L'Ange Huet, J. (1872), op. cit. p. 76, 'Tengevolge van dat niet buiten rekening laten der vooruit meegebrachte kennis, kan dan ook de empirische school spreken, alsof haar begrip van oorzakelijk verband als enkel onvoorwaardelijke opvolging, reeds bestaan kon, nog eer dat wij door causaal-inductie, die opvolging opgemerkt hadden. Terwijl toch blijkbaar voor hem, die 't woord oorzaak in den zin der empirische school als onvoorwaardelijke en constante opvolging neemt, de stelling, dat alles een oorzaak moet hebben, de samenvatting der wetenschap moet zijn, doch niet haar punt van uitgang kan zijn.' 
concludecrt Huet, als men er al van uit zou gian dat de notie 'causaliteit' reeds voorhanden zou zijn, dan moet dit een andere notie zijn dan de notie 'onvororwaardelijke opvolging'. Immers, deze notic kan alleen ontstaan als uitkomst van een inductief proces.

\section{Kritiek op Opzoomers tweede argumentatie}

Net als Spruyt bekritiseert ook Huet Opzoomers tweede argumentatie die moest aantonen dat de twee noties 'oorzaak' en 'noodzakelijkheid' uit de inwendige waarneming kunnen worden algeleid. Opzoomer had in Het wezen der kenmis beweerd dat de ervaring van het willen van iets de bron was voor het ontstaan van dic twee noties. Bovendien ging hij er van uit dat het herhaald waarnemen van het onvoorwaardelijk volgen van verschijnselen, in Huets terminologie, leidt tot de indruk van veroorzaking. Huet richt zijn kritiek op de volgende dric elementen uit Opzoomers tweede argumentatie.

Allercerst had Opzoomer geconstatecrd dat daden constant en onvoorwaardelijk op wilsbepalingen volgen; en ook dat men het verband tussen een wilsbepaling en cen daad vervolgens toepast op andere verschijnselen. Daarnaast was Opzoomer van mening dat men altijd een daad voelt volgen op een wilsbepaling. En ten slotte had Opzoomer een onderscheid gemaakt lussen wilsbepalingen en daden. ${ }^{2}$

Huct voert dric bezwaren aan tegen Opzoomers tweede argumentatie. Hij verbaast zich er over dat Opzoomer juist in het willen en doen een vaste en onvoorwaardelijke oprolging zict. Dit ligt niet voor de hand, omdat willen en doen nauwelijks van elkaar te onderscheiden zijn, en bovendien in elkaar overvlocien. ${ }^{3}$ Het tweede hezwaar betreft de oorsprong van de notic 'vaste en onvoorwaarde'lijke opvolging'. Waarom zocht de empirische school, in casu Opzoomer, nu juist in het verband tussen willen en doen de oorsprong van die nolie? Het is immers veel waarschijnlijker dat die notie door geheel andere gewaarwordingen ontstaat. ${ }^{4}$ Huets derde bezwaar is principiëler.

' cf. L'Ange Huet, J. (1872), op. cit. p. 76, 'Is er een vooruit aanwezig begrip van oorzaak en gevolg, dan moet dat begrip dus cen ander zijn dan dat van onvoorwaardelijk opvolging, want van deze kan men eerst door voortgezette causaal-inductie kennis krijgen.'

${ }^{2}$ ef. L'Ange Huet, J. (1872), op. cit. p. 76, 'Op onze wilsbepaling zouden wij namel. constant en onvoorwaardelijk de daad hebben zien volgen, en dat verband zouden wij nu overbrengen in de verschijnselen. (....) dat de mensch altijd en onvoorwaardelijk de wilsbepaling door de daad voelt volgen (....) dat (...) de wilsbepaling en de daad zich niet als één zaak bewust zou worden.'

${ }^{3}$ cf. L'Ange Huet, J. (1872), op. cit. p. 77, 'En dan vraag ik: is het verstandig te beweren, dat onder al onze in- en uitwendige observatiën een vaste en onvoorwaardelijke opvolging ons daar het eerst zou gefrappeerd hebben, waar het voorgaande en het volgende juist zoozeer in elkander vloeien, als wil en daad dat doen. In honderd en duizend gevallen veeleer zoude die vaste en onvoorwaardelijke opvolging ons gemakkelijker getroffen hebben dat juist in dit geval.'

${ }^{4}$ cf. L'Ange Huet, J. (1872), op. cit. p. 78, '...het (is) thans de vraag, of de empirische school een onderzoek meent te moeten openen naar de vraag, welke observatie den mensch 't eerst het denkbeeld van vast en onvoorwaardelijke opvolging heeft gegeven. Als ik beweer, 
Als men er van uitgaat dat de notie 'onvoorwaardelijke en vaste opvolging' ontstaat door het verband tussen willen en doen, dan betreft dat slechts één enkele waarneming daarvan. Dit wekt Huets bevreemding, omdat de empirische school er van uitgaat dat men al bekend is met een alom aanwezig verband van vaste en onvoorwaardelijke opeenvolging tussen verschijnselen; hetgeen impliceert dat men alleen nog maar op zoek hoeft te gaan bijzondere gevallen daarvan. ${ }^{1}$

Huet verbaast zich verder over Opzoomers tweede argumentatie, want wat ter wereld (kan) hem (Opzoomer) bewogen hebben, om juist dat curieuse geval van die wilsbepaling en die daad uit de gansche massa uit te kiezen ${ }^{2}$ Hij verklaart dit op grond van het feit dat Opzoomer alleen via inductie kan aangeven welke verschijnselen bij elkaar horen. Hiermee blijft Opzoomer strikt binnen de grenzen van ervaring. Huet wijst er op dat de "klassieke" notie van 'causaliteit' echter verder gaat dan dat, omdat men hiermee immers het wezen en werken der dingen wil aangeven. Echter, het laatste valt buiten de grenzen van de ervaring; iets wat voor Opzoomer onaanvaardbaar is. Immers, het empirische beginsel dicteert dat alle begrippen herleidbaar moeten zijn tot ervaring. Dit betekent dat de notie 'causaliteit' alleen het waarnemen van vaste opvolging kan inhouden. ${ }^{3}$ Om aan deze beperking te ontkomen zoekt Opzoomer daarom de bron van de notie 'causaliteit' in het zelfbewustzijn: het waarnemen van een verband tussen het willen en het doen. Het waarnemen van dit verband acht Opzoomer kennelijk anders dan het waarnemen van het verband tussen andere verschijnselen. Echter, toegepast op de notie 'causaliteit' dicteert het empirische beginsel dat ook deze notie niet méér mag inhouden dan men op grond van ervaring kan stellen. Ook al neemt men het zelfbewustzijn als uitgangspunt, dan komt men niet veel verder dan waarnemingen van opeenvolging, aldus Huet. ${ }^{4}$

dat den mensch 't eerst daarop gekomen is door het telkens observeeren, dat moe worden op inspanning volgt; heb ik dan niet meer kans om gelijk te hebben, dan wanneer bijv. de heer Opzoomer zegt, dat ' $t$ geweest is, toen de mensch altijd zijn wilsbepaling door een daad gevolgd zag?'

1 cf. L'Ange Huet, J. (1872), op. cit. p. 78, '...als de mensch al - quod absurdum, met die wil en die daad begonnen is, vaste en onvoorwaardelijke opvolging te bemerken; dan had hij dat verband immers nog slechts in dit eene geval. Terwijl de empirische school beweert, dat hij dan het algemeen bestaan van een overal aanwezig verband van vaste en onvoorwaardelijke opvolging reeds zou kennen, en verder nog slechts zou hebben uit te zocken, tusschen welke verschijnselen speciaal het te vinden is.'

${ }^{2}$ cf. L'Ange Huet, J. (1872), op. cit. p. 78.

" cf. L'Ange Huct, J. (1872), op. cit. p. 79, 'Het resultaat der inductie is ordening van bijeenbehogrende verschijnselen (...) meer niet. Het gewone begrip van oorzakelijk verband daarentegen zegt iets omtrent het wezen en werken der dingen zelve en gaat verder dan de waarneming. Maar krachtens haar empirisch beginsel mag de wijsbegeerte der ervaring in de omschrijving van dat begrip weder toch niets meer leggen, dan wat de enkele ervaring kan geven: vaste opvolging.'

${ }^{4}$ cf. L'Ange Huet, J. (1872), op. cit. p. 79, 'Men zoekt nu een feit op het gebied van hel zeltbewustzijn. 't Verband tusschen onze eigen daden en gevoelens neemt men anders waar, dan tusschen gewone verschijnselen. Met dat voorbeeld van wil en daad schijnt dus icts bijzonders gegeven. Maar, ....daar 't begrip van oorzaak toch ook weer niet meer mag 
Hij concludeert dat Opzoomers afleiding van de noties 'oorzaak' en 'noodzakelijkheid' uit wilservaringen niet is gelukt. Het herhaald waarnemen van het volgen van een verschijnsel nadat een ander verschijnsel is opgetreden, resulteerl zeker niet in een indruk dat een bepaald verschijnsel de oorzaak is van een bepaald ander verschijnsel. ${ }^{1}$ Men neemt alleen verschijnselen waar die na elkaar optreden, en niet dat het ene verschijnsel het andere veroorzaakt. "Tobben", is het eenige woord, waarmee men zulk filosofeeren naar eisch kan karakteriseeren', zo merkt Huet droogjes op. Het is overigens niet vreemd dat Opzoomer de overgang van het waarnemen van successie naar het ontstaan van een indruk van veroorzaking niet kon verklaren. Deze metamorfose komt namelijk helemaal niet voor, aldus Huet. De vruchteloze pogingen van Opzoomer om de indruk van veroorzaking te verklaren kan men terugvoeren op Hume's verkeerde formulering van het causaliteitsvraagstuk. ${ }^{3}$ Het herhaald waarnemen van successie van verschijnselen leidt namelijk nooit tot het ontstaan van een indruk van veroorzaking, omdat men alleen het volgen van verschijnselen waarneemt. Dit wijst er volgens Huet op dat de bron van de notie 'causaliteit' niet in de herhaalde waarneming van successie ligt, maar in een andere, nieuwe waarneming. ${ }^{4}$

Huet concludeert dat het herhaald waarnemen van het volgen van verschijnselen niet als de bron van de notie 'causaliteit' kan worden beschouwd. En als men het regelmatig volgen toch als de bron van deze notie ziet, zo besluit Huet zijn kritiek op Opzoomer, dan onderstelt men impliciet de notie 'causaliteit'; hetgeen circulair is. Hiermee toont Huet ten slotte ook de onjuistheid van Opzoomers stelling aan dat het warnemen van constante successie leidt tot de indruk van veroorzaking. ${ }^{5}$

bevatten, dan 't geen de ervaring alleen kan geven, moet nu toch ook weder uit dat voorbeeld van het zelfbewustzijn, juist het eigenaardige weggewerkt worden, waarom men het had opgezocht, en moet daarin als hoofdzaak weder de bloote opvolging op den voorgrond gebracht worden.'

' cf. L'Ange Huet, J. (1872), op. cit. p. 79, 'Men ziet het, ook aan die enpirici, welke meenden er wel toe in staat te zijn, is het niet gelukt, duidelijk te maken, hoe, wanneer wij slechts een genoegzaam aantal malen tusschen twee verschijnselen een post waarnemen, dat post èindigen zou met geen post te blijven doch een propter te worden.'

${ }^{2}$ ef. L'Ange Huet, J. (1872), op. cit. p. 79.

${ }^{3}$ cf. L'Ange Huet, J. (1872), op. cit. p. 79, 't Is trouwens niet te verwonderen, dat het tot nog toe niet gelukt is, deze vreemdsoortige metamorfose te verklaren; om de eenvoudige reden, dat die metamorfose geen plaats heeft, dat het probleem, zooals het door Hume gesteld en door de empirische school overgenomen is, verkeerd en niet overeenkomstig de feiten is gestcld.'

${ }^{4}$ cf. L'Ange Huet, J. (1872), op. cit. p. 80, '...en zoo is het dan niet de herhaling derzelfde of van een dergelijke waarneming maar een andere nieuwe waarneming, die mij dat nieuwe verband leert kennen.'

${ }^{5}$ cf. L'Ange Huet, J. (1872), op. cit. p. 81, '...er zijn vele gevallen, waarin tusschen twee vast op elkander volgende verschijnselen bloot een verband van opvolging, of van bijeenbehooring wordt aangenomen; ofschoon toch, indien het waar was, dat enkel herhaalde vaste opvolging op ons den indruk van veroorzaking makk, in alle gevallen oorzakelijk verband zou moeten erkend zijn. Dit bewijst, dat de stelling, hoe algemeen ook aangenomen, volgens 
Met het weerleggen van de opvattingen van Spruyt en Opzoomer effent Huet de weg voor zijn eigen causaliteitsleer. Deze theorie komt in de volgende paragraaf aan de orde.

\section{DE CAUSALITEITSLEER VAN HUET}

De kern van Huets causaliteitsleer bestaat uit twee stcllingen. Ten eerste: (...) het bewustzijn van ecn propter ontstaat door de waarneming van een post. Dat is waar. Maar (...) dat er voor het ontstaan van dat bewustzijn een herhaald post noodig zou zijn. Dat is onwaar. En ten tweede: (...) herhaalde waarneming (is) noodig om tot algemeene stellingen te komen, die in bijzondere gevallen haar bevestiging vinden. Dat is waar. - Maar (...) dat die herhaalde waarneming dan een waarneming van een post zou moeten zijn. Dat is onwaar. ${ }^{1}$ De eerste stelling betreft het ontstaan van de notie 'causaliteit'. De tweede stelling handelt over de rol van herhaalde waarneming bij het vormen van algemene uitspraken. Huet vult zijn theorie aan met nog twee stellingen. Ten cerste: (..) wij (hebben) het bewustzijn hebben van een propter. Dat is waar. - Maar (...) dat dit bewustzijn een verstandelijk weten zou zijn. Dat is onwaar. ${ }^{2}$ En ten tweede: (...) ten gevolge van herhaalde waarneming (spreken) wij affirmaties uit omtrent hetgeen wij niet waargenomen hebben. Dat is waar. - Maar (...) dat die uitspraken eenigen anderen inhoud zouden hebben dan enkel het reeds waargenomene. Dat is onwaar. ${ }^{3}$ Deze laatste twee stellingen zijn vooral gericht op de kenmerken van kennis in het algemeen.

Deze twee paren van stellingen belichten, zo betoogt Huet, elk twee facetten van de "klassieke" notie van 'causaliteit': oorzakelijkheid en voorspellen. Deze facetten haalt men dikwijls door elkaar, waardoor deze notie onduidelijk wordt. Huet wijst er op dat men gewoonlijk met causalc oordelen enerzijds een uitspraak wil doen over een geheimzinnig, niet-waarnecmbaar verband tussen verschijnselen: het wezen der dingen. Anderzijds wil men met zulke oordelen uilspraken doen over de toekomst; dat wil zeggen, uitspraken over verschijnselen die men nog niet heeft waargenomen. Beide facetten ziet men doorgaans als de keerzijden van één medaille. De "klassieke" notie van 'causaliteit' houdt derhalve in dat men eerst de innerlijke aard 't geen is

welke ' de mensch door de opmerking van een herhaald post komt tot de erkenning van een propter, en daarmee tot kennis, die verder reikt dan zijn tot nog toe opgedane ervaring. en die hem in staat stelt iets te weten omtrent de toekomst ', onjuist moet zijn.' Geciteerd naar Opzoomer; C.W. $\left(1851^{2}\right)$, op. cit. p. 63: ' De ervaring, die ons leert dat het eene feit na het andere komt, leert ons evenzeer, dat het eene door het andere ontstaat. Beide betrekkingen verschillen hemelsbreed. Niet de opvolging, maar de opvolging op een bepaalde wijze, mel bepaalde omstandigheden er bij, brengt ons tot het begrip van oorzak.'

\footnotetext{
'cf. L'Ange Huet, J. (1872), op. cit. p. 82.

${ }^{2}$ cf. L'Ange Huet, J. (1872), op. cit. p. 82.

${ }^{3}$ cf. L'Ange Huet, J. (1872), op. cit. p. 82.
} 
wil ontrafelen, om vervolgens op grond hiervan voorspellende uitspraken te doen. Deze opvatting over causaliteit acht Huet verkeerd. ${ }^{1}$

Met voorspellingen doet men een uitspraak (affirmatie) over wat men nog niet heeft waargenomen, terwijl voorspellingen eigenlijk berusten op wat men eerder heeft waargenomen; ook zulke uitspraken vormen kennis. Met causale oordelen doet men weliswaar een uitspraak over het wezen der dingen, maar zulke uitspraken zijn niet gebaseerd op verstand; zij komen tot stand via het sympathetisch gevoel. ${ }^{2}$ Beide soorten uitspraken of oordelen moet men duidelijk van elkaar onderscheiden, omdat causale uitspraken gebaseerd zijn op sympathetisch gevoel, terwijl voorspellende uitspraken berusten op verstand of op redeneren.

Huet motiveerl eerst de kern van zijn causaliteitsleer: de eerste twec stellingen. In de motivering bij de laatste twee stellingen gat hij dieper in op de aard van kennis. In die context behandelt hij onderwerpen die niel direct hebben te maken met het causaliteitsvraagstuk; dit betreft bijvoorbeeld de notie 'waarheid', de relatie tussen de notics 'waarheid' en 'wcten', en het onderscheid tussen denkbaarheid en waarheid van voorstellingen. Zulke onderwerpen vallen buiten de doelstelling van dit onderzock. De laatste twee stellingen worden daarom in deze studie alleen besproken voor zover zij licht kunnen werpen op de discussies.

\section{Huets eerste stelling}

De indruk van een causaal verband kan al ontslaan door cen eenmalige gewaarwording van hel volgen van het ene verschijnsel op het andere. Deze indruk ontstaat derhalve niet door herhaalde waarneming van het regelmatig volgen van verschijnsclen. Zo luidt Huets eerste stelling. Hieronder volgen Huets argumentaties die tot deze stelling hebben geleid.

\section{Daad als oorzaak van beweging}

Welke zijn de elementen van het gevoel in ons, dat "wij zelve iets met een ander voorwerp doen?" Wanneer ik bijv. iets voortduw, hoe koin ik dan tot het gevoel, dat

' cf. L'Ange Huet, J. (1872), op. cit. p. 82-83, 'Beide paren bestaan uit twee stellingen, omdat het gewone begrip van propter twee zijden heeft, wier verwarring en ineensmelting juist de oorzaak is van de onzuiverheid van het gewone begrip. (....) Immers, van de eene zijde bezien, gaat ieder oordeel omtrent een oorzakelijk verband door voor een uitspraak over het wezen der dingen, omtrent een geheimzinnig, nimmer rechtstreeks waarneembaar verband, dat, naar den innerlijken aard van 't geen is, tusschen de verschijnselen bestaan zou; terwijl van de andere zijde bezien, ieder zoodanig oordeel tevens is een uitspraak omtrent het nog niet waargenomene, het tockomende; (...) Volgens de gewone opvatting vallen die beide kanten van het begrip samen, en is de eene zonder de andere niet mogelijk. (...) Die redeneering, hoe plausibel ook, is verkeerd.'

${ }^{2}$ ef. L'Ange Huet, J. (1872), op. cit. p. 83, 'Wij affirmeeren als wetenschap 't geen wij nog niet gezien hebben; en toch is in ons weten niets meer voorhanden, dan juist datgene wat wij gezien hebben. Nu affirmeeren wij daarenboven, wanneer wij van oorzakelijke werking spreken, ook wel iets omtrent het wezen der dingen, maar die affirmatie komt niet langs den weg van hel verstand, maar langs dien van het sympathetisch gevoel.' 
de beweging van het voortgeduwde voorwerp mijn daad is?' Deze vragen beantwoordt Huet als volgt. Als een voorwerp door iemands daad in beweging wordt gezel, dan voelt die persoon op hetzelfde moment musculaire, tactiele en visuele gewaarwordingen. De beweging van het voorwerp leidt tot een verandering in de visuele gewaarwordingen. ${ }^{2}$ Het besef dat iemands daad de oorzaak van de beweging van een voorwerp is, kan alleen ontstaan als er sprake is van het tegelijkertijd ondergaan van musculaire en visuele gewaarwordingen. ${ }^{3}$

Om dit aan te tonen vraagt Huet zich af wat er noodig is om ons tusschen een van de laatsten (spiergevoelgewaarwordingen) en een van de eerstgenoemden (zintuiggewaarwordingen) zulk een verband te doen bespeuren, dat wij zeggen, dat die zintuiggewaarwording onze daad is? Allereerst moet er sprake zijn van een voortdurende gelijktijdigheid tussen zintuiglijke en musculaire gewaarwordingen. Bovendien moeten het waarnemen van de intensiteit van musculaire gewaarwordingen en het waarnemen van de intensiteit van zintuiglijke gewaarwordingen rechtevenredig zijn. ${ }^{5}$ Als aan die beide voorwaarden is voldaan, dan kan men geen onderscheid meer maken tussen zintuiglijke en musculaire gewaarwordingen. Hierdoor ontstaat het besef van de werking op een ander lichaam. Dit besef karakteriseert Huet als een tegenstrijdig besefvan onderscheid en identiteit tussen musculaire gewaarwordingen en dat wat men zintuiglijk waarneemt. Men beseft dat er iets verandert in datgene wat men niet zelf is, maar tegelijkertijd voelt men een verandering in zichzelf. Het gelijktijdig ondergaan van het gevoel van onderscheid en identiteit van gewaarwordingen merkt men het meest duidelijk als men een voorwerp aanraakt en als men dit langzaam in beweging zel. ${ }^{6}$ Dit tegelijkertijd waarnemen van de eigen beweging

'cf. L'Ange Huet, J. (1872), op. cit. p. 86.

${ }^{2}$ cf. L'Ange Huet, J. (1872), op. cit. p. 86, 'Mijn directe gewaarwordingen zijn in dat geval een zeker gevoel van mijn arm, in de tastzenuwen van mijn hand en tegelijk. die zekere verandering in de gezichtsgewaarwording, die ik beweging van een voorwerp noem.'

${ }^{3}$ cf. L'Ange Huet, J. (1872), op. cit. p. 86, 'Het is duidelijk, dat (....) de vereischte voor het bewustzijn van een daad van ons, die iets veroorzaakt, allereerst en in alle gevallen is het samentreffen van een gewaarwordingen van spiergevoel met zintuiggewaarwordingen.'

${ }^{4}$ cf. L'Ange Huet, J. (1872), op. cit. p. 86.

5' ef. L'Ange Huet, J. (1872), op. cit. p. 86, 'Daartoe is het nodig, dat tusschen deze beide (spier- en zintuiggewaarwordingen) die gelijktijdigheid, die tusschen zoovele zintuig- en spiergewaarwordingen bestaat, niet slechts oogenblikkelijk, maar voortdurend zij; dat het spiergevoel en de zintuiggewaarwording niet slechts tegelijk bespeurd worden, maar dat en het begin en de toe- of afnerning en het einde van beide gelijktijdig zij.'

${ }^{6}$ cf. L'Ange Huet, J. (1872), op. cit. p. 87, '...dan kunnen wij niet langer een wezenlijk onderscheid tusschen de beide zaken gevoelen; dan krijgen wij een gevoel van onze werking op een ander lichaam, dat men zou kunnen omschrijven: als een bewustzijn, tegelijk van onderscheid en van identiteit tusschen onze spiergewaarwording en het waargenomene; als dat bekende tegenstrijdige besef van een vreemd doen, een verandering in cen vreemd zijn, die toch weder ook ons eigen doen, een verandering in ons eigen zijn, is. Een dergelijke gelijktijdigheid (...) bemerken wij echter slechts dan, wanneer wij door aanraking eenig voorwerp langzaam in beweging brengen. Houdt onze beweging op, de beweging van het voorwerp eindigl.' 
en de beweging van een voorwerp dat men aanraakt is de daad ten opzichte van andere voorwerpen. ${ }^{1}$ Als het verband tussen die daad en het in beweging gebrachte voorwerp is verbroken, en het voorwerp blijft bewegen, dan kan men spreken over de eigen daad van het voorwerp. Met andere woorden: het voorwerp beweegt dan uit zichzelf. ${ }^{2}$

De rechtstreekse daden van mensen bestaan louter uit het in beweging brengen van voorwerpen. Het in beweging brengen van voorwerpen resulteert in de veranderingen van de ruimtelijke of plaatselijke verhoudingen tussen voorwerpen. Zulke veranderingen worden gevolgd door veranderingen in voorwerpen zelf, los van de rechtstreekse daden van mensen. ${ }^{3}$ Hieruit volgt dat iedere daad ten opzichte van voorwerpen gepaard gaat met het waarnemen van het veranderen van de ruimtelijke positie die men zelf inneemt ten opzichte van voorwerpen. ${ }^{4}$

\section{Verandering van plaatselijke verhoudingen}

Nadat hij heeft verklaard welke elementen deel uitmaken van het besef of gevoel wanneer men iets in beweging zet, vraagt Huet zich vervolgens af hoe (ik nu echter) kom tot het gevoel dat, wanneer ik de voorwerpen in de vereischte plaatselijke verhoudingen tot elkaar breng, de daaropvolgende verandering in een dier voorwerpen of in beide de daad is van die voorwerpen? Met andere woorden: hoe komen wij tot het gevoel, dat een voorwerp op een ander werkt? ${ }^{5}$

Huet wijst eerst op het belang van de notie 'veranderde plaatselijke verhouding' om het ontstaan van de notie 'causaliteit' of 'oorzakelijkheid' te verklaren. In de gangbare verklaringen wordt dit element ten onrechte geheel verwaarloosd. ${ }^{6}$ Immers, als men causale samenhangen - oorzakelijke werking - op het spoor is, betekent dit dat er met het veranderen van de plaatselijke verhouding tussen twee voorwerpen

${ }^{1}$ cf. L'Ange Huet, J. (1872), op. cit. p. 88.

${ }^{2}$ cf. L'Ange Huet, J. (1872), op. cit. p. 88, 'Zien wij alzoo, dat onze eigen beweging tegelijk met de beweging van het voorwerp, waarmee wij in aanraking zijn, datgene is, wat wij in de eerste plaats, onze daad ten opzichte van andere voorwerpen noemen, zoodat zelfs de voortzetting der beweging de eigen daad van het voorwerp wordt, zoodra de aanraking met ons lichaam verbroken is.'

${ }^{3}$ ef. L'Ange Huet, J. (1872), op. cit. p. 88, 'De mensch beweegt slechts de voorwerpen, en brengt ze in andere plaatselijke verhoudingen tot elkander; op die plaatsveranderingen volgen dan, terwijl de mensch de handen in den schoot legt, de veranderingen in de voorwerpen zelve.'

'cf. L'Ange Huet, J. (1872), op.cit. p. 89, '.... een gewichtig en nimmer ontbrekend element van die daden van ons, waarmee wij veranderingen in andere voorwerpen, of in een woord waarmee wij eenig verschijnsel zien samengaan, is: onze verplaatsing ten opzichte van de voorwerpen.'

${ }^{5} \mathrm{cf}$. L'Ange Huet, J. (1872), op. cit. p. 89-90.

'cf. L'Ange Huet, J. (1872), op. cit. p. 90, '... (het is) zeer te wonderen is, dat in de meeste beschouwingen over het begrip van oorzakelijkheid en het ontstaan daarvan, onder al de voorstelling, die (bij het ontstaan daarvan) een rol spelen, dit bestanddeel van veranderde plaatselijke verhouding doorgaans, om niet te zeggen altijd, geheel verwaarloosd wordt.' 
altijd een verandering in deze voorwerpen zelf optreedt. ${ }^{1}$ Dit komt duidelijk naar voren in bijvoorbeeld de natuur- en scheikunde. Hier leidt een wijziging van de plaatselijke verhoudingen van voorwerpen onderling tot veranderingen in de voorwerpen zelf. Ook bij het doen van experimenten op het gebied van de mechanica met als doel causale relaties op te sporen, is het duidelijk dat in alle gevallen de plaatselijke verhouding tussen voorwerpen wordt veranderd. Als het gaat om het gevoel van oorzakelijke verband mag men daarom niet voorbij gaan aan de rol die plaatsverandering en het naderen van voorwerpen tot elkaar bij dit gevoel spelen. ${ }^{2}$ De notie 'oorzakelijke werking' kan daarom nooit ontstaan, zo betoogt Huet, als er geen onmiddellijke indruk is van het verplaatsen en de daarop volgende verandering van verschijnselen. Deze notie is onwillekeurig en geleidelijk ontstaan door het waarnemen van verschijnselen, waarbij verplaatsing van voorwerpen door verandering in voorwerpen zelf wordt gevolgd. ${ }^{3}$ Met andere woorden: de notie 'causaliteil' of 'oorzakelijke werking' ontstaat uit de gewaarwordingen dat dit voorwerp iets doet met dat (voorwerp). ${ }^{4}$ Deze gewaarwording kan alleen ontstaan als wij de verandering (....) zien volgen op de toenadering van 't eene voorwerp tot het andere.

\section{Analogie tussen daden met voorwerpen en de interactie van voorwerpen zelf}

Er bestaat een analogie tussen iemands eigen daden en het verplaatsen van voorwerpen enerzijds en het waarnemen dat voorwerpen elkaar raken en vervolgens veranderen, los van zulke daden, anderzijds. ${ }^{6}$ Deze analogie verklaart volgens Huet

' cf. L'Ange Huet, J. (1872), op. cit. p. 89-90, '...dat telkens als wij in de natuur oorzakelijke werking bespeuren, of stellen, zoo men wil; de zaak aldus geresumeerd kan worden, dat telkens als wij in de natuur oorzakelijke werking bespeuren, of stellen, zoo men wil; de zaak aldus geresumeerd kan worden, dat met veranderde plaatselijke verhouding tusschen twee voorwerpen, verandering in deze voorwerpen samengaat.'

${ }^{2}$ cf. L'Ange Huet, J. (1872), op. cit. p. 91-93, 'Van de verschijnselen die de mechanica kent, behoeft dit wel niet nader betoogd te worden, zij zijn de veranderingen, die in de beweging der lichamen samengaan met hun veranderde plaatselijke verhouding tot andere lichamen. (....) En van de chemische verschijnselen behoeft het naauwelijks nog gezegd te worden, dat ieder van hen de verandering is in lichamen, die tot elkander gebracht worden. (..... .... want, daar de mensch bijna alle verschijnselen, die de natuur oplevert, zij 't ook op kleine schaal kan reproduceeren en te voorschijn roepen, terwijl toch de mensch niets anders kan doen, dan voorwerpen verplaatsen,.... (....) Inderdaad, het zal moeilijk vallen een geval te bedenken, waarin wij het gevoel van oorzakelijk verband hebben, zonder dat een der beide verschijnselen opgeval wordt als een plaatsverandering en toenadering.'

${ }^{3}$ cf. L'Ange Huet, J. (1872), op. cit. p. 97, '... indien er niet van den beginne af een aantal verschijnselen geweest was, bij welke men wel onmiddellijk den indruk moest krijgen van verplaatsing gevolgd door verandering, het begrip van oorzakelijke werking, nimmer zou ontstaan zijn; en dat, omgekeerd, dat begrip langzamerhand juist ontstaan is uit dienzelfden indruk, dien de mensch bij aanschouwing van een aantal verschijnselen onwillekeurig kreeg.'

'cf. L'Ange Huet, J. (1872), op. cit. p. 98.

${ }^{5}$ cí. L'Ange Huet, J. (1872), op. cit. p. 98.

${ }^{6}$ cf. L'Ange Huet, J. (1872), op. cit. p. 98, 'Juist gelijk wij om een voorwerp of zijn deelen onderling te verplaatsen, er ons heen moet begeven, en het aan moeten raken, zoo zien wij ook hier het voorwerp zich tot het andere begeven en dit aanraken, waarop dan eerst de 
echter niet geheel hoe wij bij zulke verschijnselen worden herinnerd aan onze eigen daden. De analogie verklaart ook niet hoe wij, wanneer wij een voorwerp tot een ander zien toenaderen en daarop verandering in dat voorwerp zien volgen, sympathetisch hetzelfde gevoelen als wanneer wij een voorwerp verplaatsen.' De reden hiervoor is dat de analogie beperkt is tot het door ons toedoen direct in beweging brengen van voorwerpen. ${ }^{2} \mathrm{Er}$ is daarom een verschil tussen bijvoorbeeld het zélf laten vallen van een voorwerp, en de kleurverandering van een bepaald plantensap van blauw naar rood als dit sap met zuur in aanraking komt. In dit laatste geval kan men alleen in overdrachtelijke zin spreken van een daad van het zuur, en niet van een menselijke handeling. Toch ontstaat ook hier de indruk van een causale samenhang tussen het zuur dat het plantensap nadert en de daarop volgende kleurverandering van het sap. ${ }^{3}$

Iemands directe daden ten opzichte van voorwerpen betreffen alleen het in beweging brengen van voorwerpen. Anders ligt het voor wat onze daden betreft jegens levende wezens. De reacties en de eigen daden van andere levende wezens zijn voor ons herkenbaar door sympathetisch gevoel. ${ }^{4}$ Huet leidt hieruit af dat er sprake moet zijn van twee soorten van overgaande werking: 'werking' opgevat als het direct in beweging brengen van voorwerpen, en 'werking' opgevat als het motief voor onze nieuwe daden. Het laatste vormt de bron voor het sympathetisch herkennen van de daden van andere levende wezens. ${ }^{5}$

In het allereerste stadium van het denken ziet men, aldus Huet, het geheel van voorwerpen als een levend organisme: levend en zelf-doend bestaan. Het waarnemen dat het naderen van een bepaald voorwerp resulteert in de verandering van een

verandering volgt.'

' cf. L'Ange Huet, J. (1872), op. cit. p. 98.

${ }^{2}$ ef. L'Ange Huet, J. (1872), op. cit. p. 98, 'Want, strikt genomen, bepalen zich de verschijnselen, die de mensch kan opvatten als iets gelijk aan zijn eigen rechtstreeksche daden, ook uitsluitend tot het in beweging brengen van voorwerpen, of van hun deelen door toenadering van andere voorwerpen.'

${ }^{3}$ cf. L'Ange Huet, J. (1872), op. cit. p. 99, '....en toch zullen wij, ook in dat geval, onmiddellijk den indruk krijgen van identiteit, van samenhang tusschen toenadering van dat zuur en het ontstaan van die roode kleur; wij zullen geen oogenblik aarzelen te zeggen, dat die kleurverandering de daad van dat zuur is.'

${ }^{4}$ cf. L'Ange Huet, J. (1872), op. cit. p. 99, 'Wat nu bij levenlooze voorwerpen ons onverstaanbaar zou blijven, dat begrijpen wij bij levende voorwerpen; wij kennen immers bij ons zelve de veelsoortige veranderingen, die ook bij ons zelve plaats grijpen met sommige aanrakingen van sommige voorwerpen. Die ervaring stelt ons in staat, om te begrijpen, dat is om sympathetisch te gevoelen, wanneer eenig levend wezen een eigen daad doet, in verband met een geheel andere daad, een daad van plaatsverandering, van ons of van een ander levend wezen.'

${ }^{5} \mathrm{cf}$. L'Ange Huet, J. (1872), op. cit. p. 100, 'Behalve de directe overgaande werking, die wij kennen, wanneer wij onze hand bewegen, terwijl die hand in aanraking is met een voorwerp, kennen wij dus bij onszelve nog een andere overgaande werking, die als motief dient tot nieuwe daden van ons; en wat wij bij ons zelve kennen, herkennen wij sympathetisch bij andere levende wezens.' 
bepaald ander voorwerp, kan men door middel van sympathie opvatten naar analogie van de gemotiveerde daden jegens levende wezens. De verandering van het ene voorwerp voelt men daarom als de motiveerende invloed van een ander voorwerp.' Met andere woorden: als de toenadering van een bepaald voorwerp leidt tot een verandering in een bepaald ander voorwerp, dan vat men dat in het allereerste stadium van het denken op als een gemotiveerde "daad" van het eerstgenoemde voorwerp.

\section{Drie oniwikkelingsstadia van sympathetisch besef}

Er kunnen ontwikkelingsstadia van het sympathetisch besef worden onderscheiden, zo betoogt Huet. In het eerste stadium worden verschijnselen nog niet met elkaar in verband gebracht. De dingen wordt men gewaar zoals zij zijn en doen. ${ }^{2}$ Het tweede stadium wordt gekenmerkt door het voelen van de voortdurende gelijktijdigheid en de identiteit van de plaatsverandering van zichzelf als men een voorwerp in beweging brengt en de daarop volgende verandering van plaats van dat voorwerp. Als men waarneemt dat de plaatsverandering van een bepaald voorwerp resulteert in de plaatsverandering van een bepaald ander voorwerp, dan voelt men via sympathie dat de plaatsverandering van ene voorwerp de directe daad is van het andere voorwerp. In het laatste stadium wekt het waarnemen van de daad van een bepaald voorwerp op een bepaald ander voorwerp de herinnering aan het gemotiveerde handelen van zichzelf. ${ }^{4}$ Dit gebeurt in twee stappen. De eerste stap wordt gekenmerkt door het besef dat daden altijd plaatsvinden onder bepaalde omstandigheden. Daardoor wordt onderkend dat er een nauwe relatie bestaat tussen bepaalde daden en de omstandigheden waarin daden plaatsvinden. Zulke omstandigheden zijn in alle gevallen te herleiden tot veranderingen in de plaatselijke verhouding van levende of niet-levende

' cf. L'Ange Huet, J. (1872), op. cit. p. 100, 'En daar wij nu in den aanvang onzer ontwikkeling het bestaan van voorwerpen slechts kunnen gewaarworden als een levend en zelf-doend bestaan, zoo is het zeer natuurlijk dat wij vele ja in de meeste gevallen, waarin wij op de toenadering van eenig voorwerp tot een verandering zien plaats grijpen, die verandering sympathetisch zullen gevoelen als een daad van dat voorwerp, onder den motiveercnden invloed der toenadering van het andere voorwerp.'

${ }^{2}$ cf. L'Ange Huet, J. (1872), op. cit. p. 100, '...maar ook zelf met dat bewustzijn blijft voor ons het verschijnsel niets anders dan een willekeurig doen, of een willekeurige wijze van zijn, van het voorwerp; het verschijnsel wordt zoodoende nog met geen ander verschijnsel in verband gebracht. Op dat standpunt zien wij eenvoudig de dingen zijn en doen, zooals zij zijn en toen,...'

${ }^{3}$ cf. L'Ange Huet, J. (1872), op. cit. p. 101, 'Zoodra wij een verband van voortdurende gelijktijdigheid en identiteit bemerkt hebben usschen onze eigen plaatsverandering en de plaatsveranderingen in de voorwerpen (....) kunnen wij wederom langs sympathetischen weg bij andere voorwerpen datzelfde gevoelen, wanneei wij plaatsverandering van 't eene voorwerp zien samengaan met plaatsverandering van 't andere voorwerp. Dan krijgen wij het gevoel, dat het verschijnsel der platsverandering van een voorwerp, de directe daad is van een ander voorwerp, ' $t$ welk wij tot het andere voorwerp hebben zien naderen.'

${ }^{4}$ cf. L'Ange Huei, J. (1872), op. cit. p. 101, 'Eindelijk in het derde geval, zullen verschijnseleñ ons herinneren aañ weder een ander feit van ons bewustzijn, narnel. aan ons eigen gemotiveerd handelen.' 
voorwerpen. Op grond van de kennis van zo'n relatie, kan men deze ook herkennen in situaties waarin men een daad van een levend wezen jegens een ander levend wezen waarneemt. Hierdoor kan men ook dezelfde relatie voelen als men andere mensen iets ziet doen. Dit alles gebeurt via sympathethische waarneming. De tweede stap komt neer op het volgende. Het verband tussen omstandigheden en bepaalde daden voelt men ook als men met de verandering van de plaatselijke verhoudingen van twee voorwerpen in één van die voorwerpen nog iets anders dan louter verandering van plaats waarneemt. Zo'n verandering leidt niet tot de indruk dat het een rechtstreekse daad van een voorwerp is. Via sympathie voelt men dat dit de eigen daad van een voorwerp is, die is ontstaan door de motiveerende invloed van bepaalde omstandigheden. Men vat deze verandering op naar analogie van de eigen gemotiveerde daden met voorwerpen. Dit gevoel noemt Huet oorzakelijk verband. ${ }^{1}$

Huet concludeert uit deze redenering dat de indruk of de impressie van een oorzakelijk verband of causaal verband niet ontstaat door herhaalde waarneming. Deze indruk vloeit alleen voort uit de aard van een waargenomen verschijnsel; dat wil zeggen, van een eenmalige waarneming. Herhaalde waarneming heeft een andere functie, namelijk het uitbreiden van kennis. ${ }^{2}$ Met andere woorden: als men herhaalde malen heeft waargenomen dat specifieke verschijnselen elkaar volgen, dan kan men daaruit niet concluderen dat het ene verschijnsel de oorzaak is van het andere. Huet is het eens met Hume dat men in dit geval alleen kan spreken over de constante successie van bepaalde verschijnselen, en niet over een noodzakelijk verband tussen verschijnselen. ${ }^{3}$

' cf. L'Ange Huet, J. (1872), op. cit. p. 102, 'Wij kennen bij ons zelve een nauw verband tusschen zekere om-standig-heden en zekere daden van ons; die omstandigheden (...) laten zich altijd herleiden tot zekere bepaalde platselijke verhouding met andere levenlooze of levende voorwerpen. Dit verband eenmaal bij ons zelf kennende, begrijpen wij nu vervolgens door sympathetische waarneming, en gevoelen wij datzelfde verband, die zelfde identiteit, wanneer wij onze natuurgenooten en andere levende wezens, na evenzeer in zekere omstandigheden gebracht te zijn, dergelijke daden zien verrichten, als waarvan wij bij ons den samenhang met die omstandigheden hebben gevoeld. En een dergelijk verband gevoelen wij alweder door analogie evenzeer sympathetisch, wanneer wij met een veranderde plaatselijke verhouding lussen twee voorwerpen, in een dier voorwerpen een andere daf plaatsverandering watnemen, een zoodanige verandering dus, als niet geschikt is om ons den indruk te geven van te zijn de rechistreekse daad van het andere voorwerp. Wij gevoelen alsdan sympathetisch een eigen daad van dat voorwerp, onder den, ons uit ons zelfbewustzijn bekenden, motiveerenden invloed van zekere omstandigheden. En dit laatste gevoel (...) is voornamelijk, wat wij noemen met den naam van oorzakelijk verband.'

2 cf. L'Ange Huet, J. (1872), op. cit. p. 103, 'Na dit alles zal het duidelijk zijn, dat, zoo wij de impressie krijgen van oorzakelijke werking, dit aan de aard van een waargenomen verschijnsel ligt, maar niet aan de herhaling er van. (...) 't Is waar, de herhaling der waarneming. of liever het opzoeken en doen van analoge waarnemingen, heeft een verbazend ontwikkelenden en uitbreidenden invloed op onze kennis.'

${ }^{3}$ ef. L'Ange Huet, J. (1872), op. cit. p. 104, 'Wanneer de mensch iets bloot ziet volgen, ziet hij het bloot volgen; en als hij het zeven maal zeventig maal enkel ziet volgen, ziet hij het zeven maal zeventig maa! volgen. En als de $491 \mathrm{e}$ maal komt, zal ook dat $491 \mathrm{e}$ volgen weder 
Samengevat: als men zegt dat er tussen bepaalde verschijnselen een causaal verband bestaat, ligt dit in de bijzonderen aard dier verschijnselen. Hierdoor ontstaat naar analogie van de eigen gemotiveerde daden jegens voorwerpen of andere levende wezens de sympathetische impressie van oorzakelijke werking. ${ }^{1}$ In deze impressie van oorzakelijke werking ligt de oorsprong van het causaliteitsbesef.

\section{Huets tweede stelling}

Herhaalde waarneming van gelijksoortige gevallen is noodzakelijk om algemeene stellingen te kunnen formuleren; echter, herhaalde waarneming hoeft geen betrekking te hebben op het volgen van verschijnselen. Hieronder volgt Huets argumentatie die tot zijn tweede stelling heeft geleid.

\section{Oorspronkelijke werkingswaarneming en causale oordelen}

Er moet een onderscheid worden gemaakt tussen uitspraken over oorspronkelijke werkingswaarneming en oorzakelijkheids- of causale oordelen. Een oorspronkelijke werkingswaarneming heeft betrekking op een causaal verband dat men tussen bepaalde verschijnselen in één enkel geval heeft waargenomen. Zo'n waarneming leidt tot een uitspraak dat (wij hebben gezien) dat dit of dat voorwerp iets doet met een ander voorwerp. ${ }^{2}$ Dit is een concreete bijzondere waarheid. Zulke uitspraken vormen de basis voor alle uitspraken over causale relaties in de natuur. Een causaal oordeel betreft daarentegen een causaal verband tussen voorwerpen dat men herhaaldelijk heeft waargenomen, waarbij er bovendien een grote mate van analogie bestaat tussen de waarnemingen daarvan. Causale oordelen verschillen van uitspraken over oorspronkelijke werkingswaarneming doordat causale oordelen abstracte en algemene waarheden zijn. ${ }^{3}$

een bloot volgen zijn, en zal niet op eens - gelijk Hume zelf eigenlijk enkel stelde maar niet verklaarde -iets meer en iets anders dan een enkel volgen worden. Door bloote herhaling wordt niets iets anders dan het was.'

${ }^{1}$ cf. L'Ange Huet, J. (1872), op. cit. p. 104-107, '...door dat eigenaardige der opvolgende verschijnselen krijgt hij dan de sympathethische impressie, dat hier het eene op 't andere evenzoo werkt, als hij zelf op voorwerpen of op andere levende wezens werkt, wanneer hij met hem in aanraking komt, en als op hem gewerkt wordt door zekere hem bekende toenaderingen of om-standig-heden. (...) Daarom zeiden wij (...) dat het gevoel van een propter wel ontstat uit de waarneming van een post, maar niet uit het herhaalde dier waarneming.'

'cf. L'Ange Huet, J. (1872), op. cit. p. 110.

${ }^{3}$ ef. L'Ange Huet, J. (1872), op. cit. p. 110-111, 'Het bewustzijn van een werking van 't een op ' $t$ andere treft ons (...) in gevallen, die daartoe geschikt zijn, reeds bij cene alleenstaande waanneming. De waarheid, die wij formuleeren, wanneer wij in zulk een geval dat bewustzijn uitspreken, is dus dan een concreete bijzondere waarheid; wij zeggen dan eenvoudig, dat wij dit of dat voorwerp iets met een ander voorwerp hebben zien doen. Uit dergelijke oordeelen is langzamerhand alles ontstaan, wat wij omtrent oorzakelijke werking in de natuur affirmeeren. Doch tusschen de oorspronkelijke werkingswaarnemingen en onze oorzakelijkheidsoordeelen treft ons een groot verschil. Terwijl toch de eerste uit den aard der zaak concrete en bijzondere waarheden waren, zijn de laatste evenzeer uit den aard der zaak abstracte en algemeene waarheden.' 
Huet wijst er op dat het waarnemen van werking bij herhaalde waarneming bloot toevallig is; dat wil zeggen, dat, ook los van het waarnemen van werking, herhaalde waarneming leidt tot algemene uitspraken. Herhaalde waarneming heeft louter de functie om algemene oordelen te kunnen formuleren;' zij draagt alleen bij tot het inzicht dat bepaalde zaken bij elkaar blijken te horen. Herhaalde waarneming verschaft echter geen inzicht in wat het verband is tussen bepaalde verschijnselen. Dit kan een causaal verband zijn, maar het kan evengoed een niet-causaal verband zijn. $^{2} \mathrm{Zo}$ bezien bestaat er daarom geen principieel verschil tussen de activiteiten van bijvoorbeeld een zoöloog en natuurkundige. De één wil via herhaalde waameming algemene uitspraken formuleren over eigenschappen die behoren bij bepaalde diersoorten. De natuurkundige is er op gericht via herhaalde waarneming steeds algemenere causale uitspraken te formuleren. Door het feit dat men ten onrechte van mening is dat er een verband moet zijn tussen herhaalde waarneming en het ontstaan van het causaliteitsbesef, onderkent men meestal niet dat beide activiteiten gelijkwaardig zijn. ${ }^{3}$ Zoals al in de eerste stelling naar voren kwam, ontstaat het causaliteitsbesef niet door herhaalde waarneming, maar door een bijzondere soort van waarnemingen.

Huet concludeert dat de enige functie van herhaalde waarneming bestaat uit het vergelijken van bijzondere gevallen, dat vervolgens resulteert in algemene uilspraken. Alleen de mate van algemeenheid van causale oordelen is ontleend aan herhaalde waarneming; zij leidt echter niet tot het ontstaan van het besef van causaliteit. ${ }^{4}$

' cf. L'Ange Huet, J. (1872), op. cit. p. 111, 'Die veelvuldigheid is niet de aanleiding tot dat bewusizijn, maar zij is het, die ons van zeer bijzondere, enkele gevallen omvattende, uilspraken tot zeer algemeene, zeer veel gevallen omvattende, oordeelen brengt. (...) Maar dat karakter van werking is in die herhaalde waarneming iets bloot toevalligs. Ook dan, als zij dat karakter niet hebben, brengt hare veelvuldigheid ons toch even goed tot algemeene waarheden,....'

${ }^{2}$ cf. L'Ange Huet, J. (1872), op. cit. p. 111-113, '....deze beide verstandsrichtingen, redeeneringen, combinaties van waarnemingen zijn geheel parallel; en 't maakt geen 't minste verschil, dat de tweede reeks uit zoogenaamde causaal-waarheden bestaat, terwijl in de eerste reeks van oorzakelijk verband geen sprake is. (...) Veelvuldige waarneming en inductie leeren enkel wat bij elkaar behoort, doch niet hoe dat verband is.'

${ }^{3}$ cf. L'Ange Huet, J. (1872), op. cit. p. 113, '.... de gelijkstelling (tussen de zoöloog en natuurkundige) wordt, zoo al niet miskend, toch op den achtergrond geschoven ten gevolge van 't geheimzinnig verband, dat men nu eenmaal tusschen herhaalde waarneming en 't ontstaan van ons bewustzijn van oorzakelijk verband verkeerdelijk had aangenomen.'

${ }^{4}$ cf. L'Ange Huet, J. (1872), op. cit. p. 114, '... (het) wordt duidelijk, dat - 't zij er sprake is van oorzakelijkheids-waarnemingen, ' $t$ zij van waarnemingen der bijeenhoorende eigenschappen van dieren of planten -, de voortgaande observatie altijd dezelfde taak heeft: die namelijk om door vergelijking telkens het bijkomende, toevallige, onafdoende, uit de bijzondere gevallen te ecarteren, en te eindigen met waarheden uit te spreken, niet omtrent bijzondere voorwerpen of gevallen, maar omtrent dat abstracte dat overblijft, als uit die bijzondere voorwerpen en gevallen het concreete en toevallige is op zij gezet. (...) Slechts in zooverre zij algemeene waarheden zijn, zijn onze oorzakelijkheidsuitspraken aan veelvuldige waarneming ontleend.' 
Het graduele verschil dat Huet maakt tussen de uitspraken van een zoöloog en natuurkundige kwam overigens, weliswaar in een enigszins andere vorm, al eerder naar voren in de discussie tussen Van der Wijck en Spruyt. In die discussie ging het om het onderscheid tussen uitspraken over standvastige opeenvolging en standvastig gepaard gaan van verschijnselen. Spruyt (1873) zal Huets causaliteitsleer op dit punt bekritiseren. Bovendien wordt dit onderwerp een belangrijk twistpunt in de polemiek tussen Heymans en Jelgersma.

\section{Het "klassieke" beginsel van voldoende grond}

Uitgaande van zijn opvattingen over het ontstaan van de notie 'oorzakelijke werking' en over de rol van herhaalde waarneming, neemt Huet vervolgens het "klassieke" beginsel van voldoende grond onder de loep. In Huets termen luidt dit beginsel als volgt: de mensch moet zich alles als veroorzaakt denken; of anders gezegd: de mensch moet zich alles denken als bewerkt door een oorzaak. ${ }^{1}$ Dit beginsel acht Huet echter verkeerd geformuleerd; bovendien wordt dit beginsel dikwijls ten onrechte in verband gebracht met herhaalde waarneming.

Sommige verschijnselen vat men gewoonlijk op als niet-veroorzaakı, aldus Huet. Bijvoorbeeld: de oorzaak van de zwaartekracht, de oorzaak van de orde in de natuur of de oorzaak van het bestaan der dingen. ${ }^{2}$ Het feit dat de zwaartekracht, de orde in de natuur en de dingen bestaan trekt men doorgaans niet in twijfel. Als men dat wel doet, dan ontstaat er een onaangenaam gevoel van onverklaarbaarheid. Dit leidt gemakkelijk tot de gedachte dat ook voor zwaartekracht, orde in de natuur en voor het bestaan der dingen oorzaken aangewezen zouden moeten worden; dat wil zeggen, eindoorzaken. ${ }^{3} \mathrm{Dit}$ is in een positivistische benadering natuurlijk vloeken in de kerk.

Huet acht het overigens denkbaar dat alles is veroorzaakt, maar dit betekent nog niet men zich alles als veroorzaakt moet denken. Het "klassieke" beginsel van voldoende grond gaat van het laatste wel uit. Huet werpt hier tegen in dat men veel dingen opvat als zaken die niet veranderen. Men kan zulke dingen daarom ook niet in termen van causaliteit denken. Immers, iets wat niet verandert kan niet leiden to! een impressie van veroorzaking. Het is daarentegen wel zo, dat met de uitbreiding van het aantal waarnemingen ook het aantal impressies van veroorzaking toeneemt. Bijgevolg wordt de notie 'oorzakelijke werking' of 'causaliteit' steeds algemener en abstracter. Dit leidt er toe dat het oorspronkelijke verband van deze notie met concrete werkingswaarneming losser wordt. Bovendien wordt de notie 'causaliteit' steeds vaker

' cf. L'Ange Huet, J. (1872), op. cit. p. 118.

${ }^{2}$ cf. L'Ange Huet, J. (1872), op. cit. p. 117, 'Er zijn immers een aantal verschijnselen, die wij in 't geheel niet opvatten als veroorzaakt.'

${ }^{3}$ ef. L'Ange Huet, J. (1872), op. cit. p. 117, '... wanneer wij (....) ons voorstellen, dat zij niet bestonden, en dan vragen: begrijpen wij, hoe zij nu wel bestaan? wij een onaangenaam gevoel van onverklaarbaarheid hebben, een gevoel dat zeer licht omslaat in de stelling, dat er een oorzaak ook voor die feiten moet zijn.' 
gebruikt juist vanwege de toename van het aantal waarnemingen van verandering.'

Huet concludeert dan ook dat in dit opzicht herhaalde of voortgezette waarneming bijdraagt aan het vormen van algemeene waarheden. Maar nogmaals: het is een vergissing dat herhaalde waarneming leidt tot het ontstaan van het causaliteitsbesef. ${ }^{2}$

\section{De notie 'verklaren' en het besef van causaliteit}

Het is gebruikelijk dat men met de notie 'verklaren' het aanwijzen der oorzaken op het oog heeft. Ook deze opvatting acht Huet verkeerd. Hij geeft toe dat verklaren van verschijnselen, herhaalde waarneming en algemene waarheden samenhangen. Echter, zij die de foutieve gedachte huldigen dat herhaalde waarneming de bron is voor het gevoel van oorzakelijke werking, menen doorgaans ook ten onrechte dat de notie 'verklaren' het aanwijzen van oorzaken betekent. Verklaringen zijn weliswaar het resultaat van herhaalde waarneming, maar de notie 'verklaren' en het causaliteitsbesef hebben niets met elkaar te maken. ${ }^{3}$

Huet is het eens met Comte en Büchner ${ }^{4}$ dat verklaren neerkomt op het formuleren van de algemeenere waarheid (...), waarvan de te verklaren observatie als een bijzonder geval opgevat kan worden. ${ }^{5}$ De kern van deze definitie is dat er geen verwijzing naar oorzaken meer in voorkomt. Daarnaast kan men zich ook afvragen welke de psychologische toestand is, waarin wij zeggen, behoefte aan verklaring

cf. L'Ange Huet, J. (1872), op. cit. p. 118, 'De stelling, dat de mensch zich alles kan denken als bewerkt door een oorzaak, zou vol te houden zijn; maar duidelijk is het, dat de stelling: de mensch moet zich alles denken als bewerkt door een oorzaak, onjuist is; want er zijn vele dingen, die de mensch zich niet als wordende en dus ook niet als veroorzaakt denkt. Bij het onveranderlijke hebben wij geen impressie van veroorzaking. Daarentegen hebben wij haar, hoe meer de observatie zich uitbreidt en verrijkt, des te algemeener, zoo dikwijls wij verandering bespeuren (....) Naarmate toch door voortgezette observatie het begrip van oorzakelijk werking telkens iets van zijn oorspronkelijke concreetheid verloor, werd het daardoor tevens meer geschikt om door alle veranderingen, die wij waarnemen, bij ons te worden opgewekt.'

${ }^{2}$ cf. L'Ange Huet, J. (1872), op. cit. p. 118-119, ' 't Is dus wel waar, dat wij ook op het stuk der oorzakelijke werking zonder herhaalde waarneming, en abstractie dier waarnemingen, niet tot algemene waarheden zouden gekomen zijn: (.....) Dat de herhaalde wäneming van een post bij 't opkomen van 't bewustzijn van een propter een geheel bijzondere rol zou spelen is eenvoudig een vergissing.'

cf. L'Ange Huet, J. (1872), op. eit. p. 119, Want daar het denkbeeld "verklaring" ontegenzeggeiijk samenhangt met herhaalde waarneming en het vinden van algemeene waarheden, zoo is het zeer natuurlijk, dat, wanneer velen die herhaalde observatie voor den worlel van 't gevoel van oorzakelijke werking houden, zij tevens de aanwijzing der oorzaak voor de verklaring van een verschijnsel aanzien. (...) Want, wel is het een waarheid, dat in de resultaten der herhaalde observatie de grond ligt der verklaring; maar evenmin als 't bewustzijn van oorzakelijke werking door de herhaling der waarneming gewekt wordt; evenmin heeft dat bewusizijn van oorzakelijke werking met de verklaring iets te maken.'

${ }^{4}$ cf. L'Ange Huet, J. (1872), op. cit. p. 119, 'Bij de natuur-filosofen is de juiste opvatting van het denkbeeld "verklaren" algemeen. Men vindt haar niet slechts bij Aug. Comte; maar o.a. zeer duidelijk uiteengezet bij Louis Büchner.'

scf. L'Ange Huet, J. (1872), op. cit. p. 119-120. 
te hebben. ${ }^{1}$ De verklaringsbehoefte ontstaat als men zich over iets verbaast. Dit leidt voor Huet tot de vraag hoe die verklaringsbehoefte werkt. Met andere woorden: wat is bij den mensch het meest afdoende middel is tegen verbazing $?^{2}$ Dit middel is niets anders dan het vormen van gewoonten, zo betoogt Huet. Als men ergens aan gewend is geraakt, dan verbaast men zich niet meer. De functie van het zoeken naar verklaringen is dat men zich uiteindelijk niet meer verbaast over iets wat onbekend is. Het gaat er dus om, in Huets woorden, om den schok tusschen een nieuve waarneming en onze gewone voorstellingen weg te nemen. ${ }^{3}$ Verklaren acht Huet daarom analoog aan het vormen van gewoonten. Bovendien maakt het voor verklaringen niet uit of men de notie 'oorzakelijkheid' al dan niet gebruikt. ${ }^{4}$ Immers, (er is) gelijkheid van verklaring bij oorzakelijkheidsuitspraken en bij die, waarbij van oorzaak en gevolg geen sprake is. ${ }^{5}$

Verklaren komt neer op het herleiden van nieuwe waarnemingen tot analoge, eerder gedane waarnemingen. Een nieuwe waarneming breidt de verzameling van al bekende waarnemingen uit. Hierdoor ontstaat een meer algemene waarneming. Een nieuwe waarneming is daarmee een bijzonder geval van de al bekende waarnemingen. Het samenvoegen van een nieuwe waarneming met al bekende waarnemingen leidt zo tot een meer algemene waarheid. Ook zo'n nog algemenere waarheid kan men terugbrengen tot analoge, reeds bekende waarnemingen, en zo verder. ${ }^{6}$

De uitbreiding van ervaring heeft er toe geleid dat een bepaald waargenomen verschijnsel als een element van een algemener verschijnsel wordt gezien. Dit verschijnsel vat men vervolgens op als een bijzonder element van een nog algemener verschijnsel, en zo verder; dit kan men volhouden tot men is aangekomen bij de meest algemeene verschijnselen. Deze kunnen niet meer worden gezien als een bijzonder element van een nog algemener verschijnsel. Toch probeert men die meest algemeene verschijnselen te verklaren door hiervoor een bepaalde oorzaak aan te wijzen. Men

'ef. L'Ange Huet, J. (1872), op. cit. p. 120.

${ }^{2}$ cf. L'Ange Huet, J. (1872), op. cit. p. 120.

${ }^{3}$ cf. L'Ange Huet, J. (1872), op. cit. p. 120.

4 cf. L'Ange Huet, J. (1872), op. cit. p. 120-121, 'Daar nu verklaren dienen moet om verbazing weg te nemen, zoo is het duidelijk, dat het hoofdbestanddeel der verklaring iets analoogs moet zijn met gewoonte. Want als men het nieuwe dat ons verbaast, opvat als een bijzonder geval eener algemeener waarheid, dan stelt men het gelijk met het bekende, dan vat men het op als iets wat men meer gezien heeft.'

${ }^{5}$ cf. L'Ange Huet, J. (1872), op. cit. p. 121.

${ }^{6} \mathrm{cf}$. L'Ange Huet, J. (1872), op. cit. p. 125, 'Het doel van alle verklaring is, het onbekende, het nieuwe, op te vatten als iets bekends, iets dat reeds vroeger waargenomen is. Maar dat bekende zelf, dat reeds vroeger waargenomene, wordt door de nieuwe waarneming nu ook een geval van een meer algemene waarneming, van welke het nieuwe slechts een ander geval is. Die meer algemene waarneming dus is in zooverre zelf weder iets nieuws en behoeft in zekeren zin nu ook zelf weder verklaring; ook zij moet weder opgevat kunnen worden als iets bekends; ook zij moet met iets analoogs gelijkgesteld, en weder als een geval eener wederom nog algemener waarheid worden opgevat...' 
grijpt dan echter weer terug het oorspronkelijke causaliteitsbesef. In Huets woorden: de meest algemeene verschijnselen (moeten) gevoeld worden als gevallen van bewerking van 't een op 't ander. ${ }^{2}$

De omstandigheid dat men steeds vaker verschijnselen ziet als een bijzonder element van een meer algemeen verschijnsel is in de natuurkunde, die zich richt op de levenlooze natuur, de regel. In de biologie (of de natuurlijke historie) kan dit veel minder goed. Van de levende natuur kent men daarvoor namelijk nog te weinig algemeene feiten of natuurwetten. Nieuwe verschijnselen kan men in die tak van wetenschap nog moeilijk als een element zien van een bepaalde natuurwet. Bij het bestuderen van de levende natuur staat men bovendien nog dicht bij de opvatting van de natuur als een levend en zelf-doend geheel. Daarom valt men in de biologie nog relatief vaak terug op het oorspronkelijke causaliteitsbesef; dit verklaart ook dat men in die discipline nog dikwijls zoekt naar oorzaken van verschijnselen. De natuurkunde beschikt daarentegen over zoveel natuurwetten, dat men vrijwel alle nieuwe verschijnselen als bijzondere gevallen van zulke wetten kan opvatten. ${ }^{3}$

De notie 'verklaren' in de zin van het subsumeren van bijzondere gevallen onder steeds algemenere waarheden of natuurwetten totdat men is beland bij de algemeenst bereikbare waarheden of waarnemingen, is het hoogste en enige wat men in de wetenschap kan bereiken. Wil men zulke waarheden toch nog verder verklaren, dan doet men een beroep op het oorspronkelijke causaliteitsbesef. Met andere woorden: men springt in dat geval weer over tot het zocken naar oorzaken. Als dat gebeurt, vormt het een signaal dat onze verklaring uitgeput is, dat wij niet verder verklaren kunnen. Zulke "verklaringen" hebben echter niets meer te maken met het verklaren van verschijnselen in eigenlijke zin. ${ }^{4}$

' cl. L'Ange Huet, J. (1872), op. cit. p. 128, 'Maar in onze toestand van rijke ervaring wordt ieder concreet bijzonder geval eerst terstond opgevat als een bijzonder geval van een meer algemeen verschijnsel, dat wij in veel andere gevallen reeds hebben opgemerkt; dat algemeene verschijnsel is zelf reeds weer door vroegere ervaring voor ons slechts een bijzonder geval van een nog algemeener verschijnsel, dat wij in andere gevallen reeds vroeger hebben gezien.'

${ }^{2}$ cf. L'Ange Huet, J. (1872), op. cit. p. 128.

${ }^{3} \mathrm{cf}$. L'Ange Huet, J. (1872), op. cit. p. 128, 'De levende natuur leeft in vele verschijnselen voor ons nog, zooals voor onze cerste voorvaderen de geheele natuur leefde; dat wil zeggen: bij de verschijnselen der levende natuur ontbreekt ons dikwijls het filtrum der algemeene feilen, en moeten wij telkens voor verklaring nemen ons eenvoudig sympathetisch bewustzijn, dal cr gedaan, gewerkt en bestaan wordt. Maar bij de levenlooze natuur is dat filtrum langzamerhand zoo volmaakt geworden, dat al de tallooze concrete verschijnselen, allengs, van 't een op 't andere voortgaande, enkel wijzigingen worden, enkel bijzondere gevallen, van zeer algemeene feiten, waarheden of natuurwetten.'

${ }^{4}$ cf. L'Angc Huel, J. (1872), op. cil. p. 129, 'Dit, dat een zaak ons verklaard is, wanneer wij liaar in al lraar bijzonderheden hebben opgevat als bijzonder geval van telkens algemeener waarheden, totdat wij genaderd zijn aan de algemeenst bereikbare waarheden, waarvan zij als bijzonder geval kan opgevat worden. (...) Het komen tot die algemeenste waarnemingen is voor ons de hoofdzaak, want als wij tot deze zijn doorgedrongen, kunnen wij niet verder verklaren, en moeten wij overspringen op het gebied van ons zelfbewustzijn. Dan wijzen wij, 
Huets motiveringen bij de eerste twee stellingen vormen de kern van zijn causaijteitsleer. Samenvattend kan men opmerken dat herhaalde waarneming niet leidt tot het bewustzijn van een causaal verband of van het causaliteitsbesef. Het ontstaan van dit besef berust op een eenmalige indruk van werking. Herhaalde waarneming speelt alleen een rol bij de mate van algemeenheid van kennis. Bovendien hebben de notie 'verklaren' en het causaliteitsbesef niets met elkaar te maken. Het verklaren van verschijnselen komt neer op het subsumeren van bijzondere gevallen onder naturwetten. De uitbreiding van ervaring kan er toe leiden dat men verklaringen moet aanpassen; verklaringen zijn daarom dynamisch en staan niet voor eeuwig vast.

\section{Verdere uitwerking van Huets causaliteitsleer}

Een uitvoerige bespreking van Huets motivering bij de laatste twee stellingen valt buiten de reikwijdte van deze studie. Hier wordt alleen ingegaan op enkele uitwerkingen van Huets causaliteitsleer.

\section{Causaal weten is geen verstandelijke kennis}

Huets derde stelling houdt in dat het causale weten geen verstandelijke of wetenschappelijke kennis is, omdat het uitsluitend een gevoelsmatige zekerheid vormt. Deze stelling heeft te maken met wat Huet onder de notie 'weten' verstaat. Hiervan geeft hij de volgende definitie: het hebben van een voorstelling, onvermijdelijk opgewekt door een gewaarwording en niet in strijd met eenige van de voorstellingen, die vroegere ervaring als voorstellingen der werkelijkheid heeft geleverd. 'Met andere woorden: 'weten' is het kennen van de onderlinge samenhang van voorstellingen, die ontstaan door gewaarwordingen.

De voorstelling van causaliteit of van een propter ontstaat ook door gewaarwording. Deze voorstelling komt niet in strijd met de ervaring. Het causale weten vormt echter alleen een gevoelsmatige en geen verstandelijke zekerheid. Dit sluit aan bij de motivering van Huets tweede stelling, waarin werd aangegeven dat wanneer het onmogelijk blijkt dat bijzondere gevallen niet meer kunnen worden gesubsumeerd onder algemene naturwetten, men weer teruggrijpt op het oorspronkelijke causaliteitsbesef. Met andere woorden: zulk een weten (het causale weten) begint, waar de ervaring eindigt. ${ }^{2}$

De voorstelling van causaliteit berust op een impressie van oorzakelijke werking. Als men het onistaan van het causaliteitsbesef analyseert, dan leidt dat niet tot $t$ wijfel

gelijk het heet, de corzaak aan; maar de aanwijzing vañ die oorzaak is het wel het teeken, dat anze verklaring uitgeput is, dat wij niet verder verklaren kunnen; doch de verklaring zelve was geheel iets anders.'

'cf. L'Ange Huet, J. (1872), op. cit. p. 133.

${ }^{2}$ cf. L'Ange Huet, J. (1872), op. cit. p. 133-134, 'Nu heeft men een voorstelling van een propter; men heeft die voorstelling onvermijdelijk ten gevolge van gewaarwordingen, en er is in onze ervaring niets wat met die voorstelling in strijd is. (.....) Maar wanneer wij zulk een weten niet een verstandelijk weten noemen, dan is de bedoeling, dat, (....) zulk een weten begint waar de ervaring eindigt: 
aan de waarheid van dat bewustzijn. Men zou daar alleen aan kunnen twijfelen, als men de notie 'waarheid' opvat als een correspondentie tussen voorstellingen en het (nimmer) toegankelijke zijn. ' 'Waarheid' kan men, aldus Huet, echter alleen in termen van de coherentie tussen voorstellingen opvatten.

Een verdere bespreking van Huets waarheidstheorie wordt hier niet gegeven, omdat dit buiten de discussies over causaliteit valt.

\section{Irrelevantie van het causaliteitsbesef}

Het causaliteitsbesef - het bewustzijn van een oorzakelijk verband - is niet belangrijk voor de ontwikkeling van de wetenschap, zo betoogt Huet. Immers, de zuivere inhoud onzer waarnemingen geeft alleen het volgende aan: als is waargenomen dat een verschijnsel onder bepaalde voorwaarden hoort bij een ander verschijnsel, dan leidt dit er toe dat het waarnemen van het eerste wordt gevolgd door het waarnemen van het optreden van het tweede verschijnsel. Hierbij wordt een verwijzing naar oorzaken achterwege gelaten. Huet gaat echter verder: als men in eerdere fasen van bijvoorbeeld de natuur-en scheikunde helemaal geen besef van causaliteit had gehad, dan had men door eenvoudig te onderzoeken welke verschijnselen bij elkaar horen de moeilijkste problemen (...) opgelost. ${ }^{2}$

Het causaliteitsbesef is een ander soort kennis dan wetenschappelijke kennis. Het bewustzijn van oorzakelijke werking bestaat louter uit gewaarwordingen, waardoor het minder nauw aansluit bij de waarneming. Door het uitbreiden van waarnemingen neemt de wetenschappelijke kennis toe. Het causale weten verliest daardoor gaandeweg steeds meer aan inhoud. ${ }^{3} \mathrm{Met}$ andere woorden: een weten, dat

' cf. L'Ange Huet, J. (1872), op. cit. p. 134, 'Voorzeker wordt de voorstelling, het bewustzijn 't welk de inhoud is van dit weten, door observatie gewekt (...) De analyse van ' $\mathrm{t}$ ontstaan van 't bewustzijn van oorzakelijke werking kan dan ook niet ten gevolge hebben: twijfel aan de waarheid van dat bewustzijn. Ten zij men waarheid nog steeds mocht gelieven op te vatien in den (onzinnigen) zin van (nimmer te controleeren) overeenstemming tusschen onze voorstellingen en het (nimmer) toegankelijke zijn.'

${ }^{2}$ ĉ. L'Ange Huet, J. (1872), op. cit. p. 136-138, 'Voor ons tegenwoordig weten en denken is dan ook het bewusizijn van een oorzakelijk verband betrekkelijk van zeer weinig belang. (...) Wij zouden even wijs zijn, even uitgestrekte heerschappij over te natuur hebben, (...) wanneer wij dat bewustzijn van onderlinge werking der voorwerpen op elkander lang kwiji waren, wanneer wij ons eenvoudig gehouden hadden aan den zuiveren inhoud onzer waarnemingen, dat namel. deze en die verschijnselen onder deze en die conditiën zoo bij elkaar behooren, dat wij wanneer wij het eene gezien hebben ook het andere zien plaats hebben. Dat is de zuivere inhoud onzer waarnemingen; waarin geenerlei bewustzijn of begrip van oorzakelijke werking gegeven is. (...) al had de mensch nooit het bewustzijn van oorzakelijke werking gehad, de moeilijkste problemen van physica en chemie (zouden) opgelost zijn geworden, alleen door op te letten, wat bij elkaar behoorde.'

${ }^{3}$ cf. L'Ange Huet, J. (1872), op. cit. p. 138, 'In zooverre is, hoewel door de waarneming gewekt, en onvermijdelijk gewekt, (...) het bewustzijn van oorzakelijke werking (...) van een geheel anderen aard als onze geheele wetenschap, minder nauw zich aansluitende aan de waarneming als bestaande enkel uit gewaarwordingen. (....) ... dat, terwijl door de voortgezette waarneming ons eigenlijk vruchtbaar wetenschappelijk weten steeds rijker wordt, dit weten 
in zijn verval is, dat betere dagen gekend heeft, maar al meer en meer verloopen is. $^{1}$

Men kan zich afvragen of het causaliteitsbesef überhaupt enige functie heeft gehad; is het dan tot niets nut is geweest? Of wij dat alles enkel als een menschelijke zwakheid hebben te beschouwen, een doelloze omweg, dien de menschelijke geest op zijn ontwikkelingstocht heeft gemaakt ${ }^{2}$ Huet ziet de functie van het causaliteitsbesef in het licht van de ontwikkeling van kennis. In de wetenschap gaat men tegenwoordig, zo betoogt hij, uitsluitend uit van de inhoud onzer waarnemingen. Hierbij let men er alleen nog op welke verschijnselen onder welke voorwaarden bij elkaar horen en elkaar volgen. ${ }^{3}$ In een eerder stadium van het denken was dat niet het geval, omdat men toen nog niet over zoveel ervaring beschikte. Om het volgen van verschijnselen op te merken was men toen alleen aangewezen op het sympathetische bewustzijn dat ontstond door gewaarwordingen en door het doen van waarnemingen. ${ }^{4} \mathrm{Bij}$ gebrek aan ervaring had men derhalve alleen de sympathie als drijfveer tot het doen en onthouden en combineeren van waarnemingen. Soms gaat het nog steeds zo. Immers, als waarnemingen niet meer onder algemene natuurwetten, empirische verklaringen, kunnen worden gesubsumeerd, dan valt men weer terug op het oorspronkelijke causaliteitsbesef.'

\section{Causale en voorspellende uitspraken}

Voorspellen - de wetenschap omtrent de toekomst - heeft in wezen niets te maken heeft met de oorzakelijkheidsquaestie. Er wordt echter, zoals Huet al eerder constateerde, tussen de noties 'voorspellen' en 'causaliteit' dikwijls een exclusief verband gelegd. Dit is een vergissing. Bij voorspellen gaat het er alleen om combinaties van voorstellingen, die bij elkander behooren. ${ }^{6}$

daarentegen (....) bij de voortgang der ervaring steeds meer inhoud heefi verloren.'

' cf. L'Ange Huet, J. (1872), op. cit. p. 138.

${ }^{2}$ cf. L'Ange Huet, J. (1872), op. cit. p. 140.

${ }^{3}$ cf. L'Ange Huet, J. (1872), op. cit. p. 141-142, 'Wij voor ons hebben door langdurige ervaring wel geleerd, dat het van 't hoogste gewicht is op te letten, wat bij elkander behoort, 't ziij dan in rang van opvolging, 't zij dan in gelijktijdigheid; wij hebben door ondervinding geleerd, dat alle nuttige wetenschap verkregen wordt door daarop, en daarop alleen, acht te geven.'

${ }^{4}$ cf. L'Ange Huet, J. (1872), op. cit. p. 141, 'Maar de mensch, die nog geen ervaring bezat, kon dat nog niet weten. Wat zou hem hebben geleerd juist daarop te letten en acht te geven hoe 't een op 't ander volgde? dat volgen zelf, hoe zou hij het bemerkt hebben, indien 't hem niet op een of andere wijze belang had ingeboezemd? Dat nu geschiedde door het sympathetisch bewustzijn, dal de mensch had bij 't krijgen van gewaarwordingen en 't doen van waarnemingen.'

' cf. L'Ange Huet, J. (1872), op. cit. p. 142, '.... wanneer de empirische verklaring afgeloopen is, wanneer de ervaring ons geen analogie meer biedt voor het waargenomen verschijnsel (wordi) de sympathetische gewaarwording (...) nog ook bij ons wakker,..."

${ }^{6}$ cf. L'Ange Huet, J. (1872), op. cit. p. 155-156, 'Eigenlijk heeft dan ook deze beschouwing met de oorzakelijkheidsquaestie niet te maken; en zij staat daarmede alleen zooverre in verband, als nu eenmaal de gewoonte bestaat, om zoo te spreken, als of die wetenschap 
Er is bovendien niets bijzonders aan de hand met voorspellingen. Voorspellende clementen zijn tot in de eenvoudigste waarneming (...) terug te vinden. En wat voor de eenvoudigste waarneming geldt, geldt ook voor voorspellingen dic zijn gebascerd op causale uitspraken. Maar in dat geval heeft datzelfde eenvoudige feit, o wonder? o verbazing! telkens en telkens opnieuw de hoofden der denkers in verwarring gebracht. ${ }^{1}$

De belangrijkste reden dat men aan voorspellingen die zijn gebaseerd op causale uitspraken zo'n speciale status geeft, is dat men de notie 'weten' ten onrechte associcert met objektiviteit. Dat wil zeggen, de "klassieke" opvalting dat de zekerheid van kennis berust op een correspondentie tussen voorstellingen en het bestaande. Dit acht Huet echter irrelevant. Zoals hij al in zijn proefschrift had geconstateerd, gaat het in de wetenschap alleen om de door mensen geconstateerde regels tussen verschijnselen. Het gaat derhalve niet om cen al of niet objectief bestaand verband tussen verschijnselen, en evenmin over wat achter de verschijnselen zou bestaan. De "klassieke" opvatting van kennis leidt er bovendien toe dat men niet inziet dat ook de eenvoudigste waarnemingen al voorspellend zijn. ${ }^{2}$

Met een ironische loespeling op Van der Wijck (1871), die concludeerde dat het bestaan van verwachtingen onverklaarbaar zou zijn, merkt Huet het volgende op. Is 't dan toch niet hoogst vermakelijk, hoogleraren te horen uitroepen: "Ik beken, dat het mij onverklaarbaar voorkomt, dat de mensch verwachtingen heeft omtrent de toekomst?" Terwijl in ieder woord, dat wij spreken, in iederen naam, dien wij geven, die verwachtingen omtrent de toekomst bij douzijnen worden geuit. ${ }^{3}$

Samengevat: de belangrijkste uitwerkingen van Huets causaliteitsleer komen er op neer dat het causale welen slechts als een gevoelsmatige en niet als een verstandelijke vorm van kennis moet worden gezien. Bovendien is hij van mening dat het causaliteitsbesef voor wetenschappelijke docleinden overbodig is geworden. Ten slotte merkt hij op dat verklaren en het causaliteitvraagstuk niets met elkaar hebben te maken.

aangaande de toekomst, dat is dat weten, dat eerst door toekomstige waarnemingen bevestigd kan worden, iets aan de oorzakelijks-conclusiën bijzonder eigens is. Een vergissing,... (...) .... de wetenschap omtrent de toekomst heeft niets te maken met de quaestie van oorzakelijke werking; zij is enkel en alleen een zaak van gewoonte, van combinatie van voorstellingen, die bij elkander behooren.'

'cf. L'Ange Huet, J. (1872), op. cit. p. 160.

${ }^{2}$ cf. L'Ange Huet, J. (1872), op. cil. p. 160-161, 'Omdat men altijd in het denkbeeld weten een zekere objectiviteit zocht, omdat men zich verbeeldde, dan te weten wanneer men de zekerheid had, dat onze voorstellingen overeenkwamen met het bestaande; daarom kon men niet inzien, dat iedere waarneming slechts is een voorstelling ontleend aan vroegere waarnemingen, gewekt en onvermijdelijk en werkelijk gemaakt door een gewaarwording; evenzogocd als iedere zekerheid omtrent hetgeen komen zal, is: een voorstelling, ontleend aan het vroeger waargenome, doch gewekt en onvermijdelijk en werkelijk gemaakt door een tegenwoordige gewaarwording. Wanı deze beide gevallen staan werkelijk geheel gelijk.'

'cf. L'Ange Huet, J. (1872), op. cit. p. 164. 
Tot slot van de bespreking van Huets opvattingen volgt nog zijn zienswijze over het tijdgebonden karakter van kennis. Aan het begin van dit hoofdstuk is aangegeven dat het positivisme zich ten doel stelt de historische ontwikkeling van menschelijke denkbeelden te beschrijven. In navolging van Comte stelde Huet dat iedere uitspraak als de uitkomst moet worden gezien van de natuurlijke geschiedenis van het menschelijke denken.

Het systematisch verzamelen van ervaring staat in de wetenschap centraal. Nadrukkelijk is al naar voren gekomen dat voor Huet wetenschappelijke kennis geheel op ervaring berust. Kennis acht hij relatief, omdat door de toename van ervaring wetenschap zich steeds verder uitbreidt, hetgeen impliceert dat men afscheid moet nemen van veel oude wetenschap. Enigszins retorisch zegt hij: hoe groot is niet de schat van oude wetenschap, die door de ervaring vernietigd, en tot leugen, tot onzekerheid, fantasieën en herschenschimmen gemaakt is? Waar is de alchymie, waar de astrologie gebleven? Waar is nu al wat de oude mythologie van de natuur, de oude godsdiensten van de goden wisten ? $^{1}$ En ook hoort men woorden die uit de mond van een 19de eeuws theoloog revolutionair zouden kunnen klinken: waar is de wetenschap omirent Adam en Eva en al de wonderen in alle heilige boeken van alle godsdiensțen vermeld, en al de leerstukken van 's menschen verlossing, door alle kerken en alle eeuwen in alle landen verkondigd $?^{2} \mathrm{Al}$ zulke kennis is door de toename van ervaring verdampt. Gewaarwording en waarneming - ervaring begrenzen wat men zich kan voorstellen en wat men voor waar kan houden. Door ervaring wordt de inhoud van voorstellingen onvermijdelijk, en wordt daardoor kennis. De keerzijde hiervan is wel dat veel voorstellingen die men eens voor de waarheid en kennis hield dat nu niet meer zijn; dit komt door ervaring, die ijzeren rails der ondervinding. ${ }^{3}$ Met andere woorden: zonder ervaring regeert de door traditic gedragen fantasic.

\section{Huets conclusie}

Hoe is nu de conclusie? bestaat er nu iets buiten ons, en bestaat er nu zoo iets als oorzakelijke werking, ja of neen ? $^{4}$ Zo geformuleerd acht Huet deze viaag absurd.

'cf. L'Ange Huet, J. (1872), op. cit. p. 174.

${ }^{2}$ cf. L'Ange Huet, J. (1872), op. cit. p. 179.

${ }^{3}$ cf. L'Ange Huet, J. (1872), op. cit., p. 174-175, 'Weg is al die wijsheid, al dit weten is verdwenen. Ja! de ervaring doet onze wetenschap toenemen; waar zij den voet zet, ontkiemt nieuwe wetenschap; - maar wordt tegelijk een vroegere wetenschap geknaki! (....) De gewaarwording, de waarneming, is een beperking voor onze voorstellingen. (....) Door zoo ons te perken te stellen, geeft zij aan onze voorstellingen die onvermijdelijkheid, waardoor hun inhoud weten wordt. Maar daardoor tevens dwingt zij terug allerlei voorstellingen, die men ons vroeger geleerd had te hebben, en die tengevolge dier overlevering voor ons ook onvermijdelijk, ook veel opdringender dan eenige andere, ook wetenschap en wararheid waren.'

${ }^{4}$ cf. L'Ange Huet, J. (1872), op. cit. p. 118. 
Waar het wel om gaat is de volgende vraag: (......) hebben die voorstellingen (over het bestaan van iets buiten ons en aangaande oorzakelijke werking) denzelfden grond van werkelijkheid voor ons, als bijvoorbeeld onze wetenschap stellig is, dat als wij een steen zien, dat voorwerp zwaar zal zijn, en als de voorstelling van die gewaarwording van zwaarte werkelijkheid voor ons heeft?' Deze vraag is wél te beantwoorden. Huets antwoord hierop luidt ondubbelzinnig: ja. Zowel aan het besef dat er dingen buiten ons bestaan als aan het causaliteitsbesef kan men niet twijfelen. Beide vormen van bewustzijn ontstaan bij iedere gewaarwording. Bovendien gaat iedere gewaarwording gepaard met het sympathetisch bewustzijn van een bestaan. ${ }^{2}$ Met andere woorden: het causaliteitsbesef vormt een gevoelsmatige zekerheid.

Huet wijst er vervolgens op dat men toch een verschil aanvoelt tussen bijvoorbeeld de uitspraak: 'ik weet dat suiker zoet zal smaken' en de uitspraak 'ik weet dat er causaliteit bestaat'. Alleen al het zien van suiker wekt onvermijdelijk de voorstelling van de gewaarwording van iets zoets. De tweede uitspraak berust echter op het instinct dat leidt tot sympathethische gewaarwordingen. 't Is dat verschil dat ons bij alle zekerheid in deze quaestie - blijft hinderen. ${ }^{3}$ De bron van de voorstelling van oorzakelijke werking is dezelfde als die waar het oude weten uit is ontstaan. Zulke kennis kon alleen maar als waar worden opgevat door gebrek aan ervaring ${ }^{4}$ Dit leidt er toe dat men eraan zou kunnen twijfelen of de voorstelling van oorzakelijke werking wel zo onvermijdelijk is. Deze twijfel is onnodig, zo betoogt Huet. Immers, omdat de notie 'werking' in de loop der tijd zo abstract is geworden, wordt deze ook niet door de zondvloed der ervaring bedreigd. Ervaring kan deze abstracte notie niet weerleggen, omdat zij altijd concreter is dan een abstractie, zoals de notie 'causaliteit'.

'cf. L'Ange Huet, J. (1872), op. cit. p. 179

'cf. L'Ange Huet, J. (1872), op. cit. p. 179-180, 'Het bewustzijn van een bestaan buiten ons en van oorzakelijke werking heeft op zich zelf den hoogsten graad van zekerheid, van werkelijkheid, die eenige wetenschap voor ons kan hebben. - Het is namel. onmogelijk er aan te twijfelen. Het komt onvermijdelijk op bij iedere gewaarwording; geen andere voorstelling, geen ander bewustzijn kan tegen of nevens dit opkomen; wij kunnen er niet onzeker van zijn. (...) ...even onvermijdelijk gaat met iedere gewaarwording 't sympathetisch bewustzijn van een besiaan samen.'

${ }^{3}$ cf. L'Ange Hitiet, J. (1872), op. cit. p. 180.

${ }^{4} \mathrm{cf}$. L'Ange Huet, J. (1872), op. cit. p. 180-181, 'Die wetenschap is wel is waar niet eene, die ervaringsherinneringen uitspreekt. En dat maakt, dat wij altijd 't gevoel hebben, dat zij toch een ander soort van wetenschap is dan bijv. dat als ik suiker eet, ik zoet zal proeven. Ook dat is wel alleen daarom wetenschap, omdat ik bij de gezichis-gewaarwording van suiker onvermijdelijk de voorstelling van de zoete-smaakgewaarwording krijg. Maar de onvermijdelijkheid is in dit geval 't gevolg van ervaring. Terwijl in 't andere geval 't gevolg van een natuurlijken aanleg, van de eigenschap der sympathie is. (....) Men weet, dat de voorstellingen van een bestaan buiten ons en van oorzakelijke werking ontstaan zijn uit een dergelijke bron als al het oude, bij gebrek aan ervaring ontkiemde, weten, 't welk door de ervaring allengs meer en meer teruggedreven, beperkt en vernietigd is.'

'cf. L'Ange Huet, J. (1872), op. cit. p. 181, '.....wij (weten) vooruit dat deze onze, aan die sympathethische gewaarwording ontleende, wetenschap, in haar tegenwoordige abstractie als enkel "een zijn" en "een werking", nooit ofte nimmer door de ervaring zal kunnen omverge- 
Summa summarum: wat (hebbe) men dan nu te denken van ons begrip van het bestaan van (...) oorzakelijke werking?' De notie 'causaliteit' of 'oorzakelijke werking' is even zeker als de beste waarheden onzer ervaringswetenschap, en zij kan ook niet worden aangetast door de verdere ontwikkeling van die wetenschap. De notie 'causaliteit' onttrekt zich aan de relativiteit van kennis. Het grote verschil tussen beide soorten zekerheden is echter dat het causaliteitsbesef ontspringt uit een andere bron dan wetenschappelijke, verstandelijke zekerheden. Wetenschappelijke zekerheden berusten op het samenstel van gewaarwordingen en voorstellingen. Het causaliteitsbesef berust daarentegen op het samenstel van gewaarwordingen en bevindingen van ons zelfbewustzijn. Het spreken over causaliteit begint waar de ervaring ophoudt. Met andere woorden: wetenschap berust op verstand en redeneringen en zij vormt daarom een intellectuele zekerheid. Causaliteit berust op gevoel, en is daarom een gevoelsmatige zekerheid. Ziedaar het saldo, waarmede de balans sluit.

Samengevat komt Huets argumentatie in hoofdlijnen op het volgende neer. Huet beschouwt de opvatting, dat in het herhaald waarnemen van successie van verschijnselen of de herhaalde waarneming van het volgen van verschijnselen de oorsprong zou liggen van de notie 'causaliteit', als één van de belangrijkste doelwitten voor zijn kritiek. Het belang dat aan het herhaald waarnemen van successie wordt gehecht is in de causaliteitsleren van Opzoomer en Van der Wijck reeds naar voren gekomen. $\mathrm{Zij}$ gingen uit van de stelling dat de notie 'causaliteit' een empirische oorsprong heeft, maar zij konden niet instemmen met de conclusie van Hume dat deze notie, en daarmee ook die van 'noodzakelijkheid', op gewoonte gebaseerd zou zijn. Hiertoe ontwikkelde in het bijzonder Opzoomer argumentaties die moesten aantonen dat deze noties rechtstreeks uit de ervaring zouden kunnen worden afgeleid. Het herhaald waarnemen van successie van verschijnselen speelde hierbij een belangrijke rol; het maakte hier geen verschil of dit nu het zintuiglijk waarnemen van successie betrof, of het waarnemen van successic tussen wil en daad.

Huet trekt tegen deze opvalting fel van leer. De notie 'causaliteit' ontstaat niet door het veelvuldig warnemen van successie. De oorsprong van deze notie ligt in een eenmalige impressie van oorzakelijkheid. Huet meent dat deze impressie van oorzakelijkheid berust op een sympathetische gewaarwording.

Huet gaat uit van een strikt fenomenalisme; dat wil zeggen, dat in principe alleen de eigen bewustzijnstoestanden gekend kunnen worden. Hiermee laat hij de correspondentietheorie van waarheid los. De stelling dat de waarheid van begrippen en voorstellingen getoetst zou kunnen worden door na te gaan of zij overeenkomen met

worpen of veranderd worden; omdat alle ervaring concreter is dan deze abstractie, en blijven moet binnen den wijden kring, dien dit bewustzijn, in zijn tegenwoordigen van al het conerete ontdanen, vervluchtigden, tot een afgetrokken begrip verdunden vorm, omsluit.'

${ }^{1}$ cf. L'Ange Huet, J. (1872), op. cit. p. 181. 
een objectieve werkelijkheid die buiten onze voorstellingen, en dus buiten de eigen gewaarwordingen ligt, overtreedt immers de regel dat alleen de eigen gewaarwordingen gekend kunnen worden. In plaats hiervan kan alleen over de waarheid van begrippen en voorstellingen in termen van coherentie worden gesproken; dat wil zeggen, een voorstelling of begrip kan alleen dan waar worden genoemd, als deze niet strijdig is met onze ecrdere voorstellingen.

Deze uitgangspunten leiden tot het probleem hoe het bestaan van andere mensen, dieren en dingen, kortweg: de externe werkelijkheid, aannemelijk kan worden gemaakt zonder dat men buiten de oevers van de eigen bewustzijnstoestanden treedt. Hiertoe ontwikkelt Huet een theorie van sympathetische gewaarwordingen, die op het volgende neerkomt. Als beweging wordt waargenomen voelt men, door het instinct om na te bootsen, bij zichzelf de neiging om gelijksoortige bewegingen te maken. Zulke gewaarwordingen ontstaan zowel naar aanleiding van de bewegingen van mensen, maar ook van de bewegingen van dingen. Het eigenaardige van zulke gewaarwordingen is, dat zij niet lijken op de gewaarwordingen die men gewoonlijk heeft. Door het vergelijken van de gewaarwordingen die ons vreemd zijn met die welke ons vertrouwd zijn, ontstaat het bewustzijn dat andere mensen bestaan, en vervolgens ook dat dieren en dingen bestaan. Hiermee wil Huet de val van het solipisme ontlopen, zonder zijn uitgangspunt op te geven dat men alleen de eigen bewustzijnstoestanden kan kennen. Het sympathetisch gewaarworden van beweging is bovendien de wortel van het ontstaan van het causaliteitsbesef en de abstracte notie van 'causaliteit'.

Huet stelt de relatie tussen daad en ding in het middelpunt: hierin ligt de oorsprong van wat men 'oorzakelijk verband' noemt. Het in beweging brengen van een voorwerp leidt tot het gevoel dat dit een gemotiveerde daad van onszelf is. Als men dingen los van onze daden ziet bewegen, dan kan men deze beweging opvalten naar analogie van het door een eigen gemotiveerde daad in beweging brengen van een ding. Dit leidt tot een sympathetisch gevoel of de impressic dat dingen ten opzichte van clkar zélf daden verrichten. Dit gevoel wordt een 'oorzakelijk verband' genoemd.

Als Leilmoliv in Huets causaliteitsleer loopt het onderscheid tussen het gevoel en het verstand. Causale uitspraken zijn in beginsel herleidbaar tot een sympathetisch gevoul of sympathetische gewaarwording van een oorzakelijk verband. Hierin ligt de oorsprong van het spreken over causaliteit. Omdat zulke uitspraken tot een gevoel kunnen worden herleid, zijn deze ook onbetwistbaar; zij zijn daardoor cen vorm van zekere kennis. Deze kennis is echter geen rationele of wetenschappelijke kennis, omdat wetenschappelijke kennis op verstand gebaseerd is.

Als het gaat om de vraag wat de functie is van de notie 'causaliteit' binnen het geheel van wetenschappelijk kennis, wordt gesteld dat dit door de ontwikkeling van ervaring geen nut meer heeft. In het huidige wetenschappelijke stadium van het denken gaat het er niet meer om, oorzakelijke relaties tussen verschijnselen aan te geven. Wetenschap is er uitsluitend op gericht om de wetmatige verbanden tussen verschijnselen op te sporen. Om verschijnselen te verklaren wordt alleen nog gelet op welke verschijnselen onder welke voorwaarden bij elkaar horen en elkaar volgen. 
Met andere woorden: verschijnselen worden gesubsumeerd onder algemene regels die op grond van ervaring tot stand zijn gekomen.

Als vervolgens in meer detail wordt gekeken naar enkele elementen in Huets causaliteitsleer en als deze worden geplaatst in de ontwikkeling van Nederlandse causaliteitsdiscussies tot dusver, kan het volgende worden opgemerkt.

Huet gaat uit van betekenisvragen, die hij meteen vertaalt in ontstaansvragen. De vraag: wat is de betekenis van de notie 'causaliteit'?, zet Huet dus om in de vraag: hoe ontstaat de notie 'causaliteit'? Hiermee sluit hij, meer nog dan bij Comte, nauw aan bij Hume. Ook deze benadert betekenisvragen in termen van ontstaan. ${ }^{1}$ Huets benadering past binnen het onderscheid dat in deze studie is gemaakt tussen de ontstaans- en geldigheidsbenadering. Het is inmiddels duidelijk geworden dat hij het causaliteitsvraagstuk geheel in termen van ontstaan tracht op te lossen. Hiermee sluit Huet in zekere zin aan bij Opzoomer en Van der Wijck, echter met dit verschil dat Huet in vergelijking met deze denkers veel consequenter is in de uitwerking van de ontstaansbenadering. Immers, als men uitgaat van de stelling dat alle begrippen herleidbaar zijn tot gewaarwordingen, trekt Huet hieruit terecht de conclusie dat men alleen kan spreken in termen van gewaarwordingen, hetgeen tot Huets fenomenalisme leidt. Uitgaande hiervan is het niet verwonderlijk dat de geldigheidsbenadering, waarin het accent wordt gelegd op het onderstellen van aangeboren waarnemingsvormen, door Huet geheel opzij wordt geschoven. In Huets termen zijn aangeboren waarnemingsvormen pure speculatieve constructies, die niet herleidbaar zijn tot gewaarwordingen.

Terecht stelt Huet dat de discussies tussen Opzoomer, Van der Wijck en Spruyt in een impasse terecht zijn gekomen. De "derde weg" - Huets positivisme - biedt inderdaad aanknopingspunten voor een meer vruchtbare behandeling van het causaliteitsvraagstuk, en het biedt in historisch opzicht tevens een interessante aanvulling op Comtes positivisme. Het is echter de vraag of Huets speculatieve theorie van sympathetische gewaarwordingen nodig is om het causaliteitsvraagstuk in termen van het positivisme op te lossen. De formulering die Huet van dit vraagstuk geeft, dwingt hem namelijk om op grond van tamelijk speculatieve aannamen eerst het probleem van het bestaan van een externe werkelijkheid te verklaren, voordat gesproken kan worden over het verklaren van het ontstaan van de notie 'causaliteit'.

Huets kritiek op Opzoomer bestaat uit een aanval op twee van diens stellingen. In navolging van Spruyt neemt Huet Opzoomers wilstheorie onder vuur. Het valt hierbij op dat zowel Huet als Spruyt gelijksoortige argumenten gebruiken. Interessant is dat Huet, in tegenstelling tot Spruyt, ook nog de ontologische aannamen van

' ef. Hume, D. (1739/1740), op. cit., book I, part III, section II, p. 74-75, To begin regularly, we must consider the idea of causation and see from what origin it is deriv'd. ' $T$ is impossible to reason justly, without understanding perfectly the idea concerning which we reason; and 'tis impossible perfectly to understand any idea, without tracing it up to its origin, and examining that primary impression from which it arises.' 
Opzoomers causaliteitsleer bekritiseert. Opzoomer neemt volgens Huet immers aan dat causale relaties tussen verschijnselen objectief bestaan los van de ervaring. Causale relaties worden dus "ontdekt". Terecht merkt Huet hieroverop dat deze onderstelling strijdig is met de uitgangspunten van Opzoomers empirisme. Toch gaat Opzoomer uit van de stelling dat de werkelijkheid als een aggregaat van verschijnselen moet worden gezien waartussen causale relaties bestaan. Met andere woorden: dit is de stelling dat alles een oorzaak heeft. Huets terechte kritiek is dat dit alleen kan worden beweerd op grond van ervaring; het kan derhalve geen uitgangspunt van onderzoek zijn, maar alleen als een mogelijke uitkomst hiervan.

De denkbeelden van Huet en Comte zijn nauw aan elkaar verwant. Dit blijkt bijvoorbeeld uit de definitie die Huet formuleert van wat onder de notie 'verklaren' moet worden verstaan. Deze definitie ontleent hij rechtstreeks aan Comtes positivisme, waarin geen plaats meer is voor het zoeken naar oorzaken. Huet is het met Comte eens dat verklaren neerkont op het subsumeren van waargenomen verschijnselen onder algemene regels. Er kan daarom alleen nog over wetmatigheden worden gesproken. In tegenstelling tot Comtes spreekwoordelijke weerzin om de notie 'oorzaak' zelfs maar in de mond te nemen, beschouwt Huet dit terecht in zekere zin als een nodeloze verzwakking van Comtes positivisme. Huet wil aantonen dat ook deze notie tot gewaarwordingen kan worden herleid. Echter, hij moet, om trouw te blijven aan Comtes denkwijze, ook aannemelijk maken dat de notie 'causaliteit' geen functie meer heeft in het huidige stadium van het denken. Hoewel Huet het woord niet expliciet gebruikt, maar wel aansluit bij Comtes programma om de historische ontwikkeling van menschelijke denkbeelden te beschrijven, kan worden geconcludeerd dat de notie 'causaliteit', voor zover het wordt toegepast buiten de sfeer van directe gewaarwordingen, thuis hoort in de "metafysische" fase van het denken. In het huidige wetenschappelijke (of positieve) stadium is deze notie overbodig geworden.

Ten slotte: het verwerpen van het belang van het herhaald waarnemen van successie als bron van de notie 'causaliteit', het ontwikkelen van de theorie van sympathetische gewaarwordingen, het strikte fenomenalisme en het verwerpen van de correspondentietheorie van waarheid, het onderscheid tussen gevoel en verstand, en ten slotte de conclusic dat het spreken over oorzaken geen functic meer heeft in het wetenschappelijke stadium van het denken, maken Huet in vergelijking met Opzoomer, Van der Wijck en Spruyt tot een tegendraads en origineel denker in de geschiedenis van de filosofie in Nederland.

De vraag hoe op Huets radicale opvattingen door Spruyt werd gereageerd, komt in het volgende hoofdstuk aan de orde. In aansluiting daarop wordt in dat hoofdstuk ook Spruyts eigen causaliteitsleer behandeld. 



\section{SPRUYT VERSUS L'ANGE HUET}

Huets radicale causaliteitsleer kan als de knuppel in het hoenderhok van de academische filosofie in Nederland worden gezien. Immers, niet alleen Spruyt, maar ook de belangrijkste vertegenwoordigers van het filosofische establishment in Nederland, Opzoomer en Van der Wijck, hadden er van Huet danig van langs gekregen. Echter, zij reageerden niet op Huets niet mis te verstane kritiek. Dit is opmerkelijk, omdat zij doorgaans toch nooit om een weerwoord verlegen zaten. De enige die wel reageert is Spruyt.' Spruyt is onder de indruk van Huets werk. In het artikel Oude dwalingen in een nieuw kleed, dat in 1873 in De gids verschijnt, onthaalt hij zowel Huets Methode als zijn Nieuwe oplossing met veel lof. Zonder eenigen

${ }^{1}$ Het is vermeldenswaard dat men ongeveer twintig jaar na het verschijnen van Huets Nieuwe oplossing twee (impliciete) verwijzingen naar Huets theorie aantreft. In de Inleiding tot de wijsbegeerte (1889) merkt Land over de oorsprong van het causaliteitsbesef op dat (wij) in onszelven hebben ervaren, eensdeels eigene inspanningen om buiten ons eigen lichaam veranderingen aan te brengen, anderdeels, wijziging van onzen toestand tegen ons wenschen en verlangen in. Er dringt een gebeuren van in ons naar buiten, of van daar ons eigen leven binnen. Deze voorstelling van werken en lijden, uit ondervinding aan ons zelven opgedaan, worden nu verder naar behoefte omgewerkt, tot verklaring van allerhande verandering gebezigd.' Cf. Land, J.P.N. (1889), op. cit. p. 113-114. In 1890 komt Land nogmaals terug op de oorsprong van het causaliteitsbesef. In het artikel 'Oorzaak en gevolgen' (in: $D e$ gids) treft men de volgende passage aan. 'Dat in ons bewustzijn van eigen inspanning die in een gewenschte gebeurtenis uitloopt, werkelijk de oorsprong van ons denkbeeld van veroorzaking gelegen is, daarvoor getuigt niet de onverzettelijkheid waarmede de dusgenoemde anthropomorphistische theorie der causaliteit nog steeds door geleerden wordt volgehouden, maar de (...) beschouwing der dingen, die overal aan de nuchtere wetenschappelijke voorafgaat, en alle gebeuren in de wereld tot een doen, ja het eerste ontstaan van dingen tot een maken terugbrengt, en toeschrijft aan min of meer op ons gelijkende wezens. Land zoekt dus de oorsprong van het causaliteitsbesef in het gevoel van spierinspanning.' Cf. Land, J.P.N. (1890b), op. cit. p. 485 . Hoewel hij niet expliciet naar Huet verwijst, doet Lands verklaring sterk denken aan Huets theorie over de oorsprong van het causaliteitsbesef. Het blijkt dat ook Heymans op de hoogle was van Huets causaliteitstheorie. In het besluit van de Schets merkt Heymans het volgende op. 'Naast de talrijke schrijvers, die aldus het element van noodzakelijkheid in de causale betrekking beschouwen als ontleend aan de logische betrekking tusschen premissen en conclusie, zijn er anderen, volgens welke dat element, en daarmede onze geheele voorstelling van de oorzakelijke betrekking, afkomstig zou zijn van de wilsverschijnselen. Historisch wijst deze hypothese terug op Reid (.....). Tot hare beste vertegenwoordigers in de negentiende eeuw behoort Maine de Biran; in onze dagen hebben zich Liard, Cesca, B. Erdmann, L'Ange Huet en de patholoog Stricker bij haar aangesloten.' Cf. Heymans. G. (1890a), op. cit. p. 367. Heymans verwerpt Huets theorie omlrent de oorsprong van het causaliteitsbesef en de notie 'noodzakelijkheid'. De terloopse opmerkingen van Land en Heymans over Huets theorie leidden overigens niet tot kritische discussies. Daarom wordt in dit onderzoek niet verder ingegaan op Lands en Heymans' relatie tol Huet. 
twijfel behooren zijne beide geschriften tot het voortreffelijkste, wat in de laatste jaren op wijsgerig gebied in ons land is geschreven. En: ook als wij (...) de twee werken van den schrijver toetsen aan de eischen, die men aan een goed boek mag stellen, zoo moet ons oordeel zeer gunstig zijn. Want die werken brengen ons meeningen, door de beschouwing der dingen gewekt; geen halfbegrepen stellingen, uit boeken bijeengegaard. Eene handelwijze, die even dikwijls aanbevolen, als zeldzaam gevolg wordt, en wier trouwe opvolging op zich zelve voldoende is om een geschrift tot een verdienstelijk werk te maken.' Spruyt had zich overigens al eerder terloops lovend uitgelaten over Huets Methode (Spruyt, 1871a). Daar merkte hij op dat de waarde van Huets werk zeer groot is. Geen van Comie's volgelingen heeft hem volgens mijne mening zoo goed begrepen als L'Ange Huet. ${ }^{2}$

Spruyts prijzende woorden uit 1873 zijn des te opmerkelijker, omdat Huet in 1872 Spruyts opvattingen zonder veel omhaal van woorden had verworpen. Spruyt ziet in Huets theorie een dankbaar onderwerp voor kritiek. De titel van Spruyts reactie is in dit opzicht veelzeggend. Hij beschouwt Huets positivistische theorie niet alleen als een nieuwe poging, maar ook als een oude dwaling om een empirische verklaring voor de notie 'oorzaak' te vinden.

\section{SPRUYTS KRITIEK OP HUET}

Spruyt rekent eerst af met Huets theorie van sympathetische gewaarwordingen. Dit ligt voor de hand, omdat dit voor Huet de basis vormde voor zijn theorie over de oorsprong van het causaliteitsbesef. Na volmondig Huets kritiek op Opzoomer te hebben onderschreven en Huets kritiek op Hume te hebben verworpen, neemt Spruyt Huets eerste stelling onder de loep. Ondanks prijzende woorden voor Huets originele benadering daarbij meent Spruyt dat Huets afleiding tekortschiet, omdat Huet zich kennelijk niet bewust was van het belang van het causaliteitsbeginsel. Bovendien nam Huet volgens Spruyt ten onrechte aan dat uitspraken over het volgen van verschijnselen en uitspraken ovei het samengaan van veischijnselen niet principiecl van elkaar verschillen. Ten slotte stelt Spruyt dat Huet een dubbelzinnige positie inneemt ten aanzien van de status van het beginsel van voldoende grond.

\section{Nogmaals: theorie van sympathetische gewaarwording}

Spruyt is het eens met Huet dat men in discussies over causaliteit de vraag naar de betekenis van de uitspraak 'alles heeft eene oorzaak' doorgaans niet stelt. ${ }^{3}$ Met gevoel

' cf. Spruyc, C.B. (1873), 'Oude dwalingen in een nieuw kleed'. In: De gids, p. 226.

${ }^{2}$ ef. Spruyt, C.B. (1871a), op. cit. p. 32.

${ }^{3}$ cf. Spruyt, C.B. (1873), op. cit. p. 226, 'De groote fout, die L'Ange Huet in de meeste diseussies over causaliteit bemerki, bestaat hierin, dat men vergeet te vragen wat eigenlijk de woorden "alles heeft eene oorzaak" betekeenen.' 
voor understatement acht Spruyt dit inderdaad een kleine onoplettendheid, die de vroegere sprekers over causaliteit tamelijk wel op éen lijn plaats met lieden, die beweren te kunnen zwemmen zonder ooit water te hebben gezien.'

Huet heeft deze betekenisvraag, zo betoogt Spruyt, in tegenstelling tot de meeste andere filosofen terecht wél gesteld. Huet heeft getracht om deze vraag te beantwoorden door na te gaan wat de inwendige gewaarwordingen zijn die men voelt als men zegt dat verschijnselen causaal met elkaar zijn verbonden. Echter, aan het beantwoorden van deze vraag moest volgens Hume een meer fundamentele vraag voorafgaan. Immers, de notie 'causaliteit' of de voorstelling van oorzakelijke werking onderstelt de notie of voorstelling van 'werking van 't een op 't ander'. Dit betekent dat men eerst had na te gaan hoe het besef ontstaat van dingen die buiten onszelf bestaan. ${ }^{2}$ Huet had het ontstaan van dit besef verklaard door een beroep te doen op een instinct om de bewegingen van anderen te imiteren: de aangeboren nabootsingszucht. Dit instinct leidt tot sympathetische gewaarwordingen, waardoor viteindelijk de voorstelling ontstaat van dingen die buiten onszelf bestaan.

Spruyt ziet in Huets theorie van sympathetische gewaarwording een vruchtbaar aanknopingspunt om het verschijnsel te verklaren dat kinderen in bepaalde dingen iets herkennen van aandoeningen die zij bij zichzelf gewaarworden. ${ }^{3} E n$, zo voegt hij daar aan toe, de nauwkeurige en heldere aanwijzing van den invloed, dien zij moeten uitoefenen, moet, voor zoo ver mij bekend is, iets nieuws in de philosophie heeten. ${ }^{4}$

Huet had echter ook betoogd dat het identiteitsbesef, het besef van een $i k$, en het besef van het bestaan van anderen, het besef van een niet-ik, geleidelijk ontstaan. Als baby kan men nog geen onderscheid maken tussen zichzelf en anderen. Een baby ondergaat alleen een wisseling van ongedifferentieerde gewaarwordingen. Zijn identiteitsbesef bestaat louter uit de herinnering aan een collectie voorstellingen van musculaire gewaarwordingen en van gewaarwordingen van lust en onlust, aldus Huet.

Op dit punt denkt Spruyt toe te kunnen slaan. Immers, als een baby gewaarwordingen ondergaat, dan moet men ook aannemen dat deze al een identiteitsbesef heeft: het bewustzijn van een ik. Dit besef zou in Huets termen neerkomen op datgene, wat de wisselende gewaarwordingen achterlaten. ${ }^{5}$ Aangenomen moet worden dat

'ef. Spruyl, C.B. (1873), op. cit. p. 226.

${ }^{2}$ cf. Spruyt, C.B. (1873), op. cit. p. 226-227, 'De positivist daarentegen begint met te vragen: "Welke inwendige waarwordingen gevoelde de mensch op het oogenblik, dat hij begonnen is te spreken van oorzaak en gevolg?" Daar nu de voorstelling van oorzakelijke werking van 't een op ' $t$ ander onmogelijk ontstaan kan zonder de voorstelling van 't een en 't ander dat bestaat, zoo moet hij beginnen met eerst te verklaren, "hoe het bewustzijn in ons gewekt wordt, dat iets buiten ons over het algemeen bestaat".'

${ }^{3}$ cf. Spruyt, C.B. (1873), op. cit. p. 231, 'Want de sympathetische gewaarwordingen dragen er zonder twijfel veel toe bij, om het kind in sommige voorwerpen wezens te doen zien, die vatbaar zijn voor dezelfde aandoeningen als de zijne.'

cf. Spruyt, C.B. (1873), op. cit. p. 231.

'cf. Spruyt, C.B. (1873), op. cit. p. 231. 
volwassenen inderdaad een identiteitsbesef hebben, zo betoogt Spruyt. Dit besef komt er op neer dat zij zich bewust zijn van een blijvend element, ondanks dat zij allerlei verschillende gewaarwordingen ondergaan. Ook volwassenen beschikken over het besef van een niet-ik; dat wil zeggen, dat hun besef van dingen niet samenvalt met wat zij hun identiteit noemen. Het ontstaan van het besef van een niet-ik had Huet als een moeilijk raadsel beschouwd. Spruyt vindt dit vreemd, omdat men zich namelijk allereerst zou moeten afvragen of baby's inderdaad al een identiteitsbesef hebben. ${ }^{1}$ Het laatste zou Huet volgens Spruyt zonder meer hebben ondersteld. Kortom: waarom was het toeschrijven van een identiteitsbesef aan baby's voor Huet geen probleem, en waarom was het ontstaan van het besef van een niet-ik kennelijk voor hem kennelijk wel een probleem? In Spruyts woorden: is het eerste dan eene zoo heldere zaak, dat men, zonder eenige nadere verklaring van zijne mening te geven, het bewustzijn van zijn eigen ik aan het kind mag toeschrijven? Uit welke feiten is den schrijver gebleken, dat de zuigeling eenig bewustzijn heeft van zijn ik? ${ }^{2}$

Het 'ik' is geen specifieke gewaarwording of herinneringsbeeld. Men kan de notie 'ik' op twee manieren definiëren, aldus Spruyt. Hetzij: als het aggregaat van alle gewaarwordingen en voorstellingen. In dat geval valt het 'ik' geheel samen met gewaarwordingen en voorstellingen. Of: als het gemeenschappelijk subject van alle gewaarwordingen en voorstellingen. Als van deze laatste definitie wordt uitgegaan, wordt het 'ik' als iets gezien wat los staat van gewaarwordingen en voorstellingen. ${ }^{3}$

Welke van de twee definities men ook kiest, in beide gevallen leidt dit voor Huets positivisme tot problemen, zo betoogt Spruyt. Deze problemen tracht hij duidelijk te maken met behulp van kantiaanse noties zoals 'eenheid' en 'blijvende substantie'. Of Huet nu van de ene of de andere definitie zou uitgaan, in beide gevallen zou het er toe leiden dat hij impliciet een element a priori onderstelt; en dat is nu juist wat Huet ten stelligste verwerpt.

Als Huet de notie 'ik' had opgevat, zo betoogt Spruyt, als een aggregaat van alle gewaarwordingen en voorstellingen, dan had hij impliciet aan baby's ook een vermogen a priori moeten toeschrijven om van gewaarwordingen een eenheid te maken. Hierdoor wordt het mogelijk om aan zo'n eenheid een ander soort bestaan toe te schrijven dan aan gewaarwordingen. Zo'n eenheid is een aangeboren

' cf. Spruyt, C.B. (1873), op. cit. p. 231, 'De redeenering onderstelt toch, dat de zuigeling buiten en behalve de gewaarwordingen, die hij ondervindt, ook nog het bewustzijn heeft van een ik. Dit ik wordt door den schrijver voorgesteld als "datgene, wat de wisselende gewaarwordingen achterlaten". Nu moet men zeker toegeven, dat de wisselende gewaarwordingen bij den volwassen mensch gepaard gaan met het bewustzijn van een ik, dat bij alle wisseling der gewaarwordingen blijvend is. Maar zij gaan bij den volwassen mensch evengoed gepaard met het bewustzijn, dat er zeer vele dingen bestaan, die niet tot het ik behooren.'

${ }^{2}$ cf. Spruyt, C.B. (1873), op. cit. p. 231.

${ }^{3} \mathrm{cf}$. Spruyt, C.B. (1873), op. cit. p. 231, 'Het ik is geen der gewaarwordingen of herinneringsbeelden. Het kan beschouwd worden op twee wijzen: of, als de vereeniging van alle gewaarwordingen en voorstellingen tot een aggregaat, dat als eene eenheid, een individu, beschouwd wordt; of als het gemeenschappelijk subject van alle gewaarwordingen.' 
walarnemingsvorm a priori, waardoor baby's zowel aan zichzelf als aan voorwerpen buiten henzelf een bestaan kunnen toeschrijven. Immers, hierdoor kunnen zij gropen van gewaarwordingen dic zij regelmatig tegelijkertijd ondergaan als een cenhcid beschouwen. In het identilcilsbesef ligt bovendien het besef van een blijvend bestaan besloten. Het besef van een blijvend bestaun is gebascerd op het samenstellen van wissclende gewaarwordingen tot een eenheid. Als dat zo is, dan kunnen zij ook aan vorwerpen buiten henzell een blijvend bestaan toeschrijven. Zulke voorwerpen of dingen komen neer op een collectie van gewaarwordingen die verbonden is met het besef dat iedere afzonderlijke groep van gewaarwordingen ecn enkel ding vormt.'

Als Huet de notic 'ik' daarentegen had opgevat, zo gaat Spruyt verder, als het gemcenschappelijk subject van alle gewaarwordingen, dan neemt hij in dat geval impliciet aan dat het 'ik' aan zichzelf gelijk blijft; het 'ik' ondergaat gewaarwordingen. Spruyt wijst er op dat het noodzakelijk is om een blijvende identiteit van onzen geest of het identische ik te onderstellen bij de wisscling van gewaarwordingen. Er wordt van uitgegaan dat volwassenen een identiteitsbesef hebben, ook al hebben zij cen veetheid van wisselende gewaarwordingen ondergaan. In Spruyts woorden: $i k$, die op dit oogenblik schrijf, kan niet nulaten te erkennen, dat ik dezelfde persoon ben als zeker iemand die voor twintig jaur geleden met een hocpel speelde. ${ }^{2}$ Wil men echter nagaan wat het identiteitsbesef inhoudt, dan kan er niets concreets worden aangewezen. Men kan immers niet zeggen dat alle gewaarwordingen en verstellingen die ondergaan zijn het identiteitsbescf vormen. Toch wordt er van uitgegaan dat dic gewaarwordingen en voorstellingen toestanden zijn, dic betrokken worden op icts dat gelijkblijft: het 'ik'. Echter, dat gelijkblijvende element, het identisch' ik, is lecg. Met andere woorden: het is cen begrip zonder inhoud dat men niet kan kennen. Toch wordt de notic 'ik' gebruikt, alsof het gekend wordt, aldus Spruyt.'

cf. Spruyt, C.B. (1873), op. cit. p. 232, 'Heefl de schrijver de eerste definitie voor oogen gehad, dat moet hij aan het kind het vermogen toekennen om a priori, d.i. onafhankelijk van zijne ervaring, al zijne gewaarwordingen tot eene eenheid samen te stellen, en om aan die eenheid eene andere soort van bestaan toe te kennen dan aan de gewaarwordingen zelven. Maar schrijven wij aan het kind dezen aprioristischen waarnemingsvorm toe, dan is het duidelijk, dat hij de voonverpen buiten hem even goed als bestaande kan beschouwen als zich zelven. Veel gemakkelijker toch dan hij al zijne gewaarwordingen tot de eenheid van zijn zellbewustzijn verbindt, zal hij groepen van gewaarwordingen, die herhaaldelijk gelijktijdig verschijnen, tot eene eenheid samenvatten. En berust het bewustzijn van een blijvend bestaan, dat in het ik-bewustzijn besloten ligt, op de samenstelling van voorbijgaande gewaarwordingen tot eene eenheid, dan moeten wij evenzeer een blijvend bestaan toeschrijven aan de voorwerpen buiten ons, die niets anders zijn dan groepen van gewaarwordingen, verbonden met het bewustzijn, dat ieder van die groepen een enkel ding voorstelt.'

${ }^{2}$ cl. Spruyt, C.B. (1873), op. cit. p. 232.

${ }^{3}$ cf. Spruyt, C.B. (1873), op. cit. p. 232, 'Onze tweede definitie stelt het ik (voor) als datgene wat, aan zich zelf gelijkblijvend, de gewaarwordingen ondergaat. Deze bepaling kan verdedigd worden op grond van de noodzakelijkheid, waarin wij verkeeren, om de blijvende identiteit van onzen geest bij al zijne gewaarwordingen te erkennen. (...) Gewaarwordingen en voorstellingen zijn elkander in lange reeksen opgevolgd; maar ik vind in al de leden van die lange reeksen niet den minsten grond voor mijne meening, dat die gewaarwordingen 
Spruyt concludeert uit zijn motiveringen bij beide definities het volgende. Als Huet het identiteitsbesef van baby's opvat als de wisseling van gewaarwordingen, en als hij die wisseling beschouwt als de toestanden van een subject dat ondanks de wisseling van gewaarwordingen gelijk blijtt, dan hebben wij de, op positivistisch standpunt verwerpelijke, aangeboren waarnemingsvorm in optima forma voor ons.' Huet neemt dan immers impliciet een vermogen aan om gewaarwordingen te betrekken op een eenheid. Echter, zo'n eenheid kan men niet herleiden tot gewaarwordingen. Spruyt wijst er op dat de notie 'identisch subject' analoog is aan de notie 'blijvende substantie' in de dingen. Immers, als men van mening is dat een baby alle gewaarwordingen kan betrekken op een onbekende eenheid of op het waarnemend subject; en als men er bovendien van uitgaat dat een baby door zo'n identiteitsbesef overtuigd is van het blijvend bestaan van zichzelf, dan moet men wel concluderen dat de collecties van gewaarwordingen die baby's regelmatig gelijktijdig ondergaan worden betrokken op een blijvende substantie. Hieruit kan vervolgens worden afgeleid dat baby's aan de dingen buiten henzelf een gelijksoortig bestaan toekennen als aan het bestaan van zichzelf. ${ }^{2}$

Kortom: Huet ontkomt er volgens Spruyt niet aan om aan baby's het vermogen toe te schrijven om hun gewaarwordingen te betrekken op een onbekende eenheid, het 'ik', die ondanks de wisseling van gewaarwordingen gelijk blijft. Zo'n eenheid is analoog aan de notie 'substantie'. Deze notie geeft aan dat in de dingen iets gelijkblijvends bestaat. Als men aanneemt dat baby's een identiteitsbesef hebben, opgevat als het betrekken van gewaarwordingen op een eenheid, dan ligt het voor de hand dat zij in die gewaarwordingen ook de notie 'substantie' verwerken. Daardoor kunnen baby's derhalve ook het bestaan van dingen buiten zichzelf onderkennen.

Spruyt vraagt zich vervolgens af waarom Huet enerzijds zo stellig meent dat men er op grond van het identiteitsbesef van overtuigd is dat men zelf bestaat, maar dat hij anderzijds in het besef dat men overtuigd is van het bestaan van andere mensen een probleem bespeurt. Als men zich immers op een positivistisch standpunt stelt,

mijne gewaanvordingen zijn. Toch kan ik niet nalaten te gelooven, dat al die gewaลaพvo dingen toestanden zijn geweest van een zelfde $\mathrm{lk}$. Dit identische ik echter is een begrip zonder inhoud, icts, waarvan wij niets weten, en dat toch door jeder mensch gebruikt wordt, als of hij het door en door kende:'

'cf. Spruyt, C.B. (1873), op. cit. p. 232.

${ }^{2}$ ef. Spruyt, C.B. (1873), op. cit. p. 232-233, 'Hij erkent dan in het kind het vermogen on zijne gewarwordingen met eene eenheid in betrekking te brengen, die in geen der gewaarwordingen gegeven is. Nu is echter ons begrip van eene blijvende substantie in de dingen juist van dezelfde soort als ons begrip van het identische subject. Kent men aan de zuigeling het vermogen toe om al zijie wisselende gewaarwordingen te beschouwen als op zekere wijze verbonden met eene onbekende eenheid, het waarnemend subject; meent men verder, dat hij siechts door een dergelijk ik-bewustzijn van zijn eigen blijvend bestaan overtuigd is; dan moet men ook aannemen, dat hij groepen van zijne gelijktijdige gewaarwordingen zal opvatten als verbonden met eene onbekende eenheid, substantie, en dat hij aan alle dingen, waarin hij die laatsie eenheid gelegd heeft, een soortgelijk bestaan zal toeschrijven als zijn eigen bestaan is.' 
dan moet het ontstaan van het identiteitsbesef ten minste een even groot probleem vormen als het ontstaan van het besef van het bestaan van andere mensen. In Spruyts woorden: waaraan ligi het nu, dat de schrijver niet bemerkt, dat onze overtuiging, dat wij-zelven, en niet slechts onze wisselende gewaarwordingen, bestaan, op zijn siandpunt jwist even onverklaarbaar is als onze overtuiging, dat onze medemenschen bestaan?' Spruyt meent dat Huet op een dwaalweg terecht is gekomen door aan te nemen dat men gewaarwordingen in ons lichaam voelt. Deze onderstelling ligt impliciet besloten in Huets vraagstelling, te weten: hoe komen wij uit niets anders dan gewaarwordingen in ons eigen lichaam tot de voorstelling van iets buiten ons? ${ }^{2}$ Huet had niet ingezien dat deze onderstelling nader verklaard moest worden. Als men uitgaat van de onderstelling dat men gewaarwordingen in het lichaam kan voelen, dan ligt het voor de hand om aan te nemen dat men door gewaarwordingen het bestaan van lichaamsdelen kent. Zo bezien is Huets vraag - hoe kan het dan komen tot de voorstelling van iets, dat buiten zijn lichaam is? $?^{3}-$ begrijpelijk. Echter, Huet nam van Schopenhauer een verouderde theorie over omtrent gevoels- en gezichtsgewaarwordingen, aldus Spruyt. De kern van deze theorie komt er op neer dat gewaarwordingen ontstaan door het prikkelen van bepaalde zenuwen; door dit laatste vat men gewaarwordingen op als het voelen van uitgebreidheid in de ruimte. Visuele gewaarwordingen beschouwt men dan als een prikkeling van een bepaald deel van het netvlies. Omdat Huet zich op deze, volgens Spruyt inmiddels weerlegde, theorie had gebaseerd, kon hij menen dat men zichzelf door gewaarwordingen kan ervaren als iets dat in de ruimte uitgebreidheid bezit. ${ }^{4}$ Spruyt concludeert dat men er in tegenstelling tot Huet van uit moet gaan dat men eerst moet leeren om gewaarwordingen in het lichaam te lokaliseren. Het is daarom geen gegeven dat men gewaarwordingen in het eigen lichaam voelt. Het lichaam en andere voorwerpen leert men kennen door middel van gewaarwordingen en door het feit dat men gewaarwordingen ondergaat. Met andere woorden: het besef van het bestaan van

'cf. Spruyt, C.B. (1873), op. cit. p. 233.

${ }^{2}$ cf. Spruyt, C.B. (1873), op. cit. p. 228.

3 ef. Spruyt, C.B. (1873), op. cit. p. 228.

${ }^{4}$ cf. Spruyt, C.B. (1873), op. cit. p. 233, 'Ik gelooi, dat hij op den dwaalweg geleid is cloor de uitdrukking dat wij de gewaarwordingen in ons lichaam voelen. (...) ....(men) kan meenen, dat de gewaarwording ons het bestaan van zekere lichaamsdeelen leert kennen. Op dit standpunt kan men vragen: het kind heeft niets anders dan gewaarwordingen in zijn eigen lichaam, een gevoel van rood in zijn oogje, een gevoel van aanraking in zijn handje: hoe kan het dan komen tot de voorstelling van iets, dat buiten zijn lichaam is? Dat Schopenhauer voor ruim een halve eeuw de vraag op die wijze formuleerde, is zeer natuurlijk. Men geloofde destijds algemeen, dat de gewaarwording, door gevoelszenuwen opgewekt, bestond in het voelen van uitbreiding hunner peripherische uiteinden in de ruimte; de gezichtsgewaarwording in het zien van het geprikkeld deel van het netvlies. De mensch gevoelde, volgens die voorstelling, in zijne gewaarwordingen zich zelven ais eene uitgebreidheid in de ruimte.' 
het lichaam is niet met gewaarwordingen gegeven. ${ }^{1}$ In plaats van uit te gaan van Huets vraag - hoe komen wij uit niets anders dan gewaarwordingen in ons eigen lichaam tot de voorstelling van iets buiten ons? - acht Spruyt het vruchtbaarder de volgende vraag te beantwoorden: hoe komen wij, die toch niets anders ondervinden dan voorbijgaande gewaarwordingen, die alleen na elkander volgen, tot de voorstelling van eene blijvende werkelijkheid, wier bestanddeelen zich naast elkander uitstrekken in eene ruimte van drie afmetingen ? ${ }^{2}$ Om een antwoord te geven op deze laatste vraag ontkomt men er niet aan om gebruik te maken van de kantiaanse noties van 'eenheid' en 'blijvende substantie', zoals hierboven is aangegeven.

\section{Waardering van Huets kritiek op Opzoomer en Hume}

Spruyt brengt eerst in herinnering dat Hume het ontstaan van het causaliteitsbesef of bewustzijn van oorzakelijke werking had verklaard door te wijzen op de rol van het herhaald waarnemen van het volgen van verschijnselen. Als men herhaalde malen heeft waargenomen dat een bepaald verschijnsel volgt op een bepaald ander verschijnsel, dan zal men, als men de voorstelling van het eerste verschijnsel waarneemt, de voorstelling van het tweede met meer intensiteit waarnemen dan voorstellingen van andere verschijnselen. Hume was van mening dat in het verschil van de mate vann intensiteit het eigenaardige ligt van zowel het besef van successie van verschijnselen als het causaliteitsbesef; dat laatste wil zeggen, het besef dat het ene verschijnsel het andere verschijnsel veroorzaakt. ${ }^{3}$

De empirische school had geprobeerd, zo betoogt Spruyt, om het causaliteitsbesef op een andere manier dan uit de herhaalde waarneming van het volgen van verschijnselen uit ervaring af te leiden. Spruyt is het daarom eens met Huets kritiek op de empirische school, en vooral met diens Opzoomer-kritiek. Deze kritiek is uiteraard koren op Spruyts molen. Huet had er op gewezen, aldus Spruyt, dat Opzoomer de zonderlinge stelling had verdedigd dat men er van overtuigd is dat oorzakelijke verbanden in speciale gevallen bestaan, omdat men uitgaat van de zekerheid van het causaliteitsbeginsel. Echter, en dat is het zonderlinge, dit beginsel

'cf. Spruyt, C.B. (1873), op. cit. p. 233-234, 'Geeft men echter die theorie der gevoels- en gezichtsgewaarwording op, die door een tal van feiten wederlegd wordt, dan moet men aannemen, dat de mensch al zijne gewaarwordingen moet leeren localiseren. Dan moet hij zijne lichaam even goed als, en gelijktijdig met, de andere voorwerpen door middel van zijne gewaarwordingen leeren kennen, maar het bewustzijn, dat het lichaam bestaat, is hem niet met de gewaarwording gegeven.'

${ }^{2}$ cf. Spruyt, C.B. (1873), op. cit. p. 228.

${ }^{3}$ cf. Spruyt, C.B. (1873), op. cit. p. 234, 'Gelijk men weet heeft Hume de stelling verdedigd, dat eene dikwijls waargenomen opvolging ons ten slotte een band van oorzaak-engevolg toeschijnt. Hebben wij in vele gevallen opgemerkt, dat het eene verschijnsel door het andere opgevolgd werd, dan vertoont zich, zoodra wij opnieuw het eerste verschijnsel waarnemen, de voorstelling van het tweede, "krachtiger, levendiger, onvermijdelijker" dan eenige andere. In deze kracht, levendigheid, onvermijdelijkheid van de voorstelling van het verschijnsel, dat als het gevolg beschouwd wordt, zoekt Hume het eigenaardige, waardoor zich ons bewustzijn van een propter onderschieidt van ons bewustzijn van een post.' 
berustte volgens Opzoomer op ervaring. Deze stelling leidt tot contradicties, omdat men niet over het volgen van specifieke verschijnselen kan spreken, zonder dat men de nolic 'causalitcit' al onderstelt.'

Ook valt Spruyt Huet bij in diens kritiek op Opzoomers argumentatie dat de notic 'noodzakelijk verband' uit de inwendige waarneming van een relatie tussen wilsbepalingen en daden kon worden afgeleid. Spruyt vult Huets kritiek hier aan met al eerder gehoorde argumenten (Spruyt, 1871a). Hij wijst er nogmaals op dat de notie 'noodzakelijk verband' louter ncerkomt op een wilsbepaling zoals deze in het proces van handelen subjectief wordt waargenomen. Met andere woorden: cen wilsbepaling is geen oorzaak van een handeling, maar valt daarmee samen. Bovendien, als men er al van uit zou kunnen gaan dat een wilsbepaling wordt gevolgd door een daad, dan is het volkomen duister op grond waarvan Opzoomer kon menen dat men het besef van noodzakelijk verband, dat is gebaseerd op eén enkele waarneming, kan toepassen op iedere waarneming waar alleen sprake is van de successie van verschijnselen en niet van een noodzakelijk verband. ${ }^{2}$

Zowel Huets kritiek op Opzoomers verklaring van het ontstaan van het causaliteitsbeginsel als Huets kritiek op diens afleiding van de notie 'noodzakelijk verband' vallen bij Spruyt in goede aarde. De critiek, door den schrijver van deze twee laatste verklaringswijzen gegeven, is vrij scherp, maar in mijn oog daarom niet onbillijk. "Tobben" is het eenige woord, waarmee men zulk philosopheren naar eisch kan karakteriseeren.' Ik kan niet anders zeggen dan: Ja, waarlijk, zoo is het. ${ }^{3}$

Het ligt echter anders met de waardering van Spruyt voor Huets veroordeling van Humc's formulering van het causaliteilsvraagstuk. Hume had volgens Huet ten onrechte gedacht dat het causaliteitsbesef ontstaat door het herhaald waarnemen van het volgen van verschijnselen. Niet herhaalde waarneming van verschijnselen, maar een eenmalige impressie van veroorzaking zou al voldoende zijn om dit besef te laten

' cf. Spruyt, C.B. (1873), op. cit. p. 234, ' .... de empirische school (heeft) beproefd den oorsprong van ons bewustzijn van oorzakelijke werking in iets anders te zoeken dan in de warneming van telkens herhaalde opvolging. Zij is in de zonderlinge bewering vervallen, dat wij overtuigd zijn van het bestaan van een causaal-verband in bijzondere gevallen, omdat wij zeker zijn van de waarheid der algemene stelling, dat "alles eene oorzaak moct hebben". Maar zij ziet, desalniettemin, in deze laatste stelling een resultaat van rijpe ervaring, en werpt daarmede hare eigene redeneering omver, daar onze ervaring aangaande opvolgende veranderingen niet mogelijk is zonder voortdurende toepassing van het causaliteitsbegrip.'

${ }^{2}$ cf. Spruyt, C.B. (1873), op. cit. p. 234-235, 'Ook heeft zij ons bewustzijn van causaalverband doen ontspringen uit het feit, dat wij een noodwendig verband waarnemen tusschen onze wilsbepalingen en onze daden. Maar dit noodwendig verband blijkt bij nader onderzoek hierin te bestaan, dat de wilsbepaling niets anders is dan de beginnende handeling, subjectief waargenomen. En verder, indien er in dit geval sprake zou kunnen zijn van opvolging, dan blijft het volkomen duister waarom wij ons bewustzijn van noodwendig verband, in een bijzonder geval waargenomen, zouden overdragen op elke waarneming van constante opvolging, bij welke wij volgens de empiristen zelven aanvankelijk en van nature geen noodwendig verband waarnemen.' Zie ook: Spruyl, C.B. (1871a), op. cit. p. 66.

${ }^{3}$ cf. Spruyt, C.B. (1873), op. cit. p. 235. 
ontstaan, aldus Huet. Spruyt neemt Hume tegen Huets kritiek in bescherming, omdat Huets redenering (niets) bewijst tegen Hume. Immers, Hume had herhaalde waarneming alleen als een aanwijzing willen zien dat verschijnselen elkaar regelmatig volgen. Hij zocht het ontstaan van het causaliteitsbesef derhalve niet in het waarnemen van een ander verband dan de successie van verschijnselen. Spruyt wijst er op dat het causaliteitsbesef volgens Hume ontstond door de mate van intensiteit waarin de voorstelling van het herhaald waarnemen van een bepaald verschijnsel na het optreden van een bepaald ander verschijnsel zich aan ons voordoet. ${ }^{1}$

Kortom: Huets kritiek op Opzoomer acht Spruyt volkomen terecht, maar Huets kritiek op Hume slaat de plank mis.

\section{Kritiek op Huets afleiding van de notie 'oorzaak'}

Huets eerste stelling kwam er op neer dat het causaliteitsbesef en daarmee de abstracte notie 'oorzaak' ontstaat door een eenmalige impressie van oorzakelijke werking. Deze impressie kan worden herleid tot sympathetische gewaarwordingen; deze laatste komen neer op het ondergaan van musculaire gewaarwordingen die men voelt als men voorwerpen verplaatst en in beweging zet. Verder had Huet er op gewezen dat de notie 'plaatselijke verhouding' een beslissende rol speelt bij het ontstaan van het causaliteitsbesef. In de meesterlijke uireenzeiting van de argumenten voor deze stelling ligt Huets nieuwe oplossing van een oud vraagstuk besloten, zo merkt Spruyt op. ${ }^{2}$

Het oorspronkelijke van Huets oplossing is dat hij de gewaarwording van spierinspanning, die men bij het verplaatsen van voorwerpen ondergaat, als uitgangspunt neemt voor het verklaren van het ontstaan van de notie 'kracht' of van het 'vermogen om iets te bewerken'. Spruyt wijst er op dat zo'n oplossing weliswaar al eerder door Hume en Schopenhauer was genocmd, maar vervolgens door hen werd verworpen. Aan Huet komt echter de eer toe deze theorie volledig te hebben uitgewerkt. ${ }^{3}$

Spruyt is het eens met Huet dat de oorsprong van de notie 'kracht' inderdaad gezocht moet worden in musculaire gewaarwordingen; zulke gewaarwordingen vormen zeker een element van het onbestemde begrip van oorzaak. ${ }^{4}$ Echter, het

' cf. Spruyt, C.B. (1873), op. cit. p. 235-236, 'Doch ook Hume zelf heeft volgens den schrijver het vraagstuk niet goed voorgesteld. (...) Doch het bewijst niets tegen Hume, die de herhaalde opvolging alleen nodig acht om de regelmatigheid dier opvolging te bespeuren, en die het eigenaardige van ons bewustzijn van oorzakelijken samenhang niet zoekt in de waarneming van een ander verband dan dat der opvolging zelve, maar uitsluitend in de levendigheid en onweerstaanbaaiheid, warmede de voorstelling van het dikwijls waargenomen consequens zich aan ons opdringt, zoodra wij het antecedens waarnemen.'

${ }^{2}$ cf. Spruyt, C.B. (1873), op. cit. p. 238.

${ }^{3}$ cf. Spruyt, C.B. (1873), op. cit. p. 239, 'De oplossing van L'Ange Huet blijft even nieuw, al wordt zij ook reeds door Hume (en dooi Schopenhauer) genoemd. Want beiden wijzen alleen met een enkel woord op de mogelijkheid van eene dergelijke theorie; L'Ange Huet geeft haar volledig.'

${ }^{4}$ cf. Spruyt, C.B. (1873), op. cit. p. 239. 
causaliteitsbesef bestaat niet alleen uit musculaire gewaarwordingen. In navolging van Kant merkt Spruyt op dat in dit besef ook de impliciete overtuiging besloten ligt dat verschijnselen elkaar volgens een regel volgen. 'Dit had Huet kennelijk over het hoofd gezien. ${ }^{2}$ Men neemt in de natuur namelijk niet alleen waar, zo werpt Spruyt tegen, dat bepaalde verschijnselen door bepaalde andere verschijnselen worden veroorzaakt, maar men is er ook van overtuigd dat bij gelijke omstandigheden gelijke gevolgen optreden. Met andere woorden: men gaat er van uit dat het causaliteitsbeginsel, waarvan het beginsel gelijke omstandigheden gelijke gevolgen de concrete uitwerking is, algemeen geldig is. Spruyt acht het ontoereikend om het onderzoek van het causaliteitsvraagstuk te beperken tot het ontstaan van de notie 'oorzaak', of tot de voorstelling dat het eene voorwerp op het andere werkt. Immers, zo'n onderzock biedt geen verklaring voor het besef dat bij gelijke omstandigheden gelijke gevolgen optreden. Uit de ervaring blijkt namelijk dat de manier waarop een bepaald verschijnsel op een bepaald ander verschijnsel werkt zeer verschillend kan zijn. Als men een bepaald verschijnsel heeft waargenomen en men eerder heeft geconstateerd dat er altijd een bepaald ander verschijnsel op volgt, dan blijkt dat het tweede verschijnsel toch niet altijd optreedt als men het eerste verschijnsel heeft waargenomen. Toch houdt men in zulke gevallen vast aan de algemene geldigheid van het beginsel dat bij gelijke omstandigheden gelijke gevolgen optreden. In veel gevallen blijkt immers dat men de afwijking van deze regel eenvoudig kan verklaren, doordat men bijvoorbeeld bij het doen van waarnemingen onnauwkeurig te werk is gegaan. ${ }^{3}$

' ef. Kant, I, (1787²), op. cit., B-uitgave, p. 238.

${ }^{2}$ cf. Spruyl, C.B. (1873), op. cit. p. 238-239, 'Reeds Hume bespreek! de theorie, die den schrijver ons als eene nieuwe oplossing voordraagt, en ofschoon hij haas verwerpt, erkent hij toch, dat de nisus, de spierinspanning, die wij bij het verplaatsen van voorwerpen gevoelen, hoewel zij ons geen nauwkeurig denkbeeld van krachi (power) kan geven, zeer veel bijdraagt tot de vorming van de populaire, onnauwkeurige voorstelling, die men zich van dat begrip vormt (...) Die theorie geeft ons de ontwikkelingsgeschiedenis van het begrip "kracht" of "vermogen om iets te bewerken". (...) Nu is dit onberedeneerde, onlogische, antropomorfistische begrip van kracht (...) voorzeker een bestanddeel van het onbestemde begrip van ooraak, dat algemeen gangbaar is. Voorzover dit bestanddeel zich uitstrekt, heeft de schrijver eene juiste verklaring van het begrip oorzaak gegeven. Doch als men nauwkeurig toeziet, dan bemerkt men, dat ook bij den minst ontwikkelden mensch in het bewustzijn van oorzaak•ngevolg nog een ander element ligt.'

'cf. Spruyt, C.B. (1873), op. cit. p. 239, 'Dit element is, om met Kant te spreken, de (onuitgesproken) overtuiging, dat het eene verschijnsel op het andere volgens een regel volgt. Niel slechts werking van 't een op 't ander ziet men in de natuur, maar men is ook overtuigd, dat gelijke omstandigheden gelijke gevolgen hebben. (...) Het bestaan van die overtuiging wordt niet verklaard door aan te wijzen hoe wij komen aan de voorstelling, dat het eene voorwerp op het andere werkt. Want het een zou nu eens zus en dan weer zoo op het andere kunnen werken. (...) Maar wij zijn dan zonder nader onderzock overtuigd, dat wij nog niet nauwkeurig genoeg waargenomen hebben, en dat ons onderzoek, als het maar goed wordt ingesteld, ons leeren moet, dat een zelfde samenstel van verschijnselen altijd door een zelfde samenstel van andere verschijnselen gevolgd wordt.' 
Spruyt suggereert vervolgens dat Huet het kennelijk niet nodig vond om dit element van de notie 'causaliteit' - gelijke omstandigheden gelijke gevolgen - te verklaren. Hij suggereert ook dat Huet zich in dit opzicht aansluit bij de empirische school; de vertegenwoordigers van die denkrichting zijn van oordeel dat het beginsel gelijke omstandigheden gelijke gevolgen op ervaring is gebaseerd. Echter, als dat zo is, dan had Huet tevens Hume's argumenten voor de opvatting moeten weerleggen dat dit beginsel de grondslag voor ervaring is; maar dit heeft Huet nagelaten. In plaats daarvan gaf hij een verklaring voor een ander element van de notie 'oorzaak', namelijk een verklaring van de rol van musculaire gewaarwordingen bij het ontstaan van de notie 'kracht'. Hume had dit overbodig geacht, omdat men het ontstaan van het causaliteitsbesef ook kon verklaren zonder een beroep te doen op de gewaarwordingen van de werking van 't eene op 't andere.' In één woord: Huets theorie acht Spruyt interessant voor zover het een verklaring biedt voor het ontstaan van de notie 'kracht', maar zo'n verklaring gaat geheel voorbij aan het verklaren van het belangrijkste element: het causaliteitsbeginsel.

\section{De notie 'verklaren' en het beginsel van voldoende grond}

Herhaalde waarneming leidt niet tot het besef van causaliteit. Op grond van herhaalde waarneming is het alleen mogelijk om algemene uitspraken te formuleren. Als men verschijnselen wil verklaren, dan is een verwijzing naar oorzaken overbodig. Verklaren komt louter neer op het subsumeren van bijzondere gevallen onder steeds algemenere natuurwetten. Het "klassieke" onderscheid tussen uitspraken die betrekking hebben op hel volgen van verschijnselen en uitspraken die betrekking hebben op het samengaan van verschijnselen, wordt hierdoor irrelevant. Zo luidde Huets tweede stelling.

Spruyt stemt in met Huets constatering dat natuurkundigen het verklaren van anorganische natuurverschijnselen opvatten als het subsumeren van bijzondere gevallen onder algemene natuurwetten. Echter, zo merkt Spruyt op, de methode om het formuleren van algemene uitspraken over het samengaan of gepaard gaan van eigenschappen te verklaren verschilt hemelsbreed van de methode om het doen van algemene uitspraken te verklaren die betrekking hebben op het volgen van verschijnselen. Spruyt vraagt zich zelfs af of algemene uitspraken over het samengaan van verschijnselen überhaupt de naam 'verklaring' verdienen. Immers, bij zulke verklaringen maakt men geen gebruik van het beginsel gelijke omstandigheden gelijke gevolgen. In dat geval kijkt men alleen naar de overeenkomsten en verschillen tussen voorwerpen, zoals in de "klassieke" biologie; dat wil zeggen, de natuurlijke historie. $\mathrm{Bij}$ algemene uitspraken over het volgen van verschijnselen speelt het beginsel gelijke

' cf. Spruyt, C.B. (1873), op. cit. p. 240, 'Hij deelt misschien het gevoelen van de empirische school, die in de overtuiging, dat gelijke omstandigheden gelijke gevolgen hebben, de vrucht ziet van rijpe ervaring. In dat geval was het echter noodig geweest, dat hij bij zijne kritiek van Hume de gronden weerlegd had, waarop deze beweert dat het ontstaan der ervaring niet mogelijk is zonder voorafgaande erkenning van het genoemd beginsel.' 
omstandigheden gelijke gevolgen echter wél een rol. Waarnemingen worden in zulke gevallen door dat beginsel geleid. Bijvoorbeeld: als steeds is waargenomen dat een bepaald verschijnsel altijd volgt nadat een bepaald ander verschijnsel is opgetreden, en één keer wordt geconstateerd dat dit in een bepaalde situatie niet gebeurt, dan wordt niet gezegd dat zowel het eerste als het tweede geval waar zijn. Neen: men is er van overtuigd dat het eerste geval klopt, en dat er in het tweede geval iets aan de hand is, hetgeen er toe heeft geleid dat een bepaald verschijnsel (zeg: een B) niet volgt nadat een bepaald ander verschijnsel (zeg: een A) is opgetreden. Echter, als bijvoorbeeld is gebleken dat een bepaald verschijnsel altijd is samengegaan met een bepaald ander verschijnsel; en als men waarneemt dat niet een $\mathrm{A}$, maar een ander verschijnsel (zeg: een C) blijkt samen te gaan met een B, dan leidt dat er alleen toe dat men voortaan zal zeggen dat soms een $C$ in plaats van een $A$ samengaat met een B. Dit wordt dan de uitzondering op de regel genoemd. Spruyt concludeert hieruit dat bij verklaringen over het volgen van verschijnselen, zoals in de natuurkunde, het beginsel gelijke omstandigheden gelijke gevolgen wél sturend is bij het doen van waarnemingen; ook concludeert hij dat dit niet gebeurt bij het verklaren van verschijnselen die bij elkaar horen of met elkaar gepaard gaan, zoals in de "klassieke" biologie.

Kortom: als men alleen het samengaan van verschijnselen onderzoekt, en men zich niet afvraagt wat de oorzaak daarvan is, dan maakt men geen gebruik van zo'n opperste beginsel. Het enige wat men doet is het opsporen van verschillen en overeenkomsten en lijdelijk aan te teekenen, wat de natuur ons wel wil openbaren. ${ }^{2}$

Vervolgens grijpt Spruyt Huets kritiek op het "klassieke" beginsel van voldoende grond aan om te concluderen dat Huet veeleer een medestander dan een tegenstander is van de lcer van apriorische vormen.

Huet had zich dat beginsel als volgt voorgesteld: de mensch (moet) zich alles als veroorzaakt denken, of, de mensch moet zich alles denken als bewerkt door een oorzaak. Spruyt merkt hierover op dat sommige denkers inderdaad van deze formulering uitgaan; hij laat hier echter meteen op volgen dat het onjuist is te menen

' cf. Spruyt, C.B. (1873), op. cit. p. 240-242, 'Zooals de schrijver terecht opmerkt is zijne opvatting van "verklaren" door de natuurphilosophen (...) algemeen aangenomen. Maar toch bestaat er een belangrijk verschil tusschen de methoden, die de mensch volgt, als hij algemeene stellingen vormt over het samengaan (coëxisteren) der verschijnselen, en wanner hij de opvolging der verschijnselen door het vinden van algerneene stellingen zoekt te verklaren. Dit verschil is zoo groot, dat velen zullen aarzelen aan de algemeene stellingen (...) de naam van verklaringen te geven, ofschoon zij strikt genomen recht hebben op dien titel. Bij het vormen van onze algemeene stellingen over het samengaan van verschijnselen volgen wij uitsluitend de aanwijzingen die ons de waargenomen gelijkheid en ongelijkheid der voorwerpen geeft: bij de vorming der algemeene stellingen over opvolging wordt de uitslag der waarnemingen altijd getoetst aan het beginsel, dat gelijke omstandigheden gelijke gevolgen hebben. (...) In eén woord, bij de vorming van onze wetenschap over coëxisterende verschijnselen is er geen algemeen beginsel, dat onze onderzoekingen op soortgelijke wijze leidt als de stelling van voldoende grond onze nasporingen over opvolgende verschijnselen bestuurt.'

${ }^{2}$ cf. Spruyt, C.B. (1873), op. cit. p. 243. 
dat bijvoorbeeld ook Kant en Schopenhauer deze formulering op het oog hadden. In navolging van Kant en Schopenhauer wijst Spruyt er op dat niet alles, maar alleen iedere verandering een oorzaak moet hebben. Spruyt constateert dat dit ook de formulering is waar Huet op uitkomt. Hij was immers tot de slotsom gekomen dat de mensch niet genoodzaakt is zich alle dingen als veroorzaakt te denken. Ironisch merkt Spruyt op dat Huet daardoor verkeert in het illustere gezelschap van Kant en Schopenhauer, de belangrijkste vertegenwoordigers van de leer van aprioristische vormen; een leer die Huet verwerpt. ${ }^{2}$

Spruyt neemt van Kant en Schopenhauer de formulering van het beginsel van voldoende grond over: elke verandering heeft een oorzaak, dat wil zeggen ontstaat niet, tenzij eene verandering is voorafgegaan, waarop zij volgens een regel volgt. ${ }^{3}$ Hoewel Huet niet heeft ontkend dat dit beginsel onbetwijfelbaar is, suggereert hij toch, zo betoogt Spruyt, dat ook de overtuiging van dit beginsel door ervaring is ontstaan. Op dit punt spreekt Huet zich zelf echter tegen, omdat hij er ook van uit ging dat baby's zich al volgens dit beginsel gedragen, uiteraard zonder dat zij dit kunnen verwoorden. En dat is precies wat Kant en Schopenhauer hadden betoogd! Hume's geldigheidsvraag sluit hier, aldus Spruyt, geheel op aan: waarop berust die onverdelgbare overtuiging, dat de volgorde der gebeurtenissen in de natuur vaste regels volgt, eene overtuiging, die reeds den zuigeling in zijne wieg doelmatig doet handelen ? Met andere woorden: op grond waarvan is men er van kindsbeen vast van overtuigd dat de verschijnselen in de natuur bepaalde vaststaande regels volgen? Berust dat onwankelbaar geloof aan de regelmatigheid der natuur op eene

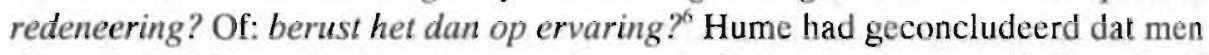
deze overtuiging noch via een redenering noch uit de ervaring kon afleiden. Toch berust iedere uitspraak die men doet over het volgen van verschijnselen op de overtuiging of het besef dat de natuur een vast patroon heeft. Dit besef gaat zelfs aan iedere ervaring vooraf. Hume's antwoord op de geldigheidsvraag acht Spruyt

'cf. Spruyt, C.B. (1873), op. cit. p. 243.

${ }^{2}$ ef. Spruyt, C.B. (1873), op. cit. p. 243, 'Doch bij Kant en Schopenhauer (...) vindt men die sielling nooit uitgestrekt over alles, maat alleen over alle veranderingen. Wanneer dan ook onze schrijver atutoont, dat de mensch niet genoodzaakt is zich alle dingen als verooraakt te denken, dan stemt hij geheel in met Kant en Schopenhauer, die hetzelfde beweren. (....) Bij Schopenhauer en Kant heeft de bedoelde stelling dezen inhoud: Elke verandering heeft een oorzaak, d.w:z. ontstaat niet, tenzij eene verandering is voorafgegaan, waarop zij volgens een regel volgt.'

${ }^{3}$ cf. Spruyt, C.B. (1873), op. cit. p. 243.

4 cf. Spruyt, C.B. (1873), op. cit. p. 244, Dat het den mensch onmogelijk is aan die stelling in dezen, yorm te twijfelen, wordt door L'Ange Huet nergens ontkend; al geeft hij met een enkel woord te kennen, dat die vaste overtuiging eerst langzamerhand zal onistaan zijn. Doch deze losse bewering wordt wederlegd door de opmerking, dat reeds de zuigeling in zijne wieg er van overtuigd is, dat gelijke omstandigheden gelijke gevolgen hebben, althans in overeenstemming met die overtuiging handelt.'

sef. Spruyt, C.B. (1873), op. cit. p. 244.

${ }^{6}$ cf. Spruyt, C.B. (1873), op. cit. p. 244. 
onbevredigend, maar het was eene verdienstelijke daad de vraag te stellen, en zoo juist te stellen. ${ }^{1}$ Huet had echter, zo concludeert Spruyt, niet ingezien dat hij ook een antwoord had moeten geven op Hume's geldigheidsvraag. ${ }^{2}$

Samengevat komt Spruyts kritiek op Huet in hoofdlijnen op het volgende neer. Spruyt stelt zich ten doel een aantal dwalingen in Huets causaliteitsleer te identificeren en te weerleggen.

Huets eerste dwaling is dat hij enerzijds aan baby's een identiteitsbesef had toegeschreven dat aan de ervaring vooraf gaat, maar dat hij er anderzijds van uit was gegaan dat dit besef geleidelijk via ervaring ontstaat. Spruyt leidt hieruit af dat Huet het ' $i k$ ' had voorgesteld als een residu van wisselende gewaarwordingen. Als dit zo zou zijn, dan zou Huets notie 'ik' kunnen worden opgevat als een aggregaat van gewaarwordingen en voorstellingen. Dit onderstelt dat baby's over een vermogen a priori zouden beschikken dat van gewaarwordingen en voorstellingen een eenheid makkt. Huets notie 'ik' zou ook kunnen worden opgevat als het gemeenschappelijke subject gewaarwordingen en voorstellingen. Dit zou onderstellen dat het 'ik' een blijvende identiteit is. Spruyt concludeert dat Huet in beide gevallen impliciet een element a priori moet aannemen, hetgeen strijdig is met Huets positivisme.

Een tweede belangrijke dwaling komt er op neer dat Huet het kennelijk niet nodig had gevonden om het ontstaan van het beginsel gelijke omstandigheden gelijke gevolgen te verklaren. Echter, als Huet met de empirische school van oordeel zou zijn dat dit beginsel door ervaring ontstaat, dan miskent hij het feit dat dit beginsel de grondslag vormt voor ervaring.

Een derde dwaling betreft Huets stelling dat verklaren en causaliteit niets met elkaar hebben te maken. Het verklaren van verschijnselen zou louter neerkomen op het subsumeren van bijzondere gevallen onder steeds algemenere natuurwetten. Hieruit had Huet afgeleid dat er geen principieel onderscheid bestaat tussen bijvoorbeeld verklaringen in de natuurkunde en die in de "klassieke" biologie. Spruyt wijst er op dat er wél een onderscheid tussen beide soorten verklaringen bestaat. In het eerste geval gaat het om het verklaren van het volgen van verschijnselen, waarbij het causaliteitsbeginsel en het concrete besef dat gelijke omstandigheden leiden tot gelijke gevolgen een leidende rol speelt; en in het tweede geval gaat het om het

'cf. Spruyt, C.B. (1873), op. cit. p. 244.

${ }^{2}$ cf. Spruyt, C.B. (1873), op. cit. p. 244, 'Berust dat onwankelbaar geloof aan de regelmatigheid der natuur op eene redeneering? Hume kon die redeneering niet vinden, en niemand heeft haar na hem kunnen ontdekken. Berust het dan op ervaring? Elk besluit, over de opvolging der verschijnselen uit de gegevens der ervaring opgetrokken, berust op die overiuiging, en wij bezitten haar reeds, als richtsnoer voor onze handelingen, als wij met onze ervaring beginnen. Het antwoord, door Hume gegeven, schijnt ook mij onvoldoende. Maar het was eene verdienstelijke daad die vraag te stellen, en zoo juist te stellen. Onze schrijver heeft daarentegen niet ingezien, dat Hume's vraag door hem beantwoord moest worden.' 
verklaren van het samengaan van verschijnselen, waarbij het causaliteitsbeginsel geen rol speelt.

Een laatste dwaling die Spruyt signaleert betreft Huets dubbelzinnige positie ten aanzien van het beginsel van voldoende grond. Enerzijds was Huet van mening dat dit beginsel door ervaring geleidelijk ontstaat, maar anderzijds had Huet gesteld dat baby's zich gedragen conform dit beginsel. Spruyt leidt hier uit af dat ook volgens Huet dit beginsel een aangeboren waarnemingsvorm moet zijn. Al met al had Huet niet begrepen dat ook hij een antwoord had moeten geven op Hume's geldigheidsvraag; dat wil zeggen, de vraag hoe men kan rechtvaardigen dat men er, voorafgaand aan iedere ervaring, van uitgaat dat de natuur een regelmatig patroon heeft.

Het vorige hoofdstuk werd afgesloten met de vraag hoe op Huets radicale standpunten werd gereageerd. Alleen al de titel van Spruyts reactie - Oude dwalingen in een nieuw kleed - spreekt in dit opzicht boekdelen. Huets causaliteitsleer vertoont volgens Spruyt in grote trekken gelijksoortige tekortkomingen als de causaliteitsopvattingen van Opzoomer en Van der Wijck. Deze dwalingen zijn nu alleen verpakt in een positivistisch omhulsel.

Spruyts negatieve wijze van argumenteren werd reeds aangetroffen bij zijn kritiek op Opzoomer en Van der Wijck. Ook in de kritiek op Huet valt Spruyts reductio ad absurdum strategie op. Eerst gaat hij na of er inconsistenties uit Huets argumentatie volgen. Zodra hij deze heeft gevonden concludeert hij zonder meer dat daarom het tegenovergestelde waar moet zijn. Treffende voorbeelden hiervan zijn Spruyts argumentaties tegen Huets theorie van sympathetische gewaarwordingen en tegen diens afleiding van het causaliteitsbesef uit zulke gewaarwordingen.

Naar aanleiding van Huets stelling over het geleidelijk ontstaan van het identiteitsbesef stelt Spruyt ten onrechte dat Huet impliciet aanneemt dat er sprake is van elementen a priori. Hij schuift met zijn argumentatie Huet echter dingen in de schoenen die hij niet kan hebben bedoeld. Immers, iedere positivist gaat uit van de gedachte dat alle noties, dus ook het ik-besef, geleidelijk ontstaan. Het ik-besef acht Huet daarom zeker niet a priori. Men kan stellen dat Spruyt Huets theorie vooral beoordeelt door de bril van zijn kantiaanse standpunt.

Ten slotte: Spruyt denkt verrassend genuanceerd over Huets ontslaansbenadering en hij heeft oog voor het nieuwe in Huets aanpak. Dit blijkt uit Spruyts waardering voor diens theorie der sympathetische gewaarwordingen die hij als een vruchtbaar aanknopingspunt opvat om het ontstaan van de notie 'kracht' te verklaren. Toch schiel Huets theorie volgens Spruyt tekort: het zegt namelijk niets over het causaliteitsbeginsel. Echter, als Huet dit beginsel ook in ontstaanstermen verklaart, leidt dit volgens Spruyt tot dezelfde circulaire redeneringen die hij bij Opzoomer en van Van der Wijck aan het licht had gebracht. Uitgaande van Spruyts reductio ad absurdum strategie moet dit wel betekenen dat het causaliteitsbeginsel aangeboren is. Hierdoor blijft voor Spruyt alleen het geldigheidsprobleem over, dat in de volgende paragraaf aan de orde komt. 
Men kan vaststellen dat Spruyt de pogingen van Opzoomer, Van der Wijck en Huet om een empirische verklaring te vinden voor het ontstan van zuwel de noties 'oorzaak' en 'noodzakclijk verband' als voor het ontstaan van het causaliteitsbeginsel en het causaliteitsbesef als mislukt had beschouwd. Hij meende hicruit te moeten alleiden dat die nolies en het causaliteitsbeginsel daarom a priori zijn: 'causaliteit' is een aangeboren waarnemingsvorm. Herhaaldelijk benadrukte Spruyt dat Hume's geldigheidsvraag moest worden beantwoord. Op deze vraag waren Opzoomer, Van der Wijck en Huet een antwoord schuldig gebleven. In een aantal gevallen had Spruyt zich expliciet bij Kant aangesloten, hetgeen duidelijk naar voren kwam in zijn kritick op Huet waarin Spruyt had opgemerkt dat in het causaliteitsbesef de impliciete overluiging besloten ligt dat verschijnselen elkaar volgens een regel volgen. Hicmec nam Spruyt met zoveel woorden Kants tweede analogie der ervaring over, die er op neer komt dat alle veranderingen geschicden volgens de wet of de regel a priori die oorzaak en gevolg met elkaar verbindt. Dit is de rode draad die men tot clusver in Spruyts argumentatics kan aantreffen. In Spruyts Proeve van ecne geschiedenis van de leer der aangeboren begrippen (1879), zijn met goud bekroonde chef d'ocuvre, komt zijn kantiaanse oriëntatie nog duidelijker naar voren.

Over het grote belang van de vraag die in de Proeve centraal staat, bestiat voor Spruyt geen enkele twijfel. In de voorrede van dat berk merkt hij op dat de richting, die de' ethiek der toekomst, en in haar gevolg de Europeesche beschaving nein'n zal zonder twijfel afhangen van de vraag, of de wet'nschappelijke inannen der eerstvolgende' geslachten over dat onderwerp zullen denken in Kantiaanschen, dan wel in empirischen geest. ${ }^{1}$ Hiermee zet hij de toon. Ook hier komt implicict de legenstelling tussen de ontstaans- en geldigheidsbenadering naar voren.

Het doel van de Proeve is om vanuit een historisch gezichtspunt een groot aantal theorieën over het probleem van het bestaan en de aard der aangeboren begrippen ${ }^{2}$ te onderzoeken. Spruyt waarschuwt dat discussies die in de geschiedenis van de filosofie over dit vraagstuk worden aangetroffen niet louter als een woordenstrijd gezien mogen worden over wat precies de betekenis zou zijn van de notie 'aangeboren begrip'. Zulke discussies verwijzen daarentegen naar veel gewichtiger vragen en veel dieper liggende gronden ${ }^{3}$; hiermee bedoelt hij de vraag wat de oorsprong der menschelijke kennis is. Spruyt constateert dat men in de discussics over de oorsprong van kennis twee hoofdrichtingen kan onderscheiden: het empirisme en het noölogisme. Deze richtingen typeert hij als volgt. Het empirisme (hecht) het grootsle gewicht aan den invloed van de dingen, die den menschelijke geest van

'cf. Spruyt, C.B. (1879), Proeve van eene geschiedenis van de leer der aangeboren begrippen, Voorrede.

${ }^{2}$ cf. Spruyt, C.B. (1879), op. cit. p. i.

${ }^{3}$ ef. Spruyt, C.B. (1879), op. cit. p. iii. 
nature vreemd zijn. ${ }^{1}$ Het noölogisme daarentegen (kent) den grootsten invloed (toe) aan datgene, wat het kennende van nature bezit. ${ }^{2}$ Discussies over het al of niet bestaan van aangeboren begrippen komen voor Spruyt uiteindelijk neer op een strijd tussen deze twee denkrichtingen.

Discussies over de oorsprong van kennis hebben een lange staat van dienst. Filosofen zoals Plato, Aristoteles, Augustinus, de Scholastici, Descartes, Locke, Condillac, Leibniz en Wolff hebben op deze vraag verschillende antwoorden gegeven. Ook in de 19de eeuw lopen de meningen over deze kwestie uiteen. Voor Spruyt komt dit vraagstuk hier op neer: welk aandeel neemt de kennende en waarnemende geest aan de vorming van onze kennis? Richt hij die kennis in volgens eischen, die hij zelf stelt, zonder met eenig ding buiten zich zelf te rade te gaan, of moet hij zich geheel of grootendeels schikken naar den invloed, dien de dingen buiten hem uitoefenen? ${ }^{3}$ Met andere woorden: het gaat hierbij om een keuze tussen de autonomie van den geest en de onderworpenheid van den geest aan het spel der gewaarwordingen. ${ }^{4}$ Spruyt wijst er vervolgens op dat dit vraagstuk door Hume en Kant in volle scherpte is geformuleerd. Het moderne empirisme wortelt in Hume's denkbeelden, het moderne noölogisme in die van Kant. (...) De vraagstukken van Hume en Kant zijn nog altijd de groote vragen van de wijsbegeerte, die men beter leert inzien door de werken van de mannen, in wier geest zij gerijpt zijn, dan door de geschriften van hunne minder consequente en minder diepzinnige leerlingen. ${ }^{5}$ Het is goed mogelijk dat Spruyt met deze laatste venijnige opmerking zijn tegenstanders op het oog had: Opzoomer, Van der Wijck en Huet.

Spruyts kantiaanse oriëntatie komt duidelijk naar voren in het slotwoord van de Proeve. Hierin constateert hij dat ook in het Nederland van de 19 de eeuw over het bestaan van aangeboren begrippen is gediscussieerd. Men denke hier natuurlijk vooral aan de discussies tussen Opzoomer, Van der Wijck en Spruyt zelf. Spruyt wijst er op dat deze discussies de strijd tussen het empirisme en idealisme weliswaar niet hebben beslecht, maar dat de ervaringswijsbegeerte wel op haar retour is. Bovendien constateert hij dat de blijvende waarheid van Kants denkbeelden steeds beter in hare waarde erkend wordt. ${ }^{6}$ Het is niet onwaarschijnlijk dat Spruyt hierbij vooral zijn eigen aandeel in de discussies op het oog had.

'cf. Spruyt, C.B. (1879), op. cit. p. iv.

${ }^{2}$ ef. Spruyt, C.B. (1879), op. cit. p. iv.

3 ef. Spruyt, C.B. (1879), op. cit. p. 155.

4 cf. Spruyi, C.B. (1879), op. cit. p. 155.

cf. Spruyt, C.B. (1879), op. cit. p. 155-156.

${ }^{6}$ cf. Spruyt, C.B. (1879), op. cit. p. 354, '.... wel heeft men bepaaldelijk ook in ons vaderland den invloed kunnen bemerken der tegengestelde stroomingen, die zich in het geestelijk leven onzer negentiende ceuw Iaten onderscheiden; doch dit alles kan op den uitslag van den strijd tusschen empirisme en noölogisme geen beslissende invioed hebben. (....) En wai de leer van Kant aangaat (...) zij wordt zonder twijlel in de tweede helft van deze ceuw veel beter in hare waarde erkend dan in de eerste.' 
In het slotwoord van de Proeve treft men ook Spruyts filosofische credo aan. Filosofie moet gericht zijn op het onderzoek van de deugdelijkheid der gronden van de overtuigingen die men er op na houdt. Het onderzoeken van de rol die ervaring hierbij als bron van kennis speelt is van groot belang. Immers, veel van zulke overtuigingen berusten op ervaring. Op dit punt trekt Spruyt echter een scherpe scheidslijn tussen Opzoomer, Van der Wijck en Huet enerzijds en hemzelf anderzijds. In tegenstelling tot deze denkers acht Spruyt het onverstandig om bij voorbaat te menen dat alle overtuigingen door ervaring ontstaan. Filosofisch onderzoek mag er niet van uitgaan dat ervaring in beginsel betrouwbaar is. Zulk onderzoek moet er juist op zijn gericht om de vraag te beantwoorden wat de geloofsbrieven der ervaring zijn.' Dit is de taak van de kritische filosofie, waarvoor Hume de basis had gelegd en die door Kant in de Kritik der reinen Vernunft was uitgewerkt. Door dit laatste onderzoek is duidelijk geworden dat er apriorische voorwaarden der ervaring in het denken besloten liggen. De belangrijkste voorwaarde a priori die in Kants kritische filosofie naar voren is gekomen, wordt gevormd door het logische element in het denken. Dit element zorgt ervoor dat men den inhoud zijner gewaarwordingen rangschikt en vereenigt op zoodanige wijze, dat zij voor hem de representanten worden van werkelijk (schoon niet onafhankelijk) bestaande voorwerpen. ${ }^{2}$ Het hoeft geen betoog dat de notie 'causaliteit' én van deze logische elementen is.

Spruyts Proeve bestrijkt vrijwel de gehele geschiedenis van het probleem van aangeboren begrippen. In deze studie worden in het navolgende twee van Spruyts belangrijkste gedachtenlijnen gevolgd zoals deze worden aangetroffen in het derde boek van de Proeve getiteld De strijd tusschen het noölogisme en empirisme sedert Hume en Kant tot op onzen tijd. De eerste gedachtenlijn betreft Spruyts kritiek op Hume's causaliteitsleer; de tweede lijn betreft zijn kantiaanse causaliteitsopvalting, waardoor men een indruk krijgt van Spruyts eigen causaliteitsleer.

\section{Kritiek op Hume en navolging van Kant}

Hume had in de Enquiry, zo betoogt Spruyt, een onderscheid gemaakt tussen, wat Spruyt noemt, abstracte en empirische kennis. Abstracte kennis bestaat uit relaties tussen ideeën (relations of ideas); empirische kennis bestaat uit feiten (matters of fact). Uitspraken of redeneeringen over feiten onderstellen altijd causale samenhangen. Bijvoorbeeld: als men suiker in de mond stopt, verwacht men dat het zoet

' cf. Spruyt, C.B. (1879), op. cit. p. 356, 'Volgens onze mening is de mensch, die zich geroepen acht wijsgeerig te denken, in de eerste plaats verplicht een onderzoek in te stellen naar de deugdelijkheid der gronden waarop zijnen overtuigingen berusten. Dat onderzoek loopt natuurlijk vooral over de beteekenis, die de ervaring als kenbron heeft, omdat verreweg de meeste van onze overtuigingen op ervaring berusien. Voor het onderzoek aan te nemen dat dit met alle overtuigingen het geval is, zou in hooge mate onwijsgeerig zijn, ofschoon het natuurlijk door het onderzoek zou kunnen blijken. Maar bij het onderzoek zelf mogen de lessen der ervaring niet als betrouwbaar beschouwd worden, daar het juist over de geloofsbrieven der ervaring loopt.'

cf. Spruyt, C.B. (1879), op. cit. p. 356. 
zal smaken. Hierbij onderstelt men dat tussen het verschijnsel dat men nu waarneemt en het bestaan van een verschijnsel dat men uit die waarneming afleidt een causaal verband bestaat.' Dit was voor Hume, aldus Spruyt, aanleiding voor de vraag hoe (wij) nu aan de overtuiging (komen), die ons doet aannemen dat er zulk een verband bestaat ${ }^{2}$ Hume's antwoord hierop was dat zo'n overtuiging ontstaat door het herhaald waarnemen van het regelmatig volgen van een bepaald verschijnsel nadat een bepaald ander verschijnsel is opgetreden. Dit had Hume echter weer tot een volgende vraag gebracht: maar waarop berusten al de besluiten, die wij uit onze ervaring afleiden?" Hume antwoordde, zo betoogt Spruyt, dat men impliciet het beginsel aanneemt dat de toekomst tot op zekere hoogte overeen zal komen met het verleden. Immers, alle redeneringen die berusten op relaties tussen feiten komen neer op het volgende. Herhaaldelijk is waargenomen dat een bepaald verschijnsel gevolgd wordt door een bepaald ander verschijnsel. Dit leidt tot de verwachting dat een bepaald verschijnsel in alle gevallen door een bepaald ander verschijnsel zal worden gevolgd. Hierbij neemt men impliciet het beginsel aan dat de toekomst overeen zal komen met het verleden. Met andere woorden: als een bepaald verschijnsel in het verleden altijd is gevolgd door een bepaald ander verschijnsel, dan zal het laatste verschijnsel in de toekomst altijd volgen nadat het eerste verschijnsel is opgetreden. Zo luidt de major-premisse die men stilzwijgend onderstelt. ${ }^{4}$ Echter: hoe komen wij aan dien verzwegen major? $?^{5}$ Dil beginsel kon volgens Hume niel door redenering zijn ontstaan; het is geen abstracte kennis. Immers, de waarhcid van uitspraken over de rclatics

${ }^{1}$ cf. Spruyt, C.B. (1879), op. cit. p. 162-163, 'Het verdient opmerking dat hij reeds in het begin van dat werk (Enquiry) een onderscheid maakt tusschen rationeele of abstracte en empirische kennis. (.....) De redeneeringen, waardoor wij tot eene bepaalde overtuiging aangaande feiten geraken, berusten alle op onze kennis van den band tusschen oorzaken en gevolgen in de natuur. (....) Als wij suiker in den mond stoppen, verwachten wij een zoeten smaak (....) Waarom doen wij dit alles dan omdat wij onderstellen, dat er een verband bestaat tusschen het verschijnsel, dat wij thans waarnemen, en het andere verschijnsel, welks bestaan wij uit onze waameming afleiden?'

${ }^{2}$ cf. Spruyt, C.B. (1879), op. cit. p. 164.

${ }^{3}$ cf. Spruyt, C.B. (1879), op. cit. p. 164.

"cf. Spruyt, C.B. (1879), op. cit. p. 164-165, 'Alleen de ervaring kan ons geleerd hebben, welke verschijnselen geregeld op andere verschijnselen volgen. De zuivere redeneering, in de wiskunde onze eenige leidsvrouw, is buiten staat ons een enkel gevolg van een verschijnsel te doen vinden. (...) Met de gevolgen van elk ander natuurverschijnsel is het evenzoo; onze natuurwetenschap berust alleen op ervaring. (....) Maar waarop berusten al de besluiten, die wij uit onze ervaring afleiden? Zij berusten op de stilzwijgend aangenomen onderstelling, dat de toekomst tot op zekere hoogte gelijken zal op het verleden. (...) Elke redeneering uit de gegevens der ervaring kan teruggebracht worden tot het volgend schema: Ik heb meermalen waargenomen dat het verschijnsel a door b gevolgd wordt; dus verwacht ik ook, dat in 't gevolg a door b gevolg zal worden. De major, die er aan zou moeten toegevoegd worden, om haar tot een syllogisme te maken, waarvan de juistheid onbetwistbaar zijn zou, luidt: Is een verschijnsel a in 't verleden altijd door b gevolgd, dat wordt het ook in de toekomst altijd door b gevolgd.'

cf. Spruyt, C.B. (1879), op. cit. p. 165. 
tussen begrippen wordt uitsluitend bepaald door het non-contradictiebeginsel. Dus, als het wél abstracte kennis zou zijn, dan zou de uitspraak 'een bepaald verschijnsel wordt niet gevolgd door een bepaald ander verschijnsel' tegenstrijdig moeten zijn; hetgeen niet zo is. Zullen wij dan zeggen dat de ervaring ons met dien major heeft bekend gemaakt ? ${ }^{\mathrm{l}}$ De premisse of het beginsel dat de toekomst overeenkomt met het verleden kon volgens Hume ook niet op ervaring berusten. Immers, het kan wel zo zijn dat men tot dusver heeft waargenomen dat een bepaald verschijnsel altijd is gevolgd op een bepaald ander verschijnsel, en dus overeenkomt met het beginsel dat de toekomst overeenkomt met het verleden, maar het is de vraag of dit ook geldt voor nog niet waargenomen gevallen. Hoe komen wij dan aan de overtuiging, die ons in de verschijnselen een noodwendig verband doet aannemen tusschen het voorafgaande en het volgende, de oorzaken en de gevolgen $?^{2}$ Hume had daar op geantwoord, dat het ontstaan van de notie 'noodzakelijk verband' berust op de kracht der gewoonte. Dit laatste is weer gebaseerd op een associatief verband tussen ideeën (ideas). Met andere woorden: het herhaald waarnemen dat een bepaald verschijnsel volgt op een bepaald ander verschijnsel, leidt tot de gewoonte te verwachten dat beide verschijnselen elkaar altijd zullen volgen. ${ }^{3}$

Spruyt acht Hume's afleiding van de notie 'oorzaak en gevolg' of 'causaliteit' uit ervaring op grond van twee argumenten onaannemelijk en onvoldoende. ${ }^{4}$

Spruyts eerste argument tegen Hume's afleiding van de notie 'causaliteit' berust op de kritiek die hij elders in de Proeve op Hume's opvatting over de geest of het bewustzijn had geleverd. Voor Hume bestond het bewustzijn niet als een éénheid, zo betoogt Spruyt, maar louter als een verzameling van gewaarwordingen en denkbeelden die via associatiewetten met elkaar zijn verbonden. Deze opvatting sloot volgens Spruyt goed aan bij de nog in onze eeuw zo geliefde opvatting, "dat de mensch niets anders kent dan zijne eigene voorstellingen". ${ }^{5}$ Echter, hierdoor wordt de betekenis van de notie 'voorstelling' miskend. Immers, het kenmerkende van deze notie is dat een voorstelling altijd een betrekking op een voorwerp impliceert. ${ }^{6}$

${ }^{\prime}$ cf. Spruyt, C.B. (1879), op. cit. p. 165.

${ }^{2}$ cf. Spruyt, C.B. (1879), op. cit. p. 165.

cf. Spruyı, C.B. (1879), op. cit. p. 165, 'Hoe komen wij aan dien verzwegen major? Zeker niet door redeneering, want er ligt geen tegenstrijdigheid in de onderstelling, dat a ook wel cens niet door b zou gevolgd worden. (...) Zullen wij dan zeggen dat de ervaring ons met dien major heeft bekend gemaakt? Maar er werd gevraagd naar het beginsel, warop alle besluiten uit de ervaring rusten. (...) Hoe komen wij dan aan de overtuiging, die ons in de verschijnselen een noodwendig verband doet aannemen tusschen het voorafgaande en het volgende, de oorzaken en de gevolgen? (...) Het is volgens Hume, de kracht der gewoonle, m.a.w. een gevolg van de ideeènassociatie, die ons er toe brengt na het warnemen van de oorzaak ook het gevolg te verwachten.'

${ }^{4}$ ef. Spruyt, C.B. (1879), op. cit. p. 168.

5 ef. Spruyt, C.B. (1879), op. cit. p. 161.

" cf. Spruyt, C.B. (1879), op. cit. p. 160, 'Natuurlijk is het niet de geest zelf, die bij Hume bepaalt, wat waar en valsch zijn zal, want die geest, als éénheid, bestaat niet. Maar de indrukken brengen volgens cigen wetten onze overtuigingen voort, en de geest is eene "groep 
Omdat Hume het bewustzijn had opgevat als een reeks zielstoestanden of subjectieve bewustzijnstoestanden die geen verband houden met voorwerpen buiten zulke toestanden, kan men dus niet spreken over object-betrokkenheid van voorstellingen, zo betoogt Spruyt. Ook Hume's verklaring van de notie 'causaliteit' berust op deze opvatting over het bewustzijn. Spruyt grijpt Hume's opvatting daarom aan om te concluderen dat die verklaring aan een bestanddeel van onze kennis het karakter der objectiviteit ontneemt, zonder welke onze kennis geen kennis mag heeten. ${ }^{\mathrm{I}}$ Met andere woorden: Hume's verklaring leidt tot subjectivisme. Bijvoorbeeld de uitspraak: 'de stoot van een bal A tegen een andere bal B, leidt onder bepaalde omstandigheden noodzakelijk tot de beweging van bal B' heeft geen betrekking op subjectieve denkbeelden of meeningen, maar op toestanden in de objectieve wereld. Hume's causaliteitsleer bood echter geen verklaring voor veranderingen in de werkelijkheid buiten het bewustzijn; en dat was nu juist wat moest worden verklaard. Hume kon hier volgens Spruyt ook geen verklaring voor bieden, omdat hij het bewustzijn had opgevat als een verzameling van zielstoestanden die geen betrekking hebben met voorwerpen buiten het bewustzijn. Dit heeft er toe geleid dat Hume de voorstelling van een objectief bestaand oorzakelijk verband als een illusie moest opvatten. $^{2}$

Zijn tweede argument tegen Hume's verklaring introduceert Spruyt met de volgende vraag: (....) heeft hij ons dan ten minste eene aannemelijke verklaring gegeven van het ontstaan der illusie, die ons aan een oorzakelijk verband tusschen de dingen doet gelooven? Kan het feit, dat wij, volgens de wetten der zoogenaamde ideeënassociatie, na de waarneming van het eene verschijnsel een ander verwachten, den sleutel geven ter verklaring van ons begrip van een onverbreekbaren causalen band in de natuur, of liever van de illusie, dat wij zulk een begrip hebben? ? $^{3}$ Ook op dit punt schiet Hume's verklaring tekort, omdat de wetten van ideeënassociatie alleen

van gewaarwordingen en denkbeelden", wier inhoud in al hare deelen door den aard der indrukken bepaald wordt. (...) (Hume's Treatise) is uiterst leerzaam, omdat het duidelijk toont, welke ongerijmde conclusies voortspruiten uit de nog in onze eeuw zo geliefde stelling, "dat de mensch niet anders kent dan zijne eigene voorstellingen", wanneer men niet in het oog houdt, dat het eigenaardige kenmerk der voorstelling bestaat in hare betrekking op een voorwerp.'

${ }^{\prime}$ cí. Spruyt, C.B. (1879), op. cit. p. 168.

${ }^{2}$ cf. Spruyt, C.B. (1879), op. cit. p. 168-169, 'Zijn eigen verklaring is vooreerst onvoldoende om dezelfte reden, die zijn geheele stelsel onhoudbaar maakt. Zij ontncemt aan een bestanddeel van onze kennis het karakler van objectiviteit, zonder welke onze kennis geen kenınis mag heeten. (...) Wanneer wij zeggen dat de stoot van den eenen bal tegen den ander onder bepaalde omstandigheden noodwendig gevolgd wordt door de beweging van den anderen bal, dan spreken wij niet over onze denkbeelden of meeningen, maar over toestanden in de objectieve wereld. Hume verklaart niet wat verklaard moest worden. (....) .... hij (ziet) ons bewustzijn aan voor eene reeks van gewaarwordingen, d.i. van zielstoestanden, die van nature niet in betrekking staan met voorwerpen buiten hen. Hij houdt niet slechts onze voorstelling van een objectief bestaand oorzakelijk verband voor eene illusie, maar brengt elke andere vocrstelling, wier inhoud niet door gewaarwordingen gegeven is, tot dezelfde rubriek.'

${ }^{3}$ cf. Spruyt, C.B. (1879), op. cit. p. 169. 
dan tot de notie 'noodzakelijk causaal verband' kunnen leiden als natuurverschijnselen elkaar volstrekt regelmatig zouden volgen. Echter, zo betoogt Spruyt, men neemt de verschijnselen in de natuur niet als volstrekt regelmatig waar. De associatie van ideeën kan daarom alleen resulteren in verwachtingen die in intensiteit variëren; dit komt doordat bepaalde verschijnselen niet volstrekt regelmatig door bepaalde andere verschijnselen worden gevolgd. Als men er van uitgaat dat kennis uitsluitend door de wetten van ideeënassociatie ontstaat, dan zou dit alleen resulteren in verwachtingen die zijn gebaseerd op het waarnemen van meer of minder sterke successieve verbanden tussen verschijnselen. Spruyt acht het echter onmogelijk dat op grond van zulke sterk wisselende ervaringen het denkbeeld van het causaliteitsbeginsel of de wet van oorzaak en gevolg zou kunnen ontstaan. Immers, dit beginsel moet overal en altijd gelden. Ervaring toont daarentegen altijd nieuwe schijnbare uitzonderingen op deze regel. Als men meent dat het causaliteitsbeginsel via associatie van ideeën ontstaat, dat weer is gebaseerd op verschijnselen welke elkaar niet volstrekt regelmatig volgen, dan kan het causaliteitsbeginsel niet algemeen geldig zijn. Dit vormt voor Spruyt een onacceptabele conclusie, omdat het waarnemen van schijnbare uitzonderingen op het causaliteitsbeginsel er niet toe leidt dat men twijfelt aan de algemene geldigheid van dat beginsel. Spruyt concludeert hieruit dat het causaliteitsbeginsel daarom niet voortvloeit uit de welten van idecënassociatie, maar haren oorsprong (moet) ontleenen aan het logisch element in 's menschen geest.'

Met deze twee tegenargumenten veegt Spruyt Hume's afleiding van de notie 'causaliteit' uit de ervaring van tafel. Echter, Hume heeft dus werkelijk, zooals Kant zegt, bij dit onderzoek zelf "geen nieuw licht gegeven", maar toch "een vonk geslagen", die een nieuw licht moest doen ontstaan, zoodra zij op de rechte plaats viel. Gelukkig dat wijsgeerige gedachten een minder kortsiondig bestaan hebben dan vonken. Want Hume's vraagstukken moesten meer dan dertig jaar blijven liggen, voordat er iemand kwam, die hun eigenlijke beteekenis verstond. ${ }^{2}$ De filosoof die een nieuw licht op het causaliteitsvraagstuk wierp, was Kant.

ef. Spruyt, C.B. (1879), op. cit. p. 169, 'Nu er echter zeer vele verschijnselen zijn, die soms wel en dan weer niet door bepaalde andere verschijnselen gevolgd worden, kan de ideeënassociatie slechts bewerken, dat er onder verschillende omstandigheden bij ons verwachtingen ontstaan van zeer verschillende sterkte. Zoo de vorming van onze kennis alleen plaats had onder den invloed van de wetten der ideeênassociatie (..) dan zouden wij de successies in de natuur wel verdeelen in meer standvastige en minder standvastige, maar het denkbeeld, dat de wet van oorzaak en gevolg altijd en overal zonder uitzondering heerscht, zou nooit kunnen ontstaan. De ervaring toont ons altijd weder nieuwe schijnbare uitzonderingen op de wet van oorzak en gevolg - gevolgen, wier oorzaken wij volstrekt niet kunnen gissen; toestanden, wier gevolgen geheel anders uitvallen dan wij uit onze vroegere ervaringen meenden te mogen afleiden. Maar al die schijnbare uitzonderingen storen den mensch volstrekt niet in zijne overtuiging, dat elke verandering hare oorzaken moeten hebben. Zulke eene overtuiging, die niet wijkt voor den invloed van de krachtigste ideënassociatie, moet haren oorsprong ontleenen aan het logisch element in 's menschen geest, en niet aan de ideëenassociatie zelve.'

${ }^{2}$ cf. Spruyt, C.B. (1879), op. cit. p. 171. 
Nadat Spruyt een weergave van Kants kenleer heeft gegeven, neemt hij de gelegenheid te baat om bij monde van Kant nogmaals zijn opvatting te demonstreren dat men de notie 'causaliteit' niet uit de ervaring kan afleiden. Wij hebben reeds vroeger de afleiding van het causaliteitsbegrip uit de ervaring nagegaan, en gezien dat die afleiding niet alleen tot dus verre mislukt is, maar uit den aard der zaak altijd mislukken zal. ${ }^{1}$ Spruyt heeft hier vooral zijn weerlegging van Hume op het oog; evenzogoed zou men daarbij ook kunnen denken aan zijn eerdere kritieken op Opzoomer, Van der Wijck en Huet. Ook zij hadden immers getracht om de notie 'causaliteit' uit ervaring af te leiden. Spruyt had daar herhaaldelijk de opvatting tegenover gesteld dat men deze notie als een aangeboren waarnemingsvorm moest beschouwen.

In de Proeve heet het dat in het hoofdstuk Transcendentale Analytik van Kants Kritik der reinen Vernunft, in het bijzonder in het hoofdstuk Grundsätze des reinen Verstandes, een bewijs werd gegeven voor de stelling dat ervaringsoordelen alleen mogelijk zijn als men daarbij waarnemingsvormen, apriorische overtuigingen of denkvormen onderstelt. Eén van die denkvormen is de notie 'causaliteit'. Spruyt merkt op dat het hoofdstuk Transcendentale Analytik van alle hoofdstukken der Kritik verreweg het moeilijkste is en hij wil daarom het echte metaal van de slakken scheiden en beproeven Kant beter te verstaan dan hij zich zelf verstaan heeft. ${ }^{2}$ Van gebrek aan moed kan men Spruyt in elk geval niet betichten.

Kant had in de Kritik vier grondslagen (Grundsätze) van het zuivere verstand (reine Verstand) aangegeven: de axioma's van de aanschouwing (Axiomen der Anschauung), de anticipaties van de waarneming (Antizipationen der Wahrnehmung), de analogieën der ervaring (Analogien der Erfahrung) en de postulaten van het empirische denken (Postulate des empirischen Denkens). Vooral de analogieën der ervaring zijn van belang voor Kants causaliteitsopvatting. Het beginsel van zulke analogieën luidt dat ervaring pas mogelijk is door de voorstelling van een noodzakelijk verband tussen waarnemingen. ${ }^{3}$ Ervaring is kennis van objecten die door waarnemingen tol sland komt. Het ordenen van objecten in de tijd kan alleen plaatsvinden door een begrip a priori dat waarnemingen noodzakelijk met elkaar verbindt. ${ }^{4}$ Kant had vervolgens drie modi van tijd onderscheiden: de permanentie in de tijd (Beharrlichkeit), het volgen in de tijd (Folge) en het tegelijkertijd bestaan (Zugleichsein). Hieruit had hij afgeleid dat er drie tijdsverhoudingen tussen de verschijnselen ondersteld moeten worden die aan iedere ervaring vooraf gaan en

${ }^{1}$ cf. Spruyt, C.B. (1879), op. cit. p. 189.

${ }^{2}$ cf. Spruyt, C.B. (1879), op. cit. p. 181.

${ }^{3}$ ef. Kant, I. $\left(1787^{2}\right)$, op. cit., B-uitgave, p. 218, 'Das Prinzip derselben (Analogien der Erfahrung) ist: Erfahrung ist nur durch die Vorstellung einer notwendigen Verknüpfung der Wahrnehmungen möglich.'

${ }^{4}$ cf. Kant, I. $\left(1787^{2}\right.$ ), op. cit., B-uitgave, p. 219, 'Da aber Erfahrung ein Erkenntnis der Objekte durch Wahrnehmungen ist (.....) so kann die Bestimmung der Existenz der Objekte in der Zeit (...) nur durch a priori verknüpfende Begriffe geschehen.' 
ervaring mogelijk maken. ${ }^{\prime}$ De analogieën der ervaring zijn regels a priori die de tijdsverhoudingen tussen verschijnselen bepalen. ${ }^{2}$ De tweede analogie der ervaring betreft de grondslag van het volgen in de tijd volgens het causaliteitsbeginsel: alle veranderingen geschieden volgens de wet die oorzaak en gevolg met elkaar verbindt. ${ }^{3}$ In de Proeve sluit Spruyt nauw aan bij Kants tweede analogie van de ervaring, hetgeen blijkt uit het volgende.

Spruyt gaat er van uit dat men bepaalde causale overtuigingen heeft die a priori zijn. Zo is men er van overtuigd dat er tussen waargenomen objecten causale relaties bestaan. Bovendien acht men het een noodzakelijke waarheid dat een gelijke toestand in alle gevallen wordt gevolgd door een zelfde tweede toestand. Ook gaat men er van uit dat bij gelijke omstandigheden altijd gelijke gevolgen optreden. Al met al: tussen omstandigheden en gevolgen is er niet alleen sprake van het volgen van verschijnselen, maar van een noodzakelijk volgen van verschijnselen. ${ }^{4}$ In één woord, wij maken een onderscheid tusschen post en propter, aldus Spruyt. ${ }^{5}$

Echter, het noodzakelijk volgen van verschijnselen kan men niet afleiden uit gewaarwordingen, waardoor men objecten in de buitenwereld kent. Als men zich strikt zou houden aan een beschrijving van de subjectieve toestanden van het bewustzijn, dan kan men bijvoorbeeld alleen zeggen dat men een gewicht heeft zien vallen, nadat men heeft waargenomen dat de plank waar het gewicht op lag, brak; dit is alles, wat onze gewaarwordingen ons mededeelen, of strikt genomen, reeds veel meer dan zij ons mededeelen. ${ }^{6}$ Men beweert namelijk dat het breken van de plank de oorzaak is van het vallen van het gewicht. Met andere woorden: men is er van

' cf. Kant, I. (17872), op. cit., B-uitgave, p. 219, 'Die drei modi der Zeit sind Beharrlichkeit, Folge und Zugleichsein. Dạher werden drei Regeln aller Zeitverhältnisse der Erscheinungen (...) vor aller Erfahrung vorangehen, und diese allererst möglich machen.'

${ }^{2}$ cf. Kant, I. $\left(1787^{2}\right)$, op. cit., B-uitgave, p. 220 , '.... alle empirische Zeitbestimmungen (müssen stehen) unter Regeln der allgemeinen Zeitbestimmung, und die Anaiogien der Erfahrung müssen dergleichen Regeln sein.'

${ }^{3}$ cf. Kant, I. (17872), op. cit., B-uitgave, p. 232, 'Grundsatz der Zeitfolge nach dem Gesetze der Kausalität. Alle Veränderungen geschehen nach dem Gesetze der Verknüpfung der Ursache und Wirkung.'

${ }^{4}$ cf. Spruyt, C.B. (1879), op. cit. p. 188, 'Wij gelooven, bijv. aan het bestaan van een verband van oorzaak en gevolg tusschen de waargenomen objecten. Wij houden het voor eene noodzakelijke waarheid, dat een zelfde toestand altijd en overal door een zelfden tweeden toestand gevolgd wordt. Wij zijn er van overtuigd, dat volmakt gelijke omstandigheden altijd en overal volmaakt gelijke gevolgen moet hebben. Wij meenen derhalve dat er tusschen die omstandigheden en hare gevolgen niet slechts eene successie, maar eene noodwendige successie bestaat.'

${ }^{5}$ cf. Spruyt, C.B. (1879), op. cit. p. 188.

'cf. Spruyt, C.B. (1879), op. cit. p. 188-189, 'Nu vinden wij echter in de gewaarwordingen, die ons met de objecten der buitenwereld bekend maken, zulk een noodwendig volgen niet. Houden wij ons bij de beschrijving van den loop der subjectieve toestanden in onzen geest, dan kunnen wij alleen zeggen dat wij een gewicht hebben zien vallen, nadat wij de plank, waarop het gewicht stond hebben zien breken. Dit is alles, wat onze gewaarwordingen ons mededeelen, of, strikt genomen, reeds veel meer dan zij ons mededeelen.' 
overluigd dat onder gelijke omstandigheden het breken van de plank niet alleen in het verieden de oorzaak was, maar ook in de toekomst de oorzaak zal zijn van het vallen van het gewicht. Uit de subjectieve opvolging van gewaarwordingen wordt daarom geconcludeerd dat zo'n opvolging van toepassing is op een aaneenschakeling van toestanden in objecten. De causaliteitswet a priori transformeert de subjectieve opvolging van gewaarwordingen tot een causale relatie tussen objecten die buiten het bewustzijn bestaan. ${ }^{1}$ In Spruyts woorden: dien band van oorzaak en gevolg knoopt ons verstand uit eigen middelen tusschen de tot objecten vereenigde gewaarwordingen. En die handeling van het verstand is eene der wijzen, waarop het de subjectieve opvolging der gewaarwordingen in ons tot eene objectieve verbinding van dingen buiten ons maakt. ${ }^{2}$ Het causaliteitsbeginsel a priori zorgt er dus voor dat een subjectieve reeks gewaarwordingen op objecten worden betrokken.

Samengevat komt Spruyts argumentatie in hoofdlijnen op het volgende neer. Filosofie is gericht op het onderzoeken van de "rechtsgeldigheid" van ervaring; zo luidt Spruyts filosofische credo. Hierbij sluit hij expliciet aan bij Kants Kritik der reinen Vernunf, en vooral bij diens stelling dat in het denken de voorwaarden a priori voor de mogelijkheid van ervaring liggen besloten. Ten aanzien van het causaliteitsvraagstuk volgt Spruyt in de Proeve twee sporen. Eerst levert hij kritiek op Hume's causaliteitsleer. Vervolgens sluit Spruyt zich aan bij Kants tweede analogie der ervaring.

Spruyt formuleert allereerst twee argumenten tegen Hume's afleiding van de notie 'causaliteit' uit ervaring.

Het eerste argument van Spruyt luidt dat Hume's afleiding is gebaseerd op de gedachte dat het bewustzijn louter bestaat uit een verzameling van subjectieve bewustzijnstoestanden. Zulke toestanden houden geen verband met voorwerpen buiten het bewustzijn. Men kan daardoor niet meer spreken over de objectbetrokkenheid van voorstellingen. Hume kon zo doende de notie of voorstelling van 'causaliteit', opgevat als een objectief verband tussen verschijnselen, slechts als een illusie beschouwen. Echter, het ging er juist om, om te verklaren hoe men deze notie als een objectief verband tussen verschijnselen kon opvatten. Dit heeft Hume niet verklaard.

' cf. Spruyt, C.B. (1879), op. cit. p. 189, 'Doch wij zeggen iets geheel anders. Wij beweren dat het vallen van het gewicht veroorzakkt werd door het breken van de plank. Daarmede bedoelen wij, dat wij overtuigd zijn, dat het breken van eene dergelijke plank. wanneer de omstandigheden gelijk staan, in het verleden steeds gevolgd is, en in de toekomst steeds gevolgd zal worden door het vallen van het gewicht dat er op stond. Op grond van de subjectieve opvolging onzer gewaarwordingen besluiten wij tot eene aaneenschakeling van toestanden in de objecten, wier waarheid niet alleen door ons, maar evengoed door elken anderen waarnemer zal moeten erkend worden.'

${ }^{2}$ cf. Spruyt, C.B. (1879), op. cit. p. 189. 
Spruyts tweede tegenargument komt er op neer dat men de notie 'noodzakelijk causaal verband' niet uit de wetten van ideeënassociatie kan afleiden. Dit zou alleen maar kunnen als natuurverschijnselen elkaar volgens een uniform patroon zouden volgen, hetgeen niet het geval is. Het enige waarin zulke wetten kunnen uitmonden is kennis van associatieve verbanden die wat sterkte betreft van elkaar verschillen. Spruyt acht het onmogelijk om het causaliteitsbeginsel te baseren op zulke wisselende ervaringen, omdat dit beginsel algemeen geldig moet zijn. Hij concludeert dat de oorsprong van het causaliteitsbeginsel daarom niet gezocht moet worden in de associatie van ideeën; het causaliteitsbeginsel moet daarentegen worden opgevat als een logisch element van het denken.

Spruyts eigen causaliteitsopvatting sluit goeddeels aan bij Kants tweede analogie der ervaring. Men gaat uit van het bestaan van bepaalde causale overtuigingen, zoals het besef dat bij gelijke omstandigheden gelijke gevolgen optreden. Tussen zulke omstandigheden en gevolgen kan men echter geen noodzakelijk verband waarnemen. De causaliteitswet a priori transformeert de subjectieve opeenvolging van gewaarwordingen van verschijnselen tot een voorstelling van een objectieve relatie tussen verschijnselen. Het verstand zorgt er derhalve voor dat subjectieve gewaarwordingen op objecten worden betrokken.

De Proeve is opvallend anders van toon en anders gericht dan Spruyts artikelen uit 1871 en 1873. Waar Spruyt bijvoorbeeld in 1871 en 1873 nog direct ingaat op Opzoomer, Van der Wijck of Huet, laat hij hen in 1879 links liggen. In plaats daarvan richt hij zich rechtstreeks tot Hume of Kant. Met andere woorden: het historische referentiekader van de discussies wordt verbreed.

Ook valt het op dat Spruyt in 1879 eindelijk een directe, maar nogal summiere argumentatie geeft voor de stelling dat de notie 'causaliteit' en het causaliteitsbeginsel aangeboren zijn. Het belangrijkste argument hiervoor is overigens rechtstreeks ontleend aan Kants bewijsvoering bij de tweede analogie der ervaring. Echt nieuwe en originele argumenten, anders dan die Kant naar voren had gebracht, komen in de Proeve niet naar voren. Bovendien kan men opmerken dat Kants bewijsvoering bij de tweede analogie der ervaring veel subticler is dan Spruyts parafrase hiervan.

Spruyl presenteert de Proeve als een objectieve beschrijving van de geschiedenis van een filosofisch vraagstuk, maar dat is het niet. Hoewel het boek zeer informatief is, mag het niet worden gezien als pure geschiedschrijving. De weergave van veel opvattingen wordt namelijk sterk gekleurd door Spruyts voorkeur voor een kantiaans georiënteerde denkwijzc. Het meest duidelijk komt dit naar voren in Spruyts bespreking van en kritiek op Hume's causaliteitsleer.

Ten slotte: interessant is de karakterisering die Spruyt in het slotwoord van de Proeve geeft van de wijze waarop filosofie beoefend moet worden. Hiermee neemt hij expliciet afstand van het empirisme van Opzoomer en Van der Wijck en het positivisme van Huet. Spruyt keert de methodologische uitgangspunten deze denkers om. Ervaring speclt weliswaar een belangrijke rol bij het ontstaan van kennis, maar men mag niet voetstoots aannemen dat ervaring betrouwbaar is. Het doel van 
filosofisch onderzoek is, volgens Spruyt, na te gaan wat de geldigheid is van ervaringsuitspraken.

Niet alleen door zijn artikelen uit 1871 en 1873, maar ook door de Proeve komt het gedachtengoed van Kant in de causaliteitsdiscussies steeds duidelijker naar voren. Dit betreft voornamelijk Kants hoofdgedachte die er op neerkomt dat ervaring door begrippen a priori mogelijk wordt gemaakt. Om met Spruyt te spreken: de logische elementen in het denken.

In de volgende twee hoofdstukken wordt nagegaan welke posities Pierson en Heymans innamen ten aanzien van de rol van zulke logische elementen in het causale denken. 
Pierson wordt tegenwoordig vooral beschouwd als vooraanstaand 19de eeuws letterkundige en als een gerenommeerd cultuurhistoricus. Vreemd genoeg was en is hij als filosoof minder bekend. Toch komt hij in zijn filosofische geschriften als een zeer scherpzinnig en radicaal denker naar voren [Van Dooren, 1983].

Piersons intellectuele wortels liggen in het Utrecht van Opzoomer. Tijdens zijn studie theologie werd hij sterk beïnvloed door diens vorm van empirisme. In 1863 werd hij wellicht daarom als kandidaat naar voren geschoven om de Groningse hoogleraar F.C. de Greuve op te volgen. Echter, in plaats van Pierson werd Opzoomers protégé Van der Wijck benoemd. Omdat Pierson zich niet meer kon verenigen met de protestantse geloofsleer, brak hij in 1864 definitief met de kerk. Het jaar daarop week hij uit naar de universiteit van Heidelberg. In de periode 1865 tot 1874 volgde hij colleges bij Helmholtz en Bunsen en werd hij daar tevens Privat Dozent. Ten slotte aanvaardde hij in Heidelberg een benoeming tot buitengewoon hoogleraar in de godsdienstgeschiedenis [Van der Veen, 1997]. De stichting van de Universiteit van Amsterdam maakte het mogelijk om Pierson in 1877 het ambt van hoogleraar in de esthetica en kunstgeschiedenis aan te bieden. Tot zijn dood in 1896 bleef hij aan deze universiteit verbonden.

Pierson vatte zijn taak als hoogleraar in de kunstgeschiedenis ruim op. Hij doceerde niet alleen over de geschiedenis van de kunst en literatuur, maar hij onderzocht ook de filosofische grondslagen van de esthetica. Wijsgeerig onderzoek. Kritische prolegomena van esthetiek (1882) was daarvan het resultaat.

De directe aanleiding voor dat boek was de zojuist verschenen Proeve van zijn Amsterdamse collega Spruyt, een geacht vaderlandsch wijsgeer, die een pleidooi had gehouden voor Kants kritische filosofie. Spruyt had vooral de gedachte over het voetlicht willen brengen dat ervaring door logische elementen in het denken wordt bepaald. Piersons oordeel over deze kantiaanse denkwijze is niet mals. In scherpe bewoordingen beoordeelt hij Kants en daarmee ook Spruyts filosofie als een achteruitgang. Hij beschouwt Spruyt als dé Nederlandse vertegenwoordiger van hêt Kantiaanse rationalisme'; een struikelblok dat uit de weg moet worden geruimd. Kants denkwijze kwalificeert hij als een doodend intellektualisme dat het zicht belemmert op een bevredigende esthetiek. ${ }^{2}$ Sterker nog: het is een troostelooze denk-

' cf. Pierson, A. (1882), Wijsgeerig onderzoek, p. 63, 'Eén der meest bezadigde en meest overtuigde aanhanger van Kant in dit vaderland is zeker de auteur van de Proeve.'

${ }^{2}$ cf. Pierson, A. (1882), op. cit. p. 4-5. 
wijze, een verlammende wijsbegeerte, waarbij de esthetiek moet kwijnen en ondergaan.'

In Wijsgeerig onderzoek heet het dat men esthetica als een onderdeel van meer algemene filosofische theorieën moet opvatten. Dit betekent dat de beginselen die in zulke theorieën naar voren komen natuurlijk invloed hebben op esthetica. Daarom wil Pierson in dat boek enkele wijsgeerige begrippen nader (...) toetsen ${ }^{2}$ : 'rede', 'verklaring', 'waarheid' en ten slotte ook 'oorzaak'.

$\mathrm{Na}$ Piersons overlijden in 1898 herdenkt Van der Wijck hem in een uitgebreid artikel dat verscheen in de serie Mannen en vrouwen van beteekenis in onze dagen. Hierin constateert hij dat Wijsgeerig onderzoek één van Piersons lastigste en, misschien daarom, minst gelezen geschriften is. Dit is volgens Van der Wijck vooral te wijten aan Piersons stijl van redeneren. Pierson was een meester in de kunst om ingewikkelde redevoeringen zoo uit elkander te rafelen, dat er van het weefsel niets dan losse en onzamenhangende draden overbleven. (....) Toch is Piersons afbrekende kritiek leerzaam in hooge mate. (....) Met uitnemend gevolg wijst de voortreffelijke stilist op de voetangels en klemmen, waarmede het veld der wijsbegeerte bezaaid is. ${ }^{3}$ In dit hoofdstuk wordt nagegaan hoe Pierson zichzelf door het filosofische mijnenveld van het causaliteitsvraagstuk loodst.

Pierson rekent eerst af met Spruyts kantiaanse causaliteitsleer. Hij tracht Spruyts causaliteitsopvatting de genadeslag toe te brengen door te wijzen op inconsistenties in het bewijs bij Kants tweede analogie der ervaring. Hiermee dringt hij door tot de kern van de zaak. Immers, Spruyt had in de Proeve het filosofische lot van zijn eigen causaliteitsleer verbonden aan de geldigheid van Kants tweede analogie. De Kantkritiek van Pierson vormt daarom een belangrijk onderdeel van zijn argumentatiestrategie om de geachte vaderlandsch wijsgeer Spruyt te weerleggen.

Nadat Pierson een aantal fatale zwakheden in Kants tweede analogie der ervaring heeft aangetoond, waardoor hij tegelijkertijd de zwakte van Spruyts causaliteitsleer heeft blootgelegd, onderwerpt hij ook Hume's notie 'oorzaak' aan een kritisch onderzoek. Een belangrijk element in Piersons kritiek is dat zowel Hume, Kant als Spruyt impliciet of expliciet onderstellen dat de notie 'causaliteit' of 'oorzakelijk verband gelijk is aan een 'vaste volgorde'. Pierson verwerpt deze onderstelling, omdat het bij causaliteit helemaal niet gaat om het ordenen van verschijnselen in de tijd. Hij pleit er daarom voor het spreken in termen van oorzaken en gevolgen geheel af te schaffen en om verschijnselen alleen te verklaren door uitsluitend gebruik te maken van natuurwetenschappelijke termen. Pierson sluit zijn beschouwing over het wijsgeerige begrip 'oorzaak' ten slotte af met een analyse van een misvalting die ten grondslag ligt aan de betekenis die doorgaans aan de notie 'oorzaak' wordt

'cf. Pierson, A. (1882), op. cit. p. 7.

${ }^{2}$ cf. Pierson, A. (1882), op. cit. p. 2.

${ }^{3}$ ci. Wijck, B.H.C.K. van der (1898a), 'Allard Pierson'. In: Mannen en vrouwen van bereekenis in onze dagen, p. 271-272. 
toegeschreven en met een beschouwing over de "klassieke" misvatting dat de notie 'oorzakelijk verband' een tijdsorde zou impliceren.

\section{PIERSONS KRITIEK OP SPRUYT}

Spruyt had in de Proeve geconcludeerd dat het causaliteitsbeginsel a priori het subjectieve volgen van gewaarwordingen omvormt tot een causale relatie tussen waargenomen objecten die buiten het bewustzijn bestaan. De argumenten voor een gelijksoortige conclusie had Kant aangegeven in de bewijsvoering bij de Grundsätze des reinen Verstandes, en in het bijzonder in zijn bewijsvoering bij de tweede analogie der ervaring. Deze analogie luidt dat de grondslag van de tijdsorde (Zeitfolge) van voorstellingen volgens de causaliteitswet (Gesetz der Kausalität) verloopt: alle veranderingen geschieden volgens de wet die oorzaak en gevolg (Ursache und Wirkung) met elkaar verbindt .'

Het struikelblok dat Pierson eerst uit de weg wil ruimen is de opvatting dat het causaliteitsbeginsel a priori of een denkvorm zou zijn. Met dit doel voor ogen formuleert hij drie argumenten tegen Kants bewijsvoering bij de tweede analogie der ervaring. Piersons weerlegging van Spruyt loopt dus via een kritiek op Kant.

\section{Kritiek op Kants tweede analogie der ervaring}

Pierson wijst er allereerst op dat Kants bewijsvoering niet aansluit bij de analogie die hij had willen bewijzen. Immers, Kant was er van uitgegaan dat alle veranderingen optreden volgens de wet die oorzaak en gevolg met elkaar verbindt: de wet van oorzaak en gevolg. Echter, was Kants eigenlijke doel niet om aan te tonen dat alle veranderingen noodzakelijk volgens deze wet optreden, zodat zij het voorwerp van wetenschap kunnen zijn? Pierson leidt uit deze retorische vraag de conclusie af dat het Kant niet ging om het feit dat verschijnselen door het causaliteitsbeginsel met elkaar worden verbonden. Kant vond het daarentegen kennelijk veel belangrijker om aan te tonen dat de kategorie van oorzaak en gevolg voor de wetenschap onmisbaar is. ${ }^{2}$

Uit Kants bewijsvoering blijkt verder dat waarnemingen elkaar altijd volgens een regel a priori zouden moeten volgen. Zo'n regel moet er voor zorgen dat waarnemingen noodzakelijk met elkaar worden verbonden. Als men zou onderstellen dat er niet zo'n regel was, dan zou de volgorde van de waarnemingen in de tijd puur subjectief zijn. Met andere woorden: men houdt dan uitsluitend een spel der voorstel-

'cf. Kant, I. (1787²), op. cit., B-uitgave, p. 233-234.

${ }^{2}$ cf. Pierson, A. (1882), op. cit. p. 238 , 'Gesteld werd: alle veranderingen grijpen; bewezen werd (in het gunstigste geval): alle veranderingen moeten plaatsgrijpen naar de wet van oorzaak en gevolg, om voorwerp van wetenschap te kunnen zijn. (Het) blijkt dat het Kant niet om verbonden zijn naar de wet van oorzaak en gevolg te doen is, maar om de onmisbaarheid van de kategorie: oorzaak en gevolg.' 
lingen (Spiel der Vorstellungen) over, dat geen enkele relatie met een object kent.' Echter, zo vraagt Pierson zich af, wil Kant met zijn bewijsvoering eigenlijk wel aantonen dat de causaliteitswet voorstellingen met elkaar verbindt? Is het niet eerder zo dat hij daarmee wil bewijzen dat de causaliteitswet veranderingen zélf met elkaar verbindt? In Piersons woorden: is dit wel een bewijs dat er verbinding naar de kausaliteitswet is, en wel een verbinding niet van onze voorstellingen, maar van veranderingen zelve $?^{2}$ En, zo betoogt Pierson verder, als Kant al een bewijs had geleverd dat betrekking heeft op voorstellingen, dan kan men dit bewijs zeker niet waterdicht noemen. Immers, als Kants bewijs dat zou zijn, dan zou het in elk geval de mogelijkheid moeten uitsluiten dat men op tallooze wijzen probeert om een volgorde in de voorstellingen aan te brengen. Kant was van mening dat dit op slechts één manier kon gebeuren. Pierson wijst echter op het feit dat men op verschillende manieren voorstellingen met elkaar tracht te verbinden, en ook dat men zulke relaties tussen voorstellingen vervolgens vaak weer opzij zet omdat zij onbruikbaar blijken te zijn. Het is bovendien mogelijk dat men voor bepaalde voorstellingen een volgorde vindt die wél blijkt te werken, omdat deze kennelijk aan onze behoefte voldoet. ${ }^{3} \mathrm{Met}$ andere woorden: bij het ordenen van voorstellingen is men helemaal niet gebonden aan één bepaalde volgorde die door de causaliteitswet zou worden gedicteerd. $I k$ voor mij geraak telkens met Kant in een soort vertwijfeling. Hij wipt zoo snel over de eigenlijke moeilijkheid heen, dat ik er niet altijd gerust op ga, duidelijk te zullen zien waar en wanneer hij wat doet. ${ }^{4}$

Het aangrijpingspunt voor Piersons tweede tegenargument is Kants opvatting dat de verbeeldingskracht of het synthetisch vermogen een belangrijke rol speelt bij het bepalen van een vaste ordening van twee voorstellingen in de tijd. Men zou daarom verwachten dat de verbeeldingskracht ook een rol zou spelen bij het verbinden

${ }^{1}$ cf. Kant, I. $\left(1787^{2}\right.$ ), op. cit., B-uitgave, p. 239-240, 'Man setze, es gehe vor einer Begebenheit nichts vorher, worauf dieselbe nach einer Regel folgen müsste, so wäre alle Folgen der Wahrnehmung nur lediglich in der Apprehension, d.i. bloss subjektiv, aber dadurch gar nicht objektiv bestimmt, welches eigentlich das Vorhergehende, und welches das Nachfolgende der Wahrnehmungen sein müsste. Wir würden auf solche Weise nur ein Spiel der Vorstellungen haben, das sich auf gar kein Objekt bezöge, d.i. es würde durch unsere Wahrnehmungen eine Erscheinung von jeder anderen, dem Zeitverhältnisse nach, gar nicht unterschieden werden; weil die Suksession im Apprehendieren allerwärts einerlei, und also nichts in der Erscheinung ist, was sie bestimmt, so dass dadurch eine gewisse Folge als objektiv notwendig gemacht wird.'

${ }^{2}$ cf. Pierson, A. (1882), op. cit. p. 238-239.

${ }^{3}$ cf. Pierson, A. (1882), op. cit. p. 239, 'Hoe kan dit de mogelijkheid uitsluiten, dat wij eerst het brengen van een volgorde in onze voorstellingen op tallooze wijzen hebben beproefd; even dikwerf de aangenomen volgorde volkomen onbruikbaar hebben gevonden, om eindelijk ten aanzien van een zeker en vrij beperkt aantal voorstellingen (..) die volgorde te vinden, waarmede wij iets konden uitrichten, omdat zij aan onze behoefle voldeed? (....) Maar wanneer iemand de waarachtigheid van de kategorie van oorzaak en gevolg belooft te zullen bewijzen, moet hij het ons onmogelijk maken eene hypothese te vormen, gelijk aan die, waaraan hier met een woord herinnerd werd.'

${ }^{4}$ cf. Pierson, A. (1882), op. cit. p. 239. 
van de afzonderlijke delen waaruit één voorstelling is opgebouwd. Dat blijkt echter niet zo te zijn, omdat zo'n verbinding volgens Kant spontaan zou ontstaan. Met andere woorden: in beide gevallen speelt de verbeeldingskracht een rol; echter, bij het verbinden van twee voorstellingen bewerkt deze een vaste ordening in de tijd tussen zulke voorstellingen, terwijl zij in het geval van de afzonderlijke delen van een enkele voorstelling alleen leidt tot een spontane verbinding tussen zulke delen. Pierson concludeert hieruit dat Kant de objectieve ordening van voorstellingen baseert op voorstellingen die toevallig tot stand zijn gekomen. Pierson werkt dit tegenargument als volgt uit.

Kant had het waarnemen van een successie van verschijnselen geanalyseerd als een verbinding van waarnemingen in de tijd; zo'n verbinding is het resultaat van een synthetisch vermogen. Het verbinden van waarnemingen is hier, volgens Kant, niet uitsluitend het werk van de zintuigen en de aanschouwing. Pierson grijpt het woord 'hier' aan om te concluderen dat het verbinden van zintuiglijke gewaarwordingen tot één enkele waarneming kennelijk wel alleen voor rekening van de aanschouwing komt. Hij vraagt zich namelijk af hoe ik een verschijnsel (kan) waarnemen, zonder reeds dat verbinden van gewaarwordingen te hebben toegepast ?' De crux ligt dus in het woord 'hier'. Kant was van oordeel dat waarnemingen ontstaan door het verbinden van zintuiglijke gewaarwordingen; dat gebeurt vanzelf. In Piersons termen komt dit neer op het werk van zinnen en spontane voorstelling. Pas als het gaat om het ordenen van voorstellingen in de tijd, zou dat dit volgens Kant echter gebeuren door een bijzonder synthetisch vermogen. ${ }^{2}$ Echter, zo vraagt Pierson zich af, waarom is hier de verbinding iets anders dan wat zij elders is $?^{3}$ Met andere woorden: wat is het verschil tussen het verbinden van waarnemingen en het verbinden van de delen van één waarneming? Het gaat bij Kant kennelijk om twee soorten verbanden: het verband tussen waarnemingen en het verband tussen de delen van én waarneming. De enige verklaring die Pierson kan bedenken, is dat Kant al eerder had aangenomen dat voorwerpen die de zintuigen prikkelen voor een deel vanzelf leiden tot voorstellingen en voor een deel daardoor het denken activeren. ${ }^{4}$ Maar, zo merkt hij op, is

${ }^{1}$ cf. Pierson, A. (1882), op. cit. p. 240.

${ }^{2}$ cf. Pierson, A. (1882), op. cil. p. 240, 'Keeren wij nog eens terug tot dat zocgenaamde bewijs weder, en houden wij den wijsgeer staande juist bij het punt waar hij den sprong waagt: "Ich nehme wahr, dass Erscheinungen aufeinander folgen. Ich verknipfe also zwei Wahrnehmungen in der Zeit. Verknüpfung ist kein Werk des blossen Sinnes und der Anschauung, sonder hier (let wel!) das Product eines synthetischen Vermögen enz." Voor ons doel genoeg. Bij het woord: hier moeten wij stilstaan en Kant doen stilstaan. Het antwoord ligt in het woordje: hier. Dat ik waarneem, geschiedt door een verbinding, maar deze verbinding is bij Kant het werk van zinnen en spontane voorstelling. Wanneer ik evenwel iets in een bepaalde tijdsorde waarneen, onderstelt dit iets anders dan zinnen en spontane voorstelling, want hier is de verbinding het werk van een bijzonder synthetisch vermogen!'

${ }^{3}$ cf. Pierson, A. (1882), op. cit. p. 240-241.

'cf. Pierson, A. (1882), op. cit. p. 241, 'Gegenstände die unsere Sinne rühren, theils von selbst Vorstellungen bewirken, teils unsere Verstandesfähigkeit in Bewegung bringen.' 
dit niet zuivere willekeur, die zich dan ook natuurlijk wreekt?

Zoals gezegd had Kant zich genoodzaakt gezien om de causaliteitswet te onderstellen, omdat men zonder die wet alleen een spel der voorstellingen over zou houden; dat wil zeggen, willekeur. Bovendien zouden voorstellingen zonder die wet geen enkele relatie met objecten hebben. De causaliteitswet moet er immers voor zorgen dat voorstellingen een objectieve waarde krijgen; dat wil zeggen, zij worden betrokken op een object. ${ }^{2}$ Kortom: als men de causaliteitswet niet onderstelt, dan wordt de volgorde van voorstellingen puur subjectief.

Pierson legt op dit punt de vinger op de zere plek in Kants redenering, want, zoo vragen wij op onze beurl: wat heeft mij dan toch bestuurd bij het vaststellen van de volgorde der deelen, waaruit elk mijner voorstellingen werd opgebouwd? ${ }^{3}$ Met andere woorden: waarom leidt de werking van de verbeeldingskracht bij het ontstaan van een afzonderlijke voorstelling tot een spontane verbinding van de delen van zo'n voorstelling, terwijl de verbeeldingskracht bij het verbinden van twee voorstellingen leidt tot een vaste ordening in de tijd? Pierson tracht deze vraag als volgt te beantwoorden.

Stel dat er twee voorstellingen (zeg: A en B) zijn. A en B staan hier voor twee verschillende zeer samengestelde verschijnselen. Men neemt waar dat B volgt op A. Als men er van uitgaat dat de causaliteitswet de volgorde van voorstellingen reguleert, dan kan de volgende vergelijking worden opgesteld: A staat tot B als oorzaak staat tot gevolg. De causaliteitswet bepaalt dus de volgorde van A en B. ${ }^{4}$ Echter, hoe zit het met het ontstaan van de volgorde van de delen van een afzonderlijke voorstelling? Met andere woorden: hoe ben ik aan A gekomen? Stel dat $\mathbf{A}$ is opgebouwd uit een aantal delen: $a, b, c, \ldots ., n$, dan is $A$ de som van deze delen. Pierson is van mening dat ook déze delen worden samengevoegd in een bepaalde volgorde. Het veranderen van die volgorde zou immers leiden tot een ander verschijnsel. ${ }^{5} \mathrm{Ik}$ had dan wellicht de pooten van een paard op zijn rug geplaatst of de kelder van een huis boven op het dak. ${ }^{6}$

Voor Pierson dringt zich de vraag op: hoe weet ik nu, dat ik de ware volgorde heb gekozen, dat ik op de beste wijze de deelen, waaruit ten slotte mijn voorstelling

${ }^{\prime}$ ef. Pierson, A. (1882), op. cit. p. 241.

${ }^{2}$ cf. Pierson, A. (1882), op. cit. p. 241, 'Zonder de wet der kausaliteit ben ik ten spel aan mijne voorstellingen, volgens Kant, want de volgorde dier voorstellingen wordt dan zuiver subjektief; daarin heerscht louter willekeur.'

3 cf. Pierson, A. (1882), op. cit. p. 241.

${ }^{4}$ cf. Pierson, A. (1882), op. cit. p. 241, 'Ik noem eene voorstelling A; de tweede die er empirisch op volgt, B. Volgens de objektieve kausaliteitswet heb ik nu, wil ik aannemen, de vergelijking $\mathrm{A}: \mathrm{B}=$ oorzaak tot gevolg. Daardoor is zeker de volgorde van $\mathrm{A}$ en $\mathrm{B}$ bepaald.'

${ }^{3}$ cf. Pierson, A. (1882), op. cit. p. 241-242, 'Laat A hier vertegenwoordigen een zeer samengesteld verschijnsel. Dan mag ik $A$ noemen de som van $a, b, c, d, \ldots . n$, maar met dit gewichtig voorbehoud, dat die som alleen verkregen wordt door a, b, c, d, ....n in een bepaalde volgorde bij elkander te voegen.'

${ }^{6}$ cf. Pierson, A. (1882), op. cit. p. 242. 
is opgebouwd, heb gegroepeerd $?^{1}$ Of anders geformuleerd: op grond van welk criterium kan men bepalen dat de volgorde van de afzonderlijke delen van één voorstelling de juiste is? Tussen de afzonderlijke delen van én specifieke voorstelling bestaat geen causaal verband. Volgens Kant speelt de causaliteitswet bij het samenvoegen van de delen van één bepaalde voorstelling immers geen rol. Pierson leidt hier uit af, dat in Kants termen de volgorde van de delen van één voorstelling zuiver subjektief is. De specifieke voorstellingen als geheel zijn dan ook zelf subjectief. ${ }^{2}$ Kant was echter van mening dat de relatie tussen oorzaak en gevolg objektiefnoodza$k e l i j k$ is. Dat wil dus ook zeggen dat de relatie tussen de voorstellingen A en B objectief en noodzakelijk is. Als volgens Kant de volgorde van delen van $A$ en de volgorde van delen van B op een toevallige wijze tot stand komen, en derhalve subjectief zijn, dan moet men uit Kants redenering afleiden dat er objectief verband zou bestaan tussen twee toevalligheden; dat wil zeggen, tussen toevallig tot stand gekomen, subjectieve voorstellingen. ${ }^{3}$

Kortom: de verbeeldingskracht leidt volgens Kant tot twee vormen van synthese. De eerste vorm is een subjectieve, spontane synthese van delen van een voorstelling buiten de tijd. De tweede is een objectieve, niet-spontane synthese van voorstellingen in de tijd. Pierson merkt op dat Kants objectieve causale verband tussen voorstellingen daarom gebouwd is op het drijfzand van een toevallige ontstane volgorde van de delen van zulke voorstellingen.

Echter, zo vraagt Pierson zich vervolgens af, wat schiet men er mee op om zoveel nadruk te leggen op de rol van het objectieve causale verband? Wat is de toegevoegde waarde hiervan? In Piersons woorden: men neme dit aan, maar men zegge tevens wat hiermede gewonnen is, en waarom ik op dat objektieve verband zoo bijzonder gesteld behoor te zijn? ? Pierson geeft aan dat er voor Kant twee mogelijkheden zijn om deze vraag te beantwoorden. Hetzij: de niet-causale volgorde van de delen die A en de niet-causale volgorde van de delen die B samenstellen zijn noodzakelijk verbonden, net zoals de causale volgorde in de tijd van A en B. Dit zou betekenen dat er een andere wet dan de causaliteitswet zou moeten bestaan, die ervoor zorgt dat deze niet-causale volgorde óók objectief is. Of: de volgorde van de delen die A

'cf. Pierson, A. (1882), ep. cit. p. 242.

${ }^{2}$ cf. Pierson, A. (1882), op. cit. p. 242, 'De kausaliteitswet, neem ik verder aan, heeft mij bij het vormen van de voorstellingen $\mathrm{A}$ en $\mathrm{B}$ geen diensten kunnen bewijzen, want men beweert niet dat de deelen, waaruit de voorstellingen werden opgebouwd, zich onderling in een oorzakelijk verband zouden bevinden. Is nu de volgorde van $a, b, c, d, \ldots n$ en van e, $f, g$, h, ...n (naar Kant) zuiver subjektief, immers niet door de kausaliteitswet aangegeven, dan verkeeren, het hoeft geen betoog $A$ en $B$ in hetzelfde geval, hetgeen ik uit wil drukken door achter A en B een vraagteken te plaatsen.'

${ }^{3}$ cf. Pierson, A. (1882), op. cit. p. 242-243, 'De reden tusschen oorzaak en gevolg is evenwel (naar Kant) objektief noodzakelijk. Dus moet ook de reden tusschen A en B noodzakelijk zijn. Zijn A en B zelf nu echter toevallig (subjektief); ben ik bij het vormen van A en B ten spel geweest aan mijne gewaarwordingen, dan zal ik hier moeten aannemen, dat er een objektief verband is tusschen twee toevalligheden.'

${ }^{4}$ cf. Pierson, A. (1882), op. cit. p. 243. 
samenstellen en de volgorde van de delen die B samenstellen zijn subjectief. Dit zou echter betekenen dat de causale volgorde in de tijd van A en B, die volgens Kant door de causaliteitswet a priori objectief en noodzakelijk is, theoretisch gezien niet veel oplevert. ${ }^{1}$ Much ado about nothing. De relatie tussen twee voorstellingen komt tot stand via een niet-spontane, objectieve vorm van synthese. Maar hoe wordt die verbinding bewerkt die een voorstelling heet $?^{2}$ Deze ontstaat spontaan, volgens Kant. Als men er van uitgaat dat de volgorde van de delen van een voorstelling spontaan (von selbst) ontstaat, en als die delen tot dingen zijn verenigd en in een bepaalde tijdsorde worden gezet, acht Pierson het overdreven om zoveel moeite te doen om voor die tijdsorde nog eens aan te tonen dat er een causaliteitswet a priori bestaat, een transcendentale noodzakelijkheid, die regelt dat de volgorde in de tijd tussen voorstellingen objectief is. ${ }^{3}$ Kant had daarom volgens Pierson consequent moeten zijn, want heb ik tegen het eerste "von selbst" geen bezwaar, dan kan ik het ook wel in het tweede geval herhalen. ${ }^{4}$

Piersons derde en laatste tegenargument betreft Kants opvatting dat voorstellingen volkomen betrouwbaar zouden zijn. Pierson leidt hier uit af dat voorstellingen, nog vóór zij door de causaliteitswet worden verbonden, al op objecten zijn betrokken. Als dat zo is, dan kan men zich wederom afvragen wat de toegevoegde waarde van de causaliteitswet is. Deze wet moet er immers voor zorgen dat de volgorde in de tijd van voorstellingen een objectieve waarde krijgen. Echter, voorstellingen zijn in Kants ogen kennelijk al object-betrokken. Pierson werkt dit laatste tegenargument als volgt uit.

Men zou van de hypothese uit kunnen gaan dat voorstellingen en de volgorde in de tijd van voorstellingen via ervaring ontstaan. Kant had echter verdedigd dat juist de volgorde in de tijd van de relatie tussen voorstellingen niet op grond van ervaring ontstaat. Immers, hierdoor zouden causale relaties niet noodzakelijk, maar evenzoo toevallig zijn als de ervaring zelve. $\mathrm{Zij}$ zouden dan zijn gebaseerd op

' cf. Pierson, A. (1882), op. cit. p. 243, 'Dus een van beide zou ik meenen; of de (niet kausale) volgorde van de deelen, waaruit de voorstellingen A en B ontstaan, is even noodwendig als de volgorde $A$ en $B$, maar dan schijn ik, naast de wet der kausaliteit, nog een tweede wet te bezitten, die deze (niet kausale) volgorde niettemin volkomen objektief doet zijn, of deze volgorde is, omdat zij niet kausaal is, inderdaad zuiver subjektief, maar dan ook de volgorde van $A$ en $B$, ofschoon op zichzelf niet subjektief, niet willekeurig en hare bruikbaarheid ontleenende aan het bestaan van een wet of regel (a priori), mij (theoretisch) niet veel baten.'

${ }^{2}$ cf. Pierson, A. (1882), op. cit. p. 243.

${ }^{3}$ cf. Pierson, A. (1882), op. cit. p. 244, 'Maar ik kan niet inzien, waarom men, na zoo rustig 'von selbst' neergeschreven te hebben ten aanzien van de volgorde der deelen, die, tot dingen vereenigd, in een zekere tijdsorde zullen worden gebracht, nog hemel en aarde beweegt om voor deze tijdsorde zelve een transcendentale noodzakelijkheid te vinden als wet die haar regelt. Hen ik tegen het eerste "von selbst" geen bezwaar, dan kan ik het ook wel in het tweede geval herhalen.'

${ }^{4}$ cf. Pierson, A. (1882), op. cit. p. 244. 
inductie. ${ }^{1}$ Pierson wijst er op dat het er bij Kant om ging voorstellingen door de causaliteitswet zo te verbinden, dat zij een hoogere waardigheid zouden krijgen; dat wil zeggen, objectiviteit, in de zin dat voorstellingen betrokken zijn op voorwerpen van ervaring. De volgorde in de tijd van de relatie tussen voorstellingen zou hierdoor worden onttrokken aan subjectieve toevalligheid. Pierson merkt op dat Kant er daardoor echter impliciet van uit was gegaan dat voorstellingen volkomen betrouwbaar, en daarom al op voorwerpen van de ervaring betrokken, zouden zijn. Dit is echter in tegenspraak met Kants opvatting dat voorstellingen alleen door de causaliteitswet een objectieve waarde krijgen. Kant had zich volgens Pierson moeten realiseren dat alle voorstellingen uiteindelijk subjectief zijn, zoals al in het tweede tegenargument naar voren kwam. Voorstellingen ontstaan willekeurig en doen zich zonder regel aan ons voor. In Piersons termen: voorstellingen zijn zuiver persoonlijk. Als Kant consistent aan deze gedachte had vastgehouden, dan was hij niet van oordeel geweest dat zulke puur subjectieve voorstellingen noodzakelijkerwijs getransformeerd zouden moeten worden tot een objectieve verbinding van voorstellingen. ${ }^{2}$ In één woord: Kants kausaliteitsbegrip kan slechts de waarde verhogen van voorstellingen die op zichzelf reeds waarde hebben. ${ }^{3}$ Echter, als die voorstellingen al een objectieve waarde hebben, dan had Kant duidelijk moeten maken wat die waarde is. Immers, Kant was van mening dat voorstellingen vanzelf ontstaan, en dat zij daarom niet volgens een bepaalde regel ontstaan die aan afzonderlijke voorstellingen objectiviteit verleent. ${ }^{4}$ Pierson constateert echter dat Kant dit niet had onderbouwd.

Pierson is ten slotte van mening dat Kant cerst de vraag had moeten beantwoorden naar welken regel hij in het algemeen de verschijnselen (...) in eene betrekking van tijdsorde tot elkander brengt. Met andere woorden: wat is de algemene regel die de ordening van verschijnselen in de tijd bepaalt? Pas als men hierop een antwoord heeft

' cf. Pierson, A. (1882), op. cit. p. 244, 'Kant wil het empirisch karakter van onze voorstelling omtrent de tijdsorde der voorstellingen juist ontgaan, omdat anders de kausaliteit even zoo toevallig zou zijn als de ervaring zelve, immers alleen rusten zou op induktie.'

${ }^{2}$ cf. Pièrson, A. (1882), op. cit. p. 244-245, 'De kausaliteit, in Kantiaanșchen zin opgevat, moet aan de voorstellingen, die anders niets dan voorstellingen zouden blijven, een hoogere "waardigheid" verleenen, gelijk hij zich uildrukt; namelijk: objectiviteit. Het is evenwel duidelijk dat Kant hierbij stilzwijgend is uilgegaan van de overtuiging, dat de voorstellingen wel nog ruwe stof zijn, maar toch reeds objektieve waarde hebben, immers volkomen betrouwbaar zijn. Had hij er zich levendig van doordrongen, dat alle voorstellingen, juist omdat zij geheel vanzelf ontstaan en dus in haar ontstaan niet te kontroleeren zijn, ook naar zijne beginselen geheel subjektief zijn, dan zou hij er allicht niet toe gekomen zijn te meenen, dat de noodzakelijke verbinding van het zuiver persoonlijke dat persoonlijke geheel van karakter doet veranderen.'

${ }^{3}$ cf. Pierson, A. (1882), op. cit. p. 245-246.

4 cf. Pierson, A. (1882), op. cit. p. 246, 'Maar hebben zij reeds waarde, dan moge Kant ons uitleggen, waarin die bestaat, en vooral hoe zij daaraan gekomen zijn in weerwil hiervan, dat zij niet ontstaan zijn door een verbinding die aan een regel was gebonden.' 
gegeven, kan men zich afvragen of zo'n regel a priori is of niet. ${ }^{1}$ Aan de hand van het volgende voorbeeld toont Pierson ten slotte aan dat het overigens geheel onnodig is te onderstellen dat de causaliteitswet a priori is.

Als men bliksem waarneemt en daarnaast het smelten van suiker in de mond, dan rijst de vraag: in welke tijdsorde moet ik deze waarneming brengen $?^{2}$ Als men aanneemt dat dit de tijdsorde van oorzaak en gevolg is, dan ontstaat vervolgens de vraag wat hier oorzaak, wat gevolg is? Men weet echter niet of het ene, de bliksem, of het andere, het smelten van suiker, de oorzaak of het gevolg is. Herhaalde waarneming leert dat suiker in de mond smelt ook al is er geen sprake van bliksem. Men neemt tussen beide verschijnselen derhalve geen causaal verband aan. Herhaalde waarneming leert dat suiker smelt door het in de mond te stoppen. Kennis van de kategorie van oorzaak en gevolg is hiervoor in het geheel niet nodig. ${ }^{3}$ Dát suiker noodzakelijk smelt als het in de mond wordt gestopt, kan men niet uit de ervaring afleiden. Echter, als men zou denken dat men voor zulke kennis een apriorischen denkvorm van causaliteit nodig heeft, dan blijkt dat alleen filosofen zo'n denkvorm nodig achten om zo aan causale relaties noodzakelijke waarheid toe te kunnen schrijven. Immers, de man van de praktijk en van het wetenschappelijk onderzoek blijkt aan zo'n denkvorm geen behoefte te hebben. Zij achten het ruimschoots voldoende om op grond van gewoonte er van uit te gaan dat de dingen causaal met elkaar zijn verbonden. Pierson voegt daar aan toe dat wetenschappelijk onderzoekers zelfs niet van de zekerheid van het causaliteitsbeginsel uit mogen gaan. Zij zijn evenwel verplicht om naar oorzaken van verschijnselen te zoeken. Echter, deze stemming waarmee zij ieder onderzoek beginnen mag geen dogmatisme worden, omdat het denkbaar is dat er verschijnselen zijn die niet zijn veroorzaakt. ${ }^{4}$

' cf. Pierson, A. (1882), op. cit. p. 254, 'Kant, die een apriorischen regel noodig heeft om te bepalen in welke tijdsorde de toestanden van een en hetzelfde voorwerp op elkander volgen, had, naar het mij voorkomt, moeten beginnen met ons te zeggen, naar welken regel hij, in het algemeen, de verschijnselen (...) in eene betrekking van tijdsorde tot elkander brengt.'

${ }^{2}$ cf. Pierson, A. (1882), op. cit. p. 7.

${ }^{3}$ cf. Pierson, A. (1882), op. cit. p. 255, 'Ik neem waar 1. weerlicht en 2. het smelten van suiker. In welke tijdsorde moet ik deze waarneming brengen? In die van oorzaak en gevolg. Ik zal dus hebben na te gaan wat hier oorzaak, wat gevolg is? Ik weet zelfs niet of het eene oorzaak, het andere gevolg kan zijn! Maak ik nu langzaamerhand de opmerking, dat er dikwerf weerlicht is zonder dat verschijnsel van smelting, of ook omgekeerd, dan zal ik dus tusschen die beide geen verband aannemen, met andere woorden: ik zal zoo dikwerf behoefte mij dringt suiker te doen smelten, niet wachten op het verschijnsel weerlicht. Daarentegen zal de ervaring mij al zeer spoedig leeren, zodra ik een stuk suiker wil doen smelten, het in den mond te steken, ook zonder dat ik van te voren of zelfs in het geheel die kategorie van oorzaak en gevolg ken.'

" cf. Pierson, A. (1882), op. cit. p. 255, 'Dat suiker in mijn en in elks mond altijd moet of zal smelten, leert mij de ervaring niet. Maar indien $i k$, om dat te weten, die apriorischen denkvorm noodig heb, dan blijkt tevens, dat alleen den wijsgeer dien denkvorm zou behoeven, om de kausaliteit als noodzakelijke waarheid vast te stellen, terwijl de man van de praktijk en van het wetenschappelijk onderzoek aan de gewoonte van de dingen in een oor- 
Pierson concludeert dat Kant niet heeft bewezen dat alle veranderingen een oorzaak moeten hebben. Zolang men nog niet de betekenis van het begrip van oorzaak heeft vastgesteld, moet men de causaliteitswet vooralsnog als een onmisbare hulphypothese beschouwen. Pas als men de betekenis van de notie 'oorzaak' heeft bepaald, kan men vervolgens de aard van die hypothese bepalen.

Samengevat: Kant had ondersteld dat verschijnselen volgens een vaste regel a priori in de tijd worden geordend. De betekenis van de notie 'causaliteit' had hij daarmee gelijk gesteld aan 'vaste volgorde' in de tijd. Dit acht Pierson onjuist. Bovendien was Kant van mening dat het causaliteitsbeginsel a priori zou zijn. Pierson concludeert echter dat het niet nodig is om zo'n apriorischen denkvorm te onderstellen. Uit de praktijk van het onderzoek blijkt dat men daar kennelijk geen bchocfte heeft aan zo'n filosofische rechtvaardiging, hoewel wetenschappclijke onderzoekers wel naar oorzaken van verschijnselen moeten zoeken.

Het is gebleken dat Piersons kritick Kants bewijs van de tweede analogie der crvaring ondergraaft. Het filosofische lot van Spruyts kantiaansc causaliteitsopvatting is daarmee, althans volgens Pierson, ook bezegeld.

\section{DE CAUSALI'TEITSLEER VAN PIERSON}

Nadat Pierson het kantiaanse struikelblok uit de weg heeft geruimd dat het causaliteitsheginsel een denkvorm zou zijn, gaat hij vervolgens dieper in op de vraag wat de notie 'oorzaak' betekent. Fundamenteler nog dan deze betekenisvraag is echter de vraag of de gelijkstelling van oorzakelijk verband en vaste volgorde gewettigd is $?^{2}$

\section{'Oorzaak', 'oorzakelijk verband' en 'vaste volgorde'}

Wij willen (......) nagaan of wij bij Hume een bruikbare bepaling vinden van hetgeen onder het woord: oorzaak is te verstaan. ${ }^{3}$ Hume had in de Enquiry (1748) de notie 'oorzaak' als volgt omschreven: onder oorzaak verstaan wij die betrekking tusschen

zakelijk verband met elkander te zien, volkomen genoeg heefi, ja, de laatstgenoemde, als stemming waarmede hij het onderzock aanvangt, meer dan deze gewoonte, bepaaldelijk de zekerheid dat alles een oorzaak moet hebben, niet kan gebruiken, aangezien hij wel verplicht is bij alles naar een oorzaak te zoeken, mar niet van te voren zich aelf beletten mag, het bestaan van iets aan te nemen (...) dat geen oorzaak heeft.'

' cf. Pierson, A. (1882), op. cit. p. 256, 'Zuiver theoretisch gesproken kunnen wij dus de stelling: alles moet een oorzaak hebben, nog niet bewezen noemen en wel in naam van Kants eigene kritiek. (.....) Die wet (der kausaliteit) is voorloopig niets anders dan een onmisbare hulphypothese, en het komt er thans op aan, den aard van die hypothese toe te lichten en dus lect begrip van oorzaak nader te onderzocken.'

2 cf. Pierson, A. (1882), op. cit. p. 260.

${ }^{3}$ cf. Pierson, A. (1882), op. cit. p. 256. 
twee feiten, tengevolge van welker bestaan de aanwezigheid van het eene feit ons de aanwezigheid van het iweede feit doet kennen in heden, verleden of toekomst. Pierson grijpt deze omschrijving aan om er op de wijzen dat de uitspraak 'a heeft in het verleden b tot gevolg gehad' en de uitspraak 'a zal in toekomst b tot gevolg hebben' niet identiek zijn en ook niet logisch uit elkaar volgen. Zolang het begrip van b niet in het begrip van a ligt besloten, kan men door bloot redeneren, a priori, niet weten of b het gevolg is van a. Men kan dat ook niet te weten komen door zintuiglijke waarneming, omdat men de kracht waardoor a tot b leidt niet kan waarnemen. Op grond van het feit dat tot dusver uit ervaring is gebleken dat er tussen a en b een vaste betrekking bestaat, kan men theoretisch gezien nooit absoluut zeker zijn of er in de toekomst tussen a en b ook zo'n betrekking zal bestaan. ${ }^{2}$ Omdat men herhaaldelijk heeft waargenomen dat twee verschijnselen in betrekking tot elkaar staan, neemt men aan dat er een vaste betrekking tussen beide verschijnselen bestaat. Dit kan men alleen verklaren door gewoonte. ${ }^{3}$

Op grond van bovenstaande bedenking stelt Pierson een verbetering voor van Hume's omschrijving van de notie 'oorzaak': ....eene in een zeker aantal gevallen gekonstateerde betrekking tusschen twee feiten, welke betrekking de gewoonte ons als onveranderlijk doet aannemen; eene onveranderlijkheid, op grond waarvan wij in heden, verleden of toekomst aan de kennis van het bestaan van het eene feit genoeg hebben, om terstond ook die van het bestaan van het tweede feit te bezitten. ${ }^{4} \mathrm{Met}$ anclere woorden: de betekenis van de notie 'oorzaak' komt volgens Pierson neer op een relatie tussen twee feiten. Door herhaalde waarneming ontstaat de gewoonte om deze relatie als onveranderlijk te beschouwen. Op grond van deze onveranderlijkheid weet men dat het tweede feit bestaat als men het eerste feit heeft waargenomen.

Uit Hume's omschrijving van de notie 'oorzaak' blijkt ook dat hij er, net als Kant, van uit was gegaan dat de notie 'oorzakelijk verband' gelijk is aan die van 'vaste volgorde'. De onderstelling dat er bij 'causaliteit' of 'oorzakelijk verband' altijd sprake moet zijn van het volgen van verschijnselen, een post, is onder filosofen een

${ }^{1}$ cf. Pierson, A. (1882), op. cit. p. 258.

${ }^{2}$ cf. Pierson, A. (1882), op. cit. p. 258-259, '... want de stelling: a heeft b voortgebracht, en de stelling: a zal b voortbrengen, zijn niet alleen niet identisch, maar ook niet als premisse en besluit met elkander verbonden. Van de eerste stelling kan geen redeenering ons voeren tot de tweede. A priori kunnen wij niet weten, dat b het gevolg is van a, zoodra in het begrip a het begrip b voor ons niet ligt opgesloten. Door bloot waarnemen komen wij er evenmin achter, want de kracht waardoor a voorbrengt $b$, valt nooit onder het bereik van de zinnelijke waarneming. (...) Theoretisch volkomen zekerheid te hebben omtrent het blijvende van de betrekking tusschen a en b, en wel op grond van de omstandigheid, dat ervaring ons die betrekking tot dusver als onloochenbaar heeft doen kennen, - is den mensch niet gegeven. Want al onze ervaring is niet in staat ons eenig denkbeeld of eenige kennis te verschaffen van de verborgen macht, waardoor a voortbrengt $b$.'

${ }^{3} \mathrm{cf}$. Pierson, A. (1882), op. cit. p. 259, 'Zoo zal er ter verklaring van het feit, dat wij een vaste betrekking aannemen tusschen twee verschijnselen die dikwerf gebleken zijn in betrekking tot elkander te staan, niet overblijven dan de gewoonte.'

${ }^{4}$ cf. Pierson, A. (1882), op. cit. p. 259-260. 
wijdverbreide mening. ${ }^{1}$ Het is echter de vraag of de gelijkstelling van oorzakelijk verband en vaste volgorde gewettigd is? $?^{2}$ Pierson wijst er op dat ook Spruyt in de Proeve van deze gelijkstelling was uitgegaan.

Spruyt had in dat boek betoogd dat men bepaalde causale overtuigingen heeft. Men is er bijvoorbeeld van overluigd dat er tussen waargenomen objecten causale relaties bestaan; en ook is men er van overtuigd dat bij gelijke omstandigheden gelijke gevolgen noodzakelijk optreden. Het noodzakelijk volgen van verschijnselen kan men niet afleiden uit de gewaarwordingen waardoor men de objecten in de buitenwereld kent. Dit had hij geillustreerd aan de hand van het voorbeeld over het breken van een plank en het vallen van een gewicht. Als men zich strikt zou houden an een beschrijving van de subjectieve toestanden van het bewustzijn, dan zou men alleen kunnen zeggen dat men heeft waargenomen dat men een gewicht heeft zien vallen, nadat men heeft gezien dat de plank waar het gewicht op stond, brak. In plaats daarvan zegt men echter dat het breken van de plank de oorzaak is van het vallen van het gewicht. Bovendien is men er van overtuigd dat het breken van de plank onder gelijke omstandigheden ook in de toekomst de oorzaak zal zijn van het vallen van het gewicht.

Pierson grijpt Spruyts voorbeeld aan om allereerst op te merken dat men moet oppassen om niet te vervallen in een al te populair spraakgebruik. Hiermee bedoelt Pierson dat Spruyt het vallen van het gewicht uitsluitend had moeten verklaren in termen van aantrekkingskracht. ${ }^{3} \mathrm{Als}$ men Spruyts voorbeeld in natuurwetenschappelijke termen verklaart, dan kan men zich vervolgens afvragen wat mu de feiten of verschijnselen (zijn), die wijop elkander zien volgen en tevens in oorzakelijk verband kunnen brengen? ? $^{4}$ Met andere woorden: welke verschijnselen ziet men op elkaar volgen? En, kan men die verschijnselen als een relatie tussen oorzaak en gevolg opvatten? Pierson antwoordt dat hij zulke verschijnselen niet ziet. Als men er al van uit zou gaan dat er tussen waargenomen objecten causale verbanden bestaan, dan kan men dat in elk geval nict zeggen over het breken van de plank en het vallen van het gewicht. Men kan alleen een verband of betrekking onderstellen tussen de aardse aantrekkingskracht en iets anders, in dit geval het gewicht, waar die kracht invloed op uiloefent. Bovendien kan men de aantrekkingskracht van de aarde niet als een

' cf. Pierson, A. (1882), op. cit. p. 260, 'Uit het medegedeelde blijkt, dat de bepaling van oorzakelijk verband, gelijk wij haar bij Hume vinden, in een opzicht niet verschilt van die welke bij Kant hebben aangetroffen. Dat verband is voor beiden vaste volgorde. Kant wijkı alleen van Hume af ten aanzien van den oorsprong en den redelijken grondslag van dat begrip. (....) Sommigen konstateeren bij corzakelijk verband en een post en een propter; anderen alleen een post; omtrent het post zelf stemmen dus allen overeen.'

${ }^{2}$ cf. Pierson, A. (1882), op. cit. p. 260.

${ }^{3}$ ef. Pierson, A. (1882), op. cit. p. 262, 'Een massa wordt aangetrokken door de aard (de massa is hier het gewicht en de plank). Een deel van die massa (de plank) wordt op alle punten gelijkelijk aangetrokken en is dus in evenwicht. Die aantrekking neemt op sommige punten toe (de plank ligt niet meer horizontaal, buigt door, het gewicht daalt). De aantrekking neemt andermaal toe (de plank, als plank verdwijnt; het gewicht daalt sterker of valt).'

${ }^{4}$ ef. Pierson, A. (1882), op. cit. p. 262. 
waarneembaar verschijnsel opvatten, maar alleen als een kracht waarvan men aanneemt dat deze bestaat; dat wil zeggen, een hypothetisch bestaande kracht.' Pierson concludeert hieruit dat de notie 'oorzaak' geen waargenomen object kan betreffen, zoals Spruyt had betoogd. De betekenis van deze notie komt volgens Pierson louter neer op een noodzakelijke betrekking tusschen een hypothetisch bestaande kracht en een waargenomen verschijnsel. ${ }^{2}$

Ook is er geen sprake van een tijdsorde tussen het breken van de plank en het vallen van het gewicht. Men kan niet zeggen dat het breken van de plank aan het vallen van het gewicht vooraf gaat. Immers, als men van mening is dat op het breken van de plank het vallen van het gewicht volgt, dan beschouwt men het breken van de plank als de oorzaak van het vallen. Naar analogie hiervan zou men dan ook van oordeel moeten zijn dat het vullen van een pen de oorzaak is dat die pen schrijft. Deze conclusie acht Pierson onacceptabel, want wat is in het gekozen voorbeeld het voorafgaande, dat tevens oorzaak is? ${ }^{3}$ Het breken van de plank is niet de oorzaak van het vallen van het gewicht, maar de aantrekkingskracht van de aarde is dat wel. ${ }^{4}$ Men moet er van uitgaan, zo betoogt Pierson verder, dat deze kracht altijd werkt. Het makt niet uit of men de massa (het gewicht en de plank) in een evenwichtstoestand waarneemt of dat die toestand overgaat in een valbeweging. Dat wil echter niet zeggen dat de aantrekkingskracht verandert, want deze werkt constant. Het enige wat verandert is de subjectieve waardering of appreciatie van de beweging. Het veranderen van de subjectieve waardering noemt men 'vallen'. Men kan dan weliswaar spreken over een situatie vóór en ná, maar deze tijdsaanduiding betreft geen waargenomen objecten. Deze tijdsaanduiding betreft alleen een verandering van de subjectieve waardering van beweging. ${ }^{5}$

' cf. Pierson, A. (1882), op. cit. p. 262, 'Wat zijn nu de feiten of verschijnselen, die wij opelkander zien volgen en tevens in oorzakelijk verband kunnen brengen? lk zie er geen. "Gelooft" dus de auteur van de Proeve aan het bestaan van oorzaak en gevolg tusschen waargenomen objekten, dan kan hier van zulk een verband geen sprake zijn. De eenige betrekking toch die wij hier aannemen is die tusschen de aantrekkingskracht der aarde, die wij niet waarnemen, en iets anders. De aantrekkingskracht is niet een verschijnsel; slechts een hypothetisch bestaande kracht.'

${ }^{2}$ cf. Pierson, A. (1882), op. cit. p. 263.

${ }^{3}$ cf. Pierson, A. (1882), op. cit. p. 263.

4 ct. Pierson, A. (1882), op. cit. p. 263, 'Geeft het gekozen voorbeeld geen verband tusschen twee waargenomen objekten; het geeft evenmin tijdsorde. Men noeme toch hetgeen hier geacht moet worden vooraf te gaan en hetgeen geacht moet worden te volgen. Zegt men: op het breken van de plank volgt het vallen van het gewicht, dus is dat breken de oorzaak van dat vallen, dat besluite men ook te zeggen: het Joslaten van den teugel is oorzaak dat het paard loopt,....'

${ }^{3}$ cf. Pierson, A. (1882), op. cit. p. 263-264, 'Als eenige oorzaak hebben wij leeren kennen: de aantrekkingskracht (naar de gewone hypothese). De aantrekkingskracht trekt altijd aan. De massa wordt voortdurend angetrokken, ook in den toestand van evenwicht, dien ik rust noem. Verandert die rust in vallen, dan schijnt inderdaad niets te veranderen dan mijn appreciatie van de beweging, waaraan ik nu, omdat ik er belang bij heb, een andere naam geef. Er is hier een voor en na, maar niet ten aanzien van waargenomen objekten.' 
In de notie 'aantrekkingskracht' ligt besloten, zo betoogt Pierson, dat deze constant werkt. Het voorspellen dat die kracht altijd zal werken, is daarom een tautologie. Men kan uitsluitend de subjectieve waardering van beweging voorspellen. Zo'n waardering berust uiteindelijk alleen op een subjectief belang om beweging op een bepaalde manier te waarderen of te beoordelen. Pierson is van mening dat zoo dikwerf ik er belang bij heb (onder gelijke omstandigheden) zal ik dezelfde openbaring van eene voortdurende aantrekking altijd vallen noemen. ${ }^{1}$ Met andere woorden: de waameming van het vallen van het gewicht door de constante aantrekkingskracht van de aarde zal men 'vallen' blijven noemen, zolang het belang dat ten grondslag ligt aan deze subjectieve waardering niet verandert. 'Vallen' is daarmee uitsluitend de uitdrukking van een subjectieve waardering. Pierson leidt hier verder uit af dat voorspellen geen betrekking heeft op voorwerpen of gebeurtenissen of op een noodzakelijk verband tussen voorwerpen buiten het bewustzijn. ${ }^{2}$ Neen, voorspellen is alleen een bevestiging van het constant blijven van een subjectieve waardering zolang iemands belang dat ten grondslag lag aan die oorspronkelijke waardering gelijk blijft. In Piersons woorden: een voorspelling is eene bevestiging ten aanzien van de bestendigheid van mijne appreciatie bij het zich gelijk blijven van het belang, dat ik oorspronkelijk bij die appreciatie had. ${ }^{3}$

Tegenover de opvaltingen dat de notie 'oorzaak' betrekking heeft op waargenomen objecten en dat de notie 'oorzakelijk verband' een noodzakelijk volgen van waargenomen objecten betreft, stelt Pierson dat men de notie 'causaliteit' of 'borzakelijk verband' moet opvatten als een constante relatic tussen een natuurwet en de subjectieve waardering daarvan. In Piersons termen: de notie 'causaliteit' komt neer op een vaste betrekking tusschen een blijvende Voorwaarde van het bestaande, en onze waardering daarvan. ${ }^{4}$ De notie 'oorzaak', zo concludeert hij, wordt hierdoor overbodig, omdat deze vaste betrekking tussen natuurwetten en de subjectieve waardering daarvan in het geheel geen causaal verband is. ${ }^{5} \mathrm{Met}$ andere woorden:

'cf. Pierson, A. (1882), op. cit. p. 264.

${ }^{2}$ cf. Pierson, A. (1882), op. cit. p. 264, 'Het eenige, dat ik hier voorspellen kan, is nu immers niet: de aantrekkingskracht zal altijd werken, want dat ligt in haar begrip opgesloten, maar dit: zoo dikwerf ik er belang bij heb (onder gelijke omstandigheden) zal ik dezelfde openbaring van de eene voortdurende aantrekking altijd vallen noemen. Deze voorspelling heeft (..) geen betrekking op voorwerpen, of gebeurtenissen buiten mij; nog minder op een noodwendig verband tusschen voorwerpen of gebeurtenissen buiten mij, maar is eene bevestiging ten aanzien van de bestendigheid van mijne appreciatie bij het zich gelijk blijven van het belang, dat ik oorspronkelijk bij die appreciatie had.'

${ }^{3}$ cf. Pierson, A. (1882), op. cit. p. 264.

${ }^{4}$ cf. Pierson, A. (1882), op. cit. p. 265.

${ }^{5}$ cf. Pierson, A. (1882), op. cit. p. 265, 'Ik zou dus eerder geneigd zij, het begrip: oorzaak los te maken van hetgeen waarmede men het tot dus verbonden heeft; in oorzakelijk verband niet te zien: vast of noodwendige opvolging van waargenomen objekten, maar een vaste betrekking tusschen een blijvende Voorwaarde van het bestaande, en onze waardering daarvan, waardoor het woord: oorzaak natuurlijk alle beteekenis verliest; niemand zal die betrekking oorzakelijk willen noemen.' 
tegen het afschaffen van het woord: oorzaak, als wijsgeerig gewettigd woord, schijmt weinig bezwaar. De woorden 'oorzaak' en 'gevolg' zijn in beginsel namen voor één en hetzelfde, namelijk natuurwetten. Deze twee woorden suggereren ten onrechte dat het om twee afzonderlijke werkelijk bestaande zaken zou gaan: oorzaak en gevolg. Dit leidt er bijvoorbeeld toe dat men aantrekkingskracht onderscheidt van een specifiek verschijnsel van aantrekking. Pierson acht dit onmogelijk, want men kan alleen over aantrekkingskracht spreken. Natuurwetten vormen de conditio sine qua non of permanente voorwaarden voor al wat bestaat; zij bestaan ook al zouden er geen mensen bestaan.' De "wet" gelijkheid van waardering bij gelijkheid van belangen is de permanente voorwaarde van het individuele bestaan. Dat wil zeggen, als belangen niet veranderen, verandert de waardering van natuurwetten ook niet. Mel de notie 'permanente voorwaarden' wordt overigens niets geheimzinnigs wordt bedoeld. Het wil alleen zeggen dat zulke voorwaarden van het bestaande identiek zijn aan alles wat bestaat. Als men dergelijke voorwaarden namelijk zou wegdenken, dan zou er niets bestaan. Bijvoorbeeld: zonder aantrekkingskracht geen beweging. ${ }^{2}$

Pierson heeft echter nog een andere troef: de woorden die men gebruikt om het "werken" van een bepaald verschijnsel op een ander verschijnsel te beschrijven, zoals 'aantrekken', 'vlieden' of 'schuwen', hebben alleen betekenis als zij op mensen betrekking hebben. Zulke woorden zijn betekenisloos als zij worden gebruikt om verschijnselen in de natuur te beschrijven, omdat dit leidt tot antropomorfisme. Pierson acht het daarom de hoofdzaak, aan dat antropomorphisme te ontkomen. ${ }^{3}$

Samengevat: Piersons conclusies zijn voornamelijk negatief. De notie 'oorzaak' heeft geen betrekking op waargenomen objecten, zoals Spruyt had betoogd, maar alleen op een noodzakelijke relatie tussen hypothetische natuurwetten en waargenomen verschijnselen. Bovendien is er geen sprake van een tijdsorde of een vaste volgorde in de tijd tussen waargenomen objecten. Men kan alleen van een volgen

${ }^{1}$ cf. Pierson, A. (1882), op. cit. p. 265, Tegen het afschaffen van het woord: oorzaak, als wijsgeerig gewettigd woord, schijnt weinig bezwaar. Reeds lang heeft het velen gehinderd dat, waar oorzaak en gevolg inderdaad geen oogenblik te scheiden zijn, er twee namen bestonden voor hetgeen in den grond een is. Er is niet een kracht, die aantrekt en dan nog eens een aantrekking, of elektrisch vermogen en dan nog eens elektriciteit enz., maar er is aantrekkingskracht, elektriciteit enz.'

${ }^{2}$ cf. Pierson, A. (1882), op. cit. p. 265, 'Er zijn Permanente Voorwaarden van al het bestaande (natuurwelten), van al hetgeen onafhankelijk van onszelf geacht wordt te bestaan, terwijl de Permanente Voorwaarde van mijn eigen bestaan is: gelijkheid van waardeering bij gelijkheid van belangen. Ook zijn die Permanente Voorwaarden, die ik hier op het oog heb, niets geheimzinnigs. De voorwaarden van het bestaande vallen met het bestaande geheel samen. (....) De aantrekkingskracht enz. is de beweging zelve der lichamen; of nog juister (...) de zich in onderlinge samenhang bewegende lichamen.'

${ }^{3}$ cf. Pierson, A. (1882), op. cit. p. 266, 'De hoofdzaak is, aan dat anthropomorfisme te ontkomen, waaraan men zich schuldig maakı, zoodra men woorden (als aantrekken, schuwen, vlieden enz.) die dan alleen een verstaanbare zin hebben, wanneer zij van menschen gebezigd worden, van iets anders dan van menschen gebruikt. In dat geval toch kunnen zij niets meer met duidelijkheid te kennen geven.' 
in de tijd spreken als het de subjectieve waardering van natuurwetten betreft. Alleen de verwachte verandering van de subjectieve waarderingen kan men voorspellen. Zulke waarderingen berusten uiteindelijk op het subjectieve belang om bepaalde veranderingen een bepaalde naam te geven. De notie 'oorzakelijk verband' komt neer op een constante relatie tussen een natuurwet en de subjectieve waardering daarvan. De notie 'oorzaak' wordt hierdoor overbodig, omdat de relatie tussen een naturwet en de subjectieve waardering daarvan geen oorzakelijk verband is. Bovendien is het traditioncle onderscheid tussen de woorden 'oorzaak' en 'gevolg' misplaatst, omdat beide woorden één en hetzelfde betreffen: natuurwetten die constant werken. Het gewoonlijk gemaakte onderscheid tussen oorzaken en gevolgen suggereert ten onrechte dat het om verschillende zaken zou gaan die werkelijk bestaan. 'Oorzaak' en 'gevolg' vallen samen, omdat de natuurkrachten en datgene wat zulke krachten bewerken één proces vormen. Ten slotte hebben woorden die het "werken" van een bepaald verschijnsel op een bepaald ander verschijnsel beschrijven alleen betekenis in een menselijke context; daarbuiten zijn zij betekenisloos.

Tot slot: Piersons opvattingen over causaliteit die hij in Wijsgeerig onderzoek ontvouwt, vormen een nadere uitwerking van een opmerking die hij eerder summier had verwoord in het artikel Een keerpunt in de wijsgeerige ontwikkeling (1871).' Bovendien zij opgemerkı dat Piersons conclusies lijken aan te sluiten bij de opvattingen over causaliteit van de Engelse positivist G.H. Lewes. In het tweede Aanhangsel bij Wijsgeerig onderzoek verwijst Pierson expliciet naar diens Problems of life and mind (1875). In dat boek komt naar voren dat 'oorzaak' en 'gevolg' één proces betreffen dat vanuit twee verschillende gezichtspunten wordt bekeken. Bovendien wijst Lewes er op dat het causaliteitsvraagstuk alleen kon ontstaan door te onderstellen dat proces en uitwerking werkelijk aparte zaken zijn; Lewes acht dit echter onjuist. Het betreft alleen het onderscheiden van bepaalde aspecten, en niet hel scheiden van zaken die in werkelijkheid zouden bestaan. Dit ten onrechte gemaakte onderscheid heeft het denken over causaliteit, zoals bij Hume en Kant,

'cf. Pierson, A. (1871), Een keerpunt in de wijsgeerige ontwikkeling, p. 472-473, 'Bij den tegenwoordigen stand van de wetenschap der natuur moet de vraag oprijzen: is er oorzakelijkheid; is zij niet als verouderd te beschouwen, die geheele kategorie van oorzaak en gevolg? en dus op de ruimen met zooveel metafysisch als de natuurwetenschap nog aankleeft? (....) Dat begrip (oorzaak) valt weg, om plaats te maken voor de erkenning van de objektieve identiteit dier verschijnselen, tusschen welke men vroeger een kausaalverband aannam, en voor de bepaling van de volgorde der vormen, waaronder $\mathrm{ik}$ mij de altijd met zichzelve identische. kracht voorstellen moet. Want zoodra het vaststaat, dat die kracht identisch blijft, wordt er niets uitgewerkt, en is er dus ook geen oorzaak. Alles wat wordt, heeft een oorzaak; maar, indien er niets word!! Elk ondergaan heeft een oorzaak; maar, indien er niet ondergaat! En dit herhaald indien sluit juist in hetgeen door de natuurwetenschap toegegeven, ja verkondigd wordt. Dic wetenschap bepaalt zich tegenwoordig, in zooverre zij reeds wetenschap is, tot de aanwijzing van volstrekte eenzelvigheid in de voor ons bewustzijn meest uileenloopende verschijnselen.' 
op een geheel verkeerd spoor gebracht.'

Pierson analyseert vervolgens de argumentaties waarop de traditionele betekenis van de notie 'oorzaak' zou zijn gebaseerd. Ten slotte gaat hij na waar de, volgens hem, "klassieke" misvatting op berust die inhoudt de notie 'oorzakelijk verband' een tijdsorde zou impliceren. Deze onderwerpen komen in het navolgende aan de orde.

\section{Onderlinge betrekking tusschen feiten?}

Om ten aanzien van het begrip dat ons bezig houdt tot meer helderheid te komen, heeft men, meen $i k$, na te denken over de meest algemeene stelling waarvan bij de vorming van dat begrip (oorzaak) de waarheid stilzwijgend wordt aangenomen. Zoo geloof ik voor mij althans het best tot een principiëele behandeling van dit gedeelte van ons onderwerp te geraken. ${ }^{2}$

Deze algemeene stelling treft Pierson aan in Hume's Enquiry. Hume was er van uitgegaan dat het redelijke denken en het onderzoek zich uitsluitend richten op twee soorten voorwerpen: op relaties tussen ideeën en op feiten. ${ }^{3}$ Zulke feiten vat Pierson op als een onderlinge betrekking tusschen feiten. In de onderstelling dat er zo'n onderlinge betrekking tusschen feiten of relaties tussen feiten mogelijk zijn, schuilt echter de dwaling die aan een tamelijk verspreide opvatting van oorzaak ten grondslag ligt. ${ }^{4}$ Want, is er (...) een betrekking tusschen feiten mogelijk? En: zijn feiten dingen, tusschen welke iets kan bestaan, dat een betrekking kan heeten? ${ }^{5}$ Piersons antwoorden op beide vragen luiden ontkennend.

Het aangrijpingspunt voor de motivering van Piersons antwoorden is Hume's argumentatie dat alle uitspraken of redeneringen over feiten berusten op de relatie tussen oorzaak en gevolg. Pierson wil aantonen dat alleen relaties tussen begrippen mogelijk zijn, terwijl relaties tussen feiten dat niet zijn. Omdat volgens Hume relaties tussen feiten berusten op de relatie tussen oorzaak en gevolg, leidt Pierson uit de onmogelijkheid van het bestaan van relaties tussen feiten af dat het ook onmogelijk

1 cf. Lewes, G.H. (1875), Problems of life and mind, p. 376, '... the process and the product are one, viewed under two aspects (...). All the vexed questions which have been raised respecting Causation turn on the illusory separation of process and product, cause and effect, which is properly a distinction of aspects, not a separation of reals; the antecedent is not one thing, and the consequent another different thing (...). When Hume puzzled the world with his sceptical argument, (...) alarmed Philosophy sought everywhere for proofs of a connexus and evidence of this power, evidence confessedly not given in sensation, and which nevertheless was assumed to be discoverable somewhere; so that Kant's announcement of causality as one of the forms of Thought, and thus one of the conditions of Experience, was eagerly welcomed.' Geciteerd in Pierson, A. (1882), op. cit. p. 307.

2 cl. Pierson, A. (1882), op. cil. p. 266.

${ }^{3}$ cf. Hume, D. (1748), op. cit., section IV, part I, p. 20, 'All the objects of human reason or enquiry may naturally be divided into two kinds, to wit, relations of ideas, and matters of fact.'

4 cf. Pierson, A. (1882), op. cit. p. 267.

st. Pierson, A. (1882), op. cit. p. 267. 
is om 'oorzakelijk verband gelijk te stellen aan een relatie tussen feiten. Deze argumentatie werkt hij als volgt uit.

In de Enquiry had Hume betoogd dat van ieder feit het tegendeel mogelijk is zonder dat er een tegenstrijdigheid ontstaat. Bijvoorbeeld: de stelling dat de zon morgen níet zal opgaan is even begrijpelijk en behelst evenmin een tegenspraak als de bewering dat de zon morgen wél zal opgaan. Bovendien had Hume naar voren gebracht dat al het redeneren over feiten schijnt te berusten op de relatie tussen oorzaak en gevolg. Uitsluitend door zo'n relatie kan men uitkomen boven de getuigenis van de herinnering en de zintuigen.'

Pierson rekent eerst af met Hume's opvatting dat er relaties tussen feiten zouden bestaan. Ik meen te kunnen aantonen, dat Hume zijne stelling niet bewezen heeft, al dadelijk omdat hij bij zijn betoog slechis in schijn over feiten handelt. ${ }^{2}$ Hume had beweerd dat het tegenovergestelde van ieder feit altijd mogelijk is, omdat het niet tot een tegenstrijdigheid leidt. Meteen daarna had Hume echter naar voren gebracht dat 'de zon zal morgen niet opgaan' een stelling is, terwijl hij 'de zon zal morgen opgaan' als een bewering had beschouwd, aldus Pierson. Hieruit blijkt volgens hem dat Hume het helemaal niet over feiten heeft, maar alleen over begrippen; immers, voor een feit stelt hij onmiddellijk een oordeel in de plaats. Pierson acht Hume's redeneerstap begrijpelijk, want wat kan beteekenen: het tegenovergestelde van een feit? $?^{3}$ Dit is een onzinnige vraag. Immers, wat het tegenovergestelde van een feit is, is evenmin te begrijpen als de vraag wat het tegenovergestelde van twee of drie zou zijn. Pierson concludeert dat 'de zon zal morgen niet opgaan' uitsluitend als een stelling kan worden opgevat en niet als een feit, omdat alleen bij cen stelling een tegenstelling mogelijk is. ${ }^{4}$ Dit leidt tot de vraag: maar met welk eene stelling hebben

' cf. Hume, D. (1748), op. cit., section IV, part I, p. 21-22, The contrary of every matter of fact is still possible; because it can never imply a contradiction, and is conceived by the mind with the same facility and dislinctness, as if ever so comfortable to reality. That the sun will not rise to-morrow is no less intelligible a proposition, and implies no more contradiction, than the affirmation, that it will rise. (...) All our reasonings concerning matter of fact seem to be founded on the relation of cause and effect. By means of this relation alone we can go beyond the evidence of our memory and senses.'

${ }^{2}$ cf. Pierson, A. (1882), op. cit. p. 268.

${ }^{3}$ cf. Pierson, A. (1882), op. cit. p. 269.

${ }^{4}$ cf. Pierson, A. (1882), op. cit. p. 268-269, 'Het tegenovergestelde, hoorden wij, van elk feit is altijd mogelijk, omdat het nooit een kontradiktic kan insluiten. Waarop dan onmiddellijk volgt: "dat de zon morgen niet zal opgaan, is een even verstaanbare en even ongerijmde stelling als de bewering: zij zal opgaan". Met bemerkt natuurlijk het eigenaardig quid pro quo. Voor feit wordt stelling in de plaats geschoven. Eerst heet het: "the contrary of every matter of fact is still possible". Onmiddellijk daarop volgt: "that the sun will not rise tomorrow, is an intelligible proposition and implies no contradiction". Hier blijkt al terstond dat Hume slechts in schijn feiten tegenover begrippen plaats. Hij moet terstond het feit laten varen, en er een oordeel voor in de plaats stellen. (....) wat kan beteekenen: het tegenovergeste!de van een feit? Het tegenovergestelde van een feit is naturlijk evenmin te begrijpen als, bijvoorbeeld, het tegenovergestelde van twee of drie. Wij hebben dus uit-sluitend met een stelling te doen. Slechts bij een stelling kan sprake zijn van een tegenstelling.' 
wij hier te doen? Met eene, die alleen betrekking heeft op een feit?' De stelling 'de zon zal morgen opgaan' betreft geen feit, maar een begrip; bovendien is die stelling niet identiek aan de stelling 'een zon gaat op', die daarentegen wél een feit kan betreffen. De eerste stelling is immers een impliciet oordeel over een mogelijkheid dat de zon zal opgaan. ${ }^{2}$ Men verwacht dat de zon die men ziet ondergaan, ook weer zal opgaan. Het denkbeeld of begrip van 'de zon' kan men verenigen met het denkbeeld of begrip van 'weer opgaan' of 'terugkeeren'. Of de zon weer opgaat, gebeurt of gebeurt niet. Als de zon inderdaad weer opgaat, dan is de stelling 'de zon zal opgaan' niet innerlijk tegenstrijdig. Immers, het is niet tegenstrijdig om te zeggen dat iets zal gebeuren als het ook kan gebeuren. Als echter blijkt dat men het begrip 'de zon' en het begrip 'weer opgaan' niet met elkaar kan verenigen, dan is de stelling 'de zon zal opgaan' innerlijk tegenstrijdig; het is immers ongerijmd om het onmogelijke toekomstig te noemen. ${ }^{3}$ Tegenover de stelling 'de zon zal opgaan' zet Pierson de stelling 'een zon gaat op'. Deze laatste stelling kan nooit tot een tegenstrijdigheid leiden, omdat het lidwoord 'een' betekent dat het denkbeeld 'zon' nog geen afgerond denkbeeld of begrip vormt. Door 'de' in plaats van 'een' voor het denkbeeld 'zon' te plaatsen gaat men er van uit dat het begrip 'zon' wél is afgerond. Vervolgens kan dan worden nagegaan of bijvoorbeeld het begrip 'weer opgaan' met dit begrip verenigd kan worden. De stelling 'de zon zal morgen niet opgaan' betreft derhalve een relatie tussen begrippen, en geen relatie tussen feiten. Dit wordt nog duidelijker als men de stelling 'de zon zal morgen op de aarde vallen' en de stelling 'de zon zal morgen opgaan' met elkaar vergelijkt. Formeel zijn beide stellingen gelijk; de eerste stelling is echter innerlijk tegenstrijdig en de tweede niet. Immers, als men de betekenis van de begrippen 'de zon' en 'op de aarde vallen' begrijpt, dan ziet men meteen in dat de stelling 'de zon zal morgen op de aarde vallen' tegenstrijdig is. Dit komt overeen met wiskundige stellingen. Het begrijpen van de betekenis van een wiskundige stelling is een noodzakelijke en voldoende voorwaarde om daarvan de tegenstrijuigheid in te zien als men bijvoorbeeld zo'n stelling zou ontkennen. Als men de stelling 'de zon zal morgen niet opgaan' niet innerlijk tegenstrijdig acht, dan

${ }^{\prime}$ cf. Pierson, A. (1882), op. cit. p. 269.

2 cf. Pierson, A. (1882), op. cit. p. 269-270, 'Met eene (stelling), die alleen betrekking heeft op een feit? Volstrekt niet; met eene die betrekking heeft op een begrip. De stelling: de zon zal morgen opgaan, heeft geen betrekking op een feit. $\mathrm{Zij}$ staat niet gelijk met de stelling: een zon gaat op. (....) .. de eerstgenoemde stelling behelst (impliciet) een oordeel over een mogelijkheid; leert (wel meer dan, maar toch ook) een mogelijkheid.'

${ }^{3}$ ef. Pierson, A. (1882), op. cit. p. 270, '... de zon die gij kent, die gij heden ziet verdwijnen, is een voorwerp, dat niet over eenige uren voor goed verdwijnen kan: het denkbeeld, dat gij $\mathrm{u}$ vormt van de zon, is vereenigbaar met het denkbeeld: terugkeeren. Dit is zoo of dit is zoo niet. Is het zoo: zijn werkelijk die beide denkbeelden vereenigbaar (zon en terugkeren), dan sluit de stelling geen kontradictie in, want te zeggen: gebeuren zal, wat gebeuren kan, is niet ongerijmd.' 
begrijpt men kennelijk niet de betekenis van de begrippen 'de zon' en 'niet opgaan'.' Kortom: relaties tussen feiten zijn onmogelijk; alleen relaties tussen begrippen zijn mogelijk. ${ }^{2}$

Nadat Pierson heeft afgerekend met Hume's opvatting dat er relaties tussen feiten zouden bestaan, is het voor hem eenvoudig om korte metten te maken met diens opvatting dat al het redeneren over feiten schijnt te berusten op de relatie tussen oorzaak en gevolg. Piersons parafrase van deze opvatting van Hume luidt: wij gaan alijd van de onderstelling uit, dat er een betrekking is tusschen een feit en een ander feit. Indien er zulk een betrekking niet bestond, zou ons besluit van het eene feit tot het andere op geheel losse schroeven staan. ${ }^{3}$ Bijvoorbeeld: als iemand een horloge vindt op een verlaten eiland, dan kan men daaruit afleiden dat daar iemand eerder is geweest. ${ }^{4}$ Echter, hel feit dat iemand op een eiland is geweest, is niet de oorzaak dat iemand anders daar een horloge vindt. Het gaat in dit voorbeeld niet om een relatie tussen feiten, maar om een relatie tussen begrippen. Met andere woorden: het is een analytisch oordeel. ${ }^{5}$ In het begrip 'een horloge op een verlaten eiland' ligt namelijk hel volgende begrip besloten: 'het werk van een mensch in een verlaten eiland'. Het is daarom niet nodig orn met behulp van de relatie van oorzaak en gevolg feiten met

' cE.. Pierson, A. (1882), op. cit. p. 270, 'Maar zijn beide denkbeelden niet vereenigbaar, dan sluit de stelling wel degelijk een kontradiktie in, daar het ongerijmd is het onmogelijke toekomstig te noemen. Beweer ik: een zon gaat op, dan kan zulk een stelling nooit aan innerlijke tegenstrijdigheid leiden, omdat het niet bepalend lidwoord, voor het woord: zon geplaatst, de afwezigheid kenteekent van elk afgerond denkbeeld, dat ik mij reeds van die zon zou hebben gemaakt. Zoodra ik evenwel dat niet bepalend lidwoord in het bepalend lidwoord verander, heb ik aangenomen dat het denkbeeld afgerond is, en kan men dus beoordelen of een nieuw denkbeeld: opgaan of terugkeeren of wat dan ook, met het eerste te vereenigen is. (...) De zon zal morgen op de aarde vallen is een stelling, formeel volkomen gelijk staande met: de zon zal morgen opgaan. Zal men nu beweeren, dat de stelling: de zon zal morgen op de aarde vallen geene kontradiktie behelst? Wie het denkbeeld de zon en het denkbeeld: ter aarde vallen begrijpt, kan die twee denkbeelden evenmin vereenigen als rood en niet-rood, zijn en niet-zijn.'

${ }^{2}$ cf. Pierson, A. (1882), op. cit. p. 271, 'Maar indien het begrijpen van de wis- of rekenkunstige stelling onmisbaar, en tevens voldoende is, om tegenstrijdigheid op te merken, die aan de ontkenning of erkenning dier stellingen verbonden is, dan zal ook het begrijpen van de stelling: de zon zal morgen niet opgaan, even onmisbaar als voldoende zijn, om ons de kontradiktie in te doen zien, die zij behelst. Hiermede is (...) de eigen grondslag weggenomen waarop die leer van Hume omtrent een betrekking tusschen feiten rust. Is zulk een betrekking er niet, dan kan ook het oorzakelijk verband zulk een betrekking niet zijn.'

${ }^{3}$ ef. Pierson, A. (1882), op. cit. p. 272.

${ }^{4}$ cf. Pierson, A. (1882), op. cit. p. 271-272, 'Alle redeenering omtrent feiten, zegt hij, schijnen te rusten op de betrekking van oorzaak en gevolg. Alleen door die betrekking zullen wij, volgens hem, meer kunnen weten dan waarneming en geheugen ons leeren. Waarom gelooven wij aan het bestaan van iets: dat wij evenwel zien noch ons herinneren? (....) lemand vindt een horloge of een andere machine in een verlaten eiland; nu besluit hij, dlat er vroeger een mensch in dat eiland is geweest.'

${ }^{5}$ cf. Pierson, A. (1882), op. cit. p. 273. 
elkaar te verbinden, omdat er al een relatie tussen begrippen is. ${ }^{1}$ Met andere woorden: de relatie van oorzaak en gevolg is overbodig.

Als men er echter van uit zou gaan dat bepaalde feiten niet met elkaar zijn verbonden, is het dan mogelijk om zulke feiten alsnog met elkaar in verband te brengen? Kan ik ze dan nog vereenigen ? ${ }^{2}$ Piersons antwoord luidt ontkennend, omdat uit het feit dat iemand op een verlaten eiland een horloge vindt niet noodzakelijk volgt dat er eerst iemand op dat eiland geweest moet zijn. Het is bijvoorbeeld mogelijk dat het horloge door iemand op het eiland is gegooid zonder een voet aan wal te zetten. Pierson concludeert dat er in dit geval twee mogelijkheden zijn. Hetzij: het laatste feit (zeg: een b) ligt reeds besloten in het eerste feit (zeg: een a). Als dat zo is, dan is het niet nodig om een a en een $b$ te verbinden. Of: een b ligt niet in een a besloten. In dat geval kan men een a en een b niet met elkaar verbinden, omdat er geen relaties tussen feiten bestaan. Hume's opvatting dat men door feiten met elkaar in verband te brengen op grond van de relatie van oorzaak en gevolg uitkomt boven de getuigenis van de herinnering en zintuigen en dat men daardoor nieuwe kennis vormt, biedt geen soelaas. Immers, ó men wist al dat een b besloten lag in een a, of men wist dit niet. In dat laatste geval kan men nooit op grond van het bekende feit het onbekende feit kennen, omdat er geen weg voert van een feit tot een feit, [....] er is geen onderlinge betrekking van feiten mogelijk. ${ }^{3}$

Kortom: Pierson verwerpt Hume's opvalting dat er relaties tussen feiten bestaan. Er bestaan alleen relaties tussen begrippen. Omdat er alleen relaties tussen begrippen bestaan, vervalt daarmee ook. Hume's opvatting dat men door feiten met elkaar in een oorzakelijk verband te brengen nieuwe kennis vormt. Hiermee meent Pierson te hebben afgerekend met de dwaling die aan een tamelijk verspreide opvatting van oorzaak ten grondslag ligt.

' cf. Pierson, A. (1882), op. cit. p. 273-274, '...Hume (heeft) geen betrekking hoegenaamd gekonstateerd, maar (heeft) uit een begrip afgeleid wat er naar zijn oordeel in opgesloten lag. (...) Hume heeft eenvoudig een analytisch oordeel geveld. (...) In het begrip horloge ligt reeds besloten, dat van menschenwerk. (....) In plaats van "een uurwerk in een verlaten eiland" kan ik evengoed zeggen "het werk van een mensch in een verlaten eiland". Nu hoef ik toch niet te verbinden wat reeds verbonden is.'

${ }^{2}$ ci. Pierson, A. (1882), op. cit. p. 274.

${ }^{3}$ cf. Pierson, A. (1882), op. cit. p. 274-275, 'Maar neem ik aan, dat zij niet reeds verbonden zijn. Kan ik ze dan nog vereenigen? Immers neen. Uit het eene feit vloeit ten aanzien van, het tweede niets voort? (...) Dus een van beide: feit b is eenvoudig reeds een deel van feit a, en dan behoef ik ze niet te verbinden; of feit b is geen deel van feit a, en dan kan ik ze niet verbinden. Om deze reden gaat het dan ook niet aan, te zeggen, dat wij door betrekking te brengen lusschen feiten, een betrekking berustende op den band van oorzaak en gevolg een kennis verkrijgen, die verder reikt dan wat zinnelijke waarneming en geheugen ons geven. Er wordt hier in het minst geene nieuwe kennis opgedaan. Of wel wij wisten reeds, dat feit b om zoo te spreken, stak in feit a, of wel wij wisten dit niet, en dan kan ons het eene, het bekende van de twee feiten, nooit helpen aan de kennis van het andere, het nog onbekende feit; om de goede reden dat er geen weg voert van een feit tot een feit, dat er geen onderlinge betrekking tusschen feiten mogelijk is.' 
Als men van de misvatting uitgaat dat de notie 'oorzakelijk verband' neerkomt op relaties tussen feiten, zo betoogt Pierson verder, dan moet men ook concluderen dat dit altijd een tijdsorde impliceert. Immers, gebeurtenissen vinden plaats in de tijd. In de gewone theorie over het oorzakelijk verband der dingen spelen tijdsaanduidingen zoals verleden, heden en toekomst daarom een belangrijke rol. Hierdoor ontstaat ook het probleem of oorzakelijk verband iets te maken heeft met tijdsorde. Botweg merkt Pierson op: ik veroorloof mij daarentegen de vraag of hier inderdaad een probleem bestaat. Het kan aan stompzinnigheid liggen, maar ik moet in alle oprechtheid verklaren, dat ik het probleem niet zie. ${ }^{1}$

Hume had zich in de Enquiry afgevraagd of men uit het feit dat brood, of een voorwerp met bepaalde zintuiglijk waarneembare hoedanigheden met de kracht om de honger te stillen dat op een bepaald moment voedzaam is gebleken, kan afleiden of een ander brood op een ander moment ook voedzaam zal zijn, en dat gelijksoortige zintuiglijk waarneembare hoedanigheden gepaard moeten gaan met de kracht om de honger te stillen. ${ }^{2}$ In Piersons termen: hoe kan ik met zekerheid voorspellen, dat het brood dat mij gevoed heeft, mij ook voeden zal? ${ }^{3}$ Deze vraag is volgens Pierson zinloos. Immers, 'het brood dat mij gevoed heeft', is opgegeten. Het ligt daarom voor de hand dat dit specifieke brood mij ook niet meer zal voeden. Deze voorspelling bevestigt alleen maar het volgende: 'als dit voorwerp een brood is, dan zal het mij voeden'. De betekenis van deze voorspelling wordt pas duidelijk als men nagaat welk begrip men met het woord 'brood' verbindt. Hume had een strikt onderscheid gemaakt tussen de zintuiglijk waarneembare hoedanigheden van brood en de voedende kracht, daarvan. ${ }^{4} \mathrm{Hij}$ had onder 'brood' alleen de zintuiglijk waarneembare hoedanigheden verstaan, waarmee hij vervolgens de voedende kracht verbond. Dit had voor Hume tot deze vraag geleid: door welke redeneering weet ik, dat die eigenschappen altijd verbonden zullen zijn met die voedende kracht? ? $^{5}$ Echter, deze tijdsaanduiding - 'zullen' - is overbodig, zo beloogt Pierson. Hel begrip 'brood' wijst immers niel alleen op

'cf. Pierson, A. (1882), op. cit. p. 279.

${ }^{2} \mathrm{cf}$. Hume, D. (1748), op. cit. section IV, part III, p. 29, The bread, which I formerly eat, nourished me; that is, a body of such sensible qualities, was, at that time, endued with such secret powers; But does it follow, that other bread must also nourish me at another time, and that like sensible qualities must always be attended with like secret powers.'

${ }^{3}$ cf. Pierson, A. (1882), op. cit. p. 279.

${ }^{4}$ cf. Pierson, A. (1882), op. cit. p. 279-280, 'Men zegt wel eens: hoe kan ik met zekerheid voorspellen, dat het brood dat mij gevoed heeft mij ook in de toekomst voeden zal. Met zulk een vraag kan men natuurlijk niets uitrichten. Het brood toch, dat mij gevoed heeft, zal mij nooit meer voeden. Hetgeen in de voorspelling, waarvan hier sprake is, bevestigd wordt, is niets anders dan het volgende: Gesteld, dat het voor mij liggend voorwerp brood is, dan zal het mij voeden. Om nu de eigenlijke strekking van deze bewering in te zien, heeft men zich slechts rekenschap te geven van het begrip dat men met het woord: brood verbindt. Hume onderscheidt zeer scherp tusschen de zinnelijk waarneembare hoedanigheden van het brood, als omvang, kleur, enz. en hetgeen ik nu noemen wil de voedende kracht van het brood.'

cf. Pierson, A. (1882), op. cit. p. 280. 
bepaalde zintuiglijk waarneembare hoedanigheden, maar het houdt ook in dat het voedzaam is of voedende kracht heeft. In het begrip 'brood' ligt al besloten dat het voedzaam is. Hieruit concludeert Pierson dat beide elementen - de zintuiglijk waarneembare hoedanigheden én voedende kracht - behoren tot de inhoud van het begrip 'brood'. Als men de voedende kracht daaruit weglaat, dan heeft men het niet meer over brood. Het maken van een onderscheid tussen de zintuiglijk waarneembare hoedanigheden van brood als oorzaak en de voedende kracht daarvan als gevolg acht Pierson dan ook onjuist.' Met andere woorden: met 'brood' wordt alleen een subjectieve waardering aangegeven; een waardering die ook een subjectieve waardering van de voedende kracht daarvan betreft.

Als men iets waarneemt dat de uiterlijke kenmerken van brood heeft, dan kan men zich afvragen hoe men uit zulke kenmerken kan afleiden of dit brood daarnaast eigenschappen heeft die men niet heeft waargenomen. In Piersons woorden: wie wil verzekeren, dat het voorwerp, behalve de eigenschappen, die men heeft kunnen waarnemen, ook eigenschappen bezit die men niet heeft kunnen waarnemen, waarvan men het bestaan op geenerlei wijze heeft kunnen konstateeren $?^{2}$ Op grond van het waarnemen van alleen de uiterlijke kenmerken van een specifiek brood zal niemand, zonder verder onderzoek te doen, willen zeggen dat dit brood inderdaad behoort tot de soort van voorwerpen die men brood noemt. Men zal alleen zeggen dat de soort van voorwerpen die men brood noemt, voedzaam is. Hiermee geeft men dus alleen een bepaalde woordbetekenis. Men kan de stelling echter ook omdraaien en zeggen: 'iets dat bepaalde uiterlijke kenmerken heeft en ook nog voedzaam is, is brood'. Of: 'als dit voorwerp, als de schijn niet bedriegt, brood is, dan zal het bepaalde uiterlijke kenmerken hebben en zal het, nadat het is opgegeten, voedende kracht blijken te hebben. ${ }^{3}$ Pierson erkent overigens echter wel dat niemand op zo'n nauwkeurige manier zal spreken. Hij is het daarom eens met Hume dat men er door gewoonte toe

${ }^{1}$ cf. Pierson, A. (1882), op. cit. p. 280-281, 'En na dit onderscheid gemaakt te hebben, stelt hij de zaak zoo voor, alsof wij, van brood sprekende, voorlopig alleen bedoclen het geheel van die uitwendige hoedanigheden, om dan later met dat geheel de voedende kracht te verbinden. Door welke redeenering weet $i k$, dat die eigenschappen altijd verbonden zullen zijn met die voedende kracht? Voor dit zullen, voor dezen toekomenden tijd, is evenwel niet de minste reden, wanneer men het denkbeeld, met het woord brood te verbinden, niet willekeurig halveert. Brood is niet alleen voorwerp dat zekere uitwendige hoedanigheden vertoont, maar dat, genuttigd, het lichaam voedt. (....) Een voorwerp dat die vereeniging bezit, daaraan geeft ik de naam brood. Zeg ik dus: brood zal voeden, dan zeg ik niets anders: brood zal brood zijn. Er is niet eerst brood, als oorzaak, en nog eens voeding als gevolg.'

${ }^{2}$ ef. Pierson, A. (1882), op. cit. p. 281.

${ }^{3}$ cf. Pierson, A. (1882), op. cit. p. 282, 'In het geval dat ons bezig houdt, zal hij (theoretisch) nooit iets anders willen zeggen dan dat de soort brood voedt, en daarmede niets anders bedoelen te geven dan de bepaling van een woord, zoodat hij ook bereid is de stelling om te keeren en te verklaren: wat die of die eigenschappen bezit en daarbij voedt is brood; waaraan hij dan, zoo hij het noodig acht, kan toevoegen; ondersteld, dat dit op brood gelijkende voorwerp door den schijn mij niet bedriegt, dan zal die en die eigenschappen en, nadat het in mijn lichaam opgenomen is, voedende kracht bezitten.' 
geneigd is om bepaalde waarneembare eigenschappen in verband te brengen met bepaalde niet-waarneembare eigenschappen. Zo'n gewoonte resulteert ten slotte in een bepaald gevoel van zekerheid.'

Het laatste - het gevoel van zekerheid - vormt voor Pierson ten slotte aanleiding voor de volgende vraag: maar wat beteekent deze gewoonte, of deze zekerheid uit een zuiver theoretisch oogpunt $?^{2}$ Hume's vraag welke redeenering ten grondslag ligt aan de overgang van de uitspraak 'het brood heeft de honger gestild' naar 'het brood zal de honger stillen' acht Pierson belachelijk. Hij wijst er op dat Hume met deze vraag twee bedoelingen gehad kan hebben. Het ging Hume hetzij om het gevoel van zekerheid van de zuiver theoretische stelling: 'dit specifieke brood zal mij voeden'. In dat geval kan men echter geen redenering aangeven waardoor men iets kan zeggen over wat men niet kan waarnemen. Of het ging Hume om een gevoel van zekerheid dat men heeft omtrent de voedende kracht van een voorwerp dat op brood lijkt. Echter, in dit geval kan een redenering niet in een gevoel van zekerheid resulteren dat praktisch nuttig is; bovendien acht Pierson het niet nodig om dit gevoel door een redenering te rechtvaardigen. ${ }^{3}$

Korlom: de misvatting dat er relaties tussen feiten bestaan, moet tot de verkeerde conclusie leiden dat 'oorzakelijk verband' een tijdsorde impliceert. Er bestaan alleen relaties tussen begrippen. Voorspellen komt daardoor uiteindelijk neer op een explicatie van wat reeds in een bepaald begrip ligt besloten. Met een volgen in de tijd heeft dit echter niets te maken.

De voorafgaande analyses van Pierson brengen hem ten slotte tot de volgende conclusies. Hij concludeert dat het in de meeste gevallen helemaal niet nodig is om de notie 'oorzaak' te gebruiken. Dit zijn bovendien juist die gevallen die leken te ondersteunen dat 'oorzakelijk verband' en 'tijdsorde' identiek zijn. Immers, de stelling dat brood de oorzaak en voeding het gevolg is, heeft niet de allergeringste theoreti-

cf. Pierson, A. (1882), op. cit. p. 282-283, 'Hume heeft er volkomen gelijk aan, dan niemand in het dagelijksch leven zoo nauwkeurig spreekt, en inderdaad iedereen door gewoonte er toe gebracht wordt, met zekere eigenschappen die hij waarneemt andere eigenschappen te verbinden die hij niel waarneemt. Door die gewoonte ontstaat ten deze een gevoe! van zekerheid,....'

${ }^{2}$ ef. Pierson, A. (1882), op. cit. p. 283.

"cf. Pierson, A. (1882), op. cit. p. 283, 'De vraag van Hume: welke redeneering brengl mij van het gevoed hebben tot het zal voeden, komt mij belachelijk voor. (....) Hume bedoelt met zijn vraag of de zuiver theoretische stelling: dit bepaalde brood zal mij voeden, - en dan kan er geen redeneering bedacht worden die mij vergunt iets te verzekeren van hetgeen waarvan ik niets weet; - of Hume bedevelt alleen de verzekerdheid die ik koester aangaande de voedende kracht van een bepaald brood op een brood gelijkend voorwerp, en dan moet geantwoord worden, dat geen redeneering ter wereld een gevoel kan doen ontstaan, een gevoel, dat praktisch nuttig blijkt, ook van geen redeneering eenige rechtvaardiging behoeft te ontvangen.' 
sche waarde.' 'Brood' is slechts de naam van een verzameling van verschijnselen. De voedende kracht van brood is één van die verschijnselen. Die kracht merkt men pas op als men het brood opeet: brood is eerst brood als het genuttigd is. Het is theoretisch ongeoorloofd om op grond van alleen het waarnemen van de uiterlijke kenmerken van een bepaald voorwerp te voorspellen dat het zal voeden. Bovendien, als men het brood eet, dan is dit strikt genomen niet de oorzaak dat men wordt gevoed. Het objectieve fysiologische proces dat er zorg voor draagt dat het brood in het lichaam wordt opgenomen is de oorzaak dat men wordt gevoed. Het gaat hierbij om een objectief proces in het lichaam en de subjectieve waardering daarvan; en dat laatste berust uiteindelijk op een persoonlijk belang. ${ }^{2}$ Maar waar blijft nu het voor en na; waar de tijdsorde? $?^{3}$ Pierson concludeert dat men daarbij geen tijdsorde of volgorde in de tijd kan aangeven. Fysiologische processen zijn natuurwetten of één der permanente voorwaarden voor het bestaande. Het feit dat er in het lichaam met het brood iets gebeurt wordt subjectief gewaardeerd; deze waardering noemt men het gevolg. Als men een bepaald feit niet zou waarderen, dan is er ook geen sprake van gevolg. Hieruit leidt Pierson af dat er in werkelijkheid niets is dat de aanleiding vormt om te spreken in termen van tijdsorde of het volgen in de tijd. ${ }^{4}$

Pierson concludeert tevens dat de wetenschap niets met absolute zekerheid kan voorspellen over specifieke gevallen. Zij kan over zulke gevallen alleen hypothetische uitspraken vormen, die bovendien tautologisch zijn. Bijvoorbeeld de uitspraak: 'als dit voorwerp een brood is en als het door het lichaam wordt opgenomen, dan zal het bepaalde kenmerken hebben'. Daar komt nog een andere tautologie bij: als belangen niet veranderen, dan verandert de subjectieve waardering van verschijnselen evenmin. Op hel eerste gezicht lijkt dit geen tautologie, omdat men geneigd is om belangen als de oorzaak van subjectieve waarderingen op te vatten. Als dat zo zou

' cf. Pierson, A. (1882), op. cit. p. 283-284, 'Is mijne kritiek van Hume gegrond, dan hebben wij in een groot aantal gevallen, waarin men het tot dusver wel deed, niet van oorzaak te spreken, en dan blijkt tevens, dat het juist die gevallen zijn, die het meest de vereenzelviging van oorzakelijk verband met tijdsorde schenen te begunstigen.'

${ }^{2}$ cf. Pierson, A. (1882), op. cit. p. 284, 'Brood is de naam van een groep van verschijnselen. Tot die verschijnselen behoort zijn voedende kracht. Dit verschijnsel grijpt eerst plaats als het brood door mij genuttigd wordt. Derhalve: hetgeen op tafel ligt heeft niet de minste voedende kracht; daarvan te zeggen: het zal voeden is, theoretisch gesproken, ongeoorloofd. En wanneer ik nu het brood heb genuttigd, dan wordt niet het brood in mij de oorzaak van mijn voeding, maar hetgeen dan met het brood gebeurt, dat is mijn voeding; dat is niets anders dan mijn voeding zelve, zoodra ik hetgeen objektief gebeurt in verband beschouw met mijn belang; dus, met andere woorden, het waardeer.'

${ }^{3}$ cf. Pierson, A. (1882), op. cit. p. 284.

${ }^{4}$ cf. Pierson, A. (1882), op. cit. p. 284-285, 'Een der permanente voorwaarden van het bestaande is, dat met de stoffen, waaruit een bepaald voorwerp is samengesteld, zoodra zij in mijn lichaam gebracht zijn, iets gebeurt. Dat, wat gebeurt, waardeer ik, en dat gewaardeerde feit noem ik het gevolg. Wat in mijn maag gebeurt, kan ook zeer wel daarbuiten gebeuren. Dan zou ik het niet waardeeren; dan zou het zoogenaamde gevolg uitblijven! Dit toont immers duidelijk, dat er in de werkelijkheid niets aanwezig is, dan aan een tijdsorde kan doen denken.' 
zijn, dan zou er wel sprake zijn van een tijdsorde of vaste volgorde. Echter, als men jets beschouwt op grond van een belang, dan ligt daar impliciet een waardering in besloten. 'Belang' en 'waardering' zijn twee woorden voor dezelfde zaak. ${ }^{1}$ Met andere woorden: ook subjectieve waarderingen impliceren geen tijdsorde.

De slotsom van dit onderzoek (....) mag op deze wijze worden opgemaakt. Het begrip 'oorzaak' heeft geene theoretische waarde. Niemand kan er den juisten inhoud van aangeven. In de praktijk is het onmisbaar, maar zijne aanwending wordt terstond gevaarlijk, wanneer het nog voor iets anders, voor iets meer dan een louter, praktisch begrip, dan een "hulpmiddel der voorstelling" aanziet. Zuiver theoretisch kan het niet gehandhaafd worden, zonder een vreemd, een mystiek of een bovennatuurlijk element in de wetenschap binnen te leiden. ${ }^{2}$

Samengevat komt de argumentatie van Pierson in hoofdlijnen op het volgende neer. Spruyts Proeve is de aanleiding van Piersons Wijsgeerig onderzoek. Kritische prolegomena van esthetiek. Pierson beschouwt Spruyt als de belangrijkste representant in Nederland van het kantiaanse rationalisme. Deze denkwijze acht Pierson echter een belemmering om een adequate esthetica te formuleren.

Spruyt had het lot van zijn causaliteitsleer, en vooral de opvatting dat het causaliteitsbeginsel a priori is, verbonden aan Kants bewijsvoering bij de tweede analogie der ervaring. Pierson rekent af met Spruyts leer door rechtstreeks lacunes in Kants bewijsvoering van deze analogie bloot te leggen.

Algemeen gesteld komen de twee kernpunten van Piersons Kant-kritiek neer op het volgende. Ten eerste: Kant had met de tweede analogie der ervaring de stelling verdedigd dat verschijnselen volgens een vaste regel a priori in de tijd worden geordend. Dit houdt in dat de betekenis van de notie 'causaliteit' of 'oorzakelijk verband' gelijk wordt gesteld aan 'vaste volgorde' in de tijd; hetgeen Pierson onjuist acht. En ten tweede: in tegenstelling tot Kant is Pierson van mening dat het geheel overbodig is te menen dat het causaliteitsbeginsel een denkvorm is. Uit de onderzoekpraktijk blijkt namelijk dat men daar aan zo'n rechtvaardiging geen behoefte heeft. De gedachte dat voor ieder verschijnsel een oorzaak is te vinden, ontstaat door gewoonte; dat laatste is een voldoende basis om wetenschap te beoefenen.

Eén van Piersons belangrijkste specifieke argumenten tegen Kants bewijsvoering bij diens tweede analogie is dat Kant aan voorstellingen kennelijk al objectiviteit verleent nog voordat zij door de causaliteitswet worden verbonden. Echter, Kant

ef. Pierson. A. (1882), op. cit. p. 285-286, 'Op grond van het aangevoerde moet ik dan ook evenzeer ontkennen, dat de wetenschap ooit tot apodiktisch voorspellen van het concrete in staat zou zijn. (...) ... een niet zeer imposante verkiaring, want dit hypothetische oordeel is louter een tautologie; waarbij dan nog deze andere tautologie kan worden gevoegd: gesteld dat mijne belangen niet veranderen, dan verandert ook mijne waardeering van die eigenschappen of van dat verschijnsel niet.'

${ }^{2}$ cf. Pierson, A. (1882), op. cit. p. 299-300. 
had betoogd dat voorsteilingen juist door de causaliteitswet een objectief karakter krijgen. Pierson vraagt zich dan ook af wat de meerwaarde van deze wet zou moeten zijn. Hij leidt uit zijn Kant-kritiek af dat Kant niet heeft bewezen dat het causaliteitsbeginsel a priori is. Bovendien leidt hij daaruit af, dat men, zolang men de betekenis van de notie 'oorzaak' nog niet heeft vastgesteld, het causaliteitsbeginsel alleen moet zien als een hulphypothese. Alleen door het bepalen van de betekenis van de notie 'oorzaak' kan men de aard van die hypothese bepalen.

Na zijin kritiek op Kant gaat Pierson vervolgens na wat de notie 'oorzaak' betekent. Hij concludeert dat Hume's omschrijving van deze notie voor verbetering vatbaar is. De betekenis van de notie 'oorzaak' komt voor Pierson neer op een relatie tussen twee feiten. Door herhaalde waarneming ontstaat de gewoonte om deze relatie als onveranderlijk te beschouwen. Op grond van deze onveranderlijkheid weet men dat het tweede feit bestaat als men het eerste feit heeft waargenomen. Bovendien wijst Pierson er op dat Hume, Kant en Spruyt ten onrechte hadden aangenomen dat de notie 'causaliteit' gelijk is aan 'vaste volgorde' in de tijd tussen waargenomen objecten. Bij het verklaren van verschijnselen moet men uitgaan van hypothetische natuurwetten. Zulke wetten werken constant. 'Causaliteit' houdt voor Pierson niets anders in dan zulke natuurwetten. 'Oorzaken' en 'gevolgen' zijn bovendien twee verschillende namen voor één en hetzelfde: natuurwetten. Als men een onderscheid maakt tussen 'oorzaak' en 'gevolg' suggereert men ten onrechte alsof het om twee afzonderlijk bestaande zaken zou gaan, terwijl het in feite alleen twee aspecten van hetzelfde betreft, wederom natuurwetten. 'Oorzaak' en 'gevolg' vallen samen, omdat de natuurkrachten en wal zulke krachten bewerken één proces vormen. Pierson leidt daaruit af dat het spreken in termen van 'oorzaken' betekenisloos is.

Pierson rekent vervolgens af met een misvatting die aan het denken over 'oorzaken' ten grondslag ligt. Deze misvatting, die zijn oorsprong vindt bij Hume, komt er op neer dat er relaties tussen feiten zouden bestaan. Pierson acht dit onmogelijk. Er bestaan alleen relaties tussen begrippen; hieruit leidt Pierson vervolgens af dat daarmee ook Hume's opvatting dat men door het in verband brengen van feiten, dat volgens Hume zou berusten op de relatie van oorzaak en gevolg, kennis zou kunnen uitbreiden. Bovendien moet de misvatting dat er relaties tussen feiten bestaan tot de verkeerde conclusie leiden dat 'oorzakelijk verband' een tijdsorde zou impliceren. Omdat er alleen relaties tussen begrippen bestaan, komt voorspellen uiteindelijk neer op een explicatie van wat reeds in een bepaald begrip ligt besloten. Met een volgen in de tijd heeft dit niets te maken.

Eén van de belángrijkste conclusies die Pierson aan zijn kritiek op Kant, Spruyt en Hume verbindt is dat de notie 'oorzaak' voor wetenschappelijke doeleinden geen meerwaarde biedt. En, als men aan deze notie meer dan alleen een praktische betekenis geeft, dan kan dit bovendien leiden tot ongewenste mystificaties.

Terecht had Van der Wijck in 1898 opgemerkt dat Piersons sterke punt is gelegen in het opsporen van voetangels en klemmen in argumentaties. Dit blijkt niet alleen uit zijn kritiek op Kant, maar ook uit zijn beschouwingen naar aanleiding van Spruyt 
en Hume. Tevens kan men opmerken dat in Piersons "analytische methode" betekenisvragen en aandacht voor taaluitingen centraal staan. Vanuit dit perspectief levert Pierson fundamentele kritiek op de benaderingen van Kant, Hume en Spruyt. Voorts kan men er op wijzen dat Pierson door zijn aandacht voor taal en betekenis in vergelijking met Opzoomer, Van der Wijck, Spruyt en Huet als een atypisch denker kan worden gezien, als een vernieuwer in methodologisch opzicht én als een vroege voorloper van de 20 ste eeuwse taalanalytische oriëntatie in de filosofie. Als een interessant voorbeeld hiervan kan worden verwezen naar Piersons beschouwing over de functie van de lidwoorden 'de' en 'een'.

Net als bij Spruyt werd opgemerkt, kan ook bij Pierson worden geconstateerd dat de discussie over causaliteit in een breder historisch kader wordt geplaatst. Hoewel de direcle aanleiding voor Piersons onderzoek Spruyts Proeve was, acht hij het effectiever om de bijl aan de wortels van Spruyts causaliteitsleer te slaan: Kants tweede analogie der ervaring. Uit historiografisch oogpunt kan men daar bovendien aan toevoegen dat de argumentatieve functie van Piersons Kant-kritiek in latere beschouwingen over Piersons filosofische werk [Boersema, 1924; De Graaf, 1962; Van Dooren, 1983] nauwelijks naar voren komt. Een verklaring hiervoor moet worden gezocht in de gebruikte onderzoekmethoden; deze zijn voornamelijk biografisch gericht [Boersema, 1924; De Graaf, 1962; Van der Veen, 1997] of zijn gericht op het typeren van Piersons opvattingen; dat wil zeggen, de doxografische benadering [Van Dooren, 1983]. De in dit onderzoek toegepaste probleemgerichte benadering laat wél duidelijk de argumentatieve functie van Piersons Kant-kritiek zien.

Piersons argumentatiestrategie is volgens twee lijnen opgezet: formele kritiek op redeneringen en kritiek op de betekenis die aan begrippen en uitspraken wordt toegeschreven. De eerste vorm van kritiek komt duidelijk naar voren in zijn commentaar op de relatie tussen Kants tweede analogie van de ervaring en de daaropvolgende bewijsvoering; Kant bewees in Piersons ogen niet wat hij wilde bewijzen. De tweede vorm van kritiek wordt duidelijk uit zijn analyse van de opvattingen van Kant, Hume en Spruyt. Belangrijke voorbeelden hiervan zijn Piersons kritiek op de onderstelling dat er relaties tussen feiten zouden bestaan, en zijn kritiek op de onderstelling dat de notie 'oorzakelijk verband' een tijdsorde impliceert.

Piersons conclusies ten aanzien van de betekenis en funclie van de notie 'oorzaak' zijn voornamelijk negatief en pragmatisch. Dit blijkt uit Piersons opvatting dat deze notie (en het causaliteitsbeginsel) voor wetenschappelijke doeleinden waarde weinig heeft. Het kan ten hoogste als een hulphypothese worden gezien. Het meer dan praktisch gebruik van deze notie kan zelfs gevaarlijk zijn, omdat het tot allerlei myslificaties kan leiden.

Zowel Pierson als Huet komen tot de slotsom dat de notie 'oorzaak' voor wetenschappelijk gebruik weinig nut heeft. Bovendien kan men opmerken dat Pierson, door zijn nadruk op de rol van natuurwetten om verschijnselen te verklaren, en door zijn conclusic dat aan de notic 'oorzaak' in de wetenschap bij voorkeur slechts een praklische betekenis moet worden toegeschreven, als één van de eerste Nederlandse 
vertegenwoordigers van de "wetenschappelijke wending" in de filosofie kan worden gezien.

Ten aanzien van Pierson argumentatiestragegie kan nog het volgende worden opgemerkt. Waar bijvoorbeeld Spruyt, Van der Wijck en Opzoomer soms autoriteitsargumenten gebruiken, blijkt dat Pierson hieraan kennelijk geen behoefte heeft. Net als Huet is Pierson zeker geen "navolger van", maar een zelfstandig denker.

Ten slotte: Pierson ziet maar weinig heil in het aannemen van "logische elementen" in het denken, hetgeen duidelijk blijkt op zijn kritiek op Kant. Hierdoor kan men spreken van een sterke familiegelijkenis tussen de opvattingen van Pierson, Opzoomer, Van der Wijck en Huet.

Piersons Wijsgeerig onderzoek kon de filosofische gemoederen maar weinig beroeren. Het voorwerp van zijn niet mis te verstane kritiek, Spruyt, reageert, men kan het niet anders zeggen, flauw. Het enige wat hij zes jaar later over zijn lippen kan krijgen in de marge van een overzichtsartikel in Archiv für die Geschichte der Philosophie, getiteld Die Geschichte der Philosophie in Holland von 1878 bis 1888 (1888), is dat voor Pierson Spruyts Proeve kennelijk een steen des aanstoots vormt. En nog weer later, veertien jaar na het verschijnen van de Proeve, levert J.D. Bierens de Haan terloops kritiek op Piersons causaliteitsleer in de brochure De psychische afkomst van het oorzaakbegrip (1895a), en wel op diens stelling dat het volgen in de tijd uit de notie 'oorzakelijk verband' geëlimineerd zou moeten worden. Bierens de Haan is het hier niet mee eens, aangezien het volgens hem bij causaliteit altijd gaat om het volgen van bepaalde toestanden in de tijd. Hij is van oordeel dat de tijdsopvolging een zeer reëele en onmisbare gedachte-inhoud vormt, en dat met de ontkenning van de realiteit des tijds in ons denken, het geheele begrip van geschieden en worden en evolutie vernietigd (is).' Bierens de Haans kritische kanttekening heeft overigens niet tot een discussie met Pierson geleid, wellicht omdat de laatste kennelijk tijd te kort kwam; Pierson stierf namelijk kort daarna, in 1896.

Met Wijsgeerig onderzoek is echter niet het laatste woord in de causaliteitsdiscussies gesproken. Uit het laatste hoofdstuk van deze studie zal blijken dat over de functie van het causaliteitsbegrip en de rol van logische elementen in het causale denken door Heymans principieel verschillend wordt gedacht.

'cf. Bierens de Haan, J.D. (1895a). De psychische afkomst van het oorzaakbegrip, p. 30. 
Heymans is tegenwoordig beter bekend als psycholoog dan als filosoof. Dit is begrijpelijk, omdat hij een zware stempel heeft gedrukt op de psychologiebeoefening in Nederland van voor de Tweede Wereldoorlog. ${ }^{3}$ Als eerste in Nederland had hij in 1892 naar voorbeeld van Wilhelm Wundt een laboratorium ingericht voor experimenteel onderzoek op het gebied van de psychologie. Heymans' belangstelling voor experimenteren blijkt al duidelijk uit de titel van zijn inaugurele rede uit 1890, getiteld Het experiment in de philosophie; deze belangstelling kwam echter vooral tot uitdrukking in het onderzoek dat hij later verrichtte op psychologisch gebied; experimenteel onderzoek dat hem wereldberoemd maakte.

Echter, veel van zijn tijdgenoten, zowel nationaal als internationaal, hadden ook vooral grote waardering voor hem als filosoof, en wel voornamelijk als de auteur van het meermalen herdrukte Einführung in die Metaphysik auf Grundlage der Erfahrung (1905), van de Einführung in die Ethik auf Grundlage der Erfahrung (1914) of van zijn methodologische hoofdwerk en leerboek Gesetze und Elemente des Wissenschaflichen Denkens (1890-1894), waarvan drie herdrukken verschenen: in $1905,1915 \mathrm{en}$ in 1923.

Toen Heymans in 1890 als opvolger van Van der Wijck de Groningse leerstoel in de geschiedenis van de filosofie, logica, metafysica en in de zielkunde aanvaardde, had hij zijn sporen in de wetenschap en filosofie reeds verdiend. Nadat hij in 1880 bij de Leidse hoogleraar Land op het proefschrift Karakter en methode der staathuishoudkunde in de politieke economie gepromoveerd was, promoveerde hij in 1882 in de filosofie op de dissertatie Zur Kritik des Utilismus aan de Universiteit van Freiburg. Vervolgens werd Heymans in 1883 als privaatdocent in de filosofie toegelaten aan de Rijksuniversiteit Leiden. In de zeven jaar tot aan zijn benoeming tot hoogleraar in 1890 hield hij zich uitvoerig bezig met ethiek en Kants kennisleer. Dit blijkt uit een serie artikelen die hij in die tijd publiceerde. ${ }^{2}$ Aan het einde van deze periode moet Heymans, naar aanleiding van een prijsvraag die het Leidse Stolpiaansch Legaat in 1888 had uitgeschreven, ook zijn begonnen met de Schets eener kritische geschiedenis van het causaliteitsbegrip in de nieuwere wijsbegeerte. Net als Spruyts Proeve in 1879, werd de Schets met goud bekroond; het werk werd vervolgens in 1890 gepubliceerd. Heymans' Schets luidt de laatste episode in van de causaliteitsdiscussies in Nederland in de tweede helft van de 19de eeuw.

' Zie hiervoor bijvoorbeeld het themanummer van De psycholoog (1992) getiteld 100 jaar psychologie in Nederland (1892-1992), dat geheel is gewijd aan Heymans als psycholoog.

${ }^{2}$ Zie: Heymans, G. (1883), (1886), (1888), (1889a) en (1889b). 
Het is opmerkelijk dat Heymans in de reeks artikelen die hij in de jaren tachtig publiceerde vrijwel niet ingaat op het causaliteitsvraagstuk. Dit maakt hij meer dan goed met de Schets, en ook met het tweede deel van zijn Gesetze und Elemente des wissenschaftlichens Denkens (1894). In beide werken formuleerde hij een causaliteitsleer waaraan hij, ondanks veel kritiek, altijd zou blijven vasthouden; dit blijkt namelijk uit veel van zijn latere filosofische geschriften.'

In dit hoofdstuk staat Heymans' causaliteitsleer centraal zoals hij deze in de Schets heeft geformuleerd. Daarnaast komen de "vroege" filosofische kritieken op Heymans' leer aan de orde: de kanttekeningen van het Curatorium van het Stolpiaansch Legaat zélf en de kritieken van H.J. Betz, D.G. Jelgersma en G.J.P.J. Bolland. Benevens komen de discussies aan de orde die zich naar aanleiding van deze kritieken ontsponnen.

De "latere" kritieken van de natuurkundigen J. Clay, Ph. Kohnstamm en J.D. van der Waals jr. op Heymans' causaliteitsleer en de discussies die daarover rond de jaren twintig van deze eeuw ontstonden, worden in deze studie buiten beschouwing gelaten, omdat dit buiten de doelstelling van dit onderzoek valt.

De hoofdgedachten die Heymans in de Schets over causaliteit ontvouwt, vindt men dikwijls letterlijk terug in zijn latere Gesetze und Elemente. Dat werk wordt in de navolgende behandeling daarom alleen betrokken voor zover het, zo te zeggen, recente aanvullingen of verduidelijkingen op Heymans' causaliteitsleer uit de Schets betreft.

Waar het in de Schets om gaat wordt duidelijk in het slotwoord. Daar merkt Heymans op dat wij hebben gezien hoe de ontdekking van Hume als een stormwind was neergekomen onder de causale begrippen; hoe zij alles wat men dienaangaande in de loop der tijden had ontdekt door elkaar had geworpen, en de wezenlijkste bestanddelen van het causale denken onder de puinhopen had bedolven. De causale axioma's die door Bacon en Locke even onvoorwaardelijk als door Descartes en Leibniz waren erkend, werden na Hume gewantrouwd of geheel verwaarloosd, door Kant en Schopenhauer niet minder dan door Mill en Spencer; de ontdekking van Hamilton bleef dientengevolge onopgemerkt; en de onderscheidende pogingen om het causaliteitsprobleem op te lossen, steunende op en getoetst aan een onvolledig feitenmateriaal, konden niet anders dan onvruchtbaar blijven. Echter, zo merkt hij verder op: aan deze verwarring nu schijnt langzamerhand een einde te komen. De wetenschap begint zich te herstellen van den doorstanen schok; zij komt op nieuw tot het inzicht dat gegeven feiten niet verwaarloosd mogen worden, ook al zijn zij onverklaarbaar. Zoo wordt dan het logische karakter der causale betrekking en de wezenlijke betekeenis der causale axioma's meer en meer erkend; en met die erkenning gaat hand in hand de steeds algemeenere aanvaarding der theorie van Hamilton, volgens welke het causale denken berust op de apriorische overtuiging van de blijvende identiteit der dingen. Over de vraag, hoe die overtuiging op hare

'Zie: Heyınans, G. (1902), (1905), (1918) en (1923). 
beurt verklaurd e'n gerechtvurdigd moet worden, loopen vorzeker de denkbelden nog zeer ver uiteen; intusschen het is reeds veel waard, wann'er zich ten unnzic"n van de verschijnselen zelve en van hun onmiddellijken gemeenschappelijken grondslag de meeningen beginnen te fixeeren. 'Kortom: Hume's ontdekking en zijn oplossing van het causaliteitsvraagstuk hadden onder filosofen grote verwarring gezaaid. Hierdoor kon Hamiltons ontdekking, die volgens Heymans de slcutel vormt voor de oplossing van dit vraagstuk, lange tijd niet naar waarde geschal worden.

Historisch gezien is de oorsprong van Heymans' belangstelling voor Hamilton overigens moeilijk te traceren. In Nederland werd voorafgaand aan Heymans' Schets vrijwel niets over Hamilton gepubliceerd. Alleen Van der Wijck gaat in het artikel Ik en niet-ik (1866) op deze denker in, waarbij hij echter allecn de kritick van J.S. Mill (1865) op Hamilton bespreekt; op het causaliteitsvraagstuk wordt in dat artikel niet ingegaan. Wel is het mogelijk dat Van der Wijcks artikel Heymans op hel spoor van Hamilton heeft gebracht. Een andere mogelijkheid is dat Land Heymans tijdens zijn sludie filosofie te Leiden op Hamiltons causaliteitsleer had gewezen. Hoe deze receptiegeschiedenis in clkaar steekt is ecn nader onderzoek waard.

Heymans formulcert in de $S$ chets allereerst het causaliteitsvraagstuk. Vervolgens schrijft hij aan Hume de ontdekking van het causaliteitsvraagstuk toe. Hume's psychologische oplossing van dat vraagstuk grijpt hij aan om een aantal ernstige tekortkomingen daarvan te constateren. Na tc hebben afgerekend met Hume, ontvouwt Heymans een op Hamiltons ideeën geënte causaliteitsleer. De uitgangspunten en consequenties van die leer roept bij een aantal denkers echter meer vragen op dan die theorie beantwoordt. Het Curatorium van het Stolpiaansch Legaat plaatst als eerste vraagtckens bij Heymans' leer, waar Heymans direct op repliceert. Toch blijkt deze repliek niet afdoende te zijn. Heymans' leer bevat kennelijk zoveel discutabele elementen dat achtereenvolgens Betz, Jelgersma en ten slotte ook Bolland hun kans schoon zien om die leer vanuit verschillende gezichtspunten met ferme kritiek te bestoken. Voor Heymans is dit weer aanleiding om zijn leer tegen deze aanvallen te verdedigen.

\section{HET CAUSALITEITSVRAAGSTUK VOLGENS HEYMANS}

Filosofie is geen bloote hersengymnastiek, maar een wetenschap die er op is gericht om waarheid te vinden, zo betoogt Heymans. Filosofie is wetenschappelijke philosophie. ${ }^{2}$ En aangezien het in de wetenschap gebruikelijk is om ieder onderzoek

${ }^{1}$ cf. Heymans, G. (1890a), Schets eener kritische geschienis van het causaliteitsbegrip in de nieuwere wijsbegeerte, p.259-260.

${ }^{2}$ cf. Heymans, G. (1890a), op. cit. p. 4, De philosophie is nu eenmaal geen bloote hersengymnastiek; zij is welenschap en wil waarheid.' 
te beginnen met een heldere formulering van de probleemstelling, gebeurt dit ook in de Schets.

Over den inhoud der verschijnselen van het causale denken heerscht geen strijd, zo betoogt Heymans. Het bestaan van een causaliteitsprobleem wordt door geen ernstig onderzoeker ontkend, en ook over de wijze waarop dat probleem moet worden gesteld bestaat in de grond der zaak geen verschil. De strijd der philosophische scholen begint eerst bij de vraag, in welke theorie de oplossing van dat probleem moet worden gezoch. ${ }^{1}$

Het feit van het causale denken dat men, op grond van het herhaald waarnemen van het onmiddellijk volgen van een bepaald verschijnsel nadat een bepaald ander verschijnsel is opgetreden, aanneemt dat er een noodzakelijk verband tussen die twee verschijnselen bestaat ${ }^{2}$, acht Heymans al voldoende om ons van 't besiaan van een causaliteitsprobleem te overtuigen. ${ }^{3}$ Immers, onmiddellijk rijst de vraag: welken grond hebben wij, om een noodzakelijk verband tusschen de gegeven verschijnselen aan te nemen? ? $^{4}$ it de inhoud of de gegevens van de waarneming kan men zo'n noodzakelijk verband niet afleiden. Men kan daaruit ten hoogste afleiden dat bepaalde verschijnselen regelmatig samengaan of elkander volgen. Echter, als men heeft waargenomen dat een bepaald verschijnsel tot dusver altijd is gevolgd door een bepaald ander verschijnsel, concludeert men toch dat het tweede verschijnsel noodzakelijk zal volgen als het eerste optreedt. Met andere woorden: het na elkaar volgen van verschijnselen (sequentie) wordt getransformeerd tot het uit elkaar volgen van verschijnselen (consequentie). Heymans acht het echter onmogelijk om deze overgang te verklaren door een beroep te doen op de inhoud onzer waarnemingen. ${ }^{5}$

Als men een bepaald verschijnsel als de oorzaak voor een bepaald ander verschijnsel beschouwt, dan constateert men dat er een relatie of betrekking bestaat die men noch heeft waargenomen noch uit de inhoud van de waarneming heeft

${ }^{1}$ cf. Heymans, G. (1890a), op. cit. p.8.

${ }^{2}$ ef. Heymans, G. (1890a), op. cit. p. 8-9, 'In bepaalde gevallen, o.a. wanneer wij meermalen een verschijnsel B onmiddellijk na een ander verschijnsel A hebben waargenomen, nemen wij aan dat er tusschen die beide verschijnselen een noodzakelijk verband bestaat. Dat wil zeggen, wij nemen aan dat, het verschijnsel A (de oorzaak) eenmaal gegeven zijnde, het niet ander kon of verschijnsel B (de werking) moest daarna komen.'

${ }^{3}$ ef. Heymans, G. (1890a), op. cit. p.9.

cf. Heymans, G. (1890a), op. cit. p.9.

s cf. Heymans, G. (1890a), op. cit. p. 9-10, 'In de gegevens der waarneming is zulk een grond niet te vinden; zij kunnen ons ten hoogste leeren dat verschillende verschijnselen, voor zoover onze ervaring reikt, regelmatig samengaan of elkander opvolgen, - niet dat wanneer het eene verschijnsel gegeven is, ook het andere noodzakelijk waar te nemen moet zijn. (....) Wij hebben waargenomen dat B op A volgt, een-, tien-, duizendmaal, - en wij concludeeren dat B met noodzakelijkheid op A volgen moet. Uit de gegeven sequentie maken wij een consequentie; het "volgen op iets" wordt tot een "volgen uit iets" verwerkt. En wij mogen den inhoud onzer waarnemingen analyseeren zoover wij willen, het gelukt ons niet daarin de elementen te ontdekken, wier aanwezigheid in onze causale oordelen zich toch onmogelijk laten wegredeneeren.' 
afgeleid. Men kan zich zelfs niet voorstellen hoe men zo'n relatie uit het waarnemen of uit de inhoud van waarnemingen zou kunnen afleiden. Men kan zich dan ook afvragen of er nog andere gegevens naast de waarnemingen zijn waar men deze relatie uit afleidt. Van zulke andere gegevens is men zich echter niet bewust; evenmin acht men het begrijpelijk dat men zich hiervan bewust zou kunnen zijn. Immers, als uit het herhaald waarnemen van het regelmatig volgen van verschijnselen een niet waargenomen oorzakelijk verband wordt afgeleid, dan gebeurt dat onmiddellijk. Men vraagt zich echter niet af op welke gronden men deze afleiding logisch kan rechtvaardigen. Deze afleiding vindt bovendien plaats zonder bewust gebruik te maken van andere gegevens dan de gegevens van de waarneming. ${ }^{1}$ Deze overweging leidt tot de volgende vragen: welke zouden die andere gegevens kunnen zijn? Hoe zouden zij, van elders komende dan van de objecten onzer causale oordeelen zelve, een voldoenden grond kunnen opleveren om over betrekkingen tusschen die objecten een oordeel uit te spreken? Het gelukt ons niet op deze vragen een bevredigend antwoord te vinden. ${ }^{2}$

Als deze feiten van het causale denken worden erkend, dan wordt ook erkend dat er een causaliteitsprobleem bestaat. Omdat mensen redelijke wezens zijn, zo betoogt Heymans, wil men de overtuigingen die men er op na houdt op redelijke gronden verklaren. Als men zulke gronden niet kan vinden, dan zal men zulke overtuigingen vaarwelzeggen. Echter, ook al wordt ingezien dat voor de overtuiging dat verschijnselen noodzakelijk met elkaar zijn verbonden geen redelijke grond gevonden kan worden, wordt toch aan deze overtuiging vastgehouden. Vandaar de verwondering, welke de verschijnselen van het causale denken, zoodra men zich van hun inhoud rekenschap geeft, bij de nadenkende opwekken; van de behoefte om die verschijnselen te verklaren. Die verklaring te leveren, den strijd tusschen meeningen over het denken en de feiten van het denken op te lossen, is in de eerste plaats de taak der causaliteitstheorie. ${ }^{3}$

Eén en ander leidt voor Heymans tot het formuleren van twee verschillende causaliteitsvraagstukken: hetpsychologische en het filosof ische causaliteitsvraagstuk.

${ }^{\prime}$ cf. Heymans, G. (1890a), op. cit. p.10, 'Het blijkt derhalve dat, zoo vaak wij een verschijnsel de oorzaak noemen van een ander verschijnsel, wij met volkomen vetrouwen het bestaan eener betrekking constateeren, die wij niet hebben waargenomen of uit waarnemingen afgeleid, en waarvan wij ons zelfs niel kunnen voorstellen hoe wij ze zouden kunnen waarnemen of uil welke waarnemingen wij ze zouden kunnen afleiden. Beschikken wij dan misschien in de aangewezen gevallen nog over andere gegevens naast de waarnemingen? Wij zijn ons niet bewst dat dit het geval zou zijn, noch ook zien wij in, hoe dit het geval zou kunnen zijn. Wanneer wij van de waargenomen regelmatige successie concludeeren tot het niet waargenomen oorzakelijk verband, dan doen wij dit onmiddellijk, zonder ons rekenschap te geven van gronden die deze stap logisch zouden kunnen rechtvaardigen, zonder met bewustzijn gebruik te maken van andere gegevens dan die, welke in de waarnemingen waarvan wij uitgaan liggen opgesloten.'

${ }^{2}$ ef. Heymans, G. (1890a), op. cit. p.10.

${ }^{3}$ cf. Heymans, G. (1890a), op. cit. p. 11. 
De formulering van het psychologische causaliteitvraagstuk luidt als volgt: hoe is het te verklaren dat in ons bewustzijn uit bepaalde waarnemingen de zekerheid ontstaat van een niet waargenomen noodzakelijk verband tusschen de objecten dier waarnemingen?' Met andere woorden: hoe kan men verklaren dat men er op grond van waarnemingen vast van overtuigd raakt, dat er tussen wat men waarneemt een niet-waarneembaar noodzakelijk verband is. Ook al zou de verwerking der waarnemingsgegevens geheel door associatiewetten - psychische grondwetten en grondkrachten - verklaard kunnen worden, dan wordt hiermee nog niet het volgende probleem opgelost. Het blijkt namelijk dat men niet alleen de subjectieve overtuiging of het subjectieve gevoel van zekerheid bezit dat er noodzakelijke verbanden tussen verschijnselen zijn, maar het blijkt ook dat latere waarnemingen de verwachtingen die berusten op zulke subjectieve overtuigingen altijd bevestigen. Er bestaat kennelijk een strenge overeenstemming tussen psychische en physische verschijnselen; dat wil zeggen, er zou een overeenstemming bestaan tussen de verwachting of het besef dat gelijke omstandigheden tol gelijke gevolgen leiden enerzijds, en bepaalde physische verschijnselen anderzijds. Het laatste wil zeggen: het feit dat de waarneming verwachtingen ook bevestigt. ${ }^{2}$ Men kan zich dan afvragen: vanwaar die strenge overeenstemming tusschen psychische en physische verschijnselen? Of: hoe koint het dat onze subjectieve, voor zoover wij zien kumnen niet aan den inhoud der waarneming ontleende zekerheid door latere waarnemingen nooit wordt gelogenstraft ? $^{3}$ Met andere woorden: hoe kan worden verklaard dat de subjectieve zekerheid van het bestaan van een noodzakelijk verband tussen verschijnselen, die niet berust op waarneming, toch altijd wordt bevestigd. Tussen de processen van het denken en de verschijnselen der buitenwereld moet daarom cen parallellie bestaan, aldus Heymans. Het is echter onduidelijk waarom beide zo verschillende processen parallel zouden zijn. Dit parallellisme vormı de kern van het filosofische causaliteitsvraagstuk: hoe is het te verklaren dat de gegeven verschijnselen zich richten naar de wetten, door het denken met de voorstelling dezer verschijnselen verbonden? Of: welke zeker-

${ }^{1}$ cf. Heymans, G. (1890a), op. cit. p. 11.

${ }^{2}$ cf. Heymans, G. (1890a), op. cit. p.12, 'Gesteld nu evenwel dat dit psychologische causaliteitsprobleem was opgelost, dat het was gelukt de verwerking der waarnemingsgegevens in den geest uit psychische grondwetten en grondkrachten te verklaren, dan nog zou er een tweede probleem overblijven. Inmers, de ervaring leert, niet slechts dat wij aangaande het bestaan van noodzakelijk verband subjectief hel gevoel van zekerheid bezitten, maar ook dat de verwachtingen op die zekerheid gebaseerd, door latere waarnemingen worden bevestigd. Wanneer ik een stuk blauw lakmoespapier, in een zure vloeistof gebracht, zich rood zie kleuren dan constateer ik vooreerst in mijn bewustzijn de overtuiging dat die kleuring een noodzakelijk gevolg was van de indompeling; maar wanneer ik vervolgens uit dat onderstelde noodzakelijke verband afleid dat onder gelijke omstandigheden die kleuring altijd zal ontstaan, dan wordt deze voorspelling door latere ervaring ten volle bevestigd. (....) Klaarblijkelijk ligt in deze feiten een nieuw probleem: vanwaar die strenge overeenstemming tusschen psychische en physische verschijnselen.'

${ }^{3}$ cf. Heymans, G. (1890a), op. cit. p. 12. 
heid hebben wij dat de toekomst onze causale verwachtingen niet zal logenstraffen?' Met andere woorden: is er cen garantie dat toekomstige waarnemingen de verwachting altijd zullen bevestigen dat er tussen bepaalde verschijnselen noodzakelijke causale verbanden bestaan?

Met deze formulering van het filosofische causaliteitsvraagstuk geeft Heymans overigens al een indicatie van de richting waarin de oplossing van dat vraagstuk gezocht moet worden. Immers, de formulering dat voorstellingen van verschijnselen zich richten naar de wetten van het denken suggereert reeds dat bepaalde elementen a priori in het denken besloten liggen. De door Heymans geformuleerde twee causaliteitsvraagstukken sluiten bovendien nauw aan bij de twee benaderingswijzen die in de discussies reeds naar voren zijn gekomen: de ontstaans- en geldigheidsbenadering.

Heymans' tweevoudige formulering van het causaliteitsvraagstuk speelt een belangrijke rol in zijn benadering van de historische ontwikkeling van dit onderwerp, zoals hij dat in de Schets uiteen zet. Voor het doel van deze studie zijn daarbij vooral twee hoofdlijnen van belang: Heymans' kritiek op Hume's oplossing van het psychologische causaliteitsvraagstuk en Heymans' uitwerking van Hamiltons postulaat.

\section{HEYMANS' KRITIEK OP HUME}

Heymans schrijft aan Hume de ontdekking van het psychologische causaliteilsvraagstuk toe: eerst Hume (.....) kwam tot het inzicht, dat wij in onze causale oordelen meer over verschijnselen zeggen dan wij in de verschijnselen hebben waargenomen, en werd zoo de ontdekker van het causaliteitsprobleem. ${ }^{2}$ Met andere woorden: Hume's ontdekking komt neer op het inzicht dat men met causale uitspraken of causale oordelen meer zegt dan op grond van alleen het waarnemen van verschijnselen mogelijk is. Hume's analyse van het causaliteitsvraagstuk had hem, zo betoogt Heymans, tot de conclusie gebracht dat het herhaald waarnemen van het regelmatig samengaan van Iwee verschijnselen tot de overtuiging leidt dat er een noodzakelijke relatie tussen beide verschijnselen is. ${ }^{3}$ De uitkomst van Hume's onderzoek was echter ogenschijnlijk strijdig met diens eigen beginsel, namelijk dat overtuigingen niet meer kunnen inhouden dan logisch ligt besloten in de waarnemingen waaruit zij zijn ontstaan. ${ }^{4}$ Ook Hume had deze tegenstrijdigheid opgemerkt, en om dit op te lossen had hij een antwoord trachten te vinden op de volgende twee vragen, in Heymans'

${ }^{1}$ cf. Heymans, G. (1890a). op. cit. p. 12.

${ }^{2}$ cf. Heymans, G. (1890a), op. cit. p. 113.

${ }^{3}$ cf. Heymans, G. (1890a), op. cit. p. 140, 'Uit de waarncming dat twee verschijnselen rege/matig samengaan ontstaat de overtuiging dat die verschijnselen noodzakelijk verbonden zijn, - ziedaar het positieve resultaat van Hume's onderzock.'

t cf. Heymans, G. (1890a), op. cit. p. 140. 
woorden: wat is eigenlijk eene overtuiging? Wat nemen wij in ons bewustzijn waar, wanneer wij zeggen van ieis overtuigd ie zijn?

In hoofdzaak komt Hume's antwoord neer op een poging om het psychologische causaliteitsvraagstuk geheel door associatiewetten te verklaren. Heymans grijpt zijn weergave van Hume's antwoord aan om te concluderen dat noch het psychologische noch het filosofische causaliteitsvraagstuk door Hume's benadering worden opgelost.

\section{Hume's oplossing en Heymans' kritiek}

De hypothese van voorstellingsintensiteit was, zo betoogt Heymans, Hume's antwoord op de vraag wat de notie 'overtuiging' inhoudt. Het gevoel van overtuiging komt neer op de ondervinding van de bizondere kracht en levendigheid eener voorstelling; die kracht en levendigheid (of intensiteit) van een voorstelling leiden er toe dat men van zo'n voorstelling overtuigd is. ${ }^{2}$ Deze hypothese zou ook een verklaring moeten bieden voor het ontstaan van causale overtuigingen. Zulke overtuigingen komen er op neer dat op grond van een enkele waarneming van een bepaald verschijnsel (oorzaak) de overtuiging ontstaat dat een bepaald ander verschijnsel (werking) zal volgen. Causale overtuigingen kunnen alleen ontstaan door eerdere waarnemingen van het regelmatig samengaan van verschijnselen. ${ }^{3}$ Dit proces kon men volgens Hume, zo constateert Heymans verder, verklaren met behulp van de associatiewet van gelijkenis en die van tijd-ruimtelijke nabijheid. Immers, als een bepaald verschijnsel lijkt op een bepaald ander verschijnsel en als beide verschijnselen optreden in elkaars tijdruimtelijke nabijheid, dan ontstaat tussen die verschijnselen een associatieve band. Zo'n band leidt er weer toe dat de voorstelling van een bepaald verschijnsel de voorstelling van een bepaald ander verschijnsel oproept. De associatic van een voorstelling die men gelijktijdig met een bepaald verschijnsel waarneemt, maakt de intensiteit van zo'n voorstelling sterker. Als de waarneming van een bepaald verschijnsel tot dusver altijd in samenhang met cen bepaald ander verschijnsel is opgetreden, dan ontstaat daardoor een sterke associatieve band. Het waarnemen van het eerste verschijnsel leidt door associatie tot een zeer krachtige en levendige voorstelling van het tweede verschijnsel. Hume, zo betoogt Heymans, had het hebben van een zeer krachtige en levendige voorstelling gelijk gesteld aan de overtuiging dat datgene waar zo'n voorstelling betrekking op heeft ook bestaat; daardoor kon

${ }^{1}$ cf. Heymans, G. (1890a), op. cit. p. 140.

${ }^{2}$ cf. Heymans, G. (1890a), op. cit. p. 143, 'De stelling dat overtuiging, of het eigenaardige gevoel waardoor zij zich kenmerkt, (is) niets anders dan de ondervinding van de bizondere kracht en levendigheid eener voorstelling,... (....) ... overal en altijd (steunt) overtuiging op kracht en levendigheid van voorstelling, en kracht en levendigheid van voorstelling (voert) overtuiging met zich.'

${ }^{3}$ cf. Heymans, G. (1890a), op. cit. p. 145, 'Hun (causale overtuigingen) algemeen karakter is (...) dat de enkele waarneming van een bepaald verschijnsel (de oorzaak) de overtuiging doet ontstaan dat een ander verschijnsel (de werking) volgen zal. De voorwaarde voor het ontstaan dezer overtuiging bleek gelegen te zijn in het vroeger regelmatig samengaan der beide verschijnselen.' 
hij ook van oordeel zijn dat het ontstaan van causale overtuigingen was verklaard door het regelmatig waarnemen van het samengaan van verschijnselen. Bovendien had Hume op grond van de hypothese van voorstellingsintensiteit en de werking van de associatiewetten geconcludeerd dat de notie 'noodzakelijk verband' alleen betrekking kon hebben op iets dat wij hebben waargenomen in ons eigen bewustzijn.'

Hume's theorie dwingt Heymans' respect af. ${ }^{2}$ Echter, Heymans' respect voor diens theorie betekent nog niet dat hij het daar mee eens is. Hij vraagt zich namelijk af: kan (Hume's theorie) als oplossing van het causaliteitsprobleem worden aanvaard? Heymans' antwoord luidt ondubbelzinnig: neen. Deze theorie zou wellicht voor het psychologische causaliteitsvraagstuk een aanknopingspunt voor een oplossing kunnen bieden, maar zij verschaft zeker geen oplossing voor het filosofische causaliteitsvraagstuk. Immers, Hume's theorie betreft alleen het vraagstuk hoe men op basis van het waarnemen van het regelmatig volgen van verschijnselen in combinatie met de associatiewetten uit het optreden van een bepaald verschijnsel (antecedens) het optreden van een bepaald ander verschijnsel (sequens) afleidt. Deze theorie verschaft echter geen antwoord op de vraag hoe men deze afleiding logisch kan rechtvaardigen. Het feil dat causale verwachtingen steeds door de verschijnselen worden bevestigd, wordt door Hume's theorie niet verklaard. ${ }^{4}$

cf. Heymans, G. (1890a), op. cit. p. 145-146, 'De ervaring leert, dat wanneer twee verschijnselen A en B op elkander gelijken, of wel in tijd en ruimte elkander aanraken, er tusschen die beide verschijnselen een band ontstaat, ten gevolge waarvan de voorstelling van het eene verschijnsel die van het andere in den geest te voorschijn roept. (...) Het blijkt derhalve, dat in het algemeen de associatie met een verschijnsel ' $t$ welk wij gelijktijdig waarnemen, de kracht en levendigheid van elke voorstelling verhoogt. Maar dan is het ook geen wonder, wanneer de waarneming van een verschijnsel, 't welk wij voortdurend met een ander verschijnsel verbonden hebben aangetroffen, en dus daarmede onverbrekelijk is geassocieerd, onmiddellijk eene zeer krachtige en levendige voorstelling van dat verschijnsel te voorschijn roept. En daar ex hypothesi eene zeer krachtige en levendige voorstelling identiek is met de overtuiging van het bestaan van haar voorwerp, is daarmede het totstandkomen van causale overtuigingen uit waargenomen regelmatig samengaan verklaard. Zie ook: Heymans, G. (1890a), op. cit. p. 153, 'Wanneer wij spreken van noodzakelijk verband, dan spreken wij van iets dat wij niet in de dingen hebben waargenomen, noch in een enkel geval op zichzelf beschouwd, noch in een reeks van gevallen gezamenlijk. Wij spreken van iets dat wij hebben waargenomen in ons eigen bewustzijn.'

${ }^{2}$ cf. Heymans, G. (1890a), op. cit. p. 152-153, 'De theorie van Hume is niel slechts, wat vele philosophische theorieën zijn, het werk van een genie, maar ook, wat slechts van weinige kan gezegd worden, het werk van een vorscher. Wij hebben hier niet te doen met een van die zeepbellen van het vernuft, die schoon zijn om aan te zien, maar uiteenspatten zoodra zij in aanraking komen met de harde werkelijkheid (....) wij hebben hier te doen met een onderzoek in den besten zin des woords. (....) Het is nauwelijks denkbaar, dat iemand tot juistere inzichten dan de zijne zou kunnen komen, zonder althans voor een oogenblik den invloed zijner denkbeelden te hebben ondergaan.'

${ }^{3}$ ef. Heymans, G. (1890a), op. cit. p. 153.

4 ef. Heymans, G. (1890a), op. cit. p. 158-159, 'Ik begin met op te merken dat hier in elk. geval alleen van een oplossing van het psychologische causaliteitsproblcem sprake kan zijn. De theorie van Hume wil verklaren hoe het komt dat wij, gegeven de tot dusver regelmatige 
Kortom: Heymans beschouwt Hume's theorie slechts als een mogelijke psychologische verklaring die het ontstaan van de subjectieve overtuiging betreft dat er tussen waargenomen verschijnselen noodzakelijke causale verbanden zijn. Deze verklaring vormt echter zeker geen oplossing van het filosofische causaliteitsvraagstuk. Zij biedt namelijk geen rechtvaardiging van de overtuiging dat verschijnselen waarvan tot dusver is gebleken dat zij causaal met elkaar zijn verbonden, ook in de toekomst causaal met elkaar zullen samenhangen.

Hume's theorie schiet toch ook ernstig tekort als oplossing van het psychologische causaliteitsvraagstuk, aldus Heymans. Los van het feit dat Hume er niet in is geslaagd om in het algemeen aan te tonen dat de intensiteit van bepaalde overtuigingen rechtevenredig is aan die van bepaalde voorstellingen, biedt zijn theorie evenmin een verklaring voor de verschijnselen van het causale denken in hun volle bizonderheden, juist zooals zij zich hebben voorgedaan. Men kan zich daarom afvragen of deze hypothese geschikt en voldoende (is) om de verschijnselen van het

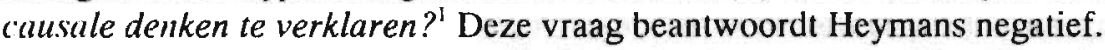

Hume had met behulp van zijn hypothese van voorstellingsintensiteit het verschijnsel verklaard dat het waarnemen van een bepaald verschijnsel uiteindelijk resulteert in de overtuiging van het werkelijk bestaan van een bepaald ander verschijnsel, omdat tot dusver is gebleken dat het eerste verschijnsel regelmatig samengaat met het tweede verschijnsel. ${ }^{2}$ Heymans vindt dit een wat mager resultaat, want, zo vraagt hij zich af, is met dit ééne verschijnsel het wezen van het causale denken uitgeput? Weten wij van het causale denken niets meer, dan dat het aan de waarneming van een verschijnsel vastknoopt het geloof aan de realiteit van een daarmede steeds in verbinding van tijd en plaats waargenomen ander verschijnsel? Hume's hypothese biedt namelijk geen verklaring van andere feiten van het causale denken, zoals de overtuiging dat alle gebeurtenissen een oorzaak hebben, de overtuiging dat onder gelijk omstandigheden gelijke gevolgen zullen optreden, de overtuiging dat verschillende gevolgen duiden op een verschillende oorzaken of de overtuiging dat er geen tijd verloopt tussen oorzaak en gevolg. Heymans concludeert dat ook zulke overtuigingen, opgevat als bewustzijnsverschijnselen, door een causali-

opeenvolging der verschijnselen en de associatiewetten, uit de verschijning van eenig antecedens tot die van het bijbehoorende sequens besluiten; maar zij beweert niet dezc conclusie logisch te kunnen rechtvaardigen. Het philosophische causaliteitsprobleem ligt buiten hatar bereik. De telkens vernieuwde bevestiging onzer causale verwachtingen door de verschijnselen onderneemt zij niet te verklaren.'

'cf. Heymans, G. (1890a), op. cit. p. 166.

? cf. Heymans, G. (1890a), op. cit. p. 166-167, 'Het algemeen karakter der verschijnselen van hel causale denken zou ongetwijfeld door Hume's hypothese verklaard kunnen worden. Wanneer het waar is dat de associatic, die kracht en levendigheid der voorstellingen versterkt, tevens het overtuigingsgevoel doet ontstaan, dan is het begrijpelijk dat de waarneming van een regelmatig samengaan van twee verschijnselen het langzamerhand onmogelijk maakt, het cene weer te zien zonder ook aan de realiteit van het andere te gelooven.'

${ }^{3}$ cf. Heymans, G. (1890a), op. cit. p. 166-167. 
teitstheorie verklaard moeten worden.' Hij vraagt zich echter retorisch af of de hypothese van Hume werkelijk in staat (is) ${ }^{2}$ om zulke overtuigingen te verklaren?

Terzijde zij opgemerkt dat Heymans de bovengenoemde overtuigingen causale axioma's noemt. Hiermee voegt hij een nieuw element aan de discussies toe, dat kennelijk bij hem opgekomen is naar aanleiding van zijn beschouwing over Leibniz' verklaringen voor specifieke verschijnselen van overdracht van beweging. ${ }^{3}$ Heymans illustreert dit aan de hand van het volgende historische voorbeeld. ${ }^{4}$ Descartes was van mening dat bij twee voorwerpen die in grootte van elkaar verschillen en met een gelijke snelheid tegen elkaar botsen, het grootste voorwerp zijn beweging voortzet, terwijl het kleinste voorwerp met dezelfde snelheid weer terugkaatst. Hij was er bovendien van uilgegaan dat voorwerpen die even groot zijn en tegen elkaar botsen, beide met dezelfde snelheid worden teruggekaatst. Leibniz had dit tegenstrijdig geacht. Immers, als men uitgaat van het tweede geval en als ćén van de voorwerpen maar iets groter zou zijn dan het andere voorwerp, dan zou men moeten onderstellen dat de beweging van het iets grotere voorwerp wordt voortgezet, terwijl het iets kleinere voorwerp met dezelfde snelheid wordt teruggekaatst. Leibniz had de onevenredig grote gevolgen door een minimale verandering van grootte ondenkbaar geacht. Deze opvatting van Leibniz onderstelt, aldus Heymans, een beginsel of het axioma dat oorzaak en gevolg evenredig aan elkaar moeten zijn: men kan de veranderingen in de oorzaken dusdanig klein maken, dat de veranderingen in de gevolgen een bepaalde grenswaarde niet overstijgen. Dit voorbeeld geeft goed aan waar Heymans aan denkt als het de notie 'causaal axioma' betreft: namelijk specifieke onderstellingen die worden toegepast bij de verklaring van verschijnselen die de overdracht van beweging betreffen. Zoals nog zal blijken, zal de notie 'causaal axioma', waarvan Heymans meent dat deze in de filosofie vanaf Hume ten onrechle was verwaarloosd", in de "vroege" kritiek op Heymans' causaliteitsleer een belangrijke rol spelen.

In zijn kritick op Hume grijpt Heymans eerst Hume's omschrijving van de notie 'oorzaak' aan om te concluderen dat diens omschrijving daarvan te eenzijdig is. Bovendien biedt die omschrijving geen voldoende verklaring voor het causaliteits-

cf. Heymans, G. (1890a), op. cit. p. 167, 'Wij vinden in het causale denken onmiskenbaar overtuigingen als deze: dat alles wat gebeurt een oorzaak heeft; dat onder volkomen gelijke omstandigheden noodzakelijk volkomen hetzelfde moet gebeuren, en dat omgekeerd iedere ongelijkheid in de werking onfeilbaar het gevolg is van eene ongelijkheid in de oorzaken; dat er tusschen de oorzaak en hare werking geen tijd kan verloopen, enz. Eene hypothese die het causale denken wil verklaren, moet ook van deze overtuigingen, als bewustzijnsverschijnselen beschouwd, rekenschap kunnen geven.'

${ }^{2}$ ef. Heymans, G. (1890a), op. cit. p. 167.

${ }^{3}$ cf. Heymans, G. (1890a), op. cit. p. 95, 'Dat elke verandering een oorzaak hebhen moet; dat deze oorzaak gelijksoortig, evenredig en gelijkwaardig moet zijn met hare werking; cn dat de oorzaak niet in tijd of ruimte van hare werking gescheiden kan zijn, - dat alles wordt. uitdrukkelijk of stilzwijgend door Leibniz als vaststaande vooropgesteld.'

${ }^{4}$ cf. Heymans, G. (1890a), op. cit. p. 91-92.

${ }^{5}$ cf. Heymans, G. (1890a), op. cit. p. 131-139. 
beginsel. Vervolgens stelt hij vast dat Hume, door de nadruk die deze denker had gelegd op het waarnemen van het regelmatig volgen van verschijnselen als bron van de notie 'oorzaak', uit het oog had verloren dat vele verschijnselen in veel gevallen niet met elkaar blijken samen te gaan. Ten slotte wijst Heymans er op dat Hume's theorie de zekerheid van de eerder genoemde causale axioma's, die in de notie 'causaliteit' liggen besloten, niet kan verklaren.

\section{Regelmatige successie en het causaliteitsbeginsel}

Hume had in de Treatise (1739/1740) twee omschrijvingen van de notie 'oorzaak' gegeven. In de Treatise heet het dat de notie 'oorzaak' het volgende betekent: een voorwerp dat vooraf gaat aan en tijd-ruimtelijk grenst aan een ander voorwerp, waarbij alle voorwerpen die lijken op het eerste voorwerp op een gelijksoortige wijze geordend zijn in de tijd en ook op een gelijksoortige wijze tijd-ruimtelijk grenzen aan de voorwerpen die met het tweede voorwerp overeenkomen; of, notie 'oorzaak' betekent bij Hume het volgende: een voorwerp dat aan een ander voorwerp vooraf gaat en daar tijd-ruimtelijk aan grenst, waarbij beide voorwerpen een zodanige eenheid vormen dat het idee van het eerste voorwerp het denken zo bepaalt dat daardoor het idee van het tweede voorwerp wordt opgeroepen, en waarbij de indruk van het ene voorwerp een krachtiger voorstelling van het andere doet rijzen. 'Echter, zo vraagt Heymans zich af, als deze omschrijvingen juist zijn hoe komen wij aan de zekerheid, dat alles wat ontstaan is een oorzaak moet hebben $?^{2}$ Met andere woorden: bieden Hume's omschrijvingen van de notie 'oorzaak' ook een verklaring voor het causaliteitsbeginsel?

Heymans wijst er allereerst op dat er vele verschijnselen zijn die juist niet met een verschijnsel dat daaraan vooraf gaat zo innig zijn geassocieerd dat de gedachte aan het eerste verschijnsel leidt tot de gedachte aan het tweede verschijnsel. ${ }^{3}$ Hume was er van uitgegaan dat de ervaring bij de successie van verschijnselen de grootst mogelijke regelmatigheid aangecft. Die regelmatigheid, zo betoogt Heymans, treedt alleen duidelijk op de voorgrond bij de wetenschappelijk verwerkte ervaring; dat wil zeggen, zodra ervaring stelselmatig is geordend en reeds vanuit een bepaald

' cf. Hume, D. (1739/1740), op. cit., book I, part III, p. 170, 'We may define a cause to be, an object precedent and contiguous to another, and where all the objects resembling the formei are plac'd in like relations of precedency and contiguity to those objects that resemble the latter'; of wel: ' an object precedent and contiguous to another, and so united with it, that the idea of the one determines the mind to form the idea of the other, and the impression of the one to form a more lively idea of the other.' Geciteerd in Heymans, G. (1890), op. cit. p. 167.

${ }^{2}$ cf. Heymans, G. (1890a), op. cit. p. 167.

3 cf. Heymans, G. (1890a), op. cit. p. 167-168, 'Er zijn toch onbelwistbaar verschijnselen genoeg, die met geen ander voorafgaand verschijnsel zoo imnig zijn geassocieerd, dat de gedachte aan het eene die aan het andere in den geest te voorschijn roept.' 
wetenschappelijk perspectief betekenis heeft gekregen. ${ }^{1}$ Als men verschijnselen niet door den bril der wetenschap beschøuwt, zoals in het vóór-wetenschappelijke stadium van de ervaring, dan kan men in de meeste gevallen niet spreken van regelmatigheid. In dat stadium neemt men weliswaar enkele regelmatigheden waar, maar het merendeel van de verschijnselen komt op ons over als toonbeelden eener chaotische verwarring. Echter, zo vraagt Heymans zich af, beperkt men in dit stadium de notie 'oorzakelijk verband' tot die gevallen, waarin de regelmatige opeenvolging der verschijnselen eene krachtige associatieve verbinding heeft tot stand gebracht? ? $^{2}$ Ook in het vór-wetenschappelijke stadium wordt naar oorzaken gezocht om verschijnselen te verklaren. Het gaat dan echter meestal om verschijnselen die juist uitzonderingen op de regel vormen; dat wil zeggen, buitengewone verschijnselen. Heymans leidt hier uit af dat de notie 'oorzaak', opgevat als het waarnemen van regelmatige successie, in het vóór-wetenschappelijke stadium nauwelijks een functie heeft. Immers, vóór-wetenschappelijke verklaringen richten zich op uitzonderingen op de regel, en niet op wat men regelmatig waarneemt. En dit is precies het omgekeerde van wat Hume's notie 'oorzaak' impliceert. ${ }^{3}$

Principiëler acht Heymans echter de volgende vraag: wat vinden wij nu, zoodra men over de gegeven verschijnselen wetenschappelijk begint na te denken $?^{4}$ Als van Hume's theorie zou worden uitgegaan, dan moet het causaliteitsbeginsel worden gezien als het resultaat van het herhaaldelijk waarnemen van het regelmatig samengaan van verschijnselen. Heymans acht dit strijdig met de historische feiten. Immers, in de tijd dat er nog geen sprake was van natuurwetenschappen, werd er al van uitgegaan dat het causaliteitsbeginsel - alles wat gebeurt (moet) zijne oorzaak hebben - de zekerheid had van een axioma. In Heymans' woorden: 't strengste determinisme (vormde) een geloofsartikel voor de oudgrieksche denkers. ${ }^{5} \mathrm{Hij}$ concludeert dat Hume's theorie ook dit historische gegeven niet kan verklaren.

${ }^{1}$ cf. Heymans, G. (1890a), op. cit. p. 168, 'Wanneer men zegt, dat de ervaring ons de grootst mogelijke regelmatigheid vertoont in de opeenvolging der verschijnselen, dan moet men vooral niet uit het oog verliezen dat dit slechts geldt voor de wetenschappelijk geïnterpretcerde, wetenschappelijk verwerkte ervaring.'

${ }^{2}$ cf. Heymans, G. (1890a), op. cit. p. 168.

${ }^{3}$ cf. Heymans, G. (1890a), op. cit. p. 168-169, '... de natuur zooals wij die door den bril der wetenschap bekijken, de uitgelegde natuur om 't zoo eens te noemen, vertoont groote regelmatigheid; maar de natuur zooals zij zich zonder wetenschappelijke uitlegging aan de onze zintuigen openbaart, vertoont, naast enkele regelmatigheden, tal van verschijnselen waarbij alle regelmaat ontbreekt. (...) Voor al die buitengewone verschijnselen schept hij (de natuurmensch) zich oorzaken, natuurlijk aanvankelijk anthropomorphistisch gekleurd: goden, goede en booze geesten, fetischen. Blijkbaar heeft dus, althans in dit stadium van ontwikkeling, het begrip oorzaak met waargenomen regelmatige opeenvolging zeer weinig te maken.'

${ }^{4}$ cf. Heymans, G. (1890a), op. cit. p. 169.

${ }^{5}$ cf. Heymans, G. (1890a), op. cit. p. 169.

${ }^{6}$ cf. Heymans, G. (1890a), op. cit. p. 169 , '... wij vinden veeleer onmiddellijk, bij den allereersten aanvang van 't wetenschappelijk onderzoek, met groote bepaaldheid en met axiomatische zekerheid uitgesproken, dat alles wat gebeurt zijne oorzaak moet hebben. Lang voor er iets bestond dat ook maar in de verte geleek op naturwetenschap, vormde 't strengste 
Hume was er van uitgegaan dat regelmatige successie de enige vorm van regelmatigheid in de natuur zou zijn. Heymans stelt daar tegenover dat er naast regelmatigheden van successie ook regelmatigheden van coëxistentie zijn, en dat zulke regelmatigheden bovendien vaker voorkomen dan regelmatigheden van successie. ${ }^{1}$

Regelmatigheden van coëxistentie of coëxistentiewetten betreffen groepen van verschijnselen die wij altijd te samen waarnemen of kunnen waarnemen. ${ }^{2}$ Zowel coëxistentiewetten als successiewetten kennen echter uitzonderingen. Bijvoorbeeld: vrijwel altijd worden kalveren met vier poten geboren, maar soms wordt er een kalf met vijf poten geboren. Dit is een voorbeeld van een coëxistentiewet en een uitzondering daarop. Of bijvoorbeeld: van een bepaald geneesmiddel is bij herhaling gebleken dat het een bepaalde ziekte geneest, maar in sommige gevallen wordt de patiënt na toediening van het medicijn niet beter. Dit is een voorbeeld van een successiewet en een uitzondering daarop.

De reacties bij afwijkingen op beide soorten wetten verschillen principieel van elkaar, zo betoogt Heymans. Dit adstrueert hij door te verwijzen naar de onderzoekpraktijk. Een uitzondering op coëxistentiewetten beschouwt men daar als een speling van de natuur, een rariteit; uitzonderingen op zulke wetten worden echter wel mogelijk geacht. Daarentegen wordı gemeend dat uitzonderingen op successiewetten onmogelijk zijn. Als een afwijking van een successiewet wordt geconstateerd, dan wordt net zo lang gezocht naar een dusdanige herformulering van zo'n wet totdat de uitzondering op de regel weer binnen de successiewet past. Bij de successie van verschijnselen gaat men er van uit dat hier wetten aan ten grondslag liggen die algemeen gelden en absoluut zeker zijn; hier geldt de eisch eener volstrekte regelmatigheid. Heymans benadrukt dat de eisen van algemene geldigheid, absolute zekerheid en volledige regelmatigheid zeker niet gelden voor coëxistentiewetten." Dit blijkt uit de volgende toelichting die Heymans geeft.

Stel dat men uitgaat van een bepaalde groep van waarnemingen (zeg: een A, een $\mathrm{B}$ en een C). Zo'n groep noemt Heymans de antecedenten. En stel nu ook dat men

determinisme een geloofsartikel voor de oudgrieksche denkers. Ik zie niet in hoe men de theorie van Hume met deze feiten in overeenstemming zou kunnen brengen.'

' cf. Heymans, G. (1890a), op. cit. p. 169, 'Regelmatigheden van successie zijn volstrekt niet de eenige, zelfs niet die welke ' $t$ meest op den voorgrond treden, onder de verschillende regelmatigheden welke de natuur ons aanbiedt. Daarnaast vinden wij in groote hoeveelheid regelmatigheden van coëxistentie.'

${ }^{2}$ cf. Heymans, G. (1890a), op. cit. p. 169.

${ }^{3}$ ef. Heymans, G. (1890a), op. cit. p. 170 , 'Uitzonderingen op coëxistentiewetten vatten wij op als een rariteit, een exceptioneel geval en verder niets, - uitzonderingen op successiewetten daarentegen vatten wij op als iets onmogelijks, als iets waarbij wij ons niet kunnen neerleggen voor wij 't tot een successiewet zonder uitzondering hebben teruggebracht. M.a.w. voor de opeenvolging der verschijnselen onderstellen wij met axiomatische zekerheid welten van volstrekte algemeenheid; voor het samengaan der verschijnselen is er van eene dergelijke onderstelling niets te bespeuren.' 
een aantal malen heeft geconstateerd dat hierop een bepaalde andere waarneming (zeg: een D) is gevolgd. Als men wederom een A, een B en een C constateert, zonder dat vervolgens een $\mathrm{D}$ optreedt, dan zal men met apodictische zekerheid beweren dat in dit laatste geval de antecedenten moeten verschillen in vergelijking met die in het eerste geval. Heymans leidt hier uit af dat er een omstandigheid (zeg: een X) moet zijn die er voor zorgt dat een D in het eerste geval wel optreedt, terwijl deze omstandigheid in het tweede geval kennelijk ontbreekt, waardoor een D niet optreedt. In het bovenstaande is de algemene vorm van een successiewet getypeerd. Heymans illustreert deze algemene vorm aan de hand van het eerder genoemde voorbeeld van de werking van een geneesmiddel. De verklaring van het feit dat een patiënt, ondanks het toedienen van een medicijn dat in het verleden altijd bleek te werken, toch niet geneest, moet worden gezocht in een nog onbekende omstandigheid die in vergelijking met andere ogenschijnlijk gelijksoortige gevallen verschilt.

Bij coëxistentiewetten ligt het echter anders. Stel dat men ook hier uitgaat van een bepaalde groep waarnemingen (zeg: een A, een B en een $C$ ). En stel dat men er wederom van uitgaat dat men herhaalde malen heeft geconstateerd dat met deze grocp van waarnemingen een bepaalde andere waarneming (zeg: een D) samengaat. Als men constateert dat met een A, een $B$ en een $C$ geen $D$ samengaat, dan gaat men er in dit geval echter niet van uit dat die beide gevallen ook nog in een ander opzicht van elkaar zouden verschillen dan alleen dat cen $\mathrm{D}$ zou ontbreken. Het bovenstaande is een typering van de algemene vorm van een coëxistentiewet. Ter illustratie: het pasgeboren kalf met de vijf poten verschilt alleen van andere kalveren door het hebben van één extra poot. ${ }^{1}$

Men zou, zo betoogt Heymans verder, regelmatige coëxistentie als een onderdeel van regelmatige successie kunnen beschouwen. Hij wijst er op dat in zulke gevallen de eisch eener volstrekte regelmatigheid ook voor coëxistentiewetten moet gelden. Als men hier van uit zou gaan, dan dient men het gegeven dat een bepaald kalf vijf poten blijkt te hebben op te vatten als een uitzondering op een successiewet. Men zal dan net zolang zoeken totdat de uitzondering op de wet dat kalveren altijd vier poten hebben is verklaard. Dit kan men doen door te zoeken naar factoren die er toe hebben geleid dat een bepaalde omstandigheid, bijvoorbeeld een omstandigheid bij de conceptie van het kalf met vijf poten, verschillend is geweest in vergelijking met

' cf. Heymans, G. (1890a), op. cit. p. 170, 'Wanneer op een groep van waarnemingen A B $C$ eenige keeren een waarneming $D$ is gevolgd, en wanneer wij dan een volgenden keer $A B C$ zien verschijnen zonder dat D er op volgt, dan zeggen wij met apodictische zekerheid: de antecedenten in dat laatste geval moeten zich van de antecedenten in de vroegere gevallen op eene of andere wijze onderscheiden hebben, er moel eene omstandigheid $\mathrm{X}$ zijn geweest die in de vroegere gevallen aanwezig was en in het laatste geval ontbrak, en ten gevolge waarvan D zich destijds wel en nu niet heeft voorgedaan. Wanneer wij daarentegen met een groep van verschijnselen A B C eenige kecren een verschijnsel D hebben zien samengaan, en een volgenden keer A B C waarnemen zonder D, dan denken wij er niet aan te beweren, dat het laatste geval zich van de vroegere nu ook in een ander opzicht moet onderscheiden.' 
die waarin kalveren normaliter worden geconcipieerd. 'Wanneer ik mij niet vergis, heeft deze geheel verschillende reactie van den geest op verschijnselen die met waargenomen coëxistentiewetten, en op verschijnselen die met waargenomen successiewetten in strijd schijnen, ten volle de betekenis van een psychologisch experiment. ${ }^{2}$ Heymans geeft hiermee overigens een treffend voorbeeld van het door hem voorgestane gebruik van het experiment in de philosophie.

Als men er van uitgaat dat de gebiedende eisch van regels zonder uitzondering successiewetten - louter het resultaat zijn van associatie van voorstellingen, dan zou dit zeker ook moeten gelden voor coëxistentiewetten. Heymans constateert echter dat deze eis bij deze laatste soort van wetten niet opgaat. Het blijkt dat er bij de zeer veel voorkomende verbinding van bijvoorbeeld de voorstelling van een kalf en die van de eigenschap dat kalveren in het algemeen vier poten hebben geen sprake is van een noodzakelijk verband. Als, zo concludeert Heymans, dit al niet het geval blijkt te zijn bij coëxistentiewetten, dan kan men in het geval van successiewetten zeker niet beweren dat de overtuiging van een noodzakelijk verband ontstaat uit de regelmatige verbinding van voorstellingen. ${ }^{3}$ Met andere woorden: ook op dit punt is Heymans van oordeel dat Hume's theorie onvoldoende is.

De scherpe kritiek die D.G. Jelgersma in het artikel Causaliteit tegen Heymans' principiële onderscheid tussen beide soorten wetten in 1891 naar voren zou brengen, is voor Heymans aanleiding om hierop in het tweede deel van Gesetze und Elemente (1894) te reageren. En ook de polemiek die in 1896 tussen Jelgersma en Heymans in het Tweemaandelijksch tijdschrift wordt uitgevochten, gaat vooral ook over dit element van Heymans' theorie.

\section{Causale axioma's}

In het causale denken gaat men, zo betoogt Heymans verder, impliciet uit van bepaalde grondstellingen die causale relaties betreffen. Zulke grondstellingen of causale axioma's liggen besloten in de notie 'oorzaak en gevolg'. Voorbeelden hiervan zijn: oorzaak en werking zijn gelijksoortig en gelijkwaardig; of: tussen oorzaak en werking verloopt geen tijd. Hume's theorie biedt geen verklaring voor het feit dat

' cf. Heymans, G. (1890a), op. cit. p. 170-171, 'Zoodra wij daarentegen de regelmatige coexxistentie opvatten als element eener regelmatige successie, m.a.w. zoodra wij 't kalf beschouwen als product zijner ouders, springt onmiddellijk weer de eisch eener volstrekte regelmatigheid te voorschijn: wij zijn overtuigd dat er 't zij in de organisatie der ouders, 't zij in de omstandigheden dic de conceptie vergezelden of daarop volgden, iets moet zijn geweest waardoor zich dit geval van andere onderscheidde.'

${ }^{2}$ ef. Heymans, G. (1890a), op. cit. p. 171.

" cf. Heymans, G. (1890a), op. cit. p. 171, 'Wanneer de gebiedende eisch van regels zonder uitzondering, op het eene terrein gesteld, eenvoudig een product was van associatie van voorstellingen, dan zou hij op het andere terrein niet achterwege kunnen blijven. Blijft hij daar achterwege, blijkt derhalve zelfs eene zoo regelmatige verbinding als die tusschen de voorstellingen van kalf en viervoetigheid niet voldoende om de overtuiging van noodzakelijk verband tot stand te brengen, dan hebben wij geen recht het ontstaan van die overtuiging elders door hel gegeven zijn van regelmatige verbinding verklaard te achten.' 
men aan zulke axioma's zekerheid toeschrijft.' Bijvoorbeeld: het feit dat men tussen verschijnselen die elkaar regelmatig volgen gelijksoortigheid en gelijkwaardigheid waarneemt, is meer uitzondering dan regel. Door het formuleren van hypothesen kan men verschijnselen zo verklaren dat zij weer in de verhoudingen van gelijksoortigheid of gelijkwaardigheid staan. ${ }^{2}$ Hume's theorie kan ook de tijdsbetrekking tussen oorzaak en werking niet volledig verklaren, aldus Heymans. Hume had alleen een verklaring geboden voor het feit dat het voorafgaande (antecedens) en het volgende (sequens) door associatie steeds nauwer mel elkaar worden verbonden. Door zo'n associatie wordt de verwachting sterker dat na de waarneming van het antecedens de sequens zal optreden. Zo'n verwachting wordt des te sterker naarmate het tijdsverloop tussen het antecedens en de sequens korter is. Echter, zo betoogt Heymans, dikwijls is er sprake van een ogenschijnlijk aanzienlijk tijdsverloop tussen het optreden van een oorzaak en het optreden van een gevolg. Toch blijft men van de zekerheid van het axioma uilgaan dat oorzaak en gevolg onmiddellijk op elkaar volgen. In zulke gevallen is men van mening dat men met middellijke werking te maken heeft. Men gaat vervolgens op zoek naar de tusschenschakels die oorzaak en gevolg weer op een onmiddellijke wijze met elkaar verbinden. ${ }^{3}$ Ziedaar feiten welke de hypothese van Hume niet verklaren kan. ${ }^{4}$ Immers, zo voegt Heymans daar aan toe, vanaf het prilste stadium van de wetenschappen heeft men zulke axioma's als noodzakelijke waarheden gezien. En, als men via een analyse van de betekenis van de woorden 'oorzaak en gevolg' de geldigheid van causale axioma's wil vaststellen, dan moet de betekenis van die woorden anders zijn dan die Hume daaraan had gegeven. Heymans is daarom van oordeel dat men via een analyse van de betekenis van de notie 'oorzaak' nooit tot het inzicht kan komen dat het causale denken uitgaat van de zekerheid van causale axioma's. Hij besluit zijn kritiek op Hume's theorie dan ook met de conclusic dat aan onze causale redeneringen (dus) een ander

' cf. Heymans, G. (1890a), op. cit. p. 171, 'Onbetwistbaar worden bij het causale denken voortdurend stilzwijgend toegepast zekere grondstellingen aangaande de betrekkingen tusschen oorzaak en werking, waarvan men meent dat zij uil de begrippen oorzaak en werking noodzakelijk voortvloeien... (...). De zekerheid dezer grondstellingen schijnt door de theorie van Hume niet te kunnen worden verklaard.'

${ }^{2}$ cf. Heymans, G. (1890a), op. cit. p. 171-172, 'Immers dat er lusschen de verschijnselen die wij regelmatig elkander zien opvolgen, eene waarneembare gelijksoortigheid of gelijkwaardigheid bestaat, is niet regel maar uitzondering; eerst door de wetenschap worden de verschijnselen op zoodanige wijze verwerkt en aangevuld, dat zij in het axioma passen.'

${ }^{3}$ ef. Heymans, G. (1890a), op. cit. p. 172, 'En wat de tijdsbetrekking tusschen oorzaak en werking betreft, de hypothese van Hume zou ten hoogste kunnen verklaren dat de associatie tusschen antecedens en sequens inniger werd, en dat dientengevolge de waarneming van het eerste een sterkere verwachting van het tweede deed ontstaan, naarmate in de tol dusverie waargenomen gevallen het tijdsverloop tusschen beide korter was geweest. Maar dat wij in tallooze gevallen, waarin wij de werking eerst eenigen tijd na de oorzaak zien intreden, met zekerheid aannemen dat wij slechts met een "middellijke" werking te doen hebben; dat wij niet rusten voor wij tusschenschakels hebben gevonden of ondersteld, waardoor de onmiddellijke opeenvolging van oorzaak en gevolg wordt gehandhaafd.'

${ }^{4}$ cf. Heymans, G. (1890a), op. cit. p. 172. 
begrip van oorzaak te grond (moet) liggen.' Welk begrip van oorzaak dat is, werkt Heymans uit in zijn eigen causaliteitsleer, die in de volgende paragraaf aan de orde komt.

\section{DE CAUSALITEITSLEER VAN HEYMANS}

Heymans bouwt zijn causaliteitsleer in drie stappen op. Allereerst zet Heymans het uitgangspunt van Hamiltons causaliteitsleer uiteen: het postulaat van de onveranderlijkheid van het werkelijk bestaande of de denkwet van de blijvende identiteit der dingen. Het verband dat wordt gelegd tussen dit postulaat en de verschijnselen van het causale denken noemt Heymans 'Hamiltons hypothese'. Vervolgens wil Heymans aantonen dat deze hypothese alle verschijnselen van het causale denken kan verklaren, inclusief de rol van causale axioma's daarbij. Echter, Hamiltons filosofische rechtvaardiging van dat postulaat acht Heymans problematisch. Daarom tracht hij ten slotte de contouren te schetsen van een adequate filosofische rechtvaardiging voor dat postulaat.

\section{Het postulaat en de hypothese van Hamilton}

Als men zich ervan bewust wordt dat iets een aanvang neemt, dan is men genoodzaakt aan te nemen dat het ook een oorzaak heeft, zo had Hamilton in zijn Lectures on metaphysics and logic (1865) betoogd. De betekenis van de uitspraak dat iets een oorzaak heeft, houdt in dat men zich niet kan voorstellen dat er iets nieuws ontstaat. Hamilton had hier uit afgeleid dat alles wat men in een nieuwe verschijningsvorm waarneemt, al eerder in een andere vorm moet hebben bestaan. Het is onmogelijk om zich voor te stcllen dat de hoeveelheid van het bestaande toe- of afneemt. Bovendicn is het unmogelijk om zich voor te stellen dat niets tot iets, of iets tot niets wordt. ' Stcrker nog: in een oor aak ligt het gevolg reeds besloten, en omgekeerd. ${ }^{3}$

' cf. Heymans, G. (1890a), op. cit. p. 172, 'Wanneer het wetenschappelijke denken, van de vroegste tijden af, aan deze en andere causale axioma's als aan noodzakelijke waarheden heeft vastgehouden, wanneer men steeds gemeend heeft zich langs zuiver analytische weg, door na te denken over de betekeenis der woorden oorzaak en gevolg, van hunne geldigheid te kunnen overtuigen, dan moet ook de betekeenis welke men aan die woorden hechtte, eene andere zijn geweest dan door Hume wordt ondersteld. Men mag nadenken zoveel men wil over den inhoud van het begrip: "voorwerp dat regelmatig door een ander voorwerp wordt gevolgd", of wel van het andere: "voorwerp dat in den geest met een ander is geassocieerd", nooit zal het gelukken door een analyse dezer begrippen tot het vermoeden, veel minder nog tot de zekerheid van de causale axioma's te geraken. Aan onze causale redeneeringen moet dus een ander begrip van oorzaak te gronde liggen.'

${ }^{2}$ cf. Hamilton, W.R. (1865), Lectures on metaphysics and logic, Lecture XXXIX, p. 377, 'When we are aware of something which begins to be, we are, by the necessity of our intelligence, constrained to believe that it has a Cause. But what does the expression, that it has a Cause, signify? If we analyse our thought, we shall find that it simply means, that as we 
Met andere woorden: er is een tautologische relatie tussen 'oorzaak' en 'gevolg'. Het causaliteitsbeginsel heeft derhalve een analytisch karakter en het berust op het substantiebeginsel, in de zin dat aan al het bestaande niets wordt toegevoegd of wordt wegnomen.

Niet Kant, maar Hamilton heeft het eigenlijke verband tussen het substantiebeginsel en het causaliteitsbeginsel ontdekt, zo betoogt Heymans in de Schets; ${ }^{1}$ dat wil zeggen, het verband tussen het beginsel dat er altijd iets blijvends moet zijn in de verschijnselen en het beginsel dat er voor alle veranderingen een oorzaak moet zijn. Hamilton had hiermee het volgens Heymans baanbrekende inzicht geformuleerd dat het causale denken product is van de apriorische overtuiging, dat het werkelijk bestaande onveranderlijk wezen moet. $^{2}$

Hamiltons inzicht wordt overigens in Gesetze und Elemente beschreven als de stelling dat een werkelijk ontstaan of vergaan onmogelijk is. ${ }^{3}$ In de Schets omschrijft Heymans dit inzicht als het postulaat van de onveranderlijkheid van het werkelijk bestaande ${ }^{4}$, of als de denkwet van de blijvende identiteit der dingen. ${ }^{5}$ Dit is ook de betekenis die Heymans geeft aan het substantiebeginsel: substanties blijven altijd gelijk aan zichzelf, alleen de relaties tussen substanties veranderen. Opgemerkt zij dat hij hiermee aanzienlijk verder gaat dan het door Kant geformuleerde substantiebeginsel dat inhoudt dat in ieder verschijnsel iets blijvends moet zijn. Tevens zij er op gewezen dat Heymans aansluit bij Schopenhauers geniale ingreep om het

cannot conceive any new existence to commence, therefore, all that now is seen to arise under a new appearance had previously an existence under a prior form. We are utterly unable to realise in thought the possibility of the complement of existence being either increased or diminished. We are unable, on the one hand, to conceive nothing becoming something, - or, on the other, something becoming nothing.' Ook geciteerd in Heymans, G. (1890), op. cit. p. 272-273, en in Heymans, G. (1894), Die Gesetze und Elemnente des wissenschaftliches Denkens, op. cit. p. 373.

${ }^{3}$ cf. Hamilton, W.R. (1865), op. cit., p. 377, 'There is (...) an absolute tautology between the effect and its causes. We think the causes to contain all that is contained in the effect; the effect to contain all nothing which was not contained in the causes.'

${ }^{1}$ Terzijde zij opgemerkt dat Heymans in de Schets voornamelijk ingaat op Kants onderscheid tussen object en subject. Dit onderwerp ligt buiten het bestek van dit onderzoek. Heymans' eigenzinnige intepretatie van Kant verdient een aparte behandeling. Uit Heymans' behandeling van en kritiek op Kant kan worden afgeleid dat hij Piersons fundamentele kritiek op Kant, zoals geformuleerd in Wijsgeerig Onderzoek, niet kende. Dit is te betreuren, te meer daar Heymans' Kant-kritiek veel aan helderheid had kunnen winnen door Piersons kritische kantlekeningen

${ }^{2}$ cf. Heymans, G. (1890a), op. cit. p. 172.

${ }^{3}$ cf. Heymans, G. (1894), op. cit. p. 373, 'Der englische Philosoph Sir W. Hamilton hat sämtliche Erscheinungen des causalen Denkens auf die Eine Grundvoraussetzung zurückzuführen versucht, dass ein wirkliches Entstehen und Vergehen nicht möglich sei.'

cf. Heymans, G. (1890a), op. cit. p. 272.

cf. Heymans, G. (1890a), op. cit. p. 290. 
causaliteitsbeginsel in verband te brengen met algemene behoudswetten. ${ }^{1}$

Als men uitgaat van Hamiltons postulaat dat het werkelijk bestaande moet worden opgevat als in beginsel onveranderlijk, dan volgt hieruit dat alle veranderingen die men waarneemt schijnbare veranderingen zijn. De waarnemingen van verandering komen echter in strijd met de overtuiging a priori dat het werkelijk bestaande onveranderlijk is. Het constateren van deze strijdigheid vormt de aanleiding om oorzaken te zoeken die de waarnemingen van verandering en de bovengenoemde overtuiging a priori weer met elkaar kunnen verenigen. Heymans makt hiermee derhalve een onderscheid tussen de veranderingen die men waarneemt en datgene wat achter de veranderingen schuil gaat; dat wil zeggen, het werkelijk bestaande.

In Gesetze und Elemente heet het dat Hamiltons postulaat de vera causa is om het causale denken te verklaren. Dit postulaat behoort tot de oudste onderstellingen van het Westeuropese denken. Ook de meer moderne natuurkundige theorieën, zo betoogt Heymans, gaan er van uit dat kracht en materie als het enige bestaande worden opgevat. Dat wil zeggen, materie wordt hierin gezien als bestaande uit nietontstane, niet-vernietigbare en onveranderlijke deeltjes; ook gaan die theorieën uit van de wet van behoud van kracht. Bovendien wijst hij er op dat Descartes en Leibniz in hun discussies over de juiste maat van kracht impliciet al uitgingen van de gedachte dat kracht onvernietigbaar is. ${ }^{2}$ Het laatste voorbeeld uit de wetenschapsgeschiedenis is voor Heymans voldoende grond om uit te gaan van de juistheid van Hamiltons postulaat. Op grond van het postulaat van de onveranderlijkheid van het werkelijk bestaande kan men vervolgens, aldus Heymans in Gesetze und Elemente, de hypothese formuleren dat dit postulaat alle verschijnselen van het causale denken kan verklaren; dit is Hamiltons hypothese. Bij het verklaren van zulke verschijnselen

' cf. Heymans, G. (1890a), op. cit. p. 262-263, 'Een (...) geniale ingreep (...) leidt Schopenhauer tot de erkenning der nauwe verwantschap tusschen het causaliteitsbeginsel en de behoudsbeginselen, in 't bizonder het substantiebeginsel. (...) Het latere onderzoek heeft deze intuittie (van Schopenhauer) ten volle bevestigd: alleen denkt men zich tegenwoordig de verhouding tusschen substantie- en causaliteitsbeginsel aldus, dat het laatste uit het eerste voortvloeit, en niet omgekeerd.'

${ }^{2}$ cf. Heymans, G. (1894), op. cit. p. 374-375, 'Die Überzeugung von der Unmöglichkeit des Enstehens und Vergehens gehört zu den ältesten Voraussetzungen des europaischen Denkens. (...) Im weiteren Verlaufe der griechischen Philosophie haben dann alle Schulen für dasjenige was sie als das wahrhaft Seiende betrachteten, die Prädicate des Unenstandenen und Unvergänglichen in Anspruch genommen; und von den Systemen der neueren Philosophie gilt genau das Nämliche. Indem sodann die Naturwissenschaft für ihr Gebiet Materie und Kraft als das einzig Seiende annehmen zu müssen glaubte, acceptierte sie einerseits den altgriechischen Gedanken, dass die Materie unenstandenen, unvergänglich und unveränderlichen kleinsten Theilen zusammengesetz sei; andererseits forderte sie sofort und mit gleicher Bestimmtheit auch die Erhaltung der Kraft. (....) Dass die von Hamilton zür Erklärung der Erscheinungen des causalen Denkens verwendete Voraussetzung wirklich als solche existirt und seit früheren Jugend der europaischen Wissenschaft existirt hat, scheint hiermit erwiesen zu sein; hypothetisch ist bloss die Beziehung dieser Voraussetzung zu den Erscheinungen des causalen Denkens.' 
dient men daarom van de overtuiging uit te gaan dat alles wat nu bestaat ook vroeger al bestond en in de toekomst ook nog zal bestaan.

In de Schets had Heymans overigens de notie "hypothese" omschreven als de onderstelling van onbekende, niet direct constateerbare reële gegevens, bestemd on de gegeven verschijnselen te verklaren. ${ }^{2}$ Hypothesen had hij onmisbaar geacht om de verschijnselen van het denken te verklaren, omdat hem was gebleken dat zulke verschijnselen niet met behulp van de bekende gegevens - de gegeven gewaarwordingen en logische wetten - begrijpelijk konden worden gemaakt: de bekende gegevens zijn onvoldoende om van de waargenomen verschijnselen (van het denken) rekenschap te geven. Als men uitsluitend zou uitgaan van zulke gegevens, dan kan men het geheel van wetenschappelijke inzichten, waarvan causale overtuigingen een element vormen, niet verklaren. Hieruit had Heymans de onderstelling afgeleid dat het denken daarom over méér materiaal moet beschikken. Echter, welk materiaal? En: hoe verkregen? $?^{3}$ Deze vragen kan men alleen beantwoorden door hypothesenvorming op grond der in- en uitwendige waarneming. ${ }^{4}$

\section{Toetsing en bevestiging van de hypothese van Hamilton}

Het zij nogmaals gezegd: filosofie is voor Heymans wetenschappelijke philosophie, en zij is gericht op het vinden van waarheid. Hij ziet het daarom als zijn taak Hamiltons hypothese te toetsen met behulp van voorbeelden uit de (toenmalige) onderzoekpraktijk. Daartoe formuleert Heymans in de Schets de volgende drie vragen: in welke gevallen, onder welke omstandigheden, wordt een oorzaak geëischt, en aan welke voorwaarden moet een verschijnsel voldoen om als oorzaak te worden aanvaard? (Is) het antwoord door de feiten op deze vragen gegeven wat het volgens Hamilton's theorie zou moeten zijn? (Laten) de (causale) axioma's (...) zich uit Hamilton's theorie verklaren?'

Ontstaan van de behoefte aan causale verklaringen

Allereerst geeft Heymans antwoord op de vraag in welke gevallen, onder welke omstandigheden, een oorzaak (wordl) geëischt. Hij onderschrijft Schopenhauers stelling dat het causale denken alleen uitgaat van waargenomen verandering. Alleen

${ }^{\prime}$ cf. Heymans, G. (1894), op. cit. p. 375-376, 'Wir werden (...) im Folgenden mit dem Ausdrucke "Hamilton'sches Postulat" oder "Hamilton'sches Princip" die thatsächliche Voraussetzung von der Unmöglichkeit des Entstehens und Vergehens bezeichnen; mit dem Ausdrucke 'Hamilton'sche Hypothese' dagegen die Annahme, dass aus jener thatsächlichen Voraussetzung das ganze: Causale Denken zu erklären ist. (...) Die Hamilton'schen Hypothese geht von der Tatsache aus, dass wir ein wirkliches Entstehen oder Vergehen für unmöglich halten, dass wir demnach überzeugt sind, alles was jetzt existirt müsse auch früher existirt haben und später noch existiren.'

${ }^{2}$ cf. Heymans, G. (1890a), op. cit. p. 248.

${ }^{3}$ cf. Heymans, G. (1890a), op. cit. p. 249.

cf. Heymans, G. (1890a), op. cit. p. 249.

s. cf. Heymans, G. (1890a), op. cit. p. 273-274. 
waargenomen verandering, zo betoogt Heymans, en niet regelmatige successie vormt het materiaal voor het causale denken. In Heymans woorden: niet elke regelmatige opeenvolging, maar alleen een waargenomen verandering, (is) materiaal voor het causale denken.' Het feit dat dit zo is, blijkt volgens Heymans uit de volgende voorbeelden.

Als iemand gezond blijft, dan wordt hiervoor geen oorzaak gezocht. Echter, als iemand die doorgaans gezond is ziek wordt, dan gaat men naar de oorzaken daarvan zoeken. Of: als een persoon die altijd opgewekt is plotseling depressief wordt, dan tracht men de oorzaak van die depressiviteit op te sporen. En: als een chemisch mengsel gelijk blijft, dan ziet niemand de noodzaak er van in de oorzaak van dit gelijk blijven te onderzoeken. Het wordt pas interessant als het mengsel verandert. Of: als de jaarlijkse misdaadcijfers ongeveer gelijk blijven, dan wordt de wetenschappelijke nieuwsgierigheid om oorzaken te zoeken niet gewekt; dit gebeurt pas als die cijfers plotseling grote veranderingen te zien geven.

Met deze voorbeelden illustreert Heymans de opvatting dat pas dan de behoefte aan causale verklaringen ontstaat, als er een ogenschijnlijke verandering optreedt in de voorwerpen onzer waarneming. Als zo'n verandering in wat men waarneemt niet optreedt, dan heeft men geen behoefte aan causale verklaringen. Of anders gezegd: als de identiteit met zichzelf van wat men waarneemt wordt verstoord, en eerdere en latere waarnemingen strijdig met elkaar zijn, dan zoekt men meteen naar een nieuwen factor die deze strijdigheid kan verklaren. Zo'n factor noemt Heymans 'oorzaak'. Met het vinden van een oorzaak wordt voldaan aan de overtuiging a priori dat het werkelijk bestaande onveranderlijk is. Hiermee acht Heymans de psychologische vraag beantwoord waardoor de behoefte aan causale verklaringen of de Causalitätstrieb wordt gewekt. ${ }^{2}$

\section{De functie en structuur van causale verklaringen}

Vervolgens beantwoordt Heymans de tweede vraag: aan welke vorrwarden 'i'n verschijnsel (moet) voldoen om als oorzaak te worden aanvaard. Anders geformuleerd: waardoor (wordt) die behoefte aan een oorzaak berredigd?" Of nog weer anders: wat (winnen) wij er eigenlijk bij, wanneer wij een waargenomen verandering $A$ oinschrijven als het product eener oorzaak $B$ ? $^{4}$

${ }^{1}$ cf. Heymans, G. (1890a), op. cit. p. 274.

${ }^{2} \mathrm{cf}$. Heymans, G. (1890a), op. cit. p. 276, 'Wij zien derhalve dat de psychologische oorzaak, die de behoefte aan causale verklaring in het leven roept, altijd gelegen is in een verandering, die ons de voorwerpen onzer waarneming aanbieden. Zoolang die voorwerpen blijven wat zij zijn, treedt de "Causalitätstrieb" niet op; maar wordt hunne identiteit met zichzelf verbroken, zijn latere waarnemingen met vroegere waarnemingen in strijd, dan or:tstaat onmiddellijk de behoefte om een nieuwen factor in te voeren, dien wij dan oorzak noemen.'

${ }^{3}$ cf. Heymans, G. (1890a), op. cit. p. 276.

${ }^{4}$ cf. Heymans, G. (1890a), op. cit. p. 276. 
Als Hamiltons hypothese juist is, dan moet een oorzaak door het voigende worden gekenmerkt. Het aanwijzen van een oorzaak leidt er toe dat de schijnbaar verbroken identiteit tusschen de objecten der vroegere en der latere waarneming wordt hersteld. Er wordt van uitgegaan dat de objecten die worden waargenomen in beginsel onveranderlijk zijn of aan zichzelf gelijk blijven. De functie van het aanwijzen van oorzaken is het herstellen van de eenheid of de identiteit van de objecten van eerdere en latere waarnemingen. In Gesetze und Elemente wordt dit laatste explicieter geformuleerd dan in de Schets. Ieder verschijnsel, zo heet het in Gesetze und Elemente, dat nieuw is of verdwijnt, leidt tot een verklaringsprobleem. Dit probleem kan men oplossen door er van uit te gaan dat iets wat ogenschijnlijk nieuw is al eerder bestond of iets wat ogenschijnlijk verdwijnt nog steeds bestaat.' Met andere woorden: veranderingen in de objecten van de waarneming zijn altijd ogenschijnlijke veranderingen. Ook dit element van Hamiltons hypothese wordt volgens Heymans bevestigd door voorbeelden uit de (toenmalige) natuurwetenschap.

Als men, bijvoorbeeld, één liter water met één liter alcohol mengt, dan blijkt dat het volume van dit mengsel kleiner is dan twee liter. Deze volumeverandering kan in termen van Hamiltons postulaat worden verklaard. Immers, water en alcohol bestaan uit moleculen. In Heymans' woorden: discreete, door tusschenruimte van elkander gescheiden deeltjes. Het vermengen van deze twee vloeistoffen leidt er toe dat water-en alcoholmoleculen zich onderling zo herordenen dat de ruimte die bestaat tussen deze beide soorten moleculen wordt gevuld. Dit verklaart de volumevermindering van het mengsel ten opzichte van de afzonderlijke volumes. De oorzaak hiervan moet derhalve worden gezocht in verandering in de ordening van deze moleculen. Hierdoor is de verandering die men heeft waargenomen (de volumevermindering) in overeenstemming gebracht met Hamiltons postulaat, in de zin dat alles wat nu bestaat ook vroeger al bestond, en in de toekomst ook nog zal bestaan. Immers, het volume dat beide soorten moleculen innemen, is gelijk gebleven. ${ }^{2}$

' cf. Heymans, G. (1890a), op. cit. p. 276, 'Is de theorie van Hamilton juist, dan zal moten blijken, hetgeen wij "oorzaak" noemen altijd deze eigenschap bezit, dat daardoor de schijnbar verbroken identiteit tusschen de objecten der vroegere en der latere warnerning wordt hersteld.' Zie ook: Heymans, G. (1894), op. cit. p. 376, 'Demzufolge muss jede Erscheinung welche neu auftritt oder verschwindet, uns zum Probleme werden; und wir versuchen dieses Problem zu lösen, indem wir annehmen, dass das scheinbar Neuenstandene thatsächlich schon früher in irgendwelcher Weise existirt habe, oder dass das scheinbar Verschwundene noch jetzt in irgendwelcher Weise fortexistire.'

${ }^{2}$ cf. Heymans, G. (1890a), op. cit. p. 276, 'Wij vermengen een liter water en een liter alcohol, en wij vinden dat het mengsel een geringer volume inneemt dan twee liter. Hoe verklaren wij die volumeverandering? Wij nemen aan dat het water en de alcohol beide reeds oorspronkelijk bestonden uit discreete, door tusschenruimte van elkander onderscheiden deeltjes, en dat nu door hunne vermenging een zoodanige verschikking van die kleinste deeltjes heeft plaatsgevonden, dat de ledige tusschenruimten gezamenlijk een geringer volume uitmaken dan te voren. De oorzaak der volumeverandering is dus de veranderde schikking der kleinste deeltjes; - maar klaarblijkelijk is door 't aannemen van die oorzaak de waargenomen verandering met de onderstelling van identieke objecten in overeenstemming gebracht. 
Heymans concludeert hieruit dat de betekenis van 'oorzaak' op niets anders neerkomt dan eene zoodanige aanvulling van de reeds bekende gegevens, dat daardoor de schijnbaar verbroken identiteit tusschen de objecten onzer vroegere en onzer latere waarnemingen wordt hersteld. ${ }^{1}$ Met andere woorden: door de overtuiging a priori dat het werkelijk bestaande onveranderlijk is, wordt men gedwongen om nieuwe gegevens te zoeken die de ogenschijnlijke strijdigheid tussen wat eerder en later is waargenomen moeten wegnemen. Zulke nieuwe gegevens noemt Heymans de 'oorzaak' die de ogenschijnlijke waargenomen strijdigheid verklaart.

Nu rijst echter de vraag: is dat nu ook zoo in andere, meer ingewikkelde gevallen? $?^{2}$ Met andere woorden: is Hamiltons hypothese generaliseerbaar? Heymans geeft toe dat de generaliseerbaarheid van Hamiltons hypothese op het eerste gezicht niet aannemelijk lijkt. Het toevoeren van warmte beschouwt men bijvoorbeeld doorgaans als oorzaak van het koken van water. Is het dan mogelijk om te beweren dat water dat niet kookt in combinatie met warmte identiek is aan kokend water? Toch is Heymans van oordeel dat Hamiltons hypothese ook voor dit meer complexe geval opgaat.

Als een bepaald verschijnsel wordt waargenomen, zo betoogt hij, en als later in plaats daarvan een bepaald ander verschijnsel wordt waargenomen, dan moet daaruit worden afgeleid dat het eerste verschijnsel niet gelijk is aan het tweede. Met andere woorden: de identiteit tussen beide waarnemingen is verbroken. Bijvoorbeeld: eerst neemt men niet-kokend water waar, en later water dat kookt. De waarneming van kokend water is uiteraard niet gelijk aan de waarneming van water dat niet kookt. In beide gevallen gaat het echter over water. Omdat men er a priori van uitgaat dat voor alle gebeurtenissen geldt dat zij een oorzaak hebben, is het noodzakelijk om voor de verandering van niet-kokend water in kokend water een oorzaak te zoeken. Daarbij moet worden uitgegaan van Hamiltons postulaat van de onveranderlijkheid van het werkelijk bestaande. ${ }^{3}$ Omdat het eerste en het tweede verschijnsel ongelijk zijn, moet deze ongelijkheid worden omgevormd tot een gelijkheid door te zoeken naar een nog onbekende oorzaak. Dit moet er uiteindelijk toe leiden dat de logische vergelijking $\mathrm{A}+\mathrm{X}=\mathrm{B}$ wordt opgelost. Hierbij staat ' $\mathrm{A}$ ' voor het verschijnsel dat het eerst is waargenomen, ' $\mathrm{B}$ ' voor het verschijnsel dat even later in de plaats van ' $\mathrm{A}$ ' is

Immers het volume der kleinste deeltjes, waardoor wij nu in onze voorstelling de schijnbaar continueele vloeistofmassa vervangen, is thans onveranderd gebleven.'

${ }^{1}$ cf. Heymans, G. (1890a), op. cit. p. 277.

${ }^{2}$ cf. Heymans, G. (1890a), op. cit. p. 277.

${ }^{3}$ cf. Heymans, G. (1890a), op. cit. p. 278, 'Wij hebben waargenomen een verschijnsel A, en wij vinden bij eene latere waarneming in plaats daarvan een verschijnsel B. B is iets anders dan $A$; de identiteit tusschen vroeger en later is derhalve verbroken, en het causaliteitsbeginsel eischt dat zij hersteld worde.' 
waargenomen, en ' $\mathrm{X}$ ' voor de onbekende oorzaak of omstandigheid waardoor de verandering kan worden verklaard.'

Waar Heymans in de Schets op dit punt alleen nog spreekt over de waarneming van verschijnselen, gaat hij in Gesetze und Elemente verder: bij de waarneming van verschijnselen moet worden aangenomen dat daaraan een ons onbekende werkelijkheid ten grondslag ligt. Immers, de consequentie van Hamiltons postulaat is dat ook waarnemingen niet uit het niets ontstaan. Daarom moet worden aangenomen dat de waarneming van een bepaald verschijnsel met een bepaalde werkelijkheid correspondeert. Consequent doorgeredeneerd leidt dit tot het volgende. Als een verschijnsel wordt waargenomen, en als later in de plaats daarvan een ander verschijnsel wordt waargenomen, dan moet hieruit worden afgeleid dat de werkelijkheden die aan de waargenomen verschijnselen ten grondslag liggen van elkaar verschillen. Hieruit wordt bovendien afgeleid dat de overgang van de ene werkelijkheid in een andere zich alleen als volgt laat denken: aangenomen moet worden dat aan de ene werkelijkheid bepaalde niet-ontstane en onvernietigbare elementen zijn toegevoegd of weggenomen. Het waarnemen van de successie van verschijnselen dient daarom te worden opgevat als een indicatie van de successie van daarmee corresponderende werkelijkheden plus of minus de onbekende factor $\mathrm{X} .^{2}$

Heymans was er in de Schets van uitgegaan dat de logische vergelijking $\mathrm{A}+\mathrm{X}=\mathrm{B}$ moest worden opgelost. ' $\mathrm{X}$ ' stond daarbij voor een nog onbekende oorzaak. Echter, waar zullen wij evenwel die oorzaak vinden? Zo'n oorzaak moet worden gezocht in een verandering in de omstandigheden (een $\mathrm{C}$ ) tussen het moment waarop een ecrste en het tweede verschijnsel is waargenomen. Als blijkt dat er inderdaad een verandering in de omstandigheden is opgetreden, dan wordt hieruit afgeleid dat deze verandering de oorzaak is voor de waargenomen verandering. Echter, zo vraagt Heymans zich af: (zijn) wij nut tot 't inzicht gekomen van de identiteit tusschen $A+C$ en $B$ ? Zijn antwoord luidt: neen. Het betekent alleen dat de indruk van het ecrste verschijnsel dat is waargenomen (een $A$ ) en de indruk van een verandering in omstandigheden (een oorzaak $\mathrm{C}$ ) tesamen identiek moeten zijn aan dalgene wat op ons de indruk maakt van een tweede verschijnsel dat is waargenomen (een B). Het aanwijzen van een $C$ als oorzaak voor de verandering van een $A$ in een $B$ moet men

' cf. Heymans, G. (1890a), op. cit. p. 278, 'Met andere woorden, de ongclijkheid: A verschilt van $B$, moet in een gelijkheid worden opgelost; en daartoe is het noodig een vorzaak $X$ aan te nemen. Die oorzaak moet van een zoodanige aard zijn, dall de logische vergelijking geldt: $\mathrm{A}+\mathrm{X}=\mathrm{B}$.'

${ }^{2}$ cf. Heymans, G. (1894), op. cit. p. 377, 'Wir hatten zuerst eine Walınehmung a, wclche (da auch eine Walınehmung nicht aus Nichts entstehen kann) auf eine unbekannte Wirklichkcil A zurückweist. Jetzt haben wir eine Wahrnehmung b: die zu Grunde licgende Wirklichkeit muss ein von A verschiedenes B scin. Aber kraft der Voraussctzung, dass ein wirkliches Entstehen oder Vergehen unmöglich sei, können wir uns den Übergang von $A$ in $B$ nur als ein Hinzukommen oder Davongehen unenstandener und unvergangener Wirklichkeitselemente zu oder von A denken. Mit anderen Worten: die erfahrungsmässige Succession der Eirscheinungen a und b fassen wir aul als Zeichen für eine Succession von wirklichen Zuständen A und At/-X.' 
daarom alleen als een voorlopige verklaring voor de verandering van een $A$ in een $\mathrm{B}$ zien. Heymans acht het derhalve noodzakelijk om de logische vergelijking $\mathrm{A}+\mathrm{C}=\mathrm{B}$ preciezer te omschrijven, en wel als volgt: $\mathrm{fA}+\mathrm{fC}=\mathrm{fB}$; dat wil zeggen, datgene wat op ons de indruk makt van een A plus datgene wat op ons de indruk van een $\mathrm{C}$ vormen tesamen de indruk van een $B$. $^{\prime}$

Echter, als op grond van ervaring blijkt dat het aanwijzen van een oorzaak $\mathrm{C}$ er niet toe leidt dat de identiteit tussen het eerste (fA) en het tweede waargenomen (fB) verschijnsel wordt hersteld, dan moet worden aangenomen dat de inhoud onzer waarnemingen niet het wezen der dingen uitdrukt. Met andere woorden: omdat de inhoud van waarnemingen doorgaans onnauwkeurig is, zijn causale verklaringen dat ook. Heymans had al eerder gesteld dat men van de geldigheid van het causaliteitsbeginsel moet uitgaan. Als men daarvan uitgaat, dan is het onmogelijk om aan te nemen dat aan een waargenomen verandering geen oorzaak ten grondslag zou liggen. Om de verandering van het eerste waargenomen verschijnsel in het tweede te verklaren formuleert men hypothesen over de wezenlijke dingen en de wezenlijke processen die aan onze waarnemingen te gronde liggen. ${ }^{2} \mathrm{Dit}$ zijn hypothesen over de achterliggende structuur en processen van de werkelijkheid. Met behulp van zulke hypothesen tracht men zich een zodanige voorstelling van de werkelijkheid te vormen dat de ogenschijjnlijke strijdigheid tussen wat eerder en later is waargenomen weer wordt hersteld. De motivatie voor deze hypothesen berust kennelijk op Hamiltons postulaat: de overtuiging a priori van de onveranderlijkheid van het werkelijk bestaande. ${ }^{3}$

'cf. Heymans, G. (1890a), op. cit. p. 278-279, 'Waar zullen wij evenwel die oorzaak vinden? In elk geval natuurlijk onder de omstandigheden die tusschen de oorspronkelijke waarneming van $\mathrm{A}$ en de latere waarneming van B zijn ingetreden. Leert ons dus de ervaring, dat er tusschen de waarneming van $\mathrm{A}$ en die van $\mathrm{B}$ slechts eene nieuwe omstandigheid $\mathrm{C}$ ingetreden is, dan concludeeren wij: $C$ is de oorzak van de verandering van $A$ in $B$. Wil dat nu zeggen dal wij 10 ' ' $t$ inzicht zijn gekomen van de identiteit tusschen $A+C$ en $B$ ? Klaarbijijkelijk niet: in de meeste gevallen is dat inzicht volstrekt niet aanwezig. Wat beteekent het dan? Het beteekent eenvoudig, dat datgene 't welk op ons den indruk maakı van $A$. plus datgene 't welk op ons den indruk makk van $C$, identiek moet zijn met datgene 't welk op ons den indruk maakt van $B$. Onze bewering: $\bar{C}$ is de oorzaak der verandering van $A$ in $B$, heefl dus slechts een voorlopig karakter. In plaats van $A+C=B$ zouden wij eigenlijk moeten gebruiken deze formule: $\mathrm{A} A+\mathrm{fC}=\mathrm{fB}$, warbij dan 't functieteken niets anders uitdrukt dat 'datgene 't welk op ons den indruk maakt van .....'

${ }^{2}$ cf. Heymans, G. (1890a), op. cit. p. 279.

${ }^{3}$ cf. Heymans, G. (1890a), op. cit. p. 279, '.... in ' $t$ algerneen derhalve: zoovaak wij een oorzaak moeten aannemen wier invoering de identiteit tusschen vroeger en later niet wordt hersteld, zoo vaak onderstellen wij ook dat de inhoud onzer waarneming niet ten volle uitdrukt het wezen der dingen. Wij hebben dan 't zeer hepaalde gevoel, dat zulk een "onverklaard" causaalverband slechts een voorlopig, - geen eindresultaat kan zijn; wij kunnen ons daarbij evenmin neerleggen als bij een verandering zonder oorzaak. Wij gaan derhalve hypothesen vormen over de wezenlijke dingen en de wezenlijke processen die aan onze waarnemingen te gronde liggen: dat wil zeggen, wij trachten ons eene zoodanige voorstelling van die dingen en processen te vormen, dat daardoor de identiteit tusschen vroeger en later 
Ook in Gesetze und Elemente gaat Heymans op dit onderwerp in. Daar heet het dat de ervaring een onvolledig of onbetrouwbaar beeld van de werkelijkheid levert. Dit inzicht acht Heymans één van de belangrijkste verworvenheden van het Westeuropese denken. De natuurwetenschap is er op gericht om de verborgen werkelijkheid achter de verschijnselen te kennen. Zij stelt zich daarom ten doel zodanige voorstellingen of hypothesen van de werkelijkheid te vormen, dat waargenomen veranderingen als schijnbare veranderingen kunnen worden opgevat.'

\section{De functie van hypothesen}

In veel gevallen is het waarnemen van een bepaalde oorzaak, opgevat als toevoeging aan wat men heeft waargenomen, al voldoende om de ogenschijnlijke tegenstrijdigheid tussen wat eerder en later is waargenomen in overeenstemming te brengen met Hamiltons postulaat. Bijvoorbeeld: als men zich afvraagt hoe het komt dat een donkere kamer lichter wordt wanneer men het met wit papier behangt, dan ligt het antwoord voor de hand. Immers, donker gekleurde stoffen nemen meer licht op, terwijl stoffen die licht gekleurd zijn licht terugkaatsen. Op grond van de overtuiging a priori dat het werkelijk bestaande onveranderlijk is, moet men er van uitgaan dat de hoeveelheid licht gelijk blijft. Omdat het witte behang meer licht terugkaatst dan het donkere behang, en er dus minder licht verloren gaat, is verklaard dat de kamer lichter wordt. De toevoeging 'het witte behang dat meer licht terugkaatst' is voldoende om de ogenschijnlijke strijdigheid tussen de eerdere waarneming - een donkere kamer - en de latere waarneming - een lichte kamer - weg te nemen. ${ }^{2}$ Dit zou men kunnen uitdrukken in deze vergelijking: een donkere kamer + wit behang dat meer licht

weer wordt hersteld. Als regulatief beginsel bij de vorming van die hypothesen vinden wij altijd weer terug het postulaat van de onveranderlijkheid van het werkelijk bestaande.'

${ }^{1}$ cf. Heymans, G. (1894), op. cit. p. 376, 'In solchen Fällen giebi es denn, sofern an der aufgestellten Forderung festgehalten werden soll, nur Einen Ausweg: was die Eifahrung uns bietet, muss ein unvollständiges oder ein ungetreues Bild der Wirklichkeit sein. Und in der That ist diese Überzeugung (....) eine der ältesten Errungenschaften der abenländischen Philosophie. Aber mit dieser Lösung des Problems in abstracto giebt sich unser Wissenstrieb nicht zufrieden; wir wollen die wahre, hinter den Erscheinungen sich versteckende Wirklichkeit erkennen; wir wollen auch wissen was in dieser geschieht, während jene uns das Bild eines Entstehens oder Vergehens vorgaukelt. Oder wenigstens: wir wollen von dieser Wirklichkeit eine Vorstellung gewinnen, welche uns die wahrgenommene Veränderung als eine bloss scheinbare verstehen lasst.'

${ }^{2}$ cf. Heymans, G. (1890a), op. cit. p. 279-280. 'Een donkere kamer wordt lichter wanneer zij met wit papier wordt behangen. Vragen wij hoe dit komt, zal men ons antwoorden dat het licht door donkergekleurde stoffen wordt opgenomen, maar door lichtgekleurde wordt teruggekaatst. Daarmede is de zaak verklaard: er komt evenveel licht in de kamer als vroeger, maar er gaat minder dan vroeger verloren. De identiteit is dus hersteld, zonder dat er eenige aanleiding bestaat om naar 't "wezen" van 't licht te vragen; licht is eenvoudig iets dat van lichtgevende voorwerpen uitgaat; de schijnbare vermeerdering van den lichtvoorraad had 't probleem doen stcllen, de gegeven verkiaring heeft ons doen begrijpen waar dat meerdere licht vandaan gekomen is.' 
terugkaatst $=$ een lichte kamer. Heymans acht het daarom niet nodig, om in dit eenvoudige geval een hypothese te formuleren over de aard of het wezen van licht.

In andere, meer complexe gevallen is het formuleren van hypothesen echter we] nodig om de identiteit tussen eerdere en latere waarnemingen weer te herstellen, en om daardoor te kunnen voldoen aan het postulaat van Hamilton. De functie van het formuleren van hypothesen maakt Heymans duidelijk aan de hand van het eerder genoemde water-voorbeeld. Eerst neemt men niet-kokend water waar, en later water dat kookt. Geconstateerd wordt dat in de tussentijd alle omstandigheden gelijk zijn gebleven, behalve één: het toevoeren van warmte. Dit wordt beschouwd als de oorzaak van de verandering van niet-kokend in kokend water. In Heymans' termen: niet-kokend water + warmte $=$ kokend water. Echter, hiermee acht Heymans deze logische vergelijking slechts voorlopig opgelost. Met deze vergelijking is immers nog niet aangetoond dat de werkelijkheid in beginsel onveranderlijk is. Het doel van het vormen van hypothesen is om deze onveranderlijkheid aan te tonen; in dit geval kan men denken aan bijvoorbeeld hypothesen over de moleculaire structuur van water en de aard van warmte. ${ }^{\prime}$

Heymans concludeert in de Schets dat het in het causale denken niet gaat om het waarnemen van regelmatige successie van verschijnselen. Het gaat er veeleer om de keten der waargenomen veranderingen met behulp van hypothesen zo te begrijpen dat de achterliggende onveranderlijke structuur van de werkelijkheid wordt

' cf. Heymans, G. (1890a), op. cit. p. 280, 'Wij nemen waar eene zekere hoeveelheid water, eerst in niet kokenden, daarna in kokenden toestand. Wij zeggen onmiddellijk: er moeten omstandigheden zijn geweest die dat koken hebben veroorzaakt. Nu vinden wij evenwel, dat alle omstandigheden dezelfde zijn gebleven, mel uitzondering van éne: er is warmte toegevoerd. Die warmte moet dus de oorzak zijn geweest. Evenwel, daarmede zijn wij niet gereed. Wij zijn, om 't zoo eens uit te drukken, een valsche vergelijking kwijtgeraakt; maar wij hebben er nog geen identieke voor in de plaats gekregen. De vergelijking: nietkokend water = kokend water was klaarblijkelijk valsch; daarbij konden wij ons niet neerleggen. Wij hebben nu daarvoor in de plaats gekregen de vergelijking: niet-kokend water + warmte $=$ kokend water; welnu wij rusten niet voor wij die vergelijking hebben opgelost, m.a.w. voor wij ze tot een identieke vergelijking hebben gemaakt. Wij gaan dus hypothesen vormen aangaande de innerlijke constitutie van 't water en aangaande 't wezen der warmte, zoo lang tot wij een voorstelling van de zaak hebben gekregen, die ons in staat stelt onze grondstelling van de blijvende identiteit der dingen te handhaven.' Zie ook: Heymans, G. (1894), op. cit. p. 378, 'Oder wir sehen dass ein Stück Eis mit einem warmen Körper in Berührung gekommen ist, schmilzt; der betreffende Körper bleibt bestehen, aber er verliert seine Wärme. Abermals wird das Zusammenkommen des Eises mit dem warmen Körper als die Ursache des Schmelzens bezeichnet; zugleich aber angenommen, dass ganze bestimmte Elemente des lezteren (diejenigen welche wir als Wärme wahmehmen) in das ersteren übergetreten sind und in Verbindung mit diesem als geschmolzenes Eis wahrgenommen werden. (...) Wir wollen von dem unbekannten Etwas (...) welches wir (...) mit Eis verbunden als Wasser wahrnehmen, eine Vorstellung gewinnen. Wir stellen Vermuthungen an über (...) das Wesen der Wärme; wir vergleichen dieselben mit anderen gegebenen Thatsachen, und wenn sie sich bewähren, so ergänzen wir mittelst derselben unsere Vorstellungen von den jeweiligen wirkenden Ursachen.' 
blootgelegd. Met andere woorden: waargenomen veranderingen vormen de sluier waarachter zich eene onveranderlijke werkelijkheid verbergt. ${ }^{1}$ Elders in de Schets spitst Heymans dit toe. Daar heet het dat het een hoofddoel, zelfs een postulaat, van natuurwetenschap is om alle verschijnselen tot mechanische processen te herleiden. ${ }^{2}$

In Gesetze und Elemente wordt deze laatste gedachte explicieter geformuleerd. Het doel van de (natuur)wetenschap is zodanige hypothesen over de werkelijkheid te vormen, dat waargenomen veranderingen als schijnbare veranderingen opgevat kunnen worden. Nauwkeuriger gezegd: zij stelt zich ten doel de verschillen tussen werkelijkheden, waarvan wordt aangenomen dat zij ten grondslag liggen aan een waargenomen verandering, te elimineren. Dit kan alleen worden bereikt als het lukt om waargenomen verandering te denken als een teken voor een samenstel van gelijkmatig voortschrijdende processen. Hierbij moeten nieuwe verschijnselen gezien worden als het resultaat van het verbinden of splitsen van niet-ontstane en onvernietigbare elementen van de werkelijkheid die met deze processen zijn verbonden. ${ }^{3}$ Heymans concludeert nu dat men de notie 'oorzaak', waarop de hypothese van Hamilton berust, als volgt kan definiëren. 'Oorzaken' zijn (fA en fC) de werkelijke toestanden en processen waarvan men postuleert dat zij aan waargenomen nieuwe verschijnselen ten grondslag liggen. Deze verschijnselen (fB) treden op als de gelijkmatige voortzetting van de toestanden en processen waarvan men aanneemt dat die oorzaken (fA en fC) daaraan ten grondslag liggen. ${ }^{4}$

De tweede vraag die Heymans ter toetsing van Hamiltons hypothese aan de orde had gesteld, was: (is) het antwoord door de feiten op deze vragen gegeven (in welke gevallen, onder welke omstandigheden, wordt een oorzaak geeischt, en aan welke voorwaarden moet een verschijnsel voldoen om als oorzaak te worden aanvaard)

' cf. Heymans, G. (1890a), op. cit. p. 281, 'Overal blijkt dat men zich niet tevreden stelt met 't vinden eener regelmatige opeenvolging van verschijnselen; overal worden de verschijnselen verwerkt en nog eens verwerkt, tot men er in geslaagd is de keten der waargenomen veranderingen voor te stellen als den sluier, waarachter zich eene onveranderijik werkelijkheid verbergt.'

${ }^{2}$ cf. Heymans, G. (1890a), op. cit, p. 130, '..... herleiding van alle natuurverschijnselen tot mechanische processen (is) een postulaat der natuurwetenschap.'

cf. Heymans, G. (1894), op. cit. p. 379, 'Aber das Ziel vorauf diese ganze Gedankenbewegung hinstrebt, bleibt immer das nämiliche: möglichste Elimination aller Verschiedenheit zwischen den Wirklichkeiten, welche wir als der früheren und der späteren Wahmehmungen z.u Grunde liegend denken. Erreicht könnte dieses Ziel nur werden, wenn es uns gelänge, die wahrgenommene Veränderung als Zeichen für einen Complex gleichmässig fortschreitender Processe, die neue Erscheinung als das Ergebniss einer durch diese Processe herbeigeführten Verbindung oder Trennung unentstandener und unvergangener Wirklich- keitselemente zu denken.'

'cf. Heymans, G. (1894), op. cit. p. 379-380, 'Wie muss nun, nach der Hamilton'schen, im Vorhergehenden erläuterten Hypothese, der allem causale Denken mehr oder weniger bewusst zu Grunde liegende Begriff der Ursache definirt werden? (...) Ursache nennen wir die zu einer wahrgenommenen neuen Erscheinung hinzupostulirten, derselben vorhergehenden wirklichen Zustände und Processe, aus denen sich die der neuen Erscheinung zu Grunde liegenden Zustände und Processe als ihre gleichmässige Fortsetzung ergeben.' 
wat het volgens Hamilion's theorie zou moeten zijn?' Op grond van zijn vooratgaande bevindingen beantwoordt Heymans deze vraag bevestigend. ${ }^{2}$

\section{Zekerheid van causale axioma's}

De laatste vraag die Heymans in verband met Hamiltons hypothese wilde toetsen, was: (laten) de (causale) axioma's (...) zich uit Hamilton's theorie verklaren ? ${ }^{3}$ Eerder had Heymans al geconstateerd dat zulke axioma's of grondstellingen in de notie 'oorzaak en gevolg' liggen besloten en dat men zulke axioma's als noodzakelijke waarheden moet beschouwen. $\mathrm{Nu}$ moet nog worden aangetoond dat Hamiltons hypothese, in tegenstelling tot Hume's theorie, de causale axioma's wél kan verklaren, in de zin dat eigenschappen van causale relaties, aan welke men een axiomatische zekerheid toeschrijft, rechtstreeks uit Hamiltons omschrijving van de aard van causale relaties volgen.

Het eerste causale axioma dat in termen van Hamiltons postulaat kan worden verklaard, is de onderstelling dat een bepaalde oorzaak leidt tot een bepaald gevolg. Uitgaande van Hamiltons postulaat dient ondersteld te worden, dat bij het waarnemen dat een bepaald verschijnsel (zeg: een $A$ ) in een bepaald ander verschijnsel (zeg: een B) verandert, een B een combinatie is van een A plus iets anders wat al cerder bestond. ${ }^{4}$

Het tweede en derde causale axioma betreffen de onderstelling dat het gevolg noodzakelijk optreedt als de oorzaak gegeven is, en de onderstelling dat het gevolg logisch kan worden afgeleid uit de oorzaak. Als van Hamiltons postulaat wordt uitgegaan - de onveranderlijkheid der dingen -, dan onderstelt dit dat verschijnselen op feiten betrekking hebben die rechtstreeks voortvloeien uit bepaalde andere feiten die daar aan vooraf zijn gegaan. Hamiltons postulaat maakt het daarom mogelijk om verschijnselen die elkaar volgen op te vatten als een opeenvolging van feiten die gehoorzamen aan logische wetten: alle feiten hangen volgens de wetten van de logica met elkaar samen. Bovendien, als men zegt dat een A niet tegelijkertijd een B en een niet-B kan zijn, dan wordt de notie 'tegelijkertijd' overbodig. Immers, een gevolg ligt logisch besloten in een oorzaak; dat wil zeggen, een gevolg kan overeenkomstig

1 cf. Heymans, G. (1890a), op. cit. p. 273.

${ }^{2}$ cf. Heymans, G. (1890a), op. cit. p. 281-282, 'De hypothese van Hamilton, volgens welke alle causale denken verklaard zou moeten worden uit de ondenkbaarheid eener schepping of vernietiging in den eigenlijken zin des woords, wordt dus door de feiten ten volle bevestigd. Zoo vaak als, en slechts dan wanneer volgens Hamilton's theorie een oorzaak zou moeten worden geeischt, wordt zij geeischt; zoovaak als, en slechts dan wanneer volgens Hamilton's theorie een verschijnsel als oorzaak zou moeten worden aangenomen, wordt het als oorzaak aangenomen.'

${ }^{3}$ cf. Heymans, G. (1890a), op. cit. p. 274.

${ }^{4}$ cf. Heymans, G. (1890a), op. cit. p. 282, 'Immers volgens die opvatting zijn wij genoodzaakt, zoo vaak wij een verschijnsel $A$ in een verschijnsel $B$ zien overgaan, aan te nemen dat $B$ uit $A$ en uit iets anders dan vroeger ook reeds bestond is samengesteld, dat derhalve dat andere bij A moest komen om B tot stand te brengen, m.a.w. dat zijne vereeniging met $A$ aan het gegeven-zijn van B moest voorafgaan.' 
het non-contradictiebeginsel uit de oorzaak worden afgeleid. Oorzaak en gevolg zijn daardoor noodzakelijk met elkaar verbonden. Deze "causale" noodzakelijkheid wijkt overigens niet af van logische noodzakelijkheid; "causale" noodzakelijkheid is, zo betoogt Heymans, slechts een bepaalde vorm van logische noodzakelijkheid.'

Ten slotte het vierde causale axioma: als men er van uitgaat dat de notie 'oorzaak' op niets anders neerkomt dan een zodanige aanvulling van de gegevens waardoor de ogenschijnlijke strijdigheid tussen wat men eerder en later heeft waargenomen wordt weggenomen, dan kan men hieruit afleiden dat oorzaak en gevolg gelijkwaardig en gelijksoortig zijn. Immers, als men waarneemt dat een A overgaat in een B, dan moet men een oorzaak $C$ onderstellen om deze overgang te verklaren. Dit laatste komt, aldus Heymans, geheel overeen met wat het causaliteitsbeginsel volgens Hamilton inhoudt. ${ }^{2}$

\section{Algemeengeldigheid en zekerheid van natuurwetenschappelijke principes}

Met behulp van de hypothese van Hamilton kan men ook de algemeengeldigheid en zekerheid van natuurwetenschappelijke principes verklaren, zo betoogt Heymans. De "klassieke" vraag hierbij was of zulke principes, bijvoorbeeld het traagheidsbeginsel, door ervaring worden ontdekt, of dat zij geheel onafhankelijk van ervaring bestaan. Als men er echter van uitgaat dat de kennis van zulke principes geheel door ervaring ontstaat, zoals Mach had gemeend, is de exceptioneele algemeenheid en zekerheid van zulke principes onverklaarbaar. Hamiltons hypothese kan dit laatste wel verklaren. Omdat men er a priori van overtuigd is dat het werkelijk bestaande onveranderlijk is, maakt men in ' $\mathrm{gegeven}$ wereldbeeld een onderscheid tussen het veranderlijke en het onveranderlijke. Een wetenschappelijke verklaring is voltooid als men het veranderlijke weet te herleiden tot iets wat niet verandert. Hamiltons hypothese verklaart dat de wetenschap altijd zoekt naar het gelijkblijvende in de wisseling van de verschijnselen. Bovendien verklaart die hypothese, dat men, op

' cf. Heymans, G. (1890a), op. cit. p. 283, 'Vervolgens: de gepostuleerde onveranderlijkheid der dingen leert ons ieder verschijnsel beschouwen als betrekking hebbende op feiten, die door de eenparige voortzetting van voorafgaande feiten zijn tot stand gekomen. Met andere woorden: zij onderwerpt de objectieve correlata van opeenvolgende verschijnselen aan de logische wetten; zij geeft ons het recht om uit de formule: $A$ kan niet tegelijkertijd $B$ en niet-B zijn, het woord "tegelijkertijd" te schrappen. Maar voor die beschouwing ligt blijkbaar het volgende in het voorafgaande logisch besloten, levert dus de compleete oorzaak de premissen, waaruit de werking als conclusie volgens het principium contradictionis kan worden afgeleid. De noodzakelijkheid die de laatste met de eerste verbindt, is dus geene. noodzakelijkheid sui generis, maar eenvoudig een bizonder geval van de logische noodzakelijkheid.'

${ }^{2}$ cf. Heymans, G. (1890a), op. cit. p. 283, 'Eindelijk: de gelijksoortigheid en de gelijkkwaardigheid van oorzaak en werking staat analytisch vast, wanneer "oorzaak" niets anders beteekent dan eene zoodanige aanvulling der aanvankelijke gegevens, dat daardoor de. identiteit tusschen de objecten van vroegere en latere waarnemingen wordt hersteld. Zoovaak. A overgaat in $\mathrm{B}$, moet eene oorzaak $\mathrm{C}=\mathrm{B}-\mathrm{A}$ aangenomen worden: ziedaar volgens Hamilton de geheele inhoud van het causaliteitsbeginsel.' 
grond van de vaststelling dat een bepaald deel of element uit een veelheid van gevallen onveranderlijk blijkt te zijn, dat element mag opvatten als hetgeen het wezen der dingen vormt of representeert. Bijvoorbeeld: als in bepaalde gevallen is geconstateerd dat snelheid en richting de beweging van een lichaam bepalen, dan wordt daaruit afgeleid dat snelheid en richting in alle gevallen de beweging van lichamen bepalen. Snelheid en richting worden daardoor opgevat als de essentiële kenmerken van bewegingsverschijnselen. Omdat men zulke kenmerken als essentieel beschouwt, onderstelt of postuleert men dat zulke kenmerken onveranderlijk zijn. Heymans concludeert daarom dat de kennis van specifieke natuurwetenschappelijke principes door ervaring ontstaat, maar dat de algemeengeldigheid en zekerheid van zulke principes berusten op de overtuiging a priori dat iets onveranderlijks aan alle verschijnselen ten grondslag moet liggen. ${ }^{1}$

Uit de voorafgaande opmerkingen over causale axioma's en specifieke natuurwetenschappelijke principes blijkt dat Heymans ook de derde vraag die hij zich had gesteld bevestigend beantwoordt: het blijkt derhalve dat de axioma's en begrippen, die, ieder voor zich en zonder dat men zich van hun verband rekenschap kon geven, door vroegere onderzoekers als kenmerkend voor de causale betrekking zijn opgesteld geworden, uit de hypothese van Hamilton zich volledig laten verklaren. ${ }^{2}$ Met een klaroenstoot concludeert Heymans ten slotte dat wij ten volle gerechtigd

' cf. Heymans, G. (1890a), op. cit. p. 285-289, 'Ten slotte nog een woord over de mechanische grondbeginselen. Over hun apriorisch of empirisch karakter heeft men heel wat gestreden: aan den eenen kant beriep men zich op het onbetwistbare feit dat deze wetten ontdekt zijn geworden, en dat men dikwijls zelfs vrij nauwkeurig de geschiedenis hunner ontdekking vervolgen kan, - aan den anderen kant op hun rationeel karakter, en op de omstandigheid dat, nadat zij eenmaal ontdekt waren, de beste denkers hun eene van alle ervaring onafhankelijke evidentie hebben toegeschreven. Het een zoowel als het ander geldt in ' $t$ bizonder ten aanzien van het traagheidsbeginsel. (......) Door de theorie van Hamilton wordt deze verklaring (dat de exceptioneele zekerheid, die feitelijk aan dat beginsel toekomt onverklaard (is) mogelijk. Volgens die theorie zijn wij van de onveranderlijkheid van het werkelijk bestaande apriori overtuigd; maken dientengevolge eene scheiding tusschen hetgeen in 't gegeven wereldbeeld veranderlijk en onveranderlijk is; en aanvaarden alleen 't laatste als eindiesultaat. Vandaar het zoeken der wetenschap naar "den ruhenden Pol in der Erscheinungen Flucht"; en vandaar ook dat wij, zoodra wij van eenige element de onveranderlijkheid in een reeks van gevallen hebben geconstateerd, dat element beschouwen als uitmakende of vertegenwoordigende het wezen der dingen, en op dien grond zijne onveranderlijkheid ook in niet-waargenomen gevallen postuleeren. Zoo met snelheid en richting eener eenmal begonnen beweging. Zoodra wij voor enkele gevallen hebben opgemerkt dat deze twee, welke inwerkingen ook het bewegende lichaam ondergaat, zich altijd onveranderd in het eindresultaat laten terugvinden, worden zij als essentialia der bewegingsverschijnselen erkend, en op dien grond hunne absolute onveranderlijkheid aangenomen. Het traagheidsbeginsel is dus ongetwijfeld door ervaring verkregen; maar ontleent zijne exceptioneele algemeenheid en zekerheid aan de apriorische overtuiging, dat er aan alle verschijnselen iets onveranderlijks te grond moet liggen.'

${ }^{2}$ cf. Heymans, G. (1890a), op. cit. p. 290. 
(zijn) aan de theorie van Hamilton alle zekerheid toe te kennen, die in de empirische wetenschappen bereikbaar is. ${ }^{1}$

Samengevat: Heymans acht Hume's theorie niet toereikend om het psychologische causaliteitsvraagstuk op te lossen, en hij meent dat men in plaats daarvan uit moet gaan van het postulaat dat het werkelijk bestaande niet verandert; dit postulaat kan de verschijnselen van het causale denken wel verklaren en het biedt ook een oplossing van het psychologische causaliteitsvraagstuk. Echter, nu komt het er voor Heymans op aan om aan te tonen wat de filosofische rechtvaardiging van dit postulaat is; dit komt in het navolgende aan de orde.

\section{Filosofische rechtvaardiging van Hamiltons postulaat}

Heymans wijst er op dat Hamiltons theorie leidt tot een sterke vereenvoudiging van het psychologische causaliteitsvraagstuk. Immers, alle verschijnselen van het causale denken kan men samenvatten in één denkwet: de blijvende identiteit der dingen. Dat wil echter niet zeggen dat daarmee het gehele causaliteitsvraagstuk is opgelost. ${ }^{2} \mathrm{Er}$ is immers ogenschijnlijk geen logische noodzakelijkheid om wanneer ons de ervaring met het gegevenzijn van eenig object heeft bekend gemaakt, aan het object onveranderlijkheid toe te schrijven. ${ }^{3}$ Met andere woorden: de overtuiging a priori dat het werkelijk bestaande onveranderlijk is impliceert niet noodzakelijk dat men op grond van het waarnemen van een bepaald object kan concluderen dat dit onveranderlijk is.

Heymans poogt daarom in het Besluit van de Schets een filosofische rechtvaardiging van Hamiltons postulaat te bieden, en daarmee ook een oplossing te geven voor het filosofische causaliteitsvraagstuk; deze rechtvaardiging vormt de theoretische slotsom van de Schets. Hij benadrukt overigens dat men haar meer moet zien als een vermoeden of als de aanduiding van een oplossingsrichting, dan als een volledig beargumenteerd standpunt.

Hamiltons postulaat kan volgens Heymans weliswaar feitelijk worden bevestigd, maar de filosofische rechtvaardiging daarvan is een probleem op zich. Dit postulaat

'ef. Heymans, G. (1890a), op. cit. p. 290.

2 cf. Heymans, G. (1890a), op. cit. p. 290-291, Het spreekt van zelf dat door deze theorie het causaliteitsprobleem niet is opgelost, - evenmin als het gravitatieprobleem door de theorie van Newton. In beide gevallen werd door de gestelde theorie het probleem slechts vereenvoudigd, tot een algemeenen vorm teruggebracht, en daardoor de oplossing voorbereid. (....) de theorie van Hamilton (maakt het mogelijk), alles wat wij tot dusver van het causale denken wisten, in de denkwet van de blijvende identiteit der dingen samen te vatten.' Zie ook: Heymans, G. (1894), op. cit. p. 402-403, 'Was wir bis jelzt erreicht haben ist bloss die Einsicht, dass Eine, in thatsächlichen Denken gegebene Voraussetzung von der Unveränderlichkeit des Bestehenden, in Verbinding mit den Erfahrungsdaten, sämmtliche Erscheinungen des inductiven Denkens nach logischen Geseizen zu erklären vermag. Damit sind allerdings eine grosse Anzahl scheinbar unverbundener Thatsachen und Geselze des Denkens auf Eine fundamentale Thatsache zurückgeführt; keineswegs aber dürfen wir glauben, damil die vorliegende Probleme endgültig gelöst zu haben.'

${ }^{3}$ cf. Heymans, G. (1890a), op. cit. p. 291. 
zou gerechtvaardigd kunnen worden door het in verband te brengen met Kants hypothese dat het verstand een rol speelt bij het in de tijd ordenen van verschijnselen. Immers, de inhoud onzer causale overtuigingen betreft de successie van verschijnselen. De inhoud van zulke overtuigingen kan men verklaren met behulp van Kants hypothese dat bepaalde subjectieve factoren een beslissende rol spelen bij het ordenen van verschijnselen in de tijd en door diens leer van de aprioriteit van de tijdsvoorstelling. Heymans acht het ten slotte in hooge mate waarschijnlijk dat men de filosofische rechtvaardiging van Hamiltons postulaat moet zoeken in hypothesen over oorsprong en wezen van die tijdsvoorstelling. ${ }^{1}$ Met andere woorden: de filosofische rechtvaardiging van het postulaat dat het werkelijk bestaande onveranderlijk is, en waar de notie 'tijd' geen betrekking op heeft, moet men zoeken door dit postulaat in verband te brengen met Kants opvatting dat verschijnselen door beginselen a priori in de tijd worden geordend.

Op dit vermoeden komt Heymans in het Naschrift bij de Schets terug; dit naar aanleiding van enkele bedenkingen van het Curatorium van het Stolpiaansch Legaat. ${ }^{2}$

' cf. Heymaṇs, G. (1890a), op. cit. p. 375, 'Hamilton eindelijk kwam tot het inzicht dat al deze tot dusver onverbonden feiten zich laten terugbrengen tot deze algemeene denkwet: dat wij buiten staat zijn een ontstaan of vergaan van het werkelijk bestaande voor waar te houden: eene wet waarvan de algemeenheid en de groote beteekenis door het latere onderzoek telkens opnieuw is bevestigd en toegelicht. Vragen wij ten slotte wat er gedaan is om deze feiten met de hypothese van Kant in verbinding te brengen, dan kan slechts op een stap van beteekenis gewezen worden. Het is de opmerking van Kant zelf, dat, daar de inhoud onzer causale overtuigingen betrekking heeft op de tijdelijke opeenvolging van zekere qualitatief en quantitatief ten opzichte van elkander bepaalde verschijnselen, hunne verklaring gezocht zal moeten worden in subjectieve factoren, die de ordening der verschijnselen in de tijd beheerschen. Brengen wij met deze opmerking in verband de door gewichtige gronden gesteunde leer van de aprioriteit der tijdsvoorstelling, dan mogen wij het in hooge mate waarschijnlijk achten, dat in hypothesen over oorsprong en wezen van die tijdsvoorstelling de eindelijke oplossing van ons probleem gevonden zal worden.'

${ }^{2}$ Het bleek niet mogelijk om de exacte formuleringen van deze bedenkingen uit het volledig ongesystematiseerde archief van het Leidse Stolpiansch Legaat te achterhalen. Het enige wat tot dusver kon worden aangetroffen is de publieke annonce van het toekennen van de prijs. Hierin wordt in bedekte termen de aarzeling van het Curatorium verwoord: 'Curatoren van het Stolpiaansch Legaat hebben op de door hen in mei 1888 uitgeschreven prijsvraag een antwoord ontvangen onder den titel: Schets eener kritische geschiedenis van het causailteitsbegrip in de nieuwere wijsbegeerte', zo werd in de annonce gesteld.' Deze verhandeling onderscheidt zich door zelfstandige studie der bronnen en wetenschappelijke opvatting der aan het onderwerp verbonden vraagpunten. De zakelijke voorstelling en de oorspronkelijke, hoewel nimmer aanmatigende kritiek, in goede orde en helderen stijl voorgedragen, maken haar naar aller oordeel tot een sieraad van onze wijsgeerige litteratuur. In weerwil van eenige bedenkingen zoowel wat de zuiverheid van taal betreft als vooral tegen de theoretische slotsom van het betoog, hebben Curatoren dan ook aanstonds besioten, het stuk met goud te bekronen. Bij het openen van het naambriefje bleek de schrijver te zijn de heer G. Heymans, lector in de wijsbegeerte aan de Leidsche Universiteit. Hem is de uitgeloofde eereprijs toegewezen en zijn werk zal op kosten van hcı Legaat ter perse worden gelegd.' 
Daar wil hij de vraag beantwoorden of zijn theoretische slotsom een logische tegenstrijdigheid vormt?

Heymans had ondersteld dat het werkelijk bestaande onveranderlijk is: dat wat werkelijk bestaat is een onveranderlijk zijnde. Hij had er echter ook op gewezen dat men alleen verschijnselen waarneemt die veranderen. De critici onder de curatoren achtten, zo constateert Heymans, de combinatie van beide stellingen ondenkbaar. Immers, als men aanneemt dat veranderlijke verschijnselen corresponderen met een daarachter liggende werkelijkheid, hoe is het dan mogelijk om vol te houden dat zo'n werkelijkheid onveranderlijk is? In Heymans' woorden: hoe kan evenwel dit zijnde zich aan zichzelf voordoen in een gedaante, met zijn eigen aard in lijnrechte tegenstelling $?^{2}$

Zijn theoretische slotsom acht Heymans voor een deel bewijsbaar, maar een ander deel moet het slechts als een bloot vermoeden worden gezien. Het bewijsbare deel betreft Hamiltons wet, opgevat als een natuurwet van het denken: het causale denken kan men volledig verklaren door het toepassen van de overtuiging dat er alleen sprake is van schijnbare verandering, en dat men deze schijnbare verandering moet herleiden tot iets wat onveranderlijk is. ${ }^{3}$ Als hier van uit wordt gegaan, ontstaat de vraag hoe het bestaan van die overtuiging kan worden verklaard. In Heymans' woorden: hoe hare feitelijke aanwezigheid te verklaren ? $^{4} \mathrm{Zijn}$ antwoord luidt eenvoudig dat de verwachtingen die op grond van deze overtuiging worden gevormd door vooridurende ervaring worden bevestigd. ${ }^{5}$ Dit laat overigens echter nog steeds de vraag open welke onbewuste gronden de feitelijke zekerheid der aangewezen overtuiging zouden kumnen verklaren? $?^{6}$ Met andere woorden: hoe kan men de overtuiging dat het werkelijk bestaande onveranderlijkheid is, rechtvaardigen? Op dit punt had Heymans de al eerder genoemde hypothese van Kant als aanknopingspunt gezien. Deze hypothese leidt tot het vermoeden dat de overtuiging dat wat werkelijk bestaat onveranderlijk is, gerechtvaardigd zou kunnen worden door de stellingen dat de voorstelling van

' cf. Heymans, G. (1890a), op. cit. p. 377, 'Men meende in hoofdzaak, dat deze slotsom eene logische tegenstrijdigheid in zich sloot; immers hel scheen ondenkbaar, dat een onveranderlijk zijnde zich aan ons zou openbaren als eene wereld van veranderlijke verschijnselen. Het 'verschijnsel der verandering' zou toch uit het zijnde moeten voortkomen.'

'cf. Heymans, G. (1890a), op. cit. p. 377.

${ }^{3}$ cf. Heymans, G. (1890a), op. cit. p. 378, 'Bewijsbaar schijnt mij de wet van Hamilton. als natuurwet van het denken opgevat: de stelling derhalve, dat het causale denken in zijn vollen omvang berust op, en verklaard kan worden uit de (al of niet bewuste) toepassing van de overtuiging, dat alle verandering schijn, en tot iets onveranderlijks terug te brengen moet zijn.'

cf. Heymans, G. (1890a), op. cit. p. 378.

' $\mathrm{cf}$. Heymans, G. (1890a), op. cit. p. 378, '... of de bedoelde overtuiging berust op voldoende, zij het ook niet met bewustzijn voorgestelde gronden, of wel zij is uit andere, niet als geldige gronden aan te merken oorzaken ontstaan. Het eerste schijnt mij in honge mate waarschijnlijk, op grond der omstandigheid, dat de ervaring de verwachtingen, op de bedoelde overtuiging gebouwd, voordurend bevestigt.'

"cf. Heymans, G. (1890a), op. cit. p. 378. 
tijd een subjectieve oorsprong heeft en dat verschijnselen door beginselen a priori in de tijd worden geordend.'

Heymans' antwoord op de vraag of de combinatie van Hamiltons postulaat en Kants stellingen niet tot eene logische tegenstrijdigheid leidt, luidt: neen. Het argument dat het waarnemen van veranderende verschijnselen strijdig zou zijn met de onderstelling dat het werkelijk bestaande onveranderlijk is, gaat alleen op als men er van uitgaat dat deze werkelijkheid of het werkelijk bestaande in de tijd niet zou veranderen. Heymans uit echter het vermoeden dat op deze werkelijkheid, die aan de wereld der verschijnselen ten grondslag ligt, het tijdsbegrip in het geheel niet van toepassing is. Dit impliceert dat men daarover noch kan zeggen dat deze werkelijkheid verandert noch dat deze voortduurt. Hij geeft weliswaar toe dat dit moeilijk voor te stellen is, maar dat betekent nog niet dat het ondenkbaar is. Hij concludeert ten slotte dat een buiten den tijd staande werkelijkheid zich in allerlei vormen aan mensen voordoel, en dat men door de bijzondere structuur of de eigenaardige organisatie van het denken de hoedanigheden waarin zo'n werkelijkheid zich aan ons voordoet overeenkomstig de tijdsvorm a priori ordent. Deze gedachtengang impliceert derhalve geene logische tegenstrijdigheid. ${ }^{2}$

Heymans besluit zijn Naschrift als volgt: wanneer evenwel door deze onderstelling gegeven feiten, zooals onze apriorische kennis van de eigenschappen des tijd en van de causale ordening der verschijnselen, kunnen worden verklaard, en wanneer wij niet inzien hoe deze feiten anders verklaard zouden kunnen worden, dan ligt daar mijns inziens een voldoende grond, om, zoo lang nadere gegevens ontbreken, aan die onderstelling althans eene zekere waarschijnlijkheid toe te kennen. ${ }^{3}$

' cf. Heymans, G. (1890a), op. cit. p. 378, '.... (ik) heb mij aangesloten bij het vermoeden, dat zij te vinden zouden zijn in gegevens, betrekking hebbende op den subjectieven oorsprong van de tijdsvoorstelling en van de ordening der verschijnselen in den tijd.'

${ }^{2}$ cf. Heymans, G. (1890a), op. cit. p. 379-380, 'Is dit (eene logische tegenstrijdigheid) het geval? Het wordt beweerd op grond der overweging, dat uit gegevens, waarin het element der verandering ontbreekt, onmogelijk de verschijning eener veranderende wereld begrepen kan worden. Inderdaad zou tegen deze overweging niets te zeggen zijn, wanneer de bedoelde gegevens als onveranderlijk in den tijd moesten worden gedacht; volgens het gestelde vermoeden evenwel zou niet eene in den tijd onveranderlijke werkelijkheid, maar eene werkelijkheid waarop het gehcele begrip van tijd niet van toepassing zou zijn, waarvan dus evenmin gezegd kan worden dat zij voorduurt als dat zij verandert, aan de wereld der verschijnselen te gronde liggen. (....) Dat cene onveranderlijk voortdurende werkelijkheid zich in een onveranderlijk voortdurend subject als eene veranderlijke wereld zou atspiegelen, is zeer zeker ondenkbaar; maar dat eene buiten den tijd staande werkelijkheid zich in het subject in eene veelheid van vormen zou uitdrukken, en dat het subject, krachtens zijne eigenaardige organisatie, deze veelheid in den tijdsvorm geordend zou waarnemen, sluit, voor zoo ver ik zien kan, geene logische tegenstrijdigheid in zich.'

${ }^{3}$ cf. Heymans, G. (1890a), op. cit. p. 380-381. 
Samengevat komt Heymans' argumentatie in hoofdlijnen op het volgende neer. Heymans maakt allereerst een onderscheid tussen het psychologische en filosofische causaliteitsvraagstuk. Het psychologische causaliteitsvraagstuk behelst de vraag hoe kan worden verklaard dat op grond van waarnemingen de vaste overtuiging ontstaat, dat er tussen bepaalde waarnemingen een niet-waarneembaar noodzakelijk verband is. Het filosofische causaliteitsvraagstuk betreft de vraag welke garantie er is dat toekomstige waarnemingen altijd de verwachting zullen bevestigen dat er tussen verschijnselen noodzakelijke causale verbanden zijn.

Omdat Hume het inzicht had geformuleerd dat met causale uitspraken of oordelen méŕr wordt gezegd dan op grond van het waarnemen van verschijnselen mogelijk is, beschouwt Heymans deze denker als de ontdekker van het causaliteitsvraagstuk. Hume had geconcludeerd dat het herhaald waarnemen van het regelmatig samengaan van twee verschijnselen tot de overtuiging leidt dat er een noodzakelijke relatie tussen beide verschijnselen is. Hij was ook van mening dat het ontstaan van deze overtuiging verklaard kon worden door de onderstelling dat de intensiteit van bepaalde overtuigingen rechtevenredig is aan die van bepaalde voorstellingen en door uit te gaan van associatiewetten.

Heymans is van oordeel dat Hume's theorie geen verklaring biedt voor het psychologische en ook niet voor het filosofische causaliteitsvraagstuk. Hij constateert bovendien dat Hume's theorie, opgevat als een oplossing van het psychologische causaliteitsvraagstuk, niet krachtig genoeg is om een aantal specifieke overtuigingen die in het causale denken besloten liggen te verklaren. De overtuiging dat alle gebeurtenissen een oorzaak hebben kan niet in termen van associatie worden verklaard, omdat dit namelijk zou betekenen dat het causaliteitsbeginsel op grond van ervaring zou zijn ontstaan. Zo'n associationistische verklaring miskent bovendien het historische gegeven dat aan dit beginsel, nog voor het eigenlijke ontstaan van de natuurwetenschappen, al de zekerheid van een axioma werd toegeschreven. Nog los van het feit dat Hume geen oog had voor andere vormen van regelmatigheid in de natuur dan de successie van verschijnselen, kan zijn verklaring van regelmatigheden van successie in termen van de associatie van voorstellingen niet duidelijk maken waarom aan zulke regelmatigheden algemeengeldigheid en absolute zekerheid wordt toegeschreven. Ten slotte: net zoals Hume's theorie geen verklaring kan bieden voor de axiomatische zekerheid die aan het causaliteitsbeginsel wordt toegeschreven, kan diens theorie ook niet de specifieke causale axioma's verklaren waar men in de natuurwetenschappelijke onderzoekpraktijk vast van overtuigd is, en waar men algemeengeldigheid en absolute zekerheid aan toeschrijft.

Om de verschijnselen van hel causale denken te verklaren gaat Heymans uit van Hamiltons postulaat: de overtuiging a priori dat het werkelijk bestaande onveranderlijk is. Dit betekent dat ondersteld moet worden dat achter de veranderingen die worden waargenomen een werkelijkheid bestaat die niet verandert. Een werkelijk ontstaan of vergaan acht Heymans ondenkbaar. Hij formuleert vervolgens de hypothese dat men op grond van dit postulaat alle verschijnselen van het causale denken kan verklaren. Deze hypothese verklaart niet alleen waarom en in welke 
gevallen men zoekt naar oorzaken van veranderingen, maar het biedt ook inzicht in de functie en structuur van causale verklaringen, de functie van het formuleren van hypothesen en de zekerheid en algemeengeldigheid die aan causale axioma's en aan specifieke natuurwetenschappelijke principes worden toegeschreven. In tegenstelling tot Hume neemt Heymans derhalve aan dat de specifieke feiten van het causale denken niet door associatie verklaard kunnen worden, maar dat dit alleen kan worden gedaan door te onderstellen dat aan zulke feiten de overtuiging a priori ten grondslag ligt dat het werkelijk bestaande onveranderlijk is. Heymans is van oordeel dat met deze hypothese het psychologische causaliteitsvraagstuk goeddeels is opgelost.

Cruciaal is echter de vraag op grond waarvan de overtuiging a priori dat het werkelijk bestaande onveranderlijk is, gerechtvaardigd kan worden. Deze overtuiging kan weliswaar feitelijk worden onderbouwd door voorbeelden uit de onderzoekpraktijk in het licht van dit postulaat te interpreteren, mar het formuleren van een lilosofische rechtvaardiging die aantoont dat men genoodzaakt is om van dic overtuiging uit te gaan, is ingewikkelder. Op dit punt meent Heymans slechts het vermoeden te kunnen uiten dat men de overtuiging a priori dat hel werkelijk bestaande onveranderlijk is, zou kunnen rechtvaardigen door het in verband te brengen met Kants hypothese dat verschijnselen door beginselen a priori in de tijd worden geordend.

De Curatoren van het Stolpiaansch Legaat waren volgens Heymans van mening dat er een tegenstrijdigheid lag besloten in de combinatie van de onderstelling dat het werkelijk bestaande onveranderlijk moet zijn en het gegeven dat men alleen verschijnselen warneemt die veranderen, omdat zulke verschijnselen zouden moeten corresponderen met het werkelijk bestaande dat onveranderlijk is. Heymans bestrijdt dat er sprake is van cen tegenstrijdigheid. Hij uit het vermoeden dat het werkelijk bestaande als tijulsneutraal moet worden opgevat, dat deze tijdsneutrale werkelijkheid zich in verschillende hoedanigheden aan mensen voordoet en, ten slotte, dat het denken dezc hoedanigheden met behulp van de notie 'tijd' a priori ordent.

Men kan allereerst constateren dat Heymans in historisch opzicht niet expliciet aansluit bij de auteurs die eerder aan de orde zijn geweest. Echter, beschouwd vanuit een probleemgerichte benadering kan worden geconcludeerd dat er wel degelijk relaties bestaan met de discussies die vooraf gingen. In tegenstelling tot bijvoorbeeld Opzoomer, Van der Wijck, Huet en Pierson is Heymans van mening dat men bij het oplossen van zowel het psychologische als het filosofische causaliteitsvraagstuk moet uitgaan van het bestaan van elementen a priori; bovendien bestrijdt hij empiristische benaderingen zoals die van Mach. Bij Heymans komt dit bijvoorbeeld neer op de overtuiging a priori dat het werkelijk bestaande onveranderlijk is en dat deze overtuiging gerechtvaardigd zou kunnen worden door Kants hypothese dat de notie 'tijd' a priori is.

Ook valt het op dat Heymans, in tegenstelling tot Huet en Pierson, de notie 'oorzaak' van groot belang acht voor het verrichten van wetenschappelijk onderzoek. 
Er is geen sprake van dat Heymans deze notie zou willen bijzetten in het museum voor filosofische antiquiteiten. Bovendien sluiten Heymans' formuleringen van zowel het psychologische als het filosofische causaliteitsvraagstuk geheel aan bij de twee benaderingen die de discussies domineren: de ontstaans- en geldigheidsbenadering.

Heymans' argumentatie dat Hume's theorie noch voor het psychologische noch voor het filosofische causaliteitsvraagstuk een oplossing biedt, en dat men daarom voor de oplossing van beide vraagslukken moet uitgaan van een geldigheidsbenadering is analoog aan de negatieve argumentatiestrategie van Spruyt. Ook valt het op dat beide auteurs in problemen komen als het er op aankomt om rechtstreekse argumenten aan te geven voor deze geldigheidsbenadering. Uit de kritieken van Opzoomer en Van der Wijck was dit laatste al duidelijk naar voren gekornen. Eenzelfde bezwaar zou men kunnen maken tegen Heymans' argumentatiestrategie. $\mathrm{Na}$ uitvoerig de voordelen van Hamiltons postulaat als verklaring van het psychologische causaliteitsvraagstuk uit de doeken te hebben gedaan, stuit Heymans op de moeilijkheid om rechtstreekse argumenten te geven ter rechtvaardiging van dit postulaat.

Bovendien hadden de Curatoren van het Stolpiaansch Legaat terecht bij Heymans' speculatieve hypothetische slotsom een vraagteken geplaatst. Men name op de vraag hoe men precies het verband moet zien tussen een onderstelde tijdsneutrale werkelijkheid die niet verandert en het gegeven dat men alleen verschijnselen waarneemt die veranderen, terwijl die verschijnselen bovendien zouden corresponderen met de onveranderlijke werkelijkheid is, geeft Heymans geen bevredigend antwoord.

Er bestaat, ondanks grote verschillen, een opvallende parallel tussen de causaliteitsopvatting van Pierson en die van Heymans. Waar Pierson spreekt over "subjectieve waardering", spreekl Heymans over "schijn"; en waar Pierson het heeft over "constantheid", betreft het bij Heymans "blijvende identiteit". Bovendien valt het op dat beide auteurs de notie 'tijd' op de cén of andere manier willen elimineren uit de notie 'causaliteit'. Voor Pierson kwam dit er op neer dat de notie 'oorzakelijk verband' geen tijdsorde impliceert, omdat men alleen kan spreken over relaties tussen begrippen en niet over relaties tussen feiten. Ook Heymans acht de notie 'tijd' niet bruikhaar bij hel verklaren van verandering, omdat alle verandering herleid zou mocten worden tot onveranderlijkheid.

Ten slotte: Heymans' causaliteitsleer berust op een speculaticve onderstelling: de onveranderlijkhcid van het werkelijk bestaande. Het argument voor de geldigheid van deze onderstelling meent hij vooral te kunnen ontlenen aan zijn interpretatie van voorbeclden uit de geschiedenis van de natuurwetenschappen. Nog los van het feit of zulke interpretaties juist zijn, vormen dergelijke voorbeelden ten hoogste bijkornstig bewijsmateriaal en zijn zij geen directe argumentatie voor deze onderstellling. 


\section{REACTIES VAN LAND, VOGELS EN BIERENS DE HAAN}

De kritiek van het Curatorium van het Stolpiaansch Legaat op Heymans' eigenzinnige theoretische slotsom is de opmaat voor discussies rond zijn causaliteitsleer. Niet alle "vroege" kritieken hebben echter tot een reactie van Heymans geleid. Zo laat hij de kritiek van zijn oud-promotor Land en die van de neothomistische geleerde I. Vogels voor wat zij zijn. Toch is het de moeite waard om kort op de bedenkingen van deze twee geleerden in te gaan.

Land had als president van het Curatorium kennelijk al de gelegenheid te baat genomen om zijn bedenkingen bij Heymans' theoretische slotsom te uitten. Meteen na de publikatie van de Schets verschijnt bovendien Lands recensie Dr. Heymans over het begrip veroorzaking (1890a). ${ }^{1}$ Hierin toont Land zich andermaal ongelukkig met Heymans' conclusies, en vooral met diens onderscheid tussen twee werelden: een wereld van verschijnselen en een onveranderlijke wereld.

Heymans had in het Naschrift bij de Schets betoogd dat aan de wereld van veranderlijke verschijnselen die men waarneemt een onveranderlijke werkelijkheid ten grondslag zou liggen waarop de notie 'tijd' niet van toepassing is. Land acht dit problematisch, omdat dit onderscheid onderstelt dat het subject of de geest door een onbewuste denkoperatie, zijne onbewuste werkzaamheid, de onveranderlijke werkelijkheid in termen van 'tijd' moet zien om te vormen. Dit impliceert dat Heymans het subject niet alleen als zelfstandig bestaande opvat. Enerzijds is het subject namelijk niet aan verandering onderhevig, omdat het buiten de tijd staat; maar anderzijds moet dat subject tegelijkertijd ook worden gezien als iets dat wél verandert en binnen de tijdsvorm werkzaam is. ${ }^{2}$ In Lands woorden: het subject is dus naast de ééne substantie buiten den tijd een tweede (substantie) in voortdurend Worden betrokken. Ondanks dit principiële probleem besluit Land zijn recensie met de volgende oprecht klinkende woorden aan het adres van zijn oud-promovendus. Of het wijsgeerig denken dat door onzen talentvollen landgenoot wordt uitgelokt, er (....) in zal slagen (....) aan zulk dualisme te ontkomen, zullen wij moeten afwachten. Vindt hij de lezers die hij verdient, die hem niet blindelings volgen maar aan zijn kloekmoedig doordenken een voorbeeld nemen, dan kan zijn werk een reeks openen van belangrijke onderzoekingen, waaraan de Nederlandsche naam op dit door ons zelden betreden gebied een nieuwen luister ontleent. Voorshands zij het boek aan

${ }^{1}$ Land hield zich in het debat over causaliteit afzijdig; dat wil niet zeggen dat hij zich niet eerder over dit onderwerp heeft uitgelaten; zie hiervoor Lands Inleiding tot de wijsbegeerte (1889). Echter, er ontstond over Lands causaliteitsopvatting geen kritisch debat.

${ }^{2}$ cf. Land, J.P.N. (1890a), 'Dr. Heymans over het begrip veroorzaking'. In: De Nederlan* sche spectator, p. 268, 'Waar aldus het subject, de geest, door zijne onbewuste werkzaamheid een wereld die buiten den tijd staat, "in den tijdsvorm uiteenlegt", daar moet dat subject toch insgelijks gedacht worden als zelfstandig bestaande, en niettemin in den tijdsvorm werkzaam, van oogenblik tot oogenblik bezig gehouden, derhalve aan verandering onderhevig.' 
de vrienden der wijsbegeerte, en reeds aan wie niet ongenegen zijn dat te worden, als levenwekkende lectuur met warmte aanbevolen. ${ }^{1}$

Heymans' causaliteitsleer blijft Land echter bezighouden. Na de recensie in De Nederlandsche spectator volgt kort daarop een uitgebreider artikel in De gids met als titel Oorzaken en gevolgen (1890b). Hierin merkt Land op dat hij hooge waardeering heeft voor de Schets; echter, de causaliteitsleer die Heymans daarin ontvouwt kan hem niet bekoren. Ook in dit artikel wijst hij op het problematische karakter van Heymans' theorie van twee werelden. Land typeert dit onderscheid hier als volgt: (....) een veranderlijke verschijning en daarachter een onveranderlijk zijn. ${ }^{2}$ Opnieuw rijst voor Land het probleem hoe die twee werelden door het subject met elkaar in verband gebracht kunnen worden. Het daarbij onderstellen van Hamiltons postulaat leidt er toe dat men meer en meer naar den kant van het eleatische denken gedrongen wordt ${ }^{3}$; hetgeen een verwijzing vormt naar de Griekse Eleaten die de onveranderlijkheid van de gehele werkelijkheid predikten.

Het postulaat van de onveranderlijkheid van de werkelijkheid wekt zelfs de woede op van de hoogleraar Vogels. In het artikel Dr. Heymans en de school van sir W. Hamilton (1894) zegt deze, in de woorden van John Stuart Mill, dat de causaliteitsleer van Hamilton en Heymans niet meer is dan een mauvaise plaisanterie. Met weerzin zet Vogels zich er toe om Heymans' theorie te weerleggen. Is dit echter (.....) niet in volle werkelijkheid de taal eens onzinnigen, met wien men de eerste maal misschien glimlacht doch later diep medelijden voelt, on de algeheele verstandsverbijstering, waaraan hij lijdende is? Oprecht gesproken: het walgt ons, zulke wijsbegeerte of liever zulke dwaasheden te moeten weerleggen. ${ }^{4}$ Even later wordt duidelijk wat Vogels' drijfveer is: Heymans' theorie leidt regelrecht tot het grofste materialisme en pantheisme; een consequentie die voor de neothomist Vogels uiteraard onaanvaardbaar is. De pasbenoemde professor Heymans is echter geen straatvechter en hij laat zich dan ook niet in met Vogels' regelrechte beledigingen.

Ook Bierens de Haan bekritiseert Heymans in De psychische afkomst van het oorzaakbegrip (1895a). Hamiltons postulaat leidt er toe, zo betoogt Bierens de Haan, dat de notie 'tijdsopvolging' ten onrechte uit de notie 'causaliteit' wordt geëlimineerd. De notie 'tijdsopvolging' acht hij een cruciaal element in een adequate theorie over causaliteit. ${ }^{5}$ Bierens de Haan concludeert dat het logisch denken juist tot taak (heeft) om de verschijnselen in hunne tijdsorde op te vatten en alle wetenschap komt mij voor, als moeielijkste en voornamelijkste taak, de veelheid der verschijnselen in hunne noodzakelijke tijdsorde te moeten rangschikken. Hierbij is het Oorzaak-begrip

${ }^{1}$ cf. Land, J.P.N. (1890a), op. cit. 268.

${ }^{2}$ cf. Land, J.P.N. (1890b), 'Oorzaken en gevolgen'. In: De gids; p. 506.

${ }^{3}$ cf. Land, J.P.N. (1890b), op. cit. p. 508.

${ }^{4}$ cf. Vogels, I. (1894), op. cit. p. 403.

${ }^{5}$ cf. Bierens de Haan, J.D. (1895a), De psychische afkomst van het oorzaakbegrip, p. 34, 'Maar nu hangt ook de betreden Oorzaak-theorie samen met de uitwerping van het Tijdselement, althans aan het begrip van tijds-opvolging als element van het Oorzaak-begrip is geen waarde gehecht....' 
het groote hulpmiddel. ${ }^{1}$ Echter, ook de kritiek van deze filosoof laat Heymans voor wat het is.

Zoals gezegd gaat Heymans niet in op de kritieken van Land, Vogels en Bierens de Haan; dit betekent echter niet dat hij kritische discussies uit de weg gaat, want hij kruiste met drie andere "vroege" critici wél de degens: H.J. Betz, D.G. Jelgersma en G.J.P.J. Bolland.

In de navolgende paragrafen wordt allereerst ingegaan op de kritiek van Betz en Heymans' reactie daarop. Vervolgens komt de uitvoerige polemiek aan de orde tussen Heymans en Jelgersma. Tot slot wordt kort ingegaan op Heymans' reactie op Bollands opvatting dat het vraagstuk van tijd en verandering als in beginsel onverklaarbaar moet worden opgevat.

\section{BETZ' KRITIEK OP HEYMANS}

H.J. Betz (1842-1902), medicus en vanaf 1875 redacteur van het door Van Vloten opgerichte tijdschrift De levensbode, is, net als L'Ange Huet, een buitenbeentje in het gezelschap van academische filosofen dat in deze studie centraal staat. Betz zocht in zijn lijtblad De levensbode voortdurend discussie met Nederlandse hoogleraren in de filosofie. Voorbeelden hiervan zijn een serie omvangrijke polemische artikelen getiteld Over den aard onzer kennis (1875) of het artikel Jong-Hollandsche wijsbegeerte (1877). Over het causaliteitsvraagstuk repte hij in deze artikelen niet of nauwelijks. Dit gebeurde wel in het boek Ervaringswijsbegeerte (1881). Hierin toonde Betz zich een voorstander van Kants denkwijze. Zo betoogde hij dat de noties 'oorzaak' en 'substantie' onloochenbaar a priori zijn. Echter, de door Kant ontwikkelde leer der categorieën riep volgens hem meer vragen op dan zij beantwoordde. ${ }^{2}$ Betz' denkbeelden die hij in Envaringswijsbegeerte ontvouwde, speelden echter geen rol in de discussies. Dit wordt anders met het artikel Bezwaren van een leek tegen het causaliteitsbegrip van dr. G. Heymans, dat in 1891 in De tijdspiegel verschijnt. In dit artikel zoekt hij rechtstreeks de confrontatie met Heymans. ${ }^{3}$

${ }^{\prime}$ cf. Bierens de Haan, J.D. (1895a), op. cit. p. 35-36.

${ }^{2}$ cf. Betz, H.J. (1881), Ervaringswijsbegeerte, p. 191, 'Dat oorzaak en substantie begrippen a priori zijn, komt mij onloochenbaar voor, en wil men ze kategorieën noemen, in dien naam zie ik natuurlijk geen bezwaar. Doch overigens geloof ik, dat men de kate-gorieënleer moeten laten varen, die, wel verre van ons iets duidelijk te maken, allerlei nieuwe moeilijkheden doet ontstaan.'

${ }^{3}$ In 1890 verscheen in De Nederlandsche spectator van Betz een lovende recensic van het eerste deel van Heymans' Gesetze und Elemente,getiteld 'Dr. G. Heymans over 's menschen kenvermogen'. Over het causaliteitsvraagstuk wordt hierin echter niet gesproken. Betz komt later nogmaals terug op het causaliteitsvraagstuk in het artikel 'Oorzaken en redenen' (in: $D e$ tijdspiegel, 1902). Hierin uit hij gelijksocirtige bezwaren tegen Heymans' theorie als in 1891 . Echter, Heymans heeft op Betz' artikel uit 1902 niet gereageerd. Dit artikel wordt in deze studie niet verder besproken. 
$\mathrm{Al}$ in het begin van dat artikel daagt Betz de hooggeleerde Heymans uit tot een reactie. Betz is namelijk van oordeel dat de filosofie in de afgelopen eeuwen maar weinig vooruitgang heeft geboekt. Want, indien het waar is, dat de wijsbegeerte, al vliegt zij niet gelijk een pijl uit den boog rechtstreeks op haar doel aan, toch evenmin in een cirkel eromheen draait, maar het, als op de windingen eener spiraal, langzaam doch zeker nadert, - dan moeten wij er tot mijn leedwezen bijvoegen, dat zij de engere windingen der spiraal totnogtoe niet bereikte. ${ }^{1}$ Met de woorden van Land (1890b) merkt Betz op dat Heymans ons weder in de buurt der Eleaten brengt. Even later voegt hij daar nog weinig diplomatiek aan toe dat Heymans' uitspraken, die vijf-en-twintig eeuwen oud zijn (...) tegenwoordig den meesten uiterst belachlijk schijnen. ${ }^{2}$ Heymans' status als serieus denker en hoogleraar die een geleerd en meestal helder boek over het causaliteitsbegrip schrijft, maakt het echter moeilijk te geloven dat zijn uitspraken geheel en al aan de zwakhoofdigheid van dezen denker en niet althans voor een deel aan eigenaardigheden van het menschelijk denken liggen zou. ${ }^{3}$ Uiteraard is dit tegen het zere been van Heymans. Immers, Heymans vatte filosofie op als wetenschappelijke philosophie, die daarom wel degelijk vooruitgang kan boeken.

Betz valt eerst Heymans' opvatting aan dat causale axioma's algemeen geldig en a priori zouden zijn. Deze aanval is de opmaat voor Betz' principiële kritiek op de grondslag van Heymans' causaliteitsleer: Hamiltons postulaat van de onveranderlijkheid van het werkelijk bestaande. Heymans' uitwerking van dit postulaat wordt door Betz aangegrepen om te concluderen dat één en ander tot ongerijmde consequenties leidt.

\section{Causale axioma's zijn niet a priori}

(Zijn) "de causale axioma's" van dr. Heymans inderdaad algemeen menschelijke. overtuigingen of algemeen-menschelijke axioma's (....), zo vraagt Betz zich af. ${ }^{4} \mathrm{Zijn}$ antwoord luidt: neen. Introspectie of zelfonderzoek leert alleen, zo betoogt hij, dat het causaliteitsbeginsel - elke verandering (moet) een oorzaak hebben - zeker is. Betz is van mening dat Heymans' causale axioma's weliswaar waarheden zijn, maar de opvatting dat zij absoluut zeker zijn en algemeen gelden acht hij onacceptabel. ${ }^{5} \mathrm{Het}$ is bijvoorbeeld denkbaar dat iemand, zonder dit overigens onder woorden te kunnen brengen, overtuigd is van het axioma dat oorzaak en gevolg altijd gelijksoortig en

${ }^{1}$ cf. Betz, H.J. (1890), 'Bezwaren van een leek tegen het causaliteitsbegrip van dr. G. Heymans'. In: De tijdspiegel, p. 315.

${ }^{2}$ cf. Betz, H.J. (1890), op. cit. p. 316.

${ }^{3}$ cf. Betz, H.J. (1890), op. cit. p. 316.

${ }^{4}$ cf. Betz, H.J. (1890), op. cit. p. 323-324

s cf. Betz, H.J. (1890), op. cit. p. 324, 'Ik moet belijden, het door zelfonderzoek nooit verder gebracht te hebben dan tot de bevinding, het voor zeker te houden, dat elke verandering een oorzaak moet hebben, dat niets vanzelf gebeurt. (...) Wat betreft de "gelijksoortigheid" en "gelijkheid" van oorzaak en werking, ik betwijfel haar niet als waarheden, doch dat het axiomatische, algemeen-menschelijke waarheden a priori zijn, wil er bij mij niet in.' 
gelijkwaardig zijn. Is het echter ook denkbaar dat er in strijd met een axioma gedacht wordt. Dit acht Betz onmogelijk, omdat een axioma als een essentieel element van het denken moet worden opgevat. Daarom acht hij het onmogelijk dat iemand zo'n element - eene algemeen-menschelijke overtuiging - zou kunnen negeren. Echter, als men bijvoorbeeld zegt dat kleine oorzaken groote gevolgen hebben, dan is dit in strijd met het causale axioma dat oorzaak en gevolg altijd gelijksoortig en gelijkwaardig zijn. Men zou misschien met behulp van de wetenschap kunnen bewijzen dat oorzaak en gevolg toch altijd evenredig zijn, maar in de praktijk blijkt dat men aan zo'n axioma wel degelijk kan twijfelen. Met andere woorden: er moet derhalve een wetenschappelijk bewijs aan te pas komen om de twijfel aan het axiomatisch karakter van Heymans' causale axioma's weg te nemen. Als zij echter werkelijk algemeen zouden gelden en a priori zouden zijn, dan zou zo'n bewijs helemaal niet nodig zijn. 'Betz voegt daar nog aan toe dat Heymans naar voren had gebracht dat de filosofen na Hume de causale axioma's hadden verwaarloosd. Echter, zo vraagt Betz zich retorisch af, hoe kunnen wij in ons denken wezenlijke bestanddeelen van ons denken te goeder trouw verdonkeremanen, hen behandelen als waren zij nul en van geene waarde $?^{2}$ Of: hoe kunnen menschen wezenlijke bestanddeelen van het wetenschappelijke denken wantrouwen of verwaarloozen $?^{3}$ Uit het feit dat de filosofen ná Hume kennelijk geen oog hadden voor causale axioma's, kan men alleen maar afleiden dat zulke axioma's kennelijk niet a priori zijn en algemeen gelden. Immers, als zij dat wel zouden zijn, dan zou het juist uitgesloten moeten zijn dat zij ná Hume kennelijk geen rol meer speelden in theorieën over causaliteit. In Betz' woorden: axioma's blijven axioma's. (....) Axioma's steunen niet op bewijzen pro, noch worden zij aan het wankelen gebracht door bewijzen contra. ${ }^{4}$ Met andere woorden: aan echte axioma's kan men niet twijfelen, en zij hebben geen bewijs nodig. Heymans' causale axioma's zijn echter geen axioma's, anders zou men daar geen bewijzen voor hoeven te zoeken.

'cf. Betz, H.J. (1890), op. cit. p. 325, 'Het is (...) denkbaar, dat iemand zich van de "gelijksoortigheid" en "gelijkheid" van oorzaak en werking vast overtuigd houdt, zonder in stat te zijn, dit behoorlijk te zeggen. Maar is het eveneens denkbaar, dat er in strijd met een axioma gedacht wordt? Mij dunkt: neen. Hoe zou een mensch kunnen denken in strijd met een wezenlijk bestanddeel van het menschelijk denken? Hoe zou hij eene algemeen-menschelijke overtuiging kunnen behandelen als bestond zij voor hem niet? Hoe verklaart dr. Heymans in verband hiermede zegswijzen als: kleine oorzaken hebben groote gevolgen; een ongeluk zit in een klein hoekje, enz? Zeker, wanneer iemand door middel van een vonk een kruithuis doet ontploffen en de halve stad verwoest, kunt gij langs wetenschappelijken weg misschien aantoonen, dat oorzaak en werking aan elkaar geëvenredigd zijn. Is dit nochtans eene waarheid a priori, hoe kan dan ooit een sterveling haar betwijfelen en door zijn twijfel u nopen tot levering van haar wetenschappelijk bewijs?'

${ }^{2}$ cf. Betz, H.J. (1890), op. cit. p. 326.

3 cf. Betz, H.J. (1890), op. cit. p. 327.

${ }^{4}$ cf. Betz, H.J. (1890), op. cit. p. 327. 
Het pièce de résistance van Betz' Heymans-kritiek betreft zowel het postulaat van de onveranderlijkheid van de werkelijkheid of het werkelijk bestaande als Heymans' (en Hamiltons) hypothese dat het causale denken met behulp van dit postulaat verklaard kan worden. Zowel Hamiltons postulaat als Heymans' hypothese acht Betz onaannemelijk. Om dit aan te tonen formuleert hij drie tegenargumentaties.

Heymans had het causale denken opgevat als het resultaat van de overtuiging a priori dat de werkelijkheid onveranderlijk is. De objecten van de waarneming blijven in beginsel aan zichzelf gelijk; zij veranderen niet, al doen zij dit ogenschijnlijk wel. Hieruit had hij weer afgeleid dat het aanwijzen van oorzaken voor het verklaren van de verandering van de objecten van een eerdere en latere waarneming de functie heeft om aan te tonen dat zulke objecten eigenlijk aan zichzelf gelijk blijven. In Heymans' woorden: het causale denken (is) het product van de apriorische overtuiging, dat het werkelijk bestaande onveranderlijk is. ${ }^{1}$ Hieruit had hij afgeleid dat, hetgeen wij "oorzaak" noemen altijd deze eigenschap bezit, dat daardoor de schijnbaar verbroken identiteit tusschen objecten der vroegere en der latere waarneming wordt hersteld. ${ }^{2}$

Betz acht Heymans' afleidingen onbegrijpelijk: de juistheid der gevolgtrekking ontsnapt mij te eenen male. ${ }^{3}$ Deze gevolgtrekking is voor hem de aanleiding voor zijn eerste tegenargumentatie.

Als men er van uitgaat, zo betoogt Betz, dat het 'werkelijk bestaande' altijd aan zichzelf gelijk blijft en onveranderlijk is, impliceert dit nog niet dat de objecten der waarneming ook onveranderlijk zijn; ook betekent het niet dat de onderlinge verhoudingen tussen de objecten van de waarneming nooit zullen veranderen. De onveranderlijkheid van zulke verhoudingen ligt echter wel besloten in Heymans' notie 'schijnbaar verbroken identiteit'. Betz concludeert daarom dat Heymans die schijnbaar verbroken identiteit tussen datgene waar de waarnemingen betrekking op hebben, en daarmee ook de overtuiging dat het werkelijk bestaande onveranderlijk is, ten onrechte als bewijsgrond had aangevoerd, zonder dat hij dit eerst zelf had bewezen. Immers, als er verandering optreedt, zo had Heymans volgens Betz geredeneerd, dan is men er zeker van dat die verandering een oorzaak heeft. Men tracht vervolgens de oorzaak voor zo'n verandering op te sporen. Als men er voetstoots van uitgaat, zo betoogt Betz, dat 'verandering' louter neerkomt op een 'schijnbaar verbroken identiteit', dan is het eenvoudig om te concluderen dat het feit dat men oorzaken zoekt op de behoefte berust om de schijnbaar verbroken identiteit te herstellen. De behoefte om causale verklaringen te zoeken had Heymans ten slotte

\footnotetext{
' cf. Heymans, G. (1890a), op. cit. p. 272.

${ }^{2}$ ef. Heymans, G. (1890a), op. cit. p. 276.

${ }^{3}$ cf. Betz, H.J. (1890), op. cit. p. 329.
} 
weer laten berusten op het postulaat dat alles onveranderlijk is. ${ }^{1}$ Met andere woorden: Heymans' redenering is volgens Betz circulair.

Een principiëler bezwaar uit Betz tegen Heymans' opvatting dat achter de verandering van de objecten van de waarneming een onveranderlijke werkelijkheid schuil zou gaan waarop de notie 'tijd' niet van toepassing is. Hieruit had Heymans geconcludeerd dat deze buiten den tijd staande werkelijkheid zich in allerlei vormen aan mensen voordoet. Men ordent de verschijningsvormen van die onveranderlijke werkelijkheid in de tijd door de bijzondere structuur van het denken.

Dit element in Heymans' redenering vindt Betz merkwaardig. De onveranderlijke wereld die zich aan mensen voordoet, zou door het denken, de geest, worden getransformeerd tot een veranderlijke wereld. Alleen dit al acht Betz moeilijk te begrijpen. Echter, het bestaan van wat men waarneemt, de objecten onzer waarneming, zou door een onbewust proces door het subject tot stand komen enerzijds, maar anderzijds zou het subject zulke objecten ook als onveranderlijk moeten opvatten. Dat laatste zou dan weer de grond moeten zijn dat het subject zich er van zou moeten overtuigen dat verandering louter neerkomt op een schijnbaar verbroken identiteit van de objecten van eerdere en latere waarnemingen. Dit klinkt Betz wonderspreukig in de oren. Want wat zou er in dit geval plaats vinden?, zo vraagt hij zich af. Het subject zou niet alleen een wereld waar het tijdsbegrip niet op van toepassing is moeten omvormen tot een wereld waarin deze notie wél kan worden gebruikt; het subject zou de wereld die zojuist in termen van tijd is omgevormd, bovendien weer moeten persen in eene buiten den tijd bestaande wereld. $^{2}$

' cf. Betz, H.J. (1890), op. cit. p. 329, 'Het "werkelijk bestaande" zij identiek met zichzelf in den zin van onveranderlijk. Daar volgt geenszins uit, dat ook de objecten onzer waarneming (....) insgelijks onveranderlijk moeten zijn of tot elkaar in onveranderlijke verhoudingen moeten staat. Toch ligt dit laatste in de onderstelling hunner "schijnbaar" verbroken identiteit m.i. opgesloten. Die "schijnbaar" verbroken identiteit is doodeenvoudig eene petitio principii. Heeft er verandering plaats, wij houden ons verzekerd, dat zij een oorzaak moet hebben; naar die oorzaak gaan wij dan zoeken. Noem de verandering "schijnbaar verbroken identiteit", en gij toont triomfantelijk aan: dat het zoeken naar een oorzaak voortvloeit uit onze behoefte aan het herstellen van "schijnbaar verbroken identiteit", welke behoefte op hare beurt wortelt in onze overtuiging, dat... het "werkelijk bestaande"? - neen, dat alles onveranderlijk is.'

${ }^{2}$ cf. Betz, H.J. (1890), op. cit. p. 329-330, 'Dat eene onveranderlijke wereld zich aan onzen geest voordoet of door onzen geest wordt opgevat als eene veranderlijke wereld, is reeds zwaar genoeg te vatten. Doch dat in deze veranderlijke wereld de objecten onzer waarneming, die - let wel - hun bestaan of schijnbaar bestaan danken aan de onbewuste werkzaamheid van het subject, door ditzelfde subject voor onveranderlijk zouden gehouden worden, op grond waarvan gezegd subject zijn uiterste best zou doen om zich te overtuigen van het slechts schijnbare hunner "verbroken identiteit", dit klinkt mij te wonderspreukig. Want wat zou er in dit geval plaats vinden? Het subject zou eene buiten den tijd bestaande wereld in den tijdsvorm uiteenleggen en tevens die nieuwe wereld ineen persen tot eene buiten den tijd bestaande wereld.' 
Heymans' opvatting dat hel aanwijzen van een oorzaak er toe leidt dat de schijnbaar verbroken identiteit tussen wat men waarneemt weer wordt hersteld, is het aangrijpingspunt voor Betz' tweede tegenargumentatie.

Heymans had deze opvatting gestaafd met het voorbeeld van de verandering van niet-kokend water naar water dat kookt. Hij had daarbij gewezen op de belangrijke rol van wetenschappelijke hypothesen. $\mathrm{Zij}$ zouden moeten aantonen dat de werkelijkheid onveranderlijk is; in dit geval waren dat hypothesen over de moleculaire structuur van water en over de aard van warmte. Hieruit had Heymans geconcludeerd dat waargenomen veranderingen de sluier (vormen) waarachter zich eene onveranderlijke werkelijkheid verbergt.

Betz wijst er op dat Heymans met deze redenering geenszins aantoont dat de werkelijkheid onveranderlijk is. Men kan zich namelijk nog steeds afvragen waarom wij dan géén schijn (zouden) moeten zien in den overgang van moleculen met onderlinge cohesie in moleculen zonder onderlinge cohesie?' Of ook: met welk recht wordt verandering in de onderlinge verhouding der moleculen dan voor identiteit, de vergelijking (moleculen met onderlinge cohesie = moleculen zonder onderlinge cohesie) voor een "identieke vergelijking" uitgegeven, welke "ons in staat stelt onze grondstelling van de blijvende identiteit der werkelijk bestaande dingen te handhaven" ? ${ }^{2}$ Betz stelt zich voor dat Heymans hier tegen in had kunnen brengen dat de hypothesen over de aard van moleculaire structuur van water en over de aard van warmte slechts voorlopige hypothesen zijn en geen eindstation vormen. Met andere woorden: men moet naar nog dieper liggende verklaringen zoeken die uiteindelijk wel zouden moeten aantonen dat de werkelijkheid onveranderlijk is. Ook zo'n verweer had Heymans echter geen soelaas kunnen bieden, zo betoogt Betz. Immers, als men eenmaal meent op het eindstation te zijn aangekomen, geldt weer hetzelfde bezwaar. Heymans leek namelijk het postulaat op het oog te hebben gehad dat de natuurwetenschap alle verschijnselen tot mechanische processen wil herleiden. Alles goed en wel, aldus Betz, maar hieruit mag men nog niet concluderen dat de werkelijkheid onveranderlijk is. Immers, de notie 'mechanisch proces' omvat de notie 'verandering': een mechanisch proces is geen stilstaande machine. Als alle verschijnselen tot een mechanisch proces zouden zijn herleid, zou de taak der natuurwetenschap volbracht zijn. Echter, ook dan nog blijft er altijd sprake van verandering. Betz concludeert daarom dat er in de natuurwetenschap geen sprake kan zijn van 'identiteit' in de betekenis van absolute onveranderlijkheid, zoals Heymans zich dat had voorgesteld.

'cf. Betz, H.J. (1890), op. cit. p. 330.

${ }^{2}$ cf. Betz, H.J. (1890), op. cit. p. 331.

${ }^{3}$ cf. Betz, H.J. (1890), op. cit. p. 331, 'En nu zegge iemand: wij zijn hier slechts bij een tusschenstation, het eindstation moeten wij nog bereiken. Mijn antwoord ware al te gemakkelijk. Aan het eindstation wacht ons hetzelfde bezwaar. Want wat is hel eindstation? "Herleiding van alle natuurverschijnselen tot mechanische processen (is) een postulaat der natuurwetenschap". Ik beaam het ten volle; ik sprak zelf nog liever van herleiding tot én mechanisch proces. Echter ligt in het begrip van mechanisch proces dat van verandering opgesloten; een 
Hij kan overigens wel enige sympathie opbrengen voor Heymans' eerder genoemde zienswijze dat de natuurwetenschap zich ten doel stelt alle natuurverschijnselen te herleiden tot mechanische processen. Hierdoor wordt immers, zo betoogt Betz, de complexiteit van waargenomen veranderingen teruggebracht tot één bepaalde vorm van verandering: mechanische processen. Deze eenvormige verandering zou men kunnen opvatten als een betrekkelijke identiteit. Echter, betrekkelijke identiteit is niet gelijk aan onveranderlijkheid. ${ }^{1}$ Met andere woorden: mechanische processen zijn relatief onveranderlijk of betrekkelijk stabiel. Dit sluit echter niet uit dat men er van uit moet blijven gaan dat ook zulke processen nooit absoluut onveranderlijk kunnen zijn, omdat het namelijk altijd denkbaar is dat ook de aard van mechanische processen verandert. Betz verbaast zich er over dat Heymans dit niet heeft ingezien. Uitdagend merkt Betz op dat de groote geleerdheid iemand nog niet tot razernij (behoeft) te brengen om hem hier of daar een eenvoudig inzicht te missen. ${ }^{2}$

Het causale denken had Heymans opgevat als het resultaat van de overtuiging a priori dat het werkelijk bestaande of de werkelijk bestaande dingen onveranderlijk zijn. De notie 'het werkelijk bestaande' of 'de werkelijk bestaande dingen' is het aanknopingspunt voor Betz' derde tegenargumentatie.

Heymans had maar liefst vier werelden of werkelijkheden onderscheiden, zo constateert Betz. De eerste wereld die Heymans onderscheidt is de alledaagse werkelijkheid, waarvan wordt ondersteld dat deze los van de subjectieve gewaarwordingen bestaat. Daarnaast is er een werkelijkheid die in natuurwetenschappelijke theorieën naar voren komt; een werkelijkheid die zou corresponderen met de alledaagse werkelijkheid. Bovendien onderstelt Heymans een werkelijkheid die ten grondslag zou liggen aan de alledaagse werkelijkheid en de werkelijkheid die in natuurwetenschappelijke theorieën naar voren komt: de werkelijk bestaande dingen of het werkelijk bestaande. Via verklaringen van de veranderlijke werkelijkheid, zoals in wetenschappelijke theorieën worden weergegeven, dringt men uiteindelijk door tot de onveranderlijke werkelijkheid. Ten slotte wijst Heymans, aldus Betz, nog op de "klassieke" onderstelling van het bestaan van het wezen der dingen. Het wezen der dingen beschouwt Heymans echter als iets anders dan het werkelijk bestaande of de werkelijk bestaande dingen. Het zoeken naar het wezen der dingen ziet hij als

mechanisch proces is geen stilstaande machine. Zijn alle natuurverschijnselen tot mechanische processen of tot één mechanisch proces herleid, dan is de taak der natuurwetenschap volbracht. Maar er bleef voor en na verandering zijn.'

' cf. Betz, H.J. (1890), op. cit. p. 331, 't Valt nochtans niet te loochenen, dat de veranderingen, welke wij waarnemen, voor ons belangrijk zouden vereenvoudigd zijn door hare herleiding tot mechanische processen. Deze herleiding stelt eenvoudige verandering in de plaats der uiterst samengestelde veranderingen, waar wij door middel onzer zintuigen kennis mede maken. Met een weinigje meegaandheid zouden wij die eenvormige verandering desnoods als betrekkelijke identiteit kunnen opvatten.'

${ }^{2}$ cf. Betz, H.J. (1890), op. cit. p. 332. 
een vruchtloze onderneming. Over dit laatste subtiele onderscheid had Betz zich overigens al eerder afgevraagd of de zaak op die manier niet te ingewikkeld wordt? ${ }^{1}$

Principiëler voor Betz is echter de vraag waar, in 's hemelsnaam, dr.Heymans de onveranderlijkheid van het "werkelijk bestaande" vandaan (haalt) $?^{2}$ Heymans had geconstateerd dat men de feiten van het causale denken niet uitsluitend kon verklaren met behulp van de bekende gegevens; dat wil zeggen, de gegeven gewaarwordingen en logische wetten. Als men geen andere, onbekende, niet direct constateerbare reële gegevens zou onderstellen, blijven de feiten van het causale denken onverklaarbaar. Met andere woorden: het formuleren van hypothesen om zulke feiten te verklaren acht Heymans noodzakelijk. Echter, zo vraagt Betz zich af, wat zou dit? Waar staat geschreven, of welke reden hebben wij om aan te nemen, dat alles verklaarbaar is? $?^{3}$ Heymans' motivatie voor de opvatting dat alles verklaarbaar zou zijn, ligt besloten, zo betoogt Betz, in diens uitgangspunt dat mensen redelijke wezens zijn en dat zij daarom altijd hun overtuigingen op redelijke gronden willen verklaren. Dit leidt regelrecht tot een regressus ad infinitum. Immers, als men voor iedere overtuiging de redelijke grond daarvan wil opsporen, dan (zouden) wij hei nimmer tot eene overtuiging brengen. Heymans had het causale denken willen verklaren door de overtuiging a priori te onderstellen dat het werkelijk bestaande onveranderlijk is. Hoewel Heymans zich had afgevraagd wat de redelijke gronden van die overtuiging zouden zijn, acht Betz een antwoord hierop uitgesloten. Ook hier is er namelijk sprake van een oneindige regressie. Immers, na die vraag moet (hij) weder eene andere vraag stellen, en daarna weder eene andere, en zoo altoos voort ........ in dulce infinitum, of ins blaue Nichts hinein. ${ }^{4}$ Heymans had bovendien ten onrechte Hamiltons postulaat als een overtuiging a priori had opgevat. Hamiltons postulaat is echter, zo betoogt Betz, geen onbewijsbaar eerste gegeven, een axioma, eene waarheid a priori, eene algemeen-menschelijke, den geest als zoodanig eigene overtuiging. ${ }^{5}$ Immers, als de overtuiging dat de werkelijkheid onveranderlijk is

' cf. Betz, H.J. (1890), op. cit. p.332-333, 'Maar de heer Heymans komt met niet minder dan vier werelden voor den dag. 1. De wereld, waarin wij leven en die door het kortzichtige realisme der overgroote meerderheid voor eene van ons onafhankelijke werkelijkheid gehouden wordt, terwijl toch vaststaat, dat b.v. alle kleuren en geuren en geluiden subjectieve gewaarwordingen zijn. 2. De aan no. 1 beantwoordende wereld der natuurwetenschap, met hare atomen, moleculen, krachtsmiddelpunten, of wat het zij volgens oudere en nieuwere hypothesen. 3. Het "werkelijk bestaande" of de "werkelijk bestaande dingen", of wat het zij volgens waar dr. Heymans den naam van het "wezenlijk" bestaande of de "wezenlijk" bestaande dingen stelselmatig aan onthoudt. Dit "werkelijk bestaande" is, of deze "werkelijk bestaande dingen" zijn bij dr. Heymans de onveranderlijke grond van no. 1 tot welken onveranderlijken grond hij meent te kunnen geraken door middel van no.2, eene veranderlijke wereld. 4. Het "wezen der dingen", waar de oude wijsbegeerte zich aan te buiten ging, doch het nieuwe licht geen enkelen straal op werpt.'

${ }^{2}$ cf. Betz, H.J. (1890), op. cit. p. 333.

${ }^{3}$ ef. Betz, H.J. (1890), op. cit. p. 333.

${ }^{4}$ cf. Betz, H.J. (1890), op. cit. p. 334-335.

${ }^{5}$ cf. Betz, H.J. (1890), op. cit. p. 335. 
inderdaad a priori zou zijn, dan zou iedereen daarvan overtuigd moeten zijn. Hiermee herhaalt Betz overigens zijn eerder genoemde argument tegen Heymans' causale axioma's in het algemeen: axiomatische overtuigingen moeten bij iedereen aangetroffen worden. Echter, de feiten tonen juist het tegendeel aan. Betz concludeert daarom dat Heymans onvoldoende met zulke feiten rekening houdt. Als hij, onze vriend der feiten, dat wel had gedaan, dan had hij zich zekerheid kunnen verschaffen omtrent den volstrekt niet "apriorischen" of axiomatischen aard dier overtuiging.'

De hoofdlijnen van Betz' kritiek op Heymans kunnen als volgt worden samengevat. Allereerst wijst Betz er op dat Heymans' zogenaamde causale axioma's niet algemeen geldig kunnen zijn, omdat uit ervaring blijkt dat niet iedereen daarvan overtuigd is. Vervolgens formuleert Betz drie argumentaties tegen het postulaat van Hamilton en de hypothese van Heymans.

Een eerste belangrijke principiële tegenargumentatie van Betz betreft Heymans' dualisme: het onderscheid dat Heymans had gemaakt tussen een werkelijkheid die onveranderlijk en tijdsneutraal is en een werkelijkheid die verandert. Het kennend subject zou enerzijds een werkelijkheid die tijdsneutraal is moeten omvormen tot een werkelijkheid waarop de notie 'tijd' wel van toepassing is, en zodra dat is gebeurd zou het kennend subject deze laatste werkelijkheid anderzijds weer moeten omvormen tot een werkelijkheid die tijdsneutraal is. Betz acht dit onbegrijpelijk.

Het aangrijpingspunt van Betz' tweede argumentatie tegen Heymans' opvatting betreft de bewering dat de functie van het aanwijzen van oorzaken neerkomt op het herstellen van de discrepantie tussen wat men eerder en wat men later heeft waargenomen. In veel gevallen zou men hiertoe hypothesen dienen te formuleren die de onveranderlijkheid van het werkelijk bestaande zouden moeten aantonen. Betz' bezwaar luidt dat, ook al zou men er van uitgaan dat de natuurwetenschap zich ten doel stelt verschijnselen door hypothesen te herleiden tot mechanische processen, niet mag worden geconcludeerd dat daardoor is aangetoond dat het werkelijk bestaande onveranderlijk is. Immers, de notie 'proces' impliceert verandering en tijd. Het door hypothesen herstellen van de discrepantie tussen wat eerder en wat later is waargenomen, leidt er daarom niet toe dat de identiteit, opgevat als onveranderlijkheid tussen de objecten van beide waarnemingen, wordt hersteld.

Met zijn derde tegenargumentatie wil Betz aantonen dat Heymans er niet in kan slagen om de redelijke gronden te geven waarop de overtuiging a priori berust dat het werkelijk bestaande onveranderlijk is. Men kan zich immers bij iedere overtuiging blijven afvragen wat hiervoor weer de gronden zijn; hetgeen tot een oneindige regressie leidt. Bovendien kan het postulaat van Hamilton geen axioma zijn, omdat uit ervaring blijkt dat niet iedereen van dit postulaat overtuigd is. Met dit laatste

${ }^{1}$ cf. Betz, H.J. (1890), op. cit. p. 335. 
argument grijpt Betz terug op zijn cerder genoemde argument tegen de onderstelde absolute zekerheid en algemeengeldigheid van Heymans' causale axioma's.

In de eerste plaats kan worden geconstateerd dat Betz een sterk argument in handen heeft tegen Heymans' opvatting dat causale axioma's a priori en algemeen geldig zijn Terecht wijst Betz er op dat échte axioma's geen bewijs nodig hebben.

Ook sterk is Betz' argument dat het herleiden van verschijnselen tot mechanische processen nog niet impliceert dat het werkelijk bestaande onveranderlijk is. Terecht merkt Betz op dat het herleiden van verschijnselen tot mechanische processen nog steeds verandering en tijd impliceert, en dat met zo'n herleiding nog niet wordt angetoond dat het werkelijk bestaande onveranderlijk zou zijn. Het laatste zou neerkomen op een puur speculatieve onderstelling.

De redenering van Betz dat het zoeken van redelijke gronden zou leiden tot een oneindige regressie is daarentegen niet erg overtuigend. Als Heymans namelijk had kunnen bewijzen dat Hamiltons postulaat werkelijk a priori zou zijn, zou er geen verdere verklaring meer nodig zijn. In dat geval zou er derhalve geen sprake zijn van de oneindige regressie, waar Betz kennelijk zo beducht voor is.

\section{HEYMANS' WEERLEGGING VAN BETZ}

Betz' kritiek is Heymans een doorn in het oog, want hij reageert direct in het eerstvolgende nummer van De tijdspiegel met het artikel Dr. Betzen het causaliteitsbegrip (1891).

De Schets, betoogt Heymans, moet in de eerste plaats als een historisch onderzoek worden gezien, en het is in 't algemeen geen geschikten grondslag voor eene theoretische discussie. Discussie over de vraag of Hamiltons theorie aannemelijk is, zou men, aldus Heymans, beter kunnen voeren aan de hand van het, toen overigens nog niet verschenen, tweede deel van Gesetze und Elemente, waarin die theorie uit den aard der zaak eene uitvoerige bespreking zal vinden. ${ }^{1}$ Met andere woorden: Betz heeft de functic van de Schets niet begrepen; bovendien spreekt hij voor zijn beurt.

Heymans haalt vervolgens venijnig uit naar Betz' stijl van debatteren. Ik wil de bezwaren, door den heer Betz in de voorlaatste aflevering van dit tijdschrift uiteengezet, met een enkel woord beantwoorden, niet zoozeer om hem genoegen te doen (want wie schrijft op den toon van den heer Betz wenscht blijkbaar zoomin inlichting als debat), als wel ten bate van diegenen onzer lezers, die bij de

' cf. Heymans, G. (1891), 'Dr. Betz en het causaliteitsbegrip'. In: De tijdspiegel, p. 63, 'Ik hat dan ook het debat over de al- of niet-aannemelijkheid der door Hamilton voorgestelde en door eene reeks van latere wijsgeeren aanvaarde causaliteitstheorie liever uitgesteld, totdat het tweede deel mijner Gesetze und Elemente des wissenschaftlichen Denkens, waarin die theorie uit den aard der zaak eene uitvoerige bespreking zal vinden, verschenen zal zijn.' 
beoordeling van de waarde zijner argumenten eenige voorlichting wenschelijk mochten achten. 'Kennelijk alleen om de lezers van De tijdspiegel een plezier te doen, gaat Heymans grootmoedig in op een aantal van Betz' bezwaren.

Als Betz' constatering juist zou zijn dat men Hamiltons causaliteitsleer kan herleiden tot het gedachtengoed van de Eleaten, dan kan men zich allereerst afvragen of dat zo erg is. Ook voor Daltons atoomtheorie of voor Darwins theorie van natuurlijke selectie kunnen oud Griekse voorlopers worden genoemd, aldus Heymans. Betz' constatering is overigens onjuist, want Hamiltons theorie houdt geen teruggang tot de Eleaten in. Zij waren weliswaar de eersten die expliciet de overtuiging hadden geformuleerd dat de werkelijkheid - het zijnde - onveranderlijk is, maar zij hadden dit niet in verband gebracht met het causale denken. Het nieuwe van Hamilton is nu juist dat hij het causale denken op deze overtuiging laat berusten. Als men meent dat Hamiltons theorie een teruggang betekent tot de Eleaten, dan zou men ook kunnen oordelen dat bijvoorbeeld de 19de eeuwse mechanische warmtetheorie niet meer is dan een herhaling van Newtons grondwetten van de mechanica. ${ }^{2}$ Met andere woorden: niemand zal het voor zijn rekening willen nemen dat nieuwe natuurwetenschappelijke theorieën louter herhalingen zijn van eerder geformuleerde theorieën; hetzelfde geldt voor filosofische opvaltingen. Betz' beroep op de geschiedenis van de filosofie als een argument tegen Hamiltons theorie, en daarmee ook tegen die van Heymans zelf, snijdt daarom geen hout. Dit verweer van Heymans vormt overigens slechts een voorgerecht voor het opdienen van drie meer inhoudelijke argumenten tegen Betz' kritiek.

Heymans' eerste inhoudelijke tegenargument betreft Betz' constatering dat in de Schets vier aparte werelden zouden worden onderscheiden die naast elkaar bestaan; deze constatering acht Heymans onjuist. De ontwikkeling van de wetenschap toont namelijk aan dat steeds meer subjectieve factoren worden ondersteld om de tegenstrijdigheden te verklaren die men in de alledaagse werkelijkheid constateert. Die vier aparte werelden betreffen daarom verschillende wereldbeschouwingen die elkaar in de geschiedenis van de wetenschap hebben opgevolgd. Men kwam in de wetenschap eerst tot de ontdekking dat aan smaak- en geurgewaarwordingen geen objectieve werkelijkheid ten grondslag lag. Deze ontdekking leidde er toe dat werd geconcludeerd dat smak en geur subjectief moeten zijn. Later werd geconcludeerd dat dit ook geldt voor warmte, geluid en kleur, en zelfs ook voor ruimte- en

' cf. Heymans, G. (1891), op. cit. p. 63.

${ }^{2}$ cf. Heymans, G. (1891), op. cit. p. 63, 'Maar het is zelfs nog minder erg: ei is hier van teruggang eenvoudig geene sprake. Aan de stelling van Hamilton, volgens welke het causale denken op de overtuiging van de onveranderlijkheid van het zijnde berust, heeft geen der eleaten ook maar gedacht. Het eenige, wat zij deden, was, dat zij de overtuiging-zelve van de onveranderlijkheid van het zijnde, buiten alle verband met het causale denken, het eersi duidelijk hebben uitgesproken. Wie de theorie van Hamilton voorstelt als een teruggang tot de eleaten, kan met hetzelfde recht de mechanische warmtetheorie voorstellen als een teruggang tot Newton, omdat deze de mechanische grondwetten het eerst duidelijk heeft geformuleerd.' 
tijdbetrekkingen.' Met het volgende argumentum ad hominem wijst Heymans op dit punt Betz terecht. Beschikt men nu over zooveel geest als de heer Betz, dan ligt de verzoeking voor de hand, om de verschillende wereldbeschouwingen, die aan de stadiën van dit proces beantwoorden, als zoovele "werelden" naast elkander te stellen en den volke te verkondigen, dat de heer Heymans met niet minder dan vier werelden voor den dag komt. De heer Betz heeft aan die verzoeking geen weerstand kunnen bieden. ${ }^{2}$

Het tweede inhoudelijke tegenargument dat Heymans aanvoert betreft Betz' vraag waar de overtuiging van de onveranderlijkheid van het zijnde of Hamiltons postulaat op gebaseerd is. Uit de Schets blijkt duidelijk, zo betoogt Heymans, dat nog niemand de gronden voor die overtuiging heeft kunnen aangeven. Bovendien was dit boek ook niet bedoeld om die gronden aan te wijzen. Wat hierin overigens wel duidelijk naar voren komt is het feit dat uit de geschiedenis van de wetenschap blijkt dat de wetenschap van deze overtuiging uitgaat. Men kan dan ook hieruit het vermoeden afleiden dat Hamiltons postulaat berust op een onbewuste redeneering; dat wil zeggen, een redenering die berust op onmiddellijke zekere, maar niet duidelijk voorgestelde praemissen. ${ }^{3}$ Echter, acht men dat vermoeden van te voren verwerpelijk? ${ }^{4}$ Dit zou onwetenschappelijk zijn. Bijvoorbeeld in de logica, algebra en meetkunde was men vroeger op het probleem gestuit dat men niet goed de redelijke gronden kon aangeven voor de zekerheid waarmee men logische en wiskundige wetten op de werkelijkheid kon toepassen; deze gronden werden pas later duidelijk. ${ }^{5}$ Heymans geeft overigens volmondig toe dat de redelijke gronden voor het causale denken nog niet zijn aangetoond. Echter, dat wij met het causale denken zoover nog niet zijn gekomen, betreur ik ten zeerste, maar ik zie niet in, waarom juist op mij de

${ }^{1}$ cf. Heymans, G. (1891), op. cit. p. 64, '..... (is) het niet mogelijk, dat iemand, zich bepalende tot de voorgestelde wereld (...) en daarin tegenstrijdigheden opmerkende, die tegenstrijdigheden tracht op te lossen met behulp der onderstelling, dat de voorgestelde wereld door subjectieve factoren medebepald, en als zoodanig bloote schijn is. Vergis ik mij niet, dan handelde aldus de natuurwetenschap, toen zij de objectieve werkelijkheid, eerst van smaken en geuren, later van warmteverschijnselen, tonen en kleuren, nog wat later yan ruimte- en tijusbetrekkingen, in twijfel meende te moeten trekken.'

${ }^{2}$ ef. Heymans, G. (1891), op. cit. p. 64.

${ }^{3}$ cf. Heymans, G. (1891), op. cil. p. 64.

${ }^{4}$ cf. Heymans, G. (1891), op. cit. p. 64.

${ }^{5}$ cf. Heymans, G. (1891), op. cit. p. 64, 'Wie mijn boek heeft gelezen, weet, dat ik mijzelf zoomin als iemand anders vooralsnog in staat acht, van die gronden (de overtuiging van de onveranderlijkheid van het zijnde) rekenschap te geven; ik heb alleen uit de evidentie, die blijkens de geschiedenis der wetenschap aan de bedoelde overtuiging toekomt, het vermoeden afgeieid, dat zij door onbewuste redeneering uit onmiddellijk zekere, maar niet duidelijk voorgestelde praemissen zou zijn tot stand gekomen. (....) men herinnere zich, dat vroeger ook van de zekerheid, waarmede wij de logische, arithmetische en geometrische wetten op de werkelijkheid toepassen, geene rekenschap kon worden gegeven, terwijl later in willekeurig vastgestelde begripsbepalingen en diep verborgen, aan de zelfwaarneming ontsnappende gegevens de gronden zijn aangewezen, waarop die zekerheid berust.' 
verplichting zou rusten, in die leemte te voorzien. ${ }^{1}$ Heymans (1891) acht zich nu kennelijk geheel ontslagen van de plicht om rechtstreekse argumenten aan te dragen voor de overtuiging dat het zijnde onveranderlijk is, hoewel hij in de Schets hiertoe toch een poging had gedaan.

Betz had betoogd dat de overtuiging a priori van de onveranderlijkheid van de werkelijkheid strijdig is met de feiten. Dit is het aanknopingspunt voor Heymans' derde tegenargument. Alleen al het feit dat men aan causale axioma's kan twijfelen, had Betz geopperd, toont aan dat zij niet a priori kunnen zijn en algemeen gelden. Bovendien was hij van mening dat échte axioma's geen bewijs nodig hebben. Ook had hij stellig beweerd dat axioma's axioma's blijven (...), dat (zij niet) steunen op bewijzen pro en bovendien dat zij noch aan het wankelen (worden) gebracht door bewijzen contra. Heymans repliceert dat juist Betz' eigen opvatting strijdig met de feiten is. Immers, er zijn vele voorbeelden in de geschiedenis van de wetenschappen aan te wijzen die aantonen dat men wél aan axioma's kan twijfelen. Welke stellingen houdt de heer Betz voor axioma's ${ }^{2}$ Illustere geesten zoals Lobatschewsky, Riemann en Helmholtz betwijfelden bijvoorbeeld de geldigheid van de grondstellingen van de meetkunde. En Descartes achtte het bijvoorbeeld denkbaar dat men door een malin genie wordt misleid in de onderstelling dat $2+3=5$ zeker is. ${ }^{3}$ Met andere woorden: het feit dat men aan bepaalde axioma's kan twijfelen, bewijst nog niets tegen de opvatting dat zij toch a priori kunnen zijn en algemeen gelden.

Tegenover Betz' argument dat het herleiden van alle verschijnselen tot mechanische processen nog niet aantoont dat de werkelijkheid onveranderlijk is, stelt Heymans dat dit juist wél het geval is. Niets is zekerder, zo voegt Heymans daar aan toe. Het wezen der dingen is inderdaad onkenbaar, omdat men zich buiten de tijdsvorm niets kan voorstellen; immers, al ons voorslellen is aan den tijdsvorm gebonden. Bovendien is hel onmogelijk om verandering te verklaren door iets dat in de tijd niet verandert. Betz' kritiek treft geen doel, omdat dit punt helemaal niet ter discussie stond. Het is belangrijker zich te realiseren dat de natuurwetenschap zich ten doel stelt veranderingen in de dingen (te herleiden) tot veranderingen in betrekkingen tusschen onveranderlijke dingen. ${ }^{4}$ Men moet daarom onderstellen dat de objecten van de waarneming onveranderlijk zijn en dat alleen in de onderlinge

${ }^{1}$ cf. Heymans, G. (1891), op. cit. p. 65.

${ }^{2}$ cf. Heymans, G. (1891), op. cit. p. 65.

${ }^{3}$ cf. Heymans, G. (1891), op. cit. p. 65, 'De heer Betz acht (...) de meening, dat aan de stelling van de onveranderlijkheid van het zijnde een apriorisch karakter toekomt, in strijd met de feiten. (...) Ik wacht op het empirische bewijs voor deze uitspraken (axioma's zijn axioma's) (...) zij steunen niet op bewijzen pro, noch worden zij aan het wankelen gebracht door bewijzen contra; voorlopig zou ik denken dat zij in strijd zijn met de feiten. Welke stellingen houdt de heer Betz voor axioma's? De grondstellingen der geometrie? Lobatschewksy, Riemann en Helmholtz hebben hare nauwkeurigheid als twijfelachtig beschouwd. De stelling, dat $2+3=5$ is? Descartes heeft de mogelijkheid aangenomen, dat hare zekerheid op misleiding door een boozen geest zou berusten.'

${ }^{4}$ cf. Heymans, G. (1891), op. cit. p. 66. 
relaties tussen de onveranderlijke dingen of substanties veranderingen optreden. Aan dit streven ligt het besef ten grondslag dat verandering in ons wereldbeeld alleen voortvloeit uit subjectieve factoren van het denken. Heymans concludeert hieruit dat het elimineren van de notie 'verandering' uit de voorstelling van de dingen of uit het wetenschappelijke wereldbeeld er toe leidt dat dit beeld steeds dichter het, overigens in beginsel onkenbare, wezen d'er dingen zal benaderen.'

Ten slotte had Betz vraagtekens geplaatst bij Heymans' opvatting dat het causale denken niet op grond van de bekende gegevens verklaard kan worden; daarom dient men hypothesen op te stellen, of zoals Heymans (1891) het formuleert, daarnaast (moet men) andere gegevens onderstellen. ${ }^{2}$ Betz had zich vervolgens afgevraagd of het een bezwaar zou zijn als het causale denken niet verklaard kan worden. Sterker nog: op grond waarvan onderstelt men dat alles verklaarbaar zou moeten zijn? Met enige verbazing en ironie merkt Heymans hierover op dat het standpunt, in deze woorden uitgesproken, (mij) even nieuw als vruchtbaar (schijnt); in elk geval brengt het eene niet te versmaden vereenvoudiging in het systeem onzer wetenschappelijke overtuigingen en begrippen. ${ }^{3}$ Aliereerst miskent Betz de natuurwetenschappelijke onderzoekpraktijk. Het is gebruikelijk, zo betoogt Heymans, om natuurverschijnselen te verklaren door hypothesen, of door hypothetische noties zoals 'ether' of 'atomen'. Bovendien is Betz' eigen gedachtengang strijdig met diens eigen opvatting dat aan alle verschijnselen onveranderlijke wetten ten grondslag moeten liggen. Als men van dit laatste uitgaat, zo concludeert Heymans, en als men bepaalde verschijnselen niet kan verklaren door reeds bekende wetten, dan wordt men er wel toe gedwongen om hypothesen te formuleren. ${ }^{4}$

' cf. Heymans, G. (1891), op. cit. p. 66, '...(ik) heb evenwel, gelijk ook door den heer Betz is opgemerkt, kennis van het wezen der dingen onbereikbaar genoemd, erkend, dat al ons voorstellen aan den tijdsvorm gebonden is, en toegegeven, dat uit het in den tijd onveranderlijke onmogelijk de verandering kan worden verklaard. Maar ik heb geconstateerd, dat de natuurwetenschap er voortdurend naar streeft, veranderingen in de dingen tot veranderingen in de betrekkingen tusschen onveranderlijke dingen te herleiden; en ik heb de mogelijkheid ondersteld, dat dit streven zou berusten op 't besef, dat het element der verandering in ons wereldbeeld van subjectieve factoren afkomstig is en dat derhalve, naarmate wij er beter in slagen uit onze voorstelling van de dingen dat element te verwijderen, die voorstelling meer zal naderen tot de (uit den aard der zaak onbereikbare) kennis van hun eigen wezen.'

${ }^{2}$ ef. Heymans, G. (1891), op. cit. p. 66.

${ }^{3}$ cf. Heymans, G. (1891), op. cit. p. 66.

${ }^{4}$ cf. Heymans, G. (1891), op. cit. p. 66-67, Tegenover de onmiskenbare voordeelen, die, dit (Betz') standpunt aanbiedt, staat, voor zoover ik zien kan, slechts één bezwaar: het is gelegen in de ook door den heer Betz als onbetwistbaar erkende stelling, "dat de natuur-(en toch ook de bewustzijns-) verschijnselen aan onveranderlijke wetten gehoorzamen". Zoolang wij aan die stelling vasthouden, schijnt inderdaad, zoo vaak wij een natuur- of een denkverschijnsel zien tol stand komen op eene wijze, die niet in de bekende wetten van de natuur of. van het denken past, hypothetische aanvulling der gegevens onvermijdelijk.' 
De hoofdlijn van Heymans' repliek op Betz kan als volgt worden samengevat. Betz had Heymans' onderscheid tussen vier werelden, te weten: de wereld van de alledaagse ervaring, de wereld die tot uitdrukking komt in de natuurwetenschappen, de wereld opgevat als een onveranderlijk zijnde en, ten slotte, het wezen der dingen, verkeerd begrepen. Men moet er niet van uitgaan dat het separate werelden betreft, omdat de ene wereld tot de andere wereld herleid kan worden.

Betz' aantijging dat Heymans niet had aangetoond waar Hamiltons postulaat op berust, acht Heymans misplaatst omdat hij dat in de Schets helemaal niet had willen aantonen.

Het argument van Betz dat men aan axioma's niet zou kunnen twijfelen, acht Heymans in strijd met de feiten. Bovendien impliceert het feit dat men aan axioma's kan twijfelen nog niet dat zij niet algemeen geldig en a priori zouden kunnen zijn.

Ook Betz' argument dat het herleiden van verschijnselen tot mechanische processen niet betekent dat het werkelijk bestaande onveranderlijk is, schuift Heymans opzij. De wetenschap beoogt waargenomen verandering te herleiden tot onveranderlijke verhoudingen tussen substanties of dingen. Dit streven kan men verklaren door te onderstellen dat de notie 'verandering' berust op subjectieve elementen in het denken. Door waargenomen verandering te herleiden tot onveranderlijke verhoudingen tussen de dingen, en door zo verandering geleidelijk uit het wetenschappelijke wereldbeeld te elimineren, benadert men het in beginsel onkenbare wezen der dingen.

Op Betz' vraag waarom men voor alles een verklaring zou moeten zoeken, en daarom ook voor het causale denken, reageert Heymans dat Betz daarmee de gangbare onderzoekpraktijk miskent. Heymans acht het een essentieel kenmerk van de wetenschap om hypothesen te formuleren over de achterliggende onveranderlijke structuur van de werkelijkheid. Bovendien spreekt Betz zich zelf tegen, omdat hij eerder had beweerd dat men moet onderstellen dat aan alle verschijnselen onveranderlijke wetten ten grondslag liggen. Met dit laatste is Heymans het volledig eens, en hij acht het daarom legitiem om via hypothesen ook een verklaring te zoeken voor de verschijnselen van het causale denken.

De weerlegging van Betz' argument dat Heymans vier separate werelden onderscheidt, is niet erg overtuigend. Heymans tracht dit argument namelijk te weerleggen door een beroep te doen op de ontwikkeling van de wetenschap. De vier werelden betreffen wereldbeelden die men als verschillende fasen in de ontwikkeling van het wetenschappelijk denken zou moeten beschouwen, en niet als separate werkelijkheden. Hierbij kan namelijk worden opgemerkı dat Heymans door dit beroep op de wetenschapsgeschiedenis geen directe argumentatie levert voor zijn opvatting dat er achter het waarnemen van veranderende verschijnselen een onveranderlijke werkelijkheid zou moeten bestaan; het blijft bij een niet bewezen, maar vaak herhaalde onderstelling.

Het argument dat de Schets niet als doel had de gronden aan te tonen dat het werkelijk bestaande onveranderlijk is, is nogal zwak. Hoewel Heymans immers 
slechts een vermoeden had geuit op welke gronden de overtuiging a priori dat het werkelijk bestaande onveranderlijk is, zou kunnen berusten, kan men zich toch niet aan de indruk onttrekken dat hij in de Schets meer belooft dan hij waar maakt. Nadat Heymans met veel aplomb heeft beweerd dat van de overtuiging a priori wordt uitgegaan dat het werkelijk bestaande onveranderlijk is, zou men toch op zijn minst ook argumenten mogen verwachten die aangeven waar deze overtuiging op berust; dat wil zeggen, argumenten die onafhankelijk zijn van interpretaties van concrete voorbeelden uit de onderzoekpraktijk.

Heymans' argumentatie tegen Bet' opmerking dat het herleiden van verschijnselen tot mechanische processen niet impliceert dat het werkelijk bestaande onveranderlijk is, vormt een herhaling van zetten. Heymans' argumentatie maakt niet veel meer duidelijk dan dat de wetenschap er naar zou streven waargenomen veranderingen met behulp van hypothesen te herleiden tot onveranderlijkheid. Afgezien van de vraag of dit het streven van de wetenschap zou zijn, kan men ook dit argument niet beschouwen als een bijdrage aan het verhelderen van de vraag wat de specifieke filosofische rechtvaardiging is voor de overtuiging a priori dat het werkelijk bestaande onveranderlijk is.

\section{JELGERSMA'S KRITIEK OP HEYMANS}

D.G. Jelgersma (1856-1930), leraar klassieke talen, was vanaf 1896 tevens als privaatdocent verbonden aan de Universiteit van Amsterdam. In 1907 werd hij toegelaten als privaatdocent aan de Rijksuniversiteit Leiden; dit bleef hij tot 1921. Veel filosofische geschriften heeft Jelgersma niet gepubliceerd. Dat neemt echter niet weg dat men 1896 als een topjaar kan beschouwen wat zijn produktie van filosofische beschouwingen betreft. In dat jaar verschenen namelijk achtereenvolgens een bundeling van zijn eerder gepubliceerde filosofische artikelen onder de naam Wijsgeerige strijdschriften (1896b), de rede Psychologie en philosophie (1896d) en het boek De ontkenning der moraal (1896e). In de bundel Wijsgeerige strijdschriften is ook het in 1891 gepubliceerde artikel Causaliteit opgenomen, waarin hij Heymans' causaliteitsleer scherp bekritiseert. Jelgersma's publikaties waren kennelijk zodanig dat de Leidse faculteit der letteren en wijsbegeerte hem in 1896 als een mogelijke opvolger beschouwde van Land, die in dat jaar met emeritaat was gegaan. Uiteindelijk werd echter G.J.P.J. Bolland en niet Jelgersma tot Lands opvolger benoemd. Dit gebeurde overigens pas nadat een andere kandidaat, Spruyt, kennelijk vanwege te hoge financiële eisen, door het Curatorium van de Rijksuniversiteit Leiden was afgewezen [Otterspeer, 1995].

Het doel van Jelgersma's artikel Causaliteit is helder: in dit artikel is het mij slechts te doen om de denkbeelden over causaliteit van den heer Heymans zelf en 
meer in het bizonder om dat deel dier denkbeelden, waarmede ik mij niet kan vereenigen. ${ }^{1}$

Tegenover Heymans' opvatting dat men het psychologische causaliteitsvraagstuk niet door associatic kan verklaren, stelt Jelgersma dat dit wél mogelijk is. Dit vormt de kern van Jelgersma's kritiek op Heymans. De twee zeer groote gebreken van de Schets zijn, zo betoogt Jelgersma, de door den heer Heymans' voorgestane oplossing van het psychologische causaliteitsvraagstuk en zijne kritiek van de oplossing van dit probleem volgens de associatieleer. ${ }^{2}$

Jelgersma grijpt eerst Heymans' formuleringen van het psychologische en filosofische causaliteitsvraagstuk aan om te concluderen dat deze verre van gelukkig zijn. Vervolgens opent hij de aanval op Heymans' kritiek op de associatieleer die inhield dat deze als verklaring voor het causale denken tekort schoot. Jelgersma wil met drie argumentaties aantonen dat deze leer wél het causale denken kan verklaren. Hiertoe tracht hij aannemelijk te maken dat de associatieleer zowel voor het ontstaan van causale overtuigingen als voor de successie- en coëxistentiewetten een verklaring kan bieden. Dit zijn de eerste twee argumentaties van Jelgersma tegen Heymans' opvatting dat het causale denken niet in termen van associatic verhelderd kan worden en dat men daarom uit zou moeten gaan van Hamiltons hypothese als verklaring ven het psychologische causaliteitsvraagstuk. Jelgersma rekent echter ook af met deze hypothese zelf door aan te tonen dat Heymans de grondslag daarvan, Hamiltons postulaat, ten onrechte had opgevat als een axioma. Bovendien schijnt het hem toe dat Hamiltons hypothese de notie 'oorzaak' niet kan verklaren. Al met al acht Jelgersma Heymans' oplossing van het psychologische causaliteitsvraagstuk ontoereikend. Deze laatste kritiek vormt een aanloop tot de derde argumentatie tegen Heymans' kritiek op de associatieleer. Tegenover Heymans' opvalting dat men causale axioma's alleen kan verklaren door uit te gaan van Hamiltons hypothese, stelt Jelgersma dat de associatieleer zulke axioma's wél kan verhelderen. Tot slot neemt hij Heymans' oplossing van het filosofische causaliteitsvraagstuk onder de loep. Hierbij merkt Jelgersma op dat deze oplossing tot tegenstrijdigheden leidt, en dat ook dit vraagstuk in termen van associatie kan worden opgelost.

\section{Kritiek op Heymans' formulering van het causaliteitsvraagstuk}

Jelgersma heeft grote moeite met Heymans' formulering van zowel het psychologische als het filosofische causaliteitsvraagstuk. Heymans had het psychologische causaliteitsvraagstuk als volgt geformuleerd: hoe is het te verklaren dat in ons bewustzijn uit bepaalde waarnemingen de zekerheid ontstaat van een niet waargenomen noodzakelijk verband wisschen de objecten dier waarnemingen? Naar aanleiding hiervan vraagt Jelgersma zich af, wat toch mijn bedoeling (is), wanneer ik $B$ na $A$ waarnemende, zeg, dat $A$ de oorzaak is van $B$ ? Deze uitspraak betekent dat men verwacht dat iedere volgende waarneming van A (zeg: A) wordt gevolgd door de waarneming

' cf. Jelgersma, D.G. (1891), 'Causaliteit'. In: De nienwe gids, p. 37.
${ }^{2}$ cf. Jelgersma, D.G. (1891), op. cit. p. 70. 
van B (zeg: B). De uitspraak 'de verwachting dat B in alle omstandigheden - overal en altijd - op A zal volgen', is even duidelijk als de uitspraak 'de verwachting dal B noodzakelijk op A zal volgen'. Jelgersma's kritick op Heymans is dat deze in diens formulering van het psychologische causaliteitsvraagstuk de betekenis van de term 'noodzakelijk' en de daarmec verwante woorden niet duidelijk omschrijft. Zolang dat nict is gebeurd acht Jelgersma het verstandiger zulke woorden helemaal nict te gebruiken, en zich strikt aan de feiten te houden. Die feiten komen er op neer dat men alleen de regelmatige successic van verschijnselen kan waarnemen. Juist ondat Heymans had betoogd dat men op grond van ervaring alleen cen regelmatige successic of een regelmalig samengaan van bepaalde verschijnselen kan constateren, acht Jelgersma het zuiverder om het psychologische causaliteitsvraagstuk als volgt te formuleren': hoe verklaren wij uit de regelmatige opeenvolging der waarneming van twee verschijnselen de verwachting, dat ook in de toekomst (d.i. overal en altijd) de waarneming van het eene verschijnsel gevolgd zal worden door de waarneming van het andere?

Na Jelgersma's semantische kritiek op Heymans' formulering van het psychologische causaliteitsvraagstuk volgt een meer inhoudelijke kritiek op diens formulering van het filosofische causaliteitsvraagstuk. Heymans had dit laatste vraagstuk als volgt geformuleerd: hoe is het te verklaren dat de gegeven verschijnselen zich richten naar de wetten, door het denken met de voorstelling dezer verschijnselen verbonden? Of: welke zekerheid hebben wij dat de toekomst onze causale verwachtingen niet zal logenstraffen? Deze formuleringen acht Jelgersma misleidend, omdat Heymans daardoor impliciet al een oplossing van dit vraagstuk laat doorschemeren. Hij onderstelt immers dat verschijnselen in de buitenwereld uiteindelijk het resultaat zijn van het denken. Bovendien onderstelt hij dat men ten onrechte aan zulke verschijnselen een bestaan buiten het denken toeschrijft. Ook gaat Heymans er zonder meer van uit dat die verschijnsclen de voorstellingen zelve zijn die met bepaalde wetten van het denken worden verbonden. Met andere woorden: de verschijnselen zouden zich richten naar de welten van het denken. Hierdoor sluil Heymans echter andere verklaringsmogelijkheden uit. Men zou zich namelijk ook kunnen afvragen, aldus Jelgersma, of het denken niet wordt bepaald door de wetten

${ }^{\prime}$ cf. Jelgersma, D.G. (1891), op. cit. p. 40-41, 'Wat is toch mijn bedoeling, wanncer ik B na $A$ waamemende zeg, dat A de oorzaak is van B? Dit dunkt mij, dat ik verwacht, dat een volgende waarneming van A, waar en wanneer ook gedaan, weder gevolgd zal worden door de waarneming van $B$. En of $i k$ nu spreek van de verwachting, dat de waarneming van $B$ overal en altijd op die van A zal volgen of van de verwachting, dat dit noodzakelijk zal geschieden, dit maakt behalve in duidelijkheid geen verschil. (....) ... het is in ieder geval beter het woord noodzakelijk en de verwante woorden in een wijgerig betoog niet te gebruiken, voor zij een duidelijk bepaalde wijsgeerige beteekenis hebben gekregen. Tot zoo lang houde men zich aan de feiten. (.....) .... de gegevens der ervaring (leeren) ons ten hoogste (zooals deze zegt), dat verschillende verschijnselen regelmatig samengaan of elkaar opvolgen, of om ons juister uit te drukken: dat verschillende verschijnselen regelmatig achtereenvolgens worden waargenomen.....'

${ }^{2}$ cf. Jelgersma, D.G. (1891), op. cit. p. 41. 
van verschijnselen; of, dat er geheel andere wetten zijn die zowel het denken als de verschijnselen bepalen. Jelgersma concludeert dat Heymans' formulering er toe leidt dat de verschijnselen bij voorbaat als onlosmakelijk met het denken opgevat moeten worden. Eén en ander brengt Jelgersma tot de conclusie dat het filosofische causaliteitsvraagstuk neutraal moet worden geformuleerd, en wel als volgl ${ }^{1}$ : hoe is het te verklaren, dat de voorstellingen in ons en de verschijnselen, die wij terecht of ten onrechte buiten ons plaatsen, zich richten naar overeenkomstige wetten? Of anders geformuleerd: hoe is het te verklaren, dat onze verwachting omtrent de toekomstige opeenvolging onzer waarnemingen door de ervaring bevestigd wordt? ${ }^{2}$

\section{Ontstaan onzer causale overtuigingen door associatie}

Heymans had geconcludeerd dat het ontstaan van causale overtuigingen niet verklaard kon worden door Hume's hypothese van voorstellingsintensiteit en door associatie. Jelgersma grijpt deze conclusie aan om het tegendeel aan te tonen.

Een associatie tussen waarnemingen kan al ontstaan, zo betoogt Jelgersma, als men in enkele gevallen heeft waargenomen dat een bepaald verschijnsel na een bepaald ander verschijnsel is opgetreden. In zulke gevallen spreekt men nog niet over 'oorzaak' en 'gevolg'. Dit gebeurt pas nadat de waarnemingen van die verschijnselen herhaaldelijk in dezelfde orde elkaar zijn gevolgd, waardoor ook een vaste associatie tussen zulke waarnemingen is ontstaan. Hieruit mag men echter niet concluderen dat de waarneming van het ene verschijnsel altijd leidt tot de gedachte dat het tweede verschijnsel bestaat. Het optreden van zo'n associatie is namelijk afhankelijk van de mate waarin aan bepaalde voorwaarden is voldaan; dat wil zeggen, gunstige omstandigheden. Deze voorwaarden houden bijvoorbeeld in dat de waarneming van het eerste verschijnsel duidelijk moet zijn, dat deze waarneming iemands belangstelling heeft en dat het denken niet door andere dingen in beslag wordt genomen die het vormen van zo'n associatie zouden verhinderen. ${ }^{3}$ Onder zulke

${ }^{1}$ cf. Jelgersma, D.G. (1891), op. cit. p. 41-42, 'Door de formule van den heer Heymans toch schijnt een bepaalde oplossing van dat probleem, ik zeg niet geponeerd, maar gesuggereerd te worden. Deze oplossing n.l. als het een oplossing mag heeten; dat de zoogenaamde verschijnselen in de buitenwereld in den grond der zaak niet anders zijn dan voortbrengselen van ons denken, die wij ten onrecht buiten onzen geest plaatsen, niets anders dan de voorstellingen zelve, waarmede het denken de becioelde wetten verbindt. Immers door te poneeren dat de verschijnselen zich richten naar de wetten van het denken, schijnt men de beide andere verklaringen, dat of het denken zich richt naar de wetten der verschijnselen, of denken en verschijnselen beide zich richten naar wetten die van elders komen, bij voorbaat uit te sluiten en daardoor bij voorbaat de verschijnselen van hun zelfstandigheid tegenover het denken te berooven.'

${ }^{2}$ cf. Jelgersma, D.G. (1891), op. cit. p. 42.

${ }^{3}$ cf. Jelgersma, D.G. (1891), op. cit. p. 46, Wanneer ik een verschijnsel B een enkele maal na een ander verschijnsel A waarneem kan er voorzeker tusschen deze waarnemingen een associatie ontstaan. (...) Ik heb nog niet te doen met wat ik oorzaak en gevolg noem. Eerst wanneer deze waarnemingen herhaaldelijk in dezelfde orde op elkander gevolgd zijn, (....) zal deze die vastheid verkrijgen, welke noodig is om ons de beide verschijnselen A en $B$ oorzaak 
voorwaarden zal de waarneming van een bepaald verschijnsel, die bovendien met geen enkele andere waarneming associatief verbonden is, altijd tot de gedachte aan een bepaald ander verschijnsel leiden. Als de gunstige omstandigheden gelijk blijven, dan is het onmogelijk om de gedachte aan het tweede verschijnsel door de gedachte aan een ander verschijnsel te verdringen. Hierdoor wordt de gedachte aan het tweede verschijnsel onontkoombaar. Deze onontkoombaarheid of onvernietigbaarheid in het bewustzijn van zo'n gedachte is bovendien het kenmerk voor het werkelijk bestaan van iets waar die gedachte betrekking op heeft. Jelgersma concludeert dat deze theorie een verklaring biedt voor het feit dat men een bepaald verschijnsel als de oorzaak van een bepaald ander verschijnsel beschouwt, als de waarneming van het eerste verschijnsel in alle gevallen wordt gevolgd door de waarneming van het tweede verschijnsel.' Met andere woorden: het ontstaan van causale overtuigingen is te verklaren in termen van associatie.

\section{Associatie ten gevolge van coëxistentie}

Heymans had betoogd dat men afwijkingen op coëxistentiewetten mogelijk acht; dit in tegenstelling tot uitzonderingen op successiewetten. In het eerste geval zoekt men net zolang naar een herformulering van een successiewet, totdat de waargenomen uitzonderingen weer in overeenstemming zijn gebracht met zo'n wet. Bovendien gaat men er bij de successie van verschijnselen van uit dat daaraan wetten ten grondslag liggen die algemeen gelden en absoluut zeker zijn. Een uitzondering op een coëxistentiewet accepteert men daarentegen als een gegeven. Jelgersma stelt daar tegenover dat er veel minder verschil is in het gedrag bij afwijkingen van coëxistentieen successiewetten dan Heymans denkt.

Jelgersma gaat in zijn tegenargumentatie uit van dezelfde voorbeelden die Heymans in de Schets had gegeven: het voorbeeld van een kalfje met vijf poten en de werking van een medicijn.

Als men, zo betoogt Jelgersma, bij de geboorte van een kalfje de kop waarneemt,

en gevolg te doen noemen. Dit wil niet zeggen, dat in ieder geval de waarneming van A gevolgd zal worden door de gedachte aan $B$ als bestaande. Dat zal slechts gebeuren onder gunstige omstandigheden, d.i. wanneer de waarneming van A duidelijk genoeg is, wanneer zij voldoende belangstelling bij mij opwekt en ik er dus mijn aandacht op vestig en wanneer er geen andere dingen in mijn geest gebeuren, die de werking der bestaande associatie verhinderen."

' cf. Jeigersma, D.G. (1891), op. cit. p. 46-47, 'In die gunstige omstandigheden evenwel zal de gedachte aan $B$ altijd bij ons opkomen en wanneer werkelijk de waarneming $A$ met geen enkele andere waarneming geassocieerd is behalve met die van B, zal het ons onmogelijk zijn de gedachte aan $\mathbf{B}$ door gepaste middelen (d.i. bij het blijven bestaan derzelfde gunstige omstandigheden) door die aan eenig ander verschijnsel te verdringen. Deze gedachte zal derhalve die onvernietigbaarheid in ons bewustzijn bezitten, waarvan wij boven gezien hebben, dat wij ze beschouwen als het kenmerk van de gedachte aan iets, dat werkelijk bestaat. Deze beschouwingswijze is (...) geschikt om het feit te verklaren dat wij $A$ de oorzaak van B noemen, wanneer de waaneming van het eene verschijnsel zonder uitzondering gevolgd wordt door die van het andere,....' 
dan verwacht men het tegelijk bestaan van een lichaam met vier poten. En: als men herhaaldelijk heeft waargenomen dat een bepaald medicijn leidt tot het verdwijnen van ziekteverschijnselen, dan verwacht men dat bij gelijke omstandigheden de ziekteverschijnselen zullen verdwijnen. Tot dusver is er geen verschil tussen beide soorten wetten. Immers, de verwachting dat er een lichaam met vier poten zal volgen is sterker dan de verwachting dat de ziekteverschijnselen verdwijnen. ${ }^{1}$ Als het kalfje echter vijf poten blijkt te hebben, dan is hiervan het gevolg dat men nagaat of men in dit geval werkelijk de kop van een kalfje heeft waargenomen. Het blijkt, zo betoogt Jelgersma, dat zowel de voorstelling van de kop van het kalf als de voorstelling van het lichaam met vijf poten onontkoombaar zijn. Deze uitzondering op de coëxistentiewet dat kalveren doorgaans vier poten hebben, brengt hem tot de constatering dat de associatie tussen de kop van het kalf en het lichaam met vier poten wordt verzwakt. ${ }^{2}$

Jelgersma vraagt zich vervolgens af hoe ik mij nu (zal) gedragen tegenover de successiewet? Als een medicijn dat voorheen altijd bleek te werken niet leidt tot het verdwijnen van bepaalde ziekleverschijnselen, dan is hiervan het eerste gevolg dat men denkt dat het hier om een ander medicijn gaat. Als dat niet zo is, dan zal men vervolgens nagaan of het inderdaad gaat om gelijksoortige eerder waargenomen ziekteverschijnselen. Zo'n onderzoek wordt echter bemoeilijkt, omdat men zich in dat geval niet kan verlaten op andere waarnemingen, maar alleen op herinneringen aan vroeger gedane waarnemingen. In tegenstelling tot actuele waarnemingen zijn herinneringen veel minder onontkoombaar; bovendien kan men herinneringen moeilijk verifiëren. Men kan er daarom nooit zeker van zijn dat het inderdaad om dezelfde soort ziekteverschijnselen gaat en dat de voorstelling daarvan onontkoombaar is. Deze omstandigheid maakt het vrijwel onmogelijk om vast te stellen of een

' cf. Jelgersma, D.G. (1891), op. cit. p. 49-50, 'Als ik den levenden kop van een kalf waarneem, verwacht ik als te gelijk daarmee bestaande te zullen waarnemen een lichaam met vier pooten; en als ik na het gebruik van een zeker geneesmiddel een aantal keeren bepaalde ziekteverschijnselen heb zien verdwijnen, verwacht ik bij dezelfde ziekteverschijnselen na het gebruik van hetzelfde middel, dat deze verschijnselen wederom zullen verdwijnen. Tot zoover geen verschil of verschil in het voordeel der coëxistentiewetten, omdat in het eerste geval, mijn verwachting een lichaam met vier pooten te zullen zien, sterker is dan mijn verwachting. dat de ziekle zal genezen in het tweede.'

${ }^{2}$ ef. Jelgersma, D.G. (1891), op. cit. p. 50, 'Nu zie ik echter dat het kalf vijf pooten heeft. Wat zal daarvan het onmiddellijk gevolg zijn? (.....) ...ik ga oogenblikkelijk onderzoeken of ik werkelijk een kalfskop en niet den kop van een of ander mij onbekend monster heb waargenomen. Het zal mij blijken dat de voorstelling van den kalfskop weerstand biedt aan alle gepaste pogingen om hat uit mijn bewustzijn te verdrijven. Evenzoo met het na den kalfskop waargenomen lichaam met vijf pooten. Ook van de voorstelling daarvan kan ik mij door gepaste middelen niet ontdoen. En het gevolg van dit alles kan geen ander zijn, dan dat de associatie tusschen den kalfskop en het lichaam met vier pooten, de coëxistentiewet, zooals de heer Heymans haar heeft genoemd, iets van hare vastheid verliest.' 
bepaalde herinnering betrekking heeft op iets dat werkelijk heeft bestaan. ${ }^{1}$ Hieruit leidt Jelgersma af dat er hier geen conflict bestaat tussen de successiewet en een voorstelling die in hoge mate onontkoombaar is. In dit geval gaat het namelijk om een voorstelling die deze eigenschap in veel geringer graad toekomt. Dit betekent echter niet dat de successiewet, opgevat als een vaste associatie, zwakker wordt. Het impliceert wel dat men door de uitzondering op de successiewet veel minder zekerheid heeft of de voorstellingen van vroegere ziektegevallen een vroegere werkelijkheid representeren. ${ }^{2}$ Met andere woorden: in beide gevallen betreft het vaste associaties tussen twee voorstellingen. In het geval van een coëxistentiewet betreft het twee voorstellingen die in gelijke mate onontkoombaar en daarom in gelijke mate zeker zijn. In het geval van een successiewet zijn beide voorstellingen echter niet in gelijke mate onontkoombaar. Het verschil tussen beide soorten wetten betreft daarom alleen een gradueel verschil in zekerheid ten aanzien van het werkelijk bestaan van iets waar een bepaalde voorstelling betrekking op heeft.

Het verschil tussen beide soorten wetten kan worden verklaard door het fundamenteele onderscheid tussen de waarnemingen van successieve verschijnselen en die van verschijnselen welke tegelijkertijd bestaan. Waarnemingen zijn in beginsel successief, zo betoogt Jelgersma. 'Coëxistentie' schrijft men alleen toe aan verschijnselen of aan voorwerpen, als men deze ook in een omgekeerde volgorde kan waarnemen. Het waarnemen van (afwijkingen van) regelmatigheden van coëxistentie betreft bovendien doorgaans voorwerpen of verschijnselen die blijvende van aard zijn, en zij kunnen door directe waarneming herhaaldelijk worden

' cf. Jelgersma, D.G. (1891), op. cit. p. 50-51, 'Na het gebruik van het gewone geneesmiddel blijven de ziekteverschijnselen bestaan, die ik vroeger steeds zag verdwijnen. Wat zal daarvan het gevolg zijn? Vooreerst twijfel ik aan de gelijkheid van het thans gebruikte geneesmiddel met het vroeger gebruikte. Herhaald gebruik van hetzelfde met meer zorg gereed gemaakte geneesmiddel is echter in staat dien twijfel bijna geheel weg te nemen. Daarna evenwel zal ik de ziekteverschijnselen, die zijn blijven bestaan, nog eens onderzoeken om, zoo mogelijk, te constateeren of ik werkelijk met dezelfde verschijnselen te doen heb als vroeger. De middelen, die mij voor dat onderzoek ten dienste staan, zijn echter zeer onvoldoende. Het zijn niet, als bij den kalfskop en het lichaam met vijt pooten, andere waarnemingen, maar herinneringen aan vroeger gedane waarnemingen. Herinneringen nu hebben nooit die onvernictigbaarheid in het bewustzijn, die een kenmerk is van waarnemingen. (.....) De onmogelijkheid nu om in dit geval een dergelijk onderzoek in te stellen en zoo te constateeren of mijn herinneringen (....) der vroeger waargenomen ziektegevallen juist en volledig zijn, zal beletten, dat de voorstelling dier ziektegevallen die onvernietigbaarheid in mijn bewustzijn verkrijgt, welke haar voor mij maakt tot een symbool eener verleden werkelijkheid.'

' cf. Jelgersma, D.G. (1891), op. cit. p. 134-135, 'De successiewet komt dus niet, zooals in het vorige geval de coëxistentiewet, in conflict met een voorstelling, die de grootst mogelijke mate van onvernietigbaarheid in het bewustzijn bezit, maar met een voorstelling, aan welke die eigenschap in veel geringer graad toekomt. En het gevolg zal zijn, dat niet de successiewet, de uitdrukking eener zeer vast in onzen geest gewortelde associatie, een gedeelte van die vastheid verliest, maar dat wij met minder groote zekerheid onze voorstellingen der vroegere ziektegevallen beschouwen als vertegenwoordigers eener vroegere werkelijkheid.' 
geverifieerd, zoals in het voorbeeld van de geboorte van het kalfje. 'Successie' schrijft men daarentegen alleen toe aan verschijnselen als zij niet in een omgekeerde volgorde waargenomen kunnen worden; het betreft in zulke gevallen gebeurtenissen; dat wil zeggen, verschijnselen die géén blijvend karakter hebben. Bovendien is het in zulke gevallen onmogelijk om door directe waarneming regelmatigheden van successie herhaaldelijk te verifiëren, omdat bepaalde voorstellingen die op associatieve wijze met bepaalde andere voorstellingen met elkaar zijn verbonden gedeeltelijk betrekking hebben op eerdere en daardoor moeilijk te verifiëren waarnemingen, zoals in het voorbeeld van de werking van het medicijn.' Jelgersma concludeert dat met bovenstaande argumentatie het geringe verschil in gedrag tegenover wetten van successie en van coëxistentie volkomen (is) verklaard. ${ }^{2}$

Kortom: het verschil in gedrag kan men verklaren door er van uit te gaan dat de onontkoombaarheid van een voorstelling het kenmerk is voor het werkelijk bestaan van iets waar zo'n voorstelling betrekking op heeft en door uit te gaan van dezelfde associatiewetten die het ontstaan van causale overtuigingen verklaren. Het verschil tussen beide soorten wetten betreft de mate van zekerheid die men daar aan toeschrijft. Bij coëxistentiewetten is het immers mogelijk om door actuele waarneming direct te verifiëren of een voorstelling betrekking heeft op iets wat werkelijk bestaat. Het criterium om te bepalen of een voorstelling betrekking heeft op iets wat werkelijk bestaat is de mate van onontkoombaarheid van zo'n voorstelling in het denken. Bij successiewetten is deze verificatie minder goed mogelijk, omdat de voorstellingen die zo'n wet door associatie met elkaar verbindt voor een deel berusten op herinneringen aan eerdere waarnemingen. Omdat zo'n verificatie minder goed mogelijk is, zijn successiewetten ook moeilijker te weerleggen.

Al met al: Heymans' opvatting dat men de wetten van successie en coëxistentie niet kan verklaren in termen van associatie acht Jelgersma door bovenstaande argumentatie weerlegd.

' cf. Jelgersma, D.G. (1891), op. cit. p. 51-52, 'Ik zie geen ander dan een zoodanig, dat een noodzakelijk gevolg is van het fundamentele onderscheid hetwelk bestaat tusschen waamemingen van opeenvolgende en van te gelijk bestaande verschijnselen. Wij moeten niet vergeten, dat onze waarnemingen zelf altijd opeenvolgend zij; dat wij alleen verschijnselen of van voorwerpen zeggen kunnen, dat zij te gelijk bestaan; dat wij dit doen, wanneer wij die verschijnselen of voorwerpen ook in omgekeerde volgorde kunnen waarnemen; en dat wij aan den anderen kant die verschijnselen opeenvolgend noemen, welke niet in omgekeerde volgorde kunnen waargenomen worden. Voegt men hierbij de omstandigheid, dat regelmatigheden, en dus ook onregelmatigheden van coëxistentie, meestal waargenomen aan voorwerpen, d.i. aan verschijnselen van blijvenden aard en daardoor aan herhaalde controle door waameming onderworpen zijn; terwijl regelmatigheden van successie worden waargenomen bij gebeurtenissen, d.i. bij verschijnselen van niet-blijvenden aard, waarbij herhaalde controle door waarneming daarom alleen reeds onmogelijk is, omdat het eerste lid der betrekking tot het verledene behoort.'

${ }^{2}$ cf. Jelgersma, D.G. (189i), op. cit. p. 52. 


\section{Heymans' oplossing van het psychologische causaliteitsvraagstuk}

Heymans was er van uitgegaan dat het causale denken verklaard kan worden door de overtuiging a priori dat het werkelijk. bestaande onveranderlijk is. Echter, zo vraagt Jelgersma zich af, wat (is) het dan toch eigenlijk, waarvan (Heymans) zegt, dat het werkelijk bestaat?' Of: wat verstaat Heymans onder de notie 'werkelijk bestaande"? Heymans had geantwoord, aldus Jelgersma, dat de notie 'werkelijk bestaande' neerkomt op de notie 'alles wat onveranderlijk is'. Jelgersma vindt dit merkwaardig, en hij stelt daarom voor om de notie 'werkelijk bestaande' te vervangen door de notie van het 'onveranderlijke'. ${ }^{2}$ Met andere woorden: de formulering dat het werkelijk bestaande onveranderlijk is, moet vervangen worden door de formulering dat het onveranderlijke onveranderlijk is; hetgeen betekent dat de overtuiging a priori dat het werkelijk bestaande onveranderlijk is niet meer is dan een tautologie.

Heymans was ook van mening dat Hamiltons hypothese de algemeengeldigheid en zekerheid van natuurwetenschappelijke principes kon verklaren. Als men een aantal malen heeft vastgesteld dat een bepaald deel of element uit een veelheid van gevallen onveranderlijk blijkt te zijn, dan vat men dat element op als een representatie van het wezen der dingen. Omdat een bepaald element onveranderlijk blijkt te zijn, onderstelt men dat dit ook zo zal zijn in gevallen die men nog niet heeft waargenomen. Specifieke natuurwetenschappelijke principes worden door ervaring gevonden. Zulke wetten kunnen echter alleen algemeen geldig en zeker zijn doordat men de overtuiging a priori bezit dat de verschijnselen berusten op iets wat niet verandert: het werkelijk bestaande.

Met deze redenering kan Jelgersma niet uit de voeten. Kennelijk stelt Heymans het wezen der dingen gelijk aan onveranderlijkheid. Om het wezen der dingen te kennen moet men daarom eerst onderzoeken welke dingen onveranderlijk zijn; pas dan is het mogelijk om de notie 'causaliteit' te gebruiken. Men kan echter alleen door ervaring vaststellen welke dingen onveranderlijk zijn. Heymans ontkomt er dan ook niet aan, zo betoogt Jelgersma, om er van uit te gaan dat men door ervaring specifieke natuurwetten vindt, zoals het principe van behoud van arbeidsvermogen, het traagheidsbeginsel en het principe van behoud van materie. Bovendien moet Heymans erkennen dat zulke wetten niet méér inhouden dan hypothesen die worden toegepast op verschijnselen die zijn waargenomen, omdat zij ontstaan zijn op grond

${ }^{1}$ cf. Jelgersma, D.G. (1891), op. cit. p. 54.

${ }^{2}$ cf. Jelgersma, D.G. (1891), op. cit. p. 54, 'Wanneer iemand met eenige nadruk verklaart, het als een gewichtige waarheid te beschouwen, dat het causale denken product is van de apriorische overtuiging, dat het werkelijk bestaande onveranderlijk wezen moet, schijnt het mij niet onbillijk hem in de eerste plaats te vragen, wat het dan toch eigenlijk is, waarvan hij zegt, dat het werkelijk bestaat. Antwoordt hij, dat hij dit zegt van alles, wat onveranderlijk is, dan staan bij een oogenblik verbluft over dit antwoord, maar eindigen toch met hem te verzoeken, dan in het vervolg liever niet te spreken van het werkelijk bestaande, maar van het onveranderlijke.' 
van het vermogen tot blijvende associaties; een eigenschap van het denken die ook tot het ontstaan van de causaliteitswet heeft geleid.'

Men zou er van uit kunnen gaan, zo betoogt Jelgersma verder, dat causale overtuigingen berusten op de ervaring dat sommige dingen onveranderlijk zijn en dat men alleen via ervaring te weten kan komen wat onveranderlijk is; bovendien zou men kunnen onderstellen dat het wezen der dingen op grond van een willekeurige definitie gelijk is aan het onveranderlijke. Echter, de bewering dat causale overtuigingen berusten op de ervaring dat sommige dingen onveranderlijk zijn, acht Jelgersma zeer moeilijk te verdedigen. ${ }^{2}$ Jelgersma laat dit vervolgens zien aan de hand van Heymans' eigen voorbeeld.

Heymans had betoogd dat het waarnemen van een bepaalde oorzaak dikwijls al voldoende is om de ogenschijnlijke tegenstrijdigheid tussen wat eerder en wat later is waargenomen weg te nemen en zo te voldoen aan Hamiltons postulaat. Bijvoorbeeld: een donkere kamer wordt lichter wanneer de kamer met wit papier wordt behangen. Hierdoor komt datgene wat eerder is waargenomen, de waarneming van een donkere kamer, ogenschijnlijk in strijd met datgene wat later is waargenomen, namelijk de waarneming van een lichtere kamer. Op grond van Hamiltons postulaat moet men er van uitgaan dat de hoeveelheid licht gelijk blijft. Heymans had gemeend dat de oorzaak van de overgang van donker naar licht op het feit berust dat donkere gekleurde stoffen meer licht absorberen dan licht gekleurde stoffen; zulke stoffen kaatsen immers meer licht terug. Omdat het witte behang meer licht terugkaatst dan donker behang, is verklaard dat de kamer lichter wordt. De hoeveelheid licht blijft constant, maar door het witte behang gaat er minder licht verloren.

Jelgersma vraagt zich nu af wat volgens Heymans de oorzaak zou moeten zijn voor het lichter worden van de kamer. De laatste was er van uitgegaan dat een oorzaak als een aanvulling moet worden opgevat van bekende gegevens, waardoor de

I cf. Jelgersma, D.G. (1891), op. cit. p. 56-57, 'Nu meen ik en uit het boven aangehaalde en uit andere plaatsen van het boek van des heeren Heymans te mogen opmaken, dat deze geen ander kenmerk van het wezen der dingen kent dan zij onveranderlijkheid. Hij zal dus bij zijn onderzoek naar het wezen der dingen, dat hij moet kennen om zijn causaliteitsbegrip te kunnen toepassen, moeten beginnen met te zoeken naar de dingen die werkelijk onveranderlijk zijn. Hoe hij dit anders kan doen dan door ervaring verklaar ik niet te begrijpen, of liever het kornt mij onmogelijk voor dit anders te doen dan door ervaring. (...) Hij zal moeten toegeven, dat deze beginselen (het traagheidsbeginsel, de onvernietigbaarheid der stof en de wet van arbeidsvermogen) slechts onderstellenderwijze op verschijnselen kunnen worden toegepast, waarbij zij niet zijn waargenomen, maar dat wij gedwongen worden deze onderstelling te maken door dezelfde eigenschap van onzen geest, door de eigenschap n.l. om blijvende associaties in zich op te nemen, waardoor wij tot de causaliteitswet gekomen zijn.'

${ }^{2}$ cf. Jelgersma, D.G. (1891), op. cit. p. 57 , 'Nu is het evenwel niet onmogelijk toe te geven, dat wij slechts door ervaring kunnen weten, wat onveranderlijk is en dat het schijnbaar apriorische van onze overtuiging, dat het wezen der dingen onveranderlijk is, een gevolg is van de willekeurige definitie: het wezen der dingen $=$ het onveranderlijke, terwijl men toch blijft beweren, dat onze causale overtuigingen berusten op de door ervaring verkregen kennis, dal enkele dingen onveranderlijk zijn. Maar ook deze bewering is zeer moeilijk te verdedigen.' 
ogenschijnlijke tegenstrijdigheid tussen wat eerder en wat later is waargenomen wordt weggenomen. Het aanwijzen van een oorzaak heeft als doel aan te tonen dat de objecten van een eerdere en een latere waarneming niet meer strijdig zijn met elkaar. In het geval van het lichter worden van de kamer kan de oorzaak, of de aanvulling van de reeds bekende gegevens, worden waargenomen. Echter, Jelgersma legt Heymans de woorden in de mond dat de oorzaak van het lichter worden van de kamer er op neerkomt dat er méér licht in de kamer is. Jelgersma acht dit antwoord onmogelijk, omdat het lichter worden van de kamer gelijk is aan het feit dát er meer licht in de kamer is. Hij vraagt zich dan ook af wat (wij dan in dit geval) de oorzaak van het lichter worden der kamer noemen? De oorzaak hiervan is dat wit behang de eigenschap heeft meer licht terug te kaatsen; dit acht Jelgersma de enig mogelijke verklaring. Deze verklaring wordt door hem voldoende geacht, omdat herhaaldelijk is waargenomen dat witte voorwerpen meer licht terugkaatsen dan donkere. Het witte behang wordt als de oorzaak voor het lichter worden van de kamer beschouwd. Door herhaalde waarneming is er in de geest of het denken een vaste associatie ontstaan tussen de indruk van licht en de terugkaatsing daarvan. Heymans' onderstelling dat een oorzaak moet worden opgevat als een toevoeging aan eerder bekende gegevens, waardoor de ogenschijnlijke tegenstrijdigheid tussen wat eerder en wat later is waargenomen wordt weggenomen, acht Jelgersma daarom overbodig; bovendien leidt zij tot merkwaardige conclusies. Immers, als men van Heymans' definitie van 'oorzaak' zou uitgaan, dan zou men moeten aannemen dat er een identiteit bestaat tussen het absorberen van licht door donkere stoffen en het terugkaatsen van licht door lichter gekleurde stoffen; dat wil zeggen, absorptie van licht = terugkaatsing van licht. In de natuurkunde zoekt men echter oorzaken van meer elementairen en abstracten aard. Een (toenmalige) natuurkundige verklaring van hetzelfde verschijnsel zou, aldus Jelgersma, uilgaan van bewegingen van moleculen. Een natuurkundige zou de oorzaak van het feit dat er meer licht in de kamer is niet verklaren door aan te nemen dal er meer ethermoleculen worden teruggekaatst, want dit is het feit zelf dát er meer licht is. Neen, een natuurkundige zoekt de oorzaak alleen in moleculaire bewegingen. Als men van Heymans' definitie van 'oorzaak' zou uitgaan, dan zou men moeten onderstellen dat moleculaire bewegingen in een bepaalde stof op een bepaalde plaats en in een bepaalde tijd identiek zijn met de toename van de bewegingen van ethermoleculen; dat wil zeggen, dat de moleculen van een stof gelijk zouden zijn aan ethermoleculen die zich bovendien op een andere plaats en in een andere tijd bevinden. Met gevoel voor understatement acht Jelgersma dit een wel zeer gewaagde bewering. ${ }^{1}$

' cf. Jelgersma, D.G. (1891), op. cit. p. 58-59, 'Wat noemen wij dan in dit geval de oorzaak van het lichter worden der kamer? Mij dunkt niets anders dan de eigenschap van het witte behangsel om het daarop vallend licht terug te kaatsen. En wij leggen ons bij die verklaring neer, niet omdat door die eigenschap de schijnbaar verbroken identiteit tusschen objecten van vroegere en latere waarnemingen wordt hersteld. Dan immers zou men het opnemen van het licht door donker gekleurde en het terugkaatsten daarvan door witte voorwerpen voor identisch verklaren. Maar wij doen dit in het dagelijksch leven, omdat wij 
Samengevat: allereerst constateert Jelgersma dat de door Heymans onderstelde overtuiging a priori dat het werkelijk bestaande onveranderlijk is, neerkomt op een tautologie. Immers, Heymans had de notie 'werkelijk bestaande' gelijk gesteld met 'alles wat onveranderlijk is'. Vervolgens wijst Jelgersma er op dat Heymans had ondersteld dat het wezen der dingen wordt uitgedrukt in bepaalde wetenschappelijke principes. Ook had Heymans het 'wezen der dingen' gelijk gesteld met 'onveranderlijkheid'. Wat onveranderlijk is kan men echter alleen te weten komen door ervaring, aldus Jelgersma. Op grond van ervaring worden bepaalde wetenschappelijke principes geformuleerd; zulke principes zijn slechts hypothesen die via associatie tot stand komen. Ten slotte: Heymans' omschrijving van de notie 'oorzaak' verklaart niet wat men 'oorzaken' noemt, en zij leidt bovendien tot onacceptabele conclusies.

Eén en ander brengt Jelgersma tot de algemene conclusie dat Heymans axioma en definitie door elkaar haalt. De overtuiging a priori dat het werkelijk bestaande onveranderlijk is, had hij als een axioma opgevat. Hierop had hij de opvatting laten berusten dat het de functie van het zoeken naar oorzaken is om de ogenschijnlijke strijdigheden tussen wat eerder en later wordt waargenomen weg te nemen: het herstellen van de identiteit tusschen de objecten der eerdere en latere waarnemingen. Jelgersma wijst er echter op dat Heymans per definitie de notie 'het wezen der dingen' gelijk stelt met de notie van het 'onveranderlijke', en dat hij hier bovendien op een tegenstrijdige manier gebruik van maakt. Enerzijds hanteert hij deze definitie namelijk om er door ervaring achter te komen wat onveranderlijk is; anderzijds gebruikt hij deze definitie ook als een axiomatische waarheid om vast te stellen wat onveranderlijk is. Bovendien acht Jelgersma Heymans' theorie ontoereikend om het verschijnsel dat men 'oorzaak' noemt te verklaren.' Kortom: Heymans' theorie biedt geen oplossing

tallooze maken hebben waargenomen, dat voorwerpen, die op ons den indruk van wit maakten, het licht terugkaatsten en donker gekleurde voorwerpen niet; omdat er dus in onzen geest een vaste associatie bestond tusschen den indruk van wit en de terugkaatsing van licht. (....) Laten wij onderstellen, dat hij (de natuurkundige) zijn verklaring zoo volkomen mogelijk is. Dat hij het geheele verschijnsel teruggebracht heeft tot bewegingen van en botsingen tusschen aethermoleculen en lichaamsmoleculen. Wat is dan voor hem de oorzaak van het meerdere licht, dat wij in de met wit papier behangen waarnemen? Vindt hij die in de meerdere aethertrillingen die teruggekaatst worden? Deze zijn wederom, zoo ik mij niel bedrieg, dat meerdere licht zelf, De oorzaak van dat licht zoekt ook hij in de eigenschappen van het witte behangsel, d.i. in de moleculaire beweging daarin; en het schijnt mij een zeer gewaagde bewering te zeggen, dat deze identiek zijn met meerdere aethertrillingen, d.i. met andere bewegingen van andere moleculen op een andere plaats en in een anderen tijd.'

${ }^{\prime}$ cf. Jelgersma, D.G. (1891), op. cit. p. 64-65, 'Wij hebben in het bovenstaande gezien, dat de causaliteitstheorie van den heer Heymans, zijn bewering dat wij oorzaak noemen een zoodanige aanvulling van de reeds bekende gegevens, dat daardoor de schijnbaar verbroken identiteit tusschen de objecten van vroegere en latere waarnemingen wordt hersteld, in de eerste plaats berust op het verwarren van axioma en defintie. Hij definieert het wezen der dingen als het onveranderlijke en wil door ervaring te weten komen, wat onveranderlijk is; en aan den anderen kant wil hij van de definitie, dat het wezen der dingen onveranderlijk is, gebruik maken als van een axiomatische waarheid om te constateeren, wat onveranderlijk is. Verder hebben wij gezien, dat zijn theorie, afgezien zelfs van deze begripsverwarring, het 
van het psychologische causaliteitsvraagstuk.

Echter, zo vraagt Jelgersma vervolgens af, waarvan is zij dan in staat wél een oplossing te geven en wat is hare beteekenis woor het causale denken?' Heymans' axioma dat het werkelijk bestaande onveranderlijk is, kan men, zo betoogt Jelgersma, alleen gebruiken als een oplossing van het psychologische causaliteitsvraagstuk door het níet als axioma te beschouwen, maar alleen als een definitie of als een ervaringswaarheid die zegt dat bepaalde zaken onvernietigbaar zijn. Hij wijst er nogmaals op dat de onontkoombaarheid of de onvernietigbaarheid in het bewustzijn van een voorstelling in het denken het kenmerk is voor het werkelijk bestaan van iets waar zo'n voorstelling betrekking op heeft. De onontkoombarheid van voorstellingen in het denken en de associatie vormen het fundament van het causale denken. Omdat men een voorstelling die niet verandert opvat als een voorstelling die aan zichzelf gelijk blijft of identisch is met zich zelf, kan men er van uitgaan dat zo'n voorstelling een werkelijkheid representeert die onveranderlijk is of een werkelijkheid die identisch is met zich zelf. De overtuiging dat een bepaalde voorstelling die onveranderlijk en onontkoombaar is ook een werkelijkheid vertegenwoordigt die onveranderlijk is, is daarom slechts een psychologische uitdrukking van Heymans' definitie dat het werkelijk bestaande gelijk is met het onveranderlijke. ${ }^{2}$ Met andere woorden: de notie 'werkelijk bestaande' komt voor Jelgersma op niets anders neer dan het besef of de beleving dat iets werkelijk bestaat.

\section{Causale axioma's verklaard door associatie}

Jelgersma betoogt verder dat ook Heymans' causale axioma's door associatie verklaard kunnen worden. Beide denkers staan op dit punt lijnrecht tegenover elkaar. Heymans had gesteld dat alleen Hamiltons hypothese, volgens welke men het causale denken alleen zou kunnen verklaren met behulp van het postulaat dat men er a priori van overtuigd is dat het werkelijk bestaande onveranderlijk is, causale axioma's kan verklaren. Jelgersma wil daarentegen aantonen dat de vier axioma's die Heymans

verschijnsel, dat wij oorzaak noemen en dat zij dus geroepen is te verklaren, niet eens bespreekt....'

${ }^{1}$ cf. Jelgersma, D.G. (1891), op. cil. p. 65.

${ }^{2}$ cf. Jelgersma, D.G. (1891), op. cit. p. 66, 'Voor zoo ver de theorie van Heymans niets anders wil zijn dan een definitie, vindt zij daarbij haar plaats. Wij zagen daar nl. dat wij aan een voorstelling werkelijkheid toeschrijven, als wij haar door gepast middelen niet kunnen wijzigen of vernietigen, d.i. geheel of gedeeltelijk uit ons bewustzijn verdrijven en dat dit de grondslag is, waarop door middel van associatie het causale denken wordt opgebouwd. Daar wij nu een onveranderd blijvende voorstelling als identisch met zich zelf herkennen en beschouwen als representant eener met zich zelf identische werkelijkheid, is dit toekennen van realiteit aan een voorstelling die deze onvernietigbaarheid in het bewustzijn bezit, de psychologische uitdrukking voor de definitie, dat het werkelijk bestaande het onveranderlijke is.' 
had genoemd door associatie verklaard kunnen worden. ${ }^{1}$

Jelgersma leidt uit zijn eigen definitie van de notie 'werkelijkheid' - opgevat als de onontkoombaarheid van een voorstelling in het denken - af, dat een bepaald gevolg onmiddellijk optreedt na het optreden van een bepaalde oorzaak. Dit is het eerste causale axioma dat in termen van associatie verklaard kan worden. Immers, zolang een voorstelling van een oorzaak onontkoombaar blijkt te zijn, schrijft men daar werkelijkheid aan toe; dit gebeurt totdat deze voorstelling wordt afgewisseld door een voorstelling van gevolg. Als de voorstelling van een oorzaak niet onontkoombaar zou zijn, dan zou men daaraan ook geen werkelijkheid toeschrijven. Hierdoor zou namelijk het fundament worden ontnomen aan de op associatie gebaseerde verwachting dat een voorstelling van een oorzaak leidt tot de voorstelling van een gevolg. ${ }^{2}$

Het tweede causale axioma dat Heymans had genoemd kwam er op neer dat het gevolg noodzakelijk optreedt na een bepaalde oorzaak. De notie 'noodzakelijkheid' kan men in termen van associatie verklaren, zo betoogt Jelgersma. Immers, als 'noodzakelijkheid' er op neerkomt dat men na het optreden van een voorstelling van één bepaalde oorzaak (zeg: een A) uitsluitend een voorstelling van één bepaald gevolg (zeg: een B) verwacht, dan houdt dit niet meer in dan dat een A uitsluitend met een B wordt geassocieerd. Als 'noodzakelijkheid' inhoudt dat men een B altijd na het optreden van een $A$ verwacht, dan betekent dit niets anders dan dat er een vaste associatie tussen een $A$ en een $B$ is. Als men 'noodzakelijkheid' echter niet opvat als een voorstelling van het denken, maar als een feit dat het altijd volgen van een $\mathrm{B}$ na een $\mathrm{A}$ buiten het denken bestaat, dan betreft dit niet het psychologische, maar juist het filosofische causaliteitsvraagstuk. ${ }^{3}$

1 cf. Jelgersma, D.G. (1891), op. cit. p. 66, 'Voor zoover echter deze theorie iets meer wil zijn dan een definitie, nl. een ervaringswaarheid, die zegt dat bepaalde zaken (....) onvernieligbaar zijn, vindt zij een zeer beperkte toepassing (....) bij de zoogenaamde causale axioma's. (...) Het niet verklaard worden dezer axioma's door de associatieleer van Hurne was het tweede nog onbesproken hoofdargument van Heymans tegen de door die leer gegeven oplossing van het psychologische causaliteitsprobleem.'

${ }^{2}$ cf. Jelgersma, D.G. (1891), op. cit. p. 67, 'Het volgen der werking op de oorzaak wordt door de associatielecr volkomen verklaard. Heymans bedoelt dan ook het onmiddellijk volgen. Dit volgt echter uit onze definitie van werkelijkheid. Zoolang ik aan de oorzaak realiteit toeken, is haar voorstelling onder de meer genoemde gunstige omstandigheden onvernietigbaar in mijn bewustzijn tot op het oogenblik, dat zij wordt afgewisseld door de voorstelling van het gevolg. Was zij dit niet, dan zou de oorzaak haar realiteit verliezen en de associatie, waardoor wij het gevolg verwachten, haar reden om te werken.'

${ }^{3}$ cf. Jelgersma, D.G. (1891), op. cit. p. 67, 'Bedoelt men met noodzakelijkheid het feit, dat wij na A geen enkel ander gevolg verwachten dan B, dan zegt men met dit woord niets anders dan dat A met geen enkel ander gevolg geassocieerd is dan met B. Bedoelt men er mede, dat ik niet alleen nu, maar altijd, zoolang mijn denkwijze onveranderd blijft, B na A zal verwachten, dan constateert men het blijven bestaan der associatie, zoolang zij bestaan blijft. Wil men eindelijk daarmede zeggen, dat niet als voorstelling in mij, maar als feit buiten mij B steeds op A volgt, dan houdt men zich bezig met het philosophische causaliteitsprobleem en niet met het psychologische, dat wij op het oogenblik behandelen.' 
Heymans' derde en vierde axioma's hielden in dat het gevolg logisch uit de oorzaak kan worden afgeleid, en dat oorzaken en gevolgen zich als gelijksoortig en gelijkwaardig tot elkaar verhouden. Jelgersma acht de logische afleiding van een gevolg uit een een oorzaak alleen mogelijk, als men bewegingsverschijnselen opvat als bewegingen van moleculen: beweging der stofdeeltjes én als men daar de drie eerder genoemde natuurkundige principes op toepast: de wet van behoud van materie, de wet van behoud van energie en het traagheidsbeginsel; de kennis van zulke principes is op grond van ervaring tot stand gekomen. Als Hamiltons postulaat wordt opgevat als een ervaringswaarheid, en niet als een overtuiging a priori, dan kan daarmee het gevolg getalsmatig worden uitgedrukt. Jelgersma is overigens echter van oordeel dat deze twee laatste axioma's noch met het psychologische noch met het filosofische causaliteitsvraagstuk iets te maken hebben. ${ }^{1}$

Jelgersma concludeert op grond van bovenstaande argumenten dat de eerste twee axioma's geheel door associatie verklaard kunnen worden, terwijl het derde en het vierde axioma voortvloeien uit de ervaringswaarheid dat het werkelijk bestaande onveranderlijk is. De laatste axioma's zijn bijgevolg ook gebaseerd op ervaring, waardoor zij in principe niet als axioma's opgevat kunnen worden. ${ }^{2}$ Hiermee verwerpt Jelgersma Heymans' opvatting dat de causale axioma's a priori zouden zijn. Kortom: dit alles gevoegd bij het voorgaande is, meen ik, voldoende tot rechtvaardiging van het oordeel, dat men aan de theorie van Hamilton en Heymans voor de oplossing der eigenlijke causaliteitsprobleem niet het minste en voor de oplossing van daarmede samenhangende problemen slechts een zeer gering gewicht kan toekennen. ${ }^{3}$

\section{Heymans' oplossing van het filosofische causaliteitsvraagstuk}

Jelgersma vatte het filosofische causaliteitsvraagstuk op als de vraag hoe het (is) te verklaren, dat onze causale verwachtingen door de ervaring bevestigd worden. Of, zoals hij dit vraagstuk aan het einde van zijn artikel fomuleert: hoe is het te verklaren, dat er in de buitenwereld betrekkingen bestaan, beantwoordende aan de betrekkingen

' cf. Jelgersma, D.G. (1891), op. cit. p. 67-68, 'Wat de mogelijkheid betreft de werking logisch af te leiden uit de oorzaak of liever uit de oorzaak en den voorafgaanden toestand, waarin door deze verandering wordt gebracht, deze mogelijkheid bestaat slechts, voor zoo ver wij de verschijnselen beschouwen als bewegingen van stofdeeltjes en bij die beschouwing daarop toepassen de drie ervaringswaarheden, die wij genoemd hebben de onvernietigbaarheid der stof, het traagheidsbeginsel en de wet van behoud van arbeidsvermogen. Het beginsel, dat het werkelijk bestaande onveranderlijk is, hetwelk de heer Heymans wil maken tot het fundament onzer causale overtuigingen, heeft daarom, als ervaringswarheid beschouwd, groote waarde voor de quantitatieve bepaling der werking, ofschoon het met de eigenlijke causaliteitsproblemen (....) rechtstreeks niets te maken heeft.'

${ }^{2}$ cf. Jelgersma, D.G. (1891), op. cit. p. 68 , 'Het blijkt dus, dat deze causale axioma's voor een gedeelte door de associatietheorie volkomen verklaard worden, voor een gedeelte, voor zoover zij gelden, gevolgen zijn van de ervaringswaarheid, waaraan Heymans apriorische zekerheid wil toekennen, en die hij beschouwt als den grondslag onzer causale overtuigingen.'

${ }^{3}$ cf. Jelgersma, D.G. (1891), op. cit. p. 68. 
in ons? Ook het filosofische causaliteitsvraagstuk kan, zo betoogt Jelgersma, door associatie worden verklaard. Als men van mening is dat dit kan, dan gaat men er echter doorgaans ten onrechte van uit dat er causale relaties of betrekkingen in de externe werkelijkheid of buitenwereld bestaan die geleid hebben tot het ontstaan van zulke relaties in het denken. Jelgersma acht dit antwoord onvoldoende, omdat de causale relaties in het denken altijd relaties in de externe werkelijkheid betreffen die vroeger bestonden. En, hoe kan men er zeker van zijn dat de causale relaties die vroeger bestonden gelijk zullen zijn aan zulke relaties in de toekomst? Waaraan ontleent men de zekerheid dat zulke relaties niet veranderen? In Jelgersma's woorden: welke zekerheid hebben wij $n u$, dat die betrekkingen in de toekomst dezelfde zullen zijn als zij in het verleden waren $?^{2} \mathrm{Hij}$ acht het onmogelijk dat men hierover ooit zekerheid kan verkrijgen. Men kan alleen onderstellen dat de causale relaties in de externe werkelijkheid onveranderlijk zijn; daarom is het slechts een hypothese dat zulke relaties niet veranderen. Zo'n hypothese heeft een schijnbaar axiomatisch karakter, aldus Jelgersma, omdat men causale verwachtingen heeft, die in het denken of bewustzijn onontkoombaar zijn. Door deze onontkoombaarheid ontstaat er een voorstelling van een gevolg, en op grond van deze onontkoombaarheid wordt aan het voorwerp waar zo'n voorstelling betrekking op heeft werkelijkheid toegeschreven. Dit betekent dat men genoodzaakt wordt aan te nemen dat er onveranderlijke causale relaties in de exterme werkelijkheid bestaan. Met een steek onder water naar Heymans merkt hij op dat deze oplossing onvoldoende (moge) schijnen aan een geest, die van de metaphysici geleerd heeft buitensporig hooge eischen te stellen. ${ }^{3}$ Toch acht Jelgersma zijn eigen oplossing praktisch en wetenschappelijk zeer voldoende. Het blijft echter slechts een hypothese die in beginsel door ervaring kan worden weerlegd. ${ }^{4}$

${ }^{1}$ ef. Jelgersma, D.G. (1891), op. cit. p. 70.

${ }^{2}$ cf. Jelgersma, D.G. (1891), op. cit. p. 70, 'Wanneer wij de oplossing van het psychologische causaliteitsprobleem, die de associatieleer geeft, aanvaarden, schijnt het antwoord voor de hand te liggen. Men is geneigd te antwoorden: omdat de betrekkingen in ons ontstaan zijn onder den invloed der buitenwereld, en dus beantwoorden aan daarin bestaande betrekkingen; daarom moeten ook omgekeerd de betrekkingen in ons beantwoorden aan die, welke in de buitenwereld bestaan. Het is echter niet moeielijk, het onvoldoende daarvan in te zien. Immers, betrekkingen in ons beantwoorden aan betrekkingen in de buitenwereld, die in het verleden bestonden. En welke zekerheid hebben wij nu, dat die betrekkingen in de toekomst dezelfde zullen zijn als zij in het verleden waren?'

${ }^{3}$ cf. Jelgersma, D.G. (1891), op. cit. p. 71.

${ }^{4}$ ef. Jelgersma, D.G. (1891), op. cit. p. 71, 'Ik kan niet inzien, dat wij daaromtrent eenige zekerheid hebben, noch ook hoe wij daaromtrent eenige zekerheid kunnen krijgen. Er blijft ons dus naar mijne overtuiging niets anders over dan de onveranderlijkheid dezer betrekkingen in de buitenwereld (niet die van de buitenwereld of van de geheele wereld zelf, zooals de heer Heymans wil) onderstellen. Haar schijnbaar axiomatisch karakter krijgt deze onderstelling door het bestaan der causale verwachtingen en door de onvernietigbaarheid in het bewustzijn, die ten gevolge daarvan de voorstelling van een gevolg onder gunstige omstandigheden bezit. Daardoor kennen wij aan het voorwerp van die voorstelling werkelijkheid toe en worden dus gedwongen die onderstelling te maken. En deze oplossing moge onvoldoende schijnen aan een geest, die van de metaphysici geleerd heeft buitensporig hooge eischen te 
Jelgersma vraagt zich ten slotte af welke nu de oplossing (is), die de heer Heymans wil geven van het philosophische causaliteitsprobleem? Hij laat hier meteen op volgen dat het zeer moeielijk is op deze vraag een bepaald antwoord te geven. ${ }^{3}$

Met drie argumenten tracht Jelgersma Heymans' oplossing te ontkrachten. Het eerste argument moet aantonen dat Heymans' oplossing tot contradicties leidt. Met zijn tweede argument wil Jelgersma duidelijk maken dat er zelfs geen sprake kan zijn van een filosofisch causaliteitsvraagstuk als van Heymans' oplossing zou worden uitgegaan. Het derde tegenargument is bedoeld om de genadeslag toe te brengen aan Heymans' opvatting dat overtuigingen a priori in beginsel nooit kunnen veranderen. Deze drie tegenargumenten worden in het navolgende toegelicht.

Heymans had betoogd dat alleen de overtuiging a priori dat het werkelijk bestaande onveranderlijk is een oplossing kan bieden voor het psychologische causaliteitsvraagstuk. Deze overtuiging a priori impliceert echter niet noodzakelijk dat het werkelijk bestaande inderdaad onveranderlijk is. De oplossing voor het filosofische causaliteitsvraagstuk zou kunnen worden gevonden in Kants hypothese van de subjectiviteit van tijd, aldus Heymans.

Jelgersma grijpt allereerst Heymans' vermoeden aan in welke richting de oplossing van het filosofische causaliteitsvraagstuk gezocht zou moeten worden, om te concluderen dat dit nergens toe leidt. Wederom neemt Jelgersma het voorbeeld van het verklaren van het lichter worden van een kamer als uitgangspunt voor zijn argumentatie. Eerder had hij al opgemerkt dat men uit Heymans' definitie van 'oorzaak' moet afleiden dat in diens termen een natuurwetenschappelijke verklaring hiervan neerkomt op het onderstellen dat er een identiteit zou moeten bestaan tussen moleculen die wat aard en tijd-ruimtelijke positie betreft totaal verschillend zijn. Als Heymans consequent zou zijn geweest, dan had hij niet alleen de subjectiviteit van tijd en ruimte moeten onderstellen, maar ook de subjectiviteit van materie en beweging. Dit zou betekenen dat de voorstellingen van materie en beweging geen betrekking hebben op iets in de externe werkelijkheid. Heymans was echter van mening dat materie en beweging deel uitmaken van het wezen der dingen, en daardoor los van voorstellingen zouden bestaan. ${ }^{2}$ Ziedaar een der vele logische tegenstrijdigheden, waartoe zijn leer hem onvermijdelijk voert. ${ }^{3}$

stellen aan onze kennis, zij is praktisch en wetenschappelijk zeer voldoende. En het is, dunkt mij, geoorloofd de hypothese, waarop zij steunt, te beschouwen als de meest zekere hypothesen, waarop het gebouw der menschelijke kennis is opgetrokken, totdat de ervaring ons van hare onjuistheid heeft overtuigd.'

'ef. Jelgersma, D.G. (1891), op. cit. p. 71.

2 cf. Jelgersma, D.G. (1891), op. cit. p. 72, 'Hieruit volgt, dunkt mij, dat het voor deze opvatting noodig is de subjektiviteit aan te nemen niet alleen van ruimte en tijd, maar ook van stof en beweging m.a.w. te beweren, dat er in de wereld buiten ons niets aan onze voorstellingen van stof en beweging beantwoordt. En deze beide behooren toch volgens Heymans wegens haar onveranderlijkheid tot het wezen der dingen.'

${ }^{3} \mathrm{cf}$. Jelgersma, D.G. (1891), op. cit. p. 72. 
Echter. zo luidt Jelgersna's tweede tegenargument, als men zou onderstellen dal de externe werkelijkheid inderdaad onveranderlijk zou zijn, één onveranderlijke wereldmonude; dat wil zeggen, cen werkelijkheid die onafhankelijk zou bestaan van subjecticve voorstellingen van tijd, ruimte, materic en beweging; en, als men bovendien zou onderstel!en dat deze werkelijkheid waar de notie 'tijd' geen betrekking op heeft zich in allerlei vormen aan mensen zou voordoen, zouden wij dan iets dichter zijn bij de oplossing van het philosophische causaliteitsprobleem? Mij dunkt, neen. ${ }^{1}$ Als men namelijk uitgaat van Heymans' oplossing, dan is er helemaal geen sprake van een filosofisch causaliteitsvraagstuk. In dat geval wordt de notie 'causaliteit' immers betrokken up een externe werkelijkheid die onveranderlijk is, en kan er geen sprake zijn van causaliteit omdat de notie 'causaliteit' alleen betrekking hecft op verandering. Men zou ook van mening kunnen zijn dat het lilosofische causaliteitsvraagstuk verband houdt met voorstellingen van het subject die te maken hebben met werkelijkheidsvoorstellingen. Zulke voorstellingen kan men onderscheiden van verwachtingsvoorstellingen dic men in verband met het psychologische causaliteitsvraagstuk tracht te verklaren. In dit geval, zo concludeert Jelgersma, beschouwt de metaphysicus van het systeem Heymans causale relaties tussen w'erkelijksvoorstellingen op een analoge wijze als de philosophische realist causaliteit in de cxterne werkelijkheid opvat, namelijk als werkelijkheidsvoorstellingen dic symbolen zijn voor de onveranderlijke causale relaties in de externe werkelijkheid. ${ }^{2}$ Met andere woorden: in het cerste geval is er géén sprake van een filosofisch causaliteitsvraagstuk, en in het tweede geval zou dit vraagsluk belrekking hebhen op voorstellingen van onveranderlijke causale relaties die los van zulke voorsiellingen zouden bestaan.

Jelgersma's laatste tegenargument betreft een beslissende onderstelling van alle min of mer Kantiaunsche philosophen. ${ }^{3}$ Zij moeten zich namelijk afvragen, aldus Jelgersma, hoe (gij) weet, dat ik morgen nog in het bezit zal zijn van die apriorische overtuiging en dat deze morgen nog in staat zal zijn al mijne causale verwachtingen

${ }^{1}$ cf. Jelgersma, D.G. (1891), op. cit. p. 72.

${ }^{2}$ cf. Jelgersma, D.G. (1891), op. cit. p. 72-73, 'Dat dus de wereld buiten ons in werkelijkheid cén onveranderlijke wereldmonade was, waarin niets beantwoordde aan onze voorstellingen van ruimte en tijd, stof en beweging. En dat daarnaast én of meerdere subjecten bestonden (....), waarin zich deze werkelijkheid in een veelheid van vormen uitdrukt. Zouden wij dan iets dichter zijn bij de oplossing van het philosophische causaliteitsprobleem. Mij dunkt, neen. Immers, of dit probleem bestaat niet voor de voorstanders dezer opvatting, omdat het betrekking heeft op een causaliteit in de wereld buiten ons, en omdat deze wereld onveranderlijk is en dus geen causaliteit toelaat. Of het probleem heeft betrekking op een soort voorstellingen van het subject, die men in onderscheiding van de verwachtingsvoorstellingen, waarmede het psychologische causaliteitsprobleem zich bezig houdt, werkelijkheidsvoorstellingen zou kunnen noemen. En dan staat de metaphysicus van het systeem Heymans tegenover de causaliteit tusschen voorstellingen juist zoo als de philosophische realist tegenover de causaliteit in de werkelijkheid, waarvan de werkelijkheidsvoorstellingen voor hem symbolen zijn.'

${ }^{3}$ cf. Jelgersma, D.G. (1891), op. cit. p. 73. 
te verklaren. ${ }^{1}$ Jelgersma beseft dat deze vraag hun zeer onzinnig en zeer kettersch in de oren zal moeten klinken; toch acht hij deze vraag relevant. De kantiaans georiënteerde filosofen zullen namelijk bij de oplossing van het psychologische causaliteitsvraagstuk genoodzaakt zijn te onderstellen dat de menschelijke geest onveranderlijk is; dit naar analogie van de philosophisch realist die bij de oplossing van het filosofische causaliteitsvraagstuk moet onderstellen dat causale relaties in de externe werkelijkheid onveranderlijk zijn. ${ }^{2}$ Jelgersma concludeert dat zijn laatste argumentatie derhalve leidt tot het volgende keuzeprobleem: aan den eenen kant dus, bij de toepassing der associatieleer, een oplossing van het psychologische en een hypothetische oplossing van het philosophische causaliteitsprobleem; en aan den anderen kant (.....) van het psychologische probleem een hypothetische en van het philosophische geen oplossing. Zelfverzekerd zegt Jelgersma ten slotte: zelfs indien er eenige grond was het dilemma zoo te stellen, zou de keus niet twijfelachtig $z i j n .^{3}$

De hoofdlijnen van Jelgersma's kritiek op Heymans komen op het volgende neer. Jelgersma's belangrijkste kritiek op Heymans' formuleringen van het psychologische en filosofische causaliteitsvraagstuk is dat daarbij geen neutrale, feitelijke beschrijving werd gegeven; dit geldt vooral voor de formulering van het filosofische causaliteitsvraagstuk. Omdat Heymans er zonder meer van uitging dat verschijnselen zich richten naar de wetten van het denken, liet hij impliciet al zijn eigen oplossing van dit vraagstuk doorschemeren en hij sloot daarmee ten onrechte andere verklaringsmogelijkheden bij voorbaat uit.

Tegenover Heymans' conclusie dat Hume's hypothese van voorstellingsintensiteit en associatie causale overtuigingen niet kan verklaren, stelt Jelgersma dat het tegendeel het geval is. Hij is van oordeel dat door herhaalde waarneming associaties in het denken ontstaan die geleidelijk een permanent of onontkoombaar karakter krijgen. Tussen de waarnemingen van bepaalde verschijnselen ontstaan vaste associaties, waardoor de gedachte aan een bepaald verschijnsel onontkoombaar zal leiden tot de gedachte aan een bepaald ander verschijnsel.

Jelgersma acht zijn eigen associatieleer voldoende om het onderscheid tussen successie- en coëxistentiewetten verklaren. In tegenstelling tot Heymans is hij van

'cf. Jelgersma, D.G. (1891), op. cit. p. 74.

${ }^{2}$ cf. Jelgersma, D.G. (1891), op. cit. p. 73-74, 'Mochten enkelen, die niet geheel bevangen zijn door de vooroordeelen van hun systeem, haar werkelijk ernstig overwegen, dan zullen zij, ik twijfel er niet aan, tot de conclusie komen, dat zij zelfs in dit gunstigste van alle denkbare gevallen gedwongen zijn voor de oplossing van het psychologische causaliteitsprobleem de onveranderlijkheid van den menschenlijken geest te onderstellen, evenals de realist gedwongen is de onveranderlijkheid te onderstellen van de betrekkingen in de buitenwereld, wanneer hij het philosophische causaliteitsprobleem wil oplossen.'

"cf. Jelgersma, D.G. (1891), op. cil. p. 74. 
oordecl dat er tussen beide soorten wetten slechts een gradueel verschil in zekerheid bestaat dic daar aan wordt toegeschreven. De zekerheid die aan cen coëxistentiewet wordt toegeschreven berust op actucle waarneming, waardoor direct geverifieerd kan worden of een voorstelling betrekking heeft op iets wat werkelijk bestaat. Het waarnemen van uitzonderingen op zo'n wet kan er toe leiden dat de associatie die in zo'n wet wordt uitgedrukt zwakker wordt. Bij successiewetten is zo'n verificatic minder goed mogelijk, omdat de voorstellingen die zo'n wet door associatie met clkaar verbindt voor een deel berusten op herinneringen aan eerdere waarnemingen. Omdat verificatie in dat geval minder goed mogelijk is, zijn successiewetten ook moeilijker te weerleggen en zullen de associaties die zulke wetten betreffen ook minder snel verzwakt kunnen worden. Net zoals het verschil in reacties op deze beide soorten wetten door associatie kan worden verklaard, is het volgens Jelgersma mogelijk om causale axioma's door associatie te verklaren.

Jelgersma is van mening dat Heymans' oplossing van het psychologische causaliteitsvraagstuk onvoldoende is. Een fundamenteel element in zijn kritiek op deze oplossing is dat Heymans er ten onrechte van uitgaat dat de overtuiging a priori dat het werkelijk bestaande onveranderlijk is als een axioma opgevat moet worden. Jelgersma acht dit echter geen axioma, maar slechts een definitie: het werkelijk bestaande is gelijk aan het onveranderlijke. Bovendien gebruikt Heymans deze definitic op een tegenstrijdige manier. Hij wil namelijk met behulp er van door ervaring te weten komen wat onveranderlijk is, maar tegelijkertijd beschouwt hij deze definitie als een axiomatische waarheid om vast te stellen wat onveranderlijk is. Men zou Heymans' definitie alleen als een waarheid kunnen opvatten die berust op de ervaring dat bepaalde zaken niet zouden vergaan of onvernietigbaar zouden zijn. Dit sluit aan bij de Jelgersma's opvatting over de onontkoombaarheid van voorstellingen; door deze onontkoombaarheid wordt aan datgene waar een voorstelling betrekking op heeft werkclijkheid toegeschreven. Heymans' definitie dat het werkelijk bestaande gelijk is aan het onveranderlijke kan men daardoor herformuleren in psychologische termen.

Ook het filosofische causaliteitsvraagstuk kan door associatie worden verklaard. De voorstelling van een gevolg is onontkoombaar, waardoor men aan datgene waar deze voorstelling betrekking op heeft werkelijkheid toeschrijft. Dit betekent dat men genoodzaakt wordt om de hypothese te formuleren dat er onveranderlijke causale relaties in de externe werkelijkheid bestaan. Ten slotte merkt Jelgersma over Heymans' oplossing van dit vraagstuk op dat deze tot contradicties leidt. Er is zelfs in het geheel geen sprake van zo'n vraagstuk als men uit zou gaan van Heymans' oplossing. Bovendien berust Heymans' oplossing op de onderstelling dat de structuur van het denken in beginsel onveranderlijk is, hetgeen echter nog maar de vraag is. Al met al zijn deze argumenten voor Jelgersma doorslaggevend om te concluderen dat het psychologische causaliteitsvraagstuk door associatie kan worden verklaard, en dat toepassing van de associatieleer leidt tot een hypothetische oplossing van het filosofische causaliteitsvraagstuk. 
Men kan allereerst constateren dat Jelgersma's ontstaansbenadering van het causaliteitsvraagstuk aansluit bij de benadering van Opzoomer, Van der Wijck en Huet, hetgeen duidelijk blijkt uit zijn uitgangspunt dat dit vraagstuk door ervaring en associatie kan worden verklaard.

Terecht merkt Jelgersma op dat in Heymans' formulering van het filosofische causaliteitsvraagstuk impliciet één bepaalde oplossing wordt gesuggereerd, namelijk het onderstellen van a priori elementen in het denken. Hierdoor sluit Heymans ten onrechte andere oplossingsmogelijkheden bij voorbaat uit.

Jelgersma's poging om causale overtuigingen inclusief de causale axioma's consequent door associatie en ervaring te verklaren, en niet door het onderstellen van elementen a priori, heeft in tegenstelling tot Heymans' hypothese het voordeel van de betrekkelijke eenvoud. Waar Heymans' in filosofische problemen komt om Hamiltons postulaat te rechtvaardigen, kent Jelgersma's benadering zulke problemen niet.

Ten slotte: de argumentatiestrategie van Jelgersma is er op gericht aan te tonen dat Heymans' oplossing van het psychologische en filosofische causaliteitsvraagstuk problematisch is. Hieruit leidt Jelgersma echter niet zonder meer af, dat daarom beide vraagstukken door associatie verklaard moeten worden. Hij doet namelijk veel moeite om mei een directe argumentatie aan te tonen dat de associatieleer inderdaad een eenvoudiger hypothese is en dat die leer minder filosofische hoofdbrekens oplevert dat Heymans' theorie.

\section{HEYMANS' POLEMIEK MET JELGERSMA}

De kritiek van Jelgersma op Heymans' opvatting dat men principieel anders zou reageren bij afwijkingen van successie- en coëxistentiewetten, is de lont in het kruitvat die een polemiek tussen beide denkers doet ontbranden. Op het eerste gezicht lijkt dit vreemd. Immers, Jelgersma had tal van bezwaren tegen Heymans' causaliteitsleer aangevoerd die op het oog veel fundamenteler schijnen. Men kan zich daarom afvragen waarom Heymans juist in dit element van Jelgersma's uitvoerige kritiek een twistappel zag.

Een verklaring hiervoor kan zijn dat Heymans betoogd had dat regelmatigheden van successie of successiewetten niet de enige vorm van regelmatigheid in de natuur zijn, omdat er ook regelmatigheden in de natuur worden aangetroffen die alleen het samengaan van verschijnselen betreffen: regelmatigheden van coëxistentie of coëxistentiewetten. De reacties bij uitzonderingen op successiewetten zouden principieel anders zijn dan die bij uitzonderingen op coëxistentiewetten; uitzonderingen op een coëxistentiewet zou men zonder meer als een gegeven accepteren, terwijl men uitzonderingen op een successiewet zelfs onmogelijk zou achten. In het laatste geval zoekt men net zolang totdat uitzonderingen op de regel in overeenstemming zijn gebracht met de successiewet. Heymans had hier uit afgeleid dat men bij 
de successie van verschijnselen wetten onderstelt die algemeen gelden en absoluut zeker zijn. Bovendien had hij geconcludeerd dat men de algemeengeldigheid en absolute zekerheid van successiewetten niet kon verklaren door associatie; alleen Hamiltons hypothese achtte hij hiertoe in staat. Tegenover Heymans' opvatting had Jelgersma gesteld dat de reacties bij uitzonderingen op beide soorten wetten veel minder van elkaar verschillen dan Heymans had gemeend. Het verschil berust op het graduele verschil in de verificatiemogelijkheid om te bepalen of de voorstellingen die deze wetten door associatie met elkaar verbinden betrekking hebben op iets dat werkelijk bestaat. Voorstellingen die een coëxistentiewet met elkaar verbindt, kan men door actuele waarneming verifiëren, terwijl een deel van de voorstellingen die een successiewet met elkaar verbindt, berust op herinnering. Het verschil tussen beide soorten wetten komt daardoor slechts neer op een verschil in de mate van zekerheid die men er aan toe kan schrijven.

De opvattingen van Jelgersma en Heymans over successie- en coëxistentiewetten staan lijnrecht tegenover elkaar. Jelgersma denkt zulke wetten te kunnen verklaren door associatie en ervaring. Omdat beide soorten wetten berusten op associatie en ervaring kan men er slechts een relatieve zekerheid aan toeschrijven. Heymans meent daarentegen dat successiewetten algemeen gelden en absoluut zeker zijn, waardoor het onmogelijk wordt om zulke wetten op associatie en ervaring te laten berusten. Om de algemeengeldigheid en absolute zekerheid te verklaren, acht Heymans het daarom noodzakelijk elementen a priori te onderstellen. Ook hier treft men overigens wederom de tegenstelling aan tussen een ontstaansbenadering en een geldigheidsbenadering.

Het is daarom geen wonder dat Heymans er kennelijk veel aan gelegen is om zijn geldigheidsbenadering tegenover Jelgersma's ontstaansbenadering te "redden". Hij doet dit al in het tweede deel van Gesetze und Elemente, dat in 1894 verschijnt.

\section{Successie- en coëxistentiewetten}

In het tweede deel van Gesetze und Elemente betoogt Heymans dat Jelgersma er van uit was gegaan dat bij coëxistentiewetten verschijnselen tegelijkertijd of beurtelings worden waargenomen. Bij successiewelten worden de gevolgen altijd na het optreden van de oorzaken waargenomen. Een coëxistentiewet wordt gekenmerkt door een associatieve band tussen twee verschijnselen (zeg: een A en een B). Als in plaats van een $B$ een ander verschijnsel (zeg: een $C$ ) tegelijkertijd of beurtelings met een A wordt waargenomen, dan leidt dit er noodzakelijk toe dat de eerder ontstane associatieve band tussen een A en een B zwakker wordt.' Het kenmerk van een

'cf. Heymans, G. (1894), op. cit. p. 365-366, 'Man könnte darauf hinweisen, dass coexistirende Erscheinungen gleichzeitig oder abwechselnd, Wirkungen dagegen nur nach den Ursachen wahrgenommen werden. Wenn demnach ein Coexistenzgesetz eine Ausnahme erleidet, indem, statt des zumeist mit A verbundenen B, eine andere Erscheinung B1 wahrgenommen wird, so müsse das gleichzeitige und dauernde Gegebensein der Wahrnehmungen $\mathrm{A}$ und $\mathrm{B} 1$ nothwendig die frühere Association zwischen $\mathrm{A}$ und $\mathrm{B}$ merklich schwächen...' 
successiewet is dat een waarneming van een $B$ doorgaans volgt nadat men een $A$ heeft waargenomen. Op het moment dat men in plaats van een $B$ een $C$ na een $A$ waarneemt, is de actuele waarneming van een $A$ reeds verdwenen. De successiewet 'een $\mathrm{C}$ volgt nadat men een $\mathrm{A}$ heeft waargenomen' komt daardoor niet in strijd met een actuele waarneming van een $\mathrm{A}$, maar alleen met de herinnering aan een $\mathrm{A}$. Het waarnemen van de uitzondering $\mathrm{C}$ leidt daardoor in tegenstelling tot het waarnemen van een uitzondering op een coëxistentiewet niet tot een verzwakking van de associatieve band tussen een $\mathrm{A}$ en een $\mathrm{B}$; dat wil zeggen, alleen de intensiteit van de overtuiging dat een $\mathrm{A}$ werkelijk aan een $\mathrm{C}$ is vooraf gegaan wordt zwakker. De overtuiging dat de successiewet 'een B volgt nadat men een A heeft waargenomen' blijft ook bij het waamemen van een uitzondering op deze regel onaangetast, aldus Heymans' parafrase van Jelgersma's argumentatie. ${ }^{\text {' }}$

Heymans formuleert vervolgens twee argumenten tegen Jelgersma's redenering die moeten aantonen dat de overtuiging dat causale wetten of successiewetten zeker zijn niet afhangt van de sterkte van een associatief verband tussen oorzaak en gevolg.

Heymans wijst er allereerst op dat Jelgersma's redenering onderstelt dat de oorspronkelijke associatie tussen coëxisterende verschijnselen sterker moet zijn geweest dan de associatie tussen successieve verschijnselen. Immers, als door een actuele strijdige waameming de associatieve verband van een coëxistentiewet zwakker wordt dan door een herinnering die daarmee in strijd is, moet een actuele waarneming die zo'n wet bevestigt deze associatieve band ook sterker maken dan een herinnering die daarvoor een bevestiging vormt. Dit impliceert, aldus Heymans, dat Jelgersma met zijn verklaring van het geringe verschil tussen beide soorten wetten met de ene hand iets geeft wat hij met de andere hand weer terugneemt. Hoe dit ook zij, het laatste acht Heymans echter niet de kern van de zaak. Zijn tweede tegenargument is namelijk principiëler: het waarnemen van een uitzondering op een coëxistentiewet of een successiewet heeft weinig invloed op de mate van zekerheid van datgene waar zulke wetten betrekking op hebben: de waargenomen feiten. Het verschil in de reacties op beide soorten wellen komt er op neer dat men bij hel waarnemen van een uitzondering op een successiewet met zekerheid onderstelt dat de nietwaargenomen omstandigheden moeten verschillen van eerdere niet-waargenomen omstandigheden; bij het waarnemen van een uitzondering op een coëxistentiewet

1 cf. Heymans, G. (1894), op. cit. p. 366, '....wenn dagegen ein Causalgesetz eine Ausnahme erleidet, indem statt des zumeist nach $\mathrm{A}$ eintretenden $\mathrm{B}$ eine andere Erscheinung B1 zur Wahrnehmung gelangt, so sei im Momente der letzteren Wahrnehmung A bereits entschwunden, das Gesetz gerathe demnach nicht mit der gegenwärtigen Wahrnehmung von $A$, sondern bloss mit der Erinnerung an $\mathrm{A}$ in Widerstreit, und es werde demnach weniger die associative Verbindung zwischen $\mathrm{A}$ und $\mathrm{B}$, als die Vorstellung des entschwundenen $\mathrm{A}$ geschwächt; d.h. also nach der Hume'schen Theorie: nicht unser Glaube an die Allgemeinheit des Gesetzes, sondern unsere Überzeugung dass wirklich ein A dem B1 vorhergegangen sei, erleide eine Intensitätsverminderung.' 
onderstelt men dat niet. ${ }^{1}$ Als men bijvoorbeeld een witte raaf zou waarnemen, dan accepteert men het feit dat zulke raven kennelijk bestaan. Deze uitzondering op een coëxistentiewet vormt derhalve geen aanleiding voor verder onderzoek naar veranderde omstandigheden. Als men echter een uitzondering op een causale wet of een successiewet waarneemt, dan gaat men er daarentegen van uit dat er icts in de omstandigheden veranderd moet zijn. Bijvoorbeeld: als een medicijn dat altijd bij hoofdpijn heeft geholpen niet blijkt te werken, dan leidt dat er niet toe dat men twijlelt aan het feit dat men hoofupijn heeft of heeft gehad. Deze uitzondering op de regel leidt echter wel tot het vermoeden dat bijvoorbeeld de aard van het waargenomen verschijnsel - de hoofdpijn - anders moet zijn dan men aanvankelijk dacht.

Jelgersma was van mening, zo betoogt Heymans verder, dat het verschil in reactie bij uitzonderingen op coëxistentic- en successiewellen uitsluitend komt door een gradueel verschil in de sterkte van de associatieve verbanden. Als men echter van een graducel onderscheid tussen beide soorten wetten zou uitgaan, dan leidt herhaling van het proces dat ten grondslag ligt aan het optreden van uitzonderingen er toe dat de associatieve band geleidelijk verzwakt wordt; ook al zou één uitzondering op een successiewet niet leiden tot cen verzwakking van de associatieve band, dan gebeurt dat wel als men vele uitzonderingen waarneemt. Echter, zo vraagt Heymans zich retorisch af, als vele malen blijkt dat een bepaald medicijn niet blijkt te werken, denkt men dan dat zulke processen niet worden behecrst door algemeen geldige wetten? Neen: bij het waarnemen van uitzonderingen op de successiewet dat een bepaald medicijn hoofdpijn verdrijft, gaat men op zoek naar omstandigheden die er toe geleid kunnen hebben dat het medicijn in bepaalde gevallen niet werkt. Kortom: het waarnemen van uitzonderingen leidt er niet toe dat men twijfelt aan de overtuiging dal successiewetten of causale wetten algemeen geldig zijn. Hiemee acht Heymans nogmaals bewezen dat de algemeengeldigheid, en daarom ook dc zckerheid van causale wetten of successiewetten, niet afhangt van de sterkte van een associatief verband tussen oorzaak en gevolg. ${ }^{2}$

' cf. Heymans, G. (1894), op. cit. p. 366-367, 'Demgegenüber lässt sich aber erstens bemerken, dass aus dem nämlichen Grunde die ursprünkliche Association zwischen coexisterenden Erscheinungen auch stärker gewesen sein müsste als diejenige zwischen succedirenden Erscheinungen; denn wenn eine widersprechende Wahrnehmung die associative Verbindung mehr lockert als eine widersprechende Erinnerung, so werden bestätigende Wahrnehmungen dieselbe auch mehr befestigen als bestätigende Erinnerungen. Zweitens aber und hauptsächlich scheint auch die Selbstwahrnehmung zu lehren, dass nicht hier der Knoten liegt. Thatsächlich ist unsere Gewissheit über den wahrgenommenen Sachverhalt nicht grösser, wenn wir einer Ausnahme von einem Coexistenzgesetze als wenn wir einer Ausnahme von einem Causalgesetz begegnen; der Unterschied ist bloss der, dass wir von den zahlreichen nichtwahrgenommenen Umständen in jenem Fall nicht, in diesem aber wohl mit Zuversicht behaupten, dass sie von den früheren verschieden sein müssen.'

${ }^{2}$ cf. Heymans, G. (1894), op. cit. p. 367, 'Nach der oben angeführten Erklärung wäre der Unterschied in unserem Verhalten gegenüber Ausnahmen von Causal- und Coexistenzgesetzen nur ein gradueller: hier stärkere Lockerung der associativen Verbindung als dort. Ein gradueller Unterschied lässt sich aber durch Wiederholung des zu Grunde liegenden Processe 


\section{Jelgersma's repliek}

Uit de aantekeningen die Jelgersma in zijn eigen exemplaar van het tweede deel van Heymans' Gesetze und Elemente maakte, kan worden afgeleid dat hij vasthoudt aan zijn eerdere kritiek. In 1896 treedt hij met deze kritiek in de openbaarheid, en wel in het artikel Causaliteit, dat in het Tweemaandelijksch tijdschrift verschijnt.

Heymans had, aldus Jelgersma, geconstateerd dat de oorspronkelijke associatie tussen coëxisterende verschijnselen sterker moet zijn geweest dan de associatie tussen successieve verschijnselen. Deze constatering acht Jelgersma volkomen juist, maar hij beschouwt het niet als een tegenargument. Het betreft hier immers alleen een verklaring van het ontstaan onzer overtuigingen over coëxistentie- en successiewetten. Heymans' constatering betreft echter niet het blijven bestaan van zulke overtuigingen, en dat is nu juist wat Jelgersma had willen verklaren. Als er een vaste associatie van verschijnselen is ontstaan, dan kan deze niet verder worden versterkt door latere waarnemingen of herinneringen die zo'n associatie bevestigen. Echter, herinneringen of latere waarnemingen die strijdig zijn met een associatie van verschijnselen, kunnen de associatic wel verzwakken of zelfs geheel teniet doen; bovendien wordt een associatie eerder door waarnemingen verzwakt of teniet gedaan dan door herinneringen. Om een associatie te laten voortbestaan is het daarom nodig dat er zo min mogelijk waarnemingen of herinneringen zijn die strijdig zijn met zo'n associatie. Jelgersma concludeert dat successiewetten veel beter aan deze laatste voorwaarde voldoen dan coëxistentiewetten, en dat het daarom veel moeilijker is om de overtuiging dat bepaalde verschijnselen regelmatig op elkaar volgen teniet te doen. Dit neemt echter niet weg dat uitzonderingen op een successiewet in beginsel wel kunnen leiden tot het teniet gaan van zo'n wet; (....) en dit is voldoende om ons verschillend gedrag tegenover uitzonderingen op successie- en op coëxistentiewetten te verklaren. ${ }^{1}$

ausgleichen: wenn Eine Ausnahme von einem Causalgesetz die Association zwischen Ursache und Wirkung nicht merklich lockert, so werden doch hundert Ausnahmen es thun. Gesetz nun dass die oben erwähnte Arznei in hundert weiteren Fälle ihre Wirkung verfehlt, wird dadurch der Glaube an die absolute Allgemeinheit der diese Processe beherrschenden Gesetze erschüttert werden? Gewiss nicht: ich werde einfach schliessen, dass sich in meiner Constitution, in der Natur meiner Krankheit, in der Zusammensetzung der Arznei, kurz in den vorliegenden Umständen, etwas geändert hat, demzufolge jetzt die Krankheitssymptome der Einwirkung der Arznei widerstehen. Damit scheint abermals bewiesen zu sein, dass der Glaube an die Ausnahmlosigkeit der causalen Gesetze von der Festigkeit der associativen Verbindung zwischen Ursache und Wirkung unabhängig ist.'

' cf. Jelgersma, D.G. (1896a), 'Causaliteit'. In: Tweemaandelijksch tijdschrift, p. 530-531, 'De gemaakte opmerking is volkomen juist, maar ze heeft alleen betrekking op het ontstaan onzer overtuigingen aan-gaande wetten van coëxistentie en successie en niet op haar blijven bestaan, als ze eens ontstaan zijn. Een bestaande associatie, die eenmaal de noodige vastheid verkregen heeft, wordt door bevestigende waarnemingen of bevestigende herinneringen niet telkens weder versterkt. Ze heeft die bevestiging niet langer noodig. Wel kan ze door tegenstrijdige waarnemingen of tegenstrijdige herinneringen verzwakt en eindelijk opgeheven worden. Door de eersten verzwakt in veel hooger mate en opgeheven veel spoediger dan door de laatsten. Voor haar blijven bestaan is het dus slechts noodig, dat de tegenstrijdige waarne- 
Deze conclusie sluit overigens aan bij Jelgersma's argument uit 1891 dat een deel van de voorstellingen die een successiewet met elkaar verbindt, berust op herinnering. Omdat herinneringen moeilijker zijn te weerleggen dan actuele waarnemingen, is het daarom minder waarschijnlijk dat de associatie die in een successiewet tot uitdrukking komt zwakker wordt gemaakt of teniet wordt gedaan.

De kern van Heymans' tweede tegenargument berust, zo betoogt Jelgersma, op een misverstand: waarin bestaat dan het verschil tusschen ons beider opvatting ? ${ }^{1}$ De discussie betrof tot dusver specifieke causale wetten of successiewetten: bizondere wetten van oorzaak en gevolg. Echter, men dient ook rekening te houden met het causaliteitsbeginsel: ieder feit, iedere gebeurtenis (heeft) haar bepaalde oorzaak. ${ }^{2}$ Als men onderstelt, zo betoogt Jelgersma, dat men het psychologische causaliteitsvraagstuk door associatie kan verklaren, dan moet men dit beginsel opvatten als een generalisatie van specifieke causale wetten. Met andere woorden: het causaliteitsbeginsel is a posteriori. Heymans gaat er echter van uit dat dit beginsel een apriorische waarheid is. Als hij spreekt over specifieke causale wetten en de empirische verklaring daarvan, dan speelt hierbij het denkbeeld dat het causaliteitsbeginsel a priori is op de achtergrond een belangrijke rol; deze opvatting influenceert Heymans' conclusiën namelijk op de volgende manier. ${ }^{3}$ Uit het waarnemen van uitzonderingen op een bepaalde successiewet leidt Heymans af dat deze specifieke wet daardoor niet algemeen geldig is. Juist omdat hij er van overtuigd is dat het causaliteitsbeginsel algemeen geldig en a priori is, is Heymans' eerste gedachte bij het waarnemen van een uitzondering op een successiewet, of hierdoor bewezen (wordt), dat de verschijnselen, die niet door de prijsgegeven wet van successie verklaard worden, in het geheel geen oorzaak hebben? In zulke gevallen luidt zijn antwoord volgens

mingen nagenoeg geheel ontbreken en dat de tegenstrijdige herinneringen niet al te talrijk zijn. En aan deze voorwaarde voldoen de associaties, die haar uitdrukking vinden in de wetten van successie veel beter dan die, welke worden vertegenwoordigd door de wetten van coëxistentie (....). (....) ik beweer slechts, dat een eens verkregen overtuiging omtrent het regelmatig opeenvolgen van bepaalde verschijnselen om de door mij aangevoerde redenen veel moeilijker gewijzigd wordt dan een dergelijke overtuiging omtrent hun regelmatig samengaan'

${ }^{\prime}$ cf. Jelgersma, D.G. (1896a), op. cit. p. 535.

${ }^{2}$ cf. Jelgersma, D.G. (1896a), op. cit. p. 535.

${ }^{3}$ cf. Jelgersma, D.G. (1896a), op. cit. p. 535, 'Er bestaat nl. behalve bizondere wetten van oorzaak en gevolg, waarover de discussie liep (...) een algemene wet van oorzaak en gevolg, die leert dat ieder feit, iedere gebeurtenis haar bepaalde oorzaak heeft. Deze wet is voor allen, die voor de verklaring onzer causale overtuigingen willen voortbouwen op de door Hume gelegde grondslagen, een generalisatie - zooals uit de bij voortduring tegen haar gevoerde oppositie blijkt, misschien zelfs een eenigszins voorbarige generalisatie - uit de bizondere wetten van oorzaak en gevolg. Voor den heer Heymans echter en voor allen, die denken als hij, is zij een aprioristische waarheid, die door hen ten grondslag gelegd wordt aan al hun denken, ook aan hun denken over deze wet zelf. Het gevolg is, dat bij den heer Heymans, als hij spreekt over de bizondere causale wetten en over haar empirische verklaring, de voorstelling van deze algemeene wet steeds op den achtergrond van zijn bewustzijn aanwezig is en op zijn conclusien influenceert.' 
Jelgersma ontkennend, omdat het causaliteitsbeginsel algemeen geldig en a priori is. Heymans is door die stellige ontkenning kennelijk zoo geheel in beslag genomen, dat hij niet inziet dat in dit geval slechts een specifieke causale wet of successiewet wordt opgegeven, en niet het causaliteitsbeginsel zélf. Een aanwijzing dat Heymans inderdaad zo redeneert is, aldus Jelgersma, diens voorbeeld van het bij herhaling niet werken van een bepaald medicijn tegen hoofdpijn. Heymans had hieruit afgeleid dat de uitzonderingen op de successiewet 'een bepaald medicijn verdrijft de hoofdpijn' niet leiden tot het opgeven van de overtuiging dat ook zulke processen beheerst moeten worden door wetten die algemeen gelden. Jelgersma is het hier volledig mee eens. Immers, het waarnemen van uitzonderingen op deze specifieke causale wet is geen rechtstreeks bewijs tegen de algemene geldigheid van het causaliteitsbeginsel; het is echter wel een bewijs tegen de geldigheid van een specifieke causale wet. ${ }^{1}$ Jelgersma wijst er op dat de algemeene wet van oorzaak en gevolg hier buiten discussie (is); er wordt slechts gesproken over de bizondere wet, die de werking beschrijft van het bedoelde geneesmiddel. ${ }^{2}$ Daarom concludeert hij ten slotte dat Heymans' argumenten tegen zijn opvatting dat het verschil in reacties bij uitzonderingen op successie- en coëxistentiewelten kan worden verklaard door associatie geen hout snijden. ${ }^{3}$

\section{Nog eens: causaliteit}

Heymans' reactie op Jelgersma laat niet lang op zich wachten. $\mathrm{Al}$ in het volgende nummer van het Tweemaandelijksch tijdschrift verschijnt een open brief gericht aan Jelgersma, getiteld Nog eens: causaliteit (1896a). Hierin attaqueert hij allereerst wederom Jelgersma's onderstelling dat de oorspronkelijke associatie tussen coëxisterende verschijnselen sterker moet zijn geweest dan de associatie tussen successieve verschijnselen. Vervolgens schuift hij Jelgersma's constatering opzij dat het misverstand tussen hen beiden uiteindelijk zou berusten op Heymans' verwarring van specificke causale wetten met het causaliteitsbeginsel.

' cf. Jelgersma, D.G. (1896a), op. cit. p. 536, 'Hij ziet uitzonderingen op een bepaalde wet van successie en merkt op dat deze wet daardoor haar geldigheid verliest. Door zijn vaste overtuiging van de absolute geldigheid der algemeene wet van oorzaak en gevolg, door zijn meening omtrent haar apriorischen oorsprong en door het feit, dat deze wet dus altijd op den achtergrond van zijn bewustzijn aanwezig is, is dan zijn eerste gedachte: wordt hierdoor bewezen, dat de verschijnselen, die niet door de prijsgegeven wet van successie verklaard worden, in het geheel geen oorzaak hebben? (....). (....) door de waargenomen uitzonderingen wordt rechtstreeks niets bewezen tegen de algemeene wet van oorzaak en gevolg, maar alles tegen de bizondere, dat deze bepaalde ziekteverschijnselen verdwijnen door deze bepaalde gencesmiddelen.'

${ }^{2}$ cf. Jelgersma, D.G. (1896a), op. cit. p. 536.

${ }^{3}$ cf. Jelgersma, D.G. (1896a), op. cit. p. 537 , 'Toch is naar mijne meening uit al het boven gezegde een zaak zeer duidelijk gebleken $\mathrm{nl}$. dit: dat mijn verklaring van het verschil in ons gedrag tegenover uitzonderingen op successie- en op coëxistentiewetten niet weerlegd wordt door de beide aangehaalde argumenten van den heer Heymans.' 
Jelgersma had betoogd dat een vaste associatie van verschijnselen niet verder kan worden versterkt door latere waarnemingen of herinneringen die zo'n associatie bevestigen. Dit onderstelt, aldus Heymans, dat de sterkte van zo'n associatie aan een bepaald maximum zou zijn gebonden. Heymans acht dit een willekeurige bewering, die bovendien door de uitkomsten van experimenteel psychologisch onderzoek niet wordt bevestigd. 'En: als het zo zou zijn dat associaties in het algemeen cen bepaalde maximale sterkte zouden kunnen bereiken, is het nog maar de vraag of zo'n maximum in de bijzondere gevallen, waarover de strijd loopt, feitelijk bereikt is. ${ }^{2}$ Heymans acht dit zelfs ondenkbaar. Immers, de vertegenwoordigers van de associationistische school in de theorie van het denken gaan er van uit dat de zekerheid in de wiskunde kan worden verklaard door zeer sterke associaties; zulke associaties achten zij nog sterker dan associaties die aan natuurwetenschappelijke zekerheden ten grondslag liggen. Als zij van mening zijn dat de zekerheden van de wiskunde op sterkere associaties berust dan die in de natuurkunde, acht Heymans het vreemd dat zij, en met name Jelgersma, van oordeel kunnen zijn dat associaties tussen verschijnselen aan een bepaald maximum gebonden moeten zijn. ${ }^{3}$ Maar nogmaals: uit empirisch onderzoek blijkt niet dat associaties een bepaalde maximale sterkte kunnen bereiken. Als men toch van deze onderstelling uitgaat, dan moet Jelgersma in termen van diens eigen associatieleer toegeven dat de maximale sterkte die hij toeschrijft aan associaties die het volgen van verschijnselen betreffen, overtroffen worden door de sterkte van associaties die ten grondslag liggen aan wiskundige zekerheden. De sterkte van associaties die betrekking hebben op het volgen van verschijnselen, kunnen daardoor niet de maximale sterkte van associaties zijn.

' cf. Heymans, G. (1896a), 'Nog eens: causaliteit'. In: Tweemaandelijksch tijdschrift, p. 180, 'Uw eerste argument komt hierop neer, dat de stevigheid van het associatief verband tusschen herhaaldelijk verbonden verschijnselen mettertijd een maximum bereikt, waarna zij door negatieve instantiën nog wel verzwakt, maar door positieve niet meer versterkt kan worden. Dit is, vergeef mij dat ik het zeg, eenvoudig eene assertio gratuita. De psychologen die zich tot dusver met het experimenteel onderzoek der associatieprocessen hebben beziggehouden (in 't bijzonder Ebbinghaus, Müller en Schumann) zijn er niet in geslaagd een dergelijk maximum te constateeren.'

${ }^{2}$ cf. Heymans, G. (1896a), op. cit. p. 180.

${ }^{3}$ cf. Heymans, G. (1896a), op. cit. p. 180-181, 'Daarenboven: gesteld ook al, dat zulk een maximum in abstracto moest worden aangenomen, dan zou nog de vraag overblijven, of het in de bijzondere gevallen, waarover de strijd loopt, feitelijk is bereikt. En dit is (....) eenvoudig ondenkbaar; immers slechts bij zeer enkele physische wetten zijn de omstandigheden, waarvan volgens de ervaring de sterkte der associatie afhangt, in ruime mate gegeven. Allerminst evenwel zou men verwachten, de aangehaalde uitsprak te vernemen van een aanhanger der associationistische school in de theorie van het denken. Tot de dogma's van deze school behoort immers de overtuiging, dat de wiskundige zekerheid op dezelfde wijze als de natuurwetenschappelijke, alleen door eene veel intensievere, "onafscheidelijke" associatie verklaard moet worden: is echter een zooveel sterker associatie dan die tusschen regelmatig verbonden natuurverschijnselen bereikbaar, dan kan de laatste moeilijk meer maximaal heeten.' 
Verder verbaast Heymans zich over Jelgersma's kritiek op zijn tweede tegenargument, omdat het misverstand, dat er aan te gronde ligt, nog grooter (is) dan ik mogelijk achtte. ${ }^{1}$ Hij verwondert zich namelijk over Jelgersma's opvatting dat de discussie tot dusver alleen maar specifieke causale wetten zou betreffen, en niet het causaliteitsbeginsel zelf. Ten onrechte had Jelgersma hem, aldus Heymans, de opvatting in de schoenen geschoven dat men bij uitzonderingen op successiewetten onderstelt dat niet alleen het causaliteitsbeginsel geldig blijft, maar dat men ook de specifieke successiewet waarop men een uitzondering waarneemt handhaaft. Maar $i k$ bid $u$, hoe hebt gij dat kunnen meenen, verzucht Heymans. ${ }^{2}$ Zowel in de Schets als in Gesetze und Elemente komt precies het tegenovergestelde tot uitdrukking. Immers, zo betoogt Heymans, het waarnemen van een uitzondering op een successiewet moet men altijd verklaren door verschillen in omstandigheden die tot zo'n uitzondering hebben geleid. Dit betekent dat men de geldigheid van een specifieke successiewet weliswaar in twijfel trekt, maar dat men daarvoor in de plaats andere specifieke successiewetten formuleert die zo'n uitzondering wél kunnen verklaren; dit laatste geeft ook duidelijk aan dat men er overtuigd blijft dat successiewetten moeten voldoen aan de voorwaarde van algemene geldigheid. ${ }^{3}$ Heymans voegt daar nog aan toe dat het causaliteitsbeginsel a priori uiteraard altijd een rol moet spelen bij het formuleren van specifieke successiewetten. Jelgersma's verbazing hierover acht hij daarom misplaatst. Het tweede deel van Gesetze und Elemente is geschreven juist om dit aan te tonen. ${ }^{4}$ Venijnig merkt Heymans op: mij dunkt, gij hadt daarvan bij gezette lezing iets kunnen bemerken.

Hautain draait Heymans Jelgersma de rug toe: waar zoo ingrijpende misverstanden (en wie weet hoeveel andere nog!) den weg versperren, schijnt voortzelting van het debat vrijwel hopeloos. In elk geval geef ik $u$ in overweging, de lezers van dit tijdschrift niet verder te vermoeien met beschouwingen, waarvoor zij zich toch

'cf. Heymans, G. (1896a), op. cit. p. 181.

${ }^{2}$ cf. Heymans, G. (1896a), op. cit. p. 181.

${ }^{3} \mathrm{cf}$. Heymans, G. (1896a), op. cit. p. 181, 'Hebt gij inderdaad steeds gemeend, dat de discussie liep over de bijzondere wetten van oorzaak en gevolg, en niet over de algemeene causaliteitswet? Hebı gij m.a.w. mij de bewering loegeschreven, dat wij, uitzonderingen op onderstelde successiewetten ontmoetende, niet slechts de algemeene causaliteitswel, maar die bijzondere onderstelde successiewetten zelve, tegen beter weten in, zouden handhaven? (....) Herhaaldelijk wordt er door mij op gewezen, dat een waargenomen uitzondering op een onderstelde successiewet altijd aan een verschil in de omstandigheden wordt toegeschreven: kan dit iets anders beteekenen, dan dat wij de onderstelde successiewet A - P laten vallen en daarvoor hypothetisch twee andere AX - P en AY - niet $\mathrm{P}$ in de plaats stellen; m.a.w. dat niet de onderstelde speciale wet, maar de eisch van volstrek geldende successiewetten in het algemeen, aan alle schijnbare negatieve instantien weerstand biedt?'

${ }^{4}$ cf. Heymans, G. (1896a), op. cit. p. 182, 'Maar diezelfde causaliteitswet was en is sleeds aanwezig op den achtergrond van het bewustzijn van al diegenen, die zich op de vaststelling en verklaring van bijzondere causale wetten hebben toegelegd. Dit feit uit de geschiedenis der wetenschap te bewijzen, de fundamenteele beteekenis daarvan voor het menschelijk denken aan te toone, te trachten het tot een dieperliggend fcit terug te brengen, was het eenige doel van het tweede deel mijner Gesetze und Elemente.' 
moeilijk kunnen interesseren. Mocht hij verdere bespreking wenschelijk achten, dan ben ik privatim of in een vaktijdschrift gaarne tot uw dienst.'

\section{Jelgersma's diagnose van de polemiek}

Jelgersma laat zich door Heymans' verbale afstraffing niet uit het veld slaan. Naast de open brief van Heymans wordt namelijk een kort weerwoord van Jelgersma aangetroffen; ook dit weerwoord heeft de vorm van een open brief, waarin hij wil nagaan waar de polemiek nu eigenlijk om was begonnen.

De grondslag voor de polemiek vormde het door beide auteurs geaccepteerde feit, zo betoogt Jelgersma, dat specifieke successie- en coëxistentiewetten door associatie ontstaan. De centrale vraag was, hoe men kan verklaren dat men uit specifieke coëxistentiewetten geen, maar uit specifieke successiewetten wél een algemeene wet kan afleiden. ${ }^{2}$ Jelgersma acht het een gegeven dat de associatie tussen voorstellingen van verschijnselen die elkaar volgen en de associatie van verschijnselen die tegelijkertijd optreden een maximale sterkte bereiken. Dit gebeurt als de associaties leiden tot een specifieke successiewet of tot een specifieke coëxistentiewet. Jelgersma meent te kunnen constateren dat Heymans het ook met deze voorstelling van zaken eens was. ${ }^{3}$ Als zulke associaties eenmaal een maximale sterkte hebben bereikt, dan worden zij door verdere bevestigingen niet nog sterker; zij kunnen door tegenvoorbeelden alleen zwakker worden. Omdat associaties tussen voorstellingen die in successiewetten tot uitdrukking komen een vaster bestaan in het denken hebben dan associaties van voorstellingen die in coëxistentiewetten worden uitgedrukt, ligt het voor de hand dat men op grond van specifieke successiewetten algemene wetten formuleert, terwijl men dat niet doet op grond van specifieke coëxistentiewetten. ${ }^{4}$ Echter, zo concludeert Jelgersma, voor Heymans was

' cf. Heymans, G. (1896a), op. cit. p. 182.

${ }^{2}$ cf. Jelgersma, D.G. (1896c), 'Nog eens: causaliteit'. In: Tweemaandelijksch tijdschrift, p. 184 , 'Die hoofdzaak is nu de volgende. Gegeven zijn een aantal bizondere wetten van successie en coëxistentie, wier ontstaan door associatie door mij aangenomen en door u niet bestreden werd. En de vraag was om, uitgaande van dezen grondslag, te verklaren, hoe het kwam, dat uit de bizondere wetten van de eerste soort wel, uit die van de tweede soort niet is afgeleid een algemeene wet.'

3 cf. Jelgersma, D.G. (1896c), op. cit. p. 185, 'Laten we nu eerst zien, wat er in onze gegevens ligt opgesloten. Zeer zeker dit, dat de associatie tusschen de voorstellingen der twee opeenvolgende verschijnselen A en B en die der twee gelijktijdige verschijnselen A1 en B1 op een gegeven oogenblik een maximum van vastheid heeft verkregen nl. dan, wanneer de eerste aanleiding heeft gegeven tot het ontstaan eener bizondere successiewet en de tweede tot dat van een bizondere coëxistentiewet. Tot zoo ver geen verzet van uw kant.'

${ }^{4} \mathrm{cf}$. Jelgersma, D.G. (1896c), op. cit. p. 185, 'Nu ga ik echter nog een stap verder en zeg: die associaties hebben haar maximum van vastheid bereikt; ze worden dus door voorbeelden, die er mee overeenstemmen, niet langer versterkl; alleen nog maar verzwakt door voorbeelden, die er mee strijden; de gevallen in strijd met de bizondere coëxistentiewetten worden met veel grooter zekerheid geconstateerd dan die, welke afwijken van bizondere successiewetten; de laatsten hebben dus een vaster bestaan in onzen geest dan de eersten; en het is derhalve verklaarbaar, dat wij uit de laatsten wel, uit de eersten niet hebben opgebouwd een algemeene 
dit kennelijk zo'n onacceptabele uitkomst, dat hij in 1896 de grondslag van de discussie in twijfel trekt, namelijk het door beiden geaccepteerde gegeven dat specifieke successie- en coëxistentiewetten door associatie van voorstellingen ontstaan. Ziedaar het feit, waarover ik me eenigzins verbaas. Ziedaar ook het feit, dat mij (....) volkomen doet instemmen met uw conclusie, dat verdere discussie tusschen ons over deze zaak, voorloopig althans, volkomen nutteloos is. ${ }^{1}$

De kern van de discussie tussen Heymans en Jelgersma betreft de vraag of de zekerheid die men successiewetten toeschrijft afhankelijk is van de sterkte van een associatief verband.

Eén van Heymans' belangrijkste argumenten tegen Jelgersma's oplossing is dat voldoende uitzonderingen op successiewetten er toe leiden dat het associatieve verband dat in zulke wetten wordt uitgedrukt zwakker wordt. De zekerheid van zulke wetten komt hierdoor echter niet in het geding, omdat men de uitzonderingen tracht te verklaren door te onderzoeken of er omstandigheden zijn geweest die er toe hebben geleid dat een bepaalde successiewet niet blijkt te gelden. Hierdoor blijft men er van uitgaan dat successiewetten algemeen gelden en zeker zijn. Bovendien is de zekerheid van zulke wetten niet afhankelijk van associatie.

Jelgersma verweert zich tegen deze kritiek door op te merken dat de discussie vooral het verklaren van het verschil in reactie bij uitzonderingen op specificke successiewetten betrof. Bovendien meent Jelgersma te kunnen constateren dat Heymans koste wat kost bij uitzonderingen op specifieke successicwelten zulke wetten wil handhaven. Jelgersma had echter niet willen beweren dat men bij uitzonderingen op specifieke successiewetten ook dc algemeengeldigheid van het causaliteitsbeginsel in twijftcl zou trekken. Hij beticht Heymans er van dat hij hem wel zo interpreteert. Daarentegen wijst Jelgersma er op dat ook het causaliteitsbeginsel door associatie is ontstaan. Het vormt echter zo'n vaste associatic dat dit beginsel immuun is geworden voor wccrlegging. Deze opvatting slaat lijnrecht tegenover de opvatting van Heymans dat het causaliteitsbeginsel a priori is.

Heymans is het oneens met Jelgersma's diagnose van de discussie. Hij acht het een misvalling dat de discussie uitsluitend specifieke successiewelten zou betreffen, en niet het causaliteitsbeginsel. Bovendien had hij niet beweerd dat men ondanks het waarnemen van uitzonderingen op specifieke successiewetten zulke wetten tracht te handhaven. Bij het constalcren van uitzonderingen geeft men een bepaalde successiewet op, en probeert men een successiewet te formuleren die zulke uitzonderingen wél kan verklaren. Men gaat hierbij van de overtuiging uit dat

wet. Thans verandert in eens uw houding. Gij gaat reageeren tegen den grondslag, waarvan wij bij de geheele discussie zijn uitgegaan.'

${ }^{\prime}$ cf. Jelgersma, D.G. (1896c), op. cit. p. 185. 
successiewetten moeten voldoen aan de voorwaarde van algemene geldigheid; en dit laatste berust op de overtuiging dat het causaliteitsbeginsel a priori is.

Jelgersma, ten slotte, verwijt Heymans dat hij de gemeenschappelijke basis voor discussie in twijfel trekt en het eerder door deze laatste ingenomen standpunt herroept, namelijk dat successie- en coëxistentiewetten door associatie van voorstellingen zijn ontstaan.

Allereerst zou men kunnen opmerken dat de Heymans-Jelgersma polemiek niet erg constructief is. Beide auteurs laten zich door elkaars argumenten niet overtuigen en zij blijven op de eerder ingenomen standpunten staan. Veel nieuwe argumenten voor beide opvattingen komen dan ook niet naar voren; de ontstaans- en geldigheidsbenaderingen blijven lijnrecht tegenover elkaar staan.

Echter, een interessant argument dat Heymans tegen Jelgersma in stelling brengt is dat deze laatste er kennelijk van uitgaat dat associaties die successiewetten betreffen, gebonden zouden zijn aan een bepaalde maximale sterkte. Als men hier van uit zou gaan, dan ontstaat het probleem hoe men kan verklaren dat er associaties zouden zijn die nog sterker zijn dan die welke ten grondslag liggen aan successiewetten: associaties die volgens de vertegenwoordigers van de associatieleer ten grondslag liggen aan de zekerheid van de wiskunde. Men kan zich overigens echter afvragen waarom er geen verschillende maxima voor verschillende soorten associatiewetten zouden gelden.

Opgemerkt kan worden dat Heymans door Jelgersma's theorie in de verdediging wordt gedrongen. Hij heeft weinig ander verweer tegen Jelgersma dan dat de laatste hem verkeerd zou hebben begrepen en dat hij daarom zijn huiswerk moet overdoen. De hooggeleerde Heymans maakt van zijn autoriteit gebruikt door de eenvoudige privaatdocent Jelgersma uit de hoogte terecht te wijzen. Inhoudelijk gezien is Heymans' argumentatie voor de opvalting dat het causaliteitsbeginsel a priori zou zijn zwak. Immers, uit het feit dat men bij uitzonderingen op successiewetten blijft zoeken naar een verklaring hiervoor, leidt hij zonder meer af dat daarom het causaliteitsbeginsel a priori zou zijn; deze redenering is indirect, en het vormt geen rechtstreeks bewijs dat dit beginsel a priori is.

\section{HEYMANS EN BOLLAND}

Na een zeer lange aanloop bracht de autodidact G.J.P.J. Bolland (1854-1922) het uiteindelijk tot de door hem felbegeerde positie van hoogleraar in de filosofie te Leiden. Bolland was voor de confrontatie geboren. Zijn leven vormt een opeenhoping van misverstanden, regelrechte beledigingen en, merkwaardige en volstrekt verwerpelijke politieke en maatschappelijke denkbeelden [Otterspeer, 1995]. Toch had hij zo nu en dan een helder moment. Dit laatste komt naar voren in zijn inaugurele 
rede Verandering en tijd (1896) waarin hij een aantal al eerder genoemde bezwaren tegen Heymans' positie herhaalt.

In de Schets had Heymans het idealisme van Hegel en de verschillende idealistische denksystemen die in de 19de eeuw opgeld deden geheel onbesproken gelaten. Hij had geoordeeld dat zulke systemen nauwelijks de naam van wetenschappelijke onderzoekingen verdienen, omdat zij door de verachting waarmee zij neerkeken op ervaring niet vatbaar waren voor een wetenschappelijke kritiek. Als men al van dit bezwaar zou afzien, dan nog zou het vruchteloos zijn om zulke systemen te bespreken, omdat zij alleen als én geheel onderzocht en beoordeeld zouden moeten worden. ${ }^{1}$ Zulk een bespreking dezer systemen als geheel zal evenwel niemand hier verwachten (.....) Zij zijn dood; en het dient tot niets ze telkens weer uit hunne graven te voorschijn te halen om te bewijzen dát zij dood zijn. ${ }^{2}$

Heymans' verwerping van het idealisme en zijn overtuiging dat filosofie in staat is om het causaliteitsvraagstuk op te lossen, komen hem in 1896 op kritiek te staan van de neo-hegeliaan Bolland.

De Curatoren van het Stolpiaansch Legaat, en later Land en Betz, hadden Heymans op het probleem gewezen dat de overtuiging dat het werkelijk bestaande onveranderlijk is, moeilijk te rijmen is met het gegeven dat men alleen veranderlijke verschijnselen waarneemt die zouden moeten corresponderen met het onveranderlijke werkelijk bestaande. Heymans had daarop het vermoeden geuit dat men de overtuiging dat het werkelijk bestaande onveranderlijk is, zou kunnen rechtvaardigen door uit te gaan van Kants hypothese dat de voorstelling van tijd een subjectieve oorsprong heeft, en dat verschijnselen door beginselen a priori in de tijd geordend worden. Het werkelijk bestaande is een werkelijkheid die buiten de tijd bestaat en die zich in verschillende hoedanigheden aan mensen voordoet. De eigenaardige organisatie van het denken zou er vervolgens voor zorgen dat men zulke hoedanigheden waarin de werkelijkheid verschijnt overeenkomstig de tijdsvorm a priori ordent. Bollands kritiek sluit hier op aan, hetgeen blijkt uit het volgende.

In zijn rede Verandering en tijd constateert Bolland dat het besef dat alles verandert of het besef van vergankelijkheid één van de meest alledaagsche en daarbij minst begrepene waarheden zijn waarmee men wordt geconfronteerd. ${ }^{3} \mathrm{Het}$ is nog vreemder, zo betoogt hij, als men tegelijkertijd beseft dat in de rusteloozen siroom van het geschieden ook een zekere permanentie of duurzaamheid bestaat. ${ }^{~ D e}$ Tijd, en daarin de Verandering, is hei onbegrijpelijke, dat alle andere of ten deele doorschouwde begrijpelijkheden hopeloos omnevelt en tot geheimenissen maakt,

${ }^{1}$ cf. Heymans, G. (1890a), op. cit. p. 238, 'Zelfs wanneer men wilde volhouden, wat ernstig betwijfeld kan worden, dat aan die systemen de betekenis van wetenschappelijke onderzoekingen moet worden toegekend; zelfs wanneer men wilde vergeten dat zij, met gelijke verachting neerziende op de ervaring en op de wetten van het denken, zich daardoor van zelve plaatsen buiten het bereik eener wetenschappelijke kritiek,.....'

${ }^{2}$ cf. Heymans, G. (1890a), op. cit. p. 238.

${ }^{3}$ cf. Bolland, G.J.P.J. (1896), Verandering en tijd, p. 5.

4 cf. Bolland, G.J.P.J. (1896), op. cit. p. 6. 
het onbegrepene waarmede men aunvangt en weder eindigt. ${ }^{1}$ Met andere woorden: 'tijd' en 'verandering' zijn in beginsel onverklaarbaar en vormen, zoals Bolland even later concludeert, een mysterie. Het ligt voor de hand dat hij de pogingen die men hecfl gedaan om 'tijd' en 'verandering' te verklaren daarom als mislukkingen beschouwt.

Bolland grijpt Heymans' onderstclling dat het werkelijk bestaande onveranderlijk is aan om te concluderen dat daarmee niets wordt verklaard. Hij merkt allereerst op dat men met de notic 'verandering' wil aangeven dat er een continuïteit bestaat tussen een nieuwe werkelijkheid en een werkelijkheid die reeds bestond, omdat het ondenkbaar is dat icts nieuws uit het niets ontstaat. Echter, de onderstelling dat dingen in beginsel niet veranderen kan men weliswaar poneren, maar zij is ondenkbaar. Als men er van uitgaat dal er iets blijvends zou beslaan achter wisselende verschijnselen, dan wordt het vergaan van een bepaald verschijnsel en het ontslaan van een nieuw verschijnsel geen zier begrijpelijker. Hij die meent dat bepaalde elementen van de werkelijkheid - gedachte bestaanseenheden - onveranderlijk zijn en dat de relaties lussen zulke elementen kunnen vergaan en ontstaan, acht Bolland theoretisch nog maar halfontwaakt tot zeljbezinning. Als men er van uitgaat, zo concludeert Bolland, dat zich achter de wereld van verschijnsclen ecn onveranderlijke werkelijkheid zou bestaan, dan neemt men aan dat er twee werelden zouden bestaan waarvan het onduidelijk is hoe zij zich tol elkaar verhouden. ${ }^{2}$

Nalar aanleiding van Heymans' vermoeden dat Hamiltons postulaat gerechtvardigd zou kunnen worden met behulp van Kants hypothese van het a priori karakter van de tijdsvoorstelling merkt Bolland op dat deze hypothese er toe leidt dat de in de ervaring gegeven verandering en afwisseling alleen op conto komen van het denken of het bewustzijn. Daamee word ontkend dat er buiten het denken sprake zou zijn van tijdelijkh'id. Dit betekent, ontdaan v'an alle nevelen cener schoolse taal, dat er buiten het denken geen sprake zou kunnen zijn van verandering of van een werkclijkheid. 'Tijd' betreft alleen veranderingen in het denken en niel veranderingen dic buiten het denken zouden bestaan. Kants hypothese komt er derhalve op neer

' cf. Bolland, G.J.P.J. (1896), op. cit. p. 9.

${ }^{2} \mathrm{cf}$. Bolland, G.J.P.J. (1896), op. cit. p. 26, 'Wij willen met het woord Verandering te verstaan geven, dat geenszins het bloote worden uit Niets tot Niets wordt aangenomen, maar de nieuwe werkelijkheid de voorzetting is der oude. Doch de wezenlijke bestendige eenheid van een ding, dat te midden van de verandering zijner toestanden en eigenschappen zich zelf blijft, is eene onderstelling die zich laat uitspreken, maar niet denken (.....). En de onderstelling van iets blijvends achter eene anders gewordene vertooning maakt ook het vergaan der eene waarneembare hoedanigheid bij het ontstaan cener andere geen zier begrijpelijker; wie gedachte bestaanseenheden als onveranderlijk stelt en argeloos daarbij de verhoudingen tusschen en toestanden aan en in die eenheden als vatbaar voor wisselend Zijn en Niet-Zijn aanmerkt, is theoretisch nog maar half ontwaakt tot zelfbezinning. Hij projecteert in zijn schimachtig onwarnembaar Zijn achter het waargenomene voorhangsel der Verandering eene Platonische, onvruchtbare dedoublure, en laat het $\mathrm{Al}$ uiteenvallen tot twee werelden zonder eenig weder $z$ ijdsch verband.' 
dat er eigenlijk niets gebeurt. ${ }^{1}$ Bolland concludeert even later dat de poging om verandering - de tijdelijkheid der gebeurtenissen - als schijn op te vatten hopeloos is. ${ }^{2}$ Bovendien, de ontkenning dat er buiten het denken geen opeenvolging zou plaatsvinden, verklaart nog niet de veranderingen in de eigen toestanden.

Al met al: hypothesen om 'tijd' en 'verandering' te verklaren leiden tot niets, omdat deze noties in beginsel onverklaarbaar zijn. In Bollands woorden: verandering is en blijfi voor ons het volstrekte a priori, dat wij nooit doorgronden zullen, maar eenvoudig hebben te laten gelden. ${ }^{3}$

Het gegeven dat de twee noties 'tijd' en 'verandering' volgens Bolland kennelijk niet verklaard kunnen worden, is voor hem tevens aanleiding om meer algemene kritiek te spuien op het streven naar het zoeken van rationeel-wetenschappelijke verklaringen überhaupt. Hij constateert dat er een geest is van zelfoverspanning der rede in nieuwerwetsche, bij uitnemendheid "wetenschappelijk" zich noemende, doch in waarheid dor eenzijdige, verstandsmenschen. ${ }^{4}$ De filosofie is aanstellerig "exact en wetenschappelijk" geworden; voor speculatief metafysische bespiegelingen is hierin geen plaats meer. Dit acht hij niet terecht, omdat dit zou leiden tot een eenzijdig beeld van de werkelijkheid, want het leven der natuur is echter rijker dan de objectief visionaire puntenwarreling waarin velen nog het Al zouden willen zien, doch waarin alles tot uitwendige verhouding is geworden, zonder gevoel of innerlijkheid. ${ }^{5}$ Naast de filosofie opgevat als wetenschap, krijgt ook de natuurkunde er van langs. De methode om de natuur te benaderen als een mechanisch geheel kan Bollands goedkeuring nog wel wegdragen, maar de natuurkunde als theorie acht hij eene bekrompene, een plat eenzijdige dwaasheid. ${ }^{6}$

Heymans voelt zich gedwongen om met het artikel Bolland's oratie (1896b) te reageren. Hij laat hierin echter Bollands specifieke argumenten tegen de filosofische verklaringen van de twee noties 'verandering' en 'tijd' links liggen. Zijn repliek beoogt vooral Bollands anti-wetenschappelijke houding bloot te leggen.

De idealistische denksystemen - wonderwerken van philosophische architectuur waren, zo betoogt Heymans, in de loop van de 19de eeuw als een kaartenhuis in

' cf. Bolland, G.J.P.J. (1896), op. cit. p. 32, 'De ervaring, dat stijfhoofdige ding, toont ons overal afwisseling en verandering, en nu zoude dat toe te schrijven zijn niet aan de wereld maar aan ons zelven; dit aanhoudende worden en vergaan, deze nimmer rustende opeenvolging van feiten zoude niets zijn dan eene wijze van opvatting, de trant waarin het menschelijk bewustzijn, overeenkomstig zijnen aard, den inhoud zijner waarnemingswereld zich voor moet stellen. Men bedenke wat dit zeggen wil. Ontdaan van alle nevelen eener schoolsche taal, wordt er mede bedoeld, dat er geen verleden is of toekomst dan in zooverre wij ons dat inbeelden, dat er in geenen zin te gelooven valt aan eene "werkelijkheid" buiten het bewuste denken. (.....) De zin der Kantische tijdshypothese is dat er eigenlijk niets gebeurt.'

${ }^{2}$ cf. Bolland, G.J.P.J. (1896), op. cit. p. 37.

${ }^{3} \mathrm{cf}$. Bolland, G.J.P.J. (1896), op. cit. p. 37.

${ }^{4} \mathrm{cf}$. Bolland, G.J.P.J. (1896), op. cit. p. 45.

${ }^{5}$ cf. Bolland, G.J.P.J. (1896), op. cit. p. 45.

${ }^{6}$ cf. Bolland, G.J.P.J. (1896), op. cit. p. 45. 
elkaar gestort. Absolute waarheid of het kennen van de zaak zelve werd langzamerhand door velen als een onbereikbaar ideaal beschouwd, en absolute waarheid werd zelfs als iets tegenstrijdigs opgevat. Men kwam tot het inzicht dat de wetenschappelijke voorstellingen die men zich van de werkelijkheid vormt mede worden bepaald door het denken, waardoor men aan wetenschappelijke kennis alleen een relatieve kenwaarde kan toeschrijven.' Heymans acht het psychologisch ten volle begrijpelijk dat een idealist als Bolland die juist streeft naar absolute waarheid met zulke relatieve kennis geen genoegen kan nemen, als een millionair die een aalmoes versmaadt.

Echter, absolute waarheid is een irrationele grootheid. Ook al zou men voor alle gegevens die bekend zijn een wetenschappelijke verklaring hebben gevonden, dan nog zal deze kennis relatieve kennis zijn; dat wil zeggen, een menschelijke voorstelling van de zaak, niet de zaak zelve. Wetenschap kan er alleen maar naar streven die absolute waarheid bij benadering te kennen; bereiken kan zij het in principe nooit. $^{2}$

Bolland weet door zijn fixatie op absolute waarheid bovendien wetenschappelijke kennis niet op waarde te schatten, die hem vóór alles ortrechtvaardig maakt tegenover de natuurwetenschap. Hoewel deze wetenschap in beginsel altijd een benadering van de waarheid zal blijven, is er in de afgelopen eeuwen grote vooruitgang geboekt in het oplossen van tal van raadselen, aldus Heymans. Bovendien is er geen alternatief voorhanden om natuurverschijnselen op een andere manier te verklaren, en daarom zal men de naturwetenschap voorloopig (moeten) erkennen als een model van goede en zorgvuldige methode. ${ }^{3}$

' cf. Heymans, G. (1896b), 'Bolland's oratie'. In: De gids, p. 506, 'Al die wonderwerken der philosophische architectuur, schijnbaar voor de eeuwigheid gebouwd, bleken droombeelden te zijn geweest, in het oogenblik van 't ontwaken tot niets vervlogen. Erger nog: men kwam of keerde terug tot het inzicht dat, hetgeen men zoo even nog meende reeds bereikt te hebben, op geenerlei wijze ooit bereikt zou kunnen worden. Het begrip van absolute waarheid werd als een samenkoppeling van onverenigbaare kenmerken, als eene tegenstrijdigheid herkend; men begreep dat de voorstellingen, door welken denkenden geest ook over de wereld gevormd, uit den aard der zaak door de eigenschappen van dien geest mede worden bepaald, en dat derhalve aan die voorstellingen nooit meer dan relatieve kenwaarde kan toekomen.'

${ }^{2}$ cf. Heymans, G. (1896b), op. cit. p.508, 'Het is denkbaar dat eenmaal een begripssysteem zal worden verkregen, op dezelfde wijze als in het begripssysteem der mechanica voor alle bewegingsverschijnselen, plaats is voor al onze ervaringen. Wij zullen daarmede geenszins aan het gebied der relatieve wetenschap zijn ontkomen; wat wij zullen bezitten, zal nog altijd eene menschelijke voorstelling van de zaak, niet de zaak zelve zijn. Maar de ontwikkeling van die toekomstige uit het de verleden en tegenwoordige voorstellingen beteekent (.....) eene voorgezetie benadering van die irrationele grootheid, die wij absolute waarheid noemen.'

${ }^{3}$ cf. Heymans, G. (1896b), op. cit. p. 508-509, 'Evenwel, voor de waarde dezer verschillende graden van altijd betrekkelijke wetenschap heeft den heer Bolland geen gevoel; en deze omstandigheid maakt hem voór alles onrechtvaardig tegenover de natuurwetenschap. (......).... in de mechanische natuurbeschouwing (....) hebben tal van raadselen hunne oplossing gevonden, en zijn tal van andere tot enkele algemeenere teruggebracht geworden. (....) 
Bollands streven naar absolute waarheid verklaart niet alleen diens afwijzende houding tegenover de natuurwetenschap, aldus Heymans, maar ook diens negatieve houding jegens het formuleren van hypothesen om de noties 'verandering' en 'tijd' te verklaren. Bolland miskent het voor Heymans vaststaande feit dat door Kants hypothese van de a prioriteit van de tijdsvoorstelling 'tijd' en 'ruimte' een goed deel van het raadselachtige (verliezen), dat hun voor de gewone opvatting aankleeft. Echter, het feit dat er nog geen alomvattende hypothese voor 'tijd' en 'verandering' is gevonden, betekent niet dat men daarom zo'n voorlopige verklaring zonder meer als onbruikbaar opzij moet schuiven; en zeker niet als men in plaats daarvan alleen de droomwereld der mystiek te bieden heeft. ${ }^{1}$ Kants hypothese, zo concludeert Heymans, moet door verder onderzoek naar nadere gegevens worden onderbouwd, en zoolang ze niet gevonden zijn, (zullen wij) waarschijnlijkheden tegen waarschijnlijkheden moeten afwegen. ${ }^{2}$

Bollands cerste argument tegen Heymans komt er op neer dat diens onderstelling dat het werkelijk bestaande onveranderlijk is tot een verdubbeling van de werkelijkheid leidt: een veranderlijke en een onveranderlijke werkelijkheid. De relatie tussen deze twee werkelijkheden of werelden is echter onduidelijk. Zijn tweede tegenargument betreft Heymans' vermoeden dat de rechtvaardiging van Hamiltons postulaat gezocht zou moeten worden in Kants hypothese van de a prioriteit van de notie 'tijd'. Echter, deze hypothese leidt tot de voor Bolland onacceptabele conclusic dat er in beginsel niets verandert. Bovendien acht Bolland pogingen op de noties 'tijd' en 'verandering' te verklaren gedoemd tot mislukken, omdat beide noties in beginsel onverklaarbaar zijn. Ten slotte plaatst hij vraaglekens bij het streven om

Voorlopig hebben wij de natuurwetenschap te erkennen als een model van goede en zorgvuldige methode.'

' cf. Heymans, G. (1896b), op. cit. p. 510-511, 'Op dezelfde wijze als zijne afwijzende houding tegenover de natuurwetenschap, is, geloof ik, het standpunt te begrijpen, door den heer Bolland ingenomen tegenover sommige pogingen, om ten aanzien van het onderwerp zijner rede tot eene naasthoogere waarheid door te dringen. Ik bedoel de door Kant verdedigde hypothese, volgens welke het ruimtelijk en tijdelijk karakter der verschijnselen (....) tot de bloot-relatieve elementen onzer kennis gerekend zou moeten worden. (.....) De apriorische evidentie van talrijke elementen onzer gegeven tijdsvoorstelling, de diepgaande analogieën tusschen deze voorstelling en die van de ruimte, de geheel bijzondere soort van werkelijkheid eindelijk, die aan beide voorstellingen wordt toegekend, verliezen voor haar een goed deel van het raadselachtige, dat hun voor de gewone opvatting aankleeft. (....) Zoolang nadere gegevens ontbreken, zal over deze zaak zeker slechts onderstellenderwijs mogen gesproken worden; wij zullen naar die andere gegevens hebben te zoeken, en zoolang ze niet gevonden zijn, waarschijnlijkheden tegen waarschijnlijkheden moeten afwegen. Maar het gaat niet aan, een hypothese als onbruikbaar te verwerpen, omdat zij niet met een slag alles verklaart; en dit allerminst, wanneer men tegenover die hypothese niets anders te stellen heeft dan de droomwereld der mystick.'

${ }^{2}$ cf. Heymans, G. (1896b), op. cit. p. 511. 
überhaupt rationeel-wetenschappelijke verklaringen voor verschijnselen te vinden, omdat dit zou leiden tot een eenzijdig beeld van de werkelijkheid.

Heymans grijpt vooral Bollands anti-wetenschappelijke houding aan. Hij verwijt Bolland vooral diens onrealistische streven naar absolute waarheid. Heymans acht dit in beginsel onbereikbaar. Het enige wat men kan bereiken is met behulp van hypothesen zo sluitend mogelijke verklaringen te formuleren voor de verschijnselen. Of het nu natuurwetenschappelijke verklaringen betreft of hypothesen om de verschijnselen van het causale denken te verklaren, men kan alleen relatieve waarheid bereiken. Ten slotte, het feit dat men voor bepaalde verschijnselen nog geen sluitende verklaring heeft gevonden, betekent niet dat men de pogingen daartoe moet opgeven om vervolgens te vervallen in een anti-wetenschappelijke houding door vraagstukken bij voorbaat als onverklaarbaar te bestempelen.

Bollands beide tegenargumenten zijn in beginsel valide tegenwerpingen en zij leggen de vinger op de zere plek in Heymans' theorie, namelijk het feit dat Heymans de filosofische rechtvaardiging daarvan niet met rechtstreekse argumenten onderbouwt. Origineel kan men deze argumenten echter niet noemen, omdal zij reeds eerder bij bijvoorbeeld Land en Betz naar voren zijn gekomen.

Ten slotte: terecht laakt Heymans de anti-wetenschappelijke houding van Bolland. De neiging van deze laatste om bepaalde vraagstukken voor onoplosbaar te bestempelen omdat daarvoor nog geen sluitendc verklaring is geformuleerd, is merkwaardig en staat haaks op een fundamentele waarde van de welenschapsbeoefening.

\section{BESLUIT: EEN OPEN EINDE}

Heymans' reactie was voor Bolland kennelijk geen aanleiding om over het causaliteitsvraagstuk verder te discussiëren. Geconstateerd wordt dat rond 1895 in Nederland de belangstelling voor causaliteit luwt, zonder dat het overigens tot een échte beslissing heeft geleid. Zoals het vaker in de filosofie gebeurt, lijkt het er op dat ieder zijns weegs gaat. Toch zijn er enkele Nederlandse filosofen die zich nog met causaliteit bezighouden. Dit blijkt bijvoorbeeld niet alleen uit de discussie die Bierens de Haan en Van Deventer in 1895 over het oorzaakbegrip voerden, maar ook uit de, overigens summiere, aandacht die Mees in 1895 en Wijnaendts Francken in 1905 en 1907 aan het causaliteitsvraagstuk besteedden. Ook de door Kohnstamm in 1904 bewerkte reactie van Spruyt op de causaliteitsleer van Heymans kan in dit verband ten slotte nog worden vermeld. Er worden echter geen nieuwe gezichtspunten meer naar voren gebracht.

De discussie tussen Bierens de Haan (1866-1943) en Van Deventer (1860-1931) valt buiten het kader van dit onderzoek, omdat geen van de hooldrolspelers op hun standpunten reageerden. Deze discussie wordt daarom als cen zijlijn van de 
hoofddiscussies opgevat. Volledigheidshalve worden hier alleen de posities van beide auteurs kort weergegeven.

J.D. Bierens de Haan bestrijdt in het geschrift De psychische afkomst van het oorzaakbegrip (1895a) het kantiaanse standpunt dat er in het denken onveranderlijke categorieën a priori besloten zouden liggen, zoals die van 'oorzaak en gevolg' en 'substantie'. Zulke categorieën acht hij het resultaat van een op waarneming gebaseerd abstractieproces. Ondanks zijn expliciete afwijzing van het kantiaanse a priori, is het opvallend dat Bierens de Haan zich toch genoodzaakt ziet om te onderstellen dat bijvoorbeeld het instinctieve besef van tijd en homogeniteit het eenig à priori van de redelijke bewustheid is.' De positie van de scheikundige en latere privaatdocent aan de Rijksuniversiteit Utrecht Ch.M. van Deventer staat loodrecht op die van Bierens de Haan. In het artikel Over het oorzaakbegrip (1895) betoogt Van Deventer dat het ontslaan van causaliteitsbesef uitsluitend berust op herinnering aan het feit dat verschijnselen zich herhalen. ${ }^{2}$ De schermutseling tussen beiden wordt besloten met Bierens de Haans artikel Strijdbaar beraad over het oorzaakbegrip (1895b). Hierin betoogt Bierens de Haan dat Van Deventer niet ruiterlijk uitkomt voor zijn empiristische standpunt en dat herinnering alleen - deze modus van associatie - onvoldoende is om het ontstaan van de notie 'oorzaak' te verklaren. ${ }^{3}$ Ook uit deze zijlijn van de hoofddiscussies blijkt nogmaals de tegenstelling tussen een geldigheids- en een ontstaansbenadering. Overigens zou de centrale rol van de notie 'tijd' bij Bierens de Haan, en latere auteurs, waarvan hier alleen L.E.J. Brouwer wordt genoemd, een nadere studic waard zijn.

In 1895 verschijnt ook het bock Opmerkingen over de vorming en den aard onzer $k_{e n} i^{4}$ van de theoloog en lid van de Tweede Kamer der Staten Generaal R.P. Mees (1834-1915). Uit dit geschrift blijkt dat hij zich aansluit bij Heymans' benadering van het psychologische causaliteitsvraagstuk. Net als Heymans geeft hij met gelijksoortige argumenten aun dat Hume's theorie ontoereikend is om causale overtuigingen te verklaren. ${ }^{5}$ En net als Heymans meent hij dat men achter de afwisseling der verschijnse/'n e'n werkelijkheid moet onderstellen die continuiteit bezit, en die niet verandert." De opvatlingen van Mees sluiten daarmee goed aan bij de geldigheidsbenadering.

De bioloog C.J. Wijnaendis Franken (1863-1944) publiceert in 1905 het boek Inleiding in de wijshegeerte, waarin hij zowel de ontslaans- als de geldigheidsbenadering van het causalitcitsvraagstuk weergceft. In dat boek neemt hij overigens geen duidelijke eigen positie in. In zijn boek David Hume: (1907) onderschrijft hij echter

${ }^{1}$ cf. Bierens de Haan, J.D. (1895a), De psychische afkomst van het oorzaakbegrip, p. 5-7.

${ }^{2}$ cf. Deventer, Ch.M. van (1895), 'Over het ooraakbegrip'. In: Tweemaandelijksch tijdschrifi, p.77.

${ }^{3} \mathrm{cf}$. Bierens de Haan, J.D. (1895b), Strijdbaar beraad over het oorzaakbegrip, p. 499.

${ }^{4}$ Van der Wijck, inmiddels bekeerd tot het kantianisme beoordeelde Mees' boek positief in Een staatsman-wijsgeer (1896).

${ }^{5} \mathrm{cf}$. Mees, R.P. (1895), Opmerkingen over de vorming en den aard onzer kennis, p. 33.

${ }^{6}$ cf. Mees, R.P. (1895), op. cit., p. 36. 
wel min of meer expliciet Hume's definitie van 'oorzaak', waardoor hij een vertegenwoordiger van de ontstaansbenadering genoemd zou kunnen worden. ${ }^{1}$

Ten slotte: het is moeilijk te zeggen aan wie de tekst van het boek Geschiedenis der wijsbegeerte (1904) moet worden toegeschreven. Het vormt een door voornamelijk door $\mathrm{Ph}$. Kohnstamm gemaakte reconstructie en uitwerking van notities die Spruyt ter voorbereiding van zijn colleges over de geschiedenis van de filosofie had gemaakt. In dat boek kan ook een korte kritiek op Heymans' causaliteitsleer aangetroffen. De conclusie van deze kritiek komt er op neer dat zijn causaliteitsleer de natuurwetenschappelijke benadering zou verabsoluteren, in de zin dat alle verschijnselen in deterministische termen verklaard zouden kunnen worden. ${ }^{2}$

'cf. Wijnaendts Francken, C.J. (1907), David Hume, p.65-66.

${ }^{2}$ cf. Spruyt, C.B. (1904), Geschiedenis der wijsbegeerte, $\$ 20$, p. 111-118. 


\section{EPILOOG}

De opvattingen van fysici zoals Kohnstamm, Clay en Van der Waals jr. geven aan dat ook in Nederland, hoewel enigszins later dan clders in Europa, de "wetenschappelijke wending" wat het causaliteitsvraagstuk betreft een duidelijk profiel krijgt." Een serieuze geschicdenis van deze nicuwe ontwikkeling in de geschiedenis van de filosofie in Nederland dient echter nog te worden geschreven, hoewel hiertoe recentelijk al eerste aanzelten zijn gedaan [Verweij, 1995; 1998; Klomp, 1997]. Verder onderzoek naar causaliteitsdiscussies in Nederland, maar dan over discussies die in de eerste hellt van de 20 ste ceuw plaats vonden, zou in elk geval aandacht moeten besteden aan de filosofische opvattingen omtrent causaliteit van de hierboven genoemde fysici.

In 1908 had Ph. Kohnstamm een benoeming tot hoogleraar in de natuurkunde aanvaard aan de Universiteit van Amsterdam met als leeropdracht thermodynamica. In zijn inaugurele rede Determinisme en natuurwetenschap (1908) komt duidelijk de "wetenschappelijk wending" jegens het causaliteitsvraagstuk naar voren: de onderzoekingen die zich in den jongsten tijd aan de (...) tweede hoofdwet (van de thermodynamica) hebben vastgeknoopt, (moeten) naar het mij voorkom bij consequente toepassing inderdaad een zeer grooten invloed hebben op alle vragen die met het vraagstuk der causaliteit in betrekking staan. ${ }^{2}$ Kohnstamm concludeert aan het einde van zijn rede dat de onderzoekingen van Boltzmann die zich vastknoopen aan de tweede hoofdwet van de thermodynamica van zoo principieelen aard zijn, dat zij een revisie eischen van bijna alles wat over het vraagstuk der causaliteit is gezegd. ${ }^{3}$

Ook de fysicus J. Clay, privaatdocent aan de Technische Hoogeschool te Delft en later hoogleraar natuurkunde te Bandung (1920) en Amsterdam (1929), benadert het causaliteitsvraagstuk vanuit het perspectief van de natuurwetenschappen. In zijn artikel Noodzakelijkheid en oorzakelijkheid (1915a) stelt hij zich ten doel aan te tonen hoe zich het causaliteitsprobleem (...) in de natuurwetenschappen hoe langer hoe meer in den werkelijken zin des woords heeft opgelost. ${ }^{4}$ Hij beschouwt de noties 'oorzaak' en 'gevolg' als vóor-wetenschappelijke begrippen die in het dagelijks

'Voor de ontwikkeling van de "wetenschappelijke wending" in de filosofie zie bijvoor-. beeid: Alexander, P. (1964), Haller, R. (1993) en Passmore, J.A. (1980).

${ }^{2} \mathrm{cf}$. Kohnstamm, Ph. (1908), Determinisme en natuuruetenschap, p.523.

${ }^{3}$ cf. Kohnstamm, Ph. (1908), op. cit. p. 563. Zie ook: Kohnstamm, Ph. (1916) en (1921).

${ }^{4}$ cf. Clay, J. (1915a), 'Noodzakelijkheid en oorzakelijkheid'. In: Tijdschrift voor wijsbegeerte, p. 369. Clay besprak in zijn Schets eener kritische geschiedenis van het begrip natuurwet in de nieuwere wijsbegeerte (1915b) Heymans' notie 'natuurwet'. Slechts in het voorbijgaan werd in dat boek ook Heymans' notie 'causaliteit' ter sprake gebracht. 
taalgebruik vaag en onduidelijk zijn; dit heeft geleid tot veel strijd en misverstand. Echter, in het wetenschappelijke denken, waar deze begrippen zuiver worden gesield, wordt dit in hoofdzaak vermeden. Clay concludeert onder andere dat de verhouding van oorzaak en gevolg (zich) in de exacte wetenschap heeft opgelost in een functioneele relatie, die eenduidig en soms eenzijdig kan zijn, en voor zover de verhouding logisch en formeel is geworden, noodzakelijk kan zijn. ${ }^{1}$

De opmerkingen van Kohnstamm en Clay waren vooral gericht aan Heymans. Deze laatste trad met hen echter over dit onderwerp niet in discussie. ${ }^{2}$ Dat gebeurde wel toen zijn toenmalige Groningse ambtgenoot J.D. Van der Waals jr. Heymans' causaliteitsleer op de korrel nam. Ook uit Van der Waals' kritiek op Heymans blijkt duidelijk de "wetenschappelijke wending". In het artikel Over de causaliteitstheorie van Hamilion-Heymans (1917) betoogt Van der Waals dat de theorie van Hamilton hem als onhoudbaar voorkomt en op hem de indruk maakt afkomstig te zijn van hetzij een mysticus of van een rationalist. Immers, beide onderstellen dat de wereld der ervaring niet de ware werkelijkheid kan zijn. De wereld der ervaring wordt gekenmerkt door veelheid en verandering, terwijl de ware werkelijkheid een eenheid zou vormen en onveranderlijk zou zijn. Net als het Curatorium van het Stolpiaansch Legaat, Land en Betz al eerder tegen dit onderscheid naar voren hadden gebracht, vraagt Van der Waals zich af wat nu de verhouding is tussen beide werelden. Niemand heeft het verband tusschen deze twee werelden kunnen aangeven. En zoo beschouwden de empiristen de eenheidswereld der mystici en der rationalisten als slechts een herschenschim. En omgekeerd vatten hun tegenstanders de ervaarbare wereld op als slechts te bestaan uit onwezenlijkheden, die de aandacht niet waard zijn, en verdiepten zij zich liever in speculaties aangaande het "Een en Al". Heymans had, zo betoogt Van der Waals, alleen Hamiltons theorie in staat geacht om het bestaan van deze twee werelden met elkaar in verband te brengen. Juist voor diegenen die in getallen het wezen der dingen ziet, is de logische causaliteitstheorie aantrekkelijk; en vooral, zo voegt Van der Waals daaraan toe, als hij zijn causaliteitstheorie hoofdzakelijk baseert op de schijnbaar eenvoudige en doorzichtige gevallen van causaliteit, waarmee wij in de mechanica kennis maken. ${ }^{4}$ Immers, de wetten van de mechanica heeft men doorgaans opgevat als de elementaire wetten der physische natuur bij uitnemendheid, waarbij alle andere physische natuurwetten zouden zijn af te leiden. ${ }^{5}$ In de mechanica gaat men er van uit dat bewegingen worden bepaald door de wet van behoud van energie en de wet van behoud van beweging. Op grond hiervan had Heymans ondersteld dat men causale wetten kan formuleren, met een volgende vorm: 'deze of gene grootheid blijft constant', waardoor het nog

'cf. Clay, J. (1915a), op. cil. p. 422-423.

${ }^{2}$ Er ontstond tussen Kohnstamm en Heymans echter wel discussie over de relatie tussen psychologie en logica, zie hiervoor Kohnstamm, Ph. (1907) en Heymans (1908).

${ }^{3} \mathrm{cf}$. Waals jr., J.D. van der (1917), 'Over de causaliteitstheorie van Hamilton-Heymans'. In: Tijdschrift voor wijsbegeerte, p.297.

${ }^{4}$ cf. Waals jr., J.D. van der (1917), op. cit. p. 298.

${ }^{5}$ ef. Waals jr., J.D. van der (1917), op. cit. p. 298. 
slechts een kleine stap zou zijn naar de formulering: 'de dingen blijven in hun wezen gelijk.' Hiermee wordt de wet der verandering herleid tot de identiteit van eenige' grootheden; in dit laatste ligt echter de zwakke zijde van zijn (Heymans') betoog. De nieuwe ontwikkeling in deze benadering van het causaliteitsvraagstuk komt er op neer dat Van der Waals aan de hand van een groot aantal natuurwetenschappelijke voorbeelden wil aantonen dat Heymans' theorie niet klopt. Immers, zo beloogl hij, uit het feit dat bepaalde grootheden constant blijven mag men nog niet de melafysische conclusie trekken dat de werkelijkheid onveranderlijk zou zijn: ... wie niet in de getallen of in het "Een en Al", dat buiten alle entaring ligt, de werkelijkheid zoekt, (komt het mij voor dat) van een onveranderlijkheid der werkelijkheid geen sprake kan zijn. ${ }^{2}$ Ten slotte wijst hij er op dat de meening dat alle natuurkundige verschijnselen tot mechanica terug te brengen zouden zijn, tegenwoordig vrij wel verlaten (is). (....) En hicrmee ontvallen aan Hamiltons theoric de argumenten, waarin ik haar sterkste (ofschoon toch nog onvoldoende) steun meende te zien. ${ }^{3}$ Het is duidelijk dat Van der Waals hicr gebruik maakt van wetenschappelijke resultaten om filosofische theorieën onderuit te halen: de "wetenschappelijke wending" in optima forma.

Heymans' reactie op Van der Waals volgt in zijn artikel Prof. van der Waals en de theorie van Hamilton (1918). Net als in zijn reactics op Betz en Jelgersma laat Heymans duidelijk merken dat zijn collega Van der Waals kennelijk weinig heeft begrepen van zijn opvattingen. Het laatste woord in deze studie is aan Heymans: (de argumenten van Van Waals treffen) zonder uitzondering niet de theorie, waartegen zij zich richten (...) maar loopen daaraan voorbij. Dat wil zeggen: ook wanneer zij alle onweersproken moesten blijven, zou daarmede tegen de stelling, dat het causale denken in zijn geheele ontwikkeling beheerscht wordt door het streven [om] de voorstelling van ontstaan en vergaan uit het wereldbeeld to elimineeren, nog niet het minste of geringste zijn bewezen. ${ }^{4}$

${ }^{1}$ cf. Waals jr., J.D. van der (1917), op. cit. p. 299.

${ }^{2}$ cf. Waals jr., J.D. van der (1917), op. cit. p. 298-299.

${ }^{3}$ cf. Waals jr., J.D. van der (1917), op. cit. p. 314.

4 cf. Heymans, G. (1918), 'Prof. v.d. Waals en de theorie van Hamilton'. In: Tiptschrift voor wijsbegeerte, p. 182. 

Als men op het voorafgaande terugblikt, kan worden geconcludeerd dat de doelstelling van dit onderzoek is bereikt: een witte vlek op de kaart van de geschiedenis van de filosofie in Nederland is ingekleurd. Immers, voor het eerst zijn de causaliteitsopvattingen van Opzoomer, Van der Wijck, Spruyt, L' Ange Huet, Pierson en Heymans in hun onderlinge samenhang beschreven.

Daarnaast is de probleemgerichte benadering een vruchtbare methode gebleken om deze discussies te onderzoeken. Door het toepassen van deze methode werd duidelijk wat de argumenten waren die hebben geleid tot een bepaalde opvatting omtrent causaliteit. Met deze methode is niet alleen verhelderd wat de verbindende elementen waren tussen deze denkers, maar ook waarom zij met elkaar van mening verschilden. Bovendien wordt door de toepassing van deze methode de stelling van Reichenbach en Passmore verder ondersteund, namelijk dat filosofie primair als een intellectuele onderneming kan worden gezien, die bestaat uit argumenteren en debatteren. De discussies die destijds in Nederland over causaliteit werden gevoerd zijn hiervan een goed voorbeeld.

Deze studie heeft ook geleid tot de bevestiging van het vermoeden dat de inhoud van het filosofisch erfgoed van Nederland uit de tweede helft van de 19 de eeuw meer te bieden heeft dan doorgaans wordt aangenomen. De analyse van de causaliteitsdiscussies heeft enkele in filosofisch-historisch opzicht interessante resultaten opgeleverd. Niet alleen Opzoomers kritiek op Mills opvalting over de uniformiteit van de natuur, maar ook Spruyts fundamentele kritiek op Opzoomers afleiding van de noties 'oorzaak' en 'noodzakelijkheid' uit wilsbepalingen en Van der Wijcks "ontdekking" van de vraag wat nu precies verwachtingen inhouden zijn hiervan goede voorbeelden. De ontdekking van Huets consequent uitgewerkte positivistische causaliteitsleer kan ook als een verrassend resultaat van dit onderzoek worden gezien. Immers, Huet leverde niet alleen fundamentele kritiek op de benaderingen van Opzoomer en Spruyt, maar hij bood ook een interessante en nieuwe aanvulling op Comtes positivisme. Piersons zeer scherpzinnige kritiek op Kants tweede analogie der ervaring en Piersons kritiek op Hume's notie van 'oorzaak' kunnen ook nu nog als actuele bijdragen in het onderzoek over deze beide denkers worden opgevat. Heymans' kritiek op Hume's causaliteitsleer, zijn uitwerking van Hamiltons postulaat tot een op zichzelf staande causaliteitsleer en Heymans' poging om dat postulaat een filosofische rechtvaardiging te verschaffen vormen uit filosofisch-historisch oogpunt interessante resultaten van dit onderzoek.

Uit deze studie is ook naar voren gekomen dat de discussies die destijds werden gevoerd zeer levendig en inhoudsrijk waren. Zij tonen aan dat dikwijls op het scherpst van de snede werd gedebatteerd. Hoewel Nederlandse filosofen van destijds in een 
aantal gevallen niet schuwden om argumenten ad hominem te gebruiken en hoewel zij zich soms verscholen achter autoriteiten om hun standpunten kracht bij te zelten, bleek dikwijls dat zij dit niet nodig hadden. In de meeste gevallen kwamen zij naar voren als zelfstandige en zelfbewuste denkers met een eigen profiel.

De specifieke argumentaties die Nederlandse filosofen naar voren brachten om het causaliteitsvraagstuk op te lossen, verschaffen een basis om ten slotte ook een antwoord te geven op de vraag welke ontwikkelingslijn in deze discussie valt te ontdekken.

Men kan concluderen dat over de gehele periode de ontstaansbenadering stond tegenover de geldigheidsbenadering. Zo stond de ontstaansbenadering van Opzoomer en Van der Wijck tegenover geldigheidsbenadering van Spruyt. Spruyts geldigheidsbenadering vormde vervolgens een tegenstelling met de ontstaansbenadering van Huet. Pierson viel de geldigheidsbenadering van Spruyt aan om daarvoor een betekenisbenadering in de plaats te stellen. Hiermee vormde Pierson de uitzondering op de regel. Ook in de discussies naar aanleiding van Heymans' causaliteitsleer kon men de tegenstelling tussen de ontstaans- en geldigheidsbenadering aantreffen. Dit kwam vooral tot uitdrukking in de uitvoerige discussie tussen Heymans en Jelgersma.

Vervolgens kan worden vastgesteld dat in de discussies drie kristallisatiepunten zijn te ontdekken: 1871-1873, 1879-1882 en 1890-1896. De aanleiding voor de discussies werd gevormd door Opzoomers publikaties uit de jaren vijftig en zestig. De discussies barstten pas echt los aan het begin van de jaren zeventig. Uit die tijd stammen de kritische reacties van Spruyt op Opzoomer en Van der Wijck, Huets kritiek op zowel Opzoomer als Spruyt en ten slotte Spruyts kritiek op Huet. Aan het eind van de jaren zeventig formuleerde Spruyt zijn eigen causaliteitsleer, die aan het begin van de jaren tachtig door Pierson fel werd bekritiseerd. Men kan concluderen dat de dertig jaar tussen het midden van de 19de eeuw en de vroege jaren tachtig de eerste fase in de discussies vormt die met Opzoomer begon en door Pierson werd afgesloten. Heymans gaf in het begin van de jaren negentig de discussies een nieuwe impuls. Zijn causaliteitsleer kon in de eerste helft van de jaren negentig op veel kritiek rekenen, vooral van de kant van filosofen als Betz en Jelgersma. $\mathrm{Na}$ omstreeks 1895 luwden de discussies over causaliteit. Ook kan worden geconcludeerd dat eerste helft van de jaren negentig de tweede fase in de discussies vormden die begon met Heymans en door Bolland werd afgesloten. Rond 1920 flakkerden de discussies nog eenmaal op. Ook toen stond Heymans' leer centraal. Zijn opvattingen werden vooral bekritiseerd door fysici zoals Clay, Kohnstamm en Van der Waals. Dit zou men als een derde fase in de discussies kunnen beschouwen. Het onderzoeken van deze fase lag buiten de grenzen van deze studie.

De methode die in deze studie is gebruikt, biedt ook aanknopingspunten voor nieuw of voor aanvullend onderzoek op het gebied van het filosofische erfgoed van Nederland. De probleemgerichte benadering zou men kunnen tocpassen op discussies die destijds door bijvoorbeeld Opzoomer, Van der Wijck, Spruyt en Land werden gevoerd over de aard van de filosofische noties 'ruimte' en 'tijd'. Men zou deze methode ook kunnen gebruiken om inzicht te verkrijgen in de argumentaties die toen 
door hen werden gcbruikt om het filosofische vraagstuk van de externe werkelijkheid op te lossen. De probleemgerichte benadering zou ook vruchtbaar kunnen blijken om een helder beeld te krijgen van discussies over ethische en sociaal-filosofische onderwerpen die destijds in Nederland actueel waren. Ten slotte kan deze methode ook bruikbaar zijn om de derde fase in de discussies over causaliteit te onderzoeken met als doel om inzicht te verkrijgen in de vraag hoe de "wetenschappelijke wending" in de filosofiebeoefening in Nederland gestalte heeft gekregen. 


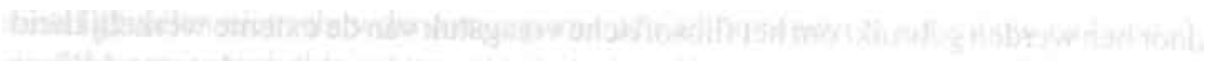

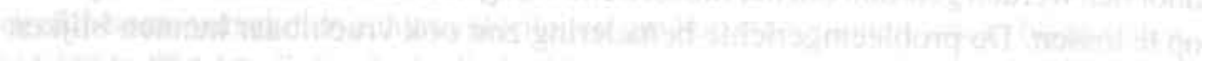

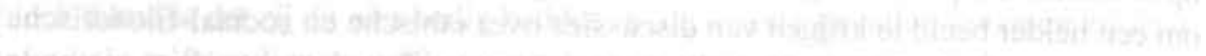

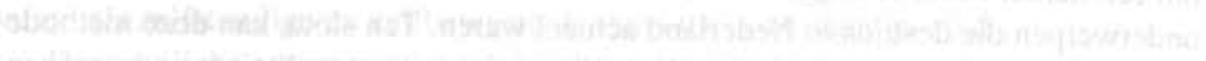

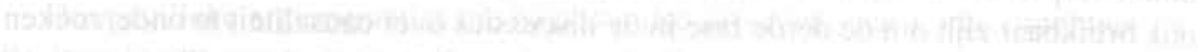

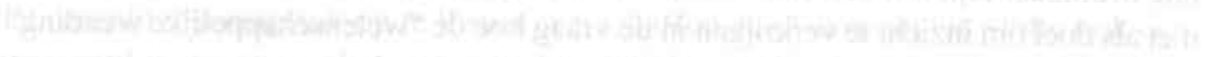

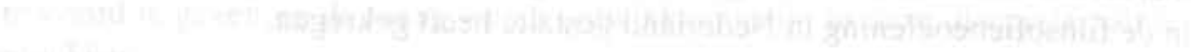




\section{CAUSE AND EFFI:CT}

Discussions on the problem of causality in the Netherlands in the second half of the 19 th century

The present study inquires into the philosophical discussions on the problem of causality, which took place in the Netherlands in the second half of the 19th century. Several prominent Dutch philosophers who played a central role in these discussions are ascribed a key-role in this study: C.W. Opzoomer (1821-1892), B.H.C.K. Van der Wijck (1836-1925), C.B. Spruyt (1842-1901), J. L'Ange Huet (1840-1924), A. Pierson (1831-1896) and G. Heymans (1857-1930). Virlually all of them occupied a chair of professor at one of the Dutch universitics, making this study a part of the written history of academic philosophy in the Netherlands.

The question this study tries to answer is: How the discussions on the problem of causality in the Netherlands developed during the second half of the 19th century? More specifically: Which argumentations were formulated by Dutch philosophers to solve the problem of causality? In order to answer these two questions a problemoriented method is used, which implies that the questions and argumentations that these philosophers formulated as regards the problem of causality, are takin the starling-points to this approach.

The key-questions which these philosophers saw as related to the problem of causality can be categorised into three kinds: questions of meaning, questions of origination and questions of justification. It is suggested that the last two kinds of questions reflect the main philosophical approaches which these discussions dominated. These approaches have been named, the origination-approach and the justification-approach. The former approach is related to empiricist and positivist points of view, whereas the lalter is related to criticist viewpoints.

Chapter I focuses on the discussion between Opzoomer and Van der Wijck on the one hand, and, Spruyt on the other hand. The main questions concerning causality which Opzoomer addresses in his De weg der wetenschap (The road of science) of 1851 and in Het wezen der kennis (The essence of knowledge) of 1863/1867 are: What does it mean to say that 'one particular phenomenon causes another particular phenomenon'? On what basis does one assume that there is regularity in nature? Is the notion of cause originated by experience or is it innate? And, can one explain that the principle of causation arises from induction? Opzoomer attempts to answer these questions in empiricist terms, maintaining that all knowledge is founded on experience and concluding that innate notions do not exist. Furthermore, he argues 
that both the notions of cause and of necessary connection, as well as the principles of causation and of regularity can be explained in terms of origination.

Spruyt fundamentally disagrees with Opzoomer in his 'Aangeboren waarnemingsvormen' (Innate forms of perception) of 1871. The main questions Spruyt puts, is: How can the ascription of universality to a rule concerning the succession of phenomena, which is only confirmed by some instances, be justified? What is the justification of the conviction that every change has a cause? Spruyt takes a criticists point of view toward knowledge; as regards causation in particular, he thinks, some innate elements play a crucial role in the acquisition of knowledge. Spruyt objects to Opzoomer in that the origination-approach leads to contradictions, maintaining that this could lead to only one possible conclusion: the notion of cause and the principle of causation have to be innate forms of perception.

In 1871, in his reply 'Een nieuwe kritiek van de wijsbegeerte der ervaring beschouwd' (A new critique of empiricism considered), Opzoomer tries to prove that Spruyt deliberately misinterpreted his position. In his De wijsbegeerte der ervaring verdedigd (Empiricism defended) of 1871, Van der Wijck defends Opzoomer's position against Spruyt's criticism. He argues that an empirical explanation of the problem of causality may exist, demonstrating that Spruyt jumps to conclusions. Spruyt replies to Van der Wijck in De laatste gedaanteverwisseling van de wijsbegeerte der ervaring toegelicht (The recent metamorphosis of empiricism explained) of 1872. In it he attempts to expose Van der Wijck as a defender of the justification-approach in disguise. Also Spruyt tries to demonstrate that Van der Wijck's empirical explanation of the problem of causality leads to nowhere, maintaining that such explanations were and will remain unsuccessful and concluding that the notion of cause and the principle of causation must be innate lorms of perception.

Chapter II focuses on L'Ange Huet's theory of causality, which he expounds in his Nieuwe oplossing voor een oud vraagstuk. De methode van het positivisme toegepast op het begrip oorzaak en gevolg (New solution of an old problem. The method of positivism applied on the concept cause and effect) of 1872 . Huet formulates his theory not only in consequence of the debate between Opzoomer, Van der Wijck and Spruyt, but also as a way of completing Comte's positivist theory.

Huet refutes both Opzoomer's and Van der Wijck's empiricist argumentations as well as Spruyt's criticists supposition that innate notions exist. He argues that they excluded an alternative: positivism. Moreover, Huet argues that they misinterpreted the problem of causation. According to Huet this problem can be brought to an adequate solution only if some fundamental questions of meaning are answered: What does the concept of cause and effect mean when one traces it back to its origin? And, what is the meaning of the principle of causation? For Huet, the meaning of abstract concepts can only be found by inquiring into one's own inner state from which such concepts arise. In other words, Huet translates questions of meaning into questions of origination. Huet explains the origin of the awareness of causal connections and the origin of the abstract notion of cause by his theory of sympathetic sensations. 
According to this theory an instinct to imitate movement leads to particular sympathetic impressions. He concludes that both the awareness of causal connections as well as the abstract notion of cause itself can be traced back to one single sympathetic impression of causal action of objects.

Furthermore, Huet argues that the notion of causation is not, and never was, useful for scientific purposes because the essence of scientific explanation is to subsume phenomena under general, law-like, rules. He also demonstrates that explanations in physics, which are focused on the explanation of the succession of phenomena, and to those in classical biology, which are focused on the explanation of the coexistence of phenomena, only differ in gradation. Huet finally conludes that the notion of causation belongs to a bygone phase of thinking.

Chapter III illustrates both Spruyt's criticism on Huet's theory as well as Spruyt's own view on causality. In 'Oude dwalingen in een nieuw kleed' (Old errors in new disguise) of 1873, Spruyt accepts Huet's criticism on Opzoomer, but he defies Huet's theory of sympathetic sensations. Spruyt demonstrates that this theory must necessarily conflict with Huet's positivism. He further disagrees with Huet on the subject of the difference between explanations in physics and in classical biology. He also maintains that Huet's theory is incomplete because Huet does not explain the origin of the principle of regularity. Spruyt concludes his criticism of Huet by showing, that the latter did not answer the question of justification: How can it be justified that, prior to any experience, one is convinced that there is regularity in nature? The discussion between Spruyt and Huet is open ended, since Huet never replied to Spruyt's critique.

Until 1873, Spruyt had approached the problem of causality from a rather negative point of view. However, in his prize-winning Proeve van eene geschiedenis van de leer der aangeboren begrippen (Outline of a history of the doctrine of innate ideas) of 1879 , Spruyt attempts to provide a positive argumentation for the necessity of assuming innate forms of perception. At this point he rejects Hume's theory of causality, thereby rejecting the origination-approach once more. Furthermore, Spruyt explicitly agrees with Kant's proof of his second analogy of experience, concluding that the principle of causation has to be a priori.

Chapter IV focuses on Pierson's Wijsgeerig onderzoek. Kritische prolegom(na van esthetiek (Philosophical investigation. Critical prolegomena of aesthetics) of 1882. In his work Pierson rejects Spruyt's Proeve, and therefore his justificationapproach, by demonstrating that there are some crucial contradictions in Kant's proof of his second analogy of experience. He concludes that Kant did not prove that the principle of causation is a priori. Morcover, Pierson maintains that there is no need to assume that this principle is a priori because, in praclice, scientists do not need such a justification for their activities. According to Pierson, the conviction that every phenomenon has a cause arises from custom, which, he belicves is a sufficient basis for doing scientific research.

Furthermore, Pierson inquires into the meaning of Hume's notion of cause and concludes that Hume's definition of that notion is inadequate. He denies that it is 
justified to assume an identity between the notion of causal connection and the notion of a fixed-time order regarding objects that are perceived. From his analysis of the meaning of the notion of cause and effect, Pierson concludes that cause and effect must be viewed as two aspects of the laws of nature. Moreover, he concludes that the notion of cause has no added theoretical value whatsoever when it comes to scientific purposes.

Contrary to what one would expect, Spruyt did not reply extensively to Pierson's criticism. His only reaction (1888) is that Pierson apparently considered the Proeve somewhat of a stumbling block.

Chapter V illustrates both Heymans' theory of causality as well as the discussions between Heymans and his critics. In his prize-winning Schets eener kritische geschiede-geschiedenis van het causaliteitsbegrip in de nieuwere wijsbegeerte (Outline of a critical history of the concept of causality in newer philosophy) of 1890 and also in the second part of his Gesetze und Elemente des wissenschaftliches Denkens (Laws and elements of scientific thought) of 1894, Heymans makes a disctinction between the psychological and the philosophical problem of causality. The psychological problem of causality refers to the following question: How can it be explained that observations cause the firm conviction to arise that there is a necessary connection between what is observed now and what will be observed in the future? The philosophical problem of causality refers to this question: How can the conviction that future observations always confirm the expectation that there are necessary causal connections between phenomena be justified?

Heymans rejects Hume's theory of association, and therefore the originationapproach, because this theory is unable to explain the universal validity of the principle of causation and the absolute certainty of the principle of regularity. To solve both the psychological problem as well as the philosophical problem of causality Heymans adheres to the postulate of Hamilton, i.e. the conviction a priori that all that exists in reality is unchangeable. This postulate implies that one has to assume an unchangeable reality behind the perceptions of change. Heymans hypothesizes that all phenomena of causal thinking can be explained by this postulate. This hypothesis lucidates, Heymans maintains, why and in which cases causal explanations are sought. It also sheds light on the function and structure of causal explanations, the function of scientific hypotheses, the certainty and absolute validity of causal axioms and of specific scientific principles.

Heymans' greatest difficulty is justifying Hamilton's postulate, which forms the philosophical basis of Heymans' theory of causality. In order to justify this postulate, Heymans suggests that this problem of justification might be solved by accepting Kant's hypothesis of the a priori structure of time as a basic assumption. However, his mere programmatic and rather speculative solution fails to convince early critics such as the philosophers H.J. Betz in his 'Bezwaren van een leek tegen het causaliteitsbegrip van dr. G. Heymans' (Objections of a layman against Heymans' concept of causality) of 1891, D.G. Jelgersma in his 'Causaliteit' (Causality) of 1891 and G.J.P.J. Bolland in his Verandering en tijd (Change and time) of 1896. Almost 
in unison these critics maintain that Heymans' hypothesis makes it difficult to reconcile the actual perceptions of change with the speculative assumption of an unchangeable, hidden reality. Although Heymans replies to these critics, he attempts to circumvent justifying the a priori conviction that all that exist in reality is unchangeable.

However, these often subtle discussions on the problem of causality, which were initiated by Opzoomer's De weg der wetenschap in 1851 and more or less ended with the criticism on Heymans' theory of causality in the 90's, remain open ended: no consensus of how to solve the problem of causality has been reached. Although other Dutch philosophers have addressed this problem, mainly as parts of monographs on more general philosophical subjects, no new discussions were initiated at the end of the 19 th century.

The Epilogue illustrates that Heymans' theory of causation was debated again in the first decades of the 20th century. This time the criticism on Heymans' theory originated not from philosophers but from physicists such as Ph. Kohnstamm (18751941), J. Clay (1882-1955) and J.D. van der Waals jr. (1873-1971). They stress that the problem of causation can be solved by way of modern theories in physics. One could say that it is these physicists who, finally, did introduce the so-called scientific turn in regard to philosophy in the Netherlands.

It can be concluded that a gap in the history of philosophy has been filled in by this piece of rescarch. Prior to the present study the prevailing discussions on philosophical questions related to the problem of causality were never examined syslematically. Moreover, the following two questions are answered by this study: How did the discussions on the problem of causality develop in the Netherlands in the second half of the 19 th century? And, which argumentations were formulated by Dutch philosophers to solve the problem of causality? It can also be concluded that these discussions have much more to offer than might generally be assumed, both from a historical and from a philosophical point of view. Furthermore, this study illustrates that the application of a problem-oriented method clarifies the connecting elements between different philosophers. Moreover, this method has also clarified why the philosophers' opinions differed. Finally, the method used might offer a fruitful approach to new or additional inquiries into the philosophical heritage of the Netherlands. 



\section{LITERATUUR EN BRONNEN}

Alberdingll ThIJM, J.A. 1848, 'De poziticve filosotie'. In: Hel alge'meen letterlicuend' maandblad, no. 22, 405-412.

AleXANDiR, P. 1964, The philosophy of science 1850-1910'. In: D.J. O'Connor (ed.) A critical history of western philosophy. New York: The Free Press, 402-425.

ANTAL, G. VON 1888, Holländische Philosophie in neunzehnten Jahrhundert. Utrecht: Breijer.

AYER, A.J. 1946, Language, truth and logic. Hamnondsworth: Penguin.

1973, The central questions of philosophy. London: Weidenfeld and Nicolson.

BAKKLR, J.A. 1848a, 'De algemeene grondslagen der stellige wijsbegeerte'. In: De tijdspiegel, no. 2, 9-14.

1848b, 'De stellige wijsbegeerte tegenover geloof en wetenschap'. In: De tijdspiegel, no. 2, 332-340.

BALKE, W. 1997, 'Allard Pierson in de klem tussen geloof en wetenschap'. In: De negentiende eelu, no. $1,51-83$.

BARNARD, M. 1987, Een weemoedige tint: agnosticisme en estheticisme bij Allard Pierson. Academisch proefschrift Amsterdam. Meppel: Krips Repro.

BEAUChamp, T. 1981, Hume and the problem of causation. Oxford: Oxford Univcrsity Press.

BECKER, F. 1873, 'Oude oplossing van een oud vraagstuk'. In: De wachter, no.2, 73-90, 203-225.

BLLL, F.B.W. VAN 1867, 'Bespreking'. In: Theologisch tijdschrift, no.1, 93-100.

BERKEl., K. VAN 1981, Natuurwetenschappen van Renaissance tot Darwin. Thema's uit de wetenschapsgeschiedenis. Den Haag: Nijhoff.

1985, In de voetsporen van Stevin. Geschiedenis van de natuurwetenschap in Nederland 1580-1940. Meppel/Amsterdam: Boom.

BETH, E.W. 1953, Inleiding tot de wijsbegeerle der exacte wetenschappen. Antwerpen/Amstcrdam: Standaard-Boekhandel.

1958, De weg der wetenschap. Inleiding tot de methodeleer der empirische wetenschappen. Haarlem: Bohn.

1964, Door wetenschap tot wijsheid. Verzamelde wijsgerige studiën. Assen: Van Gorcum.

BETZ, H.J. 1875, 'Over den aard onzer kennis'. In: De levensbode, no. 8, 3-135, 161-233, 326-423.

1877, 'Jong-Hollandsche wijsbegeerte'. In: De levensbode, no. 9, 35-85.

1881, Ervaringswijsbegeerle. Den Haag: Nijholf.

1883, Spinoza en Kant. Den Haag: Nijhoff.

1890, 'Dr. G. Heymans over 's menschen kenvermogen'. In: De Nederlandsche spectator, no. 26, 217-218. 
1891, 'Bezwaren van een leek tegen het causaliteitsbegrip van dr. G. Heymans'. In: De' tijdspiegel, no.1, 315-335.

1902, 'Oorzaken en redenen'. In: De tijdspiegel, no.l, 409-427.

BIl:, J.P. DE (c.a.) 1931, Biografisch woordenboek van protestantsche godgeleerden in Nederland. Den Haag: Nijhoff.

BIERENS DE HAAN, J.D., 1895a De psychische afkomst van het oorzaakbegrip. Amsterdam: Scheltema en Holkema.

1895b, 'Strijdbaar beraad over het oorzaakbegrip'. In: Tweemaandelijksch tijdschrift, no. 2,496-510.

BLACKMORE, J.T. 1972, Ernst Mach, his work, life and influence. Berkeley: University of California Press.

(ed.) 1992, Ernst Mach. A deeper look: documents and new perspectives. Dordrecht: Kluwer.

BOAS, G. 1969, The history of ideas. New York: Scribner.

Boersema, K.H. 1924, Allard Pierson, eene cultuur-historische studie. Academisch proefschrift Leiden. Den Haag: Nijhoff.

Вонм, D. 1963, Causality and chance in modern physics. London: Routledge \& Kegan Paul.

BOLLAND, G.J.P.J. 1896, Verandering en tijd. Leiden: Van Doesburgh.

BORN, M. 1964, Natural philsophy of cause and chance. New York: Dover Publications (orig. 1949).

Bos, P. (ed.) 1995, Beijerinck and the Delft school of microbiology. Delft: Delft University Press.

BRAAKE, H. TE 1876, 'De wijsbegeerte der ervaring op de leerstoelen der wijsbegeerte te Utrecht en te Groningen.' In: Studiën, no. 9- V.

BRAITHWAITE, R.B. 1953, Scientific explanation: a study of the function, theory, probability and law in science. Cambridge: Cambridge University Press.

BrITTON, K. 1954, John Stuart Mill. Harmondsworth: Penguin.

BROOKMAN, F.H. 1979, The making of a science policy. A historical study of the institutional conceptual tual background to Dutch science policy in a West-European perspective. Academisch proefschrift Amsterdam. Amsterdam: Academische Pers.

Brugmans, H.J.F.W. 1957, 'Gerard Heymans'. In: Algemeen Nederlands tijdschrift voor wijsbegeerte en psychologie, no. 4, 169-183.

BÜCHNER, L. 1859, 'Baron W. Constant Rebecque's "Synthetische overdenkingen in den geest van het positivisme"'. In: De tijdgenoot op het gebied der rede, no. 1, 36-45.

BUnGE, M. 1959, Causality. Cambridge (Mass.): Harvard Universily Press.

CASSIRER, E. 1937, Determinismus und Indeterminismus in der modernen Physik: historische und systematische Studien zum Kausalproblem. Göteborg: Elanders Boktrycheri Aktievolag.

CLAY, J. 1915a, 'Noodzakelijkheid en oorzakelijkheid'. In: Tijdschrifi voor wijsbegeerte, no.1, 369-424.

1915b, Schets eener kritische geschiedenis van het begrip natuurwet in de nieuwere wijsbegeerte. Leiden: Brill. 
CомTL, A. 1975, Cours de philosophic positive: philosophie premic̀re [1830]. In: M. Serres (ed.). Parijs: Hermann.

1974, Discours sur l'esprit positive: ordre el progres [1844]. Parijs: Vrin.

CONSTANT REBBECUE, W. 1846, Algemeene grondslagen der stellige wijsbegeerte. (vertaling van A. Comte, Course de philosophie positive, [1830], leçons 1 et 2). Den Haag: Belinfante.

1857, Synthetische overdenkingen in den geest van het positivisme betreffende wijsbegeerte, zedeleer en religie, of kort overzicht der positieve religic, religic der menselijkheid, gegrondvest door Aug. Comte. Den Haag: Van Cleef.

1858, 'Iets naders over het positivisme'. In: De tijdgenoot, no. 1, 50-53; 84-90.

COPLESION, F. 1964-1967, A history of philosophy. New York: Image Books.

DE PSYCHOLOOG 1992, '100 jaar psychologie in Nederland (1892-1992)', no. 10.

DeRKX, P.H.J.M. 1994, H.J. Pos 1898-1955. Objectief en onpartijdig. Biografie van een filosoof en humanist. Hilversum: Verloren.

DEVENTER, CH.M. VAN 1895, 'Over het oorzaakbegrip'. In: Tweemaandelijksch tijdschrift, no. 2, 67-83.

DIJKSTERHUIS, E.J. 1990, Clio's stiefkind. Amsterdam: Bakker.

DOOREN, W. VAN 1959/60, 'De logica van Opzoomer (1821-1892)'. In: Algemeen Nederlunds tijdschrift voor wijsbegeerte en psychologie, no. 1, 244-259.

1983, 'Het kritisch empirisme van Allard Pierson'. In: Algemeen Nederlands tijdschrift voor wijsbegeerte, no. 1, 140-152.

1990 'C.W. Opzoomer: leven en werk'. In: W. van Dooren (ed.) Cornelis Opzoomer: Het wezen der kennis. Baarn: Ambo. 11-34.

DraAisma, D. 1983 'De inductieve metafysica'. In: D. Draaisma (e.a.) Gerard Heymans. Objectiviteit in filosofie en psychologie. Weesp: Wereldvenster. 42-52.

1988, De geest in getal: beginjaren van de psychologie. Lisse: Swets \& Zeitlinger.

DuBoIS, P.H. 1977, Over Allard Pierson. Den Haag: BZZTÔH.

1992, Zonder vaandel: Belle van Zuylen, 1740-1805. Amsterdam: Van Oorschot.

EDWARDS, P. (ed.) 1967, The encyclopedia of philosophy. New York: MacMillan.

FABER, W. 1954, Wijsgeren in Nederland. Nijkerk: Callenbach.

FRANK, PH. 1932, Das Causalgeselz und seine Grenzen. Wenen: Springer.

FRENCII, P.A. (c.a.) 1984, Causation and causal theories. Minneapolis: University of Minnesola Press.

GEIER, M. 1992, Der Wiener Kreis. Hamburg: Rowohlt.

GERRITSEN, T. 1938, La philosophie de Heymans. Academisch proefschrift Groningen.

Parijs: Alcan.

GeurTS, J.P.M. 1984ㄹ, Feit en theorie. Assen: Van Gorcum.

GRAAF, D.A. DE 1962, Het leven van Allard Pierson. Groningen: Wolters.

GRACIA, J.J.E. 1992, Philosophy and its history: issues in philosophical historiography.

New York: State University of New York Press.

GrEGORY, F. 1977, Scientific materialism in nineteenth century Germany. Dordrecht:

Reidel. 
HACKING, I. 1975, Why does language matter to philosophy. London: Cambridge University Press.

1990, The taming of chance. Cambridge: Cambridge University Press.

HALER, R. 1993, Neopositivismus. Eine historische Einführung in die Philosophie des Wiener Kreises. Darmstadt: Wissenschaftliche Buchgesellschaft.

HAMILTON, W.R. 1865, 'Lectures XXXIX - XL'. In: Hamilton, W.R., Lectures on metaphysics and logic. Edinburgh: Blackwood, 376-413.

HAMLYN, D.W. 1980, Schopenhauer: the arguments of the philosophers. London: Routledge \& Kegan Paul.

HAnson, N. 1958, Patterns of discovery. Cambridge: Cambridge University Press.

HARRÉ, R. 1986 The philosophy of science: an introductory survey. Oxford: Oxford University Press.

HARTSEN, F.A. 1865a, Het empirisme van Opzoomer door zichzelven beoordeeld. Zaltbommel: Noman.

1865b, De ziel voor de waarneming: bijdrage tot de leer der aangeboren begrippen. Zaltbommel: Noman.

$1865 \mathrm{c}$, Schema van den wijsbegeerte: proeve van antwoord op de vraag 'welke zijn de kenbronnen van de waarheid'. Zaltbommel: Noman.

Heijerman, A.F (e.a.) 1986, Filosofie in Nederland. De Internationale School voor Wijsbegeerte als ontmoetingsplaats 1916-1986. Meppel-Amsterdam: Boom.

Heijmans, H.G. 1994, Wetenschap tussen universiteit en industrie. De experimentele natuurkunde in Utrecht onder W.H. Julius en L.S. Ornstein, 1896-1940. Academisch proefschrift Utrecht. Rotterdam: Erasmus Publishing.

HEYMANS, G. 1880, Karakter en methode der staathuishoudkunde. Academisch proefschrift Leiden. Leiden: Van Doesburgh.

1882, Zur Kritik des Utilisnus. Inaugural-Dissertation Freiburg. Altenburg: Pierer'sche Hofbuchdruckerei, Geibel \& Co.

1883, 'Zurechnung und Vergeltung. Eine psychologisch-ethische Untersuchung'. In: Vierteljahrschrift für wissenschaftliche Philosophie, no.7, 439-462.

1886, 'Analytisch, synthetisch'. In: Vierteljahrschrift für wissenschaftliche Philosophie, no.10, 381-390.

1888, 'Zur Raumfrage'. In: Vierteljahrschrift für wissenschaftliche Philosophie, no.12, 265-286, 429-457.

1889a, 'Erkenntnistheorie und Psychologie'. In: Philosophische Monatshefte, no.

$25,1-28$.

1889 b, 'Einige Bemerkungen über die sogenannte empiristische Periode Kant's'. In: Archiv für die Geschichte der Philosophie, no. 2, 572-591.

1889c, 'Noch einmal: analytisch, synthetisch'. In: Zeitschrift für Philosophie und philosophische Kritik, no. 96, 161-172.

$1890 \mathrm{a}$, Schets eener kritische geschiedenis van het causaliteitsbegrip in de nieuwere wijsbegeerte. Leiden: Brill.

1890b, Het experiment in de philosophie. Leiden: Van Doesburgh. 
1890c, Die Gesetze und Elemente des wissenschaftliches Denkens, ein Lehrbuch

der Erkenntnistheorie in Grundzügen. Band I: Allgemeiner Teil und Theorie des Mathematischen Denkens. Leiden/Leipzig: Van Doesburgh/Harrassowitz.

1891, 'Dr. Betz en het causaliteitsbegrip'. In: De tijdspiegel, no. 2, 63-67.

1894 Die Gesctze und Elemente des wissenschaftliches Denkens, ein Lehrbuch

der Erkenninistheorie in Grundzügen. Band II: Theoric des naturwissenschaflichen

Denkens. Leipzig: Barth.

1896a, 'Nog eens: causaliteit'. In: Tweemaandelijksch tijdschrift, no. 1, 180-182. 1896b, 'Bolland's oratie'. In: De gids, 4, 506-511.

1902, 'Erklärungshypothesen und Erklären überhaupt'. In: Ostwald's Annalen

der Naturphilosophie, no. 1, 473-485.

Barth.

1905, Einführung in die Metaphysik auf Grundlage der Erfahrung. Leipzig:

1908, 'De psychologische methode in de logica'. In: Tijdschrift voor wijsbegeerte,

no. 1, 207-238.

1909, De toekomstige eeuw der psychologie. Groningen: Wolters.

1914, Einführung in die Ethik auf Grundlage der Erfahrung. Leipzig: Barth.

1916, 'Natuurwetenschap en philosophie'. In: Tijdschrift voor wijshegeerte, no.

$1,187-197$.

1918, 'Prof. van der Waals en de theoric van Hamilton'. In: Tijdschrift voor wijsbegeerte, no. $1,180-192$.

1923, 'Wetmatigheid en determinisme'. In: Onze eeuw, no. 2, 44-92.

HelmHOLTZ, H. voN 1847, Über die Erhaltung der Kraft. Berlin: Reimer.

1867, Handbuch der Physiologische Optik. Leipzig: Voss (orig. 1860)

1879, Die Thatsachen der Wahrnehmung. Berlin: Hirschwald.

HOSPERS, J. 19903, Introduction to philosophical analysis. London: Routledge \& Kegan Paul.

HUBBIIIING, H.G. 1980a, Gerard Heymans 1857-1930: leven en werk. Groningen: Universitcitsmuseum Groningen.

1980b, 'Empirische methode versus empirisme. De strucluur van Heymans'filosofic'.

In: Algemeen Nederlands tijdschrift voor wijsbegeerte, no. 1, 1-18.

1983, 'Kenleer en methodologie'. In: D. Draaisma (c.a.), Gerard Heymans. Objectiviteit in filosofie en psychologie. Weesp: Wereldvenster, 33-41.

1988, 'Heymans'. In: H.G. Hubbeling, Gerardus Heymans. Over metafysica en esthetica. Baarn: Ambo.11-19.

HUIZINGA, J. 1951, De geschiedenis der universiteit gedurende de derde eeuw van haar bestaan, 1814-1914. In: J. Huizinga, Verzamelde werken, deel 8. Haarlem: Tjeenk Willink, 36-339.

HUME, D. 1978, A treatise of human nature [1739/1740], second edition with text revised and notes by P.H. Nidditch. Oxford: Clarendon Press.

1975, An enquiry concerning human understanding [1748], third edition with text revised and notes by P.H. Nidditch. Oxford: Clarendon Press. 
ISHIGURO, H. 1978, Pre-established harmony versus constant conjunction. London: British Academy.

JACOBS, S. 1994, 'Whewell's philosophy of science and ethics'. In: C.L. Ten (ed.) Routledge history of philosophy, vol. VII: The nineteenth century. London: Routledge \& Kegan Paul, 32-61.

Jelgersma, D.G. 1891, 'Causaliteit'. In: De nieuwe gids, no. 2, 36-74. 1896a, 'Causaliteit'. In: Tweemaandelijksch tijdschrift, no. 3, 528-537. 1896b, Wijsgeerige strijdschriften. Amsterdam: Scheltema en Holkema. 1896c, 'Nog eens: causaliteit'. In: Tweemaandelijksch tijdschrift, no. 6, 183- 185. 1896d, Psychologie en philosophie. Amsterdam: Scheltema en Holkema. $1896 \mathrm{e}$, De ontkenning der moraal. Een wijsgeerig-lellerkundige studie. Amsterdam: Scheltema en Holkema.

KamerbeeK, J. 1957, Allard Pierson (1831-1896) en Wilhelm Dilthey (1833-1911). Amsterdam: Noord-Hollandsche Uitgevers Maatschappij.

KANT, I. 1985, Kritik der reinen Vernunft [1781/1787²], I. Heidemann (hrgs). Stuttgart: Reclam.

1989, Prolegomena zu einer jeden künftigen Melaphysik die als Wissenschaft wird auftreten können [1783], R. Malter (hrgs.) Stuttgart: Reclam.

KLOMP, H.A. 1997, De relativiteitstheorie in Nederland. Breekijzer voor democratisering in het interbellum. Utrecht: Epsilon uitgaven.

KNIGHT, D. 1986, The age of science, the scientific world-view in the nineteenth century. Oxford: Blackwell.

KÖHNKE, K. 1986, Entstehung und Aufstieg des Neukantianismus. Frankfurt am Main: Suhrkamp.

Kolakowksi, L. 1972, Positivist philosophy. From Hume to the Vienna Circle. Harmondsworth: Penguin.

KonN, B. 1881, Untersuchungen über das Causalproblem auf den Boden einer Kritik der einschlägigen Lehren J.St. Mill. Academisch proefschrift Straatsburg. Wenen: Gerold.

Kohnstamm, PH. 1907, 'Psychologie en logica'. In: Tijdschrift voor wijsbegeerte, no. 1, $385-426$.

1908, 'Determinisme en natuurwetenschap'. In: Tijdschrift voor wijsbegeerte, no. $1,521-564$.

1916, Ontwikkeling en onttroning van het begrip natuurwet. Haarlem: Bohn.

1921, 'Over natuurwetten, wetmatigheid en determinisme.' In: Onze eeuw, no. $12,292-336$.

KöNIC, E. 1890, Die Entwicklung des Causalproblems in der neueren Philosophie. Leipzig: 0 . Wigand.

Körnik, S. 1955, Kamt. Harmondsworth: Penguin.

KoSSMANN, E.H. 1976, De lage landen 1780 - 1980. Anderhalve ecuw Nederland en Belgï. Amsterdam: Elscvier.

Kraft, V. 1950, Der Wicner Kre'is. Der Ursprung de's Neopositivismus. Wenen: Springer KRETZER, A. 1847, De nieuwe wijsgerige school. Utrecht: s.n. 
KROP, H.A. 1995, 'De academische fillosofie tijdens het fin de siecle'. In: Geschiedenis van de wijsbegeerte in Nederland, nos. 1-2, 3-26.

1997, Zeer kundige professoren: beoefening van de filosofie in Groningen van 1614 tot 1996. Hilversum: Verloren

LALANDE, A. 1950, Vocabulaire technique et critique de la philosophie. Parijs: Presses Universitaires de France. (6e cditie).

LAND, J.P.N 1863, 'Een wijsgeerig programma'. In: Godgeleerde bijdragen, no. 2, 545580 .

1864, 'Dienstbare wijsbegeerte'. In: De gids, no. 2, 369-423.

1871a, Het keerpunt in de wijsgerige ontwikkeling van dr. A. Pierson toegelicht. Amsterdam: Van Kampen.

1871b, 'In zake Opzoomer contra Spruyt'. In: De Nederlandsche spectator, no. 48, 381-383.

1873, Beginselen der analytische logica. Leiden: Brill.

1880, 'Critical notices'. In: Mind, no. 1, 591-596.

1889, Inleiding tot de wijsbegeerte. Den Haag: Nijhoff.

$1890 \mathrm{a}$, 'Dr. Heymans over het begrip veroorzaking'. In: De Nederlandsche spectator, no. 32, 266-268.

1890b, 'Oorzaken en gevolgen'. In: De gids, no. 3, 477-511.

1899. De wijshegeerte in de Nederlanden. Den Haag: Nijhoff.

L'ANGE HUET, J. 1866, De methode der positieve filosofie volgens August Comte. Academisch proefschrift Leiden. Leiden: Van Doesburgh.

1872, Nieuwe oplossing voor een oud vraagstuk. De methode van het positivisme toegepast op het begrip oorzaak-en-gevolg. Leiden: Van Doesburgh.

1873, 'Het standpunt der modernen'. In: De gids, no. 2, 71-118.

LAUDAN, L. 1977, Progress and its problems. Towards a theory of scientific growth. Berkeley: University of California.

LEWES, G.H. 1875, Problems of life and mind. London: Trubner.

LOCKE, J. 1975, An essay concerning human understanding [1690]. P.H. Nidditch (ed.).

Oxford: Clarendon Press.

LOSEE, J. $1980^{2}$, A historical introduction to the philosophy of science. Oxford: Oxford University Press.

MaCH, E. 1896, Die Prinzipien der Wärmelehre. Lcipzig: uitgever.

MACKIE, J.L. 1974, The cement of the universe, a study of causation. Oxford: Clarendon Press.

MAINE DE BIRAN, F.P. 1982, Mémoire sur la décomposition de la pensée [1805]. P. Tisserand (ed.). Genève: Slatkine.

MANDELBAUM, M. 1971, History, man, and reason: a study in nineteenth-century thought. Baltimore: Johns Hopkins University Press.

MAYR, E. 1991, One long argument. Charles Darwin and the genesis of evolutionary thought. Harmondsworth: Penguin.

MCCLELLAND, P.D. 1975, Causal explanation and model building in history, economics and new economic history. New York: Cornell Universily Press. 
MEES, R.P. 1895, Opmerkingen over de vorming en den aard onzer kennis. Den Haag: Nijhoff.

MIL., J.S. 1843, A system of logic: ratiocinative and inductive. London: Longmans, Green. (8e editie, 1903) 1865, An examination of sir William Hamilton's philosophy. London: Longmans, Green.

MULDER, G.J. 1849, De weg der wetenschap. Rotterdam: s.n.

NABER, S.A. 1897, Allard Pierson herdacht. Haarlem: Tjeenk Willink.

NAGEL, E. 1961, The structure of science. Problems in the logic of scientific explanation. New York: Harcourt, Brace \& World.

NELSON, J.O. 1967, 'Innate ideas'. In: P. Edwards (ed.) The encyclopedia of philosophy. New York: MacMillan, 196-198.

Nuchelmans, G. 1965, Hume. Baarn: Wereldvenster.

O'CONNER, D.J. (ed.) 1964, A critical history of western philosophy. New York: The Free Press.

OPZOOMER, C.W. 1845, De naturali obligatione. Academisch proefschrift Leiden. Leiden: S.n.

1847, De leer van God, bij Schelling, Hegel en Krause, deel I: Krause, een wijsgeerige proeve. Leiden: Gebhard.

1848a, Het wezen der deugd. Leiden: Gebhard.

1850, De twijfel des tijds. De wegwijzer der toekomst. Leiden: Gebhard.

$1851^{2}$, De weg der wetenschap, een handboek der logica. Leiden: Gebhard.

$1857,1862^{2}$, Wetenschap en wijsbegeerte. Amsterdam: Gebhard.

1859, 1862², De waarheid en hare kenbronnen. Amsterdam: Gebhard.

$1863,1867^{2}$, Het wezen der kennis, een leesboek der logica. Amsterdam: Gebhard. 1864-1867, De godsdienst. Amsterdam: Gebhard.

1871, Een nieuwe kritiek van de wijsbegeerle der ervaring beschouwd. Amsterdam:

Gebhard.

1875, Scheiding van kerk en staat. Amsterdam: Gebhard.

OTTERSPEER, W. 1992, De wiekslag van hun geest. De Leidse universiteit in de negentiende eeuw. Academisch proefschrift Leiden. Den Haag: Stichting Hollandse Historische Reeks. 1995, Bolland. Een biografie. Amsterdam: Bakker

PAP, A. 1962, An introduction to the philosophy of science. Glencoe: The Free Press.

PASSMORE, J.A. 1965, The idea of a history of philusophy'. In: History and theory, Beiheft $5,1-32$.

1980, A hundred years of philosoply. Harmondsworth: Penguin.

PICKering, M. 1993, August Comte: an intellectuel biography. Cambridge: Cambridge University Press.

PIERSON, A. 1854, Disquisitio historico-dogmatica de realismo et nominalismo quatanus vim habuerint in praecipuis placilis theologicae scholasticae, inde ab Anselmo usque at Guillelmus ab Occamo. Academisch proefschrift Utrecht. Utrecht: Kemink.

1855, Bespiegeling, gezag en ervaring: een wijsgeerige, geschicdkundige proeve. Utrecht: Kemink. 
1858, Intuitie en empiric, ecn brief over de weg der wctenschap van 4. Pierson aan ds. Chantepie de la Saussaye. Rolterdam: s.n.

1863, Rigting en leven. Haarlem: Kruseman

1867, Gods wondermacht en ons geestelijk leven. Zutphen: Thicme

1871, 'Een keerpunt in de wijsgecrige ontwikkeling'. In: De gids, no. 2, $455-$

487.

1874, 'Mill's Logika'. In: De tijdspicgel, no. 2, 277- 327.

1875a, Eene levensbeschouwing. Haarlem: Kruseman \& Tjeenk Willink.

1875b, De Orestie van Aeschylus. Den Haag: Stemberg.

1875c, 'Eene geschiedenis van het materialisme'. In: De gids, no. 1, 365-444.

1877, Een studie over de geschriften van Israëls profeten. Amsterdam: Van Kampen.

1878, De Bergrede en andere synoptische fragmenten. Amsterdam: Van Kampen.

1882, Wijsgeerig onderzoek. Kritische prolegomena van esthetick. Deventer:

Ter Gunne.

$1887 \mathrm{a}$, Israël. Haarlem: Tjeenk Willink.

1887b, Geestelijke voorouders: sıudiën over onze beschaving. Haarlem: Tjeenk

Willink.

1891a, Hellas. Haarlem: Tjeenk Willink.

1891b, Studiën over Johannes Kalvijn. Amsterdam: Van Kampen.

1893, 'Over Opzoomer'. In: De gids, no. 2, 413-441.

POORTMAN,J.J. 1948, Repertorium der Nederlandse wijsbegeerte. Amsterdam: Wereldbibliotheek.

REICHENBACH, H. 1951, The rise of scientific philosophy. Berkeley: University of California Press.

RITTER, P.H. (ed.) 1898 Licne halve ecuw, 1848-1898. Nederland onder de rege'ring tan Koning Willem III en het regentesschap van Koningin Emma. Amsterdam: Beijers \& Funke.

1904, 'Prof. dr. B.H.C.K. van der Wijck'. In: Mannen en vrouwen van beteekcnis in onze dagen. Haarlem: Tjeenk Willink, 43-150.

1906, Critische geschiedenis van het substantiebegrip in de nieuwere wijsbegeerte. Leiden: Brill.

ROESSINGI, K.H. 1914, De moderne theologie in Nederland, hare voorbereiding en eerste periode. Academisch proefschrift Leiden. Groningen: s.n.

ROMEIN, J.M. 1979, Erflaters van onze beschaving. Nederlandse gestalten uit zes eeuwen. Amsterdam: Querido. (16e druk).

1967, Op het breukvlak van twee eetwen. De westerse wereld rond 1900. Amsterdam: Quirido. (2e druk).

Roos, J. 1863, De eerste wijsgeer der ervaring aan de Groningsche Hoogeschool: kritischwijsgeerige beschouwing der inwijdingsrede van den hoogleraar B.H.C.K. van der Wijck. Utrecht: Broese.

RORTY, R. (ed.) 1984a, Philosophy in hislory: essays on the historiography of philosophy. Cambridge: Cambridge University Press. 
1984b, 'The historiography of philosophy'. In: R. Rorty (ed.) Philosophy in history: essays on the historiography of philosophy. Cambridge: Cambridge University Press, 49-75

RuSSELL, B. 1963, Mysticism and logic, and other essays. London: Allan \& Unwin. RYAN, A. 1970, The philosophy of John Stuart Mill. London: MacMillan.

SANDBERG, A.J. 1865a, Hel stelsel der ervaring van mr. C.W. Opzoomer aan de werkelijkheid getoetst. Zeist: s.n.

1865b, Is "De weg der wetenschap" van mr. C.W. Opzoomer de weg tot de wetenschap? Zeist: s.n.

SASSEN, F.L.R. 1941, 'Wijsgerig onderwijs in Nederland in de negentiende eeuw. I.

Groningen'. In: Studia catholica, no. 2, 85-119.

1947, Wijsgerig leven in Nederland in de twintigste eeuw. Amsterdam: NoordHollandse Uitgevers Maatschappij.

1954, Wijsgerig leven in Nederland in de eerste helft van de negentiende eeuw. Amsterdam: Noord-Hollandsche Uitgevers Maatschappij.

1959, Geschiedenis van de wijsbegeerte in Nederland tot het einde der negentiende eeuw. Amsterdam/Brussel: Elsevier

1961, De herleving van het criticisme in Nederland. Amsterdam: Noord-Hollandsche Uitgevers Maatschappij.

SCHARFF, R.C. 1995, Comte after positivism. Cambridge: Cambridge University Press. SCHEFFER, W. 1864, 'Een nieuw boek over logika'. In: Godgeleerde bijdragen, no. 1, 4473. 406.

1865, 'Een wijsgeerig geschil in Nederland'. In: Godgeleerde bijdragen, no. 1, 353 -

SCHLICK, M. 1918, Allgemeine Erkenntnislehre. Berlijn: Springer.

1933, Die Probleme der Philosophie in ihrem Zusammenhang. Frankfurt am Main: Suhrkamp.

SCHOPINHAUER, A. 1962, Über die vierfache Wurzel des Satzes vom zureichenden Grunde [1813/18472]. In: W. von Lohncysen (ed.). Stuttgart/Frankfurt am Main: Cotta-Insel.

SiMON, W.M. 1963, European positivism in the nineteenth century. An essay in intellectual history. Ithaca/ New York: Cornell University Press.

SOPPER, A.J. DE 1907, David Hume's kenleer en ethiek I. Academisch proefschrift Leiden. Leiden: Sijthoff.

1908, Hegel en onze tijd. Leiden: Sijthoff.

SPRUYT, C.B. 1867, De electromotorische kracht van het element van Daniell bij verschillende temperaturen. Academisch proefschrift Utrecht. Utrecht: s.n.

1871a, 'Aangeboren waarnemingsvormen'. In: De gids, no. 3, 1-68; 414-467.

$1871 \mathrm{~b}$, De laatste gedaanteverwisseling van de wijsbegeerte der ervaring toegelicht. Arnhem: Heuvelink. 505.

$1871 \mathrm{c}$, 'Het algemeene postulaat van Herbert Spencer'. In: De gids, no. 1, 445-

1872, 'De achterhoede van het idealisme'. In: De gids, nos. 2-3, 385-438; $77-$ 108. 
1873, 'Oude dwalingen in een nieuw kleed'. In: De gids, no. 1, 225-265.

1876, 'Jong-Hollandsche wijsbegeerte'. In: De gids, no. 2, 1-32.

1879, Proeve van eene geschiedenis van de leer der aangeboren begrippen. Leiden:

Brill.

1888, 'Die Geschichte der Philosophie in Holland von 1878 bis 1888 '. Sonderabdruck aus dem Archiv für die Geschichte der Philosophie, II. Band, nos. 1 en 3, 112-140; 495510.

1899, Het empiriocritisme, de jongste vorm van de 'wijsbegeerte der ervaring". Amsterdam: De Bussy.

1904, Geschiedenis der wijsbegeerte, naar dictaten van wijlen prof. C.B. Spruyt.

Bezorgd door Ph. Kohnstamm en J.D. van der Waals jr. Haarlem: Bohn.

STEGMÜLlER, W. 1969, Hauptströmungen der Gegenwartsphilosophie. Stuttgart: Kröner. STRAWSON, G. 1989, The secret connexion: causation, realism and David Hume. Oxford: Clarendon Press.

STrouD, B. 1977, Hume: the arguments of the philosophers. Oxford: Routledge \& Kegan Paul.

STUMPER, O. 1956/1957, 'La théorie de la causalité de G. Heymans, anticipation de celle

d' E. Meyerson'. In: Algemeen Nederlands tijdschrift voor wijsbegeerte, no. 4, 186-192. STRUYKER-BOUDIER, C.E.M. 1985, Wijsgerig leven in Nederland, Belgie en Luxemburg 1880-1980. Nijmegen: Katholiek Studiecentrum.

TATARKIEWICZ, W. 1973, Nineteenth century philosophy. Belmont, California: Wadsworth. TAYLOR, R. 1967, 'Causation'. In: P. Edwards (ed.) The encyclopedia of philosophy. New York: MacMillan, 56-66.

TEN, C.L. (ed.) 1994, Routledge history of philosophy, vol. VII: The nineteenth century. London: Routledge \& Kegan Paul.

THEUNISSEN, B. 1995, 'Martinus Willem Beijerinck and the beginnings of the Delft tradition in microbiology'. In: P. Bos (ed.) Beijerinck and the Delfi school of microbiology. Delft: Delft University Press, 183-192.

THOMAS, W. 1985, Mill. Oxford: Oxford University Press.

Tideman, J. 1848, De stellige wijsbegeerte tegenover geloof en bespiegeling. Den Haag: Belinfante.

VALK, J.M.M. DE 1979, 'Inleiding'. In: J.M.M. de Valk, Hel positieve denken. Meppel: Boom, 7-31.

Veen, H. VAN Der 1997, 'Achter de Duitse horizon. Piersons verblijf in Heidelberg 18651874'. In: De negentiende eeuw, no. 1, 17-29.

VeEn, H.G. VAN DER 1983, 'Levensloop'. In: D. Draaisma (e.a), Gerard Heymans. Objectiviteit in filosofie en psychologie. Weesp: Wereldvenster, 13-33.

VEER, H. VAN 'T 1961, Mr. C.W. Opzoomer als wijsgeer. Academisch proefschrift Leiden. Assen: Van Gorcum.

1962 'Het oudste positivisme in Nederland, het positivisme van W. Baron de Constant Rebecque (1807-1862)'. In: Tijdschrift voor filosofie, no.1, 279-302.

VERBEEK, TH. 1977, Inleiding tot de geschiedenis van de psychologie. Utrech//Antwerpen: Spectrum. 
VERWEY, G. 1995, 'Heymans en het equilibriummodel, wetenschappelijke soteriologie in het fin de siècle'. In: Geschiedenis van de wijsbegeerte in Nederland, 1-2, 177208 .

1998, Gerard Heymans (1857-1930) en het equilibriummodel. Nijmegen: Damon.

VISSER, H. 1987, Logical analysis and ontological reconstruction. Two programmes in the analytical tradition. Academisch proefschrift Tilburg. Alblasserdam: s.n. 1991, Wetenschappelijk humanisme. Maastricht: Maastricht University Press. 1992, 'Mach, Utrecht and Dutch philosophy'. In: J.T. Blackmore (ed.) Ernst Mach-A deeper look: documents and new perspectives. Dordrecht: Kluwer, 403-430. VlOTEN, J. VAN 1867, 'Stellige wijsbegeerte'. In: De levensbode, no. 2, 45-70.

VLuGT, W. VAN DER 1898, 'De geestelijke wetenschappen.' In: P.H. Ritter (ed.) Eene halve eeuw, 1848-1898. Nederland onder de regeering van Koning Willem III en het regentesschap van Koningin Emma. Amsterdam: Beijers \& Funke, 1-70.

VOGEL, J.G. 1965, 'Heymans' causaliteitsbegrip'. In: Algemeen Nederlands tijdschrift voor wijsbegeerte, no.2, 227-243.

VoGELS, I. 1894, 'Dr. Heymans en de school van sir W. Hamilton'. Studiën, no. 2, 399413.

VRIES, J.W. DE 1969, De Indische jaren van Busken Huet. Den Haag (onuitgegeven typoscript). WAALS JR., J.D. VAN DER 1917, 'Over de causaliteitstheorie van Hamilton-Heymans'. In: Tijdschrift voor wijsbegeerte, no. 1, 295-314.

WALKER, R.C.S. 1978, Kant: the arguments of the philosophers. London: Routledge \& Kegan Paul.

WARNOCK, G.J. 1953, Berkeley. Harmondsworth: Penguin.

WHEWELL, W. 1837, History of the inductive sciences from the earliest to the present time. London: Parker.

1840, The philosophy of discovery. London: Parker.

1858-18603, The philosophy of the inductive sciences, founded upon their history. London: Parker.

WiELema, M.R. 1987, 'Inleiding'. In: M.R. Wielema (ed.), Paulus van Hemert: gezag en grenzen van de menselijke rede. Baarn: Ambo. 13-33.

WUCK, B.H.C.K. VAN DER 1863, De oorsprong en grenzen der kennis. Groningen: Wolters. $1864^{2}$, Mr. Johannes Kinker als wijsgeer. Groningen: Wolters. 1866, 'Ik en niet-ik'. In: De gids, no 1, 209-240.

1868a, Voltaire. Amsterdam: Gebhard.

1868b, Onderscheid usschen goed en kwaad. Amsterdam: Gebhard.

1871, De wijsbegeerte der ervaring verdedigd. Groningen: Wolters.

1872, Zielkunde I. Groningen: Wolters.

1873, 'John Stuart Mill'. In: De gids, no. 2, 1-57.

1877, Spinoza. Groningen: Wolters.

1879, Het raadsel der ervaring. Groningen: Wolters.

1888, 'Prof. C.W. Opzoomer'. In: Mannen van beteekenis in onze dagen. Haarlem:

Tjeenk Willink, 1-19.

1890, Nog eens: oorsprong en grenzen der kennis. Utrecht: Ten Bokkel Huinink. 
1893, Mr. C.W. Opzoomer: een herinneringswoord. Utrecht: Breijer.

1896, 'Een staatsman-wijsgeer'. In: De gids, no. 2, 119-137.

$1898 \mathrm{a}$, 'Allard Pierson'. In: Mannen en vrouwen van beteekenis in onze dagen.

Haarlem: Tjeenk Willink, 231-286.

1898b, 'Het hooger onderwijs'. In: P.H. Ritter (ed.) Eene halve eeuw, 1848-1898.

Nederland onder de regeering van Koning Willem III en het regentesschap van Koningin

Emma. Amsterdam: Beijers \& Funke, 83-106.

1899, 'Kant in Holland'. In: Kant-Studien, no. 8, 448-466.

1904 'Levensbericht van C. B. Spruyt'. In: Jaarboek Koninklijke Academie van

Wetenschappen. Amsterdam: Noord-Hollandsche Uitgeversmaatschappij, 3-29.

1928, 'Die Niederländischen Philosophie'. In: F. Ueberweg (ed.), Grundriss der

Geschichte der Philosophie, IV. Teil. Die Philosophie des Auslandes vom Beginn des

19. Jahrhunderts bis auf die Gegenwart. Berlijn: Mittler, 279-288.

WIJNAENDIS FRANCKEN, C.J.1905, Inleiding tot de wijsbegeerte. Haarlem: Tjeenk Willink. 1907, David Hume. Haarlem: Tjeenk Willink.

1941, 'Mr. C.W. Opzoomer (1821-1892)'. In: Algemeen Nederlands tijdschrift voor wijsbegeerte en psychologie, no. 1, 35-51.

WILLINK, B. 1988, Burgelijk scientisme en wetenschappelijk toponderzoek: sociale grondslagen van nationale bloeiperioden in de 19 e eeuw in de beta-wetenschappen. Academisch proefschrift Amsterdam. Rotterdam: Universiteitsdrukkerij.

1991 'Origins of the second golden age of Dutch science after 1860: intended and unintended consequences of educational reform'. In: Social studies of science, no. 21, 503-523.

1998, De tweede gouden eeuw: Nederlandse Nobelprijzen voor natuurwetenschappen. Amsterdam: Bakker.

YAKIRA, E. 1994, La causalité de Galilée à Kant. Parijs: Presses Universitaires de France.

ZELLER, E. 1862, Über Bedeutung und Aufgabe der Erkenntniss-Theorie. Heidelberg: Groos.

ZwarT, P.J. 1967, Causaliteit. Academisch procfschrifı Nijmegen. Assen: Van Gorcum. 

Becker, F. 7, 37

Bell, F.W.B. van 87

Betz, H.J. 11, 184, 185, 224-232, 233 $238,239,271,276,280$

Bierens de Haan, J.D. 9, 11, 182, 223, 276

Bolland, G.J.P.J $\quad 11,12,14,184,185$, 224, 239, 270-276

Büchner, L. 111

Busken Huet, C. 5

Buys Ballot, C. 3

Brouwer, L.E.J. 277

Clay, J. $12,13,19,184,279-280$

Comte, A. $6,18,27,34,35,38,85-87$, $90,111,118,122,123,126$

Descartes, R. 10,142,184, 193, 202, 236

Deventer, Ch.M. van 11, 276

Donders. F.C. 3. 21

Greuve, F.C. de 4, 153

Hamilton, W.R. 10, 11, 18, 184, 185, 200,201

Harting, P. 3, 21

Hegel, G.W.F. 21, 34, 270

Helmholiz, H. von 8, 49, 50, 53, 59, 67. $80,83,153,235$

Heymans, G. $1,9-13,18,19,70,110$, $125,152,182,183-221,233-237,259-$

$262,270-275,280,281$

Hume, D. 7, 9, 11, 18, 24, 30, 31, 38-40, $49-54,55,61-63,65,70-72,74,75,78$, $79,91,95,99,107,122,126,132-134$, 136, 138, 139, 147, 150, 151, 154, 163. 164. 169, 171, 173-177, 179-181, 184 , $185,189-196,198,199,212,219,220$, 226, 242, 257, 277

Jelgersma, D.G. 11, 12, 18,70,110,184, 185. 198, 224, 239-257, 259-262, 26220.3-264, 205-267, 268-269

Kant, I. $7,8,9,10,18,19,38.40,50$, $51,53.59,61-63,74,75,135,138,141-$
$143,147-150,150-152,153,154,169$, $179-181,184,201,216,217,218,224$, $255,271,272,275$

Kohnstamm, Ph. 12, 19, 184, 276, 278, 279,280

L'Ange Huet, J. 1, 5-7, 18, 83, 85-123, $125,126-139,142,143,148,151,181$, $220,224,259$

Land, J.P.N. 4, 7, 8, 10,11, 12, 37, 125 , $183,185,225,239,271$

Leibniz, G.W.F. 142, 184, 193, 202

Lewes, G.H. 85, 169

Locke, J. 38, 61, 142, 184

Mach, E. $34,213,220$

Maine de Biran, F.P. 30,125

Mecs, R.P. 12, 276, 277

Mill, J.S. 3, 18, 21, 22, 24, 27-29, 33, $35,36,38,41,43,55,59,77,184,185$, 223

Mulder, G.J. 3, 21

Opzoomer, C.W. $1-8,10,18,21-36,37-$ $54,54-59,60,65,68,69,74,76,79,82$, $83,85,87-89,94-100,120,122,123$, $125,126,132-134,140,141,142,143$, $148,151,153,181,220,221,259$

Passmore, J. 15

Pierson, A. $1,8,9,11,152,153-182$, 220,221

Poortman, J.J. 13, 19

Reichenbach, H. 15

Richl, A. 10

Sassen, F. 9, 14, 19

Schopenhauer, A. $18,49-51,53,59,131$, $134,138,184,202,203$

Spruyt, C.B. 1, 3-10, 18, 19, 36, 37-54, $54-59,60,65,67,69,72-76,76-83,87-$ $89,94,95,97,100,110,122,123,125-$ $140,141-152,153-155,163,165,166$, $168,179,180,181,182,221,239.276$, 278

Vloten, J. van $60,87,224$ 
Vogels, I. 11, 221, 223

Waals jr., J.D. van der 12, 13, 19, 184 , 279, 280, 281

Whewell, W. 18, 23-26

Wijck, B.H.C.K. van der $1,3-7,9,10$, $18,19,37,59,60-76,76-83,87,88$, $110,117,120,122,123,125,141-143$, $148,151,153,154,180,181,183,185$, 221, 259

Wijnaendts Francken, C.J. 12, 277

Windelband, W. 9 
Aangeboren bcgrippen $3,23,24,35,38$, $61,73,83,141-143$

Aanschouwing(svorm) 40,53, 65

Associatie 30, 65, 71, 147, 151, 190, $198,199,219,240,242-246,248,250$ $253,258,259,261,263-266,268-269$, 277

Associatieleer 239, 240, 257, 266, 269 Associatiewetten 146, 147, 188, 190 , $191,219,246$

Beginsel van voldoende grond 50,51 , $75,110,126,136-138,140$

Buitenwereld 149, 165, 188, 241, 253

Causale axioma's 10, 184, 193, 194, $198,199,212,214,219,225,226,232$, 236, 240, 251-253

Causaliteitsbeginsel $3,4,18,26,29,30$, $32-34,35,36,38,40-42,51,53,59,63$, $64,68-70,72,73,74,77,80-83,95,96$, $126,132,135,136,139-140,147,149-$ $151,155,162,163,179,180,194,195$, $202,208,213,219,225,264-267,269$, 270

Causaliteitsbesef $108,109,111,113$, $114,116,117,119-121,126,132-134$, 136, 140, 141, 277

Correspondentie(theorie) $115,117,120$

Denkvorm 148, 155, 162, 163, 179

Eindoorzaken 27, 35, 86, 110

Externe werkelijkheid 121, 122, 254-256, 258

Geldigheidsbenadering $17,19,53,74$, $82,83,122,141,189,221,260,270$, 277

Gewoonte(vorming) 30, 39, 62, 70-72, $74,75,78,79,82,112,120,145,164$, $176,177,180$

Hamiltons hypothese 200, 202, 203 , 204, 205, 206, 211-213, 239, 240, 247, 251,260
Hamiltons postulaat $13,189,202,205$ $210,212,215,216,219,221,223,225$, $227,232,235,238,240,248,253,259$, 272

Herhaalde waarneming $39,51,64,71$, $73,95,99,100,101,107-111,114,120$, $132-134,136,162,164,180,249,257$

Hypothesen 203, 208-211, 229, 231, $232,237,273,275$

Natuurwetten $18,23,27,40,64,86,113$, $114,116,136,139,168,169,178,180$, 181,247

Noodzakelijk verband $16,30,43,46,47$, $49,51,52,59,62,107,133,141,145$, $148,151,167,186,188,198,219$

Ontstaansbenadering $17,19,53,74,82$, $83,122,140,141,189,221,259,260$, 277

Plaatselijke verhouding $103,104,106$, 107, 134

Probleemgerichte benadering $1,13,15$, $20,53,83,181,220$

Regelmatigheidsbeginsel $\quad 16,18,28,35$, $41,51,63,64,70,80$

Substantiebeginsel 201

Successic- en coëxistentiewetten 70,196 , $198,243,245,246,257,259,260-262$, $263,264,267-270$

Sympathetische gewaarwordingen 93,94 , $121-123,126,127,134,140$

Synthese 159, 160

Tijd-ruimtelijke nabijheid $31,54,190$

Tijdsorde $75,155,160-162,166,168$, $170,175,177,178,180,181,221$

Tijdsvoorstelling 216, 272, 275

Uniformiteit 26, 28, 72, 74

Verwachtingen $65,71,72,74,78,79$, $82,117,147,188,191,217,241,253$, 256

Verklaren $111-114,117,122,123,136$ 
Verstandsvorm 40,57

Vourspellen 100, 101. 116, 117, 107.

$175,177,180$

Voorstellingsintensitcit $190,192,242$, 257

Waarncmingsvorm $4,7,37,53,56-58$, $65,67,68,73,78,82,88,94,122,129$, $130,140,141,148$

Werkingswaarneming 108, 110

Wetenschappelijke wending 19,279, 281

Wetmatige verbanden $36,38,87,121$

Wilsbepaling $31,32,36,44-49,52,58$, $59,97,133$ 


\section{AUTEUR}

Gerrit Jan Leendert Scheurwater werd te Den Haag geboren op 4 december 1963. $\mathrm{Na}$ het Voorbereidend Wetenschappelijk Onderwijs aan het Marnix Gymnasium te Rotterdam (1976-1983), studeerde hij in de periode 1983-1989 filosofie aan de Faculteit der Wijshegecrte van de Erasmus Universiteit Rotterdam, en in de periode 19851987 theorie en guschicdenis van de psychologie aan de Universiteit Leiden en de Universiteit Utrecht. In 1988 werd hem het Joost-van-den-Vondel Reisestipendium uilgereikt vanwege de Stiflung FWS zu Hamburg. In het kader daarvan verbleef hij een aantal maanden voor voortgezette studie aan de Faculteit der Letteren en Wijsbegeerte van de Rijksuniversiteit Gent, België. Het propaedeutisch examen filosofie (1984) en het doctoraal examen filosofie (1989) behaalde hij cum laude. Na zijn doctoraal examen vervulde hij in de periode 1989-1990 zijn militaire dienstplicht. In de periode 1991-1992 werkte hij als projectmedewerker bij het Onderwijs Media Instiluut van de Universiteit Utrecht. Van 1992 tot 1997 was hij werkzaam als beleidsmedewerker bij de Dienst Onderwijs en Onderzoek van het Bureau van de Technische Universitcil Delft. Sinds 1997 is hij werkzaam als senior-beleidsmedewerker bij de Staf College van Bestuur van de Technische Universiteit Delft. De auteur is gehuwd en heeft een dochter. 


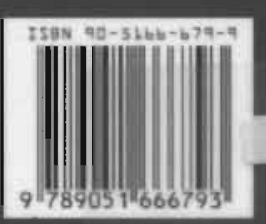

